\title{
NORTHEAST OREGON
}

HATCHERY PROJECT

Final Siting Report

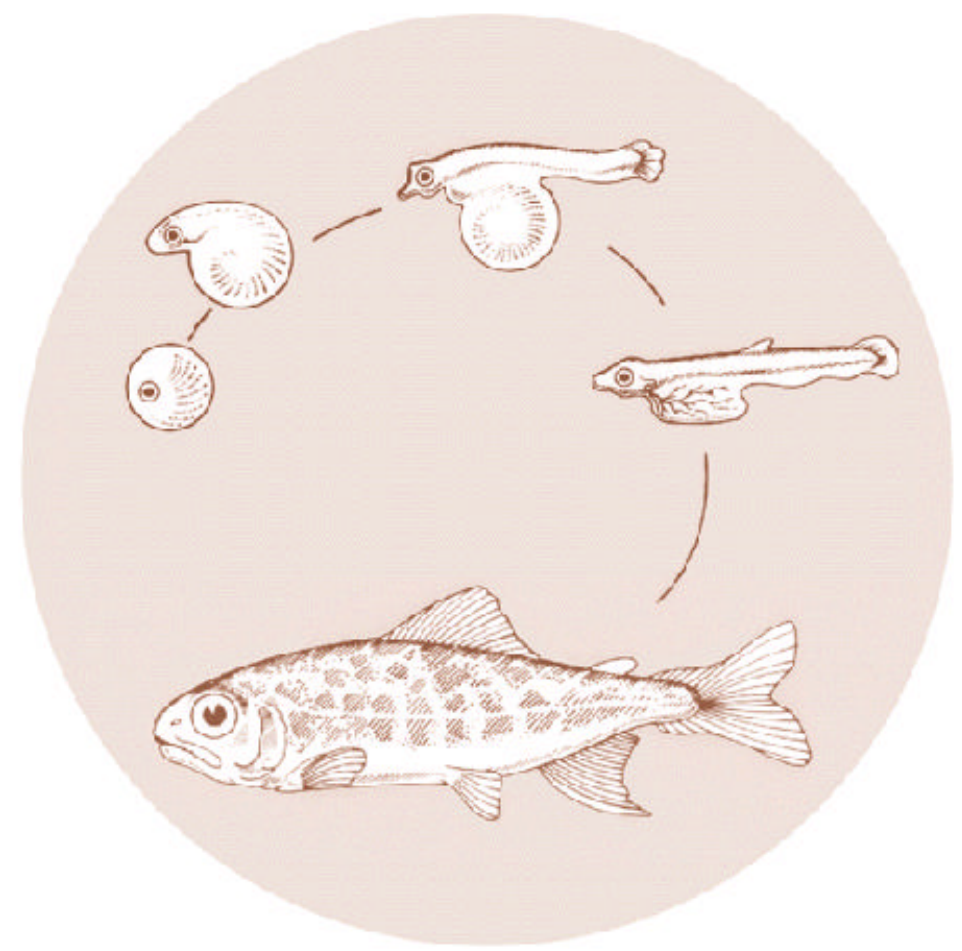

DOE/BP-11466-2 
This report was funded by the Bonneville Power Administration (BPA), U.S. Department of Energy, as part of BPA's program to protect, mitigate, and enhance fish and wildlife affected by the development and operation of hydroelectric facilities on the Columbia River and its tributaries. The views of this report are the author's and do not necessarily represent the views of BPA.

This document should be cited as follows:

Montgomery Watson, 1995, Northeast Oregon Hatchery Project, Final Siting Report, Report to Bonneville Power Administration, Contract No. 1991BP11466, Project No. 198805300, 279 electronic pages (BPA Report DOE/BP-11466-2)

This report and other BPA Fish and Wildlife Publications are available on the Internet at:

\section{http://www.efw.bpa.gov/cgi-bin/efw/FW/publications.cgi}

For other information on electronic documents or other printed media, contact or write to:

Bonneville Power Administration

Environment, Fish and Wildlife Division

P.O. Box 3621

905 N.E. 11th Avenue

Portland, OR 97208-3621

Please include title, author, and DOE/BP number in the request. 


\section{NORTHEAST OREGON HATCHERY PROJECT FINAL SITING REPORT}

Prepared by:

Montgomery Watson

Bellevue. WA

Prepared for:

U.S. Department of Energy

Bonneville Power Administration

Environment, Fish and Wildlife

P. 0. Box 3621

Portland. OR 97208-362 1

Project Number 88-53

Contract Number DE-AC7991BP1 1466

March 1995 
TABLE OF CONTENTS

SECTION

PAGE NO.

LIST OF TABLES

$\mathrm{V}$

LIST OF FIGURES

vii

ACKNOWLEDGMENTS

viii

EXECUTIVE SUMMARY

ix

INTRODUCTION

CURRENT AND HISTORIC DISTRIBUTION OF SPECIES

GRANDE RON-DE BASIN

Spring Chinook

Fall Chinook

Summer Steelhead

IMNAHA BASIN

Spring Chinook

Fall Chinook

Summer S teelhead

3

4

WALLA WALLA BASIN

Spring Chinook

Summer Steelhead

PRODUCTION AND RELEASE OBJECTIVES 8

$\begin{array}{lr}\text { INTRODUCTION } & 8\end{array}$

PRODUCTION AND FACILITY NEEDS 8

CURRENT PRODUCTION WITHIN THE NEOH PROJECT AREA 9

FISH PROPAGATION CRITERIA 13

$\begin{array}{ll}\text { INTRODUCTION } & 13\end{array}$

$\begin{array}{ll}\text { WATER CHEMISTRY } & 13\end{array}$

Oxygen 13

Ammonia

Carbon Dioxide

$\mathrm{PH}$

WATER QUALITY CRITERIA FOR SALMON-ID REARING 
Minimum Oxygen Levels 16

Ammonia Criteria 16

Carbon Dioxide 16

$\mathrm{PH}-16$

$\begin{array}{lr}\text { PROCESS CRITERIA } & 18\end{array}$

General Process Criteria $\quad 18$

Length-Weight Relationship $\quad 21$

Development Rate $\quad 21$

Feed Consumption $\quad 21$

Oxygen Consumption 22

Ammonia Production 22

Carbon Dioxide $\quad 22$

Suspended Solids $\quad 22$

Phosphate $\quad 22$

Rearing Mortalities $\quad 23$

Rearing Density 24

Flow Requirements $\quad 27$

WATER AND SPACE REQUIREMENTS 29

$\begin{array}{ll}\text { INTRODUCTION } & 29\end{array}$

$\begin{array}{ll}\text { FACILITY DESCRIPTIONS } & 29\end{array}$

Adult Capture $\quad 29$

Adult Holding - Single Facility $\quad 30$

Adult Holding - Facilities in Each Basin 32

Incubation and Early Rearing - Single Facility 34

Incubation and Early Rearing - Facilities in Each Basin 36

Full Term (Satellite) Rearing - Single Facility 39

Full Term (Satellite) Rearing - Facilities in Each Basin 40

Direct Release 43

Final (Extended) Rearing/Acclimation Facilities $\quad 44$

Small-Scale Hatchery $\quad 45$

ADVANCED TECHNOLOGY APPROACHES 46

Adult Holding 46

Incubation $\quad 46$

Rearing $\quad 46$

$\begin{array}{llll}\text { Enhanced Species Introduction } & 47\end{array}$

SURFACE WATER AND GROUNDWATER AVAILABILITY AND QUALITY 48

$\begin{array}{ll}\text { SURFACE WATER } & 48\end{array}$

Surface Water Quantity $\quad 48$

Surface Water Quality 49

Flood Frequency Data $\quad 52$

$\begin{array}{ll}\text { GROUNDWATER } & 52\end{array}$ 
Aquifers

Grande Ronde River Basin Sites $\quad 56$

Wallowa River Sites $\quad 58$

Lostine River Sites $\quad 59$

Imnaha River Basin Sites $\quad 59$

Walla Walla River Basin Sites $\quad 60$

Powder River Basin Sites $\quad 61$

Summary of Sites $\quad 61$

RECOMMENDATIONS FOR FURTHER GROUNDWATER EVALUATIONS

Miriam-Wallowa Confluence $\quad 63$

Imnaha Area 63

Upper Grande Ronde Basin - Catherine Creek 64

Lostine River - Suathearn Ranch 66

$\begin{array}{ll}\text { Summary of Recommendations } & 67\end{array}$

REVIEW OF EXISTING FACILITIES AND ASSESSMENT OF
EXPANSION POTENTIAL

$\begin{array}{lr}\text { INTRDUCTION } & 68\end{array}$

$\begin{array}{ll}\text { ASSESSMENT OF EXPANSION POTENTIAL } & 68\end{array}$

Wallowa Hatchery $\quad 68$

Lookingglass Hatchery $\quad 69$

Irrigon Hatchery $\quad 70$

Umatilla Hatchery 70

Lyons Ferry Trout Hatchery $\quad 71$

Springfield Aquaculture Facility $\quad 72$

$\begin{array}{ll}\text { SITE ANALYSIS AND SCREENING } & 74\end{array}$

$\begin{array}{ll}\text { INTRODUCTION } & 74\end{array}$

$\begin{array}{ll}\text { REVISED SITE LIST AND FACILITY SUMMARY } & 74\end{array}$

$\begin{array}{ll}\text { INITIAL SITE ANALYSIS } & 74\end{array}$

$\begin{array}{ll}\text { PROGRAM DEVELOPMENT } & 110\end{array}$

$\begin{array}{lr}\text { INTRODUCI'ION } & 110\end{array}$

PROPOSED NEOH PROGRAM ALTERNATIVES 110

$\begin{array}{ll}\text { REFERENCES } & 119\end{array}$

APPENDIX A - SUMMARY OF STREAMFLOW DATA A-1

APPENDIX B - SUMMARY OF WATER TEMPERATURE DATA B-1

APPENDIX C - SUMMARY OF WELLS LOGS C-1 
APPENDIX D - SITE DATA SHEETS

D-1 
LIST OF TABLES

NO.

PAGE

TABLE $1 \quad$ SUMMARY OF NEOH PRODUCTION GOALS 8

TABLE 2 LONG TERM PRODUCTION GOALS IN THE GRANDE RONDE BASIN

TABLE 3 LONG TERM PRODUCTION GOALS IN THE IMNAHA BASIN

TABLE 4 LONG TERM PRODUCTION GOALS IN THE WALLA WALLA BASIN

TABLE 5 LONG TERM PRODUCTION GOALS IN THE UMATILLA BASIN (NEOH COMPONENT)

TABLE 6 DISSOLVED OXYGEN AS A FUNCTION OF TEMPERATURE 14

TABLE7 UN-IONIZED AMMONIA AS A PERCENTAGE OF TOTAL AMMONIA IN FRESHWATER AT VARIOUS TEMPERATURES Ah?) $\mathrm{PH}$

$\begin{array}{lll}\text { TABLE } 8 & \text { WATER QUALITY CRITERIA FOR SALMONIDS } & 17\end{array}$

$\begin{array}{lll}\text { TABLE } 9 & \text { PROCESS CRITERIA FOR NEOH }\end{array}$

TABLE 10 FEEDING COEFFICIENT AT VARIOUS WATER TEMPERATURES 21

TABLE 11 ASSUMED SURVIVAL RATE BY LIFE STAGE AND SPECIES 23

TABLE 12 DENSITY AND FLOW INDICES USED BY VARIOUS AGENCIES IN THE PACIFIC NORTHWEST FOR OUTDOOR RACEWAYS (>800/LB.)

TABLE 13 DENSITY AND FLOW INDICES USED BY VARIOUS AGENCIES IN THE PACIFIC NORTHWEST FOR EARLY REARING $(<800 /$ LB. $)$

TABLE 14 PROPOSED DENSITY INDICES BY LIFE STAGE FOR NEOH 26

TABLE 15 FLOW REQUIREMENTS AS A FUNCTION OF TEMPERATURE 27

TABLE 16 FLOW INDEX RELATED TO WATER TEMPERATURE AND ELEVATION 28

$\begin{array}{ll}\text { TABLE } 17 & \text { SUMMARY OF STREAMFLOW GAGES IN THE NEOH } \\ \text { STUDY AREA }\end{array}$

TABLE 18 USGS TEMPERATURE STATIONS IN THE NEOH STUDY AREA 
TABLE 19 DEQ WATER QUALITY MONITORING STATIONS IN THE NEOH STUDY AREA 49

TABLE 20 GRANDE RONDE BASIN - WATER QUALITY (4191) 50

TABLE 21 WALLA WALLA AND IMNAHA BASINS - WATER QUALITY (4/91) 51

TABLE 22 QUALITATIVE EVALUATION OF FLOOD POTENTIAL AT PROPOSED SITES

TABLE 23 REVISED SITE LIST - GRANDE RONDE BASIN 75

TABLE 24 REVISED SITE LIST - IMNAHA BASIN 76

TABLE 25 REVISED SITE LIST - WALLA WALLA BASIN 76

$\begin{array}{lll}\text { TABLE } 26 & \text { SITE AND FACILITY SUMMARY } & 77\end{array}$

TABLE 27 GRANDE RONDE ADULT CAPTURE SCREENING CRITERIA 80

TABLE 28 GRANDE RONDE ADULT HOLDING SCREENING CRITERIA 84

TABLE 29 GRANDE RONDE INCUBATION AND FRY REARING SCREENING CRITERIA $\quad 88$

TABLE 30 GRANDE RONDE SATELLITE REARING SCREENING CRITERIA $\quad 91$

TABLE 3 I IMNAHA RIVER BASIN ADULT CAPTURE SCREENING CRITERIA 94

TABLE 32 IMNAHA RIVER BASIN ADULT HOLDING SCREENING CRITERIA $\quad 96$

TABLE 33 IMNAHA RIVER BASIN INCUBATION AND FRY REARING SCREENING CRITERIA 98

TABLE 34 IMNAHA RIVER BASIN SATELLITE REARING SCREENING CRITERIA $\quad 99$

TABLE 35 WALLA WALLA RIVER BASIN ADULT CAPTURE SCREENING CRITERIA $\quad 101$

TABLE 36 WALLA WALLA RIVER BASIN ADULT HOLDING SCREENING CRITERIA

TABLE 37 WALLA WALLA RIVER BASIN INCUBATION AND FRY REARING SCREENING CRITERIA

TABLE 38 WALLA WALLA RIVER BASIN SATELLITE REARING SCREENING CRITERIA 
TABLE 39 UPPER GRANDE RONDE SPRING CHINOOK

TABLE 40 CATHERINE CREEK SPRING CHINOOK 112

$\begin{array}{lll}\text { TABLE } 41 & \text { LOSTINE SPRING CHINOOK }\end{array}$

$\begin{array}{lll}\text { TABLE } 42 & \text { IMNAHA SPRING CHINOOK } & 114\end{array}$

TABLE 43 WALLA WALLA AND TOUCHET SPRING CHINOOK 115

TABLE44 GRANDE RONDE FALL CHINOOK 116

$\begin{array}{lll}\text { TABLE } & \text { IMNAHA FALL CHINOOK } & 117\end{array}$

$\begin{array}{lll}\text { TABLE } & \text { W6 WALA WALLA } & 118\end{array}$

LIST OF FIGURES

PAGE

NO.

FIGURE 1 GRANDE RONDE BASIN ANADROMOUS FISH SPAWNING AND REARING DISTRIBUTION

FIGURE 2 IMNAHA BASIN ANADROMOUS FISH SPAWNING AND REARING DISTRIBUTION 6

FIGURE 3 WALLA WALLA BASIN ANADROMOUS FISH SPAWNING AND REARING DISTRIBUTION

$\begin{array}{lll}\text { FIGURE } 4 \text { GRANDE RON-DE BASIN } & 107\end{array}$

$\begin{array}{lll}\text { FIGURE } 5 & 108\end{array}$

$\begin{array}{lll}\text { FIGURE } 6 \quad \text { WALLA WALIA BASIN } & 109\end{array}$ 


\section{ACKNOWLEDGMENTS}

Montgomery Watson would like to thank all the members of the Northeast Oregon Hatchery Project Technical Work Group, including representatives from Bonneville Power Administration, Oregon Department of Fish and Wildlife, the Confederated Tribes of the Umatilla Indian Reservation, and the Nez Perce Tribe for all their efforts in this project. The assistance and guidance provided by Jay Marcotte, Project Manager for Bonneville Power Administration, is especially appreciated.

Funding for the project was provided by the Bonneville Power Administration under Contract No. DE-AC79-9 1 BP1 1466. 


\section{EXECUTIVE SUMMARY}

This report presents the results of site analysis for the Bonneville Power Administration Northeast Oregon Hatchery Project. The purpose of this project is to provide engineering services for the siting and conceptual design of hatchery facilities for the Bonneville Power Administration. The hatchery project consists of artificial production facilities for salmon and steelhead to enhance production in three adjacent tributaries to the Columbia River in northeast Oregon: the Grande Ronde, WaIla Walla, and Imnaha River drainage basins. Facilities identified in the master plan include adult capture and holding facilities; spawning incubation, and early rearing facilities; full-term rearing facilities; and direct release or acclimation facilities. The evaluation includes consideration of a main production facility for one or more of the basins or several smaller satellite production facilities to be located within major subbasins.

The historic and current distribution of spring and fall chinook salmon and steelhead was summarized for the Columbia River tributaries. Current and future production and release objectives were reviewed. Among the three tributaries, forty seven sites were evaluated and compared to facility requirements for water and space. Site screening was conducted to identify the sites with the most potential for facility development. Alternative sites were selected for conceptual design of each facility type. A proposed program for adult holding facilities, final rearing/acclimation, and direct release facilities was developed. 


\section{INTRODUCTION}

This report presents the results of work carried out under Tasks 1 and 2 of the contract between Bonneville Power Administration (BPA) and Montgomery Watson for the Northeast Oregon Hatchery Project (NEOH). The report is divided into 10 sections and an appendix which contain the following information:

Introduction

Current and Historic Distribution of Species

Production and Release Objectives

Fish Propagation Criteria

Water and Space Requirements

Surface Water and Groundwater Availability and Quality

Review of Existing Facilities and Assessment of Expansion Capabilities

Site Evaluation and Screening

Program Development

Literature Cited

Appendices.

The majority of the information contained in these sections has been previously presented to BPA and the NEOH Technical Work Group (TWG), which is comprised of BPA, Oregon Department of Fish and Wildlife (ODF\&W), the Confederated Tribes of the Umatilla Indian Reservation (CTUIR), and the Nez Perce Tribe (NPT). The information was presented in a number of working papers which were subsequently reviewed and discussed by the TWG, then revised as necessary by Montgomery Watson.

This report includes discussions of production goals, the bioengineering criteria for various facility types, reviews available data on surface water and groundwater availability and quality, discusses existing facilities and their potential for expansion, and documents the site/facility screening process carried out to arrive at a proposed program to be carried forward into conceptual design.

The project study area includes three adjacent tributaries to the Columbia River: the Grande Ronde, Walla Walla, and Imnaha River drainage basins in northeastern Oregon. Basin master planning for production goals has been carried out previously by affected tribes, state resource agencies, and the federal government. The purpose of this project is to evaluate site locations and provide conceptual design for fish production facilities designed to enhance and/or reestablish salmon stocks in these river basins and meet the production goals identified in the basin master plans.

Salmonid stocks under consideration include spring and fall chinook salmon and steelhead. Facilities required include adult capture and holding facilities; spawning, incubation, and early rearing facilities; full-term rearing facilities; and direct release or acclimation facilities. The 
evaluation includes consideration of a main production facility for one or more of the basins or several smaller satellite production facilities to be located within major subbasins.

Site evaluation for these facilities is conducted in several phases. The first phase involved a review of available water quality and water quantity data, definition of fish propagation criteria specific to the program, definition of production and release objectives specific to the program, and definition of water and space requirements. Once these criteria were defined, site evaluations were carried out by project team field visits. The site reconnaissance teams included project staff with training in engineering and biology. Sites were evaluated for physical and environmental characteristics and a site data base developed. Following the site visits, site screening was conducted based on the project criteria and the site evaluations in order to identify a prioritized listing of sites for development of a program to meet basin production goals.

Conceptual design will be carried out for those facilities and sites that comprise the proposed program for each basin. 


\section{CURRENT AND HISTORIC DISTRIBUTION OF SPECIES}

\section{GRANDE RONDE BASIN}

The following information on the current and historic distribution of salmon in the Grande Ronde Basin has been obtained from CBFWA (1990). The major spawning and rearing areas for spring and fall chinook are shown on Figure 1.

\section{Spring Chinook}

The Grand Ronde drainage historically produced large runs of spring chinook salmon. Prior to dam construction on the Snake River, a spawning escapement of than 12,200 fish was estimated.

Spring chinook are widely distributed throughout the basin. Twenty-one streams historically supported spring chinook. The Wenaha River, Catherine Creek, Minam River, Lookingglass Creek, Lostine River, and upper Grande Ronde were highly productive streams in the past. Riparian and instream habitat degradation has severely impacted spring chinook production potential. This is due to livestock overgrazing, mountain pine beetle damage, limited quality rearing habitat, low stream flows, logging activities, road construction, mining and unscreened diversion ditches. The current escapement is in the range of 300 to 1,700 fish. Return goals for spring chinook in the Grande Ronde Basin are 16,400 .

\section{Fall Chinook}

Early and late fall chinook were historically distributed throughout the lower part of the river system. Currently only a few fish spawn in the lower Grande Ronde River, primarily below the Wenaha River. The current low spawning escapement is attributed to the Columbia River harvest, passage mortality at Columbia and Snake River dams, and habitat degradation within the basin. Return goals for fall chinook in the Grande Ronde Basin are an annual average return of 10,000 .

\section{Summer Steelhead}

The Grande Ronde basin historically produced large runs of summer steelhead. The size of the historical runs are unknown, but an estimate 15,900 to the mouth of the Grande Ronde was given prior to the construction of the Snake River Dams.

Summer steelhead spawn and rear throughout the basin. Principal spawning areas include: middle and upper mainstem tributaries, Joseph Creek, Wenaha River, Wallowa River, Minam River, Deer Creek, Bear Creek, and Lostine River. The current run is estimated to be 11,000. Return goals for summer steelhead in the Grande Ronde Basin are 27,500.

\section{IMNAHA BASIN}

The following information on the current and historic distribution of salmon in the Imnaha basin has been obtained from CBFWA (1990). The major spawning and rearing areas for spring and fall chinook are shown on Figure 2.

\section{Spring Chinook}


Spring chinook spawn in the mainstem (Freezeout Creek to the Blue Hole), Big Sheep Creek (Coyote Creek to 0.25 miles above Lick Creek), and Lick Creek (from the confluence to the crossing of Forest Service Road 39). Spawning historically occurred in Little Sheep Creek and was documented for the first time in the South Fork Imnaha River in 1988. The historical run size is believed to be in the range of 4,000-7,000 fish. The current run is in the range of 132 to 1,400 fish. Return goals for spring chinook in the Imnaha River Basin are 5,700.

\section{Fall Chinook}

The Imnaha River fall chinook is extinct. The historic distribution of fall chinook in the subbasin is not known, but probably extended upstream as far as the town of Imnaha. Snake River stock is the preferred stock for re-introduction of fall chinook into the Imnaha Basin.

\section{Summer Steelhead}

The Imnaha River was historically an important producer of summer steelhead. Prior to the construction of the four lower Snake River dams in the late 1960s, adult escapement was approximately 4,000. Steelhead spawn throughout the basin. Low flows could be a problem in the the upper Big and Little Sheep Creeks due primarily to irrigation withdrawals for the Wallowa Valley Improvement Canal.

\section{WALLA WALLA BASIN}

The following information on the current and historic distribution of salmon in the Walla Walla Basin has been obtained from CBFWA (1990). The major spawning and rearing areas for spring chinook and steelhead are shown on Figure 3.

\section{Spring Chinook}

Although once abundant in the Walla Walla Basin, this species has been eliminated as a result of passage blocks, dewatering of the Walla Walla and Touchet rivers, and degradation of headwater habitat and mortalities at mainstem Columbia River Dams. An estimated 61 stream miles of spring chinook spawning and rearing habitat exists in the Walla Walla Basin including the upper mainstem Walla Walla River in Washington, and the South Fork in Oregon, and upper mainstem Touchet River, North and South Fork Touchet rivers, and the Wolf, Burnt, and Griffin forks in Washington. Return goals for spring chinook salmon in the Walla Walla River Basin are 5,000 (2,000 natural production + 3000 hatchery production).

\section{Summer Steelhead}

Historically, summer steelhead spawned and reared throughout a large area of the middle and upper reaches of the mainstem Walla Walla and Touchet rivers and their tributaries. Widespread habitat degradation resulting from irrigation, dryland farming, livestock grazing and logging has reduced usable spawning habitat by approximately $50 \%$. The historical run size is believed to be in the range of 4,000-5,000 fish. The current run is in the range of 1,000 to 2,000 fish. Return goals for summer steelhead in the Walla Walla River Basin are 11,000 (3,000 natural production $+8,000$ hatchery production). 


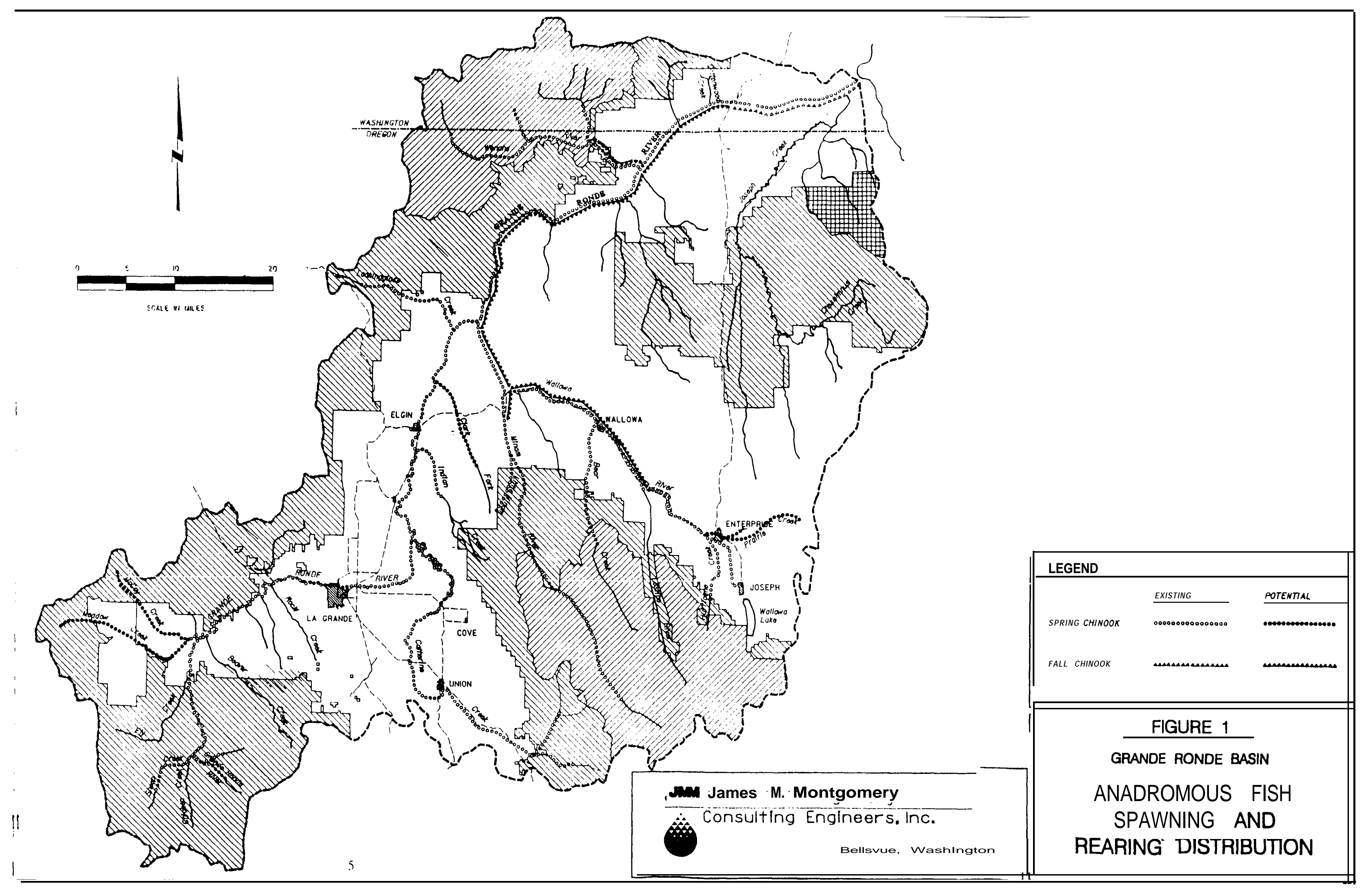




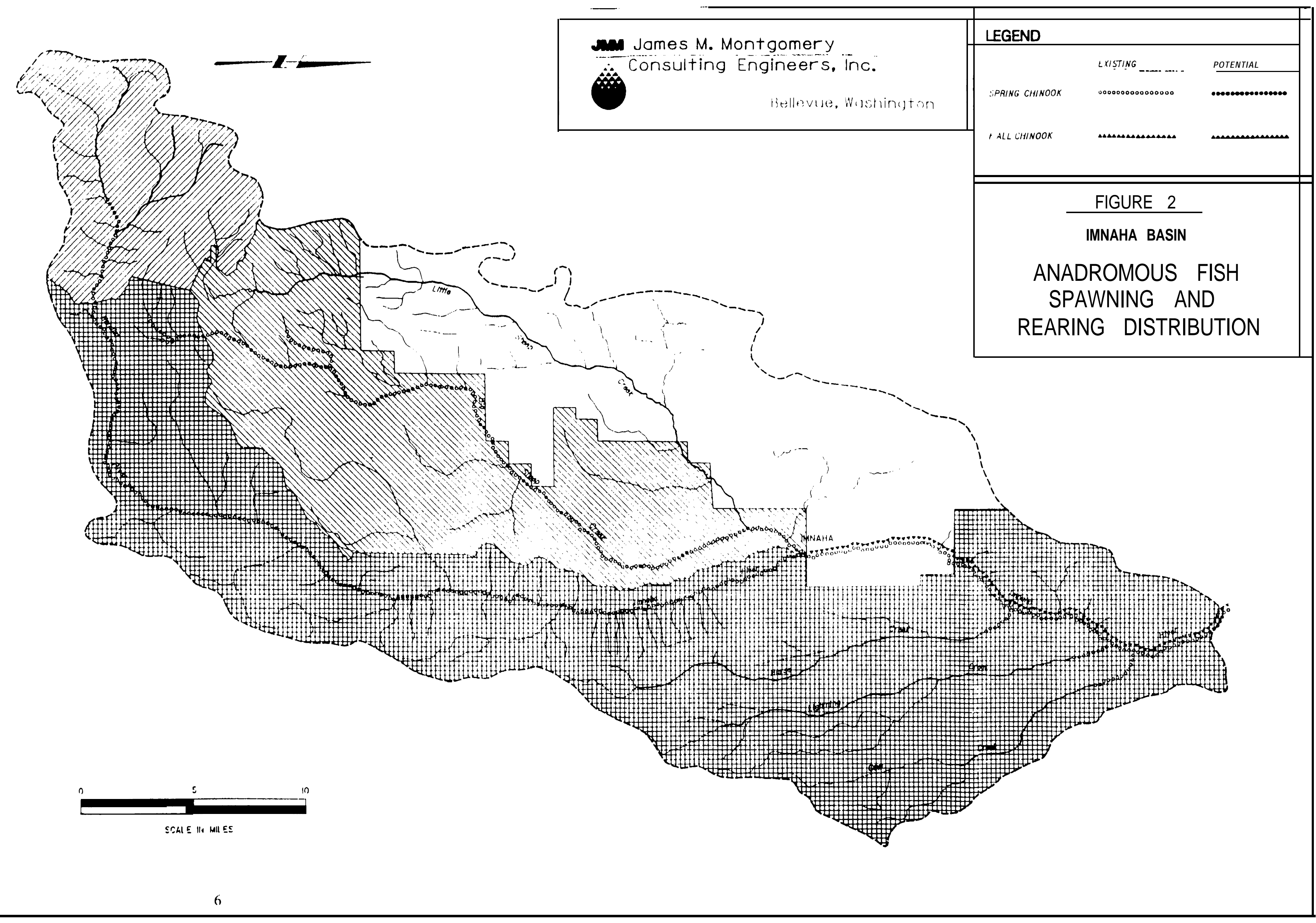




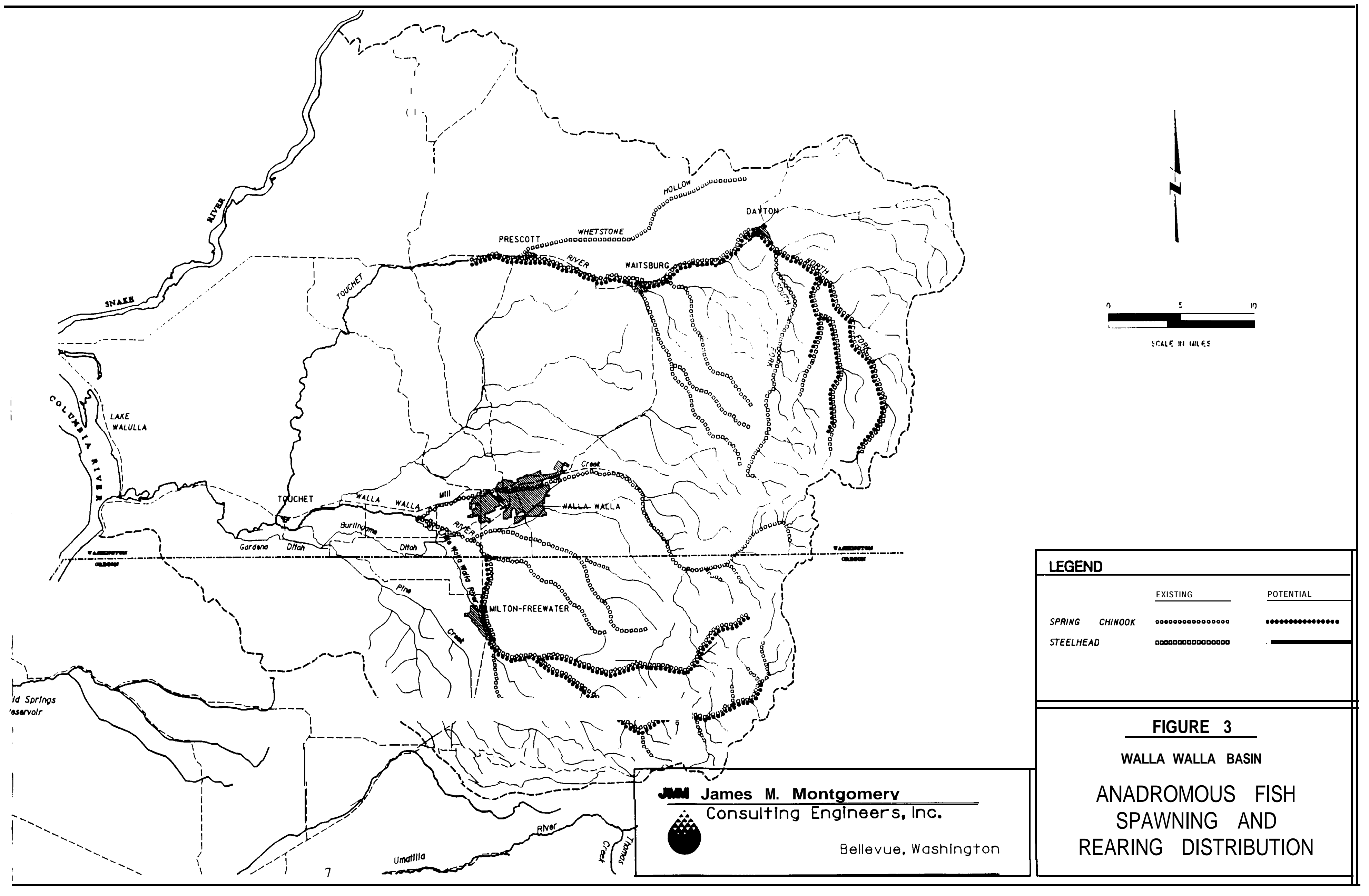




\section{PRODUCTION AND RELEASE OBJECTIVES}

\section{INTRODUCTION}

A broad range of policy issues that are under discussion will affect the eventual design of the fisheries program for the $\mathrm{NEOH}$ project area. These issues include:

1) Direct release vs acclimation

2) Out-basin rearing of fry and fingerlings

3) Impact of other fish released in the basin

4) Impact on other fish in the basin

\section{PRODUCTION AND FACILITY NEEDS}

Production goals for the NEOH Project are summarized below (Table 1).

TABLE 1

\section{SUMMARY OF NEOH PRODUCTION GOALS}

\begin{tabular}{|c|c|c|c|c|}
\hline Species & No. of Broodstock & No. \& Size & Lbs. of Fish & $\begin{array}{c}\text { Group (See Tables } \\
2 \text { to 5) }\end{array}$ \\
\hline \multirow{6}{*}{$\begin{array}{l}\text { Spring } \\
\text { Chinook }\end{array}$} & 559 & $550,000 @ 10 / 1 b$ & 55,000 & $1-2$ \\
\hline & 400 & $\begin{array}{c}544,150 @ 15 / 1 b \\
150,000 @ 150 / \mathrm{b}\end{array}$ & $\begin{array}{c}32,277 \\
1,000 \\
\end{array}$ & $\begin{array}{c}4,6 \\
5 \\
\end{array}$ \\
\hline & 296 & 401,000@15/lb & 26,733 & $7-10$ \\
\hline & 392 & $\begin{array}{r}392,500 @ 15 / \mathrm{lb} \\
230,000 @ 150 / \mathrm{b}\end{array}$ & $\begin{array}{c}26,167 \\
1,533 \\
\end{array}$ & $14-15$ \\
\hline & 548 & 589,000@10/\# & 58,900 & 17 \\
\hline & 2,195 (Total) & & 201,610 (Total) & \\
\hline \multirow[t]{4}{*}{ Fall Chinook } & & & & \\
\hline & 640 & $1,350,000 @ 40 / \mathrm{lb}$ & 31,250 & 11 \\
\hline & 66 & $120,000 @ 70 / 1 \mathrm{~b}$ & 1,714 & 16 \\
\hline & 706 (Total) & & 32,964 (Total) & \\
\hline \multirow[t]{2}{*}{ Steelhead } & 80 & 100,000@10/lb & 10,000 & 3 \\
\hline & 80 (Total) & & 10,000 (Total) & \\
\hline All Species & 2981 & & 244,574 & \\
\hline
\end{tabular}


Long-term production goals and facility needs are presented in detail on Tables 2 through 5 .

\section{CURRENT PRODUCTION WITHIN THE NEOH PROJECT AREA}

The following hatcheries and satellite facilities are within the boundaries of the NEOH Project or are used for fisheries programs within the basin:

Irrigon Hatchery

Lyons Ferry Hatchery

Lookingglass Hatchery

Wallowa Hatchery and Acclimation Ponds

Imnaha River Satellite and Acclimation Ponds

Little Sheep Creek Satellite and Acclimation Ponds

Big Canyon Satellite and Acclimation Ponds

Cottonwood Acclimation Ponds

Dayton Conditioning Ponds

These facilities have been funded totally or in part by the Lower Snake River Compensation Plan (LSRCP). Fish produced or released by the LSRCP were not included in Tables 2 through 5. A review of these facilities and their expansion potential is presented in a later section. 
TABLE 2

LONG TERM PRODUCTION GOALS IN THE GRANDE RONDE BASIN

\begin{tabular}{|c|c|c|c|c|c|c|c|c|c|c|c|}
\hline Specticen & Group & Basis & Number of Adultio & Broodencect Souroe & \begin{tabular}{|l|l|} 
Adul Holding \\
\end{tabular} & Thaubation and & Production & Purpose E & Relesence Dase & Relene Siles & Acclimution Sited \\
\hline $\begin{array}{l}\begin{array}{l}\text { CHS } \\
\text { (Lonive } \\
\text { Stock) }\end{array} \\
\end{array}$ & Grow 4 & NBaH & 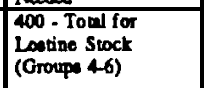 & Lostine Stock & $\begin{array}{l}\text { Thupping and } \\
\text { holding facility } \\
\text { noceded }\end{array}$ & \begin{tabular}{|l} 
Faciliy noeded \\
\end{tabular} & $516,000 @ 15 / \mathrm{b}$ & fint & Mar-May & & 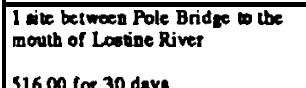 \\
\hline COHS & Group 5 & NBOA & Included with Group 4 & Dosotine Slock & 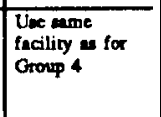 & Psciliy needed & $\begin{array}{l}150,000 @ 1500 \\
b \\
(45,000 \text { amolt } \\
\text { cquivelents) }\end{array}$ & Tikb & Juil & 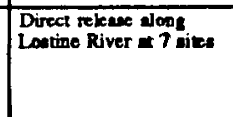 & \\
\hline CHS & Group 6 & NBOH & Induded with Group 4 & Loesine Stock & 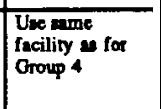 & Frecility needed & 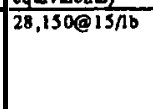 & risth & Mar-May & & 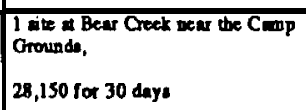 \\
\hline 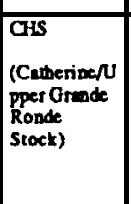 & Grow 7 & NBOA & 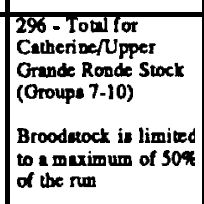 & $\begin{array}{l}\text { Calkerine/ / pper Grande } \\
\text { Roode) }\end{array}$ & 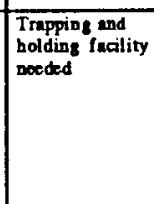 & \begin{tabular}{|l} 
Fucility needed \\
\end{tabular} & $\mid \begin{array}{l}161,000 @ 15- \\
20 / 16\end{array}$ & fianh & Mar-May & & $\begin{array}{l}1 \text { aive on Mein atem of Cabbrine } \\
\text { Crek. } \\
161.000 \text { for } 30 \text { deyt }\end{array}$ \\
\hline Cis & Group 8 & NBOA & Included with Group & 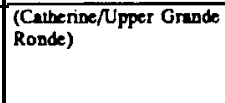 & 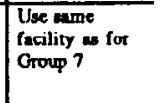 & Fwility needed & $\mid \begin{array}{l}112,000 @ 15- \\
20 / 1 \mathrm{~b}\end{array}$ & fisb & Mar-May & & 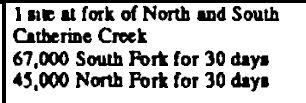 \\
\hline$\overline{\mathrm{CHS}}$ & Oroup 9 & $\overline{\mathrm{NaOH}}$ & Included with Group & 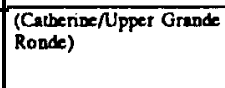 & 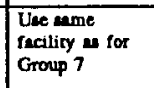 & Facilty neceded & $\begin{array}{l}100,000 @ 15 . \\
20 / 1 \mathrm{~b}\end{array}$ & fish & Mas. May & & 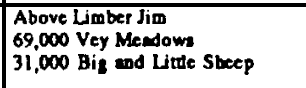 \\
\hline GHS & Group 10 & $\mathrm{NBOH}$ & Included with Grou & $\begin{array}{l}\text { (Cablendec/Upper Grande } \\
\text { Ronde) }\end{array}$ & 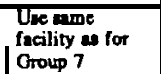 & Facility needed & $\begin{array}{l}28,000 @ 15- \\
20 / 1 \mathrm{~b}\end{array}$ & fisb & Mer-May & & $\begin{array}{l}\text { Indian Crock } \\
28,000 \text { for } 30 \text { days }\end{array}$ \\
\hline GAP & Oroup 11 & NBOH & 640 & 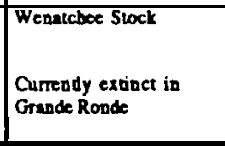 & $\begin{array}{l}\text { Noed trapping } \\
\text { and adul } \\
\text { hold ding facility } \\
\text { an soon an finh } \\
\text { surt to renum to } \\
\text { besis } \\
\end{array}$ & Facility needed & $\begin{array}{l}1,350,000 @ 90 \\
40-50 \mathrm{nb}\end{array}$ & fizb & Jun & 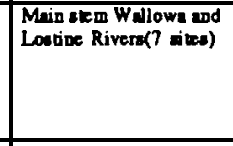 & \\
\hline \begin{tabular}{|l|} 
Coho \\
Sockeyc_I
\end{tabular} & $\begin{array}{l}\text { Group } 12 \\
\text { Croup } 13 \\
\end{array}$ & & $\begin{array}{l}\text { extinct in basin } \\
\text { exnncl in basio }\end{array}$ & & & & & & & & \\
\hline
\end{tabular}


TABLE 3

LONG TERM PRODUCTION GOALS IN THE IMNAHA BASIN

\begin{tabular}{|c|c|c|c|c|c|c|c|c|c|c|c|}
\hline Species & Groxp & Bacio & \begin{tabular}{|l|} 
Number of Aditit \\
Norded
\end{tabular} & Broodelock Sourve & Adul Holding & $\begin{array}{l}\text { Woubation and } \\
\text { Rearing }\end{array}$ & \begin{tabular}{|l|}
$\begin{array}{l}\text { Production } \\
\text { Goall }\end{array}$ \\
\end{tabular} & $\begin{array}{l}\text { Purposed at } \\
\text { Obiectives }\end{array}$ & Releare Dat & Relemes sives & Acdimation Sites \\
\hline $\begin{array}{l}\text { Cits } \\
\text { Pull-kerm } \\
\text { Smolt }\end{array}$ & Group 14 & NeaA & 260 & $\begin{array}{l}\text { lomnaha Wild Netural } \\
\text { Stock }\end{array}$ & $\begin{array}{l}\text { Fecility soeded } \\
\text { for adult } \\
\text { urapping and } \\
\text { bolding }\end{array}$ & Pacility needed & $\begin{array}{l}392,500 \Theta \\
25 / 16\end{array}$ & fish & Mar 15-May 1 & & 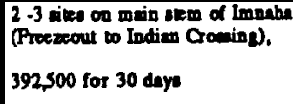 \\
\hline$\frac{\text { pimed releare }}{\text { CHP }}$ & Oroup 16 & NBOH & 66 & 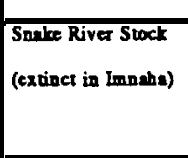 & 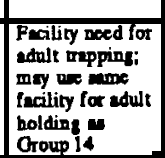 & Fecility noeded & $\begin{array}{l}120,000 @ 9 \\
70 / 16\end{array}$ & fiabs & May 1 & $\begin{array}{l}\text { Direct release on Lower } \\
\text { Immatu at Mar Site }\end{array}$ & \\
\hline
\end{tabular}


TABLE 4

LONG TERM PRODUCTION GOALS IN THE WALLA WALLA BASIN

\begin{tabular}{|c|c|c|c|c|c|c|c|c|c|c|c|}
\hline Species & Orous & Buis & $\begin{array}{l}\text { Nomber of Adulti } \\
\text { Nuocted }\end{array}$ & Brodetiock Sources & Adult Holding & $\begin{array}{l}\text { lnabation and } \\
\text { Resting }\end{array}$ & $\begin{array}{l}\text { Protuction } \\
\text { Dooll }\end{array}$ & $\begin{array}{l}\text { Puppose } \\
\text { Objectives }\end{array}$ & Retom Das & Relemes Sirse & Acclimation Siles \\
\hline OHS & Group 1 & NiBCH & 359 & 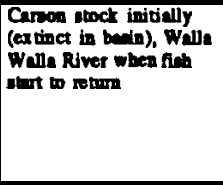 & $\begin{array}{l}\text { Atult collection } \\
\text { mod bolding will } \\
\text { be requined when } \\
\text { atoch retum to } \\
\text { river. }\end{array}$ & Fecility nooded & 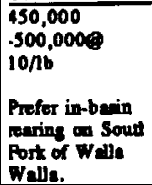 & fioh & Mrr-Apt & $\begin{array}{l}\text { May boed additiond } \\
\text { relameo ciles }\end{array}$ & I dike of Soutt Pork Walle Walle \\
\hline CHS & Croup 2 & NBCH & Induded with Group 1 & 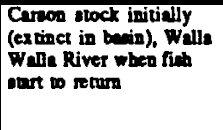 & $\begin{array}{l}\text { Adult collection } \\
\text { and bolding will } \\
\text { be required when } \\
\text { stoch retumn to } \\
\text { river. }\end{array}$ & Pecility necoded & \begin{tabular}{|l|}
100,000 \\
$150,000-$ \\
$101 \mathrm{ib}$
\end{tabular} & fish & Mar-Apr & $\begin{array}{l}\text { Mey soed addidiosel } \\
\text { rekenoe dives }\end{array}$ & 1.2 wites high on the Toucbet \\
\hline STS & Orous 3 & $\mathrm{NaCH}$ & 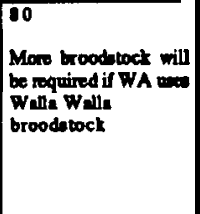 & $\begin{array}{l}\text { Walle Walla River } \\
\text { (600-800 cuncontly) }\end{array}$ & 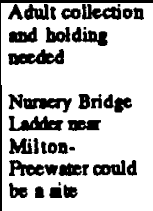 & $\begin{array}{l}\text { May be able o } \\
\text { une Irisioe of } \\
\text { Umatila for } \\
\text { locibation and } \\
\text { rearing. }\end{array}$ & 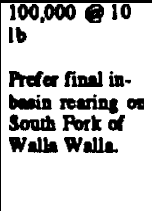 & fing & Mrr-AF & $\begin{array}{l}\text { May noed additional } \\
\text { rekeos itea }\end{array}$ & 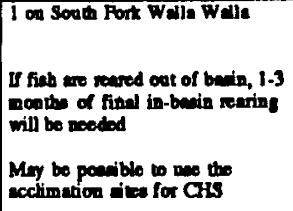 \\
\hline
\end{tabular}

TABLE 5

LONG TERM PRODUCTION GOALS IN THE UMATILLA BASIN

(NEOH COMPONENT)

\begin{tabular}{|c|c|c|c|c|c|c|c|c|c|c|c|}
\hline Species & Oroup & Bacis & Number of Adults & Broodatock Sourte & Adult Holding & $\begin{array}{l}\text { Incubation sod } \\
\text { Rearin\& }\end{array}$ & $\begin{array}{l}\text { Production } \\
\text { Oonls }\end{array}$ & $\begin{array}{l}\text { Purpowe a } \\
\text { Objectives }\end{array}$ & Relenel Dave & Relesce Sited & Acclimation Sitean \\
\hline CHS & Group 17 & $\mathrm{NBOH}$ & 548 & Umatilla River & $\begin{array}{l}\text { Pacility reeded } \\
\text { for adult bolding }\end{array}$ & Fraility noeded & $\begin{array}{l}359,000 \text { Q } \\
10 / \mathrm{ib}\end{array}$ & fient & $\begin{array}{l}\text { Spring (Mar- } \\
\text { Apr) }\end{array}$ & Upper Umatilh meinster & $\begin{array}{l}4 \text { nocoded } \\
400,000 \text { for } 30 \text { dane }\end{array}$ \\
\hline
\end{tabular}




\section{FISH PROPAGATION CRITERIA}

\section{INTRODUCTION}

The biocriteria proposed for salmon culture for the NEOH Project are based on similar projects in the Pacific Northwest and discussion with agency and tribal personnel. These criteria will be used for planning level process design and facility layout.

\section{WATER CHEMISTRY}

Fundamental to facility planning is an understanding of various aspects of water chemistry, in both a general and site-specific sense.

\section{Oxygen}

The oxygen content of water used in fish rearing is important because the fish will consume varying amounts of oxygen as they develop and also, a certain minimum concentration of dissolved oxygen is required in order to provide an acceptable environment. For these reasons it is desirable to know the approximate dissolved oxygen concentration of the water supply and how it may vary with the degree of gas saturation, temperature, salinity, and site elevation.

The maximum amount of oxygen that can be dissolved in water is referred to as the saturation concentration. The saturation concentration depends on temperature, elevation (or barometric pressure), and salinity. Increasing temperature decreases the saturation concentration of oxygen (Table 6). Salinity (total dissolved solids) will have an insignificant effect on oxygen solubility at the NEOH sites.

\section{Ammonia}

Ammonia is produced by fish as a metabolic byproduct. In addition, water supplies often contain ammonia from pollution or natural sources. Fish have a limited tolerance to ammonia under certain conditions. Ammonia is a weak base, and occurs as ionized $\left(\mathrm{NH}_{4}{ }^{+}\right)$and un-ionized forms (NH3). Unionized ammonia moves easily across biological membranes and is generally considered the most toxic of the two forms. The concentration of un-ionized ammonia in freshwater is primarily a function of $\mathrm{pH}$ and temperature (Table 7).

\section{Carbon Dioxide}

Fish have limited tolerance to carbon dioxide. Carbon dioxide is produced by fish as a respiratory byproduct, and water supplies often contain high concentrations of carbon dioxide. Under typical conditions, $1.375 \mathrm{mg}$ of carbon dioxide is produced per $1 \mathrm{mg}$ of oxygen consumed. The excretion of carbon dioxide by fish in intensive culture situations (a) increases the dissolved carbon dioxide concentration, (b) reduces the $\mathrm{pH}$, and (c) reduces the concentration of un-ionized ammonia due to the decrease in $\mathrm{PH}$. The reduction of $\mathrm{pH}$ depends on the initial carbon dioxide concentration, alkalinity of the water, and amount of carbon dioxide produced. 
TABLE 6

DISSOLVED OXYGEN AS A FUNCTION OF TEMPERATURE $(2,000$ FEET ELEVATION)

\begin{tabular}{|c|c|c|c|c|c|c|c|c|c|c|}
\hline & \multicolumn{10}{|c|}{ DT (F) } \\
\hline $\begin{array}{l}\text { Temp } \\
\text { (F) }\end{array}$ & 0.0 & 0.1 & 0.2 & 0.3 & 0.4 & 0.5 & 0.6 & 0.7 & 0.8 & 0.9 \\
\hline 32 & 13.61 & 13.59 & 13.57 & 13.55 & $\overline{13.53}$ & 13.51 & 13.49 & 13.46 & 13.44 & $\overline{13.42}$ \\
\hline 33 & 13.40 & 13.38 & 13.36 & 13.34 & 13.32 & 13.30 & 13.28 & 13.26 & 13.24 & 13.22 \\
\hline 34 & 13.20 & 13.17 & 13.15 & 13.13 & 13.11 & 13.09 & 13.07 & 13.05 & 13.03 & 13.01 \\
\hline$\overline{35}$ & 12.99 & 12.97 & 12.95 & 12.93 & 12.91 & AL.90 & 12.88 & 12.86 & 12.84 & 12.82 \\
\hline 36 & 12.80 & 12.78 & 12.76 & 12.74 & 12.72 & 12.70 & 12.68 & 12.66 & 12.64 & 12.63 \\
\hline 37 & 12.61 . & 12.59 & 12.57 & 12.55 & 12.53 & 12.51 & 12.49 & 12.48 & 12.46 & 12.44 \\
\hline 38 & $\overline{12.42}$ & 12.40 & 12.38 & 12.37 & 12.35 & 12.33 & 12.31 & 12.29 & 12.27 & 12.26 \\
\hline 39 & 12.24 & 12.22 & 12.20 & 12.18 & 12.17 & 12.15 & 12.13 & 12.11 & 12.10 & 12.08 \\
\hline 40 & 12.06 & 12.04 & 12.031 & 12.011 & 11.991 & 11.971 & 11.96 & 11.94 & 11.92 & 11.91 \\
\hline 41 & 11.89 & 11.87 & 11.85 & 11.84 & 11.82 & 11.80 & $11 . \overline{9}$ & 11.77 & 11.75 & 11.74 \\
\hline 42 & 11.72 & 11.70 & 11.69 & 11.67 & 11.65 & 11.64 & 11.62 & 11.60 & 11.59 & 11.57 \\
\hline 43 & 11.55 & 11.54 & 11.52 & 11.51 & 11.49 & 11.47 & 11.46 & 11.44 & 11.43 & 11.41 \\
\hline 44 & 11.391 & 11.38 & 11.36 & 11.35 & 11.33 & 11.31 & 11.30 & 11.28 & 11.27 & 11.25 \\
\hline$\overline{45}$ & 11.24 & 11.22 & 11.21 & 11.19 & 11.17 & 11.16 & 11.14 & 11.13 & 11.11 & 11.10 \\
\hline 46 & $11.08 i$ & 11.07 & 11.05 & 11.04 & 11.02 & 11.01 & 10.99 & 10.98 & 10.96 & 10.95 \\
\hline 47 & $10.93 i$ & 10.92 & 10.90 & 10.89 & 10.87 & 10.86 & 10.85 & 10.83 & 10.82 & 10.80 \\
\hline$\overline{48}$ & 10.79 & 10.77 & 10.76 & 10.74 & 10.73 & 10.72 & 10.70 & 10.69 & 10.67 & 10.66 \\
\hline 49 & 10.64 & 10.63 & 10.62 & 10.60 & 10.59 & 10.57 & 10.56 & 10.55 & 10.53 & 10.52 \\
\hline 50 & 10.501 & 10.49 & 10.48 & 10.46 & 10.45 & 10.44 & 10.42 & 10.41 & 10.40 & 10.38 \\
\hline 51 & $i_{1} n .2,7^{\prime \prime}$ & 10.35 & 10.34 & $i_{4} n, 2,3$ & 10.31 & 10.30 & 10.29 & 10.27 & 10.26 & 10.25 \\
\hline 52 & 10.24 & 10.22 & 10.21 & 10.20 & 10.18 & 10.17 & 10.16 & 10.14 & 10.13 & 10.12 \\
\hline 53 & 10.10 & 10.09 & 10.08 & 10.07 & 10.05 & 10.04 & 10.03 & 10.02 & 10.00 & 9.99 \\
\hline 54 & 9.98 & 9.96 & 9.95 & 9.94 & 9.93 & $9 . \overline{91}$ & 9.90 & 9.89 & 9.88 & 9.87 \\
\hline 55 & 9.85 & 9.84 & $\overline{9.83}$ & $\overline{9.82}$ & 9.80 & 9.79 & 9.78 & 9.77 & 9.76 & 9.74 \\
\hline 56 & 9.73 & 9.72 & 9.71 & 9.69 & 9.68 & 9.67 & 9.66 & 9.65 & 9.64 & $\overline{9.62}$ \\
\hline 57 & 9.61 & 9.60 & 9.59 & 9.58 & 9.56 & 9.55 & $\overline{9.54}$ & 9.53 & 9.52 & 9.51 \\
\hline 58 & 9.50 & 9.48 & 9.47 & 9.46 & 9.45 & $\overline{9.44}$ & 9.43 & 9.41 & 9.40 & 9.39 \\
\hline 59 & 9.38 & 9.37 & 9.36 & 9.35 & $\overline{9.34}$ & $9 . \overline{32}$ & 9.31 & 9.30 & 9.29 & 9.28 \\
\hline 60 & 9.27 & 9.26 & 9.25 & 9.24 & 9.23 & 9.21 & 9.20 & 9.19 & $\overline{9.18}$ & 9.17 \\
\hline$\overline{61}$ & 9.16 & 9.15 & $\overline{9.14}$ & 9.13 & 9.12 & 9.11 & 9.10 & 9.08 & 9.07 & $\overline{9.06}$ \\
\hline 62 & 9.05 & 9.04 & 9.03 & 9.02 & 9.01 & 9.00 & 8.99 & 8.98 & 8.97 & 8.96 \\
\hline$\overline{63}$ & 8.95 & 8.94 & 8.93 & 8.92 & 8.91 & 8.90 & 8.89 & 8.88 & 8.87 & 8.86 \\
\hline$\overline{64}$ & 8.85 & 8.83 & 8.82 & 8.81 & $\overline{8.80}$ & $\overline{8.79}$ & 8.78 & 8.77 & 8.76 & 8.75 \\
\hline 65 & 8.74 & 8.73 & 8.72 & 8.71 & 8.70 & 8.69 & 8.69 & 8.68 & 8.67 & \\
\hline 66 & 8.65 & 8.64 & 8.63 & 8.62 & 8.61 & 8.60 & 8.59 & 8.58 & 8.57 & 8.2 \\
\hline 67 & 8.55 & 8.541 & 8.531 & 8.52 & 8.51 & 8.50 & 8.49 & 8.48 & & 8.46 \\
\hline 68 & & 8451 & 844. & $\overline{8.8 .45}$ & 8.42 & 8.41 & 8.40 & 8399 & $8 . \overline{38}$ & 8.37 \\
\hline 70 & 82236 & 8.35 & 8.34 & 8.34 & 8.33 & 8.32 & 8.83211 & 8.210 & 8.291 & 8.28 \\
\hline & & & & & & & & & & \\
\hline
\end{tabular}




\section{TABLE 7}

UN-IONIZED AMMONIA AS A PERCENTAGE OF TOTAL AMMONIA IN FRESHWATER AT VARIOUS TEMPERATURES AND $\mathrm{PH}$

\begin{tabular}{|c|c|c|c|c|c|c|c|c|c|c|c|c|c|c|}
\hline $\begin{array}{c}\text { Temp. } \\
\mathrm{C}\end{array}$ & $\begin{array}{l}\text { Tems } \\
\mathrm{F}\end{array}$ & $\begin{array}{l}\text { pH@ } \\
6.9\end{array}$ & $\begin{array}{l}\mathrm{pH} @ \\
7.0\end{array}$ & $\begin{array}{l}\text { pH@ } \\
7.1\end{array}$ & $\begin{array}{l}\text { pH@ } \\
7.2 \\
\end{array}$ & $\begin{array}{l}\text { pH@ } \\
7.3 \\
\end{array}$ & $\begin{array}{c}\text { pH@ } \\
7.4 \\
\end{array}$ & $\begin{array}{c}\text { pH@ } \\
7.5 \\
\end{array}$ & $\begin{array}{l}\text { pH@ } \\
7.6 \\
\end{array}$ & $\begin{array}{c}\text { pH@ } \\
7.7 \\
\end{array}$ & $\begin{array}{c}\text { pH@@ } \\
7.8 \\
\end{array}$ & $\begin{array}{r}\text { pH@ } \\
7.9 \\
\end{array}$ & $\begin{array}{c}\text { pH@ } \\
8.0 \\
\end{array}$ & $\begin{array}{c}\text { pH@ } \\
8.1 \\
\end{array}$ \\
\hline $\begin{array}{l}4.44 \\
5.00\end{array}$ & $\begin{array}{l}40.0 \\
41.0\end{array}$ & $\begin{array}{l}0.09 \% \\
0.10 \%\end{array}$ & $\begin{array}{l}0.12 \% \\
0.12 \%\end{array}$ & $\begin{array}{l}0.15 \% \\
0.16 \%\end{array}$ & $\begin{array}{l}0.19 \% \\
0.20 \%\end{array}$ & $\begin{array}{l}0.24 \% \\
0.25 \%\end{array}$ & $\begin{array}{l}0.30 \% \\
0.31 \%\end{array}$ & $\begin{array}{l}0.37 \% \\
0.39 \%\end{array}$ & $\begin{array}{l}0.47 \% \\
0.49 \%\end{array}$ & $\begin{array}{l}0.59 \% \\
0.62 \%\end{array}$ & & & & \\
\hline 5.56 & 42.0 & $0.10 \%$ & $0.13 \%$ & $0.16 \%$ & $0.21 \%$ & $0.26 \%$ & $0.33 \%$ & $0.41 \%$ & $0.52 \%$ & $0.65 \%$ & $0.82 \%$ & $1.02 \%$ & $1.29 \%$ & $1.61 \%$ \\
\hline 6.11 & 43.0 & $0.11 \%$ & $0.14 \%$ & $0.17 \%$ & 0 . & $7 \%$ & $4 \%$ & $3 \%$ & $0.54 \%$ & $0.68 \%$ & $0.85 \%$ & $.07 \%$ & $34 \%$ & $1.69 \%$ \\
\hline $\begin{array}{l}6.67 \\
7.22\end{array}$ & $\begin{array}{l}44.0 \\
45.0\end{array}$ & $\begin{array}{l}0.11 \% \\
0.12 \%\end{array}$ & $\begin{array}{l}0.14 \% \\
0.15 \%\end{array}$ & $\begin{array}{l}0.18 \% \\
0.19 \%\end{array}$ & $\begin{array}{l}0.23 \% \\
0.24 \%\end{array}$ & $\begin{array}{l}0.28 \% \\
0.30 \%\end{array}$ & $\begin{array}{l}0.36 \% \\
0.37 \%\end{array}$ & & $\begin{array}{l}0.56 \% \\
0.59 \%\end{array}$ & $\begin{array}{l}0.71 \% \\
0.74 \%\end{array}$ & & & $\begin{array}{l}1.40 \% \\
1.47 \%\end{array}$ & \\
\hline 7.78 & 46.0 & $0.12 \%$ & $0.16 \%$ & $0.20 \%$ & $0.25 \%$ & $0.31 \%$ & $0.39 \%$ & $0.49 \%$ & $0.62 \%$ & $0.77 \%$ & $0.97 \%$ & $1.22 \%$ & $1.53 \%$ & $1.92 \%$ \\
\hline 8 & 47.0 & $0.13 \%$ & $0.16 \%$ & $0.20 \%$ & $0.26 \%$ & $0.32 \%$ & $0.41 \%$ & $0.51 \%$ & $0.64 \%$ & $0.81 \%$ & $1.02 \%$ & $1.28 \%$ & $1.60 \%$ & $2.01 \%$ \\
\hline $\begin{array}{l}8.89 \\
9.44\end{array}$ & $\begin{array}{l}48.0 \\
49.0\end{array}$ & $\begin{array}{l}0.13 \% \\
0.14 \%\end{array}$ & $\begin{array}{l}0.17 \% \\
0.18 \%\end{array}$ & $\begin{array}{l}0.21 \% \\
0.22 \%\end{array}$ & $\begin{array}{l}0.27 \% \\
0.28 \%\end{array}$ & $\begin{array}{l}0.34 \% \\
0.35 \%\end{array}$ & & & & & & & & \\
\hline 10.00 & 50.0 & $0.15 \%$ & $0.19 \%$ & $0.23 \%$ & $0.29 \%$ & $0.37 \%$ & $0.46 \%$ & $0.58 \%$ & $0.73 \%$ & $0.92 \%$ & $1.16 \%$ & $1.45 \%$ & $1.82 \%$ & $2.28 \%$ \\
\hline $\begin{array}{l}10.56 \\
11.1 \\
11.67\end{array}$ & $\begin{array}{c}51.0 \\
152.0 \\
53.0\end{array}$ & $\begin{array}{c}0.15 \% \\
0.16 \% \\
0.17 \%\end{array}$ & $\begin{array}{r}0.19 \% \\
0.20 \% \\
0.21 \%\end{array}$ & $\begin{array}{c}0.24 \% \\
0.25 \% \\
0.27 \%\end{array}$ & $\begin{array}{c}0.31 \% \\
0.32 \% \\
0.33 \%\end{array}$ & $\begin{array}{c}0.39 \% \\
0.40 \% \\
0.42 \%\end{array}$ & $\begin{array}{l}0.48 \% \\
0.51 \% \\
0.53 \%\end{array}$ & & $\begin{array}{l}0.77 \% \\
0.80 \% \\
0.83 \%\end{array}$ & $\begin{array}{l}0.96 \% \\
1.00 \% \\
1.05 \%\end{array}$ & $\begin{array}{l}1.21 \% \\
1.26 \% \\
1.32 \%\end{array}$ & $\begin{array}{l}1.52 \% \\
1.58 \% \\
1.65 \%\end{array}$ & $\begin{array}{l}1.90 \% \\
1.98 \% \\
2.07 \%\end{array}$ & $\begin{array}{l}2.38 \% \\
2.49 \% \\
2.59 \%\end{array}$ \\
\hline 12.22 & 54.0 & $0.17 \%$ & $0.22 \%$ & $0.28 \%$ & $0.35 \%$ & $0.44 \%$ & $0.55 \%$ & $0.69 \%$ & $0.87 \%$ & $1.09 \%$ & $1.37 \%$ & $1.72 \%$ & $2.16 \%$ & $2.70 \%$ \\
\hline $\begin{array}{l}12.78 \\
13.33\end{array}$ & $\begin{array}{l}55.0 \\
56.0\end{array}$ & $\begin{array}{l}0.18 \% \\
0.19 \%\end{array}$ & $\begin{array}{l}0.23 \% \\
0.24 \%\end{array}$ & $\begin{array}{l}0.29 \% \\
0.30 \%\end{array}$ & $\begin{array}{l}0.36 \% \\
0.38 \%\end{array}$ & $\begin{array}{l}0.46 \% \\
0.48 \%\end{array}$ & $\begin{array}{l}0.58 \% \\
0.60 \%\end{array}$ & $\begin{array}{l}0.72 \% \\
0.75 \%\end{array}$ & $\begin{array}{l}0.91 \% \\
0.95 \%\end{array}$ & $\begin{array}{l}1.14 \% \\
1.19 \%\end{array}$ & $\begin{array}{l}1.43 \% \\
1.49 \%\end{array}$ & $\begin{array}{l}1.80 \% \\
1.87 \%\end{array}$ & $\begin{array}{l}2.25 \% \\
2.35 \%\end{array}$ & $\begin{array}{l}2.82 \% \\
2.94 \%\end{array}$ \\
\hline 13.89 & 57.0 & $0.20 \%$ & $0.25 \%$ & $0.31 \%$ & $0.40 \%$ & $0.50 \%$ & $0.63 \%$ & $0.79 \%$ & $0.99 \%$ & $1.24 \%$ & $1.56 \%$ & $1.95 \%$ & $2.45 \%$ & $3.06 \%$ \\
\hline 4.445 & 58.00 & $.21 \% \quad 0$ & $.26 \% \quad 0$ & $0.33 \% \quad 0$ & $0.41 \% \quad 0$ & $0.52 \% \quad 0$ & $0.65 \% \quad 0$ & $0.82 \%$ & $1.03 \%$ & $1.29 \%$ & $1.62 \%$ & $2.04 \%$ & $2.55 \%$ & $3.19 \%$ \\
\hline $\begin{array}{l}15.44 \\
16.44\end{array}$ & $\begin{array}{l}59.0 \\
60.0\end{array}$ & $\begin{array}{l}0.22 \% \\
0.24 \%\end{array}$ & $\begin{array}{l}0.28 \% \\
0.30 \%\end{array}$ & $\begin{array}{l}0.35 \% \\
0.38 \%\end{array}$ & $\begin{array}{l}0.45 \% \\
0.48 \%\end{array}$ & $\begin{array}{l}0.56 \% \\
0.60 \%\end{array}$ & $\begin{array}{l}0.70 \% \\
0.76 \%\end{array}$ & & $\begin{array}{l}1.11 \% \\
1.20 \%\end{array}$ & & $\begin{array}{l}1.75 \% \\
1.88 \%\end{array}$ & $\begin{array}{l}2.19 \% \\
2.36 \%\end{array}$ & $\begin{array}{l}2.74 \% \\
2.95 \%\end{array}$ & $\begin{array}{l}3.43 \% \\
3.69 \%\end{array}$ \\
\hline 17.44 & 61.0 & $0.26 \%$ & $0.33 \%$ & $0.41 \%$ & $0.52 \%$ & $0.65 \%$ & $0.82 \%$ & $1.03 \%$ & $1.29 \%$ & $1.62 \%$ & $2.03 \%$ & $2.54 \%$ & $3.17 \%$ & $3.96 \%$ \\
\hline 18.44 & 62.0 & $0.28 \%$ & $0.35 \%$ & $0.44 \%$ & $0.56 \%$ & $0.70 \%$ & $0.88 \%$ & $1.10 \%$ & $1.39 \%$ & $1.74 \%$ & $2.18 \%$ & $2.73 \%$ & $3.41 \%$ & $4.25 \%$ \\
\hline
\end{tabular}


$\mathrm{PH}$

$\mathrm{pH}$ has a major role in determining the toxicity of ammonia, heavy metals, and hydrogen sulfide. The $\mathrm{pH}$ of the process water can be changed due to the metabolic activity of the fish and biological filters.

\section{WATER QUALITY CRITERIA FOR SALMONID REARING}

Water quality criteria that provide general guidance in salmonid aquaculture planning are shown on Table 8.

\section{Minimum Oxygen Levels}

The minimum criterion for acceptable dissolved oxygen levels for salmonid culture (as the water leaves the raceways) is:

$$
\text { Fry \& Fingerlings } \quad 7.0 \mathrm{mg} / \mathrm{l}
$$

As the incubation temperature increases, dissolved oxygen problems may occur just prior to hatching when dissolved oxygen demand is highest. The critical dissolved oxygen level may be above the local saturation concentration at those times.

\section{Ammonia Criteria}

Ammonia is a weak base and exists in ionized $\left(\mathrm{NH}_{4}^{+}\right)$and un-ionized (NH3) form. Unionized ammonia is more toxic to fish because it can move across biological membranes much faster than the ionized form. Chemical tests measure the amount of total ammonia $\left(\mathrm{NH}_{4}{ }^{+}+\mathrm{NH} 3\right)$ which is generally expressed as nitrogen (molecular weight $=14.00$ $\mathrm{g} / \mathrm{mol}$ ). The concentration of un-ionized ammonia depends on total ammonia, $\mathrm{pH}$, and temperature. High $\mathrm{pH}$ and temperature favor the un-ionized form. Various criteria for the maximum allowable un-ionized ammonia concentration for salmonids range from 0.006 to $0.015 \mathrm{mg} / \mathrm{L}$ as NH3-N (Table 8). A recent review of ammonia toxicity (Meade, 1985) concluded that un-ionized ammonia is probably not the cause of gill hyperplasia, as previously assumed. He also stated that "A truly safe, maximum acceptable concentration of un-ionized, or total,ammonia for fish culture systems is not known". For this project, un-ionized ammonia criteria will be set at a concentration not to exceed $0.015 \mathrm{mg} / \mathrm{l}$.

\section{Carbon Dioxide}

To determine carbon dioxide water quality criteria, it is also necessary to define critical levels. Recently, Piper et al. (1982) proposed an upper limit concentration of $10 \mathrm{mg} / \mathrm{l}$, although others have suggested up to $20 \mathrm{mg} / \mathrm{l}$ (SECL, 1983). For NEOH planning $10 \mathrm{mg} / \mathrm{l}$ will be used as the carbon dioxide criterion. The carbon dioxide criteria may also depend on the relationship between carbon dioxide, alkalinity, and $\mathrm{pH}$.

\section{$\mathrm{PH}$}

Criteria for $\mathrm{pH}$ depend on species, life stage, and ionic composition of the water. For incubation and early fry rearing, SECL (1983) recommended that the $\mathrm{pH}$ be maintained between 6.5 - 8.5. This range will be used for NEOH planning. 
TABLE 8

WATER QUALITY CRITERIA FOR SALMONIDS

\begin{tabular}{|c|c|c|c|c|}
\hline Parameter & $A D F \& G^{l}$ & SEP $^{2}$ & WDF $^{3}$ & USFWS $^{4}$ \\
\hline Alkalinity & undetermined & $>15$ & & $10-400$ \\
\hline Aluminium & $<0.01$ & $<0.10$ & $<0.01$ & \\
\hline Ammonia (total as N) & & $<0.05$ & & \\
\hline Ammonia (un-ionized as N) & $<0.010$ & & 0.010 & $<0.010$ \\
\hline Arsenic & $<0.05$ & & $<0.05$ & $<0.05$ \\
\hline Barium & $<5.0$ & & $<5$ & $<5$ \\
\hline$<100 \mathrm{mg} / \mathrm{L}$ Alkalinity & $<0.0005$ & $<0.0003$ & $<0.0002$ & $<0.0004$ \\
\hline$>100 \mathrm{mg} / \mathrm{L}$ Alkalinity & $<0.005$ & & & $<0.003$ \\
\hline Carbon Dioxide & $<1.0$ & $<10$ & $<1$ & $0-10$ \\
\hline Chloride & $<4.0$ & & & $<4$ \\
\hline Chlorine & $<003$ & & & $<0.03$ \\
\hline Chromium & $<0.03$ & $<0.04$ & $<0.01$ & $<0.03$ \\
\hline$<100 \mathrm{mg} / \mathrm{L}$ Alkalinity & $<0.006$ & $<0.0002$ & $<0.05$ & $<0.006$ \\
\hline$>100 \mathrm{mg} / \mathrm{L}$ Alkalinity & $<0.03$ & & & \\
\hline Dissolved Oxygen - mg/L (\%) & $>7.0$ & $(>95)$ & & $(95-100)$ \\
\hline Fluoride & $<0.5$ & & $<0.5$ & $<0.5$ \\
\hline Hydrogen Sulfide & $<0.003$ & $<0.002$ & $<0.003$ & $<0.002$ \\
\hline Hardness & & $>20$ & $<200$ & $10-400$ \\
\hline Iron & $<0.1$ & $<0.3$ & $<0.1$ & $<0.15$ \\
\hline Lead & $<0.02$ & $<0.004$ & $<0.02$ & $<0.03$ \\
\hline Magnesium & $<15$ & & $<15$ & needed \\
\hline Manganese & $<0.01$ & $<0.1$ & $<0.01$ & $<0.01$ \\
\hline Mercury & $<0.0002$ & $<0.0002$ & $<0.0002$ & $<0.00005$ \\
\hline Nickel & $<0.01$ & $<0.045$ & $<0.01$ & $<0.01$ \\
\hline Nitrogen Gas (\%) & $<103$ & & $<110$ & $<110$ \\
\hline Nitrate as $\mathbf{N}$ & $<0.2$ & & $<0.2$ & $0-0.7$ \\
\hline Nitrite as N & $<0.03$ & $<0.015$ & $<0.03$ & $<0.03$ \\
\hline Ozone & & & & $<0.005$ \\
\hline PCBS & & & & $<0.002$ \\
\hline Petroleum (Oil) & $<0.001$ & & & \\
\hline $\mathrm{pH}$ (units) & $6.5-8.0$ & $7.2-8.5$ & $6.5-8.0$ & $6.5-8.0$ \\
\hline Potassium & $<5.0$ & & $<5$ & $<5$ \\
\hline Salinity $(\mathrm{mg} / \mathrm{kg}$ ) & $<5.0$ & & & \\
\hline Selenium & $<0.01$ & $<0.050$ & $<0.002$ & $<0.01$ \\
\hline Silver & $<0.003$ & $<0.0001$ & $<0.003$ & $<0.003$ \\
\hline Zinc & $<0.005$ & & $<0.005$ & $<0.03$ \\
\hline Sodium & $<75$ & & $<75$ & $<75$ \\
\hline Sulfate & $<50$ & & $<50$ & $<50$ \\
\hline Suspended Solids & & $<3$ & & \\
\hline Temperature ("C) & $0-15$ & $5-10$ & & \\
\hline Total Dissolved Solids & $<400$ & & & \\
\hline Total Settleable Solids & $<80$ & & & $<80$ \\
\hline Total Gas Pressure (\%) & $\mathrm{cl} 10$ & $<103$ & & \\
\hline
\end{tabular}

All units $\mathrm{mg} / \mathrm{L}$ unless otherwise noted

(1) ADF\&G 1983.

(2) Shepherd 1984.

(3)Schroeder 1984.

(4) Piper et al. 1982. 


\section{PROCESS CRITERIA}

Process criteria serve as the basis for conceptual design and layout. They will change as site- or program-specific information is developed.

\section{General Process Criteria}

General process criteria for NEOH are shown on Table 9.

Table 9

Process Criteria for NEOH (Adult Hauling - Incubation)

\begin{tabular}{|c|c|c|c|}
\hline Parameter & $\begin{array}{c}\text { Spring } \\
\text { Chinook }\end{array}$ & Fall Chinook & $\begin{array}{l}\text { Summer } \\
\text { Steelhead }\end{array}$ \\
\hline \multicolumn{4}{|l|}{ Adult Hauling } \\
\hline Date & Apr 15-Jul 15 & Sep-Dec & Oct-May \\
\hline Weight (lb) & 13 & 15 & 6 \\
\hline \multicolumn{4}{|l|}{ Adult Holding } \\
\hline Date & Apr 15-Sep 15 & Sep-Dec & Oct-May \\
\hline Weight (lb) & 13 & 15 & 6 \\
\hline $\begin{array}{l}\text { Temperature }(\mathrm{F}) \\
\text { Optimum } \\
\text { Average Monthly Range } \\
\text { Maximum Daily Temperature }\end{array}$ & $\begin{array}{c}50 \\
45-55 \\
63(\text { Apr-Jul) } \\
60 \text { (Aug-Sep) } \\
\end{array}$ & $\begin{array}{c}50 \\
45-55 \\
63\end{array}$ & $\begin{array}{c}50 \\
40-55 \\
60\end{array}$ \\
\hline Density (cf/fish) & 8 & 7 & 2.5 \\
\hline Flow (gpm/fish) & $-1.5+0.05 \times \mathrm{T}$ & $-1.5+0.05 \times \mathrm{T}$ & $-0.5+0.05 \times \mathrm{T}$ \\
\hline Survival (\%) (Capture-Spawning) & 75 & 80 & 75 \\
\hline \multicolumn{4}{|l|}{ Spawning } \\
\hline Date & Aug 5-Sep 15 & Oct 15-Dec & Mar 15-May \\
\hline Female/Male Ratio & $1: 1$ & $1: 1$ & $1: 1$ \\
\hline Eggs/female & 4,200 & 4,500 & 5,200 \\
\hline \multicolumn{4}{|l|}{ Incubation } \\
\hline Date & Aug-Dec & Oct 15-Feb & Mar 15-Jun \\
\hline Eggs/Tray (1 female/tray) & 4,200 & 4,500 & 5,200 \\
\hline Flow/8 trays (gpm) & 6 & 6 & 6 \\
\hline Time to Hatch 50F(d) & 93 & 93 & 54 \\
\hline $\begin{array}{l}\text { Temperature (F) } \\
\text { Optimum } \\
\text { Average Monthly Range } \\
\text { Maximum Daily Temperature }\end{array}$ & $\begin{array}{c}42->39->42^{b} \\
45-55 \\
60\end{array}$ & $\begin{array}{c}52 \\
45-55 \\
60 \\
\end{array}$ & $\begin{array}{c}52 \\
45-55 \\
60 \\
\end{array}$ \\
\hline Survival (green egg to feeding) & 90 & 90 & 90 \\
\hline DD to Feeding & 1665 & 1665 & 975 \\
\hline Length at Feeding (inches)) & 1.34 & 1.45 & 1.02 \\
\hline Weight at Feeding $(\sharp / \mathrm{b})$ & 1100 & 1100 & 2800 \\
\hline
\end{tabular}

(a) Maximum Daily Temperatures are based on 75 percentile values

(b) This temperature profile may be used to delay the development of the eggs 
Table 9 (Continued)

Process Criteria for NEOH (Rı aring)

\begin{tabular}{|c|c|c|c|}
\hline Parameter & $\begin{array}{c}\text { Spring } \\
\text { Chinook }\end{array}$ & Fall Chinook & $\begin{array}{l}\text { Summer } \\
\text { Steelhead }\end{array}$ \\
\hline \multicolumn{4}{|l|}{ Length-Weight $\left(\mathrm{W}=\mathrm{CL}^{\mathrm{n}}\right.$. inches, lb) } \\
\hline $\mathrm{C}$ & $2,959 \times 10^{-7}$ & $2,959 \times 10^{-7}$ & $3,405 \times 10^{-7}$ \\
\hline $\mathrm{n}$ & 3.00 & 3.00 & 3.00 \\
\hline \multicolumn{4}{|l|}{ Early Rearing (Feeding to $200 / / \mathrm{b}$ ) } \\
\hline Date & Nov-Jan & Jan-Mar & May-Jul \\
\hline Length at Start (inches) & 1.34 & 1.45 & 1.02 \\
\hline Weight at Start (\#//b) & 1100 & 1100 & 2800 \\
\hline Duration (d)@ @0F & 32 & 32 & 64 \\
\hline \multicolumn{4}{|l|}{ Temperature (F) } \\
\hline $\begin{array}{l}\text { River-Well Water Mix } \\
\text { Average Monthly }\end{array}$ & $\begin{array}{c}46 \\
35-60\end{array}$ & $35-60$ & $\begin{array}{c}50 \\
35-60\end{array}$ \\
\hline Maximum Daily Temperaturea & 65 & 65 & 65 \\
\hline DI & 1.00 & $1.00^{b^{-}}$ & 1.00 \\
\hline FI (based on Table 8) & Table 8 & Table 8 & Table 8 \\
\hline Survival (\%) & 98 & 90 & 90 \\
\hline $\mathrm{DD} /$ inch & 840 & 840 & 810 \\
\hline Length at End (inches) & 2.57 & 2.57 & 2.45 \\
\hline Weight at End $(\# / \mathrm{lb})$ & 200 & 200 & 200 \\
\hline \multicolumn{4}{|l|}{ Rearing (200/lb to Transport) } \\
\hline Date & Feb & Jan-May 15 & May-Apr \\
\hline Length at Start (inches) & 2.57 & 2.57 & 2.45 \\
\hline Weight at Start $(\# / \mathrm{lb})$ & 200 & 200 & 200 \\
\hline Duration (d)@ @50F & $12-205$ & $50-85$ & 189 \\
\hline \multicolumn{4}{|l|}{ Temperature (F) } \\
\hline Optimum & 55 & 55 & 55 \\
\hline Average Monthly & 40.5 & $35-65$ & $35-65$ \\
\hline Maximum Daily Temperaturea & 70 & 70 & 70 \\
\hline DI & 0.18 & 0.18 & 0.18 \\
\hline FI (based on Table 8 ) & Table $8 / 1.25$ & Table $8 / 1.25$ & Table $8 / 1.25$ \\
\hline Survival (\%) & 98 & 92 & 92 \\
\hline DD/inch & 840 & 840 & 810 \\
\hline Length at End (inches) & $2.82-6.97$ & $3.64-4.39$ & 6.65 \\
\hline Weight at End $(\# / \mathrm{lb})$ & $150-10$ & $70-40$ & 10 \\
\hline
\end{tabular}

a Maximum Daily Temperatures are based on 75 percentile values

b DI - lbs/cu ft./in length no greater than 0.3 
Table 9 (Continued)

Process Criteria for NEOH (Direct Release and Acclimation)

\begin{tabular}{|l|c|c|c|}
\hline Parameter & $\begin{array}{c}\text { Spring } \\
\text { Chinook }\end{array}$ & Fall Chinook & $\begin{array}{c}\text { Summer } \\
\text { Steelhead }\end{array}$ \\
\hline Fry Hauling for Direct Release & & & \\
\hline Date & Jun-Sept & May & \\
\hline Length (inches) & 2.82 & $3.64-4.39$ & \\
\hline Weight (\#/b) & 150 & $70-40$ & \\
\hline Survival (\%) & 99.7 & 99.7 & \\
\hline Direct Release & & & \\
\hline Distance between sites & $5-10$ & $5-10$ & \\
\hline Number of Fish/Release Site/Mile/Week & varies & varies & \\
\hline & & & \\
\hline Smolt Hauling for Acclimation & & & \\
\hline Date & March & Mar-May 15 & Feb-Apr \\
\hline Length (inches) & $6.08-6.97$ & $3.64-4.39$ & 6.65 \\
\hline Weight (\#//b) & $16-17$ & $70-40$ & 10 \\
\hline Survival (\%) & 99.5 & 99.5 & 99.5 \\
\hline Acclimation and Release & & & \\
\hline Date & Apr. 1 & Apr-May 15 & Mar-Apr \\
\hline Distance between Sites & $5-10$ & $5-10$ & $5-10$ \\
\hline Length at Start (inches) & $6.08-6.97$ & $3.64-4.39$ & 6.65 \\
\hline Weight at Start (\#/b) & $16-17$ & $70-40$ & 10 \\
\hline Duration (d)@ 55F (days) & 30 & 3 to 30 & 3 to 30 \\
\hline Temperature (F) & & & \\
Optimum & 43 & 55 & 55 \\
Average Monthly & $35-65$ & $35-65$ & $35-65$ \\
Maximum Daily Temperaturea & 70 & 70 & 70 \\
\hline DI & 0.11 & 0.11 & 0.11 \\
\hline FI (based on Table 8) & Table 8/1.25 & Table 8/1.25 & Table 8/1.25 \\
\hline Survival (\%) & 99.5 & 99.5 & 99.5 \\
\hline DD/inch & no growth & no growth & no growth \\
\hline Length at End (inches) & $6.08-6.97$. & $3.64-4.39$ & 6.65 \\
\hline Weight at End (\#//b) & 15 & $70-40$ & 10 \\
\hline
\end{tabular}

a Maximum Daily Temperatures are based on 75 percentile values 


\section{Length-Weight Relationship}

The weight of a fish in relation to its length, at any time, is expressed as follows:

$$
\mathrm{W}=\mathrm{C} \times \mathrm{L}^{3}
$$

where $\mathrm{W}=$ weight in pounds, $\mathrm{L}=$ length in inches, and $\mathrm{C}$ is the condition factor for the specific species.

\section{Development Rate}

Eggs. Egg development rate is based on the number of degree days above $32 \mathrm{~F}$.

Fry. Fry development rate is based on the number of degree days to achieve an inch of growth.

\section{Feed Consumption}

The amount of food to be fed to the fish must be known in order to predict oxygen demand, ammonia concentrations, and suspended solids production levels. Generally, the daily feeding rate is determined from information provided by feed companies or as summarized in Piper et al. (1982). This information can be converted to simple feeding coefficients $(\mathrm{Fc})$ that relate feeding rate to water temperatures and growth rate.

TABLE 10

FEEDING COEFFICIENT AT VARIOUS WATER TEMPERATURES

(a)

\begin{tabular}{|cc|}
\hline $\begin{array}{c}\text { Temperature } \\
\left({ }^{\circ} \mathrm{F}\right)\end{array}$ & $\begin{array}{c}\text { Feeding } \\
\text { Coefficient-(b) }\end{array}$ \\
& \\
46 & 7.38 \\
49 & 8.54 \\
52 & 9.70 \\
55 & 10.86 \\
58 & 12.02 \\
\hline
\end{tabular}

(a) Based on feeding rates presented in Table 25 of Piper et al. (1982) for fish growing at $900 \mathrm{DD} /$ inch length increase.

(b) Feeding Coefficient $=($ Water temperature -26.94$) \times 0.387$

To determine the daily amount of feed offered to fish, one would use the formula:

$$
\% \text { of Body Weight to Feed }=\mathrm{Fc} / \mathrm{L}
$$

Where Fc is the feeding coefficient, and $\mathrm{L}$ is the length of fish in inches. 


\section{Oxygen Consumption}

The calculations of oxygen levels and consumption will be based on the following relationship between feed $(\mathrm{F})$ and oxygen consumption in raceways $(\mathrm{Oc})$ :

$$
\mathrm{Oc}=0.25 \times \mathrm{F}
$$

Stated in another way, for each 100 pounds of food introduced to a raceway, 25 pounds of oxygen will be consumed in that raceway in the same period of time. This is probably conservative in that a general value of $\mathrm{Oc}=0.22 \times \mathrm{F}$ was proposed by Willoughby for a dry diet. Values of Oc ranging from 0.22 to 0.25 are probably valid for fingerlings under production conditions. Higher values may needed for smaller fish and for fry and fingerlings fed restricted rations.

\section{Ammonia Production}

The calculation of ammonia production is based on the following relationship between feed (F) and total ammonia produced, TAN (total ammonia expressed as nitrogen):

$$
\mathrm{TAN}=0.029 \times \mathrm{F}
$$

This relationship is based on work by Mayo \& Liao at the Cowlitz Trout Hatchery and verified by other sources.

\section{Carbon Dioxide}

As proposed by Piper et al (1982) the dissolved carbon dioxide produced per pound of feed will be based on the following relationship between feed $(F)$ and carbon dioxide production $(\mathrm{Cp})$ :

$$
\mathrm{Cp}=0.28 \times \mathrm{F}
$$

\section{Suspended Solids}

Suspended solids sources in the effluent of a production unit consist of materials in the influent water, fecal solids, uneaten feed, and other materials that have fallen or have been blown in the water. Pollution control requirements may be based in part on effluent suspended solids (SuS) levels. The calculations of SuS generated will be based on the following relationship between feed $(F)$ and total SuS:

$$
\mathrm{SuS}=0.35 \times \mathrm{F}
$$

Because of the number of materials that can contribute to suspended solids, operational considerations, and site-specific factors, the above relationship may not be valid for all locations.

\section{Phosphate}

Phosphate sources in intensive culture include uneaten feed, fecal matter, and direct excretion from the kidneys. The amount of phosphates added to the water also depends on the type of solids removal system used. Commonly, the amount of phosphate added to the diet is in excess of that needed by the fish. Because of discharge restrictions on phosphate 
in North America and Europe, major research has been directed towards the reduction in the amount of phosphate in the diet and development of operational procedures to reduce the phosphate concentration in the discharge water. Based on work reported by Liao and Mayo (1974), the phosphate production rate will be based on the following relationship between feed $(\mathrm{F})$ and total P04:

$$
\mathrm{PO} 4=0.016 \times \mathrm{F}
$$

\section{Rearing Mortalities}

To develop a hatchery model, it is necessary to have an estimate of mortalities that may be expected in the facility. Typically, survival is lowest at the beginning of a cycle and highest at the end. Survival assumptions for $\mathrm{NEOH}$ are shown on Table 11:

TABLE 11

ASSUMED SURVIVAL RATES BY LIFE STAGE AND SPECIES

\begin{tabular}{|l|c|c|c|}
\hline Life Stage & Spring Chinook & Fall Chinook & Summer Steelhead \\
\hline Capture-Spawning & 75 & 80 & 75 \\
\hline Eggs-Smolt & 72 & 75 & 75 \\
\hline Eggs-Feeding & 90 (assumed) & 90 (assumed) & 90 (assumed) \\
\hline Feeding-200/\# & 90 (assumed) & 90 (assumed) & 90 (assumed) \\
\hline 200/\#-Release & 92 (assumed) & 92 (assumed) & 92 (assumed) \\
\hline Smolt Hauling & 99.5 (assumed) & 99.5 (assumed) & 99.5 (assumed) \\
\hline & & 99.5 (Assumed) & 99.5 (Assumed) \\
\hline Acclimation Ponds & 99.5 (Assumed) & 99 &
\end{tabular}




\section{Rearing Density}

Density criteria (maximum weight of fish per cubic foot) is developed in terms of the Density Index approach. The Density Index (DI) is:

$$
\text { DI }=\frac{\text { Fish density }\left(\mathrm{lb} / \mathrm{ft}^{3}\right)}{\text { Length of fish (inches) }}
$$

or

$$
\text { Density }\left(\mathrm{lb} / \mathrm{ft}^{3}\right)=\text { DI } x \text { length in inches }
$$

Detailed information on DIs for a number of similar projects is shown on Tables 12 and 13. 
TABLE 12

DENSITY AND FLOW INDICES USED BY DIFFERENT AGENCIES IN THE PACIFIC NORTHWEST FOR OUTDOOR RACEWAYS (>800/LB.)

\begin{tabular}{|c|c|c|}
\hline Agency/Project & $\begin{array}{l}\text { Density Index } \\
\text { (Ib/(cf } \sum \mathbf{i n )}\end{array}$ & $\begin{array}{c}\text { Flow Index } \\
\left(\mathbf{l b} / \mathbf{g p m} \sum \mathbf{i n}\right) \\
(\mathbf{a}) \\
\end{array}$ \\
\hline $\begin{array}{l}\text { ODF\&W Design Values (Based on } \\
\text { FMC, 1984) }\end{array}$ & $0.22-0.30 \quad($ mean $=0.26$ & 65 \\
\hline \multicolumn{3}{|l|}{ ODF\&W (Recent Hatcheries) } \\
\hline Willamette (standard) & $0.16(\max )$ & 50 \\
\hline Umatilla (ChS) & $0.16(\max )$ & 78 \\
\hline Umatilla $(\mathrm{ChF})$ & $0.17(\max )$ & 83 \\
\hline WDF Design Values & undetermined & 100 \\
\hline \multicolumn{3}{|l|}{ WDF (Recent Hatcheries) } \\
\hline Issaquah (chinook) & $0.08(\max )$ & 96 \\
\hline Lyons Ferry (ChS) & $\begin{array}{c}0.03-0.23(\text { mean }= \\
0.10)\end{array}$ & 60 \\
\hline Lyons Ferry (ChF) & $\begin{array}{l}0.06-0.27(\text { mean }= \\
0.16)\end{array}$ & 60 \\
\hline $\begin{array}{l}\text { Yakima/Klickitat Production Design } \\
\text { Values }\end{array}$ & $\begin{array}{c}0.175 \text { raceways (max) } \\
0.150 \text { ponds (max) } \\
0.110 \begin{array}{c}\text { acclimation ponds } \\
\text { (max) }\end{array}\end{array}$ & $\begin{array}{c}4 \text { (available } 02, \mathrm{mg} / \mathrm{l}) \\
(\% \text { food fed)(length, in.) } \\
\text { (b) }\end{array}$ \\
\hline 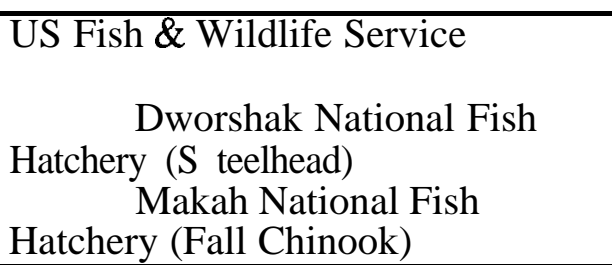 & $\begin{array}{l}0.25(\max ) \\
0.50(\max )\end{array}$ & --- \\
\hline $\begin{array}{l}\text { Piper et al., } 1982 \text { (Salmon } \\
\text { and Trout) }\end{array}$ & $0.50(\max )$ & 100 \\
\hline $\begin{array}{l}\text { Bonneville Power Administration } \\
\text { (Assessment of Present } \\
\text { Anadromous Fish Production . . . . } \\
\text { 1990) }\end{array}$ & $\begin{array}{c}0.25 \mathrm{ChS}(\max ) \\
0.30 \mathrm{ChF}(\max ) \\
0.25 \mathrm{~S} \text { teelhead (max) }\end{array}$ & 100 \\
\hline
\end{tabular}

(a) Percent of Table 8, Piper et al. (1982).

(b) Depending on specific rearing cycle and temperatures, the FIs computed from this equation range from $110-130 \%$ of the values shown on Table 8, Piper et al. (1982). 
TABLE 13

DENSITY AND FLOW INDICES USED BY VARIOUS AGENCIES IN THE PACIFIC NORTHWEST FOR EARLY REARING (<800/LB.)

\begin{tabular}{|l|c|c|}
\hline Agency/Project & $\begin{array}{c}\text { Density Index } \\
\left(\mathbf{I b} / \mathbf{( f f} \sum \mathbf{i n}\right)\end{array}$ & $\begin{array}{c}\text { Flow Index } \\
\left(\mathbf{l b} / \mathbf{g p m} \sum \mathbf{i n}\right) \\
(\mathbf{a})\end{array}$ \\
\hline $\begin{array}{c}\text { South Tacoma Hatchery } \\
\text { Rainbow Trout }\end{array}$ & $01.5-1.7$ & $65-86$ \\
\hline $\begin{array}{c}\text { Cowlitz Hatchery } \\
\text { S teelhead and Cutthroat }\end{array}$ & $2.3-2.5$ & $104-114$ \\
\hline $\begin{array}{c}\text { Mossyrock Hatchery } \\
\text { Rainbow Trout }\end{array}$ & Similar to Cowlitz & Similar to cowlitz \\
\hline
\end{tabular}

(a) Percent of Table 8, Piper et al. (1982).

For NEOH, the following DIs are proposed for planning purposes (Table 14):

TABLE 14

PROPOSED DENSITY INDICES BY LIFE STAGE FOR NEOH

\begin{tabular}{|l|c|}
\hline Phase & Density Index (lb/cf in ) \\
\hline Early Rearing & $\begin{array}{c}1.00 \\
\text { (possibly up to } \begin{array}{c}.00 \text { depending on feeding } \\
\text { response }\end{array}\end{array}$ \\
\hline Rearing in Raceways & 0.17 \\
\hline Acclimation in Raceways & 0.17 \\
\hline Acclimation in Earthen Ponds & 0.11 \\
\hline Acclimation in Large Earthen Ponds & no information available \\
\hline Acclimation in Side Channels & no information available \\
\hline
\end{tabular}




\section{Flow Requirements}

The water requirements in an intensive culture salmon hatchery are determined by six factors: (1) The amount of oxygen consumed, (2) the oxygen levels in the influent water supplied to the raceways, (3) tolerance to lowered oxygen levels, (4) ammonia in the incoming water supply, (5) metabolites, primarily ammonia, carbon dioxide, and suspended solids, produced in the rearing process, and (6) tolerance to the metabolites, specifically un-ionized ammonia, carbon dioxide and suspended solids. In turn, oxygen consumption and metabolite production is directly related to the amount of feed.

Plow requirements for adult holding as a function of temperature $\left({ }^{\circ} \mathrm{F}\right)$ are based on Senn et. al. (1984) and are shown on Table 15.

TABLE 15

FLOW REQUIREMENTS AS A FUNCTION OF TEMPERATURE (T)

\begin{tabular}{|l|c|}
\hline Species & gpm/fish \\
\hline Spring Chinook & $-1.5+0.05 \mathrm{~T}$ \\
\hline Fall Chinook & $-1.5+0.05 \mathrm{~T}$ \\
\hline Summer S teelhead & $-0.5+0.05 \mathrm{~T}$ \\
\hline
\end{tabular}

Loading criteria for rearing (pounds of fish per gallon per minute) are developed in terms of the Flow Index approach. The Flow Index (FI) is:

$$
\text { FI }=\frac{\text { Loading }(\mathrm{lb} / \mathrm{gpm})}{\text { Length of fish (inches) }}
$$

or

$$
\text { Loading }(\mathrm{lb} / \mathrm{gpm})=\text { FI } \mathrm{x} \text { length in inches }
$$

The flow indices proposed for NEOH are shown on Table 16 and are based on Piper et al. (1982). For rearing and acclimation, Piper's values are derated by a factor equal to 1.25. Therefore, more water is required compared to Piper's table. 
TABLE 16

FLOW INDEX RELATED TO WATER TEMPERATURE AND ELEVATION

\begin{tabular}{|l|l|l|l|l|l|l|l|l|l|l|l|}
\hline $\begin{array}{l}\text { Temp } \\
\left({ }^{\circ} \mathrm{F}\right)\end{array}$ & 0 & 1,000 & 2,000 & 3,000 & 4,000 & 5,000 & 6,000 & 7,000 & 8,000 & 9,000 \\
\hline 40 & 2.70 & 2.61 & 2.54 & 3.43 & 2.34 & 2.25 & 2.16 & 2.09 & 2.01 & 1.94 \\
\hline 41 & 2.61 & 2.52 & 2.44 & 2.35 & 2.26 & 2.18 & 2.09 & 2.02 & 1.94 & 1.87 \\
\hline 42 & 2.52 & 2.44 & 2.35 & 2.27 & 2.18 & 2.10 & 2.02 & 1.95 & 1.88 & 1.81 \\
\hline 43 & 2.43 & 2.35 & 2.27 & 2.19 & 2.11 & 2.03 & 1.94 & 1.88 & 1.81 & 1.74 \\
\hline 44 & 2.34 & 2.26 & 2.18 & 2.11 & 2.03 & 1.95 & 1.87 & 1.81 & 1.74 & 1.68 \\
\hline 45 & 2.25 & 2.18 & 2.10 & 2.03 & 1.95 & 1.88 & 1.80 & 1.74 & 1.68 & 1.61 \\
\hline 46 & 2.16 & 2.09 & 2.02 & 1.94 & 1.87 & 1.80 & 1.73 & 1.67 & 1.61 & 1.55 \\
\hline 47 & 2.07 & 2.00 & 1.93 & 1.86 & 1.79 & 1.73 & 1.66 & 1.60 & 1.54 & 1.48 \\
\hline 48 & 1.98 & 1.91 & 1.85 & 1.78 & 1.72 & 1.65 & 1.58 & 1.53 & 1.47 & 1.42 \\
\hline 49 & 1.89 & 1.83 & 1.76 & 1.70 & 1.64 & 1.58 & 1.51 & 1.46 & 1.41 & 1.36 \\
\hline 50 & 1.80 & 1.74 & 1.68 & 1.62 & 1.56 & 1.50 & 1.44 & 1.39 & 1.34 & 1.29 \\
\hline 51 & 1.73 & 1.67 & 1.62 & 1.56 & 1.50 & 1.44 & 1.38 & 1.34 & 1.29 & 1.24 \\
\hline 52 & 1.67 & 1.61 & 1.56 & 1.50 & 1.44 & 1.39 & 1.33 & 1.29 & 1.24 & 1.19 \\
\hline 53 & 1.61 & 1.55 & 1.50 & 1.45 & 1.39 & 1.34 & 1.29 & 1.24 & 1.20 & 1.15 \\
\hline 54 & 1.55 & 1.50 & 1.45 & 1.40 & 1.34 & 1.29 & 1.24 & 1.20 & 1.16 & 1.11 \\
\hline 55 & 1.50 & 1.45 & 1.40 & 1.35 & 1.30 & 1.25 & 1.20 & 1.16 & 1.12 & 1.07 \\
\hline 56 & 1.45 & 1.40 & 1.35 & 1.31 & 1.26 & 1.21 & 1.16 & 1.12 & 1.08 & 1.04 \\
\hline 57 & 1.41 & 1.36 & 1.31 & 1.27 & 1.22 & 1.17 & 1.13 & 1.09 & 1.05 & 1.01 \\
\hline 58 & 1.36 & 1.32 & 1.27 & 1.23 & 1.18 & 1.14 & 1.09 & 1.05 & 1.02 & 0.98 \\
\hline 59 & 1.32 & 1.28 & 1.24 & 1.19 & 1.15 & 1.10 & 1.06 & 1.02 & 0.99 & 0.95 \\
\hline 60 & 1.29 & 1.24 & 1.20 & 1.16 & 1.11 & 1.07 & 1.03 & 0.99 & 0.96 & 0.92 \\
\hline 61 & 1.25 & 1.21 & 1.17 & 1.13 & 1.08 & 1.04 & 1.00 & 0.97 & 0.93 & 0.90 \\
\hline 62 & 1.22 & 1.18 & 1.14 & 1.09 & 1.05 & 1.01 & 0.97 & 0.94 & 0.91 & 0.87 \\
\hline 63 & 1.18 & 1.14 & 1.11 & 1.07 & 1.03 & 0.99 & 0.95 & 0.92 & 0.88 & 0.85 \\
\hline 64 & 1.15 & 1.12 & 1.08 & 1.04 & 1.00 & 0.96 & 0.92 & 0.89 & 0.86 & 0.83 \\
& & & & & & & & & & \\
\hline
\end{tabular}

NOTE: Based on optimum index of FI $=1.5$ at $50 \mathrm{~F}$ and 5,000 Feet Elevation. Oxygen Concentration is Assumed to be at or Near 100\% Saturation (Piper et al., 1982). 


\section{WATER AND SPACE REQUIREMENTS}

\section{INTRODUCTION}

In order to adequately evaluate the NEOH program objectives, the potential facilities that may be necessary to satisfy both the production goals and biological requirements of the program have been evaluated. These preliminary descriptions and design criteria were used for analyzing the candidate sites' available land area, water supply, water quality and major institutional issues.

The following information defines the critical factors that are required for preliminary screening of alternatives and evaluation' of options. The criteria presented are based upon information obtained from BPA, ODF\&W, CTUIR, NPT as well as Montgomery Watson's experience. These criteria are presented to elicit comment, to assist and to facilitate discussion, and are intended to be modified as necessary.

Because the NEOH project area covers 3 separate basins, the number and mix of facilities could vary widely. To simplify this section, only two program options have been considered for the Fianl Siting Report:

1) A single, centralized facility for the entire $\mathrm{NEOH}$ project area

2) Separate facilities for adult holding, incubation, and rearing in each basin.

The facilities used to meet the production goals will be based on the information collected during site evaluation. The following sections present basic information for each of the life stages involved in planning.

\section{FACILITY DESCRIPTIONS}

\section{Adult Capture}

\section{Location}

Walla Walla (2)

Grande Ronde (2 or more)

Imnaha (1)

Umatilla (1)

Schedule

Apr 15 -December

Minimum Flow Necessary

$10 \mathrm{cfs}$ 


\section{Facilities Necessary or Desirable for Adult Capture}

1. Weir

2. Ladder

3. Holding (short-term)

4. Security (Personnel on-site during operations, security guard during holding).

5. Small office/storage

6. Small trailer or bunkhouse for personnel

Adult Holding - Single Facility

Number of Adult Fish (Assumed)

$\begin{array}{ll}\text { CHS } & 2195 \\ \text { CHF } & 706 \\ \text { STS } & 80\end{array}$

Flow Criteria

Temperature
$50^{\circ} \mathrm{F}$
$55^{\circ} \mathrm{F}$
$60^{\circ} \mathrm{F}$
$65^{\circ} \mathrm{F}$

$\begin{gathered}\text { CHS } \\ \text { gpm/fish }\end{gathered}$
1.00
1.25
1.50
1.75

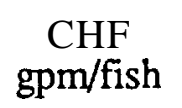

STS gpm/fish

1.00

1.25

1.50

1.75

2.00

2.50

3.00

3.50

Holding Volume Criteria

$\begin{array}{lc} & \text { Unit (cf/fish) } \\ \text { CHS } & 8 \\ \text { CHF } & 7 \\ \text { STS } & 2.5\end{array}$

Schedule

\begin{tabular}{ll} 
& \multicolumn{1}{c}{ Period } \\
\cline { 2 - 2 } CHS & \multicolumn{1}{c}{ April 15 -1 October } \\
CHF & September-December \\
STS & November-May
\end{tabular}




\section{Holding Volume and Flow Requirement}

Based on a design temperature of $55^{\circ} \mathrm{F}$, the required volumes and flows are:

\begin{tabular}{|l|c|c|}
\hline Species & $\begin{array}{c}\text { Volume } \\
\text { (cf) }\end{array}$ & $\begin{array}{c}\text { Flow } \\
\text { (gpm) }\end{array}$ \\
\hline CHS & 13,176 & 2,744 \\
\hline CHF & 4,942 & 883 \\
\hline STS & 200 & 200 \\
\hline
\end{tabular}

The maximum holding volume and flows will be computed based on the assumption that during the month of September, $100 \%$ of the Spring Chinook and 25\% of the Fall Chinook must be held. This would require 14,412 cf of holding space and 2,965 gpm. Seven different stocks of fish mush be held. At least 5 stocks may be held at one time.

Therefore, assuming a minimum holding volume/stock of 5,000 cf, a total adult holding volume of 25,000 cf will be required.

\section{Summary}

Maximum Volume Required - 25,000 cf

Maximum Sustained Temp. - $55^{\circ} \mathrm{F}$

Maximum Flow Required - 6.6 cfs (2965 gpm)

Facilities Necessary or Desirable for Adult Holding Facility

1. Water supply

2. Ponds or Raceways (2 min)

3. Office/storage

4. Sanitary facilities

5. Utilities

6. Carcass Disposal

7. Limited bunk house

8. Security

9. Access

1b. Effluent discharge / water treatment

11. Egg taking station

Assumed Size (General) for Complete Facility Layout

10 acres 
Adult Holding - Facilities in Each Basin

Number of Adult Fish

\begin{tabular}{|l|l|l|l|}
\hline Basin & CHS & CHF & STS \\
\hline Walla Walla & 559 & & 80 \\
\hline Grande Ronde & 696 & 640 & \\
\hline $\begin{array}{l}\text { Imnaha } \\
\text { Umatilla }\end{array}$ & 392 & 66 & \\
\hline Total & 548 & & \\
\hline
\end{tabular}

Flow Criteria

$\begin{array}{cccc}\text { Temperature } & \begin{array}{c}\text { CHS } \\ \text { gpm/fish }\end{array} & \begin{array}{c}\text { CHF } \\ \text { gpm/fish }\end{array} & \begin{array}{c}\text { STS } \\ \text { gpm/fish }\end{array} \\ 50^{\circ} \mathrm{F} & 1.00 & 1.00 & 2.00 \\ 55^{\circ} \mathrm{F} & 1.25 & 1.25 & 2.50 \\ 60^{\circ} \mathrm{F} & 1.50 & 1.50 & 3.00 \\ 65^{\circ} \mathrm{F} & 1.75 & 1.75 & 3.50\end{array}$

Holding Volume Criteria

\section{$\underline{\text { Unit (cf/fish) }}$}

$\begin{array}{lc}\text { CHS } & 8 \\ \text { CHF } & 7 \\ \text { STS } & 2.5\end{array}$

Holding Schedule

\begin{tabular}{ll} 
& \multicolumn{1}{c}{ Period } \\
\cline { 2 - 2 } CHS & \multicolumn{1}{c}{ April 15 -1 October } \\
CHF & September-December \\
STS & November-May
\end{tabular}

Holding Volume and Flow Requirement

The maximum holding volume and flow will be computed based on the assumption that during the month of September 100\% of the Spring Chinook and 25\% of the Fall Chinook must be held. Based on a design temperature of $55^{\circ} \mathrm{F}$, the required volumes and flows by basin are: 
VOLUME REGUIREMENT (cubic feet)

\begin{tabular}{|l|c|c|c|c|}
\hline Basin & CHS & CHF & STS & $\begin{array}{c}\text { Design } \\
\text { Value }\end{array}$ \\
\hline Walla Walla & 4,472 & & 200 & 4,500 \\
\hline Grande Ronde & 5,568 & 4,480 & & 6,700 \\
\hline Imnaha & 3,136 & 462 & & 3,300 \\
\hline Umatilla & 4,384 & & & 4,400 \\
\hline
\end{tabular}

FLOW REQUIREMENTS (gpm)

\begin{tabular}{|l|c|c|c|c|}
\hline Basin & CHS & CHF & STS & $\begin{array}{c}\text { Design } \\
\text { Value }\end{array}$ \\
\hline Walla Walla & 699 & & 200 & 700 \\
\hline Grande Ronde & 870 & 800 & & 1,100 \\
\hline Imnaha & 490 & 83 & & 510 \\
\hline Umatilla & 685 & & & 700 \\
\hline
\end{tabular}

SUMMARY

\begin{tabular}{|l|c|c|}
\hline Basin & $\begin{array}{c}\text { Volume } \\
(\mathbf{c f})\end{array}$ & $\begin{array}{c}\text { Flow } \\
(\mathbf{g p m})\end{array}$ \\
\hline Walla Walla & 4,500 & 700 \\
\hline Grande Ronde & 6,700 & 1,100 \\
\hline Imnaha & 3,300 & 510 \\
\hline Umatilla & 4,400 & 700 \\
\hline
\end{tabular}


Facilities Necessary or Desirable for Adult Holding

1. Water supply

2. Ponds or Raceways (2 min)

3. Office/storage

4. Sanitary facilities

5. Utilities

6. Carcass Disposal

7. Limited bunk house

8. Security

9. Access

lb. Effluent discharge / water treatment

11. Egg taking station

Assumed Size (General) for Complete Facility Layout

5 acres

Incubation and Early Rearing - Single Facility

Incubation and early rearing is defined as rearing of fish from green eggs to 200/pound.

Number of Eggs and Fry

\begin{tabular}{|l|l|l|}
\hline Species & Fry Needed & Eggs Needed \\
\hline CHS - & $3,174,000$ & $3,919,000$ \\
\hline CHF - & $1,489,000$ & $1,838,000$ \\
\hline STS - & 109,000 & 134,000 \\
\hline Total & $4,772,000$ & $5,891,000$ \\
\hline
\end{tabular}

Schedule

\begin{tabular}{|l|l|l|}
\hline Species & Incubation & Early Fry Rearing \\
\hline CHS - & Aug-Dec & Nov-Feb \\
\hline CHF - & Oct 15-Feb & Jan-Mar \\
\hline STS - & March 15-Jun & May-Jul \\
\hline
\end{tabular}


Temperature and Flows Required (total program)

Incubation

Maximum Water Temperature $55^{\circ} \mathrm{F}$

Water Temperature Range -45 to $55^{\circ} \mathrm{F}$

CHS Design flow (120 stack of 8 trays @ 8 gpm) 960 gpm

CHF Design flow (52 stack of 8 trays @8 gpm)416 gpm

STS Design flow (4 stack of 8 trays @8 gpm) 32 gpm

Controlling Flow $=1,376 \mathrm{gpm}(\mathrm{CHS}+\mathrm{CHF})$

Early Rearing

Maximum Water Temperature $55^{\circ} \mathrm{F}$

Water Temperature Range -45 to $56^{\circ} \mathrm{F}$

Design Flow

$\mathrm{FI}=1.35,\left(55^{\circ} \mathrm{F} / 3,000 \mathrm{ft}\right.$ elevation $)$

Loading $=3.47 \mathrm{lb} / \mathrm{gpm}$

$6,900 \mathrm{gpm}$

Density

$$
\begin{aligned}
& \mathrm{DI}=1.0 \\
& \mathrm{D}=2.47 \mathrm{lb} / \mathrm{ct} \\
& \text { Volume }=10,000 \mathrm{cf}
\end{aligned}
$$

\section{Water Source}

Groundwater (first priority)

Disinfected Surface Water (second priority)

Facility Size (generic)

2 acre (max.)

Facilities Necessary or Desirable for Incubation/Early Rearing

1. Groundwater supply (1st option)

2. Disinfection facilities (secondary option)

3. Loading facility

4: Incubation room (controlled environment)

5. Office lab area

6. Personnel facilities

7. Sanitary facilities

8. Early rearing facilities

9. Effluent disinfection

Incubation and early rearing would be developed with other facilities at a particular site, such as full-term rearing or adult holding, so infrastructure would be in place. 
Incubation and Early Rearing - Facilities in Each Basin

Incubation and early rearing is defined as rearing of fish from green eggs to 200/pound.

Number of Eggs and Fry

\section{Eggs}

\begin{tabular}{|l|l|l|l|}
\hline Basin & CHS & CHF & STS \\
\hline Walla Walla & 738,000 & & 134,000 \\
\hline Grande Ronde & $1,470,000$ & $1,677,000$ & \\
\hline Imnaha & 835,000 & 161,000 & \\
\hline Umatilla & 790,000 & & \\
\hline
\end{tabular}

Fry

\begin{tabular}{|l|l|l|l|}
\hline Basin & CHS & CHF & STS \\
\hline Walla Walla & 598,000 & & 109,000 \\
\hline Grande Ronde & $1,190,000$ & $1,359,000$ & \\
\hline Imnaha & 677,000 & 130,000 & \\
\hline Umatilla & 1640,000 & & \\
\hline
\end{tabular}

Schedule

\begin{tabular}{|l|l|l|}
\hline Species & Incubation & Early Rearing \\
\hline CHS - & Aug-Dec & Nov-Feb \\
\hline CHF - & Oct 15-Feb & Jan-Mar \\
\hline STS - & March 15-Jun & May-Jul \\
\hline
\end{tabular}


Temperature and Flows Required

Incubation

Maximum Water Temperature $55^{\circ} \mathrm{F}$

Water Temperature Range -45 to $55^{\circ} \mathrm{F}$

Water flow per 8 trays $=8 \mathrm{gpm}$

It is assumed that both CHS and CHF are in the incubators at the same time.

Number of Stacks

\begin{tabular}{|l|l|l|l|l|}
\hline Basin & CHS & CHF & STS & Total \\
\hline Walla Walla & 22 & & 4 & 22 \\
\hline Grande Ronde & 44 & 47 & & 91 \\
\hline Imnaha & 25 & 5 & & 30 \\
\hline Umatilla & 24 & & & 24 \\
\hline
\end{tabular}

Water Flow (gpm)

\begin{tabular}{|l|l|l|l|l|}
\hline Basin & CHS & CHF & STS & Total \\
\hline Walla Walla & 176 & & 32 & 176 \\
\hline Grande Ronde & 352 & 376 & & 728 \\
\hline Imnaha & 200 & 40 & & 240 \\
\hline Umatilla & 192 & & & 192 \\
\hline
\end{tabular}

Early Rearing

Maximum Water Temperature $55^{\circ} \mathrm{F}$

Water Temperature Range - 45 to $56^{\circ} \mathrm{F}$

Assume $100 \%$ of CHS and 50\% of CHF in raceways during January and February

Design Flow

$\mathrm{FI}=1.35,\left(55^{\circ} \mathrm{F} / 3,000 \mathrm{ft}\right.$ elevation $)$

Loading $=3.47 \mathrm{lb} / \mathrm{gpm}$ 
Density

$$
\begin{aligned}
& \mathrm{DI}=1.0 \\
& \mathrm{D}=2.47 \mathrm{lb} / \mathrm{ct}
\end{aligned}
$$

Rearing Volume (cf)

\begin{tabular}{|l|l|l|l|l|}
\hline Basin & CHS & CHF & STS & Total \\
\hline Walla Walla & 1,200 & & 220 & 1,200 \\
\hline Grande Ronde & 2,410 & 2,800 & & 3,810 \\
\hline Imnaha & 1,370 & 263 & & 1,400 \\
\hline Umatilla & 1,300 & & & 1,300 \\
\hline
\end{tabular}

Water Flow (gpm)

\begin{tabular}{|l|l|l|l|l|}
\hline Basin & CHS & CHF & STS & Total \\
\hline Walla Walla & 962 & & 160 & 962 \\
\hline Grande Ronde & 1,800 & 1,960 & & 2,780 \\
\hline Imnaha & 976 & 190 & & 1,070 \\
\hline Umatilla & 922 & & & 920 \\
\hline
\end{tabular}

Water Source

Groundwater (first priority)

Disinfected Surface Water (second priority)

Facility Size (generic)

1 acre (max.)

Facilities Necessary or Desirable for Incubation/Early Rearing

1. Groundwater supply (1st option)

2. Disinfection facilities (secondary option)

3: Loading facility

4. Incubation room (controlled environment)

5. Office lab area

6. Personnel facilities 
7. Sanitary facilities

8. Early rearing facilities

9. Effluent disinfection

Incubation and early rearing would be developed with other facilities at a particular site, such as full-term rearing or adult holding, so infrastructure would be in place.

\section{Full Term (Satellite) Rearing - Single Facility}

Full term rearing is defined as rearing of fish from 200/pound to release, it does not include incubation and early fry rearing.

\section{Number of Fish Total}

ChS would be the limiting factor for rearing because of the longer rearing period and larger biomass. CHS programmed for release at $150 / \mathrm{b}$. have not been considered as they will be planted early in the rearing cycle.

$$
\begin{array}{ll}
1,139,000 @ 10 / 1 b & 6.97 ” \\
1,338,000 @ 15 / 1 b & 6.08
\end{array}
$$

Schedule

Rearing Period - 15 months

Schedule - April to May release

Size initial - 200/lb

Flows Required (total program)

$$
\begin{aligned}
& \mathrm{FI}=0.93(3000 \mathrm{ft} \& 60 \mathrm{~F}) \\
& \text { Loading }=6.48 \mathrm{lb} / \mathrm{gpm} @ 10 / \mathrm{b} \\
& \text { Loading }=5.65 \mathrm{lb} / \mathrm{gpm} @ 15 / \mathrm{b}
\end{aligned}
$$

Flow@10/b=17,577 gpm

Flow@ 15/lb = 15,788 gpm

Total Flow $\quad=\quad 33,365 \mathrm{gpm}(74.5 \mathrm{cfs})$

Volume Required

$\mathrm{DI}=0.18$

Density=1.25 lb/cf @ 10/lb

Density=1.09 lb/cf@15/lb

$\begin{array}{lll}\text { Volum e @ 10/lb } & & 91,120 \mathrm{cf} \\ \text { Volume@15/lb } & = & 81,835 \mathrm{cf} \\ \text { Total } & = & 173,000 \mathrm{cf}\end{array}$

\section{Summary}

Maximum Holding Area Required - 173,000 cf

Temperature Range - $45-65^{\circ} \mathrm{F}$

Peak Maximum diurnal temperature $60-65^{\circ} \mathrm{F}$

Maximum Flow Required - 74.5 cfs

Maximum summer critical flow - 56 cfs ( $75 \%$ of maximum) 
Facilities Necessary or Desirable for Full Term Rearing Facilities

1. Water supply

2. Water treatment

3. Loading facilities

4. Office/storage/lab

5. Personnel facilities

6. Raceways/ponds

7. Sanitary facilities

8. Access

9. Utilities

1b. Security

11. Effluent water treatment and return

Assumed Size of Complete Facilities

10 acres

Full Term (Satellite) Rearing - Facilities in Each Basin

Full term rearing is defined as rearing of fish from 200/pound to release, it does not include incubation and early fry rearing.

\section{Number of Fish Total}

The CHS planted at $150 / \mathrm{b}$ have not been considered in this computation because of the small amount of biomass.

\begin{tabular}{|l|l|l|l|}
\hline Basin & CHS & CHF & STS \\
\hline Walla Walla & $550,000 @ 10 / \#$ & & $100,000 @ 10 / \#$ \\
\hline Grande Ronde & $945,155 @ 15 / \#$ & $1,250,000 @ 40 / \#$ & \\
\hline Imnaha & $392,500 @ 15 / \#$ & $120,000 @ 70 / \#$ & \\
\hline Umatilla & $589,000 @ 10 / \#$ & & \\
C H S 10/b & $6.97 ”$ & \\
C H S 15/b & $6.08 ”$ & \\
C H F 40/b & $4.39 ”$ & & \\
C H F 70/b & $3.64 ”$ & & \\
S T S 5/1b & $8.37 ”$
\end{tabular}


Schedule

CHS

Rearing Period - 200 days

Release Period - April to May

$\mathrm{CHF}$

Rearing Period - 50 days

Release Period - April to May

STS

Rearing Period - 189 days

Release Period - April to May

Flows Required

Water flows are based on CHS + STS as these two species will be in the raceways at the same time. The overlap between the CHS and CHF will be considered during concept design.

Design Flow Index

$\mathrm{FI}=1.35(3000 \mathrm{ft} \& 55 \mathrm{~F})$

$\mathrm{SCH}$

Loading=6.48 lb/gpm @ 10/lb

Loading =5.65 lb/gpm@15//b

CHF

Loading = 4.08 lb/gpm @ 40/lb

Loading = 3.39 lb/gpm@ 70/lb

STS

Loading=7.78 lb/gpm @ 5/lb 


\section{Water Flow (gpm)}

\begin{tabular}{|l|c|c|c|c|}
\hline Basin & CHS & CHF & STS & Total \\
\hline Walla Walla & 8,488 & & 2,570 & 9,800 \\
\hline Grande Ronde & 11,152 & 7,659 & & 11,200 \\
\hline Imnaha & 4,631 & 506 & & 4,600 \\
\hline Umatilla & 9,090 & & & 9,100 \\
\hline
\end{tabular}

Volume Required

Volumes are based on CHS + STS as these two species will be in the raceways at the same time. The overlap between the CHS and CHF will be considered during concept design.

Design Density Index

$$
\mathrm{DI}=0.18
$$

\section{CHS}

Density=1.25 lb/cf@10/lb

Density=1.09 lb/cf @15/lb

\section{$\mathrm{CHF}$}

Density=0.73 lb/cf@40/lb

Density=0.61 lb/cf@70/lb

STS

Density=1.40lb/cf@5/b

Volume (cf)

\begin{tabular}{|l|c|c|c|c|}
\hline Basin & CHS & CHF & STS & Total \\
\hline Walla Walla & 44,000 & & 14,200 & 51,100 \\
\hline Grande Ronde & 58,000 & 43,000 & & 58,000 \\
\hline Imnaha & 24,000 & 2,800 & & 24,00 \\
\hline Umatilla & 47,000 & & & 47,000 \\
\hline
\end{tabular}




\section{Summary}

Maximum flow and volume listed above

Maximum summer critical flow at $75 \%$ of maximum

Facilities Necessary or Desirable for Full Term Rearing Facilities

1. Water supply

2. Water treatment

3. Loading facilities

4. Office/storage/lab

5. Personnel facilities

6. Raceways/ponds

7. Sanitary facilities

8. Access

9. Utilities

1b. Security

11. Effluent water treatment and return

Assumed Size of a Complete Facilities

10 acres

Direct Release

Number of Fish

1.37 million CHF

0.380 million CHS subsmolt

Some portion of the remaining 2.47 million CHS smolts

Site Locations

Greater than 3 river miles between sites.

Schedule

- $\quad$ Spring Chinook

June-July-September (subsmolts)

- $\quad$ Fall Chinook

April-May

Summer S teelhead

None planned 


\section{Facilities Necessary or Desirable for Direct Release}

1. Access to river (safety consideration)

2. Flowing "pool" near access

3. Public parking if access is open (2-3 spaces)

\section{Final (Extended) Rearing/Acclimation Facilities}

Final rearing/acclimation of fish may occur over a period of time ranging from 3 to 30 days.

Number of Fish

CHS

Some portion of the 2.47 million CHS smolts

STS

100,000@5/lb

\section{Unit Assumption}

Assume 1 unit equal 100,000 fish @ 5/lb (arbitrary but convenient)

Schedule

- $\quad$ Spring Chinook March-May

Summer Steelhead March-April

Flow Required

Approximately 4 cfs/unit $(0.018$ gpm/fish $)$

Acclimation Unit Options to be Considered

Option 1 - Holding Raceway - Concrete Trough

A minimum of 2 independent sub units (tanks) per unit Volume each unit 8,600 cf

Area per unit - 2 acres

Option 2 - Pond (Earthen or FML Lined)

One or more ponds per unit

Volume each unit $20,000 \mathrm{cf}$

Area per unit (general) 4 acres

Option 3 - Flow through Natural Pond

Environment with developed cover and vegetation

One pond per unit 
Volume each unit 20,000 (plus) cf

Area per unit (general) 4 (plus) acres

Option 4 - Natural Side Channel

One per unit

Volume per unit $-10,000 \pm \mathrm{cf}$

Area per unit - depending upon site selection

Facilities Necessary or Desirable for Final Rearing/Acclimation Facility for the NEOH Basins

1. Water intake and supply

2. Raceway tankage/pond

3. Access

4. Security

5. Water discharge and return facilities

6. $\quad$ Release structure

7. Weir ladder and holding area if adult collection included

8. $\quad$ Fish barrier/ screens

Small-Scale Hatchery

Facility Size per Unit

50,000 smolts (10/lb) (preliminary assumption)

Water Quality

River water $8 / \mathrm{gpm}=700 \mathrm{gpm}(1.6 \mathrm{cfs})$

Groundwater 2.15/gpm 50 gpm

All incubation and early rearing (up to 500/lb) must be on groundwater or a disinfected surface water supply $\left(50^{\circ} \pm 5\right)$

\section{Facilities Required}

1. Water source surface and ground (disinfected surface water)

2. Egg source

3. Egg incubation (boxes, trough, etc.)

4. Raceways (2)

5. Utilities

6. Security

7. Sanitary Facilities

8. Personnel facilities 


\section{ADVANCED TECHNOLOGY APPROACHES}

\section{Adult Holding}

1. Conventional flow through facilities and refrigeration to use available water.

Assumptions:

Single Facility

2,965 gpm flow
Would require a peak $\left(\Delta \mathrm{T}=10^{\circ} \mathrm{F}\right)$ chiller capacity of approximately 1200 tons which equates to $830 \mathrm{kWh}$

2. Reuse and Refrigeration

Assumption:

$\begin{array}{ll}2965 \mathrm{gpm} & \\ 297 \mathrm{~g}-\mathrm{pm} & \text { Influent } 90 \% \text { recycle } \\ 30 \mathrm{gpm} & \text { Influent } 99 \% \text { recycle }\end{array}$

3. Influent detention basin to reduce peak daily maximum temperatures

Assumptions

$\begin{array}{cc}\begin{array}{c}\text { Detention Time } \\ \text { (hours) }\end{array} & \begin{array}{l}\text { Volume } \\ (\mathrm{ft})\end{array} \\ 2 & 48,000 \\ 4 & 95,000 \\ 6 & 143,000\end{array}$

4. Reduced flow during day + pure oxygen aeration

4000 gpm during night and early morning

$1000 \mathrm{gpm}$ recirculation flow during the afternoon

Incubation

1. Moist incubation for reduced groundwater use and refrigeration cost.

Assumptions:

Single Facility (1,376 gpm)

$50 \mathrm{gpm}$ needed

\section{Rearing}

1. Reuse for rearing supply.

Assumptions:

Single Facility $(33,365$ gpm) 
$90 \%$ reuse reduces flow from 74.5 to $7.5 \mathrm{cfs}$ with increased costs and complexity but workable in a water shortage.

2. Use of pure oxygen for satellite rearing to reduce water demand in combination with refrigeration.

Assumptions:

Single Facility $(33,365$ gpm)

74.5 cfs flow through water

24.8 cfs with 02 supplementation

Enhanced Species Introduction

Eggs Collected from Wild Stock or other Sources

1 ,OOO,OOO eggs (200 spawning pairs)

Adult Objective

500 adults at 1: $1(\mathrm{M}: \mathrm{F})$

Adults raised to full term from egg source for brood stock purpose.

Water Flow Necessary

Temperature $=55^{\circ}$

Loading $=3$ gpm/fish

Water Flow $=1,500 \mathrm{gpm}$

Volume Required

Density $=25 \mathrm{cf} /$ fish

Volume $=12,500 \mathrm{cf}$

\section{Facilities Required}

1. Complete hatchery facility

2. Brood stock tanks (no salt water)

3. Net pens

4. Brood stock tanks (salt water or recycle)

Potential Existing Site

Ore-Aqua facilities at Springfield or Newport, Oregon 


\section{SURFACE WATER AND GROUNDWATER AVAILABILITY AND QUALITY}

\section{SURFACE WATER}

\section{Surface Water Quantity}

The NEOH study area includes the Grande Ronde, Imnaha and Walla Walla Rivers. Streamflow data in these basins was obtained from the U.S. Geological Survey (USGS). The location of the gages with period of record greater than ten years is shown on the individual river basin drainage maps. Tabulated values and graphs of minimum, maximum and average streamflow, by month may be found in Appendix A. Table 17 summarizes the streamflow gages in these river basins, their source and period of record.

TABLE 17

\section{SUMMARY OF STREAMFLOW GAGES IN THE NEOH STUDY AREA}

\section{SOURCE}

USGS 13292000

USGS 13318500

USGS 13318800

USGS 13319000

USGS 13320000

USGS 13320000

USGS 13323500

USGS 13323600

USGS 13327500

USGS 13329500

USGS 13330000

USGS 13330500

USGS 13331500

USGS 13332500

USGS 13333000

USGS 14010000

USGS 14010500

USGS 14010800

USGS 14011000

USGS 14018500

USGS 14017000

USGS 14015000

USGS 14013000

\section{LOCATION}

Imnaha River at Imnaha

Grande Ronde River near Hilgard

Grande Ronde River at Hilgard

Grande Ronde River at La Grande

Catherine Creek nr Union (before diversion)

Catherine Creek nr Union (after diversion)

Grande Ronde River near Elgin

Indian Creek near Imbler

Wallowa River at Joseph

Hurricane Creek near Joseph

Lostine River near Lostine

Bear Creek near Wallowa

Minam River at Minam

Grande Ronde River at Rondowa

Grande Ronde River at Troy

S. Fork Walla Walla near Milton

S. Fork Walla Walla below PP\&L. nr Milton

N. Fork Walla Walla nr Milton-Freewater

N. Fork Walla Walla nr Milton

Walla Walla River near Touchet, WA

Touchet River at Bolles

Mill Creek at Walla Walla, WA

Mill Creek nr Walla Walla. WA
PERIOD

1929-1982

1938-1956

1\%7-1982

1904-1982

1912-1936

1938-1982

1956-1981

1939-1950

1905-1982

1925-1978

1913-1982

1925-1982

1966-1982

1927-1982

1945-1982

1907-1982

1904-1945

1970-1982

1931-1969

1951-1989

1941-1989

1941-1989

1939-1989 


\section{Surface Water Quality}

Water quality information for the NEOH study area included temperature measurements recorded by the USGS at three stations, Oregon Department of Environmental Quality (DEQ) water quality monitoring stations at 9 locations, and ongoing water temperature monitoring at a number of sites conducted by NPT Fisheries Department. Appendix B contains summaries of water temperature for a number of sites within the NEOH study area.

Three USGS gages in the NEOH study area included water temperature data (Table 18). Daily maximums and minimums are available for the period of record shown. The Minam River gage is a USGS hydrologic bench-mark station where extensive water quality data is available for the period of record.

TABLE 18

\section{USGS TEMPERATURE STATIONS IN THE NEOH STUDY AREA}

\begin{tabular}{lccc}
\multicolumn{2}{c}{ SOURCE } & \multicolumn{1}{c}{ LOCATION } & PERIOD \\
\hline & & & \\
USGS & 13331500 & Minam River at Minam & $1965-1985$ \\
USGS & 13329900 & Wallowa River at Wallowa & $1976-1977$ \\
USGS & 13330200 & Lostine River at Lostine & $1976-1977$ \\
\hline
\end{tabular}

There is extensive water quality data available in the Grande Ronde River basin. Table 19 lists DEQ monitoring stations where water quality data is available. The analysis performed for the DEQ monitoring stations is designed to determine basic water quality conditions. This data should be obtained in a site-specific basis for conceptual design purposes.

TABLE 19

\section{DEQ WATER QUALITY MONITORING STATIONS IN THE NEOH STUDY AREA}

\section{SOURCE}

\begin{tabular}{ll}
\multicolumn{2}{c}{ SOURCE } \\
\hline & \\
STORET & $\mathbf{4 0 2 3 9 8}$ \\
STORET & $\mathbf{4 0 2 3 9 7}$ \\
STORET & 402919 \\
STORET & 402400 \\
STORET & 402167 \\
STORET & 402396 \\
STORET & 402399 \\
STORET & 402080 \\
STORET & 402395
\end{tabular}
LOCATION PERIOD

Near Red Bridge State Park

Hilgard St. Park

Highway 82 Bridge

Catherine Creek at Cove

$3.8 \mathrm{mi}$. S. of Elgin

Hwy 82 E. of Elgin

Wallowa Lk. discharge

Wallowa River at Minam

Hinhwav 3
1967-1968

1967-1972

1966-67,1973

1960-1968

1962-1974

1967-1968

1966-1968

1968-1974

1966-1968

Spot observations of temperature and and other water quality parameters are available for the following drainages: Catherine Creek, Grande Ronde River, Lostine River, Indian Creek, Wallowa River, Minam River, and Prairie Creek.

Water samples for general minerals and other water quality parameters were collected at sites within each basin during initial site visits (Tables 20 and 21). 
TABLE 20

GRANDE RONDE BASIN - WATER QUALITY (4/91)

Sample Locations

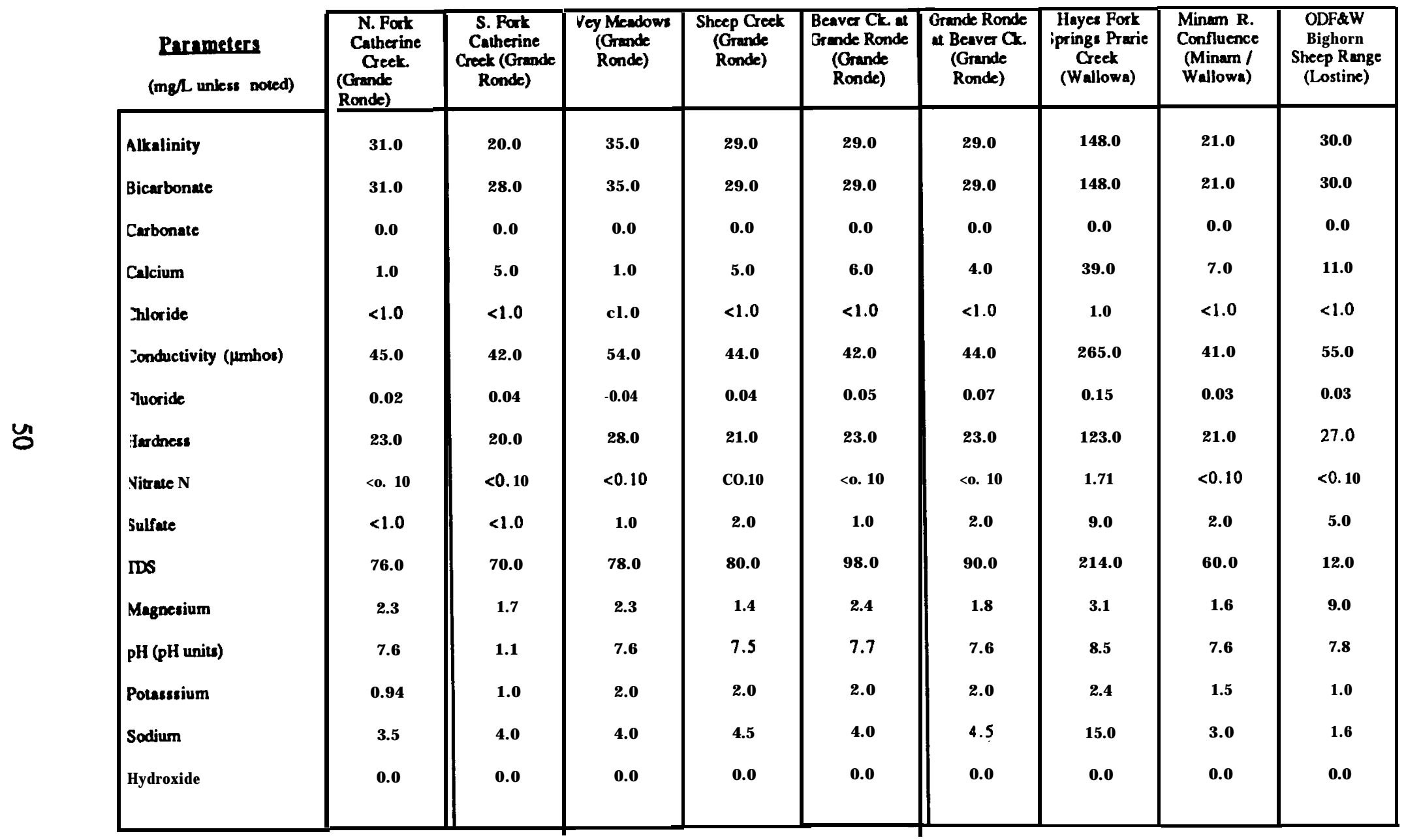


TABLE 21

WALLA WALLA AND IMNAHA BASINS - WATER GUALITY (4/91)

Sample Locations

\begin{tabular}{|c|c|c|c|c|c|}
\hline $\begin{array}{c}\text { Parameters } \\
\text { (mg/L unless noted) }\end{array}$ & $\begin{array}{c}\text { Touchet R. } \\
\text { at Dayton } \\
\text { (Touched/ } \\
\text { Walla } \\
\text { Walla) } \\
\end{array}$ & $\begin{array}{c}\text { S. Fork at } \\
\text { Harris Park } \\
\text { (Walla } \\
\text { Walla) }\end{array}$ & $\begin{array}{l}\text { Big Sheep } \\
\text { Creek } \\
\text { (Imnaha) }\end{array}$ & $\begin{array}{c}\text { Marr } \\
\text { Ranch } \\
\text { (Imnaha) }\end{array}$ & $\begin{array}{c}\text { Fence } \\
\text { Creek } \\
\text { near Marr } \\
\text { Ranch } \\
\text { (Imnaha) }\end{array}$ \\
\hline Alkalinity & 35.0 & 29.0 & 40.0 & 57.0 & 81.0 \\
\hline Bicarbonate & 35.0 & 29.0 & 40.0 & 57.0 & 81.0 \\
\hline Carbonate & 0.0 & 0.0 & 0.0 & 0.0 & 0.0 \\
\hline Calcium & 8.0 & 6.0 & 11.0 & 17.0 & 17.0 \\
\hline Chloride & c 1.0 & $\mathrm{c} 1.0$ & $<1.0$ & $<1.0$ & 1.0 \\
\hline $\begin{array}{l}\text { Conductivity } \\
\text { ( } \mu \text { mhos) }\end{array}$ & 62.0 & 51.0 & 89.0 & 115.0 & 136.0 \\
\hline Fluoride & 0.08 & 0.07 & 0.08 & 0.07 & 0.14 \\
\hline Hardness & 26.0 & 20.0 & 35.0 & 58.0 & 57.0 \\
\hline Nitrate N & $<0.10$ & $<0.10$ & $<0.10$ & $<0.10$ & $<0.10$ \\
\hline Sulfate & 1.0 & c 1.0 & 11.0 & 11.0 & 3.0 \\
\hline TDS & 80.0 & 70.0 & 110.0 & 110.0 & 140.0 \\
\hline Magnesium & 3.0 & 2.0 & 5.0 & 3.0 & 5.0 \\
\hline $\mathrm{pH}$ (pH units) & 7.0 & 7.1 & 7.9 & 8.2 & 7.9 \\
\hline Potassium & 1.6 & 1.6 & 1.7 & 1.7 & 5.1 \\
\hline Sodium & 2.3 & 2.1 & 6.5 & 4.5 & 8.8 \\
\hline Hydroxide & 0.0 & 0.0 & 0.0 & 0.0 & 0.0 \\
\hline
\end{tabular}




\section{Flood Frequency Data}

The Federal Emergency Management Agency Flood Insurance Studies for the drainage basins have been obtained from FEMA. These contain flood flow statistics and stages in the creeks and river as well as floodplain boundaries.

The Flood Insurance Study for each county or city with proposed sites was reviewed for flooding information or documentation. The 100-year return period flood boundary has been defined by The Federal Emergency Management Agency (FEMA) on the larger creeks and major rivers, and Table 22 indicates whether the site falls within the 10O-year flood boundary.

The flooding potential at each of the proposed sites was qualitatively evaluated and rated as low, moderate or high. This judgement was based on field observation, local knowledge and published documentation. Low flood potential means there were no evident signs of flood potential at the site, and no documented flood history. Moderate flood potential means there is a known or documented history of moderate flooding, or that the site lies within the FEMA defined 10O-year floodway, or if evidence of flooding was observed in the field. Sites were rated as having a high flood potential if there is a known or documented history of recurrent flooding.

\section{GROUNDWATER}

Groundwater potential for facility water supply has been evaluated to determine the potential for development of disease-free groundwater supplies ranging from 500 to 5000 gpm for egg incubation, fry rearing, and general hatchery water supply. Groundwater temperatures in the 50 to $60^{\circ} \mathrm{F}$ range are preferable.

The preliminary evaluation indicates that there is moderate to good potential for development of 500 to $1000 \mathrm{~g}$-pm wells at the identified sites in the Grande Ronde and Wallowa River drainages. There is poor to moderate potential for development of 500 to $1000 \mathrm{gpm}$ wells at the identified sites in the Imnaha River drainage. Test drilling as part of the Umatilla Satellite and Release Sites Project determined probable well yields in the 250 gpm range for an identified site on the South Fork Walla Walla River.

The evaluation is based primarily upon published geologic and hydrologic data and well logs on file with the Oregon Department of Water Resources. The well logs examined are nearly all domestic wells, typically drilled to the first water bearing zone of significance. As such, they do not give a true indication of groundwater potential at depth. Except for the test well drilling on the South Fork Walla Walla River, no field investigations of groundwater potential have been performed as part of this evaluation. A summary of the well logs that were reviewed is contained in Appendix C.

This evaluation describes groundwater development "potential", based upon regional data and limited local data. Thus, it is possible that only low yield wells might be developed at sites identified as having "good potential", or high yield wells might be developed at sites described as having "poor potential". Additional investigations will be required at all sites selected for further study. This additional study may consist of further well log review, conversations with local well drillers and residents, and field examination of 
TABLE 22

QUALITATIVE EVALUATION OF FLOOD POTENTIAL AT PROPOSED SITES

\begin{tabular}{|c|c|c|c|c|}
\hline Sites In Grande $\begin{array}{c}\text { Rone River Dralnsge } \\
\text { Basin }\end{array}$ & River & $\begin{array}{c}\text { Flood } \\
\text { Potential } \\
\end{array}$ & $\begin{array}{l}\text { SIte Withln 100: } \\
\text { Year Floodway }\end{array}$ & Comments \\
\hline 1. Catherine Creek N\&S forks confluence & Catherine Creek & High & NoFEMAdata & bottom freezing, ice jams \\
\hline 2. Catherine-Milk Creek confluence (OSU site) & Catherine Creek & Moderate & NoFEMAdata & \\
\hline 3. Catherine Creek at Union (Old Hatchery) & Catherim Creek & Moderate & NoFEMAdata & \\
\hline 4. Vey Meadows & Grade Ronde & Low & NoFEMAdata & \\
\hline 5. SheepCreek & Sheep Creek & Low & NoFEMAdata & \\
\hline 6. Beaver Creek & Beaver Creek & High & NoFEMAdata & South side is braided river chamel \\
\hline $\begin{array}{l}\text { 7. Sanderson Springs/Mill Creek (site } \\
\text { ellmlnated) }\end{array}$ & & & & \\
\hline $\begin{array}{l}\text { 8. Lower Wlllow Crk near Elgln (site } \\
\text { ellmlnated) }\end{array}$ & & & & \\
\hline 9. Indian Creek near Elgin & Indian Creek & Low & No FEMA data & \\
\hline 10. Gmnde Ron\& near Elgin (b) & Grande Ronde & Moderate & Yes & \\
\hline 11. Looking Glass Hatchery & Looking Glass Crk & Low & No FEMA data & \\
\hline 12. Wildcat Creek Area & Wildcat Creek & Moderate & Yes & \\
\hline 13. Fish Ladder (Former USFWS Research Site)) & Grande Ronde & Moderate & Yes & \\
\hline 14. Flora Grade (Schoolbus Flats) & Grande Ronde & Moderate & Yes & \\
\hline 15. Cottonwood Creek & Grande Ronde & Low & No FEMA data & \\
\hline 16. Wallowa Lake & Wallowa R. & Moderate & Yes & \\
\hline \multicolumn{5}{|l|}{$\begin{array}{l}\text { 17. Hayes Fork-Prarle Creek (site } \\
\text { ellminated) }\end{array}$} \\
\hline 18. Wallowa Hatchery & Wallowa R. & Low & No & \\
\hline 19. Big Canyon Creek & Wallowa R. & Moderate & Yes & \\
\hline 20. Minam River confluence with Wallowa & Wallowa R. & Low & No & \\
\hline 21. ODFW Bighorn Sheep range & Lostine R. & High & Yes & icing conditions, gravel deposition \\
\hline 22. Strathearn Ranch & Lostine R. & Moderate & Yes & \\
\hline 23. Lostine Darn & Lostine R. & Moderate & Yes & \\
\hline 24. Cross-Valley diversion & Lostine R. & High & Yes & site in floodplain \\
\hline
\end{tabular}


Table 22 (cont.)

\begin{tabular}{|l|c|c|c|c|}
\hline \multicolumn{1}{|c|}{ SItes in Imnaha RIver Drainage Basin } & RIver & $\begin{array}{c}\text { Flood } \\
\text { Potential }\end{array}$ & $\begin{array}{c}\text { Site Withln 100- } \\
\text { Year Floodway }\end{array}$ & Comments \\
\hline 1. Indian Crossing & Imnaha River & Low & No FEMA data & \\
\hline 2. Gumbout Creek (Fish Weir) & Gumboot Crcek & Low & No FEMA data & \\
\hline 3. Grouse Creek-Imnaha confluence & Imnaha River & Moderate & Yes & \\
\hline 4 Big Sheep-Lick Creek confluence & Big Sheep Creek & Low & No FEMA dala & \\
\hline 5. Big Sheep Creek & Bigg Sheep Creek & Moderate & Yes & \\
\hline 6. Big Sheep-Little Sheep confluent & Big Sheep Creek & Moderate & YeS & \\
\hline 7. Little Sheep Creek & Little Sheep Creek & Low & No FEMA data & \\
\hline 8. Gene Marr Ranch & Imnaha River & Moderate & YeS & \\
\hline 9. Horse Creek (slte eliminated) & & & & \\
\hline
\end{tabular}

\begin{tabular}{|l|c|c|c|c|}
\hline Sites In Walla Walla River Drainage Basin & River & $\begin{array}{c}\text { Flood } \\
\text { Potentlal }\end{array}$ & $\begin{array}{c}\text { Site Within 100- } \\
\text { Year Floodway }\end{array}$ & Comments \\
\hline 1. NE 8th Street Bridge (Milton Freewater) & Walla Walla River & Low & No & \\
\hline 2. 9rh and Walnut (Milton Freewater) & Walla Walla River & Low & No & \\
\hline 3. Harris Park (at park) & S Fork Walla Walla & Low & No & \\
\hline 4. Harrls Park No. 2 (site ellminated) & & & & \\
\hline $\begin{array}{l}\text { 5. S. Fork/Elbow Creek confluence (site } \\
\text { ellm) }\end{array}$ & & & & \\
\hline 6. Russell Walker property & S Fork Walla Walla & Moderate & Yes & \\
\hline 7. Wolf Fork Confluence & Wolf Fork & undetermined & undetermined & \\
\hline 8. WDW Dayton Conditioning Pond & Touchet River & undetermined & undetermined & \\
\hline 9. Railroad Bridge (a) & Walla Walla River & undetermined & undetermined & \\
\hline 10. Pond at FS houndary & N Fork Touchet River & undetermined & undetermined & \\
\hline
\end{tabular}


sites. Test well drilling is recommended at all sites selected for further study of the potential for development of incubation/early rearing facilities

A technical term frequently used in the following discussions is "specific capacity". Specific capacity is an expression of the productivity of a well, and is derived by dividing well yield by water-level drawdown. Specific capacity is typically expressed by $\mathrm{gpm} / \mathrm{ft}$. For instance, a well that yields $400 \mathrm{gpm}$ with 100 feet of water level drawdown would have a specific capacity of $4 \mathrm{gprn} / \mathrm{ft}$. In general, specific capacities of less than one gpm/ft indicate poor production potential.

\section{Aquifers}

Aquifers in the NEOH study area include the following general units:

$$
\begin{aligned}
& \text { Basalt aquifers } \\
& \text { Sedimentary aquifers } \\
& \text { Igneous and metamorphic aquifers. }
\end{aligned}
$$

These units are briefly discussed below in order of importance. Much of the following discussion is based upon information taken from Gonthier (1985).

Basalt Aquifers. Basalt aquifers in northeastern Oregon consist of layered sequences of lava flows with some sedimentary interbeds, tuff, and flow breccia. The basalt aquifers are part of the Columbia River Group, a major interstate aquifer system. The basalt aquifers are highly developed in the irrigated areas west and north of Pendleton, but are largely undeveloped in the upland areas to the east. Typical high capacity wells in the basalt aquifers yield 500 to $1000 \mathrm{gpm}$, with specific capacities typically ranging from 5 to 50 gpm/ft.

Hampton (1964) noted that in the Grande Ronde Valley, there is a 50 percent chance of obtaining $1 \mathrm{gpm} / \mathrm{ft}$ of drawdown per 100 feet of saturated basalt penetrated. In other words, specific capacity would average $2 \mathrm{gpm} / \mathrm{ft}$ for a 200 -foot well or $4 \mathrm{gpm} / \mathrm{ft}$ for a 400 foot well. Thus, the potential yield from a well completed in the basalt is generally directly proportional to the saturated thickness of rock penetrated.

Sedimentary Aquifers. Sedimentary aquifers consist of layered sequences and mixtures of clay, silt, sand, and gravel. Within the NEOH study area, sedimentary aquifers are most prominent in the Grande Ronde Valley and in the Enterprise area. The Grande Ronde Valley sediments are as much as 2000 feet thick, and consist primarily of sand and clay. The best aquifers are typically sand units in the upper 300 feet of the sediments, and coarse-grained alluvial fan deposits near the large inflowing streams at the valley margins. Specific capacities of wells in the Grande Ronde Valley are typically in the range of 5 to $10 \mathrm{gpm} / \mathrm{ft}$, although yields appear to vary considerably with location. In the Enterprise area, the aquifers are found in glaciofluvial, ground moraine, and alluvial deposits.

In addition to deep sediment sequences, Quaternary alluvium (surface sand and gravel) is present at many sites. Where deep enough, the alluvium often has potential for groundwater production. However, groundwater from the alluvium is often obtained from surface water infiltration and is thus subject to variations in temperature and quality.

Igneous and Metamorphic Aquifers. Igneous and metamorphic rocks of Cretaceous to Devonian age form the cores or basement beneath much of highlands in northeastern Oregon. These aquifers are exposed in areas such as the lower Imnaha River where 
erosion has cut through the overlying blanket of Columbia River basalt. The igneous and metamorphic aquifers typically have low permeability, with typical specific capacities of less than $0.5 \mathrm{gpm} / \mathrm{ft}$.

\section{Grande Ronde River Basin Sites}

Beaver Creek Area. The Beaver Creek area is mapped as Columbia River Basalt, with overlying sediments in areas. Potential aquifers are found in the basalt. Groundwater potential at this site should be considered similar to other areas of basalt aquifer in the upper Grande Ronde basin. That is, there is a 50 percent chance of $500 \mathrm{gpm}$ yield from a 500foot well with a 100-foot pumping level. However, the well logs from the Beaver Creek area suggest that yields from moderately deep wells may be slightly less than average for the Grande Ronde Basin (Appendix C).

Catherine Creek at Union. At Union, the surficial geology is alluvial fan material, with Columbia River Basalt exposed at the surface to the east of Union. The Columbia River Basalt is below the fan material at Union at depths of more than 150 feet on the west side of town. Basalt is at the surface on the east side of town. High capacity wells in town would tap basalt aquifers.

Groundwater potential at this site should be considered as similar to other areas of basalt aquifer in the upper Grande Ronde basin. That is, there is a 50 percent chance of $500 \mathrm{gpm}$ yield from a 500-foot well with a 100-foot pumping level. Note that the City of Union has drilled three deep (1200 to 1695 feet) municipal wells with high yields (800 to $1922 \mathrm{gpm}$, Appendix C). However, these wells also have relatively high temperatures (68 to $\left.72^{\circ} \mathrm{F}\right)$.

Hampton (1963) reported that a 337-foot well completed in the Catherine Creek alluvial fan about 2 miles northwest of Union produced 3,000 gpm sustained yield with a 95-foot pumping level. Temperature from this well was reported to be 58 degrees. This suggests good potential from sediments in the area north and west of Union.

In general, chances for development of facility groundwater supplies are good at Union, although cold groundwater may need to piped one mile or more to a hatchery facility at the primary site being considered. Warm groundwater should be available from wells in close proximity to town.

Catherine Creek at OSU Site. The geology at the OSU site consists of alluvial sediments in the valley bottom which are underlain by Miocene basalt and Triassic marine sedimentary rocks and volcanics. Thickness of the alluvium is unknown, but might be in the range of 100 to 150 feet. The older rocks are exposed at the surface to the south and east, near the forks of Catherine Creek and in the southeast comer of the valley. The older rocks have relatively low groundwater potential, and the bedrock groundwater target will be fractured basalt along identified shear zones. The character of the Columbia River basalts in this area of Catherine Creek is different than other areas of the Grande Ronde basin, with the rock having a somewhat andesitic appearance. The groundwater potential from these rocks is not well known, given a lack of wells in the vicinity of the site. The nearest successful well is at Catherine Creek State Park. The driller's log for this well reported that it is 365 feet deep and flowed $80 \mathrm{gpm}$ of $70^{\circ} \mathrm{F}$ water. No shut-in pressure was reported on the $\log$.

There appears to be potential for warm groundwater from deep basalt wells and cold groundwater from alluvial sediments in this area. A groundwater investigation at this site would probably best be accomplished by conducting a geophysical (seismic refraction) 
survey to determine bedrock profiles across the valley. Based upon the seismic profiles, a shallow test well could be drilled at the site with the greatest thickness of alluvial fill. A deep test well would also be recommended. The deep well would preferentially be sited along one of the identified faults in the vicinity of the site.

Lower Willow Creek near Imbler. According to Hampton (1964), an irrigation well located one mile east of Imbler (1S/38E-24) is 1,150 feet deep and flowed 3,500 gpm with a shut-in pressure of 43 psi and a temperature of 84 degrees. The well penetrated sand and clay to a depth of 685 feet, including 29 feet of coarse sand at 541 feet that flowed $65 \mathrm{gpm}$. Thus, it appears that the Imbler area has good potential for high capacity wells, although well depth may exceed 500 feet and temperature may be a problem with deeper (greater than 700 feet) wells.

Well logs for this area show moderate potential from sediments above 500 feet, and good potential from basalt aquifers below 500 feet (Appendix C). However, we anticipate that temperatures from the deep wells will be in excess of $60^{\circ} \mathrm{F}$.

Grande Ronde River near Elgin. Groundwater at Elgin could be obtained from either the basalt or the overlying lake-bed sediments. Hampton (1964) reported that two municipal wells for the City of Elgin were completed in basalt below the lake bed sediments, with total depths of 350 and 655 feet. Each well cut about 100 feet of basalt. Yield from the deeper well was tested at 1,095 gpm with 87 feet of drawdown (12.6 $\mathrm{gpm} / \mathrm{ft})$, and $552 \mathrm{gpm}$ with 27 feet of drawdown $(20.4 \mathrm{gpm} / \mathrm{ft})$. Yield from the shallower well was $590 \mathrm{gpm}$ with 62 feet of drawdown $(9.5 \mathrm{gpm} / \mathrm{ft})$ and $300 \mathrm{gpm}$ with 38 feet of drawdown $(7.9 \mathrm{gpm} / \mathrm{ft})$. The deep well temperature was 52 OF with $140 \mathrm{ppm}$ total dissolved solids. These wells suggest good potential for high capacity (500 to $1000 \mathrm{gpm}$ ) basalt wells in this area.

Well logs from the area northwest of Elgin show relatively poor yields from the sediments. For instance, the Ronald Rademacher well penetrates "clay, rocks, and sand" to 400 feet (Appendix C). Although these wells are not constructed for efficient production, it appears that the gravels and sands tapped in this area are typically too clayey for high yield. Thus, the shallow (sediment aquifer) groundwater potential west of Elgin should be considered relatively poor.

Sanderson Springs Area (Mill Creek). This area is located north of Summerville within the Grande Ronde structural basin. The area is mapped as containing alluvial fan deposits underlain by lake-bed sediments. The logs indicate a considerable amount of gravel and sand, but most appear to be mixed with clay. Therefore, it may be difficult to intercept a clean, coarse layer of sand or gravel for high capacity wells. The Marvin Peterson well went into rock at 88 feet, indicating that basalt may be shallow in some places (Appendix C).

Given the success of deep wells near Imbler (discussed in connection with the Lower Willow Creek site), there is good potential for development of high capacity (500 to 1000 gpm) deep wells in this general area. However, temperature could be a problem with deep basalt wells.

Lookingglass Hatchery. Lookingglass Hatchery was evaluated during a June 18-19 site visit. There appears to be considerable potential for additional groundwater development at the Lookingglass Hatchery. The hatchery manager, Scott Lusted, provided information for their current water supply situation. It appears that fish production is currently limited by some relatively minor problems, most of which appear to be solvable. 
In terms of groundwater, the hatchery manager does not feel comfortable with increasing production from the system for the following reasons.

He was told that the pipeline from Tempering Well No. 2 is sized for 2000 gpm, so they limit their pumping in that pipeline to only $2000 \mathrm{gpm}$. (Tempering Well 2 is equipped with a nominal 2000 gpm pump, but the well is capable of much more).

He does not think that they have sufficient water rights to produce more water.

Operation of Tempering Well No. 1 causes interference in the nearby domestic well, which results in domestic well pump cavitation. Therefore, they do not operate Tempering Well No. 1.

Following the site visit, well logs were obtained from ODWR for the four wells at the facility (Tempering Well No. 1, Tempering Well No.2, Test Well BI, and the domestic well). A copy of Hvdroeeological Evaluation - Lookineglass Fish Hatchery prepared for the Corps of Engineers by SRH Environmental Management was also reviewed. SRI-I concluded that Tempering Well No. 2 is capable of 3000 to $4000 \mathrm{gpm}$. They predicted pumping well drawdown of only 39 feet after 30 days of continuous pumping at 3000 gpm. The well is about 500 feet deep with a 130-foot static water level. SRH recommended increasing production from Tempering Well No. 2 and construction of an additional well north of the facility along Jarboe Creek.

Based upon the SRI-I report and our conversation with the hatchery manager, there appears to be good opportunities to increase groundwater production at the facility. This would require abandoning or deepening both Tempering Well No. 1 and the nearby domestic well so that pump exposure is not a problem. The pump size in Tempering Well No. 2 could be increased, and additional production wells drilled. It is realistic to expect that the hatchery groundwater production couId be more than doubled (i.e. to $5000 \mathrm{gpm}$ or more), at least for seasonal uses such as tempering. Also, it appears that temperature is not a problem with their existing wells, so that deeper wells could also be completed at the site.

\section{Wallowa River Sites}

Wallowa Hatchery. The well log from a deep production well at the Wallowa Hatchery in Enterprise suggests poor production potential at this site (Appendix C). This well was 942 feet deep with 19 psi artesian pressure but only produced 120 gpm with a 335-foot pumping level. A shallower (288-foot) production well at the same site produced $183 \mathrm{gpm}$ with 42 feet of drawdown, suggesting that production potential is highly variable. Most of the water at the hatchery site may be derived from the shallower basalt aquifers. Other well $\operatorname{logs}$ from the Enterprise area are either completed in relatively shallow gravel aquifers or in basalts. The gravels appear to be too thin or shallow for large capacity wells. The basalts typically do not show significant production potential.

Information obtained during a June 18, 1991 site visit to the Wallowa Hatchery suggests that additional water supplies might be developed with a groundwater exploration program. Existing wells include a moderate producer $(200 \mathrm{gpm} \pm, 288$ feet deep), a poor producer (150 gpm, \pm 942 feet deep), and an almost dry hole (10 gpm, \pm 255 feet deep). Although it does not appear likely that high capacity wells could be constructed in this area, an exploration program consisting of six-inch diameter 500-foot test holes could probably develop a total of 300 to 500 hundred gpm. 
Hayes Fork - Prairie Creek. The geology in this area appears to consist of basalt which is overlain by alluvium, fanglomerate, and glacial moraine. Depth to basalt bedrock ranges from less than 10 feet to more than 150 feet. As with the Enterprise area, the gravels appear to be too thin or shallow for large capacity wells and the basalts typically do not show significant production potential (Appendix C).

Minam-Wallowa Confluence. The geology of this area is all Columbia River Basalt. Two well logs are available, both completed in Columbia River Basalt (Appendix C). The logs show moderate to good potential for high capacity (greater than $500 \mathrm{gpm}$ ) wells.

\section{Lostine River Sites}

The Strathearn Ranch on the Lostine River is located at the lower end of a glacially formed valley. The geology of the Srratheam site consists of alluvial and glacial sediments in the valley floor, generally underlain by Columbia River basalt. Near the upstream (southern) property boundary at the Strathearn Ranch, one of the Wallowa Mountain range frontal faults cuts across the valley. The fault separates the basalts to the north from Triassic-age marine sediments found on the south, or upthrown, side of the fault.

Successful cold water $\left(50-55^{\circ} \mathrm{F}\right)$ wells can probably be developed in the alluvial/glacial sediments. In addition, the alluvial sediments may be sufficiently permeable to permit the use of shallow "collector-type" wells or laterals for water supply. Potential for development of successful cold water wells is rated at 60 percent.

There is potential for warmer $\left(>55^{\circ} \mathrm{F}\right)$ water wells completed in the basalt at the Strathearn site.. Potential for successful warmer water wells is rated at 50 percent.

Five well logs from the vicinity of the Strathearn Ranch range from 70 to 240 feet in depth, and all are in sand and gravel (Appendix C).

\section{Imnaha River Basin Sites}

Four potential facility sites have been examined for groundwater potential in the Imnaha River Basin. They are the Big Sheep Creek - Imnaha River Confluence, the Little Sheep Creek - Big Sheep Creek Confluence, the Gene Mar-r Ranch and the mouth of Horse Creek. In addition to the identified sites, the Imnaha River area upstream of Imnaha has also been evaluated.

Big and Little Sheep Creeks are in areas of Columbia River basalt. Driller's logs from these areas suggest that the basalt flows do not have significant sedimentary interbeds or highly permeable inter-flow zones, suggesting that this area may have less than average production potential in comparison to other areas of of the Columbia River Basalt aquifer.

Gene Marr Ranch. The Marr Ranch and the mouth of Horse Creek sites are located in areas of partially metamorphosed sedimentary and igneous rocks of Triassic and Permian age. These rocks are probably present as basement rocks beneath the Columbia River Basalt throughout much of the Imnaha Basin, and are exposed by erosion in the lower portion of the canyon. We anticipate poor production potential for wells completed in these rocks, unless significant fractured zones are encountered.

A field reconnaissance to the Gene Mar-r Ranch to evaluate groundwater potential was made on June 18. The geology at the Gene Marr Ranch is not conducive to groundwater development by wells. The geology at the site consists of a fine-grained mafic intrusive rock (perhaps andesite or dacite). This rock crops out along the river at the upstream end 
of the Marr Ranch and continues downstream for more than a mile. Anticipated well yields at the ranch site would be less than $50 \mathrm{gpm}$. Groundwater might also be warm at this site, as a fault-related warm spring is present along the river about one-quarter mile downstream of the ranch.

Although on-site wells do not appear to be practical, there is groundwater available from springs. These springs surface from a permeable basalt layer a few hundred feet above the river level. The combined flow of the springs which supply Fence Creek (at the upper end of the property) and Fall Creek (at the lower end of the property) is probably about $4 \mathrm{cfs}$ (1500 to $2000 \mathrm{gpm}$ ).

An additional source of groundwater for this site might be obtained by drilling wells into the basalt upstream of the Marr Ranch and piping it to a facility at the ranch. For instance, the Clyde Simmons well (about one-half mile upstream) has a specific capacity of $6 \mathrm{gpm}$ per foot and a total depth of about only about 100 feet. A total of a few hundred gpm might be developed from shallow basalt wells in this area.

The well logs available for the Imnaha basin are all domestic wells, typically drilled to the first water bearing zone of significance (Appendix C). As such, they do not give a true indication of groundwater potential in the Imnaha River Basin. However, in general the well logs show relatively poor production, with many drilled to over 100 feet below the water table before encountering enough water for domestic use. Thus, the potential for high-yield water supply wells appears to be relatively low in comparison to other areas of basalt aquifers in northeast Oregon. Probable yields are a few hundred gallons per minute from deep wells, with possible yields of less than $100 \mathrm{gpm}$. Probable temperatures from deep (400 to 800 feet) wells would be in the mid to upper 50's.

A test well at the Little Sheep Creek Hatchery site was 100 feet deep, with a specific capacity of $3 \mathrm{gpm}$ per foot of drawdown, and a static water level of 10 feet. Assuming that the hydrogeology is relatively consistent with depth at that site, we might expect yields in the range of $500 \mathrm{gpm}$ from a well 500 to 1000 feet deep with at 250-foot pumping level. However, this facility is several miles upstream from the proposed sites and may not be representative of aquifer conditions at the proposed Big Sheep Creek - Imnaha River Confluence and Little Sheep Creek - Big Sheep Creek Confluence sites.

In general, it appears that the Big Sheep Creek - Imnaha River Confluence and Little Sheep Creek - Big Sheep Creek Confluence sites have the best groundwater potential of the four identified Imnaha basin sites, based upon geology and well logs. Probable deep (400 to 800 feet) well yields would be in the range of a few hundred gallons per minute. Similar groundwater potential is available along the river upstream of Imnaha. At the Horse Creek and Gene Marr Ranch sites, deep well yields might be less than a hundred gallons per minute because the wells would be completed in igneous and metamorphic aquifers rather than the basalt aquifers present further upstream.

\section{Walla Walla River Basin Sites}

Four potential facility sites have been evaluated on the South Fork of the Walla Walla River. These sites are Harris Park No. 1, Harris Park No. 2, South Fork - Elbow Creek Confluence, and the South Fork area between Harris Park and the mouth of the North Fork. Potential aquifers within the South Fork of the Walla Walla basin are all Yakima Basalt. Anticipated aquifer characteristics in this area are similar to those of basalt aquifers in the Umatilla River area. 
A test well was drilled at the Russell Walker site (located between Harris Park and the mouth of the North Fork) for the Umatilla Satellite and Release Sites Project. The well was 450 feet deep and is projected to be capable of a sustained yield of approximately 250 gpm. However, the groundwater is warm $\left(68^{\circ} \mathrm{F}\right)$ and has about 1 ppm hydrogen sulfide.

Review of well logs suggests that the potential sites on the South Fork of the Walla Walla River can be considered to all have similar aquifer characteristics and groundwater development potential (Appendix C). As such, we would expect poor to moderate potential for $500 \mathrm{gpm}$ yields from deep basalt wells. Chances for warm $\left(>60^{\circ} \mathrm{F}\right)$ water temperatures are high at all sites, and hydrogen sulfide may be a problem, although a local resident reported that sulfur odor is not present in wells completed in the Harris Park area.

\section{Powder River Basin Sites}

Eagle Creek (upstream from Newbridge) - This site is located about four miles above Newbridge in an area mapped as basalt. Thus, we anticipate that wells would be completed in basalt aquifers.

Well logs indicate that wells in this area are all completed in basalt and all have very low yields (Appendix C). Thus, the groundwater potential appears to be relatively low .

\section{Summary of Sites}

\section{Grande Ronde River Basin Sites}

Beaver Creek - Grande Ronde Confluence. Moderate potential for high yield (>500 gpm) wells based upon geology and local well logs. Basalt aquifers.

Catherine Creek at Union. Good potential for 500 to 1000 gpm wells based upon geology and local well logs. Basalt aquifers or nearby sedimentary aquifers. Temperatures will be-high from high-yield, deep basalt wells.

Catherine Creek at OSU Site. Low to moderate potential for $500 \mathrm{gpm}$ wells completed in bedrock aquifers. Fair potential for development of groundwater supplies from alluvium.

Lower Willow Creek (near Imbler). Moderate to good potential for 500 to 1000 gpm wells based upon geology and local well logs. Basalt aquifers or sedimentary aquifers. Temperatures will be high from deep, high-yield basalt wells.

Grande Ronde River (near Elgin). Good potential for 1000 gpm wells based upon geology and local well logs. Basalt aquifers.

Sanderson Springs (Mill Creek). Moderate to good potential for 500 to $1000 \mathrm{gpm}$ wells based upon geology and local well logs. Basalt aquifers or nearby sedimentary aquifers. Temperatures may be high from deep, high-yield basalt wells.

\section{Wallowa River Basin Sites}

Wallowa Hatchery. Low to moderate potential for high yield wells. Basalt aquifers.

Hayes Fork - Prairie Creek. Low to moderate potential for high yield wells. Basalt aquifers. 
Minam River - Wallowa River Confluence. Moderate to good potential for high yield (>500 gpm) wells based upon geology and local well logs. Basalt aquifers.

Lostine River - ODFW Bighorn Sheep Range. Moderate potential for $500 \mathrm{gpm}$ wells based upon geology and local well logs. Glacial or alluvial aquifers.

Lostine River - Strathearn Ranch. Moderate potential for high yield wells based upon geology and local well logs. Glacial or alluvial aquifers.

\section{Imnaha River Basin Sites}

Gene Marr Ranch. Low potential for 500 gpm wells based upon geology and local well logs. Igneous and metamorphic aquifers.

Horse Creek - Imnaha River Confluence. Low potential for 500 gpm wells based upon geology. No local well log data. Igneous and metamorphic aquifers.

Big Sheep Creek - Imnaha River Confluence. Moderate potential for 500 gpm wells based upon geology and local well logs. Basalt aquifers.

Little Sheep Creek - Big Sheep Creek Confluence. Moderate potential for 500 gpm wells based upon geology and local well logs. Basalt aquifers.

Imnaha River Upstream of Imnaha. Moderate potential for high yield wells based upon geology and local well logs. Basalt aquifers.

\section{South Fork Walla Walla River Basin Sites}

Harris Park No. 1. Low to moderate potential for high yield (>500 gpm) wells based upon geology and local well logs. Basalt aquifers.

Harris Park No. 2. Low to moderate potential for high yield (>500 gpm) wells based upon geology and local well logs. Basalt aquifers.

South Fork - Elbow Creek Confluence. Low to moderate potential for high yield (>500 gpm) wells based upon geology and local well logs. Basalt aquifers.

South Fork area between Harris Park and the mouth of the North Fork. Low to moderate potential for high yield (>500 gpm) wells based upon geology and local well logs. Basalt aquifers.

\section{Powder River Basin Sites}

Eagle Creek. Very low potential for high yield wells. Basalt aquifers.

\section{RECOMMENDATIONS FOR FURTHER GROUNDWATER EVALUATIONS}

With the selection of four potential incubation/early rearing sites within the NEOH project area (see Section 8-Program Development), more detailed groundwater evaluations at these sites are recommended prior to conceptual design. Siting has been based upon location, surface water quality and availability, and groundwater potential. The four sites are (1) the confluence of the Minam and Wallowa Rivers, (2) the Imnaha River, (3) Catherine Creek 
upstream of Union, and (4) the Lostine River at the Strathearn Ranch. Discussions of site geology, well location criteria, and proposed test well designs follow.

Information in this section builds upon the information presented above for specific sites. The initial groundwater evaluation consisted of a review of regional geology and hydrogeology, and review of driller's logs for wells completed near identified potential facility sites.

\section{Minam-Wallowa Confluence}

The Minam-Wallowa confluence site is located on the south bank of the Wallowa, just downstream of the mouth of the Minam. The geology of this area consists of Columbia River Basalt, with a basalt intrusive mapped on the north side of the river downstream of the confluence. Significant thicknesses of saturated alluvium do not appear to be present, and there are no mapped faults or geologic structures in the vicinity of the proposed hatchery site.

A test well site near the confluence, probably in the vicinity of the electrical substation is recommended. This location takes advantage of the intersection of linear topographical features. Linear features may indicate fractures or zones of weakness in the basalt, which could potentially increase groundwater potential. The proposed well location also would be at the upper end of any hatchery facilities, in the proximity of any potential surface water intake structures where de-icing water may be needed. Potential for a successful (500 $\mathrm{gpm})$ test well is rated at 60 percent at this site.

A test well at this site would be drilled to a projected depth of 600 feet. The well would be completed with 8-inch well casing to approximately 150 feet. The well would be completed as an open hole below 150 feet unless caving conditions are encountered. If caving is encountered, the hole will be lined with 6-inch perforated casing.

\section{Imnaha Area}

Gene Marr Ranch. Two areas are being considered for hatchery development on the Imnaha River. The downstream area would obtain groundwater from springs while the upstream areas would obtain groundwater from wells. The downstream site, Gene Marr Ranch, has spring water available from Fall Creek for disease free purposes, and spring water from both Fall Creek and Fence Creek for cooling or de-icing. Although Montgomery Watson has not measured flows from these sources, visual estimates suggest that 600 to 1000 gallons per minutes are available from each, for a total groundwater supply of about $1500 \mathrm{gpm}$.

The geology at the Marr Ranch site consists of what appear to be intrusive volcanic rocks of late Triassic age. Overlying the Triassic volcanics are younger Miocene-age basalts of the Columbia River Group. The springs that supply Fall and Fence Creeks issue from springs located along a permeable basalt layer at an approximate elevation several hundred feet above the river level. A normal fault is located in the vicinity of the Fall Creek springs. The relationship between the fault and the springs is not clear, but the fault related fracturing may be partly responsible for the significant flow from the Fall Creek springs.

The Triassic volcanics at the Marr Ranch have poor potential for significant groundwater production from wells. Expected well yields from these rocks would be less than $50 \mathrm{gpm}$. If groundwater from wells is needed, it might be possible to obtain some supply from wells located upstream of the Gene Marr Ranch, were basalt is present in the canyon bottom. However, it is possible that the Triassic volcanics are also present below the basalt in these 
areas at relatively shallow depths, so that well yields might be limited to a less than a hundred gallons per minute.

A warm spring located approximately one-quarter mile downstream of the Marr Ranch emerges from the Triassic volcanics in the canyon bottom. The spring appears to flow a few gallons per minute or less, and is located along a large fracture that is visible on both sides of the river. There might be potential to develop water along this fracture with a well, but significant yields (i.e., more than $50 \mathrm{gpm}$ ) would not be expected.

Upstream Sites. Potential hatchery sites were identified on river bars a few miles above the town of Imnaha. The geology at these sites consists of Columbia River Group basalts informally named the Imnaha Basalt (Walker 1979). There are no geologic structures mapped in the vicinity of these properties. A basalt intrusive body is mapped by Walker (1979) along the west side of the river, above the Royes property. This intrusive body forms a prominent high terrace above the river, and was formerly mapped as a fault (Walker, 1977). It is unlikely that this feature will contribute to the water bearing properties of the rocks at the potential sites.

As no significant geologic structures have been identified at these sites, the wells should be located along linear features (i.e., at the mouths of creeks or draws) when practical. The linear features could indicate zones of weakness or more pervasive fracturing. However, these features may not significantly increase the chances of a successful well and we suggest that test wells be located where convenient. Potential for successful (500 gpm) wells at either of these sites is rated at 40 percent.

Well construction at these sites should consist of 8 -inch well casing extending to an approximate depth of 150 feet. The wells should be completed as open-holes below the 8inch casings to a target depth of 600 feet, unless caving conditions are encountered In the event of caving, the holes should be lined with 6-inch perforated casing.

\section{Upper Grande Ronde Basin - Catherine Creek}

Catherine Creek and the Grande Ronde River (above LaGrande) have been investigated for groundwater potential. The investigation suggests moderate groundwater potential at sites on both Catherine Creek and the upper Grande Ronde River. Based upon a combination of groundwater and surface water considerations, Catherine Creek has been chosen as the preferred alternative at the present time. However, if suitable groundwater supplies cannot be proven at Catherine Creek, test well drilling on the Grande Ronde is warranted.

Two sites have been identified at Catherine Creek. The downstream site, at the town of Union, appears to have good potential for groundwater supplies but poorer quality surface water. The groundwater potential at Union has been confirmed by local municipal and irrigation wells. The upstream site, at the OSU property above the State Park, has good surface water supply but less groundwater potential. Based upon our evaluation, we recommend test well drilling at the upstream (OSU) site to attempt to identify potential groundwater supplies. If insufficient groundwater is available at the upstream site, groundwater at the Union site can probably be confirmed at a later date following conceptual design. Probable success for developing groundwater is rated at 50 percent at the OSU site and 90 percent at Union (assuming that groundwater may have to pumped in from off-site wells). These two sites are discussed in more detail below.

Union Site. The Union site is located at the upstream end of the town of Union, at the location of the Union Sportsman's Park. This site was a former hatchery that apparently failed because of warm surface water temperatures. 
The geology at the Union site consists of Columbia River basalt grading into sediments of the Catherine Creek fan. The sediments increase in thickness to the northwest and west of town, with known thicknesses in excess of 500 feet within about one mile of the site. Well yields in excess of 1000 gpm of mid-50 degree water are possible where these sediments are coarse and thick. However, at the proposed facility location we anticipate that the sediments extend to only about 125 feet. As such, we would not expect significant production from these sediments. Instead, production from wells at the Union site would be obtained from basalt aquifers at depths in excess of 500 feet. These aquifers are located along the Grande Ronde Valley frontal fault system and typically have water temperatures above 65 degrees. For instance, the City of Union has three deep wells drawing from basalt aquifers with tested yields averaging $1400 \mathrm{gpm}$ and average water temperatures of 70 'F. These wells average 1400 feet in depth. Thus, we expect that production at the Union site would require deep wells with mechanical cooling to achieve water temperatures of less than 60 degrees unless colder groundwater is piped to the site from wells located north or west of the City.

If cold groundwater is desired, off-site wells could be located approximately one mile northwest or west of the site. These wells would tap alluvial sand and gravel deposits of the Catherine Creek fan. Well depths would probably range from 300 to 600 feet. Well yields in the range of 1000 to $2000 \mathrm{gpm}$ are probable with temperatures in the range of 54 to $58^{\circ} \mathrm{F}$.

OSU Site. The OSU site has better surface water supply potential than the Union site. Groundwater potential is not well known, given a lack of wells in the vicinity of the site.

The geology at the OSU site consists of alluvial sediments in the valley bottom which are underlain by Miocene basalt and Triassic marine sedimentary rocks and volcanics. Thickness of the alluvium is unknown, but might be in the range of 100 to 150 feet. The older rocks are exposed at the surface to the south and east, near the forks of Catherine Creek and at in the southeast comer of the OSU valley. The older rocks have relatively low groundwater potential, and the bedrock groundwater target will be fractured basalt along identified shear zones. The character of the Columbia River basalts in this area of Catherine Creek is different than other areas of the Grande Ronde basin, with the rock having a somewhat andesitic appearance. The groundwater potential from these rocks is not well known, given a lack of wells in the vicinity of the site. The nearest successful well is at Catherine Creek State Park. The driller's log for this well reported that it flowed $80 \mathrm{gpm}$ of $70^{\circ} \mathrm{F}$ water. No shut-in pressure was reported on the $\log$.

There appears to be potential for warm groundwater from deep basalt wells and cold groundwater from alluvial sediments in this area. Therefore, we recommend drilling two test wells, one deep and one shallow, at this site. The work should be conducted in phases, with the shallow well drilled in the first phase and, based upon further site evaluation, the deeper well drilled in a second phase.

The deep well will be located on the southside of the highway at the west end of the valley, along one of the mapped northeast-trending faults bordering the south side of the valley. The best location would be at the south end of the valley, where a northeast-trending linear feature following Little Catherine Creek may intersect the mapped northwest-trending fault. Other potential deep well sites would be located farther east along northwest-trending fault at the base of the slope along the south side of the valley. Construction would consist of 8inch casing to about 150 feet, with 8-inch open hole to 600 feet.

The shallow well will be located at the center of the valley where geophysical surveys suggest the greatest thickness of alluvial fill. The well would be constructed with 6 -inch 
casing drilled to bedrock. Estimated depth is 100 feet. Well screen would be install opposite potential water bearing zones; alternatively, the casing would be perforated with a rotary perforator in lieu of well screen. The well could be tested at pump rates in the range of $100 \mathrm{gpm}$.

\section{Lostine River - Strathearn Ranch}

The Lostine River site would be located at the Strathearn Ranch. The Strathearn Ranch is located at the lower end of a glacially formed valley. The geology of the site consists of alluvial and glacial sediments in the valley floor, generally underlain by Columbia River basalt. Near the upstream (southern) property boundary, one of the Wallowa Mountain range frontal faults cuts across the valley. The fault separates the basalts to the north from Triassic-age marine sediments found on the south, or upthrown, side of the fault.

We anticipate that successful cold water $\left(50-55^{\circ} \mathrm{F}\right)$ wells can be constructed in the alluvial/glacial sediments. In addition, the alluvial sediments at the upstream end of the site may be sufficiently permeable to permit the use of shallow "collector-type" wells or laterals for primary water supply. Collector-type systems could eliminate the need for a surface water intake structure, and the associated problems from icing and stream stabilization.

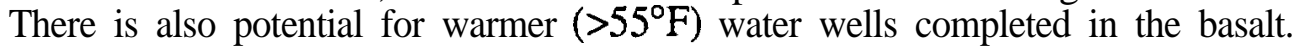

Both the shallow alluvial and deep basalt bedrock should be investigated in an attempt to locate groundwater supplies for this site. Potential for development of successful cold water wells is rated at 60 percent. Potential for successful warmer water wells is rated at 50 percent.

Strathearn Ranch - Alluvial Drill Sites. The key to successful alluvial/glacial wells will be locating drill sites with deep, clean alluvial or glacial outwash materials. Choice of these locations will be aided by a geophysical survey of the site. The geophysical survey will consist of seismic profiles of the valley bottom to identify the areas with the thickest accumulations of saturated glacial and alluvial materials.

Our conceptual geologic model of the Strathearn Ranch area suggests that valley glaciers have deposited glacial moraines at the southern end of the Strathearn property and again farther downstream of the Strathearn property. The moraines probably acted in a manner similar to the end moraine at present-day Wallowa Lake, and formed a shallow lake within the present Stratheam property. The materials within the moraine may be poorly sorted with relatively low potential for high capacity wells. However, there may be significant accumulations of coarse-grained materials behind or beneath these moraines. In particular, there is a good chance for success at the southern end of the property, where coarsergrained glacial outwash and alluvial material may have been deposited into the basin or lake behind the end moraine. Farther to the north, the thickness of the deposits may increase, although the deposits may become finer grained However, there is potential for the presence of buried channel deposits beneath the moraine or beneath the basin created by the moraine. For instance, the wells on the Stratheam property are located on upstream side of the end moraine. The logs of these wells suggest the presence of permeable sands and gravels at depths below 60 feet.

We recommend two shallow drill sites (phase 1) and potentially a third shallow drill site (phase 2) to assess the alluvial/glacial groundwater potential. The three sites will be located along the axis of the valley, at the locations showing the greatest potential for success based upon geophysical surveys. The first hole will probably be located at the southern border of the property. This area has good potential for accumulations of coarse-grained alluvial materials. The second hole will probably be located in the center of the property, near the 
southeast comer of the lake. The third hole will be located in the northern third of the property, which appears to have the least potential.

The shallow alluvial drilling will consist of drilling and driving 6-inch steel casing to bedrock. These casings will then be perforated opposite potential water bearing zones. This well construction should permit testing at flow rates in the range of $100 \mathrm{gpm}$.

Strathearn Ranch - Bedrock Drill Site. We recommend a deep well drillsite in a phase 2 evaluation of this site. The bedrock drill site with the best potential is at the upstream end of the property where a Wallowa Mountains frontal fault crosses the Lostine valley. The frontal fault may have increased the fracture permeability of the rock in this vicinity. The well would be located on the basalt side (north) of the fault as the presence of limestone on the south side of the fault is less conducive for groundwater production compared to the basalt.

The basalt bedrock well will be constructed by drilling and driving 8-inch casing to rock, with open hole 8-inch drilling through the rock. If caving conditions are encountered, 6inch steel liner will be set opposite the caving zones. Projected depth of this well is 600 feet. This well construction will allow pumping tests at rates of up to several hundred gallons per minute.

\section{Summary of Recommendations}

Test well drilling programs are outlined above for four sites in the upper Grande Ronde Basin. The drilling program will consist of the following:

Minam-Wallowa Confluence. One 600-foot, 8-inch diameter test well completed in Columbia River basalt is recommended. Potential for $500 \mathrm{gpm}$ yield is rated at 60 percent.

Imnaha Area. At the Gene Marr Ranch property, approximately $1500 \mathrm{gpm}$ of groundwater is available from springs. There is very little potential for development of significant additional groundwater from wells. Upstream, at the Marks or Royes properties, or other as yet unidentified areas, one 600-foot, 8-inch diameter test well is recommended. This well would be completed in Imnaha basalt, with chances of obtaining a $500 \mathrm{gpm}$ yield from a single well rated at 40 percent.

Catherine Creek - At the OSU site, a shallow (approximately 10O-foot deep) 6-inch diameter test well is recommended as a first phase to assess the shallow alluvial groundwater potential. A deep well (600-foot, 8-inch diameter) to evaluate the groundwater potential from basalt aquifers is appropriate as a second phase of investigation. Potential for success in developing $500 \mathrm{gpm}$ from the two wells is rated at 50 percent. No test well drilling is recommended for the Union Site at the present time, although the potential for developing adequate groundwater supplies is rated at 90 percent, assuming that cold groundwater would be piped in from off site.

Lostine River at the Strathearn Ranch - A drilling program consisting of a first phase of two shallow wells and a potential second phase of one deep well is recommended for the Strathearn Ranch. The shallow wells will be six inches in diameter with probable depths of 200 feet. These wells will explore the groundwater potential from aquifers in glacial and alluvial sediments. The deep well will be approximately 600 feet deep, completed in basalt along a Wallowa Front fault. Potential for success in developing 500 gpm from a single or multiple wells completed in the alluvial/glacial deposits is rated at 70 percent. Potential for developing $500 \mathrm{gpm}$ from the deep well is rated at 50 percent. 


\section{REVIEW OF EXISTING FACILITIES AND ASSESSMENT OF EXPANSION POTENTIAL}

\section{INTRODUCTION}

Implementation of the NEOH Basin Plan will require additional hatchery production and related fisheries facilities. The purpose of this section is to review and assess the expansion potential of existing hatcheries and facilities in the Columbia River Basin. The use or expansion of existing facilities (if possible) may offer significant economic saving in capital and operating costs. The information presented in this section is based on published information, site visits, and discussion with agency, tribal, and fisheries personnel.

The following hatcheries/fisheries facilities have been evaluated for use in the implementation of the NEOH Basin Plan:

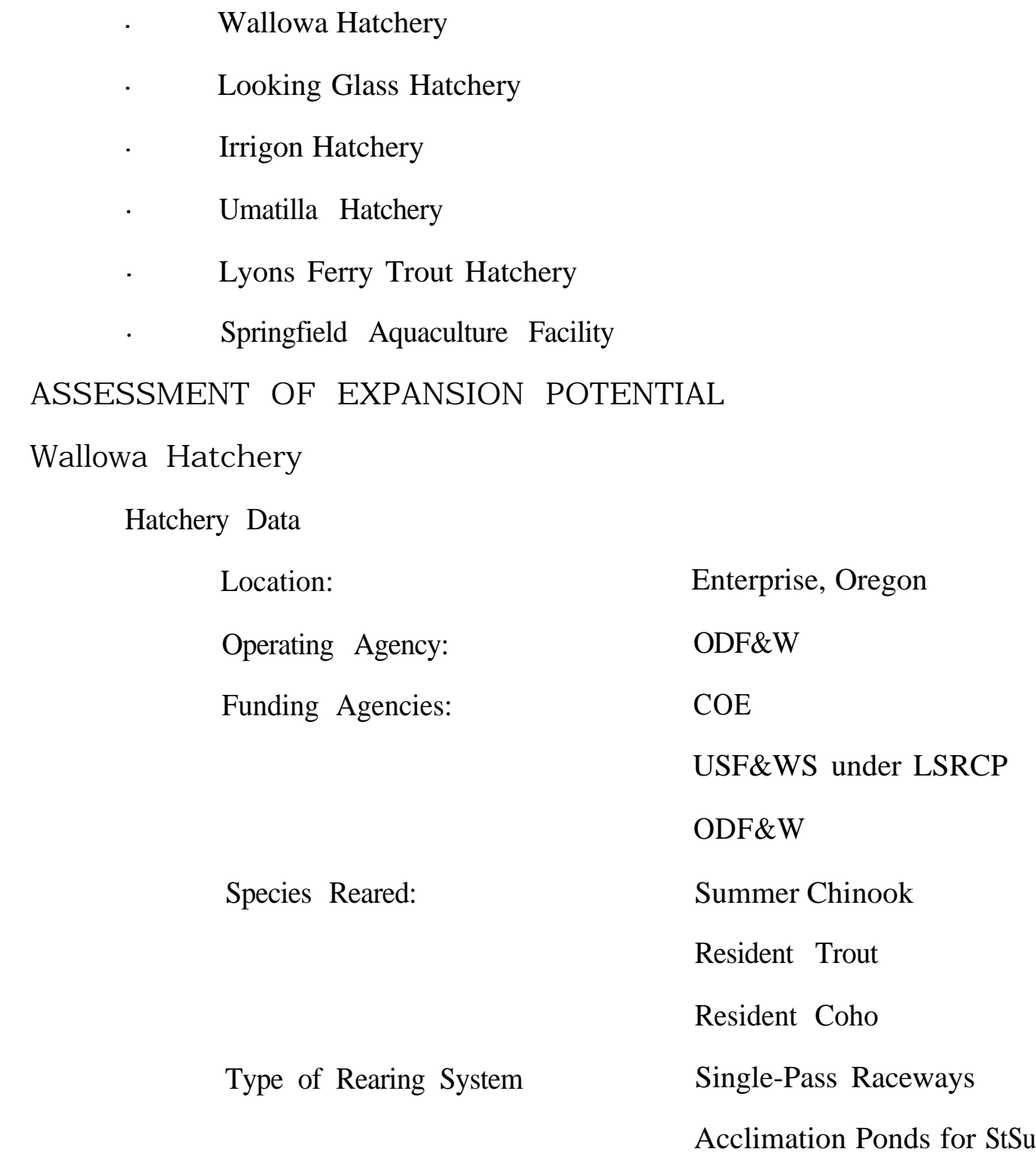


Water Supply
Groundwater

Springs

Spring Creek

Wallowa River

\section{Expansion Potential}

The expansion of this hatchery would require additional water. For groundwater this would entail a test well drilling program to evaluate the additional yield available from shallow and deep aquifers (see discussion of this site in section on Grande Rhonde River Basins). Surface water supplies include Spring Creek and the Wallowa River. Spring Creek is impacted by agricultural run-off and has poor water quality at times. Low flows and high temperatures are experienced during the summer. Plans to provide increased flows in the Wallowa River could also allow increased production at this hatchery.

Additional Information:

Assessment of Present Anadromous Fish Production Facilities in the Columbia River Basin, Volume 3, Bonneville Power Administration.

\section{Looking Glass Hatchery}

Hatchery Data

Location:

Operating Agency:

Funding Agency:

Species Reared:

Type of Rearing System

Water Supply near Elgin, Oregon

ODF\&W

USF\&WS under LSRCP

Spring Chinook

Single Pass Raceway

Groundwater

Looking Glass Creek

Expansion Potential

The operation of this hatchery is complicated by winter access problems, icing in Lookingglass Creek, and low water temperatures that limit fish growth in winter and early spring. It appears possible to increase groundwater supply to provide more water (see discussion of this site in section on Wallowa River Sites). The expansion of this hatchery would also require additional raceway space which could require relocation of existing staff housing.

Additional Information: 
Assessment of Present Anadromous Fish Production Facilities in the Columbia River Basin, Volume 3, Bonneville Power Administration.

\section{Irrigon Hatchery}

Hatchery Data

Location:

Irrigon, Oregon

Operating Agency:

ODF\&W

Funding Agency:

USF\&WS under LSRCP

Species Reared:

Fall Chinook

Spring Chinook

Summer S teelhead

Type of Rearing System

Two-pass Standard Oregon Raceways

Water Supply

Groundwater

Expansion Potential

The expansion of this hatchery would require additional water and space. If oxygen supplementation is proven effective and/or additional water is developed, this facility could have the potential to increase production.

Additional Information:

Assessment of Present Anadromous Fish Production Facilities in the Columbia River Basin, Volume 3, Bonneville Power Administration.

\section{Umatilla Hatchery}

Hatchery Data

Location:

Irrigon, Oregon

Operating Agency:

ODF\&W/CTUIR

Funding Agency:

Bonneville Power Administration

Species Reared:

Fall Chinook

Spring Chinook

Summer S teelhead

Type of Rearing System

Two-pass Standard Oregon Raceways

Three-pass Michigan Raceways with Supplemental Oxygen 
Water Supply Groundwater

Expansion Potential

This hatchery is testing the use of supplemental oxygen to increase the production of fall and spring chinook. If oxygen supplementation is proven effective, production could be expanded by construction of additional raceways. Because of the duration of the oxygen experiment, the potential expansion of this hatchery would not be possible for at least 5-6 years.

Additional Information:

Umatilla Fish Hatchery - Construction Drawing. 1989. U.S.Corps of Engineers, Walla Walla District, Walla Walla

Umatilla Hatchery Master Plan. 1989. Prepared by the Oregon Department of Fish and Wildlife and The Confederated Tribes of the Umatilla Indian Reservation. Prepared for the Northwest Power Planning Council.

Evaluation of the Pure Oxygen System at the Umatilla Hatchery. 1991. Fish Factory, Prepared for Bonneville Power Administration.

\section{Lyons Ferry Trout Hatchery}

Hatchery Data

Location:

Starbuck, Washington

Operating Agency:

WDW

Funding Agency:

USF\&WS under LSRCP

Species Reared:

Summer S teelhead

Resident Trout

Type of Rearing System

Singe-pass early rearing raceway

Large Ponds (3)

Water Supply

Groundwater 
Expansion Potential

The expansion of this hatchery would require additional groundwater. The amount of additional available groundwater is unknown. Because only 3 large ponds are available for fry rearing, species/stock isolation and segregation may be difficult at this hatchery

Additional Information:

Assessment of Present Anadromous Fish Production Facilities in the Columbia River Basin, Volume 5, Bonneville Power Administration.

\section{Springfield Aquaculture Facility}

Hatchery Data

Location:

Operating Company:

Species Reared:

Type of Rearing System

Adult Holding Capacity

Incubation Capacity

Maximum Rearing Capacity:

Maximum Yearly Rearing Capacity:

Water Supply
Springfield, Oregon

Alleco Financial Corporation

Coho

Chinook

Single-pass raceway system with oxygen supplement

50,000 adult fish

$25,000,000$ eggs

$500,000 \mathrm{lb}$

$1,200,000 \mathrm{lb}$

McKenzie River

Heated Process water from paper mill

\section{Expansion Potential}

This is a large-scale hatchery. It has the ability to mix river and heat process water to adjust hatchery water temperature. All influent water is disinfected with chlorine prior to use. This hatchery has one of the lowest cost per smolt ratios in the industry. Species/stock isolation can be maintained from adult holding through rearing. This hatchery is approximately 400 miles from LaGrande. The use of this facility for rearing would probably require the use of extended rearing/acclimation sites for any fish transported into the NEOH Basins.

This hatchery is available for purchase at the present time. Due to the facility's large size, it has good potential for $\mathrm{NEOH}$ production. Distance from the NEOH basins is a negative feature. 
Additional Information:

Spring Hatchery Presentation. 1991. Alleco Financial Corporation. Prepared for The Columbia River Inter-Tribal Fish Commission.

Letter to Mr. Jerry Bauer, dated April 2, 1991 from Mr. Ron Mayo, James M. Montgomery, Consulting Engineers, Inc., Bellevue, Washington. 


\section{SITE ANALYSIS AND SCREENING}

\section{INTRODUCTION}

This section presents information that relates potential sites in the NEOH study area to various program options available to meet NEOH production objectives. This information includes:

the revised Master Site Lists for the Grande Ronde, Imnaha, and Walla Walla basins (Tables 23 through 25)

- $\quad$ site and facility summaries for each basin (Table 26)

- $\quad$ site and facility screening evaluation matrices for each basin (Tables 27 through 38)

site data collected during site reconnaissance visits (Appendix D).

\section{REVISED SITE LIST AND FACILITY SUMMARY}

Tables 23 through 25 present the revised site list for the Grande Ronde, Imnaha, and Walla Walla River basins, respectively. Sites that were eliminated from further evaluation are still shown, but are noted as being eliminated. These sites are depicted on Figures 4 through 6 which are included at the end of this section.

Facility types that appear to have potential at each site, based on reconnaissance visits to the sites (Appendix D), review of available water quality and quantity data, and comments from the Initial Site Analysis Workshop are shown on Table 26.

\section{INITIAL SITE ANALYSIS}

The facility types shown at a site on Table 26 were analyzed using engineering and environmental screening criteria to identify and prioritize sites that may warrant further investigation. This screening and subsequent review by the NEOH TWG formed the basis for the recommended programs presented in the section titled SITE ANALYSIS AND SCREENING.

Tables 27 through 30 present a screening level analysis of Grande Ronde River sites for adult capture, adult holding, incubation and fry rearing, and full term (satellite) rearing facilities. The "hatchery" and "incubation and fry rearing" facilities shown on Table 26 were considered identical for site screening purposes and a separate evaluation for a hatchery was not included. Further, the final rearing/acclimation/direct release sites were not evaluated beyond the information presented in Table 26. The sites being considered could accommodate all or most of the required functions.

Similar screening matrices are shown on Tables 31 through 34 for the Imnaha basin and 35 through 38 for the Walla Walla basin. 
TABLE 23

\section{REVISED SITE LIST - GRANDE RONDE BASIN}

Site Name

1. Catherine Creek N\&S forks confluence

2. Catherine-Milk Creek confluence (OSU site)

3. Catherine Creek at Union (Old Hatchery)

4. Vey Meadows

5. Sheep Creek

6. Beaver Creek

7. Sanderson Springs - Mill Creek

8. Lower Willow Creek near Elgin

9. Indian Creek near Elgin

10. Grande Ronde near Elgin

11. Looking Glass Hatchery

12. Wildcat Creek Area

13. Fish Ladder (Former USFWS Research Site)

14. Flora Grade (Schoolbus Flats)

15. Cottonwood Creek

16. Wallowa Lake

17. Hayes Fork-Prarie Creek

18. Wallowa Hatchery

19. Big Canyon Creek

20. Minam River confluence with Wallowa

21. ODFW Bighorn Sheep range

22. Strathearn Ranch

23. Lostine Dam

24. Cross-Valley Diversion (Clearwater Ditch)

25. Catherine Creek at Davis Dam

26. Minam River $1 / 4$ to 1 mile above Wallowa Confluence

27. Wallowa River $1 / 2$ mile below Minam confluence

28. Wenaha River 1/4 mile above Troy

\section{Comments}

EIP measure site (a)

EIP measure site (a)

includes splash dam site

site eliminated during screening site eliminated during screening

site eliminated during screening

site eliminated during screening

site eliminated during screening

location changed, see Site 27

(a) Early Implementation Plan Measure 2.3: "Portable adult collection/holding and juvenile acclimation/release systems". Catherine Creek demonstration project.

(b) Early Implementation Plan Measure 2.2: "Protecting endemic spring chinook in Minam and Wenaha Rivers (Grande Ronde subbasin)“. 
TABLE 24

REVISED SITE LIST - IMNAHA BASIN

Site Name

Comments

1. Indian Crossing

2. Gumboot Creek (Fish Weir)

3. Grouse Creek-Imnaha confluence

site eliminated during screening

4. Big Sheep-Lick Creek confluence

5. Big Sheep Creek

6. Big Sheep-Little Sheep confluence

7. Little Sheep Creek

8. Gene Marr Ranch

9. Horse Creek

site eliminated during screening

TABLE 25

REVISED SITE LIST - WALLA WALLA BASIN

Site Name

Comments

1. NE 8th Street Bridge (Milton Freewater)

2. 9th and Walnut (Milton Freewater)

3. Harris Park (at park)

4. Harris Park No. 2

site eliminated during screening

5. S. Fork - Elbow Creek confluence

site eliminated during screening

6. Russell Walker property

7. Wolf Fork Confluence

8. WDW Dayton Conditioning Pond

9. Railroad Bridge

10. Pond at FS boundary 
TABLE 28 (1 OF 3)

STE AND FACLITY SUMMARY
GRANDE RONOE RIVER BASIN

EACIITIY

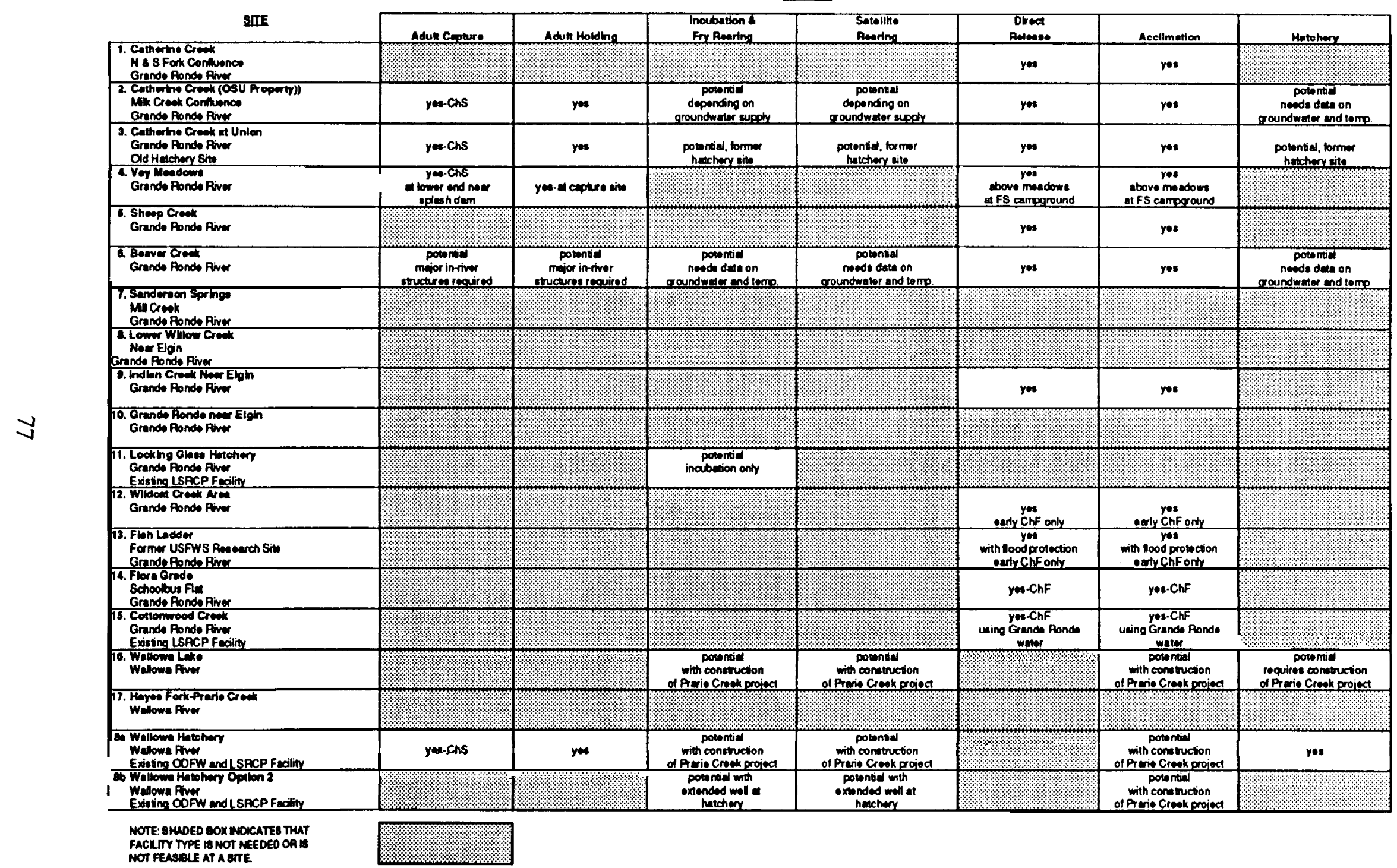


TABLE 26 (2 d 3)

SITE AND FACMITY SUMMARY

GRANDE ROMDE RIVER BASIN

EACIITY

\begin{tabular}{|c|c|c|c|c|c|c|c|}
\hline sne & Adull Copturn & Adull Holding & $\begin{array}{l}\text { Incubation } 2 \\
\text { Fy Roante }\end{array}$ & $\begin{array}{l}\text { Setollite } \\
\text { Rearinge }\end{array}$ & $\begin{array}{l}\text { Dlreat } \\
\text { Becenes }\end{array}$ & Accllmation & Hulchory \\
\hline $\begin{array}{l}\text { 19. B1. Canyon Creak } \\
\text { Wollowa River } \\
\text { Exiding LSACP Facily }\end{array}$ & 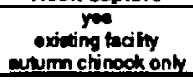 & $\begin{array}{c}\text { potomial } \\
\text { eutumn chinock only }\end{array}$ & & & & potential & \\
\hline 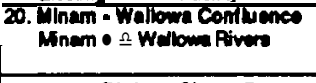 & 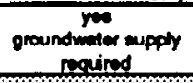 & 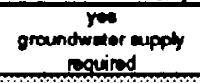 & $\begin{array}{l}\text { potwential } \\
\text { groundwatbor upphy } \\
\text { required }\end{array}$ & $\begin{array}{c}\text { yen } \\
\text { grounownator woppy } \\
\text { requirod }\end{array}$ & you & yem & $\begin{array}{l}\text { Yow with groundwator } \\
\text { chiling during roaring } \\
\text { polentially roquired }\end{array}$ \\
\hline $\begin{array}{l}\text { 21. OOFW Bghorm Shap Alange } \\
\text { Loetino Piver }\end{array}$ & & & & & $y=$ & porantial & \\
\hline $\begin{array}{l}\text { 22. Strathoam Aanch } \\
\text { Loetine Fiver }\end{array}$ & yowerss & yom & $\begin{array}{l}\text { potonitial } \\
\text { nowde groundmatio } \\
\text { dete }\end{array}$ & $\begin{array}{l}\text { potontial } \\
\text { neods groundwator } \\
\text { dete }\end{array}$ & yos & yos & $\begin{array}{l}\text { polonital } \\
\text { neods groundwator } \\
\text { date }\end{array}$ \\
\hline $\begin{array}{l}\text { 23. Lostine Dom } \\
\text { Loeine Piver }\end{array}$ & yoochs & potential & & & & & \\
\hline $\begin{array}{l}\text { 24. Crose-valley DIweraion } \\
\text { Lomine Piver }\end{array}$ & pocomtialchs & potontial & & & & & \\
\hline
\end{tabular}

STIE AND FACRITY SUMMARY IMNAHA RIVER BASIN

EACIIIY

\begin{tabular}{|c|c|c|c|c|c|c|c|}
\hline SIIE & Captum & Holdhe & $\begin{array}{l}\text { noubalion a } \\
\text { Fry Roerng }\end{array}$ & $\begin{array}{l}\text { Sotollite } \\
\text { Rearting }\end{array}$ & $\begin{array}{l}\text { Direct } \\
\text { Relecen }\end{array}$ & Accllmation & Hutehory \\
\hline $\begin{array}{l}\text { 1. Indian Crowsing } \\
\text { minatia Fiver }\end{array}$ & & & & & $y=$ & yes & \\
\hline 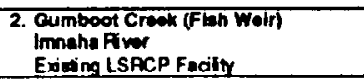 & not & yen & & & you & 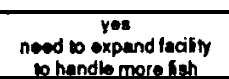 & \\
\hline $\begin{array}{l}\text { 3. Groume Creactimnahe Contluence } \\
\text { Imnahs } K \mathrm{~m}\end{array}$ & - potiential & $\begin{array}{l}\text { potential } \\
\text { availate hand } \\
\text { limited }\end{array}$ & & $\begin{array}{l}\text { potontial } \\
\text { maileblo land } \\
\text { Imiled }\end{array}$ & potential & potential & \\
\hline $\begin{array}{l}\text { 4. Blg Sheop-Likt Crodk Confuence } \\
\text { lmneha Pror }\end{array}$ & & $\%$ & $1 \%$ 1\%. & ঋै। & $\begin{array}{l}\text { timed robesece } \\
\text { fod fir }\end{array}$ & imed ratoan of & ঋै৮ै। \\
\hline $\begin{array}{l}\text { 8. Blg Shoop Croak } \\
\text { Imnatia Fiver }\end{array}$ & & porensial & potonial & potontial & yot & yen & potoníal \\
\hline 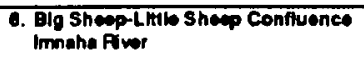 & not dowrmined & not downimined & & $\begin{array}{l}\text { potortial } \\
\text { emretsecaboperation }\end{array}$ & yet & rem & emall-scalos coporation \\
\hline 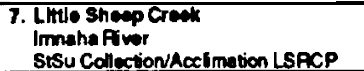 & & & $\begin{array}{l}\text { Youe } \\
\text { potonsial deponding on } \\
\text { ground water everiebisty }\end{array}$ & & & potontial & \\
\hline $\begin{array}{l}\text { Done Marr Geneh } \\
\text { Imahe Fiver }\end{array}$ & reschif & 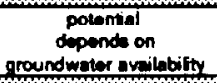 & 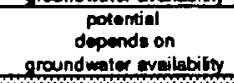 & 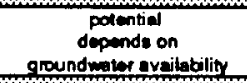 & yes & 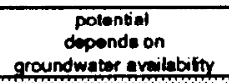 & 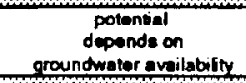 \\
\hline $\begin{array}{l}\text { 9. Hores Crock } \\
\text { Imana Fiver }\end{array}$ & & & & & & 10 & \\
\hline
\end{tabular}


TABLE $26(3 \mathrm{~d} 3)$

STE AND FACILTY SUMMAAY

WALLA WALLA RIVER BASIM

EACIIIX

\begin{tabular}{|c|c|c|c|c|c|c|c|}
\hline SIII & Adult Cupture & Adult Holding & $\begin{array}{l}\text { Incubation \& } \\
\text { Fry flearing? }\end{array}$ & $\begin{array}{l}\text { Setallito } \\
\text { Aagaring }\end{array}$ & $\begin{array}{l}\text { Dreet } \\
\text { Rebees }\end{array}$ & Acellimition & Hetchery \\
\hline 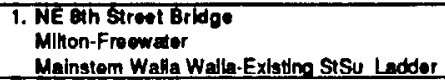 & potentlad-STSU & & & & & & \\
\hline $\begin{array}{l}\text { 2. Th and Woinut } \\
\text { Minon.Freowalor } \\
\text { Malnstem Walla Walla-Existing Trep }\end{array}$ & $\begin{array}{l}\text { poremial for smoh } \\
\text { collioation }\end{array}$ & & & & & & \\
\hline $\begin{array}{l}\text { 3. Harria Park No. } 1 \\
\text { A Heris Park } \\
\text { Sounh Fork Walla Walla }\end{array}$ & polentlad-1t neoded & yos & $\begin{array}{l}\text { polowitial } \\
\text { neod proundweter data }\end{array}$ & $\begin{array}{l}\text { porontital } \\
\text { neod groundwater data }\end{array}$ & men & yos & $\begin{array}{l}\text { polontal } \\
\text { moods data on } \\
\text { groundwater }\end{array}$ \\
\hline $\begin{array}{l}\text { 4. Harpis PPonth No. } 2 \\
\text { Approx. } 1 \text { milo above Herris Parth } \\
\text { South Fork Wella Walle }\end{array}$ & & & & & & & \\
\hline $\begin{array}{l}\text { 5. S. Fork-Elbow Creek Confluences } \\
\text { Approx. } 2 \text { milos abovo Harls Park } \\
\text { SouthFork Walla Walla }\end{array}$ & & & & & & & \\
\hline $\begin{array}{l}\text { 6. Ruseofl Walker property } \\
\text { approx. } 2 \text { miles below Harris Park } \\
\text { S. Fork Walla Walla }\end{array}$ & polentialiti nooded & yos & $\boldsymbol{\varphi}$ & yos & yos & yos & you \\
\hline $\begin{array}{l}\text { 7. Woll Fork Conlluence } \\
\text { Touchot Pilver } \\
\text { Walla Walla Basin }\end{array}$ & & potontial & & & yes & yos & \\
\hline $\begin{array}{l}\text { 8. WDW Ooyton Conditioning Pond } \\
\text { Touchet River at Dayton } \\
\text { Walla Walla Basin }\end{array}$ & not detormined & potontial & & potental & $n$ & you & \\
\hline 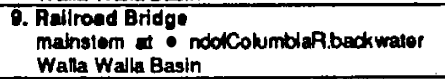 & you & & & & & & \\
\hline $\begin{array}{l}\text { 10. Pond FS boundary } \\
\text { Touchat Piver } \\
\text { Walla Walla Basin }\end{array}$ & & & & & rom & poternlad & \\
\hline
\end{tabular}

STIE AND FACILITY SUMMARY

OEATOFACILIT SUMATIONS

EACILITY

\begin{tabular}{|c|c|c|c|c|c|c|c|}
\hline SIIE & Adult Capture & Adun Holding & $\begin{array}{l}\text { Incubation } \\
\text { Fry Rearing }\end{array}$ & $\begin{array}{l}\text { Satelihto } \\
\text { Poourling }\end{array}$ & $\begin{array}{l}\text { Direct } \\
\text { Rolesece }\end{array}$ & Acellimetion & Hatchery \\
\hline $\begin{array}{l}\text { 7. Eaglo Croek } \\
\text { Powder River Drainage } \\
\text { Location noeds to be determined }\end{array}$ & & & poternlal & potontial & & & potential \\
\hline $\begin{array}{l}\text { 2. Springfield Aquacullure Facility } \\
\text { Whlamonte River } \\
\text { Springfiel, OR }\end{array}$ & & & potential & potential & & & potontal \\
\hline
\end{tabular}


TABLE 27 (1 of 4)

ADULT CAPTURE SCREENING CRITERIA

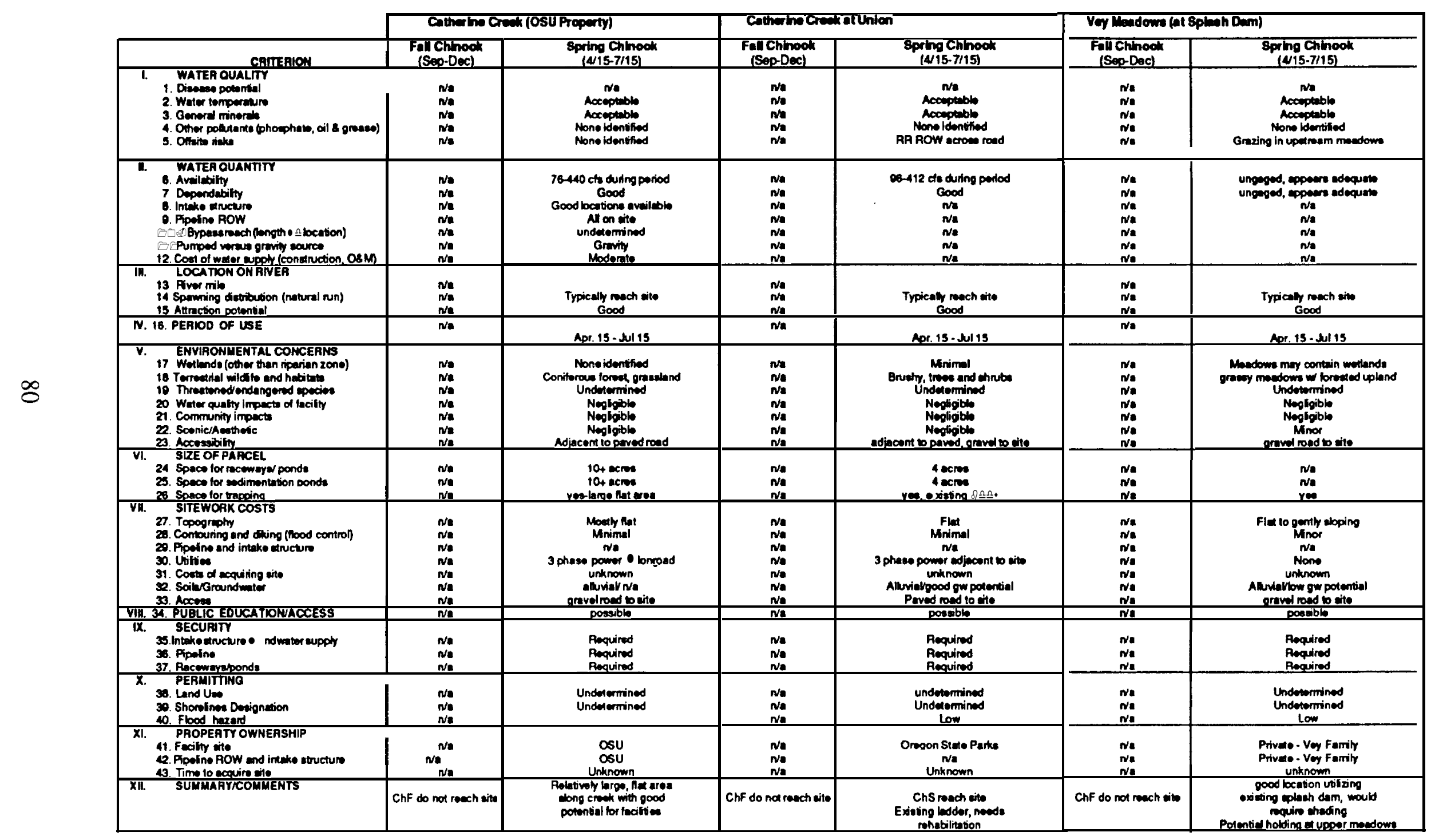


TABLE 27 (2 of 4)

ADULT CAPTURE SCREENING CRITERIA

\begin{tabular}{|c|c|c|c|c|c|c|c|}
\hline & & \multicolumn{2}{|c|}{ Beaver Croek } & \multicolumn{2}{|c|}{ Grande honde near Elgln } & \multicolumn{2}{|c|}{ Wallowa Hatchory } \\
\hline \multirow{13}{*}{$\infty$} & CRIERION & Fall Chinook & Spring Chinook & Fall Chinook & Spring Chinook & Full Chinook & 8prtho Chinook \\
\hline & 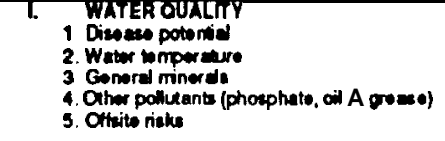 & $\begin{array}{l}n / a \\
n / a \\
n / a \\
n / a \\
n / a\end{array}$ & 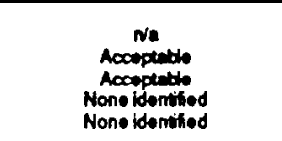 & 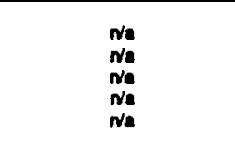 & 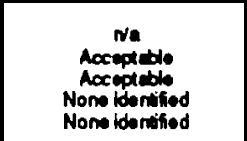 & $\begin{array}{l}n / a \\
n / a \\
n / a \\
n / a \\
n / a\end{array}$ & 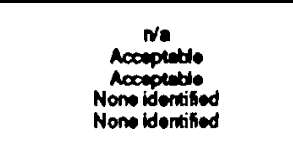 \\
\hline & 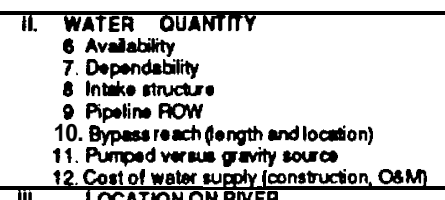 & 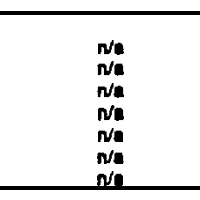 & 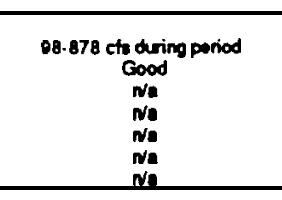 & 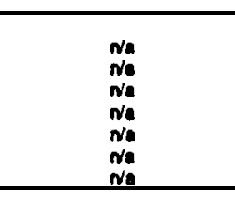 & $\begin{array}{c}\text { 173-1764 ch during poriod } \\
\text { Good } \\
\text { Nad } \\
\text { Na } \\
\text { Nad } \\
\text { Nad } \\
\text { Nad } \\
\end{array}$ & $\begin{array}{l}n / a \\
n / a \\
n / a \\
n / a \\
n / a \\
N / a \\
n / 4\end{array}$ & 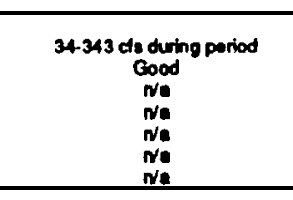 \\
\hline & 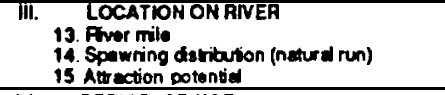 & 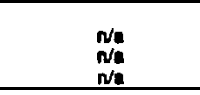 & $\begin{array}{l}\text { GA } 170 \\
\text { Typically rouch in } \\
\text { Good }\end{array}$ & 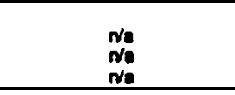 & $\begin{array}{c}\text { Typically pouse rito } \\
\text { Good }\end{array}$ & 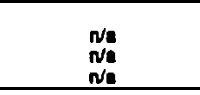 & 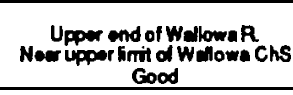 \\
\hline & N. 16. PERIOD Of USE & $n / a$ & Apr. 15 . Jul 15 & nea & An. 15 - Jul is & nin & Aor. $15 \cdot$ Nul 15 \\
\hline & 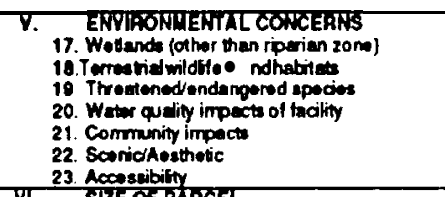 & 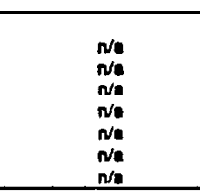 & 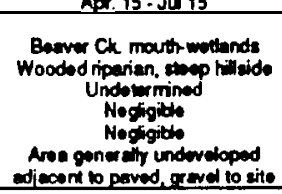 & 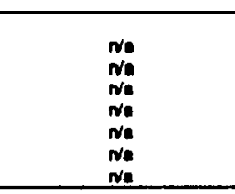 & 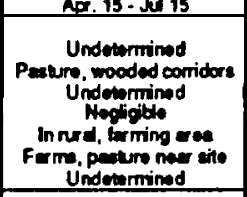 & 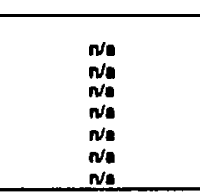 & 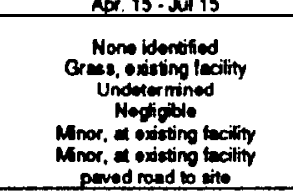 \\
\hline & 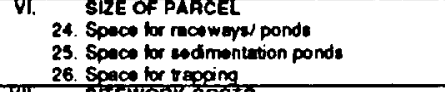 & $\begin{array}{l}n / 1 \\
n / 1 \\
n / 4\end{array}$ & $\begin{array}{c}5-10 \text { eacm } \\
5.10 \text { erom } \\
\text { mem }\end{array}$ & 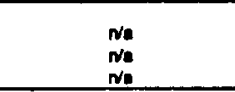 & 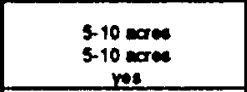 & 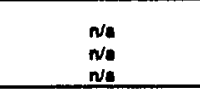 & 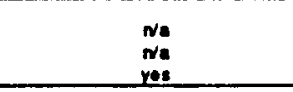 \\
\hline & 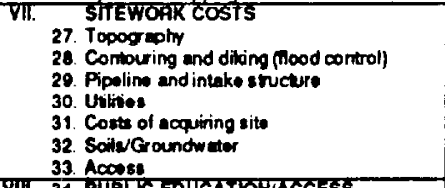 & 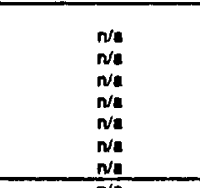 & 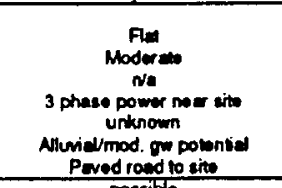 & $\begin{array}{l}\mathrm{Na} \\
\mathrm{wa} \\
\mathrm{wa} \\
\mathrm{wa} \\
\mathrm{wa} \\
\mathrm{Na} \\
\mathrm{Na} \\
\mathrm{Na} \\
\end{array}$ & 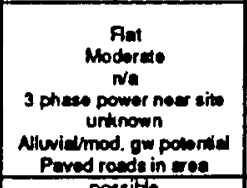 & 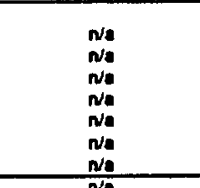 & 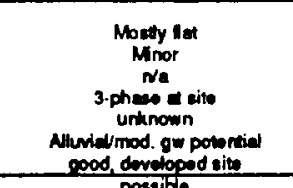 \\
\hline & 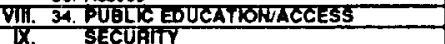 & $\sqrt{n}$ & pouscible & na & possith & no & possibe \\
\hline & $\begin{array}{l}\text { 35. Intake structure and watur supply } \\
\text { 36. Propline } \\
\text { 37. Racomereponds }\end{array}$ & $\begin{array}{l}n_{a} \\
n a \\
n=1\end{array}$ & $\begin{array}{l}\text { Required } \\
\text { Pequirod } \\
\text { Required }\end{array}$ & $\begin{array}{l}\mathrm{na} \\
\mathrm{Na} \\
\mathrm{na} \\
\mathrm{na}\end{array}$ & 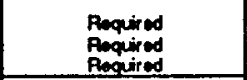 & $\begin{array}{l}N_{0} \\
\text { ne } \\
N \in\end{array}$ & $\begin{array}{l}\text { Pequitiod } \\
\text { Pegined } \\
\text { Peovised }\end{array}$ \\
\hline & $\begin{array}{l}\text { X. PE. Land Unew } \\
\text { 30. Shorelines Do rignation } \\
\text { 10. Flood heperd }\end{array}$ & $\begin{array}{l}n / a \\
n / a \\
n / a\end{array}$ & $\begin{array}{l}\text { Undow mined } \\
\text { Undowr mined } \\
\text { Modercow on Bequer Ck }\end{array}$ & $\begin{array}{l}\text { na } \\
\mathrm{na} \\
\mathrm{na}\end{array}$ & 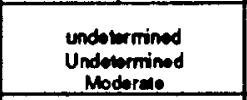 & $\begin{array}{l}\text { No } \\
\text { No } \\
\text { nos }\end{array}$ & $\begin{array}{l}\text { Exining teacitity } \\
\text { Undelewminad } \\
\text { Low }\end{array}$ \\
\hline & 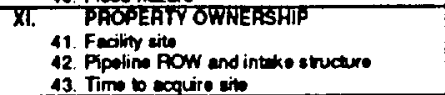 & $\begin{array}{l}n / a \\
n / a \\
n / a\end{array}$ & $\begin{array}{c}2 \text { priven awnors } \\
\text { Name } \\
\text { Unknown }\end{array}$ & 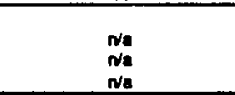 & $\begin{array}{l}\text { Undewrminod } \\
\text { Undowrminod } \\
\text { Undewermined }\end{array}$ & $\begin{array}{l}n / 2 \\
n=a \\
n=0\end{array}$ & $\begin{array}{c}\text { Oofw } \\
\text { ODfw } \\
\text { me }\end{array}$ \\
\hline & 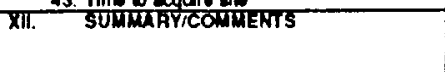 & ChF do not reach wito & 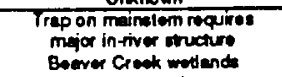 & 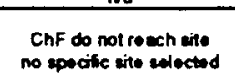 & 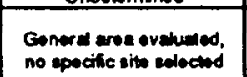 & ChF do not romect eine & $\begin{array}{l}\text { Sho localod in lpost } \\
\text { ponion of Wellown ChS hetita }\end{array}$ \\
\hline
\end{tabular}


TABLE 27 ( 3 of 4)

ADULT CAPTURE SCREENING CRITERIA

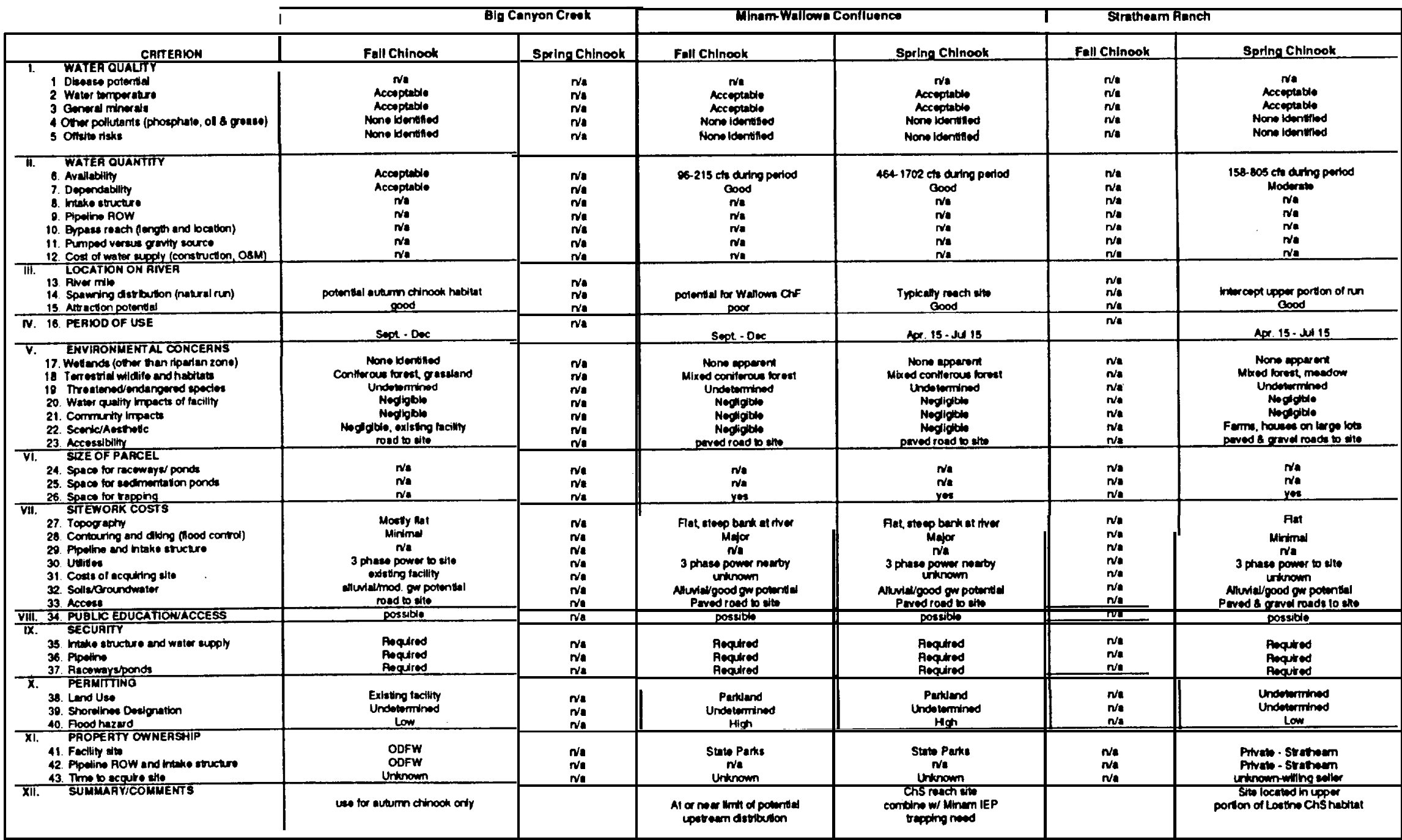


TABLE 27 (4 of 4)

ADULT CAPTURE SCREENING CRITERIA

\begin{tabular}{|c|c|c|c|c|c|}
\hline \multirow{2}{*}{\multicolumn{2}{|c|}{ CRITERION }} & \multicolumn{2}{|c|}{ Lastine Dam } & \multicolumn{2}{|c|}{ Coaed Valley Divoretion } \\
\hline & & Fall Chlnook & Spring Chinook & Fall Chhook & Spring Chinodk \\
\hline $\begin{array}{l}1 \\
1 \\
2 \\
3 \\
4 \\
5\end{array}$ & 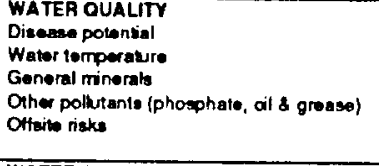 & 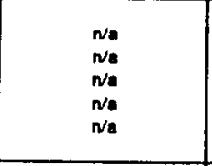 & 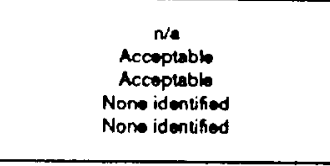 & 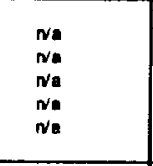 & 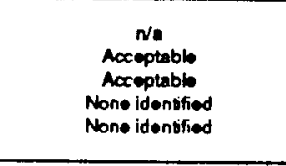 \\
\hline $\begin{array}{l}\text { II. } \\
7 \\
7.1 \\
9 \\
9 \\
10 . \\
11 . \\
12 . \\
\text { III. }\end{array}$ & 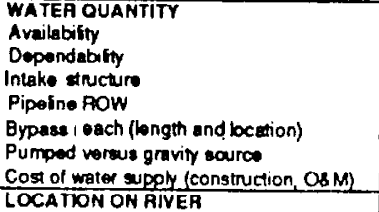 & 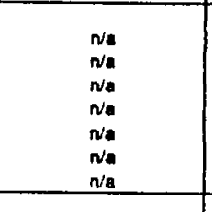 & 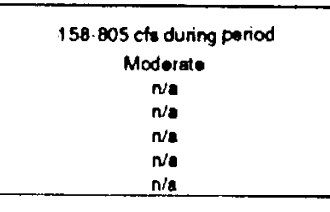 & 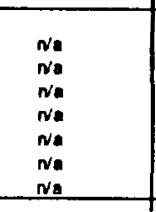 & 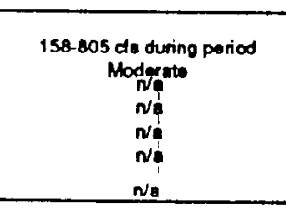 \\
\hline $\begin{array}{l}13 \\
145 \\
15 \\
\end{array}$ & $\begin{array}{l}\text { River mile } \\
\text { Spewning distribution (naturalrun) } \\
\text { Atraction potential }\end{array}$ & $\begin{array}{l}n a \\
N / a \\
n / a\end{array}$ & $\begin{array}{l}\text { ypically reach site } \\
\text { good }\end{array}$ & 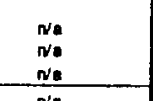 & $\begin{array}{c}\text { ypically moach site } \\
\text { good }\end{array}$ \\
\hline N. 16 & PERIOD OF USE & n/: & Apr 15 - Nel 15 & ra & Apr. 15 - Jul 15 \\
\hline $\begin{array}{l}17 . \\
18 . \\
19 \\
20.1 \\
21 \\
22 \\
23 \\
\text { VI. }\end{array}$ & 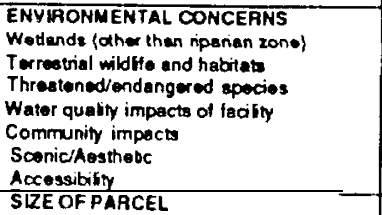 & 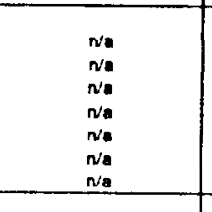 & 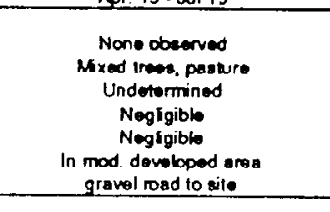 & 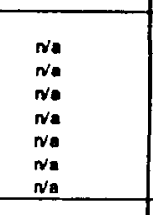 & 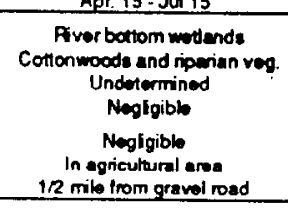 \\
\hline $\begin{array}{l}245 \\
25.5 \\
26.5 \\
\text { VII. }\end{array}$ & $\begin{array}{l}\text { SLE OFF PACEL } \\
\text { Space for racoways ponds } \\
\text { Space for sedimentation ponds } \\
\text { Space for tregping } \\
\text { SITEWOAK COSTS }\end{array}$ & $\begin{array}{l}\text { wo } \\
\text { Na } \\
\text { wa } \\
\end{array}$ & 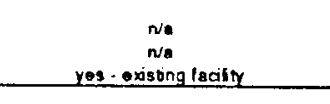 & 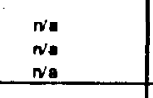 & $\begin{array}{l}\text { ne } \\
\text { neas } \\
\text { yes }\end{array}$ \\
\hline 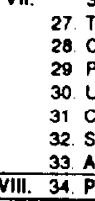 & 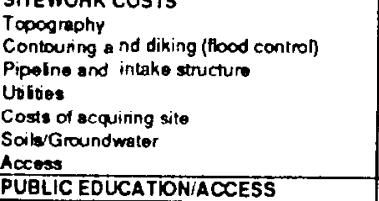 & 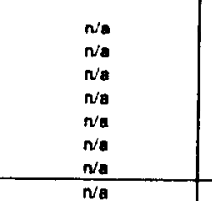 & 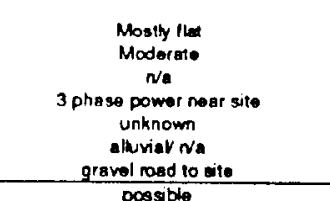 & 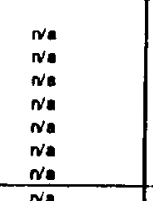 & 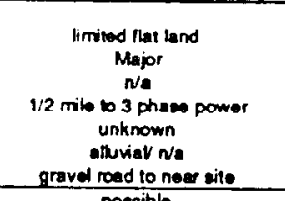 \\
\hline $\begin{array}{l}\text { VIII. } 34 . \bar{P} \\
1 \times .5\end{array}$ & $\begin{array}{l}\text { PUBLIC EDUCATION/ACCESS } \\
\text { SECUAITY }\end{array}$ & N/a & possible & $\mathrm{Na}$ & possible \\
\hline $\begin{array}{r}35 \mathrm{In} \\
36 . \mathrm{P} \\
37 . \mathrm{P} \\
\times \quad \mathrm{P}\end{array}$ & $\begin{array}{l}\text { Intake srueture and water supply } \\
\text { Pipoine } \\
\text { Pacowersponds } \\
\text { PERMITIIIG }\end{array}$ & $\begin{array}{l}n_{k} \\
n_{a} \\
n=a\end{array}$ & $\begin{array}{l}\text { Required } \\
\text { Required } \\
\text { Hequired }\end{array}$ & $\begin{array}{c}N a \\
N a \\
N / a \\
N a\end{array}$ & $\begin{array}{l}\text { Required } \\
\text { Proquired } \\
\text { Fequired }\end{array}$ \\
\hline $\begin{array}{l}381 \\
395 \\
40.1 \\
\end{array}$ & $\begin{array}{l}\text { LeRLITING } \\
\text { Land Uso } \\
\text { Shooines Designation } \\
\text { Flood hazard }\end{array}$ & $\begin{array}{l}n / a \\
n / a \\
n / a\end{array}$ & $\begin{array}{c}\text { Mixed urten and larming } \\
\text { Undelormined } \\
\text { Low }\end{array}$ & $\begin{array}{l}n / 1 \\
N / 1 \\
N / a\end{array}$ & 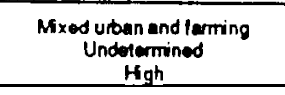 \\
\hline $\begin{aligned} & x \mid 11 \\
& 42 P \\
& 437 \\
&\end{aligned}$ & 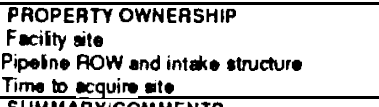 & $\begin{array}{l}n / a \\
n / 1 \\
n / 8\end{array}$ & $\begin{array}{c}\text { Privalo } \\
\text { nes } \\
\text { Unknown } \\
\end{array}$ & 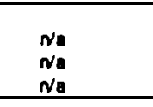 & $\begin{array}{c}\text { Jory McCban } \\
\text { Nom } \\
\text { Unknown }\end{array}$ \\
\hline$\overline{x \| l .}$ & SUMMAAY/COMMENTS & $\begin{array}{c}\text { ChF do not resech aito } \\
\text { apresont }\end{array}$ & 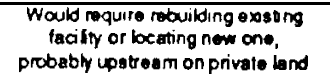 & & 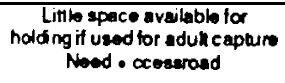 \\
\hline
\end{tabular}


TABLE 28 (1 of 4)

ADULT HOLDING SCREENING CRITERIA

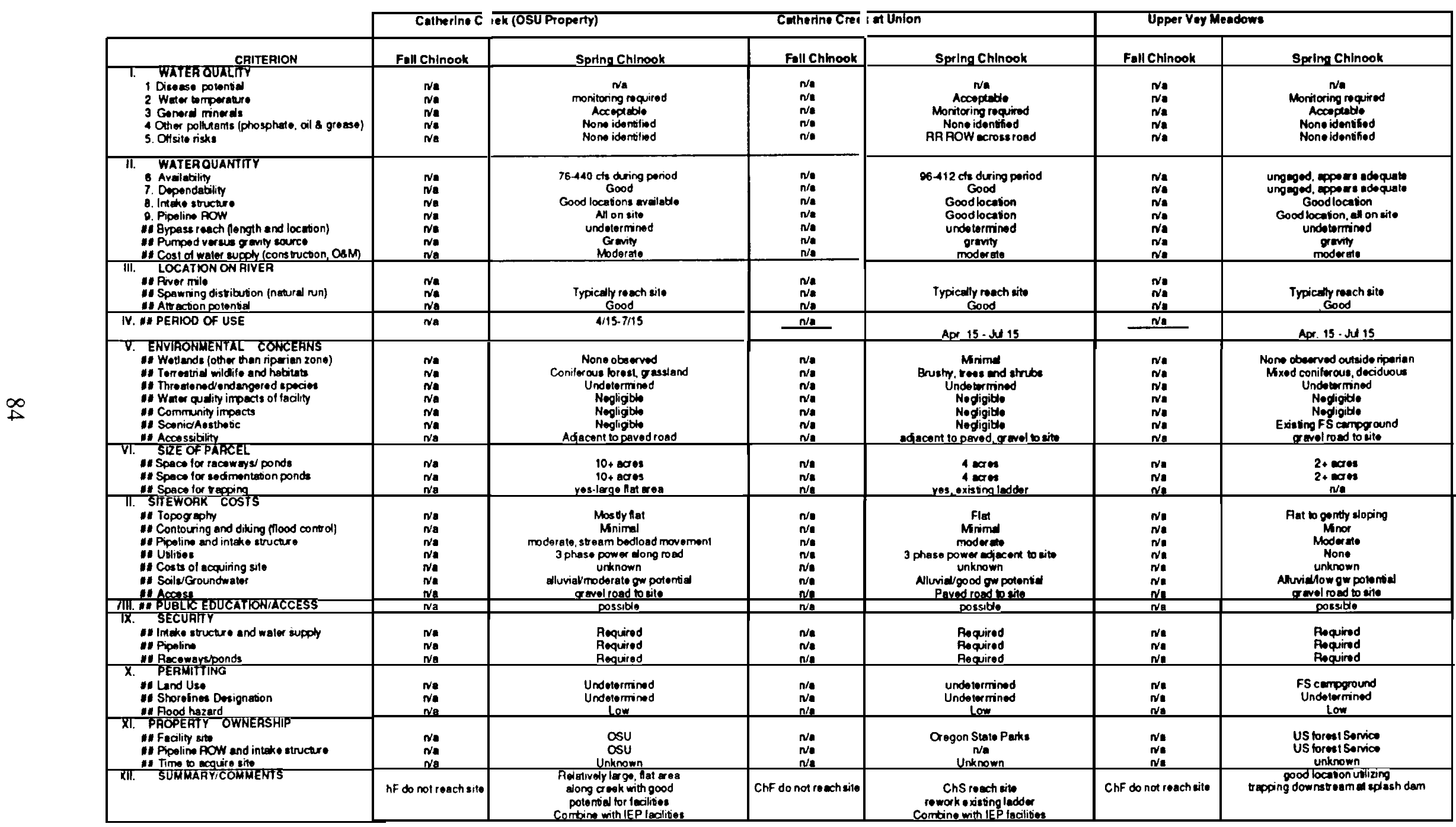


TABLE 28 (2 of 4)

ADULT HOLDING SCREENING CRITERIA

\begin{tabular}{|c|c|c|c|c|c|c|}
\hline \multirow[b]{2}{*}{$\begin{array}{r}\text { CAITERION } \\
\end{array}$} & \multicolumn{2}{|c|}{ Beaver Creek } & \multicolumn{2}{|c|}{ Grande Ronde near Elain } & \multicolumn{2}{|c|}{ Wallowa Hatchery } \\
\hline & Fall Chinook & Spring Chinook & Fall Chinook & Spring Chinook & Fall Chinook & Spring Chlnook \\
\hline 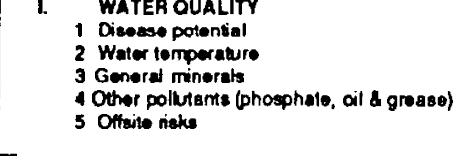 & $\begin{array}{l}n / a \\
n / a \\
n / a \\
n / a \\
n / a\end{array}$ & $\begin{array}{l}n / a \\
\text { monilonng required } \\
\text { Acceptablo } \\
\text { None idenified } \\
\text { None identified }\end{array}$ & 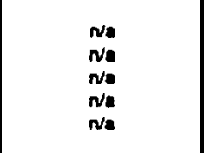 & 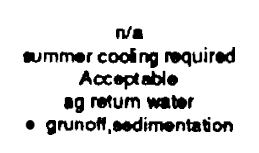 & $\begin{array}{l}n / 4 \\
n / a \\
n / a \\
n / 4 \\
n / a\end{array}$ & $\begin{array}{l}\text { Na } \\
\text { neod eummor cooling } \\
\text { Aocoptutho } \\
\text { None identified } \\
\text { Nono identified }\end{array}$ \\
\hline 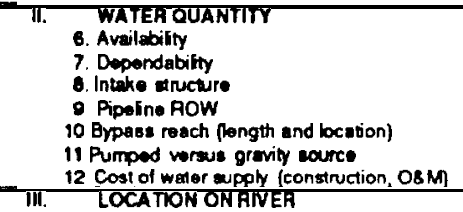 & $\begin{array}{l}n / a \\
n / a \\
n / a \\
n / a \\
n / a \\
n / a \\
n / a\end{array}$ & 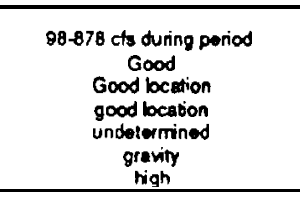 & 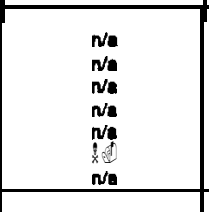 & $\begin{array}{l}\text { 175-1764 cts during poriod } \\
\text { Good } \\
\text { undotermined } \\
\text { Undetermined } \\
\text { undetermined } \\
\text { grevity } \\
\text { undetermined }\end{array}$ & $\begin{array}{l}n / a \\
n / 4 \\
n / 4 \\
n / 1 \\
n / 4 \\
n / a \\
n / a\end{array}$ & 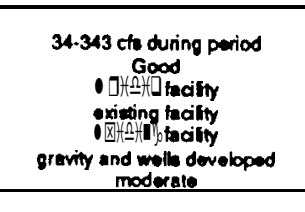 \\
\hline $\begin{array}{l}13 \text { Piver mib } \\
\text { 14 Sparning distribution (natural run) } \\
\text { is Alraction poientiel }\end{array}$ & $\begin{array}{l}n / a \\
n / a \\
n / a\end{array}$ & $\begin{array}{l}\text { GA } 179 \\
\text { Typreally rouch ate } \\
\text { Good }\end{array}$ & $\begin{array}{c}n / 4 \\
n / 4 \\
n / 4\end{array}$ & $\begin{array}{l}\text { Typically pass site } \\
\text { Good }\end{array}$ & $\begin{array}{l}n / a \\
n / a \\
n / a\end{array}$ & $\begin{array}{l}\text { Uppor and of Wallowe R } \\
\text { Noer uppor Init of Wallowa ChS } \\
\text { Good }\end{array}$ \\
\hline N. 16 PEAKD OF USE & $n / a$ & Apr 15 - Jul is & na & Apx. 15 - Jul 15 & Na & App 15 - Jul 15 \\
\hline 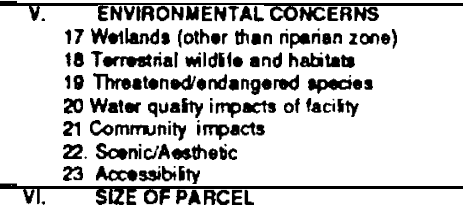 & 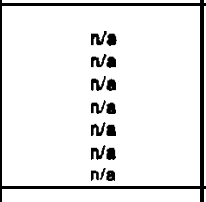 & 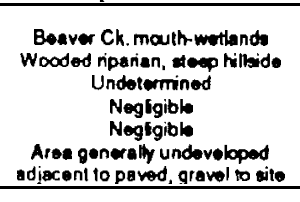 & $\begin{array}{l}n / 4 \\
n / 2 \\
n / 2 \\
n / 0 \\
n / 2 \\
n / a \\
n / 2\end{array}$ & 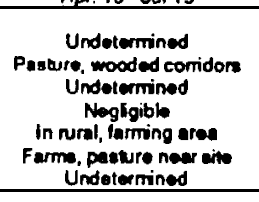 & 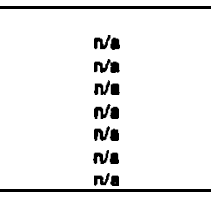 & 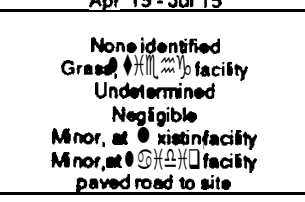 \\
\hline 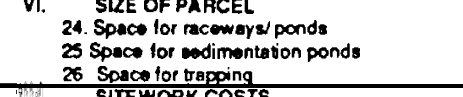 & $\begin{array}{l}n / a \\
n / m \\
n / a\end{array}$ & $\begin{array}{c}\text { 5-10 ecres } \\
\text { yes }\end{array}$ & 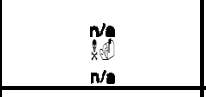 & 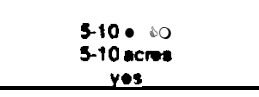 & $\begin{array}{l}n / 4 \\
n / 4 \\
n / 2\end{array}$ & 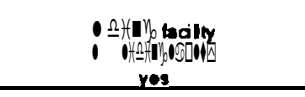 \\
\hline 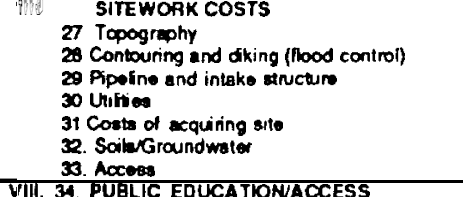 & $\begin{array}{l}n / a \\
n / a \\
n / a \\
n / a \\
n / a \\
n / a \\
n / a\end{array}$ & 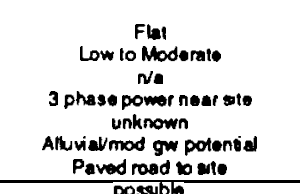 & 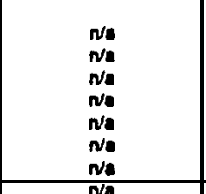 & 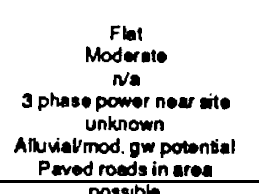 & 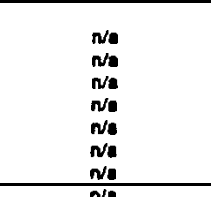 & 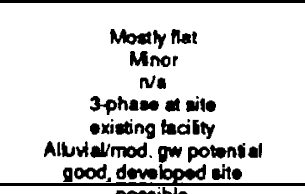 \\
\hline $\begin{array}{l}\text { VIIII. 3. PUELIC EDUCATION/ACCESS } \\
\text { IX. SECURITY }\end{array}$ & $n / \mathbf{a}$ & posatho & n/a & possible & n/1 & possible \\
\hline $\begin{array}{l}\text { 35. Intake entucture and water supply } \\
\text { 35. Pippinno } \\
\text { 37. Racowaysponds }\end{array}$ & $\begin{array}{l}n / a \\
n / a \\
n / a\end{array}$ & $\begin{array}{l}\text { Required } \\
\text { Required } \\
\text { Roguired }\end{array}$ & $\begin{array}{l}n / 4 \\
n / a \\
n / 4\end{array}$ & $\begin{array}{l}\text { Requirod } \\
\text { Roquirod } \\
\text { Roquired }\end{array}$ & $\begin{array}{l}n=1 \\
N=1 \\
n / 4\end{array}$ & $\begin{array}{l}\text { Peoquired } \\
\text { Pequired } \\
\text { Peovired }\end{array}$ \\
\hline 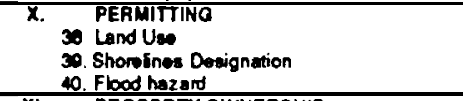 & $\begin{array}{l}n / 1 \\
n / 6 \\
n / 8\end{array}$ & $\begin{array}{l}\text { Undoterminod } \\
\text { Undetermined } \\
\text { Moderato on Bogver Ck }\end{array}$ & 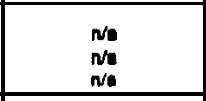 & 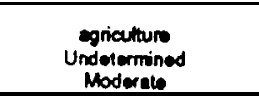 & $\begin{array}{l}N / 4 \\
N / 6 \\
n / 6\end{array}$ & $\begin{array}{l}\text { Exideting thality } \\
\text { Undetermined } \\
\text { Low }\end{array}$ \\
\hline 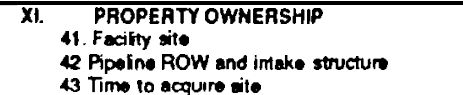 & $\begin{array}{l}n / 1 \\
n / a \\
n / a\end{array}$ & $\begin{array}{c}2 \text { privalo owners } \\
\text { N/e } \\
\text { Unknown }\end{array}$ & $\begin{array}{l}n / 4 \\
n / a \\
n / 4\end{array}$ & $\begin{array}{l}\text { Undolermined } \\
\text { Undoworniaded } \\
\text { Undotorminod }\end{array}$ & $\begin{array}{l}n / a \\
n / a \\
n / a\end{array}$ & $\begin{array}{l}\text { ODFW } \\
\text { ODFW } \\
n / \mathbb{n}\end{array}$ \\
\hline XNI. SUMMAAYICOMMENTS & ChF do not reach wite & 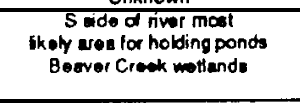 & ChF do not reach atto & 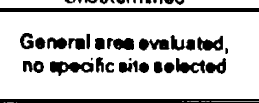 & $\begin{array}{l}\text { ChF do not reach wito } \\
\text { diatribution }\end{array}$ & 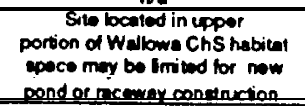 \\
\hline
\end{tabular}


TABLE 28 (3 of 4)

ADULT HOLDING SCREENING CRITERIA

\begin{tabular}{|c|c|c|c|c|c|c|c|}
\hline & & & iyoncreek & Minam-Wallo & Wonat & Strathea & \\
\hline & $\begin{array}{r}\text { CAMTERION } \\
\end{array}$ & Fall Chinook & Spring Chinook & Fall Chinook & Sping Chinook & Fall Chinook & Spring Chinook \\
\hline & 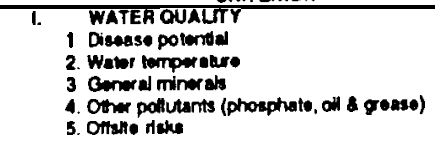 & 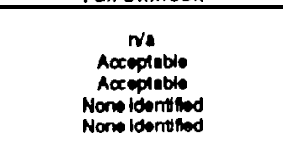 & 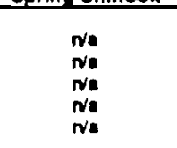 & 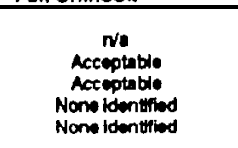 & 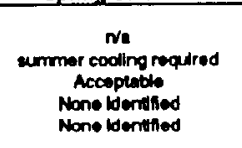 & $\begin{array}{l}n / a \\
n / a \\
n / a \\
n / a \\
n / a\end{array}$ & 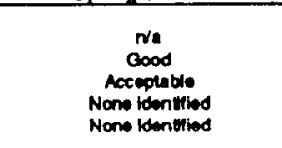 \\
\hline & 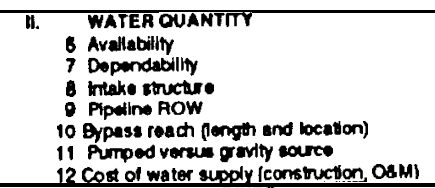 & 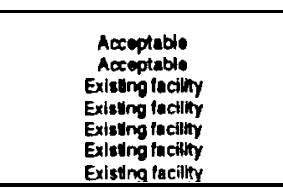 & 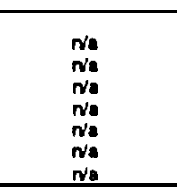 & 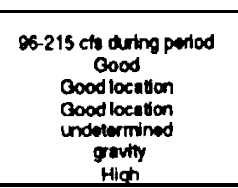 & 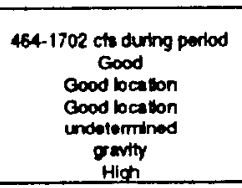 & 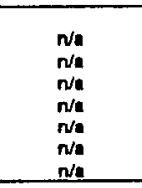 & 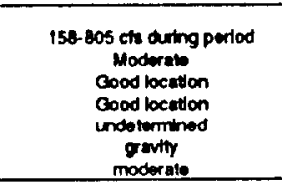 \\
\hline & 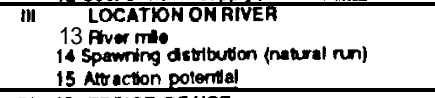 & $\begin{array}{l}\text { porented autumn ctinnoch habilat } \\
\text { good }\end{array}$ & 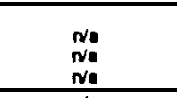 & $\begin{array}{l}\text { potentel tor Wallowa ChF } \\
\text { Dod }\end{array}$ & $\begin{array}{l}\text { Typlealy reach wite } \\
\text { Good }\end{array}$ & $\begin{array}{l}n / a \\
n / a \\
n / a \\
n\end{array}$ & $\begin{array}{l}\text { intweopt upper portion of num } \\
\text { Qood }\end{array}$ \\
\hline & N. 16 PERIOD OF USE & Sept-Dect & Nit & Sept-Dec & Asc. 15 - Jul 15 & Na & Apr. 15 . 1011 is \\
\hline$\alpha+2$ & 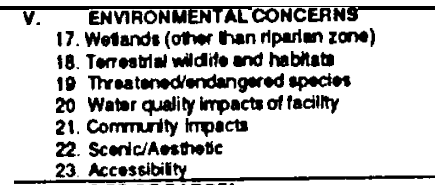 & 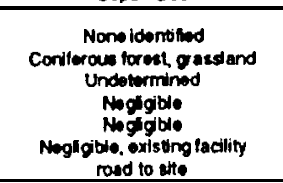 & 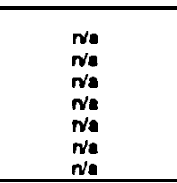 & 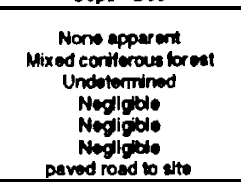 & 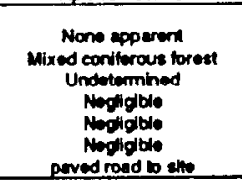 & 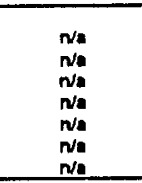 & 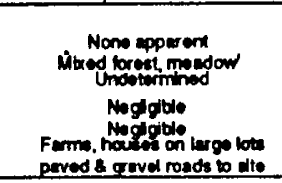 \\
\hline & 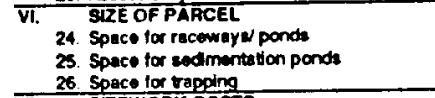 & $\begin{array}{l}\text { Exiryng focility } \\
\text { Existing tacility } \\
\text { Yos }\end{array}$ & 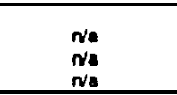 & 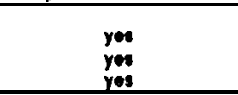 & 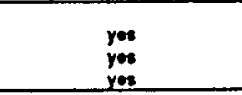 & $\begin{array}{l}n / 4 \\
n / a \\
N=1\end{array}$ & 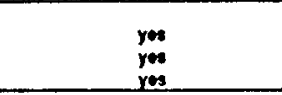 \\
\hline & 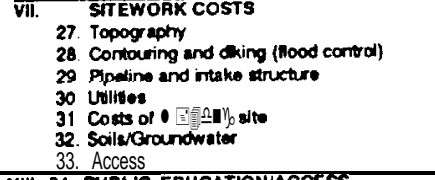 & 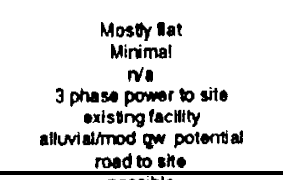 & 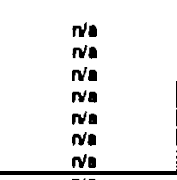 & 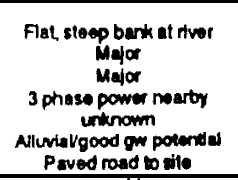 & 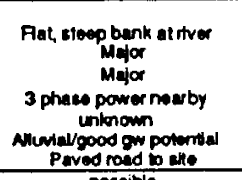 & 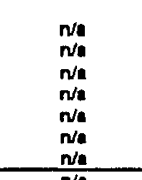 & 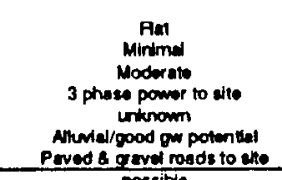 \\
\hline & $\begin{array}{l}\text { VIH. 34. PUELLC EDUCATKONIACCESS } \\
\text { SECURTY }\end{array}$ & possible & $\mathrm{Na}$ & Dossible & possible & na & possibie \\
\hline & 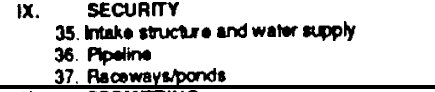 & $\begin{array}{l}\text { Aogutiod } \\
\text { Pogutiod } \\
\text { Reguted }\end{array}$ & 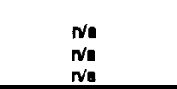 & $\begin{array}{l}\text { Aequired } \\
\text { Aequired } \\
\text { Aegured }\end{array}$ & $\begin{array}{l}\text { Required } \\
\text { Reputred } \\
\text { Resuliod } \\
\end{array}$ & 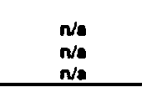 & $\begin{array}{l}\text { Aogated } \\
\text { Aoquted } \\
\text { Aequited }\end{array}$ \\
\hline & 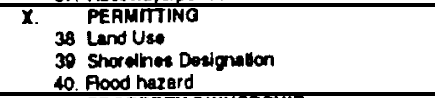 & $\begin{array}{l}\text { Eulading facillyy } \\
\text { Undetermined } \\
\text { Low }\end{array}$ & 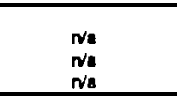 & $\begin{array}{l}\text { Purtlend } \\
\text { Undotwmined } \\
\text { High }\end{array}$ & $\begin{array}{c}\text { Pentelend } \\
\text { Undotimines } \\
\text { Hight }\end{array}$ & 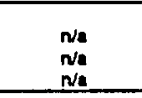 & 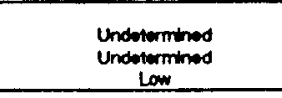 \\
\hline & 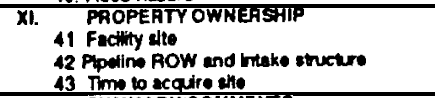 & $\begin{array}{l}\text { ODFW } \\
\text { ODFW } \\
\text { Unknown }\end{array}$ & $\begin{array}{l}W_{a} \\
W_{a} \\
W_{d}\end{array}$ & $\begin{array}{l}\text { Suth Panks } \\
\text { Num } \\
\text { Urknown }\end{array}$ & $\begin{array}{l}\text { Stum Panks } \\
\text { No } \\
\text { Unturown }\end{array}$ & $\begin{array}{l}n / 4 \\
n / 4 \\
n / 11\end{array}$ & 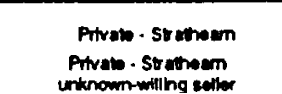 \\
\hline & XH. SUMMAAYICOMMENTS & 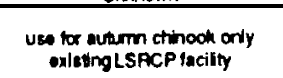 & & 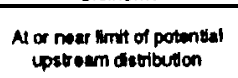 & 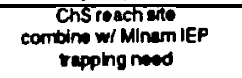 & & 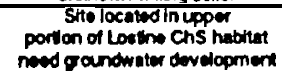 \\
\hline
\end{tabular}


TABLE 28 (4 of 4)

ADULT HOLDING SCREENING CRITERIA

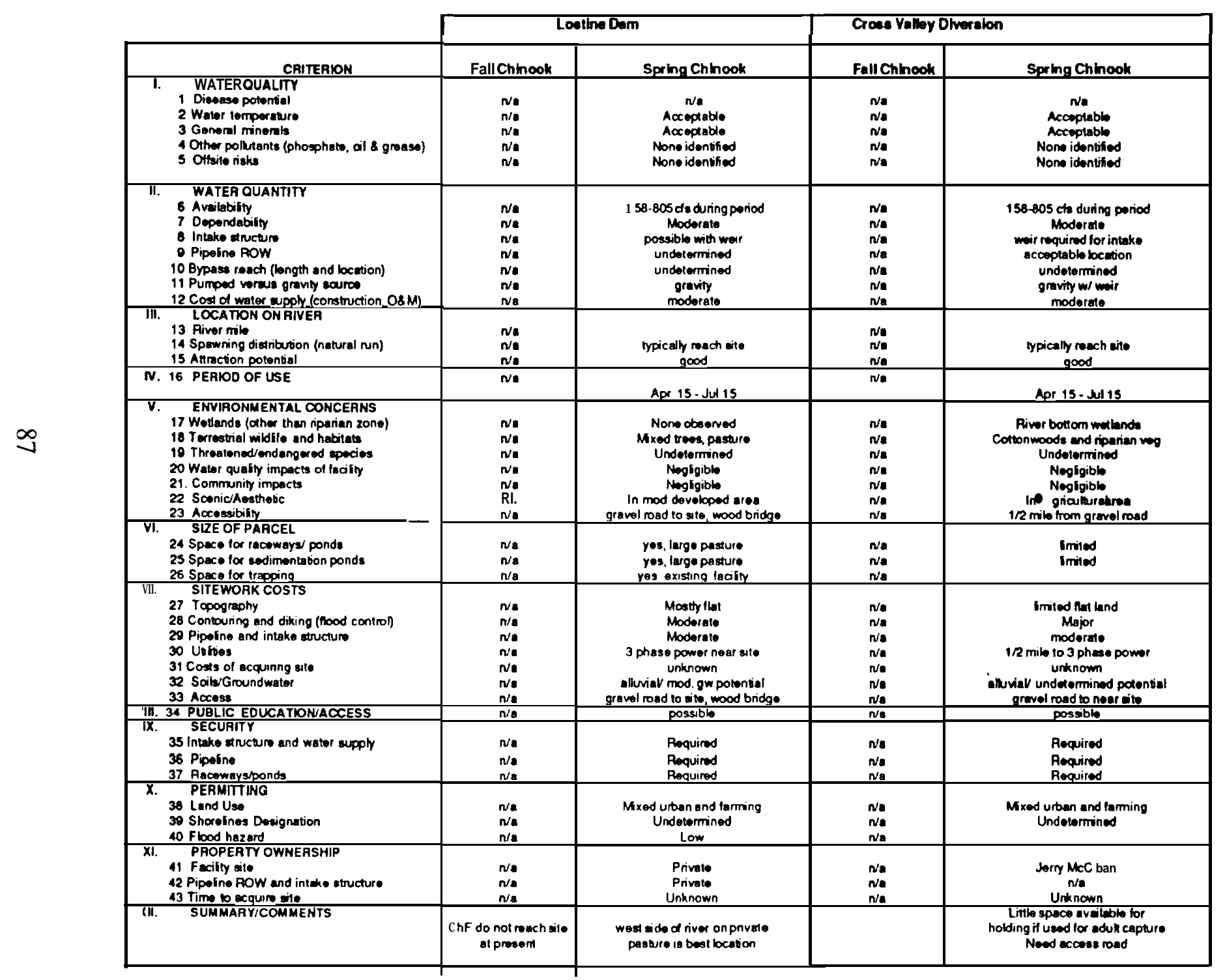


TABLE 29 (1 of 3)

GRANDE RONDE INCUBATION AND FRY REARING SCREENING CRITERIA

\begin{tabular}{|c|c|c|c|c|c|c|c|}
\hline & & \multicolumn{2}{|c|}{ Calherlne Creek (OSU Property) } & \multicolumn{2}{|c|}{ Caltherine Creek at Unlon } & \multicolumn{2}{|c|}{ Beaver croek } \\
\hline & CATIEAKON & Fall Chinook & Spring Chinook & Fall Chinook & Spring Chinook & Fall Chinook & Sprlng Chlnook \\
\hline $\begin{array}{l}1 . \\
1 \\
2 \\
3 \\
5 \\
5\end{array}$ & 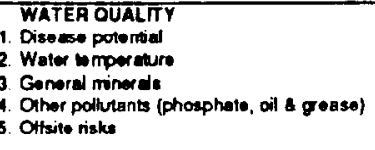 & 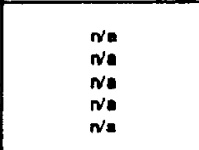 & 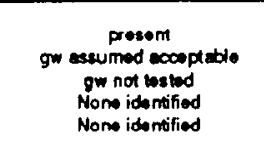 & $\begin{array}{l}n / 2 \\
n / n \\
n / n \\
n / m \\
n / m\end{array}$ & 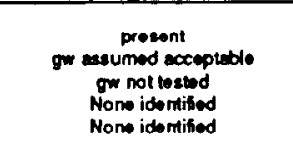 & 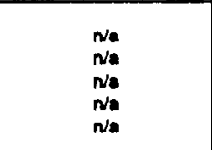 & 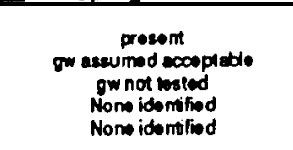 \\
\hline $\begin{array}{r}11 . \\
7 \\
8 \\
10 . \\
11 . \\
12 \\
\end{array}$ & 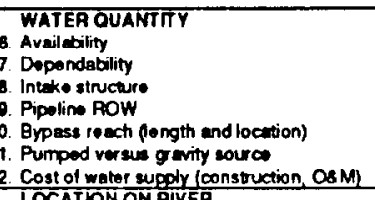 & 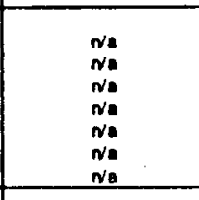 & 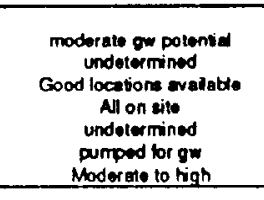 & 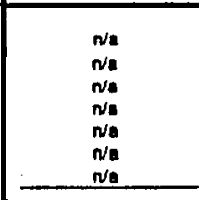 & 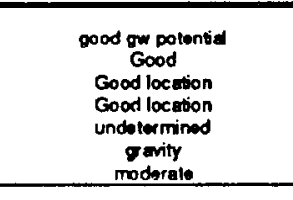 & 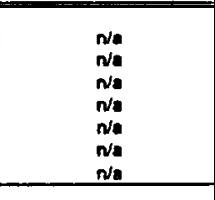 & $\begin{array}{l}\text { modoraw gom potontid } \\
\text { undolowinined } \\
\text { Good location } \\
\text { good location } \\
\text { undetermined } \\
\text { grevity } \\
\text { riah }\end{array}$ \\
\hline $\begin{array}{r}13 \\
14 \\
15 \\
\end{array}$ & 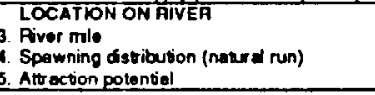 & 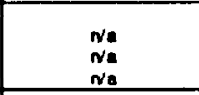 & $\begin{array}{l}\text { Typically roech wite } \\
\text { Good }\end{array}$ & $\begin{array}{l}N_{0} \\
N / 0 \\
N a\end{array}$ & $\begin{array}{l}\text { Typically rooch aito } \\
\text { Good }\end{array}$ & $\begin{array}{c}n / a \\
n a \\
n=0\end{array}$ & $\begin{array}{c}\text { GP irg } \\
\text { Typicaly rouch site } \\
\text { Good }\end{array}$ \\
\hline iv. 18. & 8. PEAKOO OF USE & $N / \mathbf{a}$ & Aug : Fob & $\pi / a$ & Aug - Fob & $n / \mathbf{n}$ & Aug F Fob \\
\hline $\begin{array}{l}17 . \\
18 . \\
10 \\
20 \\
21 . \\
22 \\
23 \\
\end{array}$ & 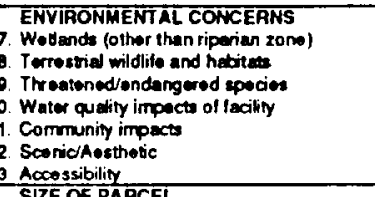 & 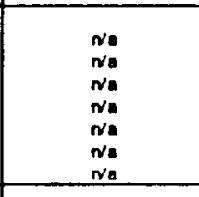 & 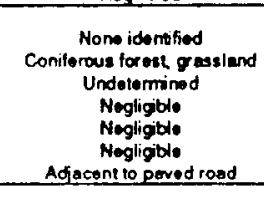 & $\begin{array}{l}n / a \\
n / a \\
n / a \\
N / a \\
N / a \\
N / a \\
N / a\end{array}$ & 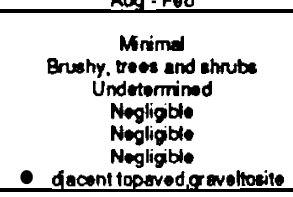 & $\begin{array}{l}n / a \\
n / a \\
n / a \\
n / a \\
n a d \\
n / a \\
n / a\end{array}$ & 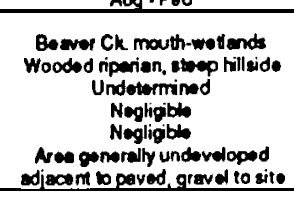 \\
\hline $\begin{array}{l}24 \\
25 \\
26 \\
\end{array}$ & 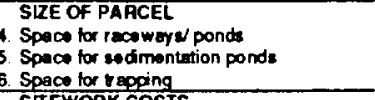 & $\begin{array}{l}\mathrm{Na} \\
\mathrm{Na} \\
\mathrm{Na} \\
\mathrm{Na}\end{array}$ & 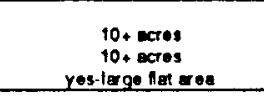 & $\begin{array}{l}n / \mathbf{a} \\
N / \mathbf{a} \\
N / \mathbf{a}\end{array}$ & $\begin{array}{c}\text { 1ecres } \\
\text { imoes } \\
\text { yes, exsingleodder }\end{array}$ & 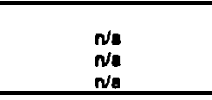 & $\begin{array}{c}5-10 \operatorname{coses} \\
5-10 \operatorname{cosen} \\
\text { yest }\end{array}$ \\
\hline $\begin{array}{l}27 \\
28 \\
29 \\
30 \\
31 \\
32 \\
33 \\
\end{array}$ & 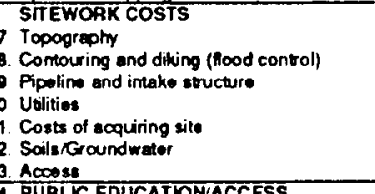 & 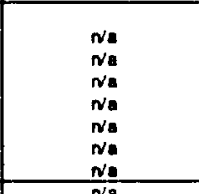 & 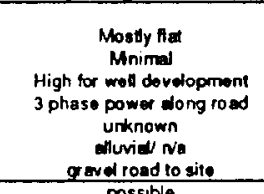 & $\begin{array}{l}n / a \\
n / a \\
n / a \\
n / a \\
n / a \\
n / a \\
n / a\end{array}$ & 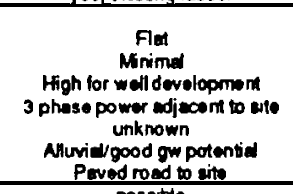 & 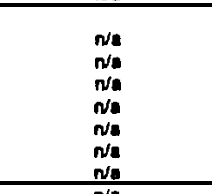 & 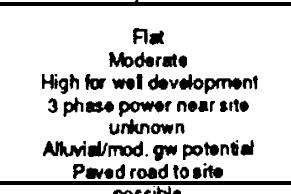 \\
\hline$\frac{5 i i 1.34 .}{i x .3}$ & $\begin{array}{l}\text { 4. PUBLIC EDUCATIONACCESS } \\
\text { SECUAITY }\end{array}$ & Na & possible & $n / 4$ & possiblo & $n / 4$ & possibio \\
\hline $\begin{array}{r}35 \\
36 \\
37 \\
\end{array}$ & 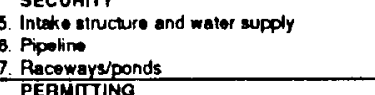 & 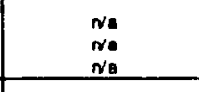 & $\begin{array}{l}\text { Requinod } \\
\text { Poquinod } \\
\text { Aoguired }\end{array}$ & $\begin{array}{c}n / a \\
n / a \\
n / a\end{array}$ & $\begin{array}{l}\text { Proquired } \\
\text { Roquirod } \\
\text { Proquirod }\end{array}$ & $\begin{array}{l}n / a \\
n / \\
n / 4 \\
n\end{array}$ & $\begin{array}{l}\text { Required } \\
\text { Requered } \\
\text { Required }\end{array}$ \\
\hline $\begin{array}{r}36 . \\
390 \\
40 \\
\end{array}$ & 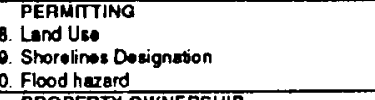 & 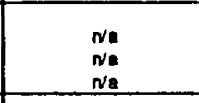 & $\begin{array}{l}\text { Undolominined } \\
\text { Undelorminod } \\
\text { Low }\end{array}$ & $\begin{array}{l}n / a \\
n / a \\
n / a\end{array}$ & $\begin{array}{l}\text { Undetorminod } \\
\text { Undotorminod } \\
\text { Low }\end{array}$ & $\begin{array}{c}n / 1 \\
n / 1 \\
n / 1\end{array}$ & $\begin{array}{l}\text { Undowormined } \\
\text { Undetorminod } \\
\text { Moder ate on Beever Ck }\end{array}$ \\
\hline $\begin{array}{l}41 . \\
42 \\
43\end{array}$ & $\begin{array}{l}\text { PROPEPTY OWNEASHIP } \\
\text { 1. Fucility sito } \\
\text { 2 Pipeline ROW and intake encucture } \\
3 \text { Tims to acquire ute }\end{array}$ & $\begin{array}{l}\text { Na: } \\
n: \\
n: \\
N a\end{array}$ & $\begin{array}{c}\operatorname{csu} \\
\operatorname{sos} U \\
\text { Unknown }\end{array}$ & $\begin{array}{l}\mathrm{Na} \\
\mathrm{Na} \\
\mathrm{Na}\end{array}$ & $\begin{array}{l}\text { ODFsw } \\
\text { OOFsw } \\
\text { Unknown }\end{array}$ & $\begin{array}{c}n / 4 \\
n / 1 \\
n / a\end{array}$ & $\begin{array}{c}2 \text { privuto ownors } \\
\text { nka } \\
\text { Unknown }\end{array}$ \\
\hline $\bar{x}$ XII. & SUMMAAY/COMMENTS & ChF do not roseh site & 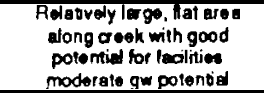 & GhF do not reach silo & & ChF do not roach site & 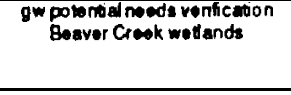 \\
\hline
\end{tabular}


TABLE $29(2$ of 3$)$

GRANDE RONDE INCUBATION AND FRY REARING SCREENING CRITERIA

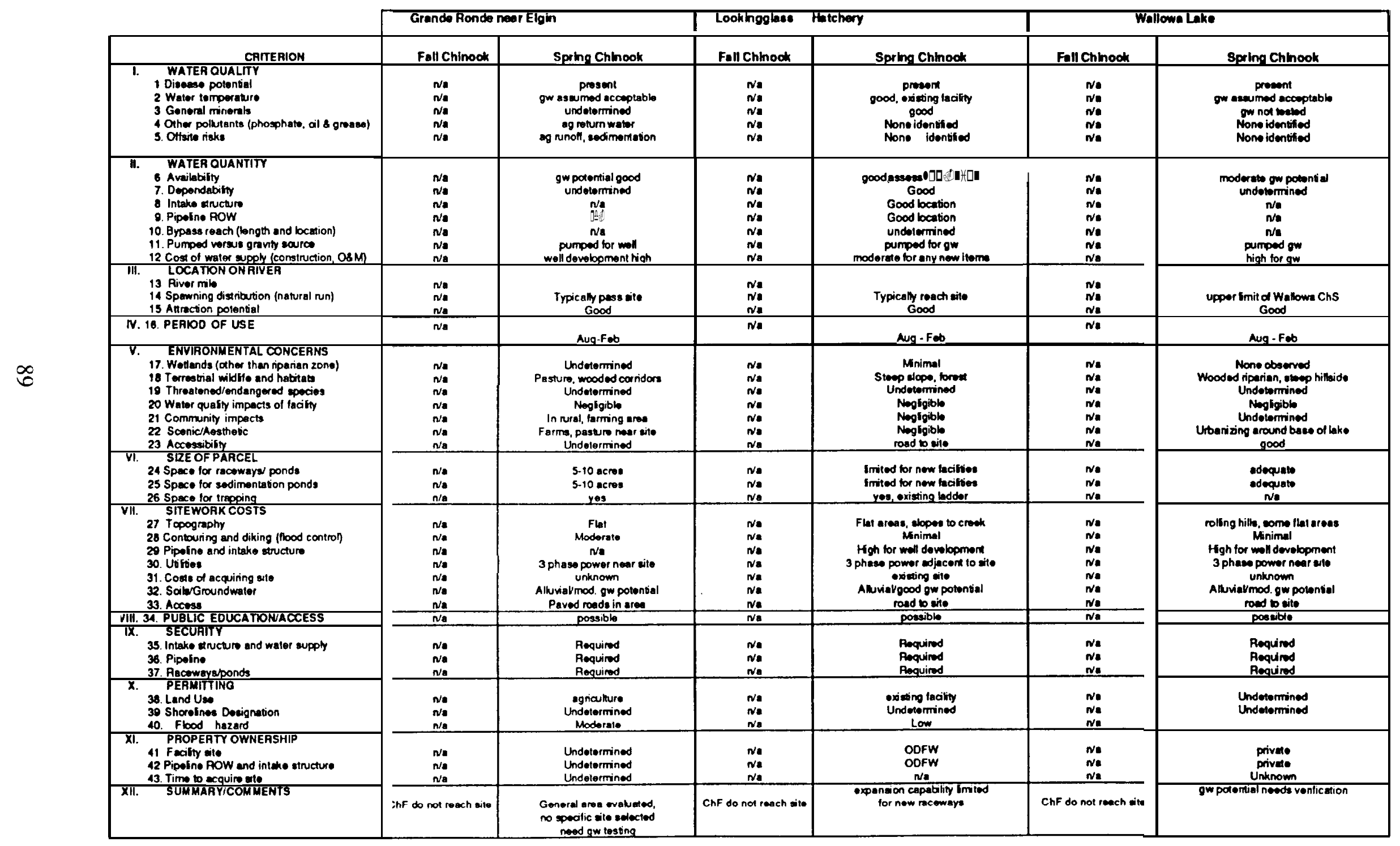


TABLE 29 (3 of 3)

GRANDE RONDE INCUBATION AND FRY REARING SCREENING CRITERIA

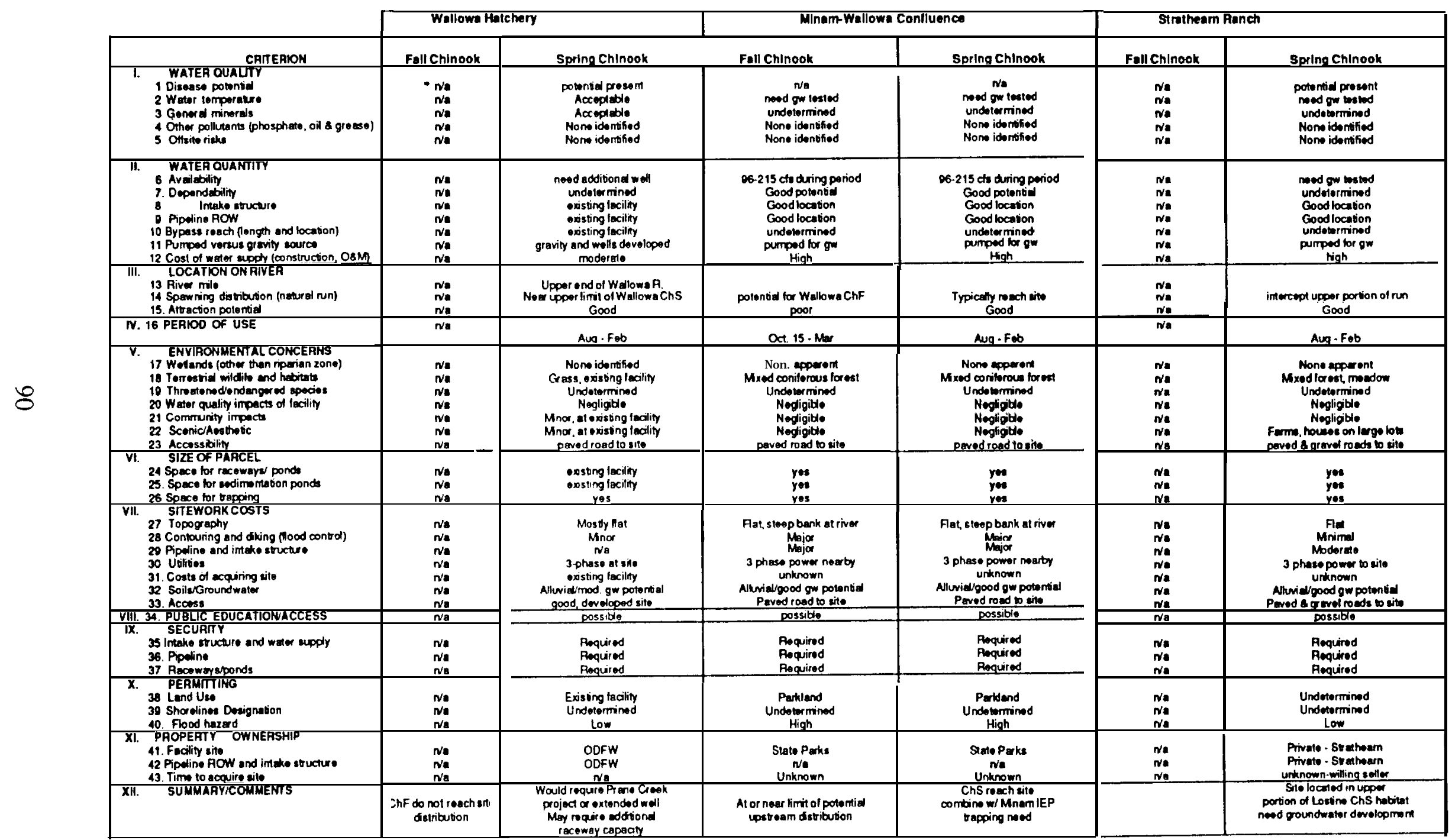


TABLE 30 (1 of 3)

GRANDE RONDE SATELLITE REARING SCREENING CRITERIA

\begin{tabular}{|c|c|c|c|c|c|c|c|}
\hline \multirow{2}{*}{\multicolumn{2}{|c|}{$\begin{array}{r}\text { CAMTERION } \\
\end{array}$}} & \multicolumn{2}{|c|}{ Catherine Creek (OSU Property) } & \multicolumn{2}{|c|}{ Cather hine Creek af Union } & \multicolumn{2}{|c|}{ Beaver Croek } \\
\hline & & Fall Chinook & Spring Chmook & Fall Chlnook & Spring Chlnook & Fall Chinook & Spring Chinook \\
\hline $\begin{array}{ll}1 . \\
2 \\
3 \\
4 \\
5\end{array}$ & 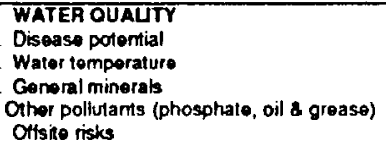 & $\begin{array}{l}N a \\
n a a \\
N / a \\
n / a \\
N a\end{array}$ & $\begin{array}{l}\text { presont } \\
\text { neod ow for wintor mixing } \\
\text { acceptable } \\
\text { None identitiod } \\
\text { Nono identified }\end{array}$ & $\begin{array}{l}w_{a} \\
N / a \\
N a \\
N a \\
N a \\
N a\end{array}$ & $\begin{array}{l}\text { present } \\
\text { nead gw lor wimer mixing } \\
\text { moceptable } \\
\text { None identiliod } \\
\text { None identitiod }\end{array}$ & 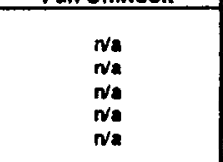 & $\begin{array}{l}\text { prosont } \\
\text { nood gu for wind or miring } \\
\text { acceoplable } \\
\text { None idontiliod } \\
\text { None identified }\end{array}$ \\
\hline $\begin{array}{r}71 . \\
6 . \\
7 . \\
8 \\
9 \\
10 . \\
11 . \\
12 . \\
\end{array}$ & 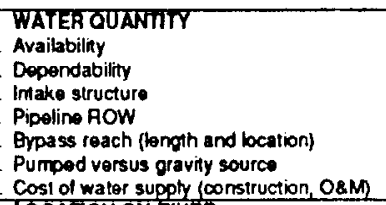 & $\begin{array}{l}\mathrm{Na} \\
\mathrm{naz} \\
\mathrm{Na} \\
\mathrm{Na} \\
\mathrm{Na} \\
\mathrm{Na} \\
\mathrm{Na} \\
\mathrm{Na} \\
\mathrm{Na}\end{array}$ & $\begin{array}{l}\text { Adequate } \\
\text { undelermined } \\
\text { Cood locations available } \\
\text { Al on site } \\
\text { undetermined } \\
\text { pumped lor gw } \\
\text { Moderate bo high } \\
\end{array}$ & 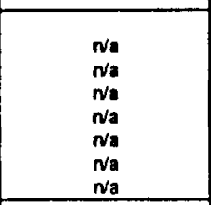 & $\begin{array}{l}\text { adequate } \\
\text { Good } \\
\text { Good boation } \\
\text { Good bcation } \\
\text { undelermined } \\
\text { gravity } \\
\text { moderate } \\
\end{array}$ & 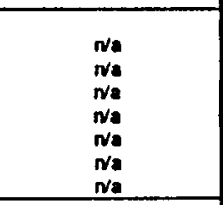 & $\begin{array}{l}\text { adequate } \\
\text { undetermined } \\
\text { Good location } \\
\text { good location } \\
\text { undetermined } \\
\text { oravity } \\
\text { high }\end{array}$ \\
\hline $\begin{array}{l}\text { जा. } \\
13 . \\
14 . \\
15 .\end{array}$ & $\begin{array}{l}\text { Livot milo } \\
\text { Spawning distribution (natural run) } \\
\text { Atraction potemtial }\end{array}$ & $\begin{array}{l}n=a \\
n / a \\
n / a\end{array}$ & $\begin{array}{l}\text { Typically roach sito } \\
\text { Good }\end{array}$ & $\begin{array}{l}N / 2 \\
N / 2 \\
N / 3\end{array}$ & $\begin{array}{l}\text { Typically roach sito } \\
\text { Good }\end{array}$ & $\begin{array}{l}\text { Na } \\
n / a \\
N / a\end{array}$ & $\begin{array}{l}\text { CA } 179 \\
\text { Typically reach sino } \\
\text { Good }\end{array}$ \\
\hline IV. 16. & PEFIOD OF USE & n/a & Doc-May 15 (18mos) & $N^{\prime} / \mathbf{a}$ & Dec-May 15 (18mos) & wa & Dec-May 15 (18mos) \\
\hline $\begin{array}{l}\text { v. } \\
17 . \\
187 \\
19 \\
20 \\
21 . \\
22 . \\
23 . \\
\end{array}$ & 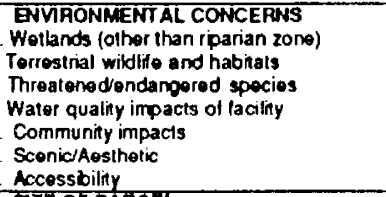 & $\begin{array}{l}\text { Na } \\
\text { wa } \\
\text { wa } \\
\text { Na } \\
\text { wa } \\
\text { Na } \\
\text { Na }\end{array}$ & 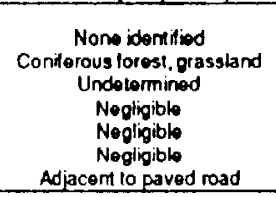 & $\begin{array}{l}N_{a} \\
N a \\
N= \\
N a \\
N a \\
N / a \\
N a \\
N a \\
N a\end{array}$ & $\begin{array}{l}\text { Mininal } \\
\text { Brushy, troos and thrubs } \\
\text { Undolormined } \\
\text { Nogligblo } \\
\text { Nogligblo } \\
\text { Noglipblo } \\
\text { adjacent to paved gravel lo sto }\end{array}$ & 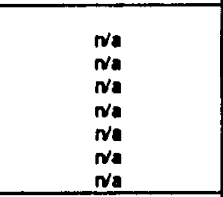 & 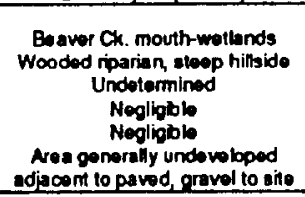 \\
\hline $\begin{array}{l}\text { VI. } 24 \\
25 \\
26 \\
\end{array}$ & 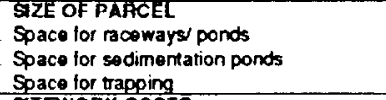 & $\begin{array}{l}\mathrm{Wa} \\
\mathrm{Na} \\
\mathrm{Na}\end{array}$ & $\begin{array}{c}10+\text { actos } \\
\text { 10+ acos } \\
\text { yes-large flat area }\end{array}$ & $\begin{array}{l}\mathrm{Na} \\
\mathrm{N} / \mathrm{a} \\
\mathrm{Na}\end{array}$ & $\begin{array}{c}4 \text { acros } \\
\text { 4 acros } \\
\text { yes, oxisting ladder }\end{array}$ & 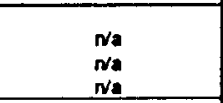 & $\begin{array}{c}5-10 \text { acros } \\
\text { 5-10 acros } \\
\text { yes }\end{array}$ \\
\hline $\begin{array}{l}\text { Vil. } \\
27 \\
28 \\
29 \\
30 \\
31 \\
32 \\
33 \\
\end{array}$ & 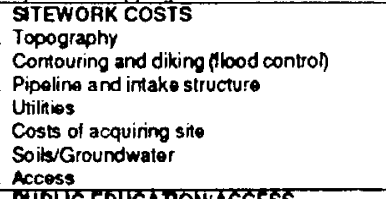 & $\begin{array}{l}N a \\
N / a \\
N a \\
N / a \\
N / a \\
N a \\
N a \\
\end{array}$ & $\begin{array}{c}\text { Mostly flat } \\
\text { Minimal } \\
\text { Moderate } \\
\text { 3 phase power along road } \\
\text { unknown } \\
\text { alluvialy na } \\
\text { gravel raad to site } \\
\end{array}$ & 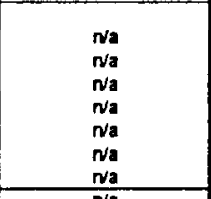 & $\begin{array}{c}\text { Flat } \\
\text { Minimal } \\
\text { Modorato } \\
\text { 3 phase power adjacent bo site } \\
\text { unknown } \\
\text { Alluvisugood gw polential } \\
\text { Paved rosed wo sine }\end{array}$ & 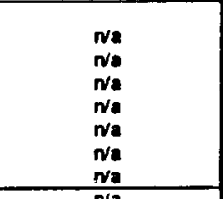 & $\begin{array}{l}\text { Flat } \\
\text { Modorate } \\
\text { High for woll dovelopmomt } \\
3 \text { phase powor noar site } \\
\text { unknown } \\
\text { Alluvialmod. gw potemial } \\
\text { Pavod roud to sine }\end{array}$ \\
\hline$\frac{711 .}{7 x} 34$ & PJEUC EDUCA TONACCESS & na & possible & Na & possble & Na & possible \\
\hline $\begin{array}{r}35 \\
36 \\
37\end{array}$ & $\begin{array}{l}\text { SECURTr } \\
\text { Intike structure and water supply } \\
\text { Pipeline } \\
\text { Racewaysponos }\end{array}$ & $\begin{array}{l}n / a \\
\text { na } \\
\text { na } \\
\text { Na }\end{array}$ & $\begin{array}{l}\text { Aequired } \\
\text { Required } \\
\text { Aequired }\end{array}$ & $\begin{array}{l}\mathrm{wa} \\
\mathrm{n} / \mathrm{a} \\
\mathrm{Na}\end{array}$ & $\begin{array}{l}\text { Roquired } \\
\text { Required } \\
\text { Required }\end{array}$ & 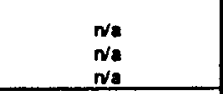 & $\begin{array}{l}\text { Requirnod } \\
\text { Required } \\
\text { Required }\end{array}$ \\
\hline $\begin{array}{l}38 . \\
39 . \\
40 \\
\end{array}$ & $\begin{array}{l}\text { PERMITIING } \\
\text { Land Use } \\
\text { Shorolines Dosignation } \\
\text { Flood hazard }\end{array}$ & $\begin{array}{l}\text { wa } \\
\text { wa } \\
\text { naa }\end{array}$ & $\begin{array}{l}\text { Undelermined } \\
\text { Undelermined } \\
\text { Low }\end{array}$ & $\begin{array}{l}n / a \\
n / a \\
n / a\end{array}$ & $\begin{array}{l}\text { Undetermined } \\
\text { Undelormined } \\
\text { Low }\end{array}$ & $\begin{array}{l}n / a \\
\text { wa } \\
\text { wad }\end{array}$ & $\begin{array}{l}\text { Undolormined } \\
\text { Undotormined } \\
\text { Modernito on Boaver Ck. }\end{array}$ \\
\hline $\begin{array}{l}\text { xi. } \\
42 . \\
43 . \\
4\end{array}$ & $\begin{array}{l}\text { PAOPEATY OWNEFSHIP } \\
\text { Facility sto } \\
\text { Pipoline ROW and irtake structure } \\
\text { Time to acquire site }\end{array}$ & $\begin{array}{l}\mathrm{N} / \mathrm{a} \\
\mathrm{N} / \mathrm{a} \\
\mathrm{N} / \mathrm{a}\end{array}$ & $\begin{array}{c}\text { OSU } \\
\text { osu } \\
\text { Unknown } \\
\end{array}$ & $\begin{array}{l}n_{a} \\
n / a \\
n a\end{array}$ & $\begin{array}{l}\text { ODFW } \\
\text { ODFW } \\
\text { Unknown }\end{array}$ & $\begin{array}{l}N_{2} \\
w_{2} \\
N_{2}\end{array}$ & $\begin{array}{c}2 \text { private owners } \\
\text { Ne } \\
\text { Unknown }\end{array}$ \\
\hline प्रा1. & SUMMAAYICOMMENTS & ChF do not reach site & $\begin{array}{l}\text { Relatively large llat area } \\
\text { abong creek with pood } \\
\text { potontial for lacillios } \\
\text { moderale gu potemial }\end{array}$ & ChF do not reach site & & ChF do not reach sito & $\begin{array}{l}\text { gw polerial noods verfication } \\
\text { Be evver Crook wortands }\end{array}$ \\
\hline
\end{tabular}


TABLE $30(2$ of 3)

GRANDE RONDE SATELLITE REARING SCREENING CRITERIA

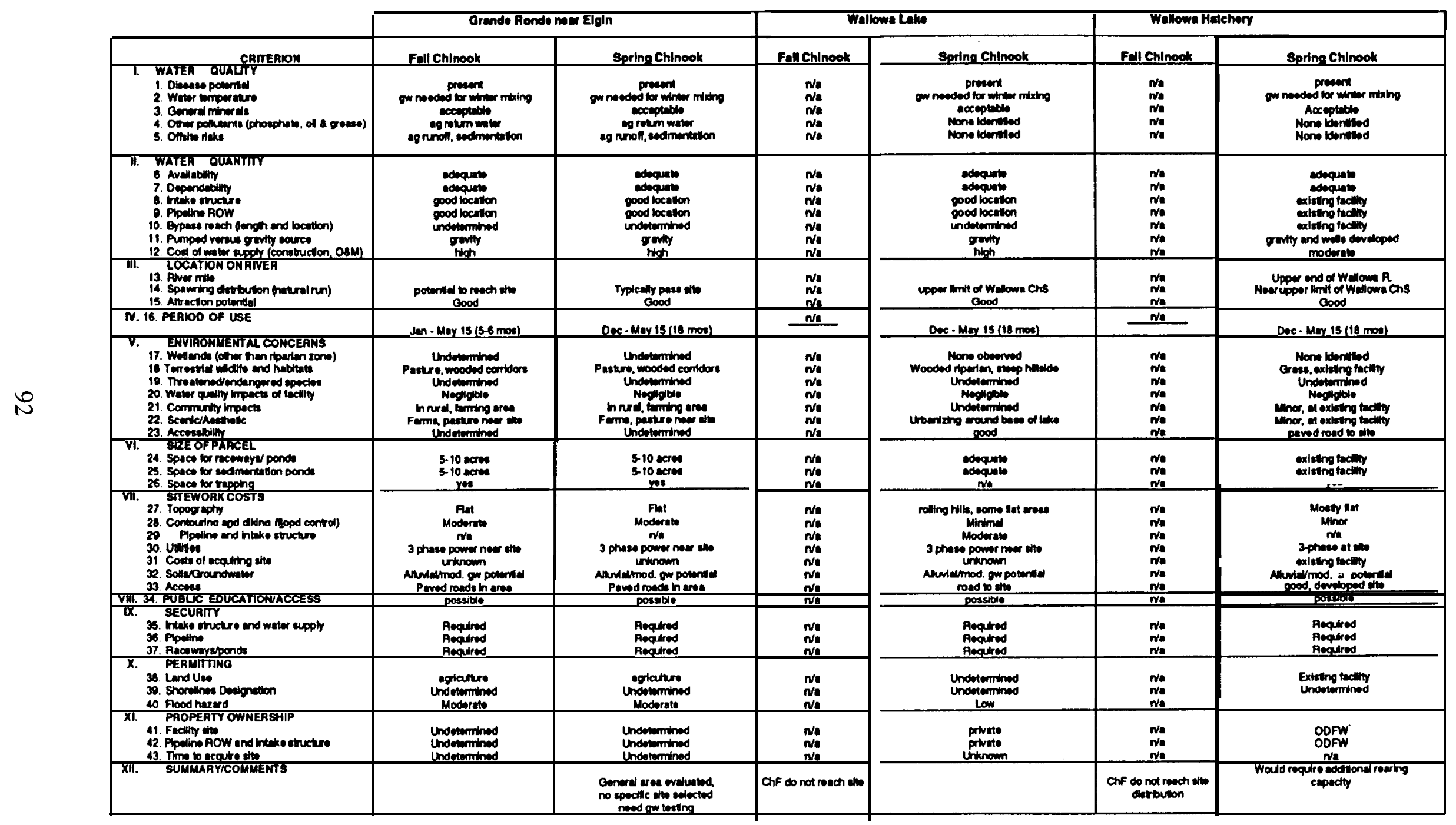


TABLE 30 (3 of 3)

GRANDE RONDE SATELLITE REARING SCREENING CRITERIA

\begin{tabular}{|c|c|c|c|c|}
\hline \multirow[b]{2}{*}{ CATERION } & \multicolumn{2}{|c|}{ Mham-Wallowa Confiluence } & \multicolumn{2}{|c|}{ Strathearn Ranch } \\
\hline & Fall Chinook & Spror Chinook & Fall Chhook & Spring Chlnook \\
\hline 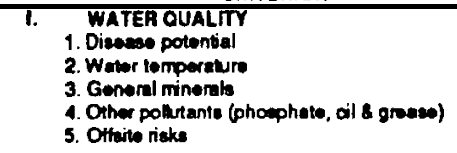 & $\begin{array}{l}\text { Procent } \\
\text { nead ow for winter mixing } \\
\text { cocopteblo } \\
\text { None toentified } \\
\text { None identified }\end{array}$ & $\begin{array}{l}\text { Prowent } \\
\text { need ow tor winter mixing } \\
\text { nocoptible } \\
\text { None identified } \\
\text { None identified }\end{array}$ & 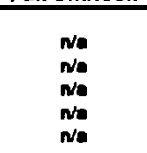 & $\begin{array}{l}\text { Prownt } \\
\text { nead gw br winter mixing } \\
\text { socoptablo } \\
\text { Nono identified } \\
\text { Nono identified }\end{array}$ \\
\hline 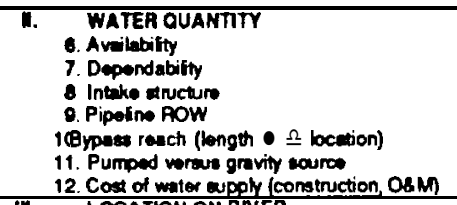 & 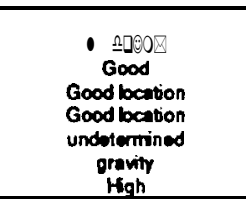 & $\begin{array}{l}\text { odequante } \\
\text { Good } \\
\text { Good boction } \\
\text { Good bection } \\
\text { undelemined } \\
\text { grevity } \\
\text { High }\end{array}$ & 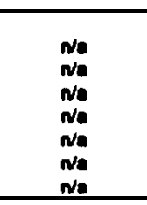 & $\begin{array}{l}\text { Goquatio } \\
\text { Good } \\
\text { Good bocalion } \\
\text { Good bocation } \\
\text { undatemined } \\
\text { grovity } \\
\text { high }\end{array}$ \\
\hline 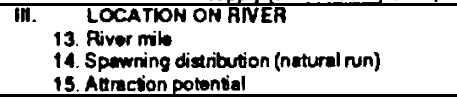 & $\begin{array}{c}\text { potentid tor Wallowa ChF } \\
\text { poor }\end{array}$ & $\begin{array}{c}\text { Typicaly reach itite } \\
\text { Good }\end{array}$ & 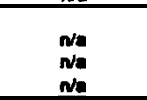 & $\begin{array}{l}\text { inbroupl upper portion of nun } \\
\text { Good }\end{array}$ \\
\hline N. 16. PERIOD OF USE & $\operatorname{Jan} \cdot M$ ar $15(5$ to $6 \mathrm{mos})$ & Dec-Mar 15 (18 mos) & $n / 4$ & Doc - Mory 15 (10 mos) \\
\hline 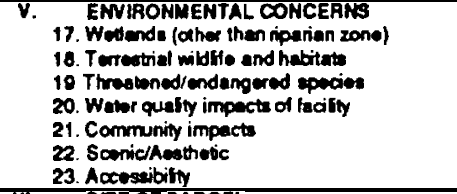 & 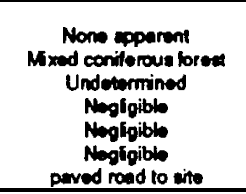 & 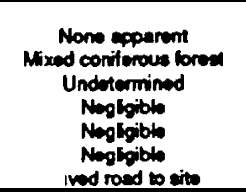 & 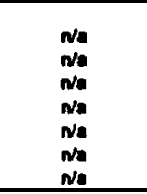 & 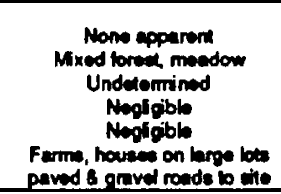 \\
\hline 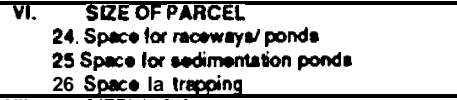 & $\begin{array}{c}\text { yoe } \\
\text { you } \\
\text { yos }\end{array}$ & $\underset{y \omega u}{y \infty u}$ & 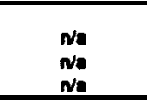 & 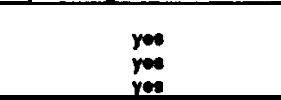 \\
\hline 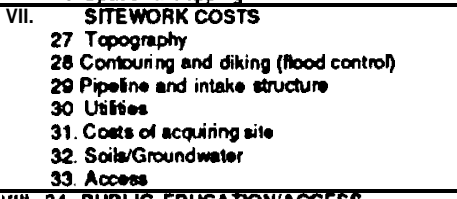 & 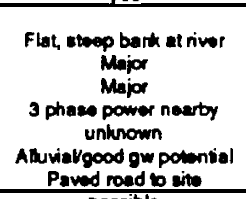 & 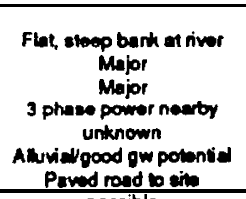 & 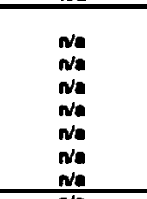 & 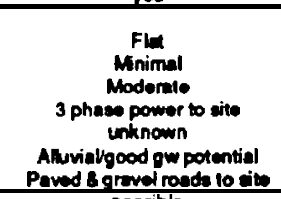 \\
\hline 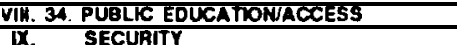 & Possible & 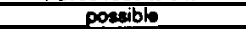 & n/a & Dorsible \\
\hline 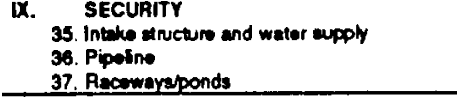 & $\begin{array}{l}\text { Aequinod } \\
\text { Ropuivod } \\
\text { Pequired }\end{array}$ & $\begin{array}{l}\text { Aequires } \\
\text { Required } \\
\text { Pequired }\end{array}$ & $\begin{array}{c}\text { na } \\
\text { na } \\
\text { na }\end{array}$ & $\begin{array}{l}\text { Requined } \\
\text { Raquired } \\
\text { Required }\end{array}$ \\
\hline $\begin{array}{l}\text { X. PER Land Uew } \\
\text { 30. Shorolines Dorignation } \\
\text { 40. Fbod hezerd }\end{array}$ & $\begin{array}{c}\text { Parkland } \\
\text { Undetwmined } \\
\text { Hogh }\end{array}$ & $\begin{array}{c}\text { Partlend } \\
\text { Underturmined } \\
\text { High }\end{array}$ & 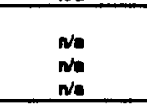 & $\begin{array}{c}\text { Undecomined } \\
\text { Undetomininos } \\
\text { Low }\end{array}$ \\
\hline 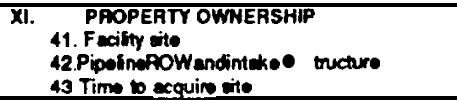 & $\begin{array}{l}\text { Sieno Parke } \\
\text { Nak } \\
\text { Unknown }\end{array}$ & $\begin{array}{c}\text { STate Parke } \\
\text { Na } \\
\text { Unknown }\end{array}$ & $\begin{array}{l}\text { Na } \\
\text { nat } \\
\text { nea }\end{array}$ & $\begin{array}{l}\text { Privalo - Strathearn } \\
\text { Privete - Stratheom } \\
\text { unknown-wiling mellor }\end{array}$ \\
\hline XH. SUMMMARYCOCMMENTS & $\begin{array}{l}\text { At of noer Imit of potential } \\
\text { upeteam diatribution }\end{array}$ & $\begin{array}{l}\text { ChS reach ino } \\
\text { contine w/Minem EIP } \\
\text { rapping nead }\end{array}$ & & 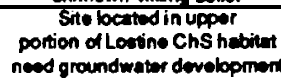 \\
\hline
\end{tabular}


TABLE 31 (1 of 2)

IMNAHA RIVER BASIN

ADULT CAPTURE SCREENING CRITERIA

\begin{tabular}{|c|c|c|c|c|c|c|c|}
\hline & & \multicolumn{2}{|c|}{ Gumbool Creeh (flioh Weir) } & \multicolumn{2}{|c|}{ Grouse Creck-tinnatha Confluence } & \multicolumn{2}{|c|}{ Blg Sheop-Litile Shoep Conturence } \\
\hline & CRITERION & $\begin{array}{l}\text { Fall Chhook } \\
\text { (Sep-Dec) }\end{array}$ & $\begin{array}{c}\text { Spring Chlnook } \\
(4 / 15.7 / 15)\end{array}$ & $\begin{array}{l}\text { Fall Chinook } \\
\text { (Sep-Dec) }\end{array}$ & $\begin{array}{c}\text { Spping Chinook } \\
(4 / 15-7 / 15)\end{array}$ & $\begin{array}{c}\text { Fall Chinook } \\
\text { (Sep-Dec) }\end{array}$ & $\begin{array}{c}\text { Spring Chlnook } \\
(4 / 15-7 / 15)\end{array}$ \\
\hline & 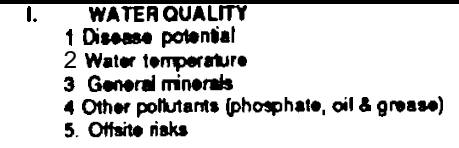 & $\begin{array}{l}n / a \\
n / a \\
n / a \\
n / a \\
N / 4\end{array}$ & $\begin{array}{l}\text { Na } \\
\text { Accoptablo } \\
\text { Accoptable } \\
\text { Nono identifiod } \\
\text { Nono identifiod }\end{array}$ & $\begin{array}{l}\text { wa } \\
\mathrm{Na} \\
\mathrm{Na} \\
\mathrm{Na} \\
\mathrm{wa} \\
\mathrm{wa}\end{array}$ & 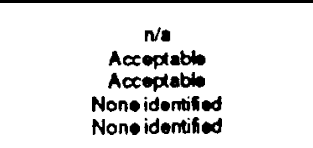 & $\begin{array}{l}n / 1 \\
n / a \\
n / 1 \\
n / a \\
n / 2\end{array}$ & 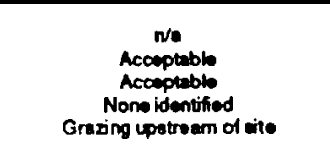 \\
\hline & 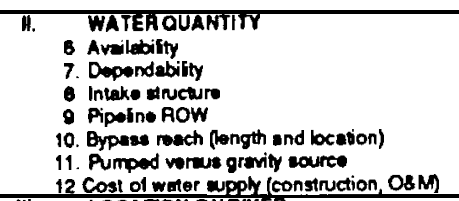 & 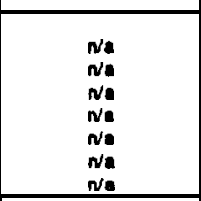 & 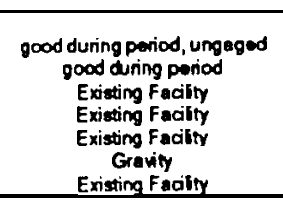 & 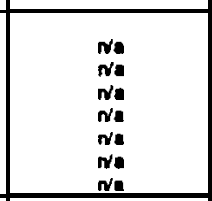 & 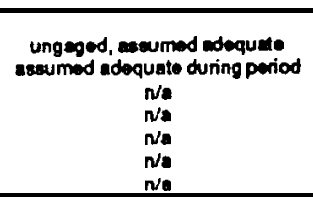 & $\begin{array}{l}n / 2 \\
n / a \\
n / a \\
n / a \\
n / a \\
n / a \\
n / a \\
n / a\end{array}$ & 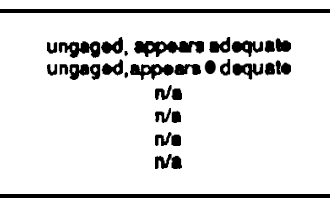 \\
\hline & 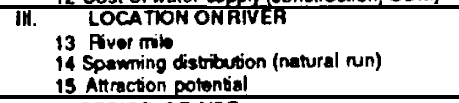 & $\begin{array}{l}n / 4 \\
n / 4 \\
n / 4\end{array}$ & $\begin{array}{l}\text { Typically rosech eito } \\
\text { Good }\end{array}$ & 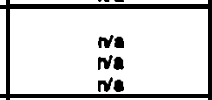 & $\begin{array}{l}\text { Typically roach wis } \\
\text { Good }\end{array}$ & $\begin{array}{c}n / 1 \\
n / 4\end{array}$ & $\begin{array}{l}\text { Typically reach eito } \\
\text { Good }\end{array}$ \\
\hline & N. 16. PEAKOD OF USE & $\mathrm{n} / \mathbf{a}$ & Apr 15 - & N/a & Apr. 15 - Jul 15 & n/a & Apr. 15 - Jul 15 \\
\hline \multirow[t]{8}{*}{$\stackrel{\wp}{\not}$} & 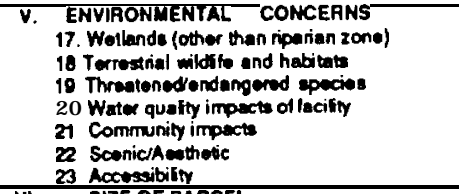 & 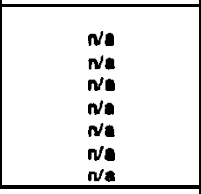 & 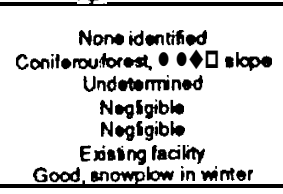 & 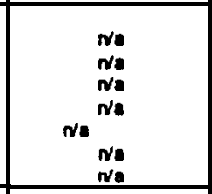 & 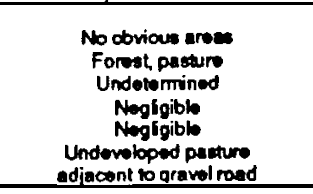 & 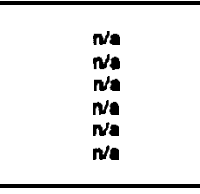 & 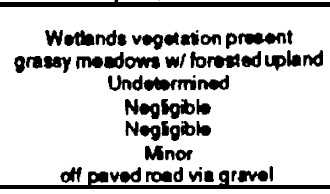 \\
\hline & 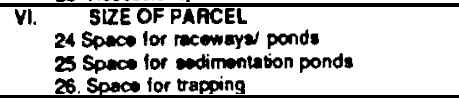 & 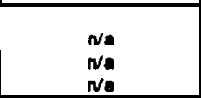 & 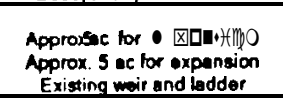 & $\begin{array}{l}n / \mathbf{a} \\
n / \mathbf{a} \\
n / a\end{array}$ & $\begin{array}{l}\text { vory fimited } \\
\text { vory imited } \\
\text { yes }\end{array}$ & $\begin{array}{l}n / a \\
n / a \\
n / a\end{array}$ & $\begin{array}{l}<2 \text { acroes } \\
<2 \text { ycres } \\
\text { yes }\end{array}$ \\
\hline & 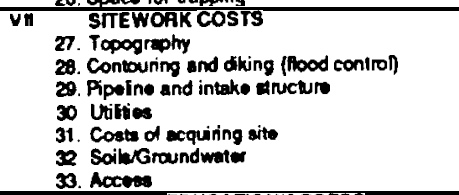 & 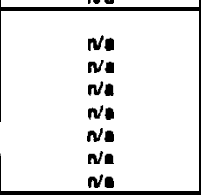 & 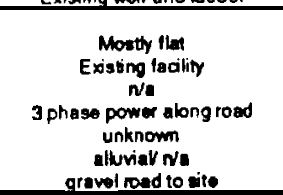 & $\begin{array}{l}\mathrm{Na} \\
\mathrm{Na} \\
\mathrm{Na} \\
\mathrm{Na} \\
\mathrm{Na} \\
\mathrm{wa} \\
\mathrm{wa} \\
\mathrm{Na} \\
\mathrm{na}\end{array}$ & 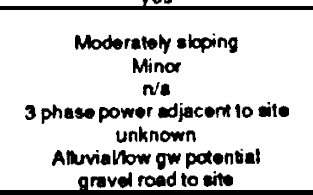 & $\begin{array}{l}n=1 \\
n / 1 \\
n: a \\
n / a \\
n / a \\
n / a \\
n / 2\end{array}$ & 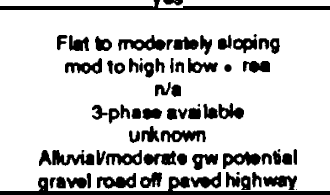 \\
\hline & VIA. 34. PUBLLC EDUCATHONAOCCESS & $\mathrm{n} / \mathbf{a}$ & 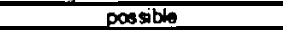 & $\mathrm{n} / \mathrm{a}$ & Dossible & $\mathrm{n} / \mathbf{2}$ & Doasibh \\
\hline & $\begin{array}{l}\text { IX. SECURITY } \\
\text { 35. Intake atuctum and water euppty } \\
\text { 36. Pippine } \\
\text { 37. Raceweryeponds }\end{array}$ & $\begin{array}{l}n / a \\
n / 4 \\
n / a\end{array}$ & $\begin{array}{l}\text { Requirod } \\
\text { Requirod } \\
\text { Required }\end{array}$ & $\begin{array}{l}\mathrm{Wa} \\
\mathrm{Wa} \\
\mathrm{Na} \\
\mathrm{Na}\end{array}$ & $\begin{array}{l}\text { Pequirod } \\
\text { Poguired } \\
\text { Ploguired }\end{array}$ & $\begin{array}{l}n=1 \\
n: 1 \\
n / 1 \\
n=1\end{array}$ & $\begin{array}{l}\text { Required } \\
\text { Requirud } \\
\text { Recuired }\end{array}$ \\
\hline & 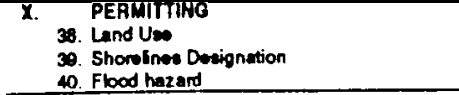 & $\begin{array}{l}n= \\
n= \\
n / 8\end{array}$ & $\begin{array}{l}\text { Existing tacility } \\
\text { Underormined } \\
\text { Low }\end{array}$ & $\begin{array}{l}\text { Wa } \\
\text { wa } \\
\text { na }\end{array}$ & $\begin{array}{l}\text { Undolemmines } \\
\text { Undoterminad } \\
\text { Low }\end{array}$ & $\begin{array}{l}n / a \\
n / a \\
n / a\end{array}$ & $\begin{array}{l}\text { Undowermined } \\
\text { Undewrmined } \\
\text { Mod to high in low areas }\end{array}$ \\
\hline & 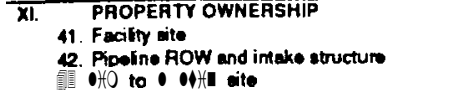 & 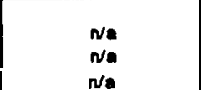 & $\begin{array}{c}\text { OOFsW } \\
\text { ODFBW } \\
N / a\end{array}$ & $\begin{array}{l}w_{a} \\
n a \\
n a\end{array}$ & 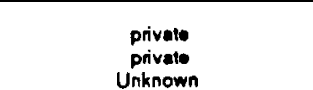 & $\begin{array}{l}n / 1 \\
n / a\end{array}$ & $\begin{array}{c}\text { Private } \\
\text { Prival } \\
\text { unknown }\end{array}$ \\
\hline & GWU SUMMAAYICOMMEENTS & ChF do not reach wite & 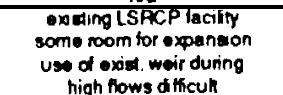 & ShF do not mach into & $\begin{array}{l}\text { Limiled area fol uses other } \\
\text { than trapping } \\
\text { Landowner may not bo } \\
\text { cooperative }\end{array}$ & $\begin{array}{l}\text { Beyond inmit of ChF } \\
\text { detribution }\end{array}$ & 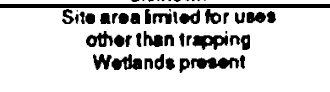 \\
\hline
\end{tabular}


TABLE 31 (2 of 2)

IMNAHA RIVER BASIN

ADULT CAPTURE SCREENING CRITERIA

\begin{tabular}{|c|c|c|c|}
\hline & & \multicolumn{2}{|c|}{ Gene Mart Ranch } \\
\hline & $\begin{array}{l}\text { CAITERION } \\
\end{array}$ & $\begin{array}{l}\text { Fall Chinook } \\
\text { (Sep-Dec) }\end{array}$ & $\begin{array}{c}\text { Spring Chinook } \\
(4 / 15-7 / 15)\end{array}$ \\
\hline $\begin{array}{l}1 \\
1 \\
3 \\
3 \\
4 \\
5\end{array}$ & 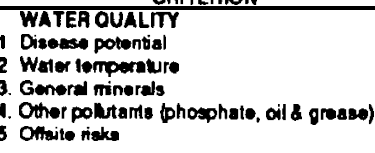 & 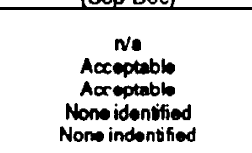 & 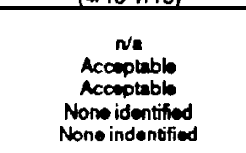 \\
\hline $\begin{array}{l}\text { II. } \\
? \\
8 \\
9 \\
10 \\
11 \\
12 . \\
\end{array}$ & 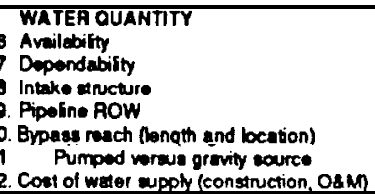 & $\begin{array}{c}143-210 \text { de during poriod } \\
8000 \text { cts minimum } \\
n / 1 \\
n / 1 \\
n / 1 \\
n / a\end{array}$ & 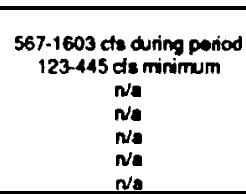 \\
\hline $\begin{array}{l}13 . \\
13 \\
15 \\
15 \\
\end{array}$ & 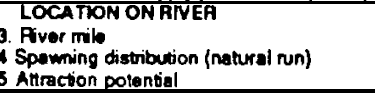 & $\underset{\text { Wil not inbroupt entive un }}{\text { good }}$ & $\begin{array}{c}\text { All the nun peasen ine } \\
\text { modorete }\end{array}$ \\
\hline N. 16 & 5 PERIOD OF USE & 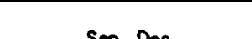 & Aner 15. \\
\hline $\begin{array}{l}17 \\
18 \\
10 \\
10 \\
20 \\
21 \\
22 \\
23 \\
\end{array}$ & 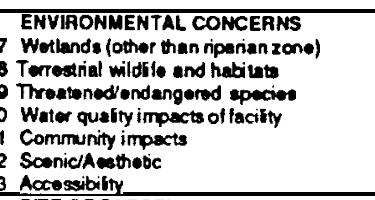 & 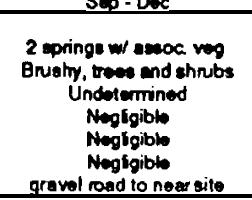 & 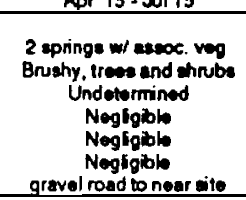 \\
\hline $\begin{array}{l}\text { VI. } \\
24 \\
25 \\
26\end{array}$ & 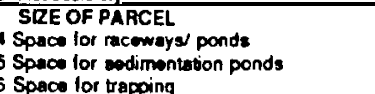 & $\begin{array}{l}3+\text { acron } \\
\text { S+ acres }\end{array}$ & $\begin{array}{l}5+\operatorname{acns} \\
5+\operatorname{acos} \\
\text { yes }\end{array}$ \\
\hline $\begin{array}{l}\text { Vil. } 20 \\
27 \\
198 \\
20 \\
30 \\
31 \\
30 \\
33 \\
30\end{array}$ & 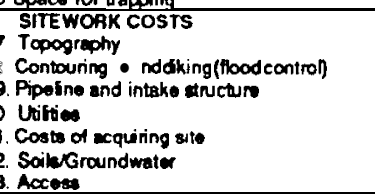 & 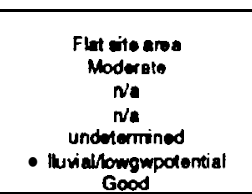 & 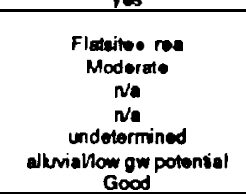 \\
\hline$\frac{9}{\text { VII. } 34}$ & PUELIC EDUCATION/AOCESS & possible & Dossibio \\
\hline $\begin{array}{l}35 . \\
36 \\
37 \\
37\end{array}$ & $\begin{array}{l}\text { SECURITY } \\
\text { Intake structure and wator supply } \\
\text { S. Pipoline } \\
\text { Pacewayzenonds }\end{array}$ & $\begin{array}{l}\text { Requires } \\
\text { Roquired } \\
\text { Required }\end{array}$ & $\begin{array}{l}\text { Required } \\
\text { Requirod } \\
\text { Requirod }\end{array}$ \\
\hline $\begin{array}{l}x . \\
30 \\
30 \\
40\end{array}$ & 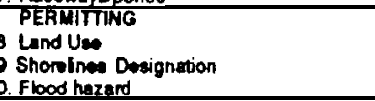 & $\begin{array}{l}\text { underermined } \\
\text { Undetermined } \\
\text { Low to moderato }\end{array}$ & $\begin{array}{l}\text { Undetormined } \\
\text { Undolomined } \\
\text { Low to modorate }\end{array}$ \\
\hline $\begin{array}{l}41 . \\
42 \\
43 \\
4\end{array}$ & $\begin{array}{l}\text { PROPEFTY OWNERSHIP } \\
\text { Facilty sito } \\
\text { 2. Pipolno ROW and intake structure } \\
\text { 3. Time to ecouire sito }\end{array}$ & $\begin{array}{c}\text { Gone Marr } \\
\text { Gone Marr } \\
\text { Undetormined_willing solibr }\end{array}$ & $\begin{array}{l}\text { Gono Marr } \\
\text { Gono Mar } \\
\text { underomined, willing wallar }\end{array}$ \\
\hline$\overline{x \text { XI. }}$ & SUMMARY/COMMENTS & $\begin{array}{l}\text { Would not intorcapt all ChF } \\
\text { Some wotlands on ito } \\
\text { Permit issues with weit }\end{array}$ & $\begin{array}{l}\text { Sorme wollonds on with } \\
\text { Pormit issues with wait }\end{array}$ \\
\hline
\end{tabular}


TABLE 32 (1 of 2)

IMNAHA RIVER BASIN

ADULT HOLDING SCREENING CRITERIA

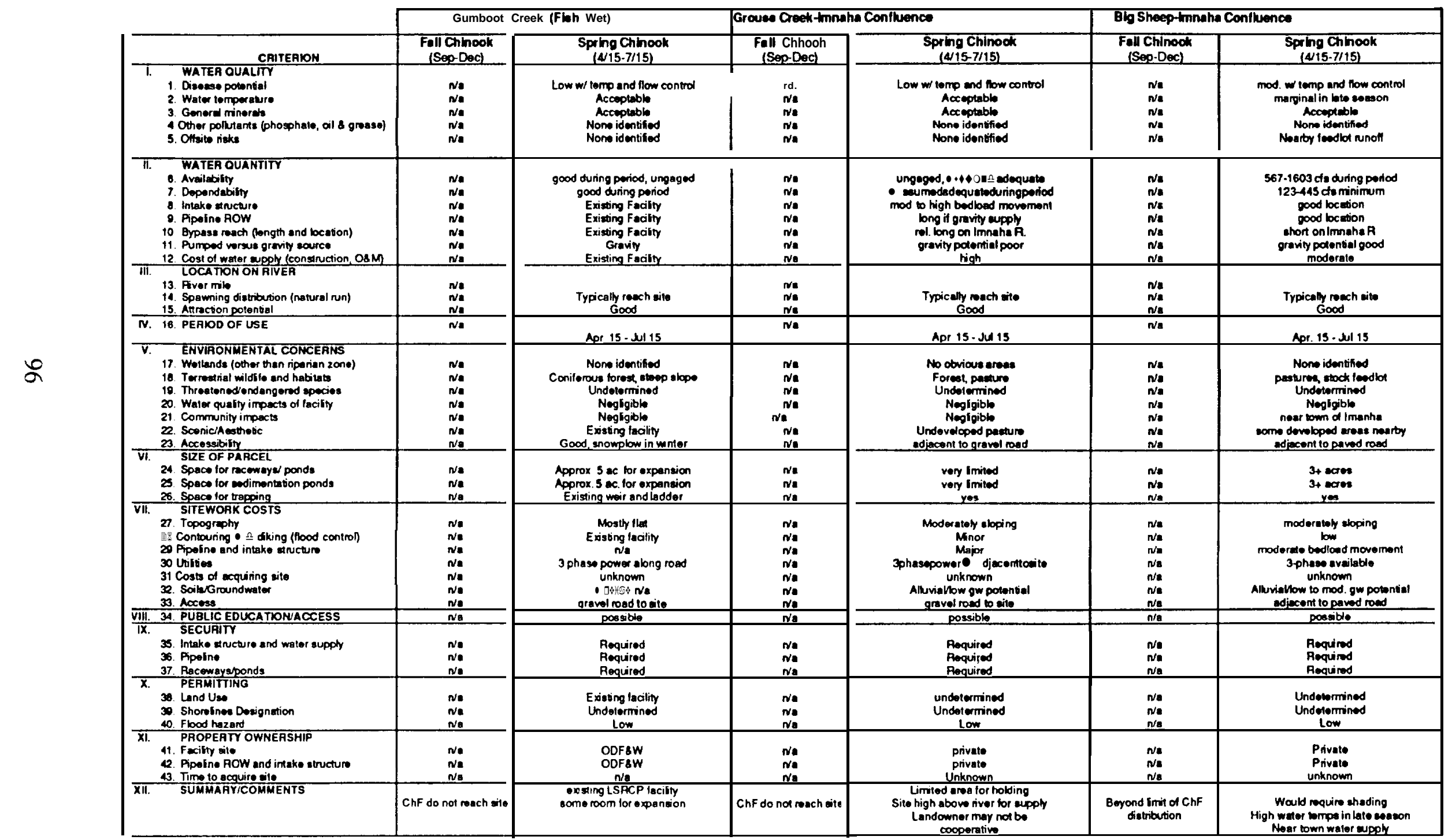


TABLE 32 (2 of 2)

IMNAHA RIVER BASIN

ADULT HOLDING SCREENING CRITERIA

\begin{tabular}{|c|c|c|c|c|}
\hline & \multicolumn{2}{|c|}{ Ho Sheep-Littlo Sheep Confluence } & \multicolumn{2}{|c|}{ Gene Marr Hanch } \\
\hline CAITERION & $\begin{array}{c}\text { Fall Chhook } \\
\text { (Sop-Doc) }\end{array}$ & $\begin{array}{c}\text { Spring Chinook } \\
(\$ 115-7 / 15) \\
\end{array}$ & $\begin{array}{l}\begin{array}{l}\text { Fall Chhook } \\
\text { (Sep-Dec) }\end{array} \\
\end{array}$ & $\begin{array}{c}\text { Sprhg Chhook } \\
(4 / 15-7 / 15) \\
\end{array}$ \\
\hline 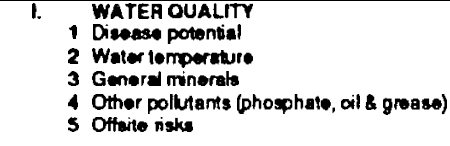 & 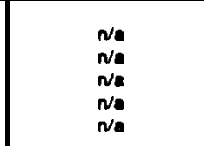 & 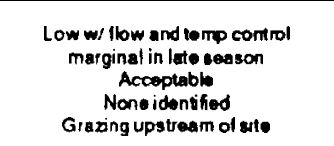 & 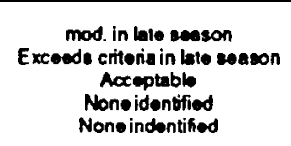 & 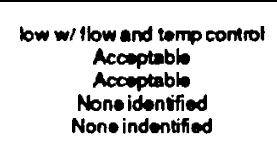 \\
\hline 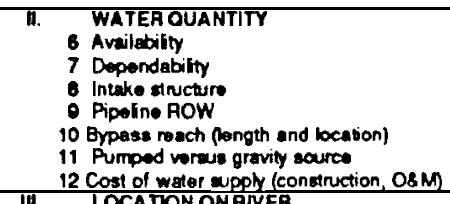 & 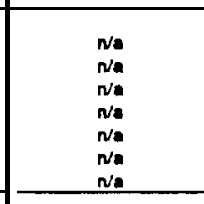 & 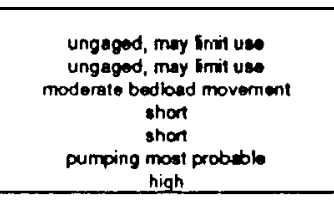 & 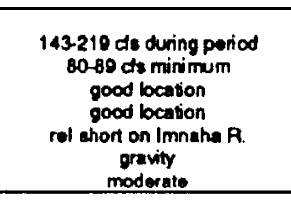 & 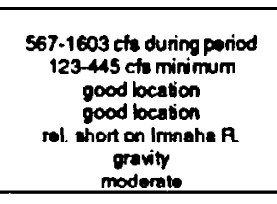 \\
\hline 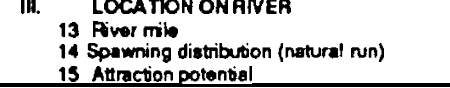 & 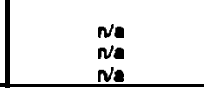 & $\begin{array}{l}\text { Typically mosch site } \\
\text { Good }\end{array}$ & Wil not interoopt entive run & $\begin{array}{l}\text { All the run pascose aite } \\
\text { moderato }\end{array}$ \\
\hline N. 16. PERIOD OF USE & $\frac{n_{*}}{n_{m}}$ & Aor 15 - Jul 15 & s & \\
\hline 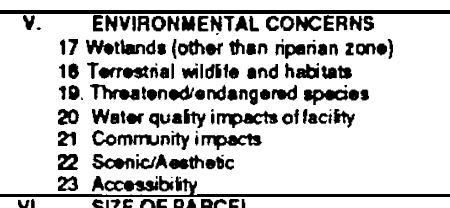 & 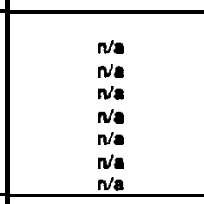 & 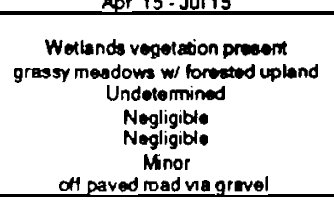 & 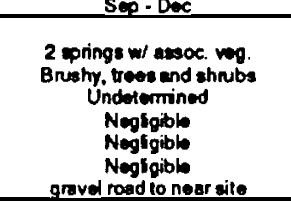 & 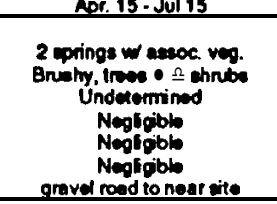 \\
\hline 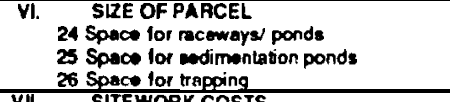 & 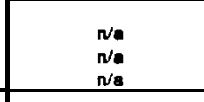 & 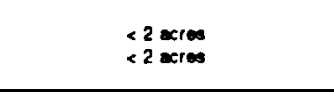 & 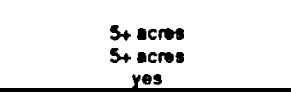 & 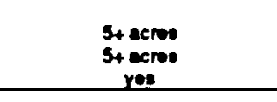 \\
\hline 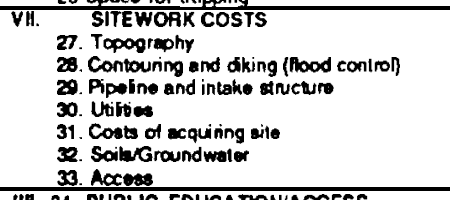 & 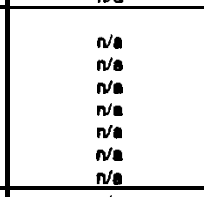 & 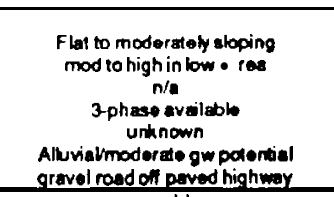 & 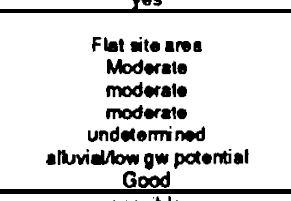 & 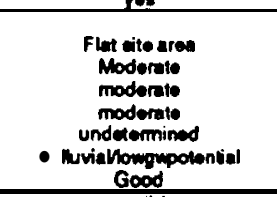 \\
\hline $\begin{array}{l}\text { Jith. W4. PUQLLC EDUCATONAOCESS } \\
\mathrm{IX} \text { SECURITY }\end{array}$ & $\mathrm{n} / \mathrm{s}$ & Dossable & possatio & posatiblo \\
\hline 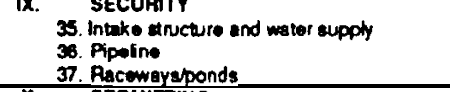 & $\begin{array}{l}\mathrm{Na} \\
\mathrm{Na} \\
\mathrm{nab}\end{array}$ & $\begin{array}{l}\text { Aoquirod } \\
\text { Aogainod } \\
\text { Roguvired }\end{array}$ & $\begin{array}{l}\text { Required } \\
\text { Alequired } \\
\text { Required }\end{array}$ & $\begin{array}{l}\text { Required } \\
\text { Required } \\
\text { Required }\end{array}$ \\
\hline 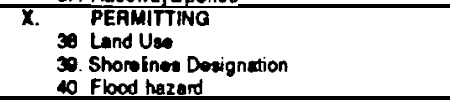 & 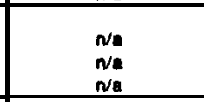 & 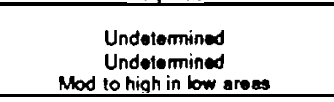 & 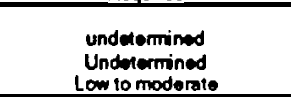 & $\begin{array}{l}\text { undoleminined } \\
\text { Undolomined } \\
\text { Low to moderate }\end{array}$ \\
\hline 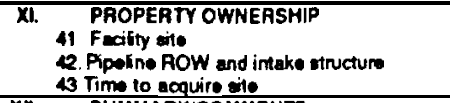 & 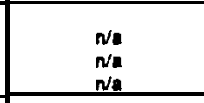 & $\begin{array}{c}\text { Pive: } \\
\text { Prvivat: } \\
\text { unknown } \\
\end{array}$ & $\begin{array}{c}\text { Gone Marr } \\
\text { Gone Marr } \\
\text { und determinod, wiling seller }\end{array}$ & $\begin{array}{l}\text { Gone Mar } \\
\text { Gone Merr } \\
\text { undelermined, willing wallor }\end{array}$ \\
\hline XW. SUMMARY'COMMENTS & $\begin{array}{l}\text { Beyondismin aChF } \\
\text { distritution }\end{array}$ & 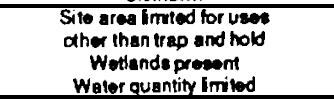 & 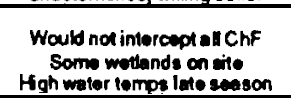 & Somo wotlends on ine \\
\hline
\end{tabular}


TABLE 33 ( 1 of 1 )

IMNAHA RIVER BASIN

INCUBATION AND FRY REARING SCREENING CRITERIA

\begin{tabular}{|c|c|c|c|c|c|c|c|}
\hline & & Bhshoopthing & onfluenos & Lhto She & & Genel & \\
\hline & contemar & FallChinook & Spring Chhook & Fall Chinook & Spring Chhook & Falf Chinook & Spring Chinook \\
\hline & 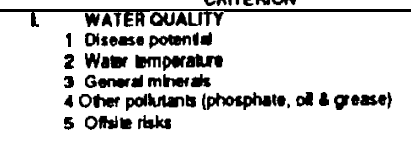 & 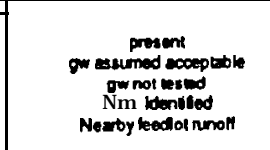 & 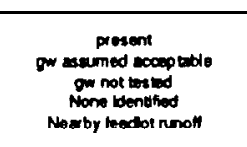 & 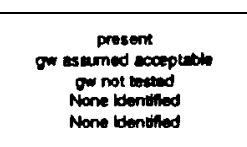 & 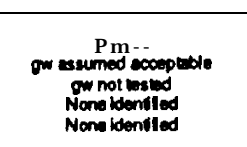 & 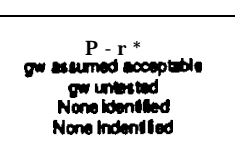 & 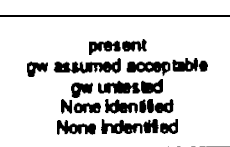 \\
\hline & 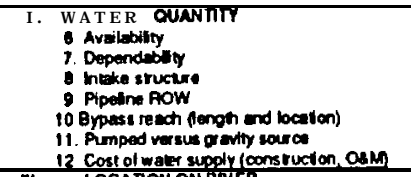 & 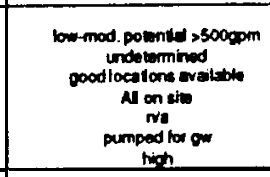 & 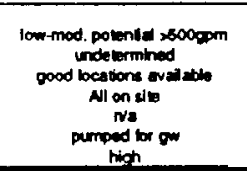 & 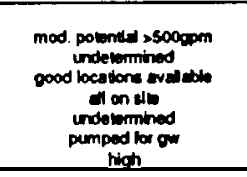 & 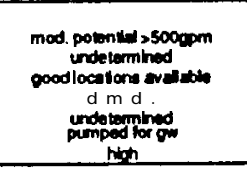 & 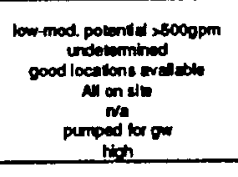 & 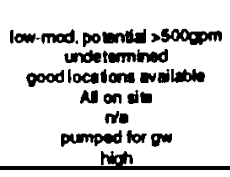 \\
\hline & 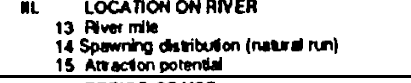 & $\begin{array}{l}\text { Abovemosiol datsiburion } \\
\mathrm{Nat}\end{array}$ & 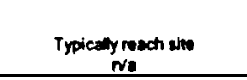 & $\begin{array}{l}\text { Nowe normul chertbution } \\
\text { nore }\end{array}$ & $\begin{array}{l}\text { Typlcally reacti iv } \\
\text { Good }\end{array}$ & 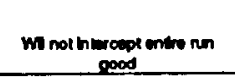 & Not the run peasen whe \\
\hline & IV. 16 PERMOD Of USE & Dats.Me & Aug Feb & Ot is. Mar & Aug F Feb & Da $15 \cdot M=$ & Ang - Feb \\
\hline$\infty$ & 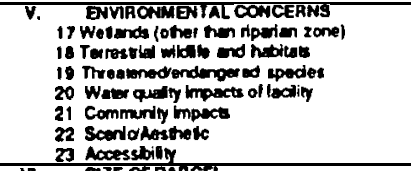 & 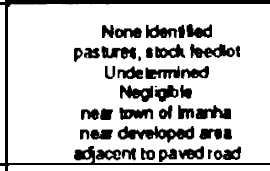 & 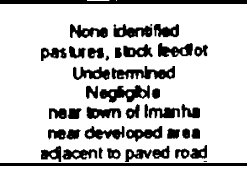 & 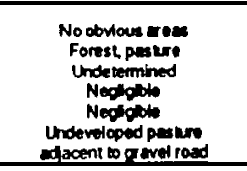 & 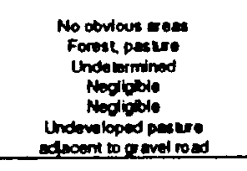 & 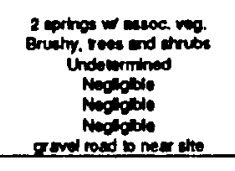 & 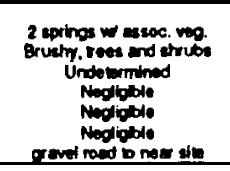 \\
\hline & 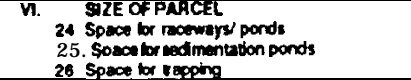 & 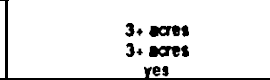 & $\begin{array}{l}\text { 3. excet } \\
\text { 3. eoces } \\
\text { yes }\end{array}$ & 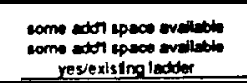 & 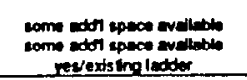 & $\begin{array}{c}\text { s. eave } \\
\text { s. pare } \\
\end{array}$ & $\begin{array}{l}\text { 5. eavi } \\
\text { 5. yout } \\
\text { ret }\end{array}$ \\
\hline & 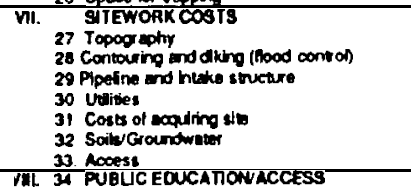 & 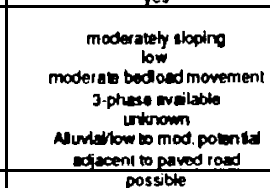 & 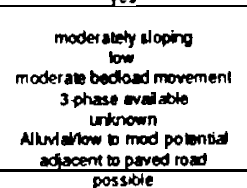 & 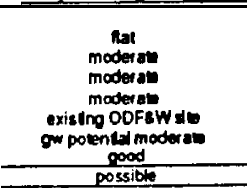 & 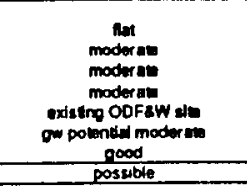 & 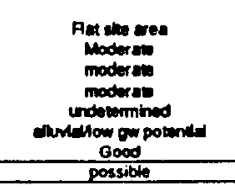 & 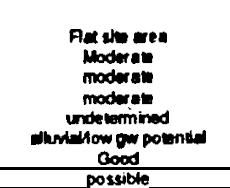 \\
\hline & 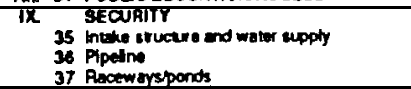 & $\begin{array}{l}\text { Aleogired } \\
\text { Alogived } \\
\text { Reguired }\end{array}$ & $\begin{array}{l}\text { Peatiod } \\
\text { Reaitud } \\
\text { Reauined }\end{array}$ & 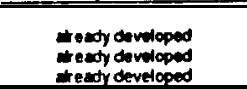 & 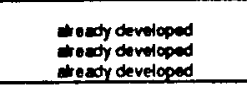 & $\begin{array}{l}\text { Recpibed } \\
\text { Ropited } \\
\text { Reguted }\end{array}$ & $\begin{array}{l}\text { Pequlted } \\
\text { Aopitiod } \\
\text { Requted }\end{array}$ \\
\hline & 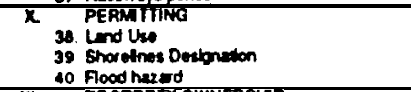 & $\begin{array}{l}\text { Unoevermined } \\
\text { Undereminined } \\
\text { Low }\end{array}$ & $\begin{array}{l}\text { Undevermineos } \\
\text { Undelermined } \\
\text { Low }\end{array}$ & $\begin{array}{l}\text { exis thit beding } \\
\text { unthrown } \\
\text { Low }\end{array}$ & 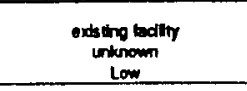 & 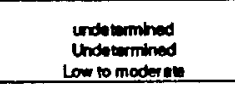 & $\begin{array}{l}\text { undotwomined } \\
\text { Unde wimined } \\
\text { Lou bo noder at }\end{array}$ \\
\hline & 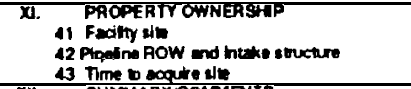 & $\begin{array}{l}\text { Privaw } \\
\text { Privaw } \\
\text { inturown }\end{array}$ & $\begin{array}{c}\text { Patras } \\
\text { Prthate } \\
\text { intrown }\end{array}$ & 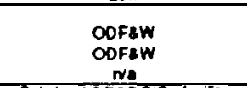 & $\begin{array}{c}\text { Oofaw } \\
\text { oofew } \\
\mathrm{mI}\end{array}$ & 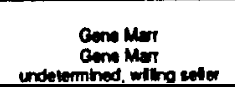 & 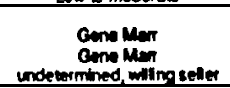 \\
\hline & XII. SUMMATYCOMNENTS & on polventew meest & $\begin{array}{l}\text { ow pownid neech } \\
\text { evdusion }\end{array}$ & 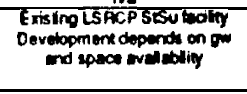 & 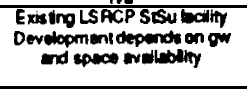 & 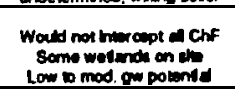 & 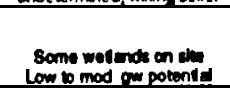 \\
\hline
\end{tabular}


TABLE 34 (1 of 2)

IMNAHA RIVER BASIN

SATELLITE REARING SCREENING CRITERIA

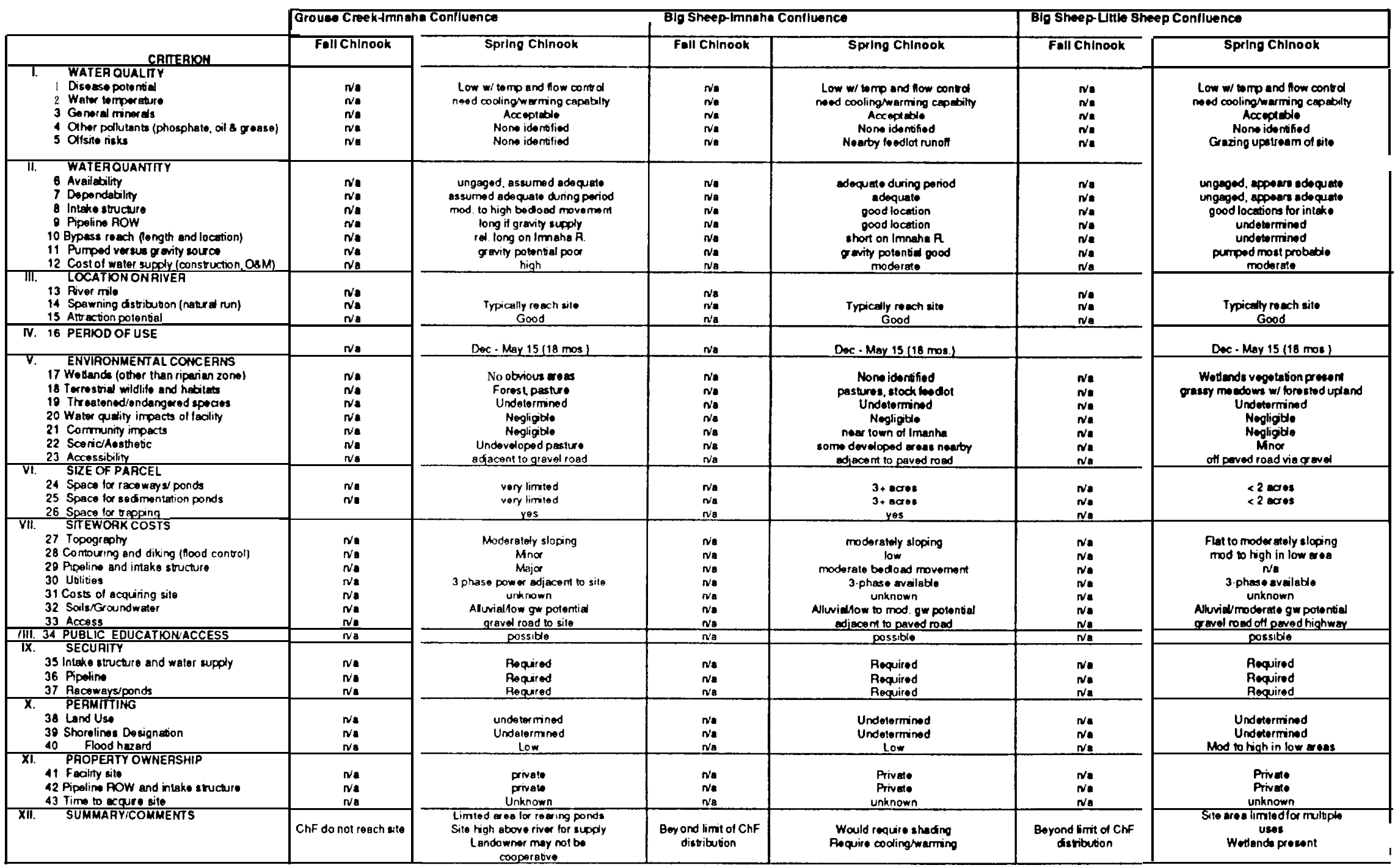


TABLE 34 ( 2 of 2)

IMNAHA RIVER BASIN

SATELLITE REARING SCREENING CRITERIA

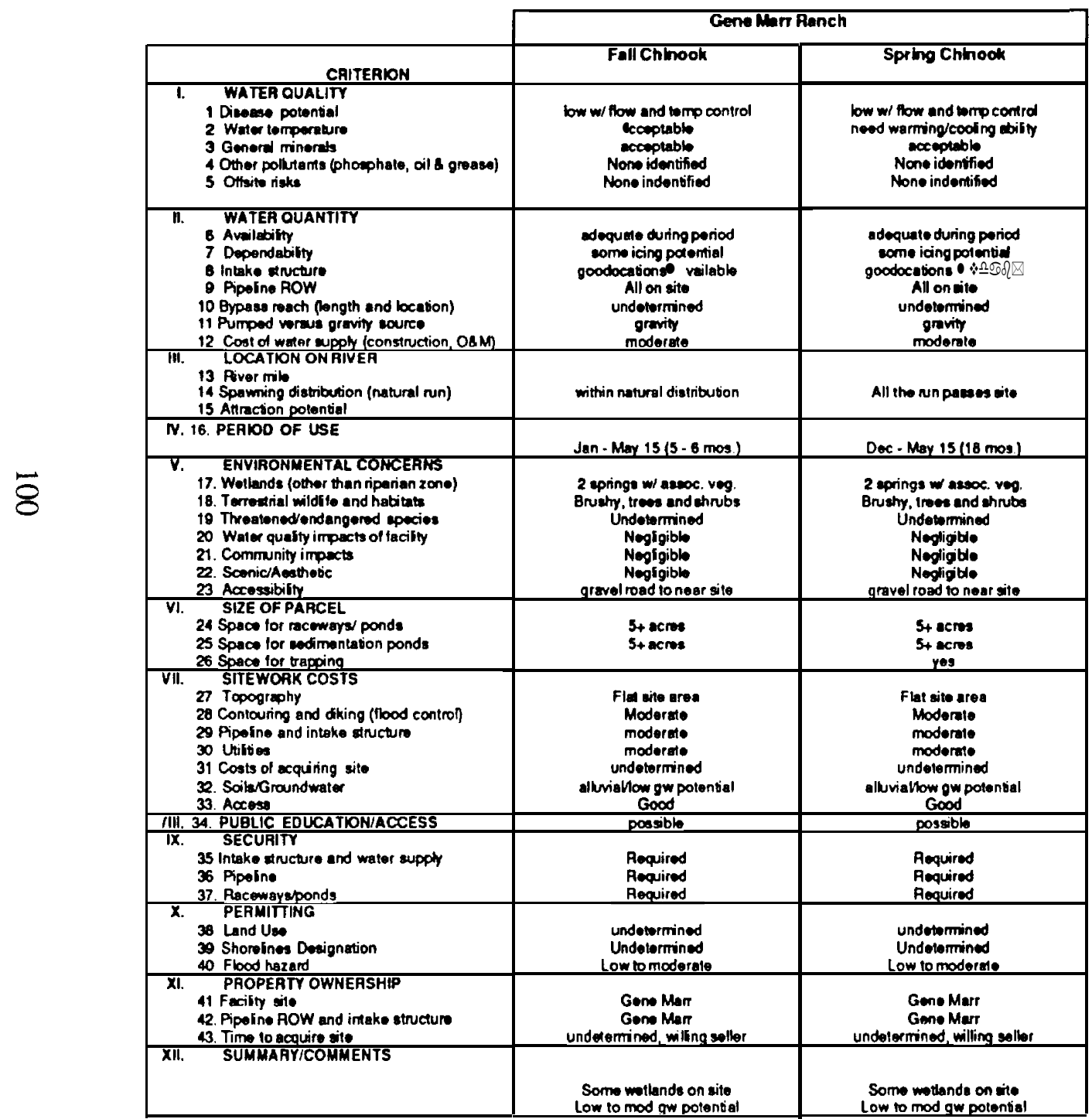


TABLE 35 (1 of 2)

WALLA WALLA RIVER BASIN

ADULT CAPTURE SCREENING CRITERIA

\begin{tabular}{|c|c|c|c|c|c|c|}
\hline & \multicolumn{2}{|c|}{ NE Bth SL Bikge } & \multicolumn{2}{|c|}{ Othe nowainut } & \multicolumn{2}{|c|}{ Harrio Park No. 1} \\
\hline CATERION & Sicelhend & Sprlng ChInook & $\begin{array}{l}\text { Stoelhead } \\
\text { (kell and smoll trapping) }\end{array}$ & Spring Chlnook & Stoelhead & Spring Chinook \\
\hline 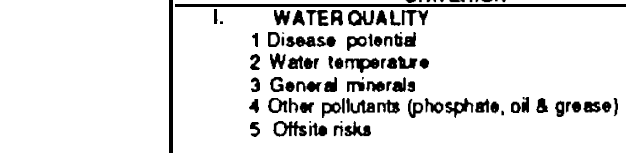 & 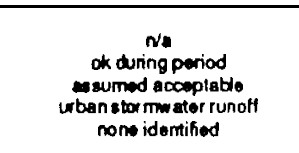 & $\begin{array}{l}\text { W: } \\
\text { W: } \\
\text { Na } \\
\text { We } \\
\text { Ne }\end{array}$ & 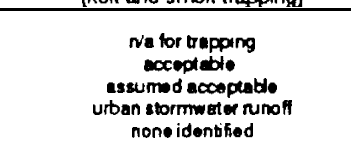 & 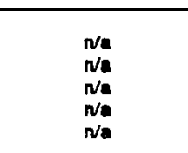 & $\begin{array}{l}n / a \\
n / a \\
n / a \\
n / a \\
n / a\end{array}$ & 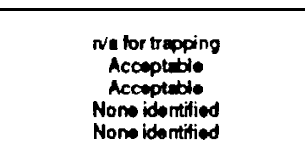 \\
\hline 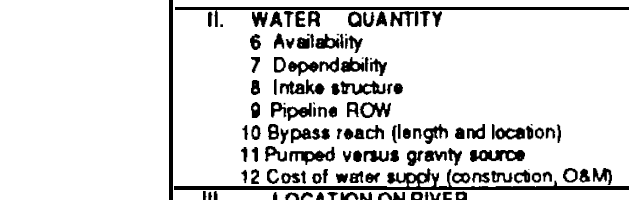 & 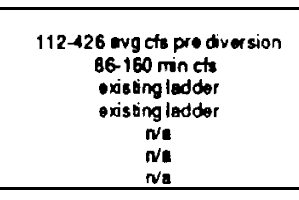 & 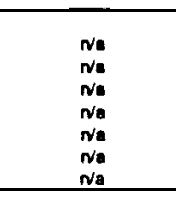 & 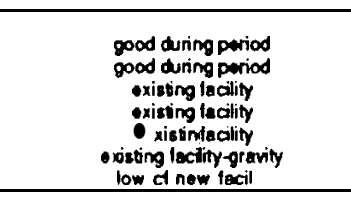 & 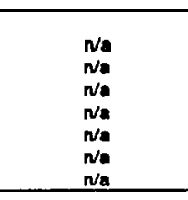 & 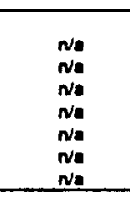 & 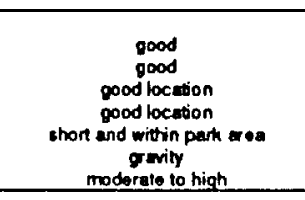 \\
\hline 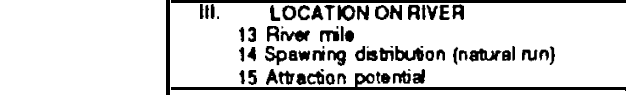 & $\begin{array}{c}\text { mainstion } 4 \text { mi bolow forks } \\
\text { SiSu spown woove site } \\
\text { good }\end{array}$ & $\begin{array}{l}\text { Na } \\
\text { Na } \\
\text { Nata } \\
\text { nata }\end{array}$ & $\begin{array}{c}\text { mainstom } 3-4 \text { milos bolow forks } \\
\text { StSu spewn above sito } \\
\text { good }\end{array}$ & $\begin{array}{l}n / a \\
n / a\end{array}$ & $\begin{array}{l}n / a \\
n: a \\
n a \\
n a t\end{array}$ & $\begin{array}{l}\text { aprox. AM B on S. Fork } \\
\text { apper1/2 potomtied S Fork range } \\
\text { Good }\end{array}$ \\
\hline IV. 16 PERIOD OF USE & Oct Mar & N/4 & $\begin{array}{l}\text { kette: Mar } 15 \cdot \text { Mor } \\
\text { smolts: Mer } \cdot \text { Ap } \\
\end{array}$ & N/m & na & Ap 15 . Jul 15 \\
\hline 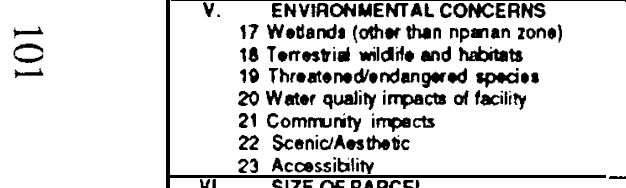 & 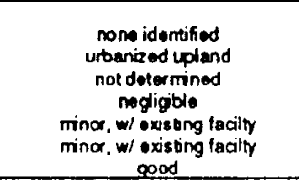 & 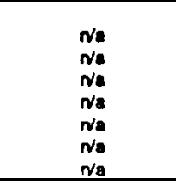 & 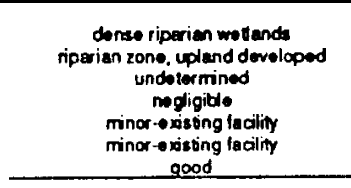 & 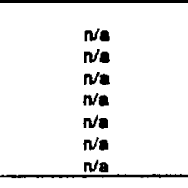 & 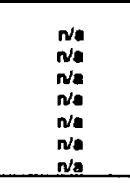 & 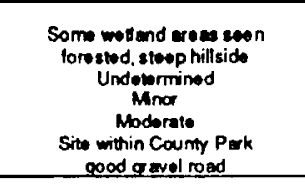 \\
\hline 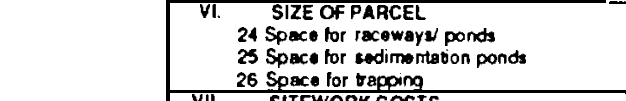 & $\begin{array}{l}\text { <i acre for holding } \\
\text { ntro } \\
\text { yes, existing ladder }\end{array}$ & 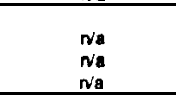 & $\begin{array}{l}\text { \&t acco tor holding } \\
\text { Ne } \\
\text { yeer-existing trap }\end{array}$ & $\begin{array}{l}\text { Na } \\
\text { Ne } \\
\text { Ne }\end{array}$ & 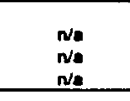 & $\begin{array}{c}\text { Wa bo trapping } \\
\text { Na for trapping } \\
\text { pess }\end{array}$ \\
\hline 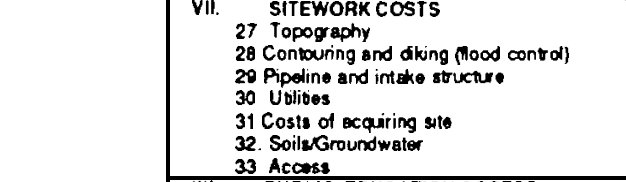 & 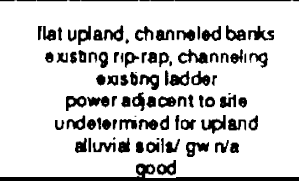 & $\begin{array}{l}\mathrm{Na} \\
\mathrm{Na} \\
\mathrm{Na} \\
\mathrm{Na} \\
\mathrm{Na} \\
\mathrm{Na} \\
\mathrm{Na} \\
\mathrm{Na} \\
\mathrm{Na}\end{array}$ & 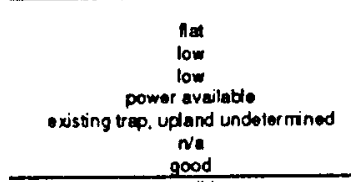 & 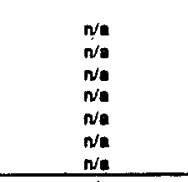 & 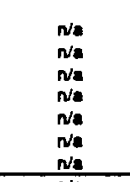 & 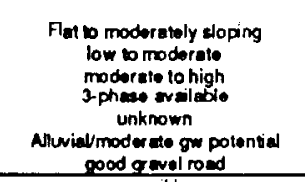 \\
\hline $\begin{array}{l}\text { III. 34. PUBLIC EDUCATHONACCESS } \\
\text { SECURTY }\end{array}$ & Dossiblo & Na & posside & $n / a$ & Ne & possido \\
\hline $\begin{array}{l}\text { IX. SECURTY } \\
\text { 35 Intake structure and water supply } \\
36 \text { Piptins } \\
\text { 37. Recowarystponds }\end{array}$ & $\begin{array}{c}\text { required during use peirod } \\
\text { Nat } \\
\text { N/ta }\end{array}$ & 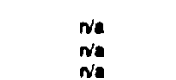 & $\begin{array}{l}\text { requiriod } \\
\text { required } \\
\text { required }\end{array}$ & $\begin{array}{l}N_{n} \\
N= \\
n=a\end{array}$ & 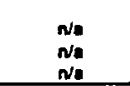 & $\begin{array}{l}\text { Poquired } \\
\text { Pequired } \\
\text { Required }\end{array}$ \\
\hline 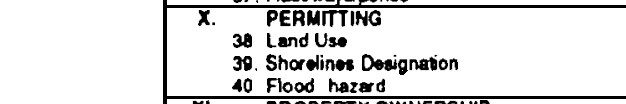 & $\begin{array}{l}\text { undotumined } \\
\text { undotermined } \\
\text { sppesss to be low }\end{array}$ & 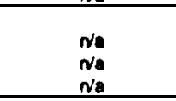 & $\begin{array}{l}\text { oxisting tacility } \\
\text { undowermined } \\
\text { low }\end{array}$ & $\begin{array}{l}n / 4 \\
n / a \\
n / a\end{array}$ & $\begin{array}{l}\mathrm{N} \\
\mathrm{N} / \\
\mathrm{N} / \\
\mathrm{Na}\end{array}$ & $\begin{array}{l}\text { oxising park } \\
\text { Undowininod } \\
\text { low to modorale }\end{array}$ \\
\hline 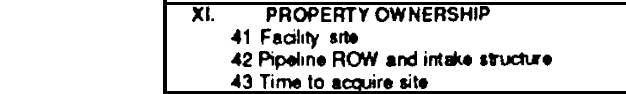 & $\begin{array}{c}\text { undetermined for upland } \\
n / a \\
\text { undetermined }\end{array}$ & $\begin{array}{l}N_{a} \\
N_{a} \\
N a\end{array}$ & $\begin{array}{l}\text { undolermined for uplend } \\
\text { undotemined for upland } \\
\text { undotermined for upland }\end{array}$ & $\begin{array}{l}n= \\
n / a \\
n / a\end{array}$ & $\begin{array}{l}n=1 \\
n / 1 \\
n / 1\end{array}$ & $\begin{array}{c}\text { Ummotha Co. Parke } \\
\text { Umecilla Co. Parke } \\
\text { Unknown }\end{array}$ \\
\hline XII SUMMAFY/COMMENTS & 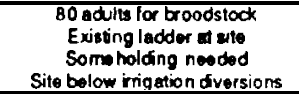 & & $\begin{array}{l}\text { Existing smoh and keth trap } \\
\text { Would bone fit tor upgrading }\end{array}$ & & & 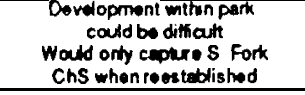 \\
\hline
\end{tabular}


TABLE 35 (2 of 2)

WALLA WALLA RIVER BASIN

ADULT CAPTURE SCREENING CRTTERIA

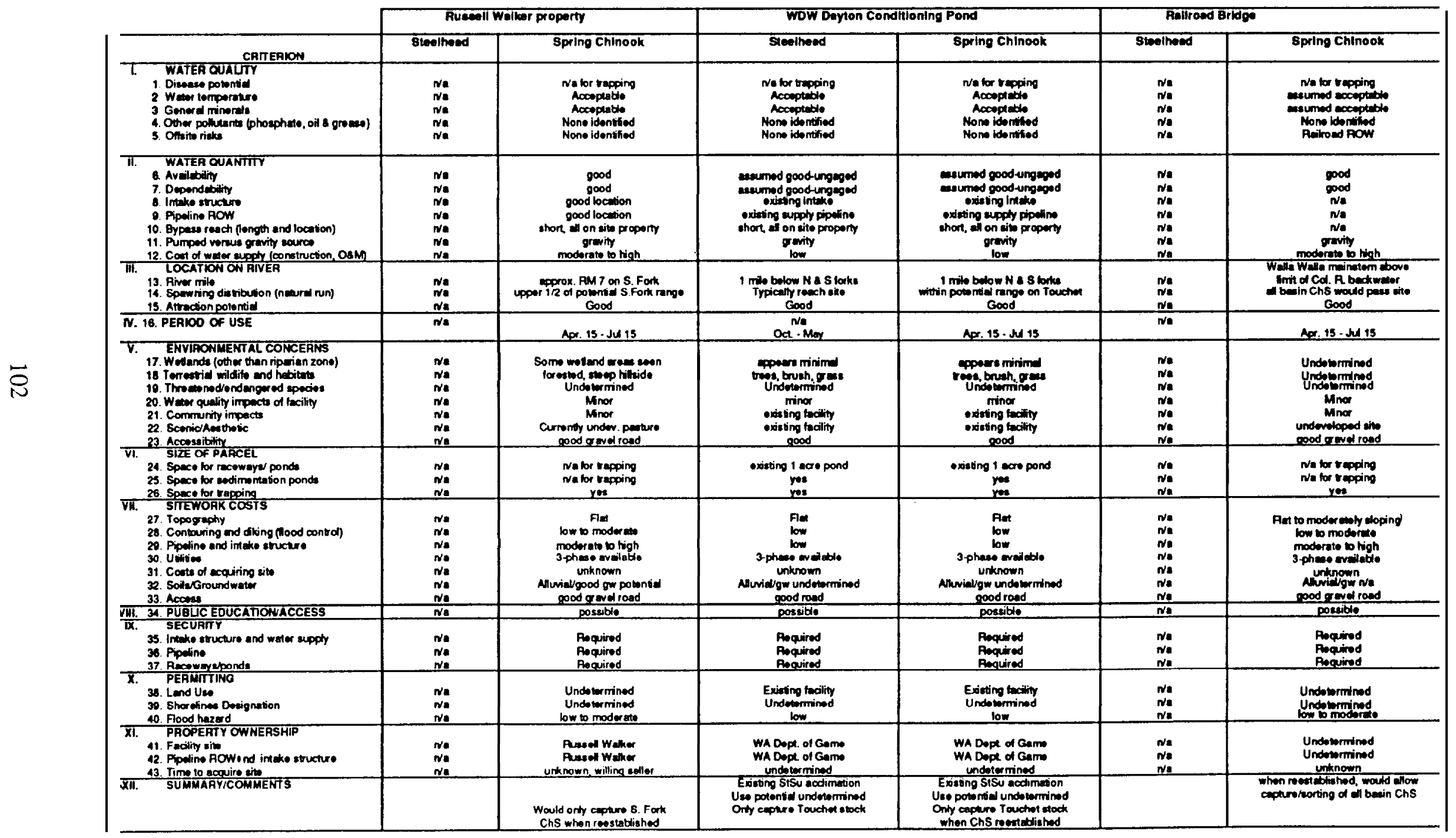


TABLE 36 ( 1 of 2)

WALLA WALLA RIVER BASIN

ADULT HOLDING SCREENING CR TTERIA

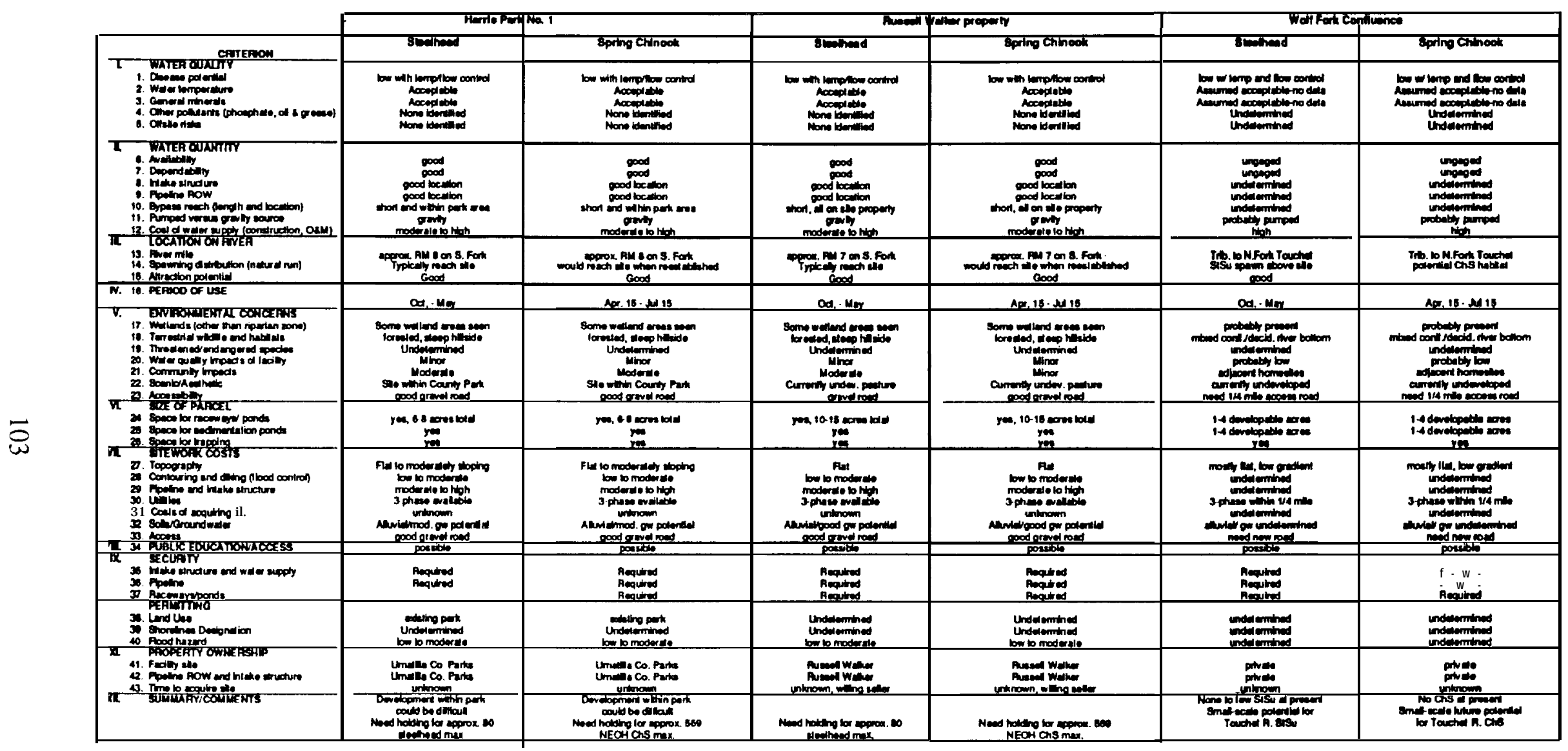


TABLE 36 ( 2 of 2)

WALLA WALLA RIVER BASIN

ADULT HOLDING SCREENING CRITERIA

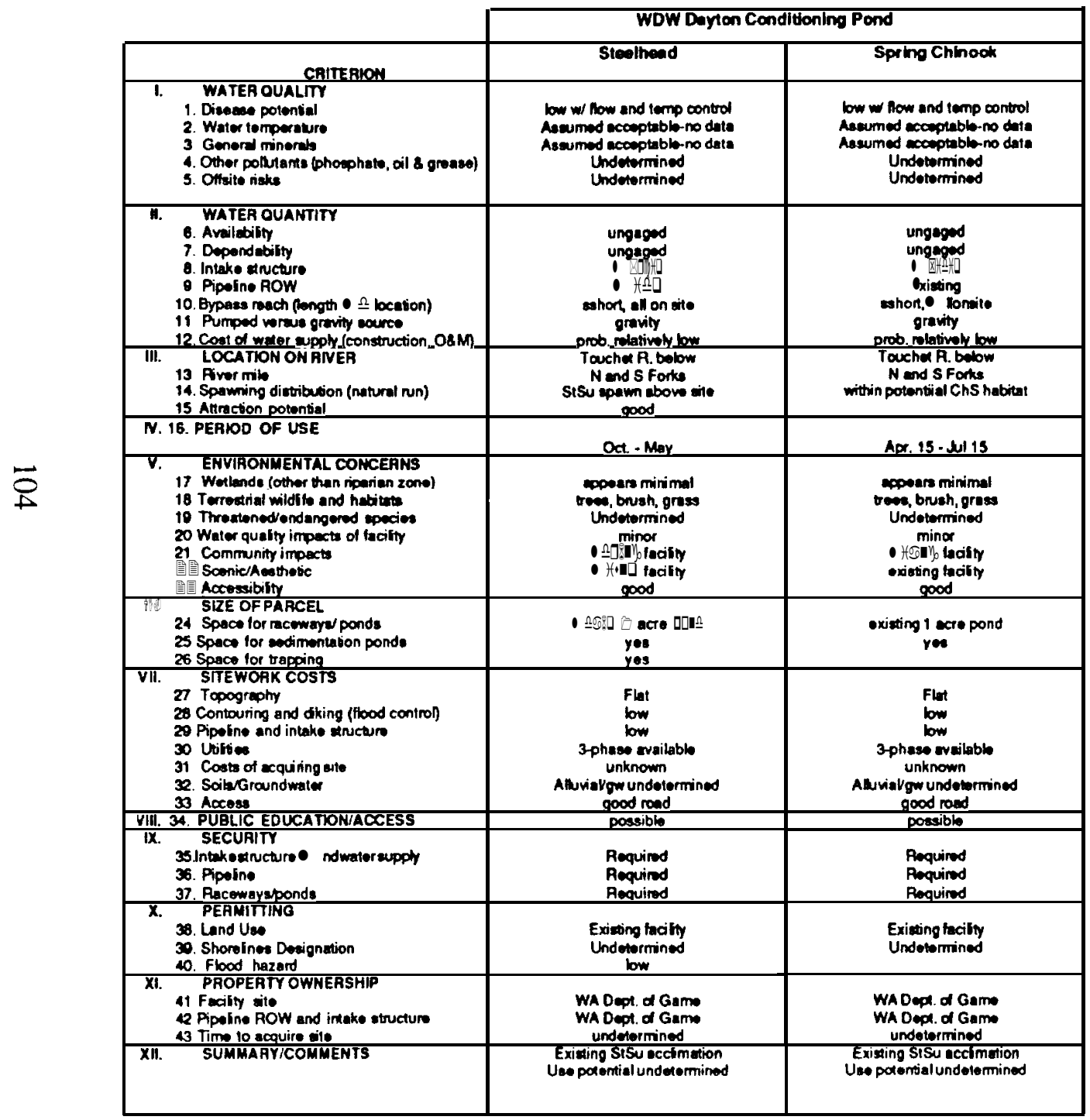


TABLE 37 (1 of 1)

WALLA WALLA RIVER BASIN

INCUBATION AND FRY REARING SCREENING CRITERIA

\begin{tabular}{|c|c|c|c|c|c|}
\hline & & Harrs & & & Ther property \\
\hline & Correoman & Foolhoad & Spring Chinook & Sloelhend & Spring Chinook \\
\hline $\begin{array}{ll}\text { T. } & 1 . \\
2 . \\
3 . \\
1 . \\
5 .\end{array}$ & 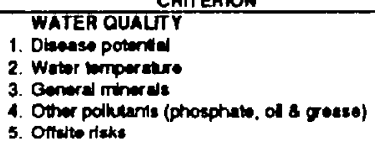 & 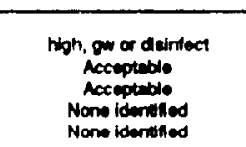 & 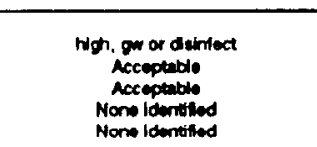 & 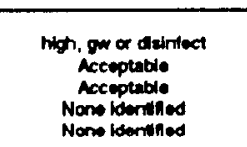 & 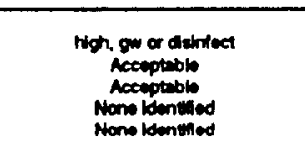 \\
\hline $\begin{array}{cc}11 . \\
7 \\
8 \\
0 \\
10 \\
11 \\
12 \\
\end{array}$ & 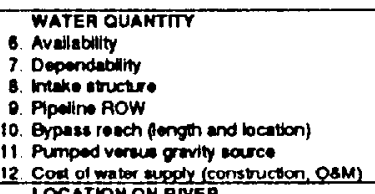 & 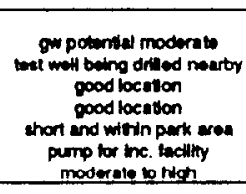 & 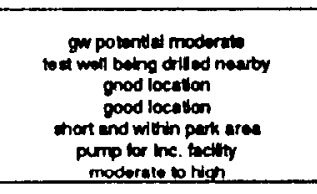 & 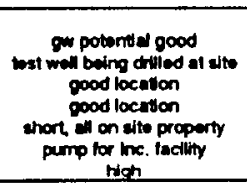 & 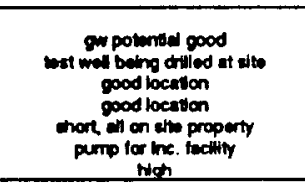 \\
\hline $\begin{array}{r}11 . \\
13 \\
14 \\
13 \\
\end{array}$ & 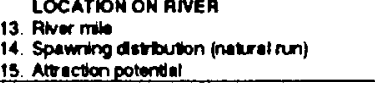 & 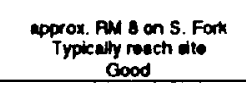 & 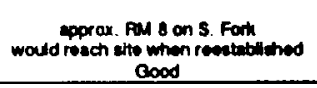 & $\begin{array}{l}\text { approx. AM } 7 \text { on S. Fork } \\
\text { Typically rouch atto } \\
\text { Good }\end{array}$ & 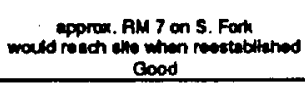 \\
\hline N. 16. & 16. PERIOD OF USE & 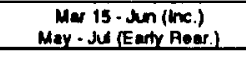 & $\begin{array}{c}\text { Aug - Ooc (nc.) } \\
\text { Nor-Fob (Em Roer.) }\end{array}$ & 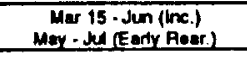 & 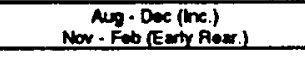 \\
\hline $\begin{array}{l}17 \\
18 \\
19 \\
20 . \\
21 . \\
22 \\
23 \\
\end{array}$ & 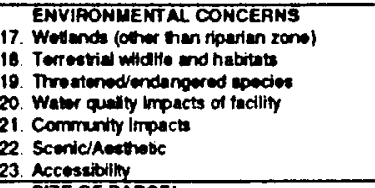 & 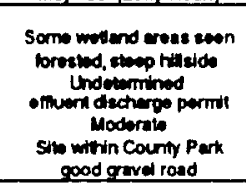 & 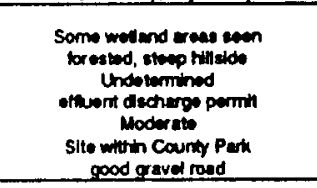 & 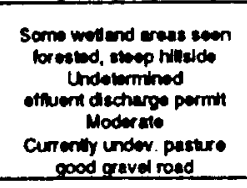 & 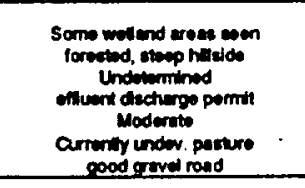 \\
\hline & 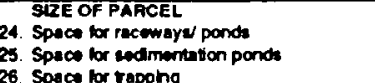 & 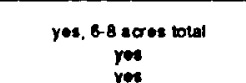 & 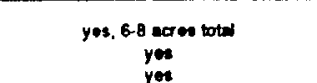 & 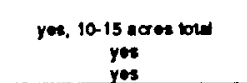 & 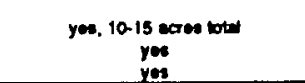 \\
\hline $\begin{array}{l}\text { जा. } \\
27 . \\
28 . \\
20 . \\
30 \\
31 \\
32 .\end{array}$ & 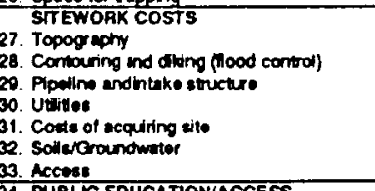 & 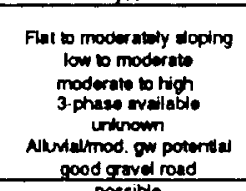 & 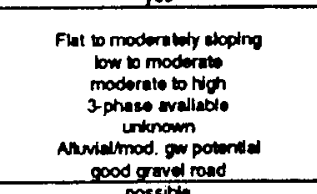 & 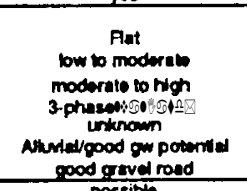 & 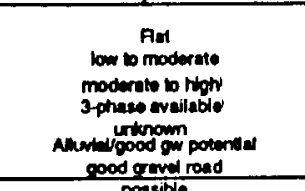 \\
\hline 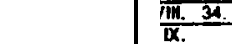 & 34. PUQLLC EDUCATION/ACCESS & possible & possibe & possible & ponsible \\
\hline & 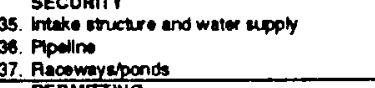 & $\begin{array}{l}\text { Aequired } \\
\text { Rogurred } \\
\text { Aleavired }\end{array}$ & $\begin{array}{l}\text { Aequired } \\
\text { Acauted } \\
\text { Aecoured }\end{array}$ & $\begin{array}{l}\text { Requined } \\
\text { Requtrod } \\
\text { Required }\end{array}$ & $\begin{array}{l}\text { Regured } \\
\text { Required } \\
\text { Rexured }\end{array}$ \\
\hline & 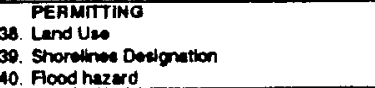 & 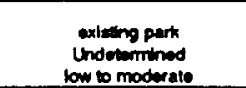 & 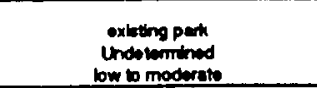 & $\begin{array}{l}\text { Undowiminad } \\
\text { Undowmined } \\
\text { bow to moderatio }\end{array}$ & 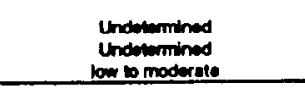 \\
\hline $\begin{array}{ll}x T . & 4 . \\
4 . \\
4 . \\
4 .\end{array}$ & 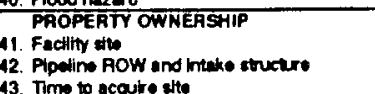 & 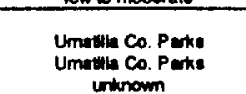 & 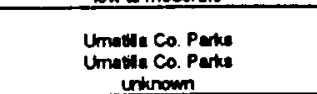 & 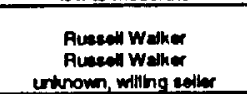 & 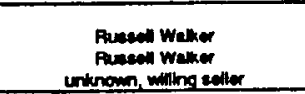 \\
\hline$\frac{.3 .}{x \mathrm{xn} .}$ & SUMMAAYICOMMENTS & 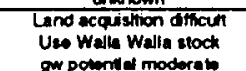 & 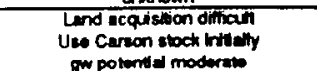 & 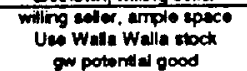 & 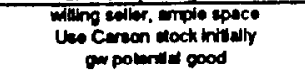 \\
\hline
\end{tabular}


TABLE 38 (1 of 1)

WALLA WALLA RIVER BASIN

SATELLITE REARING SCREENING CRITERIA

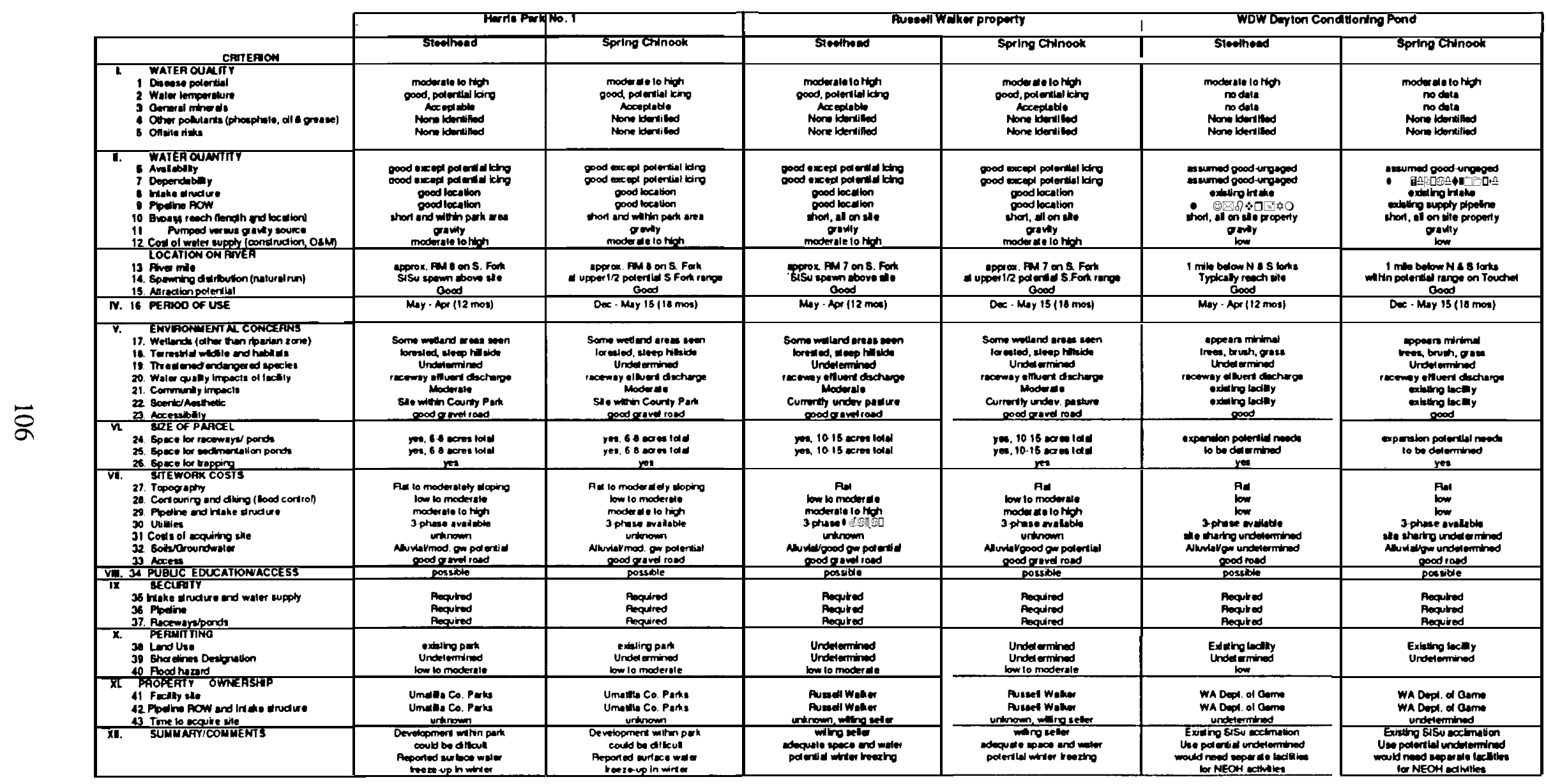




\section{GRANDE RONDE DRAINAGE BASIN}

\begin{tabular}{|c|c|}
\hline FACLLITY SITES & STREAMFLOW GAGES \\
\hline 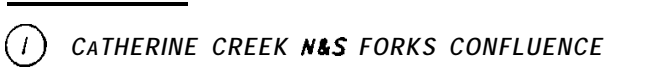 & A 13333000 \\
\hline 02 CATHERINE-U/LK CREEK CONFLUENCE (OSU SITE) & 令 13332500 \\
\hline (3) CATHERINE CREEK AT UNION OLLD HATCHERY) & C 13323500 \\
\hline (4) VEY WEADOWS & L0 $133 / 9000$ \\
\hline (5). SHEEP CREEK & (E) 13318800 \\
\hline (6) BEAVER CREEK & A 13318500 \\
\hline o 7 SANDERSON SPRINGS - MILL CREEK & $\widehat{S} 3331500$ \\
\hline (8) LOWER WILLOW CREEK NEAR ELGIN & $\widehat{A} 13330500$ \\
\hline (9) inOAN CREEK NEAR ELGIN & $\widehat{\triangle} 13330000$ \\
\hline (10) GRANDE RONDE NEAR ELGIN & $\Delta 13329500$ \\
\hline (11)LOOKING GLASS HATCHERY & $\widehat{\Delta} 13327500$ \\
\hline (12) WILDCAT CREEK AREA & $\triangle 13323600$ \\
\hline (13) FISH LADDER (FORUER USFWS RESEARCH SITE) & 会 13320000 \\
\hline
\end{tabular}
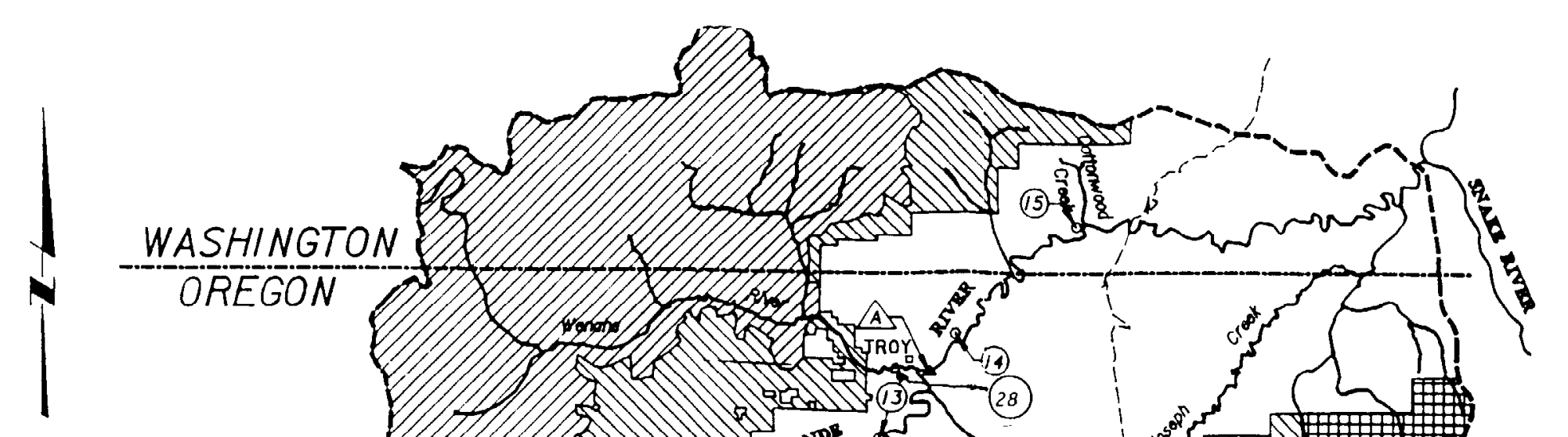

(14)FLORA GRADE

(15) COTTONWOOD CREEK

(16.) WALLOWA LAKE

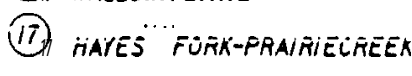

(18) HALLOWA HATCHER 1

199. BIG CAMTON CREEK

(20) MIMAM RIVER CONFLUence With Hallowa

(21.) OOFW BIGHORN SHEEP RANGE

(22) STRATHEARM RANCH

(23) LOSTINE DAY

(29.) Cross-valley diversion

(25) DA VIS DAM

26. Minam ABOVE WALlowa RIVER

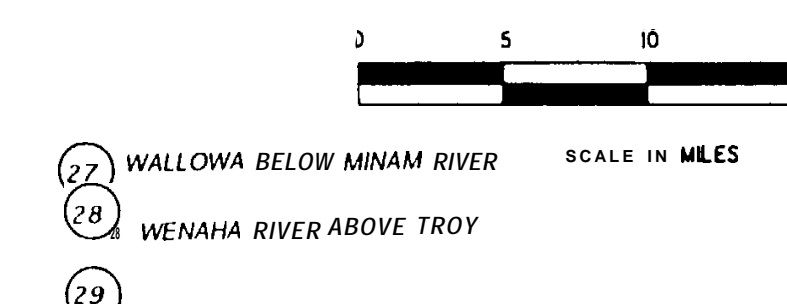

(29)

(ه) Existing acclimation ponos

$\infty$ existing hatcherles

00000 SNOLT OR AOULT TRAPS

-... bas IN boundaAt

CRIVER OR CREEK

-D- ROADS

NATIONAL FOREST

DEDO WILDERNESS AREA

NATIONAL RECREATION AREA

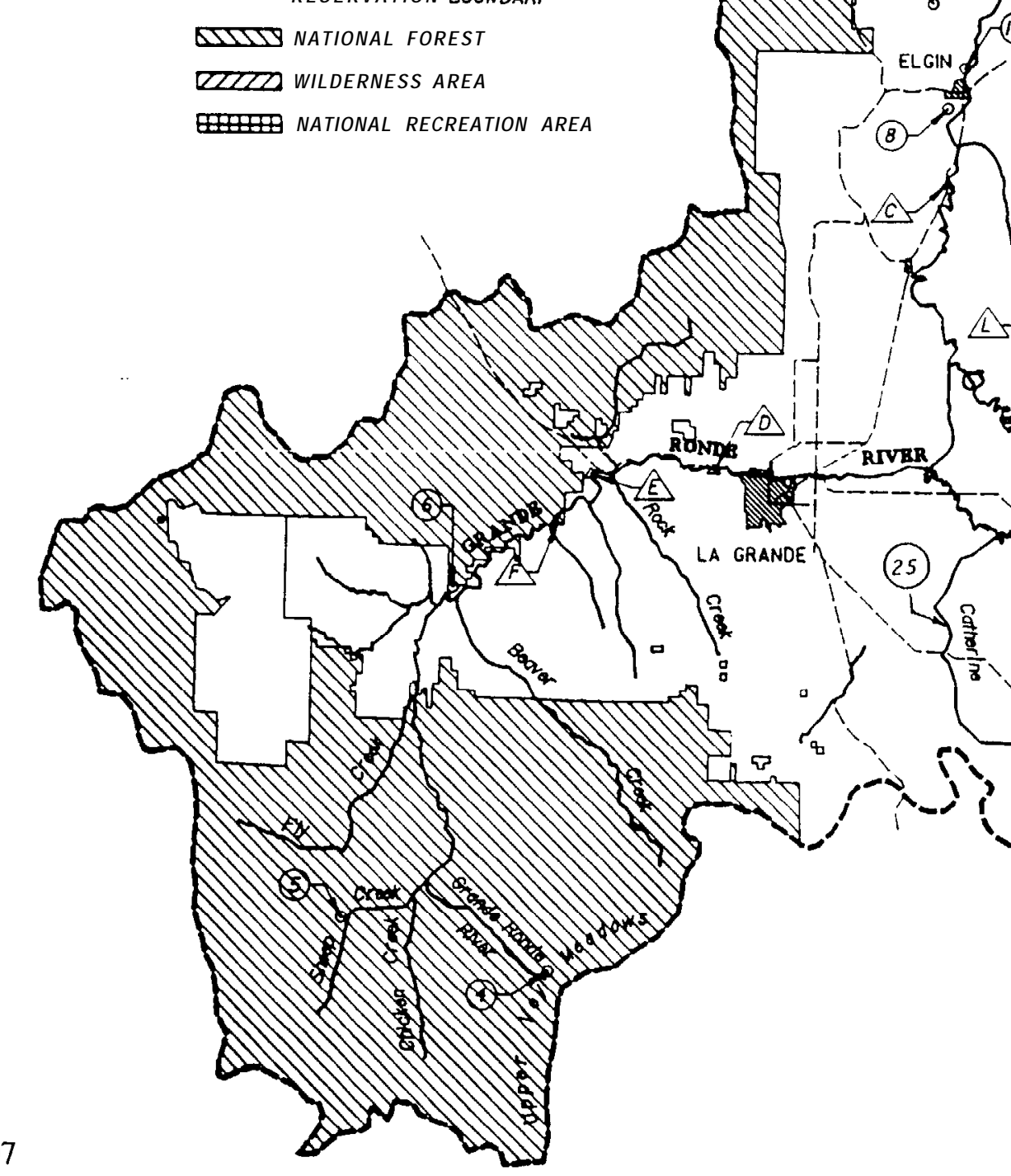

FIGURE 4 


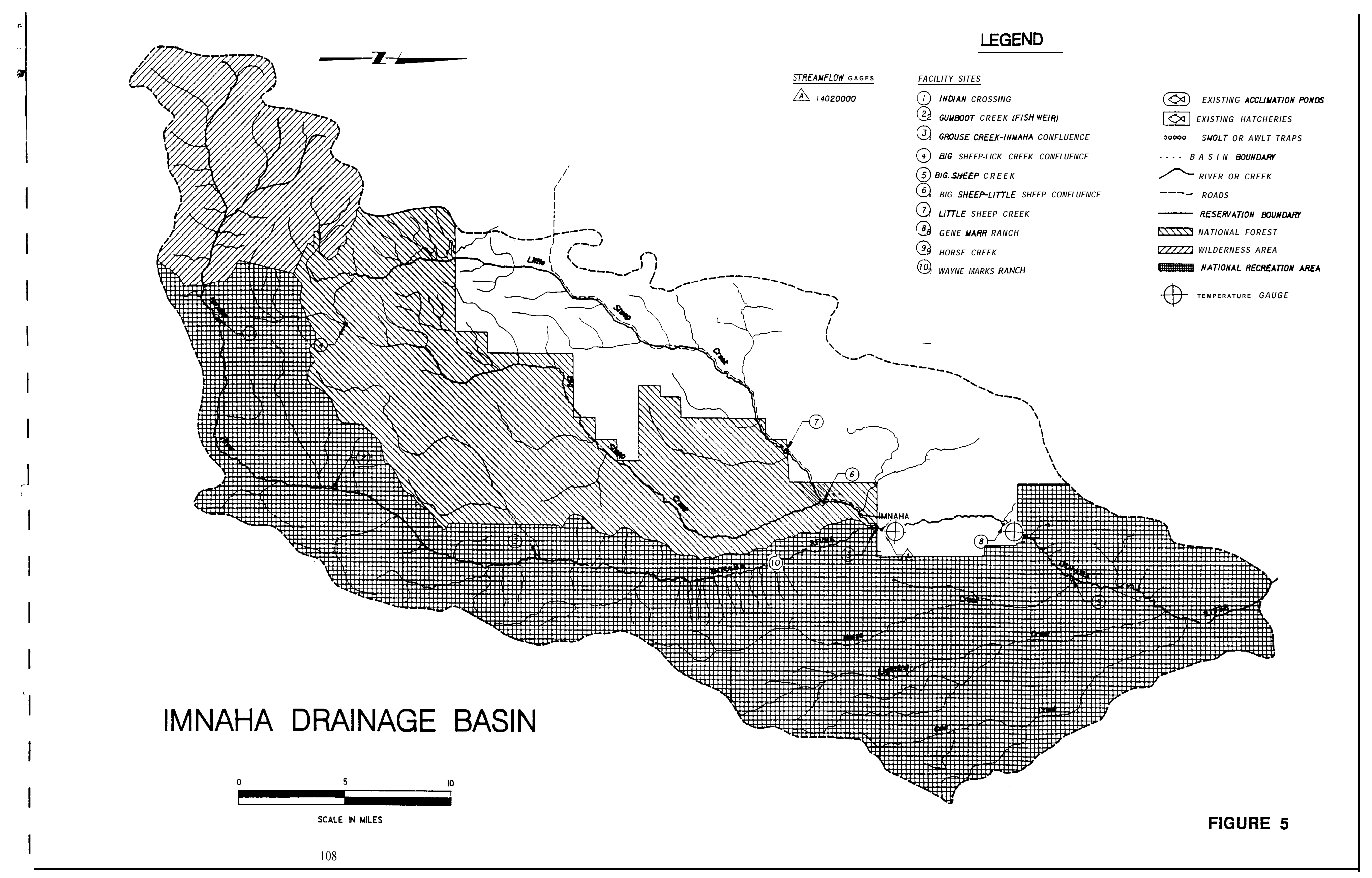




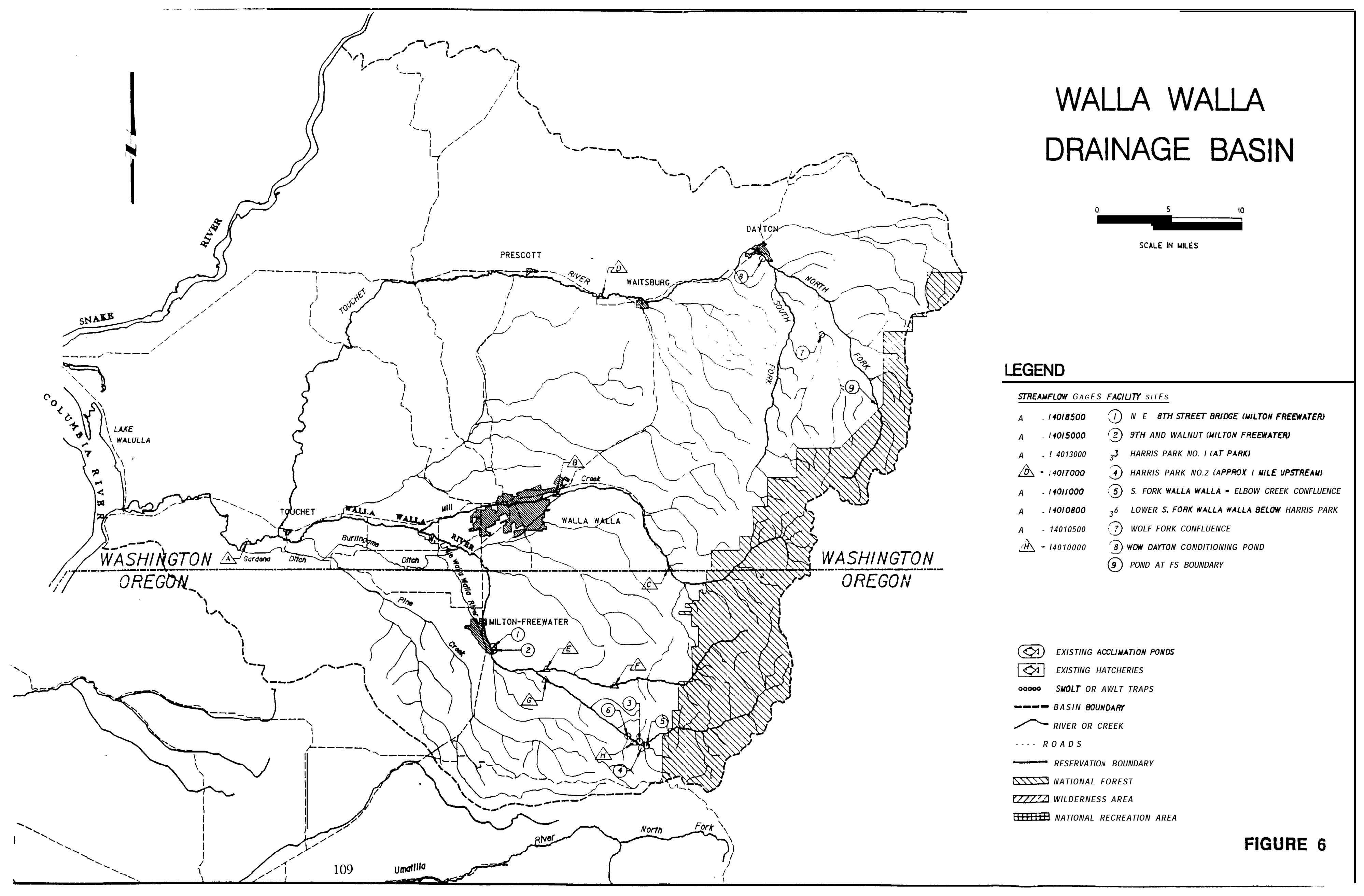




\section{PROGRAM DEVELOPMENT}

\section{INTRODUCTION}

The objective in identifying program alternatives is to provide an overall view of the way facilities could be combined to accomplish production goals for a particular species. The following tables present alternatives, by species, for the NEOH basins. They are developed from Tables 26 through 38 presented in the previous section. Where multiple sites are indicated for a facility, the first ones listed generally appear to have the best potential based on the screening criteria.

One purpose in listing multiple options at this time is to facilitate future NEPA environmental review which may require the analysis of several alternatives. A preferred alternative may be identified, however, one or more alternatives should be retained through the conceptual design phase.

\section{PROPOSED NEOH PROGRAM ALTERNATIVES}

These alternatives, and their priorities, were reviewed and revised at a 10/16/91 NEOH TWG meeting in La Grande. These revised lists will form the basis for the proposed NEOH facilities to be described in Conceptual Design.

Alternative programs are presented by subbasin and species, including:

Upper Grande Ronde spring chinook (Table 39)

Catherine Creek spring chinook (Table 40)

Wallowa - Lostine spring chinook (Table 41)

Imnaha spring chinook (Table 42)

Walla Walla and Touchet spring chinook (Table 43)

Grande Ronde fall chinook (Table 44)

Imnaha fall chinook (Table 45)

Walla Walla and Touchet steelhead (Table 46) 
TABLE 39

\section{UPPER GRANDE RONDE SPRING CHINOOK}

UPPER GRANDE RONDE SPRING CHINOOK

\begin{tabular}{|c|c|ccc|c|}
\hline $\begin{array}{c}\text { Broodstock } \\
\text { Source }\end{array}$ & $\begin{array}{c}\text { Broodstock } \\
\text { Number }\end{array}$ & $\begin{array}{c}\text { Production Goal } \\
\text { No. \& Size }\end{array}$ & \multicolumn{2}{c|}{$\begin{array}{c}\text { Acclimation } \\
\text { Sites }\end{array}$} & \multicolumn{2}{c|}{$\begin{array}{c}\text { Siting Report } \\
\text { Reference }\end{array}$} \\
\hline Catherine Creek & $\begin{array}{c}74 \\
\text { (Limited to 50\% of } \\
\text { the run) }\end{array}$ & 100,000 @ 15-20/lb & $\begin{array}{c}\text { 2 sites above } \\
\text { Limber Jim Creek: } \\
\text { (1) Upper Vey } \\
\text { Meadows and (2) } \\
\text { Sheep Creek }\end{array}$ & Table 3-2 Group 9 \\
& & & & \\
\hline
\end{tabular}

\begin{tabular}{|ll} 
Adult Capture: & $\begin{array}{l}\text { Alternative 1 - Davis Darn on Catherine Creek (see Table 9-2) } \\
\text { Alternative 2 - Vey Meadows at Splash Darn (a) }\end{array}$ \\
Adult Holding: & $\begin{array}{l}\text { Alternative 1 - Upper Vey Meadows } \\
\text { Alternative 2 - Catherine Creek incubation site }\end{array}$ \\
Incubation: (b) & $\begin{array}{l}\text { Alternative 1 - Catherine Creek incubation site } \\
\text { Alternative 2 - Stratheam Ranch }\end{array}$ \\
Early Rearing: & $\begin{array}{l}\text { Alternative 1 - Catherine Creek incubation site } \\
\text { Alternative 2 - Stratheam Ranch }\end{array}$ \\
Full Term Rearing: & $\begin{array}{l}\text { Alternative 1 - Catherine Creek incubation site } \\
\text { Alternative 2 - Stratheam Ranch }\end{array}$ \\
Final Rearing/Acclimation & and/or Direct Release Sites: \\
& $\begin{array}{l}\text { Site 1 - Upper Vey Meadows (69,000 smolts) } \\
\text { Site 2 - Sheep Creek (31,000 smolts) }\end{array}$
\end{tabular}

Notes:

(a) To be used in future as returns increase. Will collect adults initially at Catherine Creek capture site.

(b) Preferred alternative incubation site dependent on outcome of further groundwater investigations. Catherine Creek incubation site includes either the Union or OSU sites. Strathearn Ranch site would be used if Catherine Creek incubation site is not feasible based on groundwater investigations. 
TABLE 40

\section{CATHERINE CREEK SPRING CHINOOK}

\begin{tabular}{|c|c|c|c|c|}
\hline $\begin{array}{c}\text { Broodstock } \\
\text { Source } \\
\end{array}$ & $\begin{array}{c}\text { Broodstock } \\
\text { Number }\end{array}$ & $\begin{array}{c}\text { Production Goal } \\
\text { No. \& Size }\end{array}$ & Acclimation Sites & $\begin{array}{c}\text { Siting Report } \\
\text { Reference }\end{array}$ \\
\hline Catherine Creek & $\begin{array}{l}222 \\
\text { (Limited to } 50 \% \text { of } \\
\text { the run) }\end{array}$ & $\begin{array}{l}161,000 @ 15-20 / \mathrm{lb} \\
112,000 @ 15-20 / \mathrm{lb} \\
28.000 @ 1520 / \mathrm{lb}\end{array}$ & $\begin{array}{l}1 \text { site on mainsrem } \\
\text { Catherine Creek } \\
\text { N \& S. forks } \\
\text { confluence site } \\
\text { Indian Creek site }\end{array}$ & $\begin{array}{l}\text { Table 3-2 Group } 7 \\
\text { Table 3-2 Group } 8 \\
\text { Table 3-2 Group } 10\end{array}$ \\
\hline Catherine Creek & 70 & $94,500 @ 20 / 1 b$ & OSU site & EIP measure 2.3 \\
\hline Rapid River & 260 & 350,000@20/lb & OSU site & EIP measure 2.3 \\
\hline
\end{tabular}

\begin{tabular}{|c|c|}
\hline Adult Capture: & $\begin{array}{l}\text { Alternative } 1 \text { - Davis Darn (EIP site) } \\
\text { Alternative } 2 \text { - Catherine Creek at Union } \\
\text { Alternative } 3 \text { - OSU Site }\end{array}$ \\
\hline Adult Holding: & $\begin{array}{l}\text { Alternative } 1 \text { - OSU Site } / \mathrm{NEOH}+\mathrm{EIPJ} \\
\text { Altcmative } 2 \text { - Catherine Creek at Union } \underline{\mathbf{N E O H} \text { onlv) }}\end{array}$ \\
\hline Incubation: (a) & $\begin{array}{l}\text { Alternative } 1 \text { - OSU Site } \\
\text { Alternative } 2 \text { - Catherine Creek at Union } \\
\text { Alternative } 3 \text { - Strathearm Ranch }\end{array}$ \\
\hline Early Rearing: & $\begin{array}{l}\text { Alternative } 1 \text { - OSU site } \\
\text { Alternative } 2 \text { - Catherine Creek at Union } \\
\text { Alternative } 3 \text { - Stratheam Ranch }\end{array}$ \\
\hline Full Term Rearing: & $\begin{array}{l}\text { Alternative } 1 \text { - OSU site } \\
\text { Alternative } 2 \text { - Catherine Creek at Union } \\
\text { Alternative } 3 \text { - Strathea rn Ranch }\end{array}$ \\
\hline $\begin{array}{l}\text { Final Rearing/Acclimation } \\
\qquad \begin{array}{l}\text { Site } 1- \\
\text { Site } 2 \\
\text { Site } 3\end{array}\end{array}$ & $\begin{array}{l}\text { and/or Direct Release Sites : } \\
\text { N \& S Fork Confluence }(112.000 \text { smolts }) \\
\text { OSU Site }(3 \text { groups: } 161,000.94 .500 \text { [EIP]. 350,000 [EIPI } \\
\text { Indian Creek }(28,000 \text { smolts })\end{array}$ \\
\hline
\end{tabular}

Notes:

(a) Preferred alternative incubation site dependent on outcome of further groundwater investigations. Both the Union and OSU sites have moderate 10 good groundwaler potential. Union site probably has the better overall groundwater potential. 
TABLE 41

WALLOWA-LOSTINE SPRING CHINOOK

\begin{tabular}{|c|c|c|c|c|}
\hline \multicolumn{1}{|c}{$\begin{array}{c}\text { Broodsrock } \\
\text { Source }\end{array}$} & $\begin{array}{c}\text { Broodstock } \\
\text { Number }\end{array}$ & \multicolumn{2}{c|}{$\begin{array}{c}\text { Production Goal } \\
\text { No. \& Size }\end{array}$} & \multicolumn{2}{c|}{$\begin{array}{c}\text { Acclimation or } \\
\text { Release Sites }\end{array}$} & \multicolumn{1}{c|}{$\begin{array}{c}\text { Siting Report } \\
\text { Reference }\end{array}$} \\
\hline Lostine River & 400 & 516,000 @ I5/lb & $\begin{array}{c}1 \text { acclimation site } \\
\text { on Lostine } \\
7 \text { release sites } \\
\text { on Lostine }\end{array}$ & Table 3-2 Group 4 \\
& & Table 3-2 Group 5 \\
& 150,000 @ 150/lb & $\begin{array}{c}\text { acclimation site } \\
\text { at Bear Creek }\end{array}$ & Table 3-2 Group 6 \\
\hline
\end{tabular}

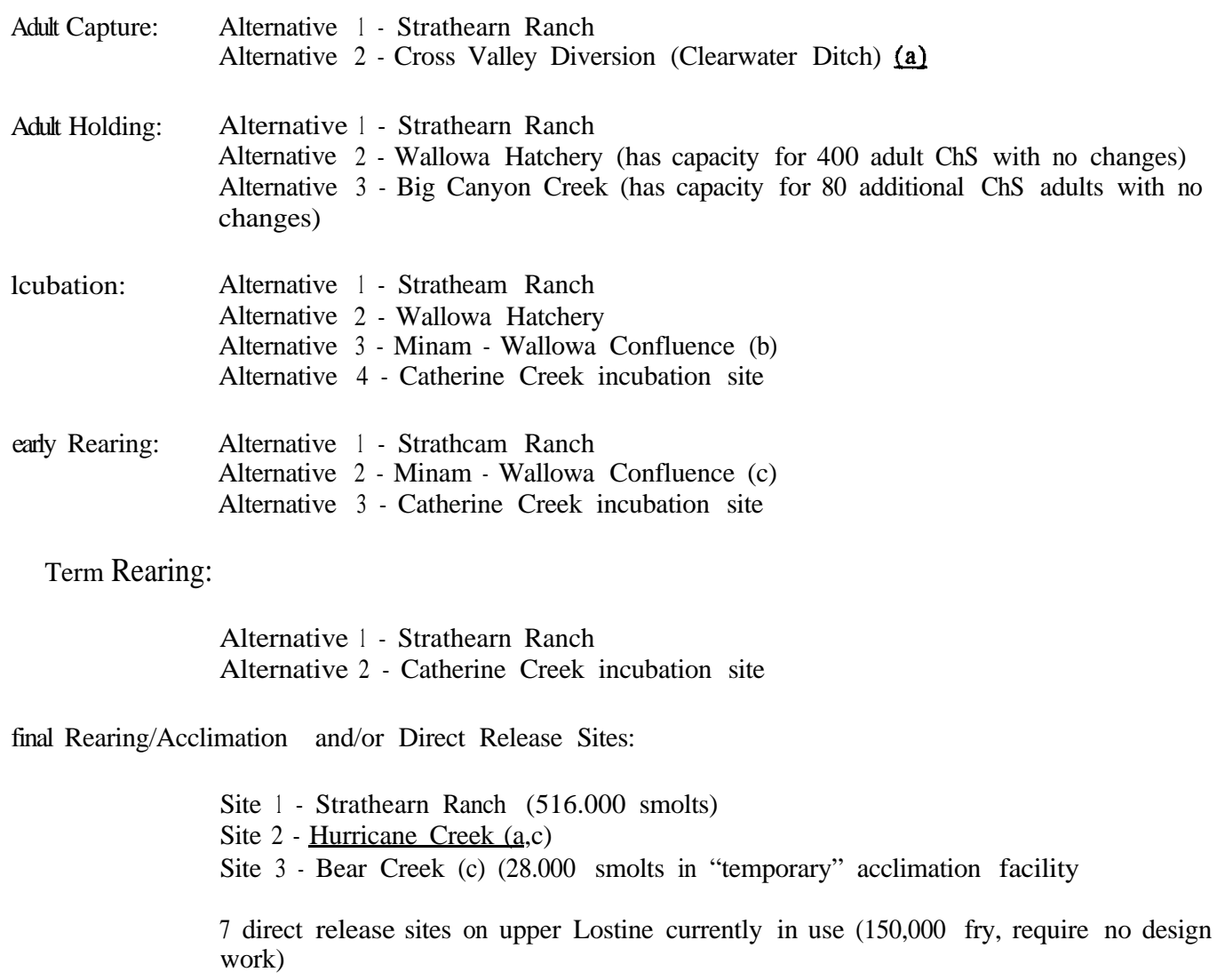

Alternative 1 - Strathearn Ranch

Alternative 2 - Catherine Creek incubation site

final Rearing/Acclimation and/or Direct Release Sites:

Site 1 - Strathearn Ranch (516.000 smolts)

Site 2 - Hurricane Creek (a,c)

Site 3 - Bear Creek (c) (28.000 smolts in "temporary" acclimation facility

7 direct release sites on upper Lostine currently in use $(150,000$ fry, require no design work)

Notes:

(a) Will remain as identified alternative but no concentual design planned at this time.

(b) Potential $\mathrm{ChS}$ site if developed for $\mathrm{ChF}$ incubation and early rearing.

(c) These sites not yet evaluated. 
TABLE 42

IMNAHA SPRING CHINOOK

\begin{tabular}{|c|c|c|c|c|}
\hline \multicolumn{1}{|c}{$\begin{array}{c}\text { Broodstock } \\
\text { Source }\end{array}$} & $\begin{array}{c}\text { Broodstock } \\
\text { Number }\end{array}$ & $\begin{array}{c}\text { Production Goal } \\
\text { No. \& Size }\end{array}$ & $\begin{array}{c}\text { Acclimation or } \\
\text { Direct Release } \\
\text { Sites }\end{array}$ & $\begin{array}{c}\text { Siting Report } \\
\text { Reference }\end{array}$ \\
\hline Imnaha Wild Stock & $\mathbf{2 6 0}$ & $\mathbf{3 9 2 , 5 0 0 ~ @ ~ 1 5 - 2 0 / 1 b}$ & $\begin{array}{c}2-3 \text { acclimation } \\
\text { sites between } \\
\text { Gumboot and } \\
\text { Freezeout Cks. }\end{array}$ & Table 3-3 Group 14 \\
direct release & Table 3-3 Group 15 \\
\hline
\end{tabular}

\begin{tabular}{|c|c|}
\hline Adult Capture: & $\begin{array}{l}\text { Alternative } 1 \text { - Gumboot Creek (Fish Weir) } \\
\text { Alternative } 2 \text { - Wayne Marks Ranch }\end{array}$ \\
\hline Adult Holding: & $\begin{array}{l}\text { Alternative } 1 \text { - Wayne Marks Ranch } \\
\text { Alternative } 2 \text { - Gumboot Creek (Fish Weir) }\end{array}$ \\
\hline Incubation: & $\begin{array}{l}\text { Alternative } 1 \text { - Wayne Marks Ranch } \\
\text { Alternative } 2 \text { - Stratheam Ranch } \\
\text { Alternative } 3 \text { - Catherine Creek at Union }\end{array}$ \\
\hline Early Rearing: & $\begin{array}{l}\text { Alternative } 1 \text { - Wayne Marks Ranch } \\
\text { Alternative } 2 \text { - Stratheam Ranch } \\
\text { Alternative } 3 \text { - Catherine Creek at Union }\end{array}$ \\
\hline Full Term Rearing: & $\begin{array}{l}\text { Alternative I - Wayne Marks Ranch } \\
\text { Alternative } 2 \text { - Stratheam Ranch } \\
\text { Alternative } 3 \text { - Catherine Creek at Union }\end{array}$ \\
\hline \multicolumn{2}{|c|}{ Final Rearing/Acclimation and/or Direct Release Sites: } \\
\hline & Big Sheep - Lick Creek Confluence (230,000 fry) \\
\hline & $\begin{array}{l}\text { ion sites (not yet identified) between Gumboot and Freezeout Creeks } \\
\text { tural" side channel type facility }(392,500 \text { smolts) }\end{array}$ \\
\hline
\end{tabular}


TABLE 43

\section{WALLA WALLA AND TOUCHET SPRING CHINOOK}

\begin{tabular}{|c|c|c|c|c|}
\hline $\begin{array}{c}\text { Broodstock } \\
\text { Source }\end{array}$ & $\begin{array}{c}\text { Broodstock } \\
\text { Number }\end{array}$ & $\begin{array}{c}\text { Production Goal } \\
\text { No. \& Size }\end{array}$ & $\begin{array}{l}\text { Acclimation or } \\
\text { Release Sites }\end{array}$ & $\begin{array}{c}\text { Siting Report } \\
\text { Reference }\end{array}$ \\
\hline Carson stock & 559 & $350.000-400.000$ & S. Fork Walla Walla & Table 3-4 Group 1 \\
\hline & & $\begin{array}{c}\text { @10/1b } \\
\frac{200.000-250.000}{10 / 1 b} @\end{array}$ & upper Touchet & Table 3-4 Group 2 \\
\hline $\begin{array}{l}\text { Umatilla River } \\
\text { (Carson stock) }\end{array}$ & 548 & $589,000 @ 10 / 1 b$ & $\begin{array}{c}\text { upper Umatilla } \\
\text { mainstem }\end{array}$ & $\begin{array}{c}\text { Table } 3-5 \text { Group } \\
17\end{array}$ \\
\hline
\end{tabular}

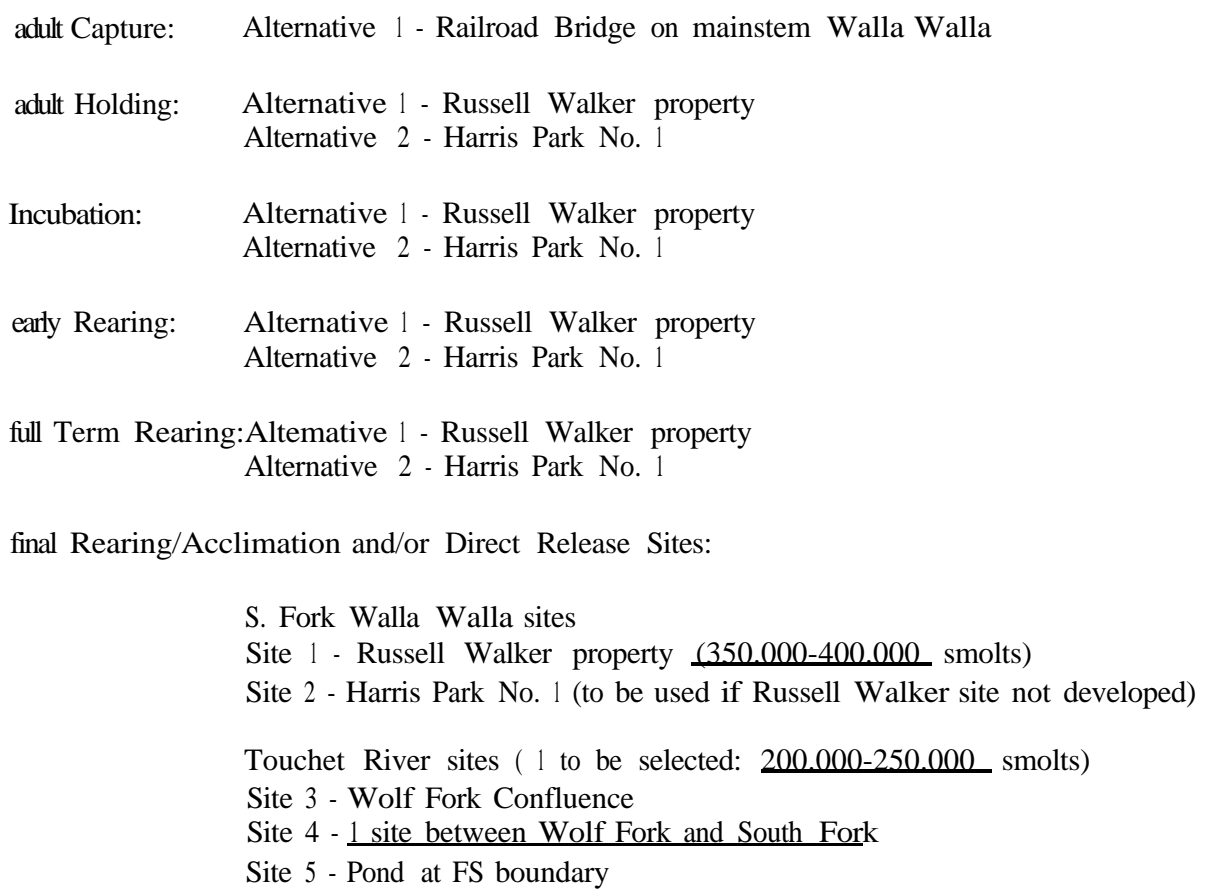

final Rearing/Acclimation and/or Direct Release Sites:

S. Fork Walla Walla sites

Site 1 - Russell Walker property (350.000-400.000 smolts)

Site 2 - Harris Park No. 1 (to be used if Russell Walker site not developed)

Touchet River sites ( 1 to be selected: 200.000-250.000 smolts)

Site 3 - Wolf Fork Confluence

Site 4 - 1 site between Wolf Fork and South Fork

Site 5 - Pond at FS boundary 
TABLE 44

GRANDE RONDE FALL CHINOOK

\begin{tabular}{|c|c|c|c|c|}
\hline $\begin{array}{c}\text { Broodstock } \\
\text { Source } \\
\end{array}$ & $\begin{array}{c}\text { Broodstock } \\
\text { Number }\end{array}$ & $\begin{array}{c}\text { Production Goal } \\
\text { No. \& Size } \\
\end{array}$ & $\begin{array}{c}\text { Acclimation or } \\
\text { Direct Release Sites }\end{array}$ & $\begin{array}{c}\text { Siting Report } \\
\text { Reference } \\
\end{array}$ \\
\hline $\begin{array}{l}\text { Wenatchee Stock } \\
\text { (October spawners) } \\
\text { [Snake River stock } \\
\text { is potential] }\end{array}$ & 1,000 & $\begin{array}{c}1,350,000 @ 40- \\
50 / 1 b\end{array}$ & $\begin{array}{l}\text { Direct release at } 7 \\
\text { sites on mainstem } \\
\text { Grande Ronde and } \\
\text { Wallowa Rivers }\end{array}$ & $\begin{array}{c}\text { Table 3-2 Group } \\
11\end{array}$ \\
\hline
\end{tabular}

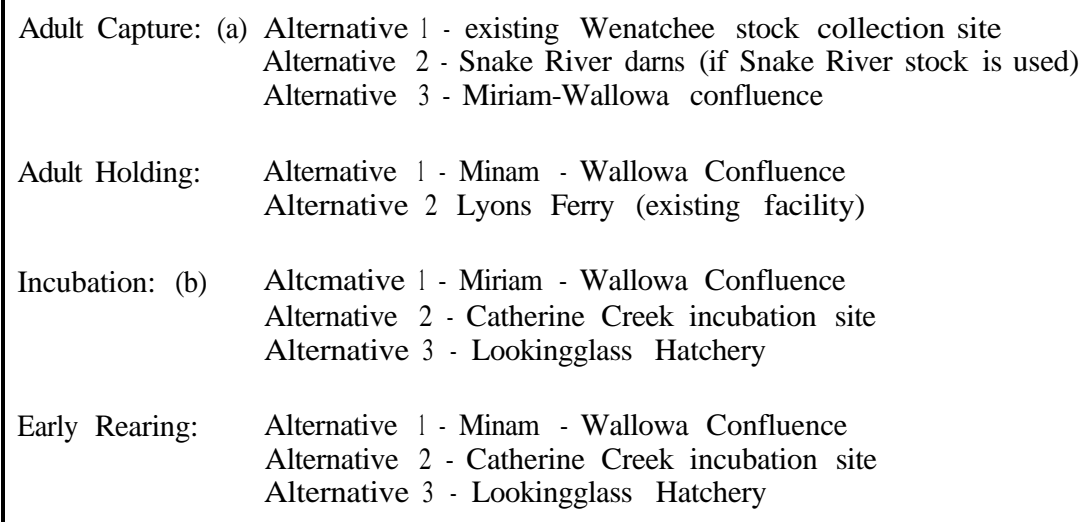

Full Term Rearing:

Alternative 1 - Minam - Wallowa Confluence

Alternative 2 - Catherine Creek incubation site

Alternative 3 - Lookingglass Hatchery

Final Rearing/Acclimation and/or Direct Release Sites (c):

Site 1 - Flora Grade (Schoolbus Flats) (develop existing natural side-channel)

Site 2 - Cottonwood Creek (use existing pond, develop GRR water supply)

Site 3 - Minam - Wallowa Confluence

Notes:

(a) Initial use of Wenatchee broodstock to rebuild the run is preferred. Snake River stock is a second choice for broodstock if Wenatchee stock cannot be used. Capture facility at Minam-Wallowa confluence will be planned and designed for potential future use.

(b) Preferred alternative incubation site dependent on outcome of further groundwater investigations. Depending on groundwater investigations, there may be opportunity to combine $\mathrm{ChF}$ and $\mathrm{ChS}$ incubation at one facility.

(c) These sites will be designed as the initial acclimation/release sites. Additional sites may be needed in future as total production goals are approached. If Snake River stock is used, Cottonwood Creek would be the only fmal rearing/release site. 
TABLE 45

IMNAHA FALL CHINOOK

\begin{tabular}{|c|c|c|c|c|}
\hline $\begin{array}{c}\text { Broodstock } \\
\text { Source } \\
\end{array}$ & $\begin{array}{c}\text { Broodstock } \\
\text { Number } \\
\end{array}$ & $\begin{array}{c}\text { Production Goal } \\
\text { No. \& Size } \\
\end{array}$ & $\begin{array}{c}\text { Acclimation or } \\
\text { Direct Release Sites }\end{array}$ & $\begin{array}{c}\text { Siting Report } \\
\text { Reference } \\
\end{array}$ \\
\hline $\begin{array}{c}\text { Snake River Stock } \\
\text { (November } \\
\text { spawner) }\end{array}$ & 66 & 120,000@70/lb & $\begin{array}{c}\text { Direct release on } \\
\text { lower Imnaha at } \\
\text { Marr Ranch }\end{array}$ & $\begin{array}{c}\text { Table 3-3 Group } \\
16\end{array}$ \\
\hline
\end{tabular}

\begin{tabular}{|ll|}
\hline Adult Capture (a): & $\begin{array}{l}\text { Alternative 1 - Snake River darns } \\
\text { Alternative } 2 \text { - Gene Marr Ranch }\end{array}$ \\
Adult Holding: & $\begin{array}{l}\text { Alternative 1 - Lyons Ferry (existing facility) } \\
\text { Alternative 2 - Gene Marr Ranch }\end{array}$ \\
Incubation: (b) & Alternative 1 - Gene Man Ranch \\
Early Rearing: & Alternative 1 - Gene Marr Ranch \\
Full Term Rearing: & Alternative 1 - Gene Man Ranch \\
Final Rearing/Acclimation & and/or Direct Release Sites: \\
& Site 1 - Gene Marr Ranch (120,000 fish)
\end{tabular}

Notes:

(a) Initial use of Lyons Ferry (or other Snake River) broodstock to rebuild the run. Facility required when sufficient adults returning for broodstock capture.

(b) Assuming use of Falls Creek for incubation water supply. 
TABLE 46

\section{WALLA WALLA STEELHEAD}

\begin{tabular}{|c|c|c|c|c|}
\hline $\begin{array}{c}\text { Broodstock } \\
\text { Source }\end{array}$ & $\begin{array}{c}\text { Broodstock } \\
\text { Number }\end{array}$ & $\begin{array}{c}\text { Production Goal } \\
\text { No. \& Size }\end{array}$ & $\begin{array}{c}\text { Acclimation or } \\
\text { Direct Release Sites }\end{array}$ & \multicolumn{1}{c|}{$\begin{array}{c}\text { Siting Report } \\
\text { Refence }\end{array}$} \\
\hline $\begin{array}{c}\text { Walla Walla River } \\
\text { Stock }\end{array}$ & 80 & 100,000 @ $5 / \mathrm{lb}$ & $\begin{array}{c}1 \text { Final rearing / } \\
\text { release site on S } \\
\text { Fork Walla Walla }\end{array}$ & Table Group 3 \\
\hline
\end{tabular}

\begin{tabular}{|c|c|}
\hline Adult Capture: & Alternative 1 - NE 8th St. Bridge \\
\hline Adult Holding: & $\begin{array}{l}\text { Alternative } 1 \text { - Russell Walker property } \\
\text { Alternative } 2 \text { - Harris Park No. } 1\end{array}$ \\
\hline Incubation: & $\begin{array}{l}\text { Alternative } 1 \text { - Umatilla Hatcherv (a) } \\
\text { Alternative 2 - Russell Walker property } \\
\text { Alternative 3 - Harris Park No. } 1\end{array}$ \\
\hline Early Rearing: & $\begin{array}{l}\text { Alternative } 1 \text { - Umatilla Hatcherv (a) } \\
\text { Alternative } 2 \text { - Russell Walker property } \\
\text { Alternative } 3 \text { - Harris Park No. } 1 \\
\end{array}$ \\
\hline Full Term Rearing: & $\begin{array}{l}\text { Alternative } 1 \text { - Umatilla Hatcherv (al } \\
\text { Alternative 2 - Russell Walker propertv } \\
\text { Alternative 3 - Harris Park No. } 1\end{array}$ \\
\hline Final Rearing/Acclin & $\begin{array}{l}\text { and/or Direct Release Sites: } \\
\text { Site } 1 \text { - Russell Walker property (100,000 fish) } \\
\text { Site } 2 \text { - Harris Park No. } 1 \text { (if Site } 1 \text { is not used) }\end{array}$ \\
\hline
\end{tabular}

Notes:

(a) This alternative would invlove transferring the Walla Walla steelhead production to the Umatilla Hatchery, and in exchange, an equivalent amount of Umatilla Hatchery $\mathrm{ChS}$ production would be transferred to the Russell Walker site. 


\section{REFERENCES}

CBFWA. 1990. Integrated system plan for salmon and steelhead production in the Columbia River basin. Columbia Basin System Planning. Columbia Basin Fish and Wildlife Authority. 90-12. August 1, 1990. 449 p.

FEMA. 1978. Flood Insurance Study for the City of Union. Federal Emergency Management Administration.

FEMA. 1978. Flood Insurance Study for the City of Elgin. Federal Emergency Management Administration.

FEMA. 1979. Flood Insurance Study for Union County. Federal Emergency Management Administration.

FEMA. 1983. Flood Insurance Study for Walla Walla County. Federal Emergency Management Administration.

FEMA. 1988. Flood Insurance Study for Wallowa County. Federal Emergency Management Administration,

Gonthier, J.B., 1985, A Description of Aquifer Units in Eastern Oregon. USGS WaterResources Investigations Report 84-4095.

Hampton, E.R., and S.G. Brown, 1964, Geology and Ground-Water Resources of the Upper Grande Ronde River Basin, Union County, Oregon. USGS Water-Supply Paper 1597.

Piper, R. G., I. B. McElwain, L. E. Orme, J. P. McCraren, L. G. Fowler, and J. R. Leonard. 1982. US Fish \& Wildlife Service, Washington, D.C.

Senn, H. J. Mack, and L. Rothfus. 1984. Compendium of low-cost Pacific Salmon and steelhead trout production facilities and practices in the Pacific Northwest, Fish Management Consultants, Olympia, Washington.

Walker, G.M., 1977, Geologic Map of Oregon East of the 121st Meridian. USGS Miscellaneous Investigations Series Map I-902.

Water Well Reports. State of Oregon. Department of Water Resources. Salem, OR. 


\section{APPENDIXA}

\section{SIJMMARY OF STREAMFLOW DATA}

This Appendix contains tabular and graphic summaries of minimum, maximum, and average monthly streamflows at the NEOH project area USGS gaging stations listed below. This information was used to determine if seasonal surface water availability at particular sites was adequate to meet projected facility flow requirements. This information was then used in the site screening analysis contained in Section 8.0.

TABLE A-1

STREAMFLOW GAGES IN THE NEOH STUDY AREA

SOURCE

$\begin{array}{lr}\text { USGS } & 13292000 \\ \text { USGS } & 1331.8500 \\ \text { USGS } & 13318800 \\ \text { USGS } & 13319000 \\ \text { USGS } & \mathbf{1 3 3 2 0 0 0 0} \\ \text { USGS } & 13320000 \\ \text { USGS } & 13323566 \\ \text { USGS } & 133.23600 \\ \text { USGS } & 13327566 \\ \text { USGS } & 13329599 \\ \text { USGS } & \text { EB30000 } \\ \text { USGS } & 13330500 \\ \text { USGS } & 13331566 \\ \text { USGS } & 13332596 \\ \text { USGS } & 13333000 \\ \text { USGS } & 14010000 \\ \text { USGS } & 14010500 \\ \text { USGS } & 14010800 \\ \text { USGS } & 14011000\end{array}$
LOCATION

Imnaha River at Imnaha

Grande Ronde River near Hilgard

Grande Ronde River at Hilgard

Grande Ronde River at La Grande

Catherine Creek nr Union (before diversion)

Catherine Creek nr Union (after diversion)

Grande Ronde River near Elgin

Indian Creek near Imbler

Wallowa River at Joseph

Hurricane Creek near Joseph

Lostine River near Lostine

Bear Creek near Wallowa

Minam River at Minam

Grande Ronde River at Rondowa

Grande Ronde River at Troy

S. Fork Walla Walla near Milton

S. Fork Walla Walla below PP\&L, nr Milton

N. Fork Walla Walla nr Milton-Freewater

N. Fork Walla Walla nr Milton
PERIOD

1929- 1982

19381956

1967-1982

1904-1982

1912-1936

19381982

19561981

19391950

19051982

1925-1978

19131982

19251982

19661982

1927-1982

19451982

1907-1982

1904-1945

1970-1982

1931-1969 
MONTHLY STREAMFLOW DATA

Data hum U.S. Geological Survey

Monthly Streamflow, in cfs

\begin{tabular}{|c|c|c|c|c|c|}
\hline \multicolumn{4}{|c|}{ lmnaha River imnaha } & \multirow{2}{*}{$\begin{array}{r}13292000 \\
\text { MAX }\end{array}$} & \multirow[t]{14}{*}{ 1929-1982 } \\
\hline & & $\mathrm{MmN}$ & MEAN & & \\
\hline OCT & & 82 & 159 & 501 & \\
\hline NOV & & 80 & 187 & 625 & \\
\hline $\mathrm{DEC}$ & & 89 & 219 & 806 & \\
\hline JAN & & 69 & 193 & 393 & \\
\hline FEB & & 82 & 236 & 569 & \\
\hline MAR & & 114 & 377 & 869 & \\
\hline APR & & 345 & 942 & 1760 & \\
\hline MAY & & 445 & 1603 & 2804 & \\
\hline JUN & & 423 & 1365 & 2612 & \\
\hline Jul & & 123 & 567 & 1348 & \\
\hline AUG & & 79 & 193 & 380 & \\
\hline SEP & & 83 & 143 & 256 & \\
\hline \multirow[t]{2}{*}{ Grande } & Rondc & River near Hilgard & & 13318500 & $1938-56$ \\
\hline & & $\mathrm{MnN}$ & MEAN & MAX & \\
\hline OCT & & 18 & 35 & 128 & \\
\hline NOV & & 20 & 73 & 323 & \\
\hline DEC & & 17 & 145 & 467 & \\
\hline JAN & & 25 & 118 & 301 & \\
\hline FEB & & 29 & 200 & 493 & \\
\hline MAR & & 72 & 455 & 841 & \\
\hline APR & & 387 & 878 & 1590 & \\
\hline MAY & & 230 & 788 & 1922 & \\
\hline JUN & & 48 & 420 & 1096 & \\
\hline JUL & & 13 & 98 & 246 & \\
\hline AUG & & 7 & 28 & 55 & \\
\hline SEP & & 14 & 25 & 71 & \\
\hline \multirow[t]{2}{*}{ Grandc } & Ronde & River a Hilgard & & 13318800 & $1967-1982$ \\
\hline & & MIN & MEAN & MAX & \\
\hline OCT & & 25 & 36 & 56 & \\
\hline $\mathrm{NOV}$ & & 31 & 71 & 236 & \\
\hline DEC & & 33 & 159 & 481 & \\
\hline JAN & & 27 & 272 & 681 & \\
\hline FEB & & 49 & 288 & 521 & \\
\hline MAR & & 75 & 544 & 1668 & \\
\hline APR & & 181 & 787 & 1481 & \\
\hline MAY & & 256 & 882 & 1340 & \\
\hline JUN & & 85 & 421 & 825 & \\
\hline JUL & & 22 & 101 & 253 & \\
\hline AUG & & 12 & 36 & 81 & \\
\hline SEP & & 17 & 31 & 51 & \\
\hline
\end{tabular}


Imnaha River at Imnaha, Gage No. 13292000

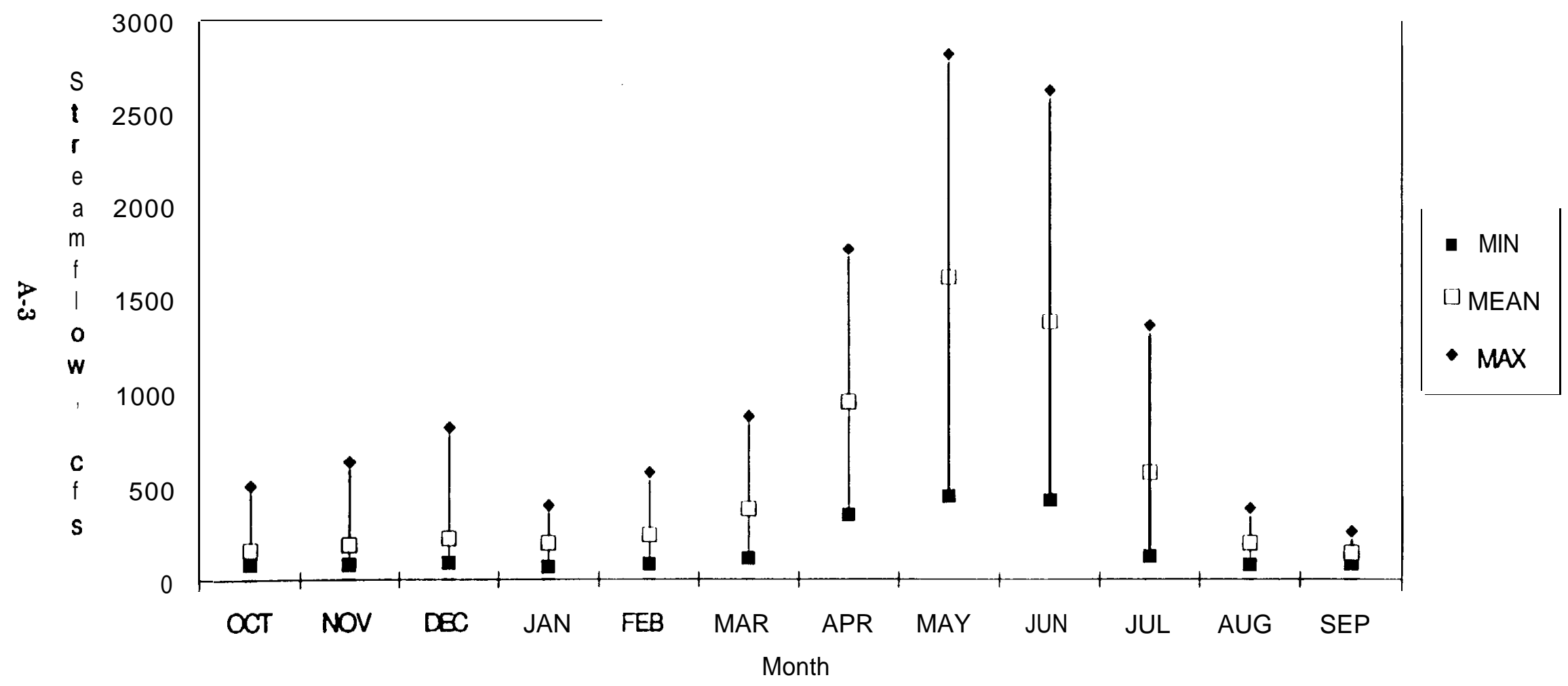


Grande Ronde River near Hilgard, Gage No. 13318500

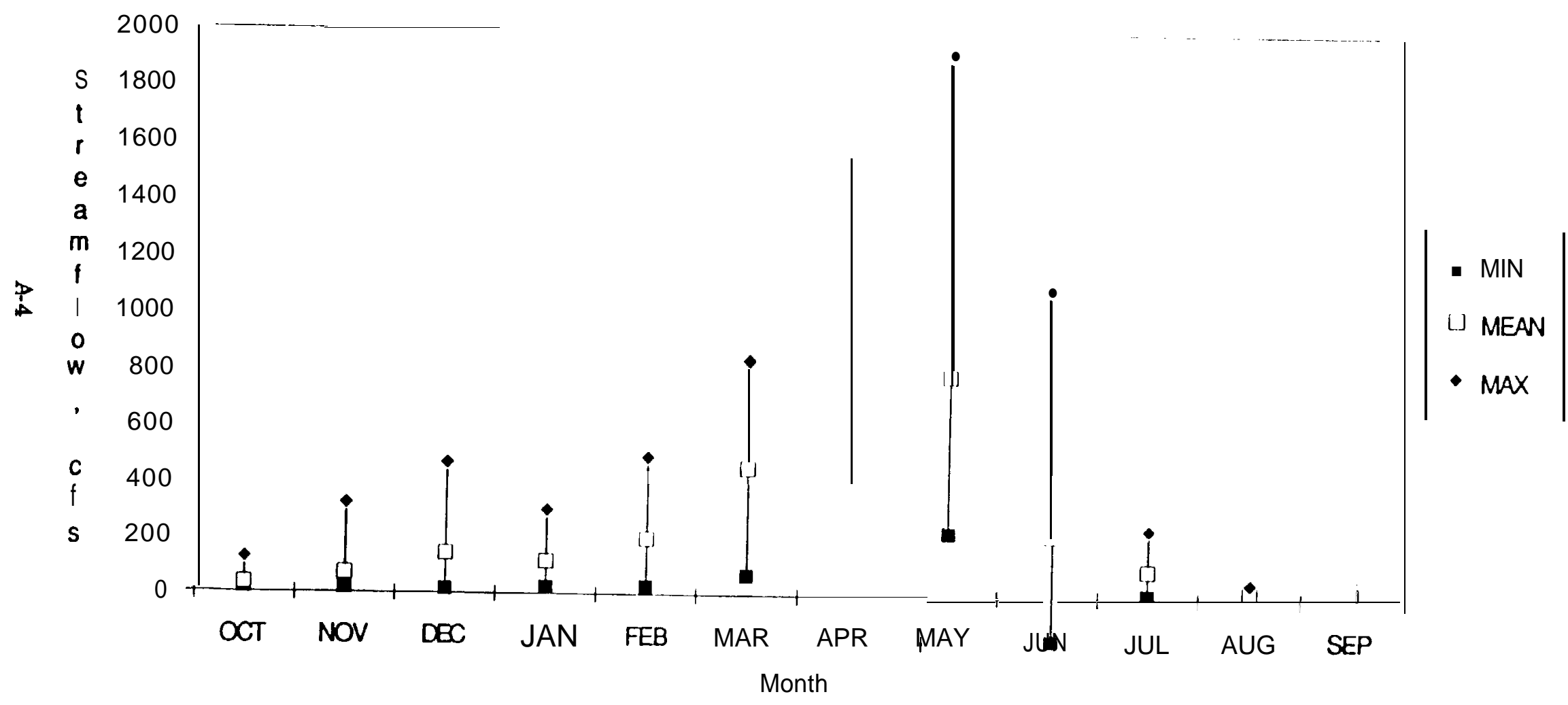


Grande Ronde River at Hilgard, Gage No. 1318800

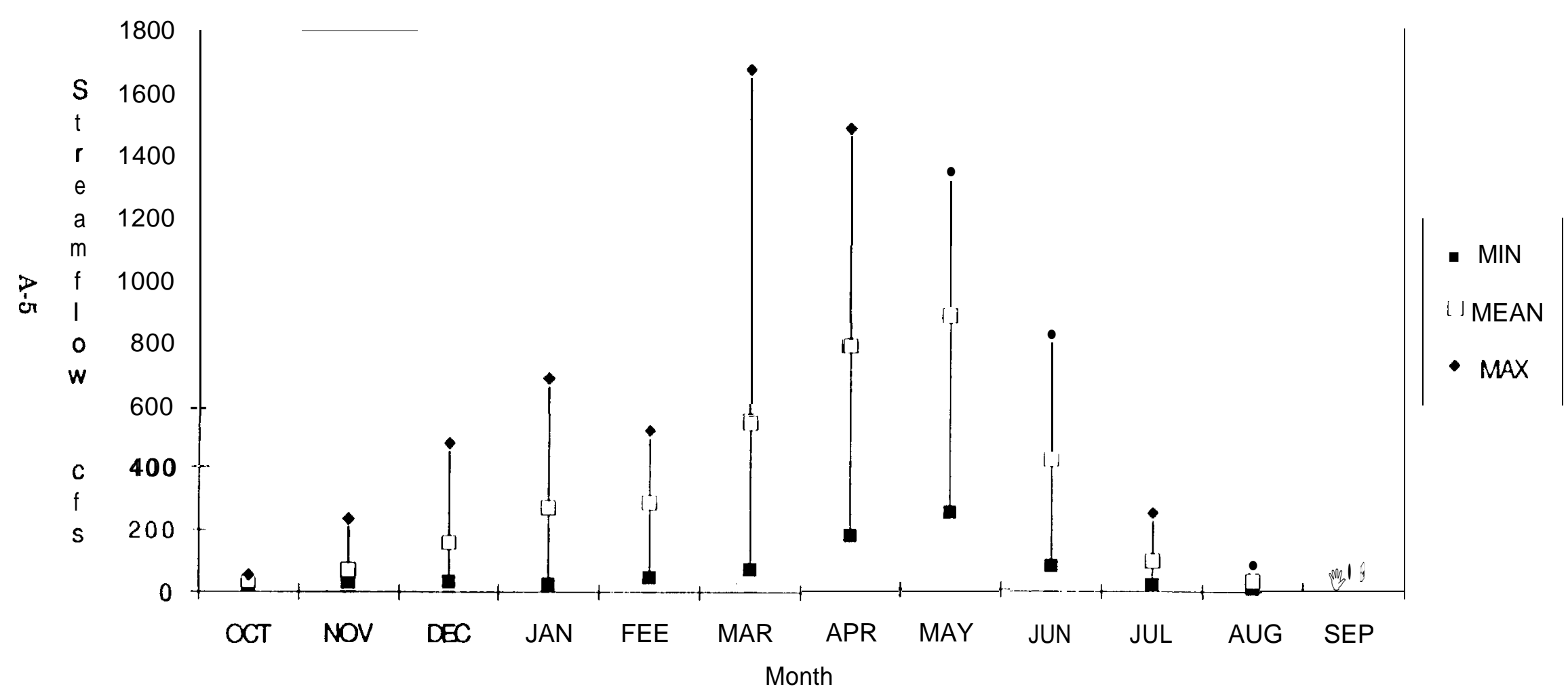


MONTHLY STREAMFLOW DATA

Data fmm U.S. Geological Survey

Monthly Streamflow. in cfs

\begin{tabular}{|c|c|c|c|c|}
\hline \multicolumn{3}{|c|}{ Grande Ronde River at La Grande } & 13319000 & \multirow[t]{14}{*}{$1904-82$} \\
\hline \multirow[b]{2}{*}{ OCT } & $\mathrm{MON}$ & MEAN & MAX & \\
\hline & 16 & 42 & 145 & \\
\hline NOV & 22 & 93 & 700 & \\
\hline $\mathrm{DEC}$ & 20 & 178 & 669 & \\
\hline JAN & 12 & 218 & 1295 & \\
\hline FEB & 25 & 334 & 1379 & \\
\hline MAR & 83 & 757 & 3700 & \\
\hline APR & 237 & 1291 & 3372 & \\
\hline MAY & 118 & 1068 & 2675 & \\
\hline JUN & 58 & 459 & 1328 & \\
\hline JUL & 18 & 104 & 600 & \\
\hline AUG & 7 & 31 & 88 & \\
\hline SEP & 8.8 & 30 & S2 & \\
\hline \multicolumn{3}{|c|}{$\begin{array}{l}\text { Catherinc Creek nr Union } \\
\text { bcforc completion of Big Creek diversion }\end{array}$} & 13320000 & $1912-36$ \\
\hline & MIN & MEAN & MAX & \\
\hline OCT & 21 & 34 & 103 & \\
\hline NOV & 14 & 41 & 157 & \\
\hline $\mathrm{DEC}$ & 13 & 37 & 105 & \\
\hline JAN & 12 & 38 & 95 & \\
\hline HEB & 22 & 42 & 74 & \\
\hline MAR & 51 & 95 & 203 & \\
\hline APR & 158 & 95 & 203 & \\
\hline MAY & 139 & 776 & 440 & \\
\hline JUN & 66 & 289 & 632 & \\
\hline JUL & 26 & 76 & 145 & \\
\hline AUG & 11 & 29 & 63 & \\
\hline SEP & 16 & 26 & 50 & \\
\hline \multicolumn{3}{|c|}{$\begin{array}{l}\text { Calhcrine Creek } \boldsymbol{n} \mathbf{r} \text { Union } \\
\text { after completion of } \mathrm{BgCreek} \text { diversion }\end{array}$} & 13320000 & $1938-82$ \\
\hline & $\mathrm{Mm}$ & ME A N & MAX & \\
\hline OCT & 20 & 33 & 138 & \\
\hline NOV & 22 & 39 & loo & \\
\hline DEC & 20 & 48 & 125 & \\
\hline JAN & 23 & 48 & 101 & \\
\hline FEB & 23 & 60 & 135 & \\
\hline MAR & 28 & 90 & 213 & \\
\hline APR & 83 & 230 & 445 & \\
\hline MAY & 121 & 412 & 742 & \\
\hline JUN & 86 & 313 & 686 & \\
\hline JUL & 34 & 96 & 226 & \\
\hline AUG & 19 & 38 & 62 & \\
\hline SEP & 18 & 31 & 58 & \\
\hline
\end{tabular}


Grande Ronde River al La Grande Gage No. 13319000

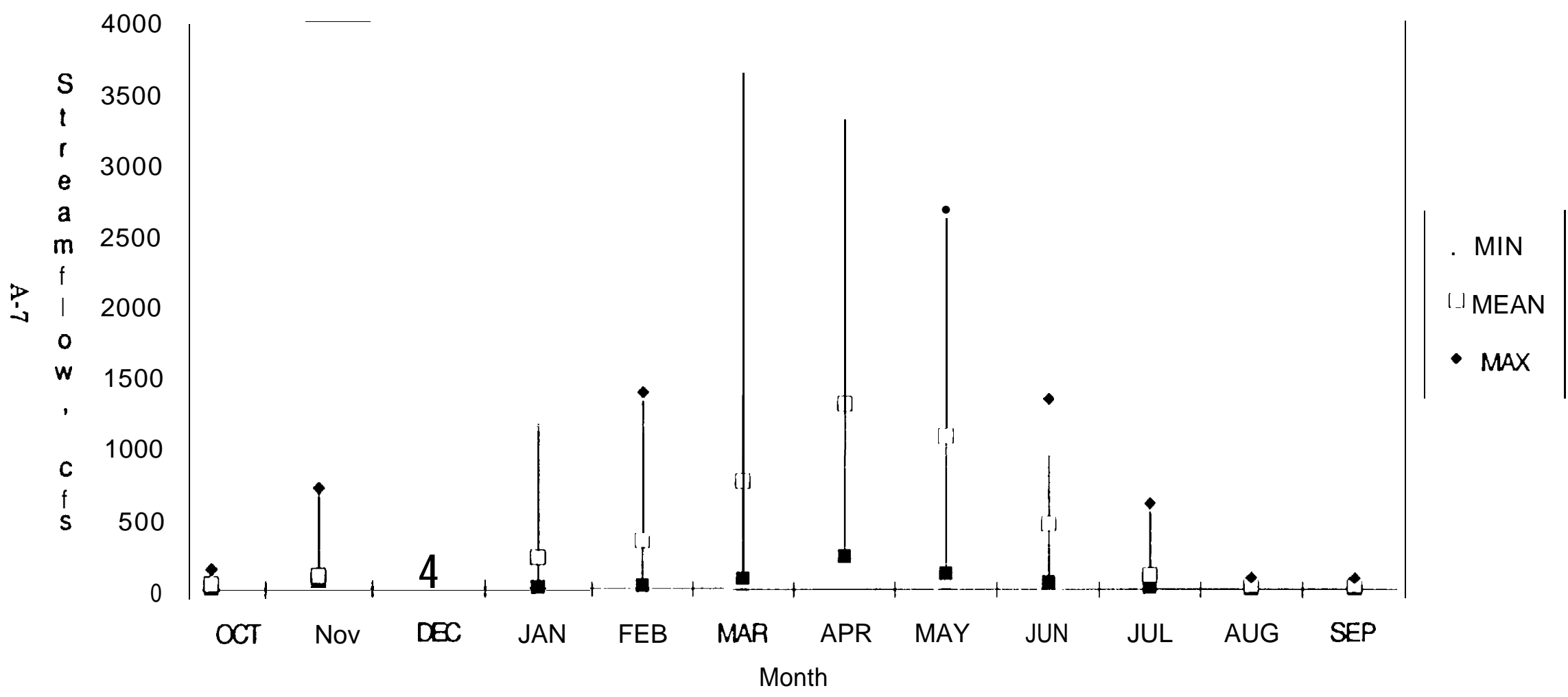


Cathrene Creek near Union, Gage No. 13320000

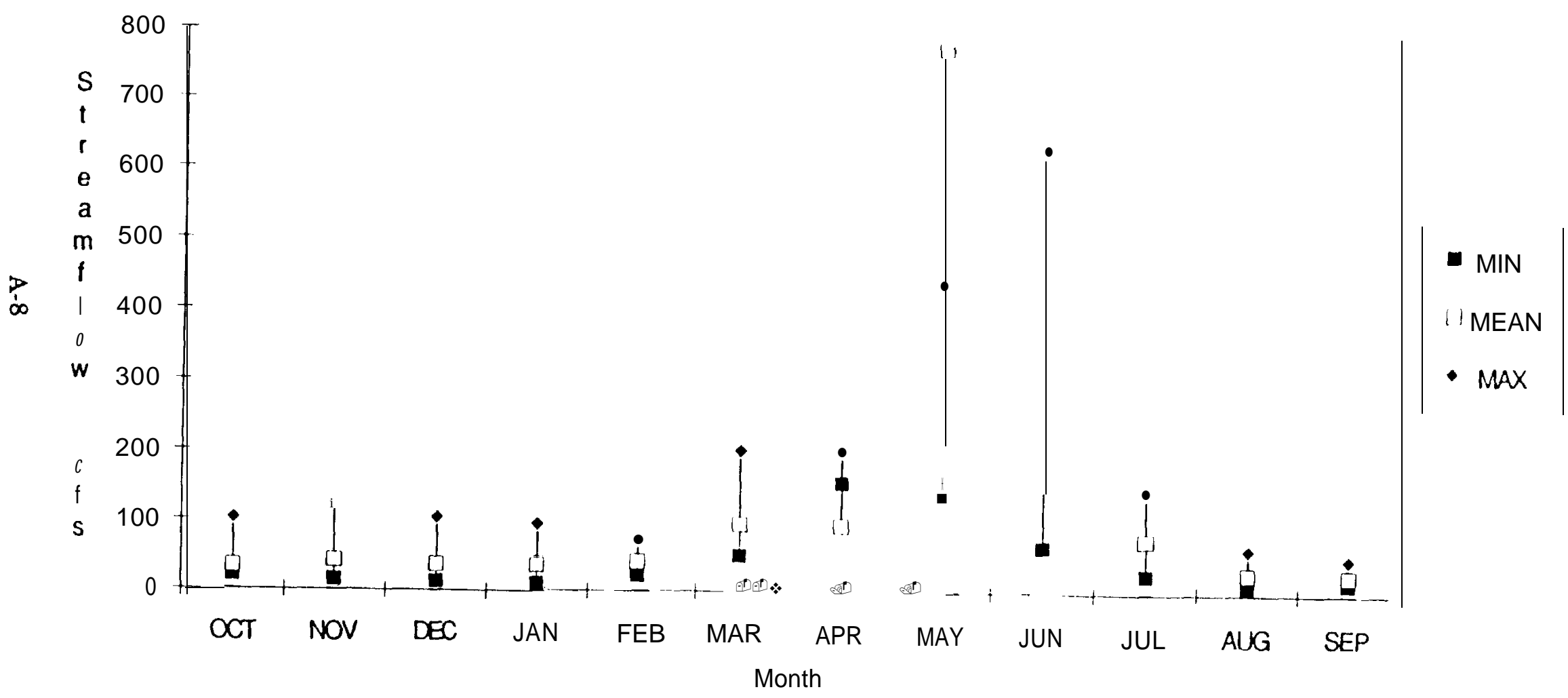


MONTHLY STREAMFLOW DATA

Data fmn U.S. Geological Survcy

Mothly Streamflow. in cfs

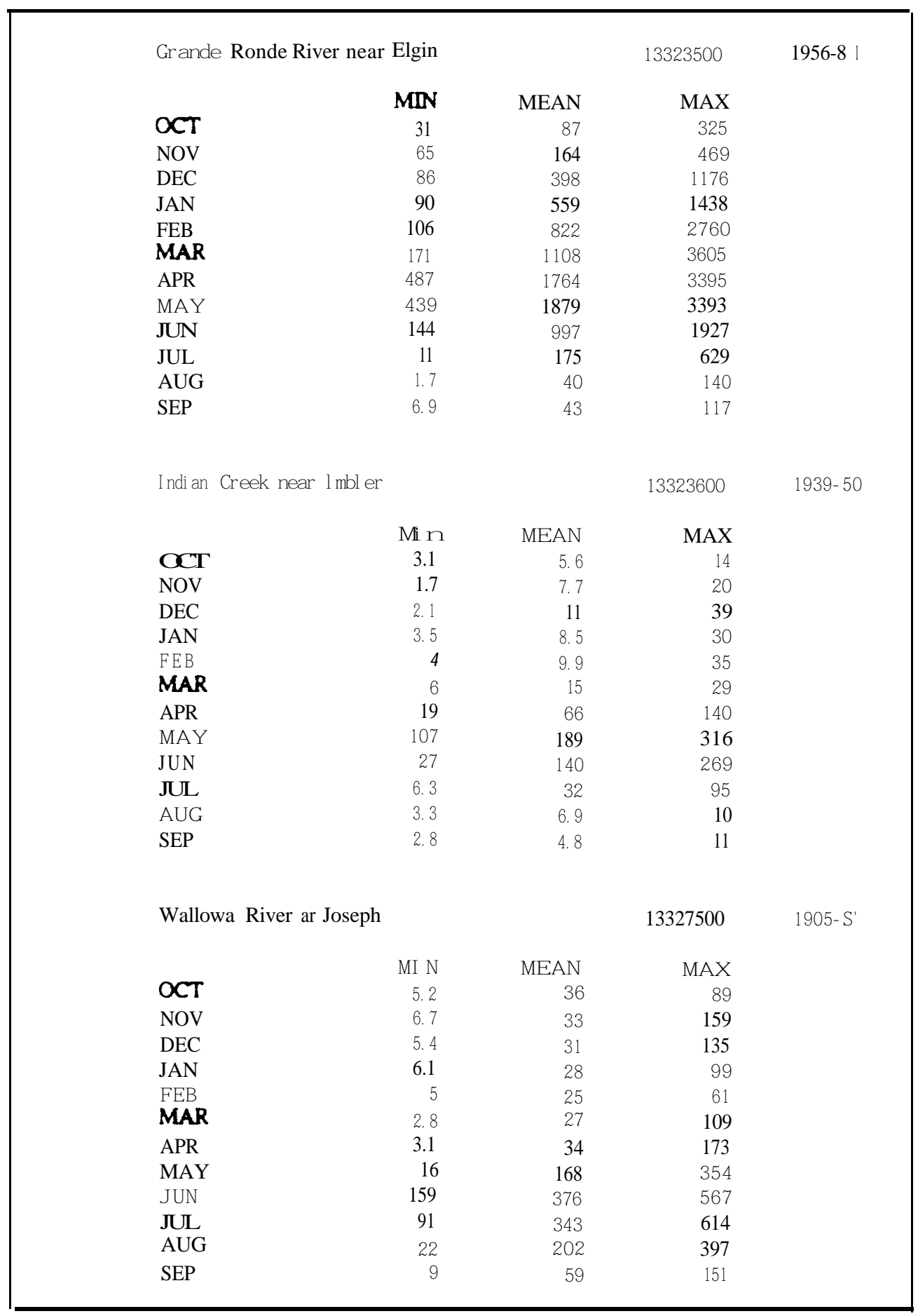


Grande Ronde River nar Elgin, Gage No. 13323500

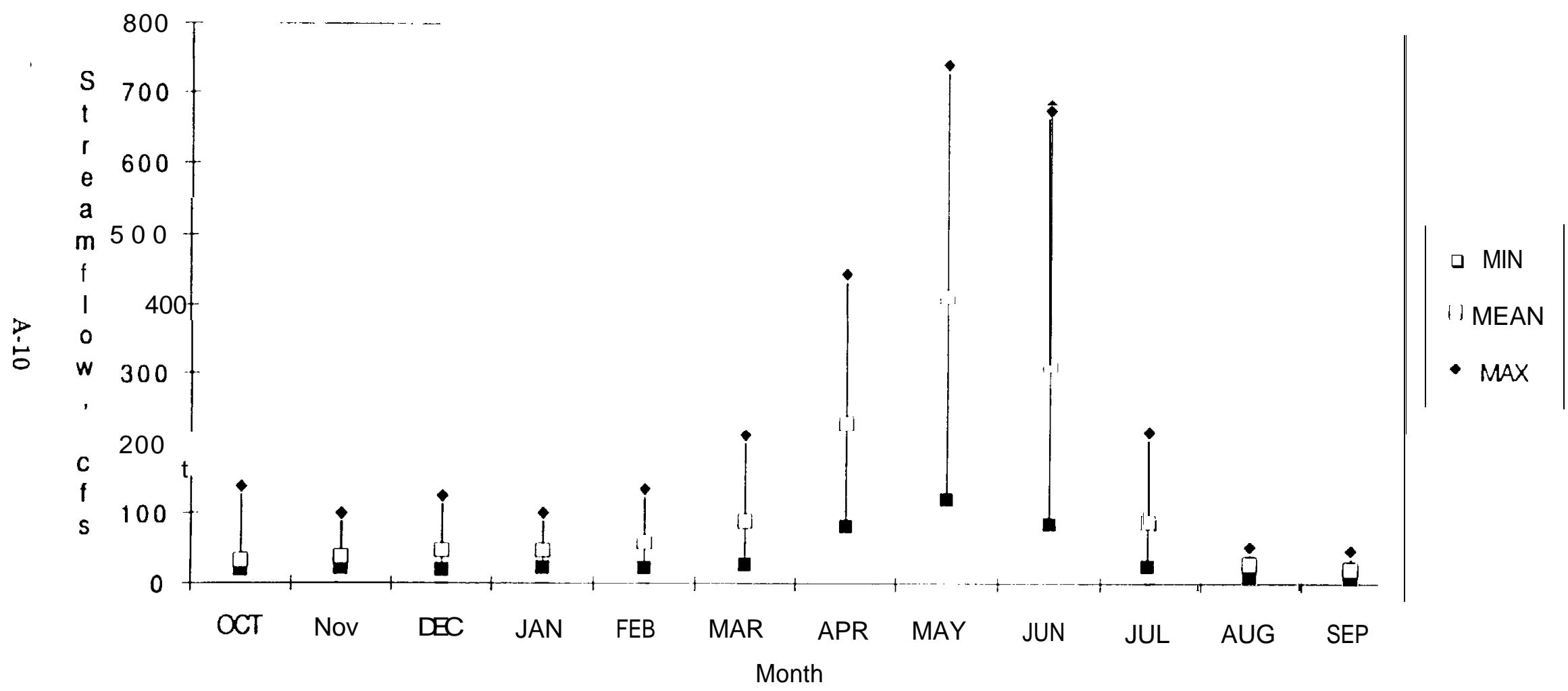


Indian Creek near Imbler, Gage No. 13323600

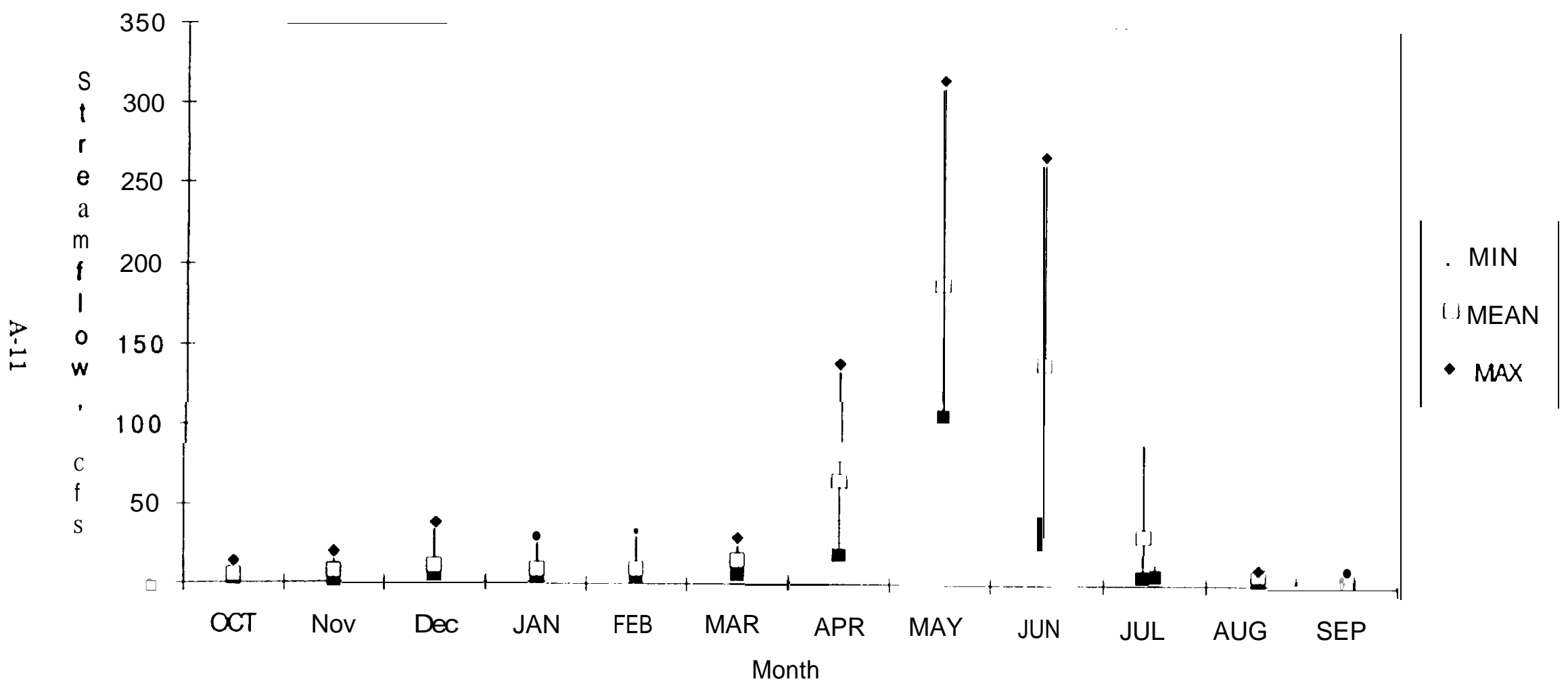


Wallowa River at Joseph, Gage No. 13327500

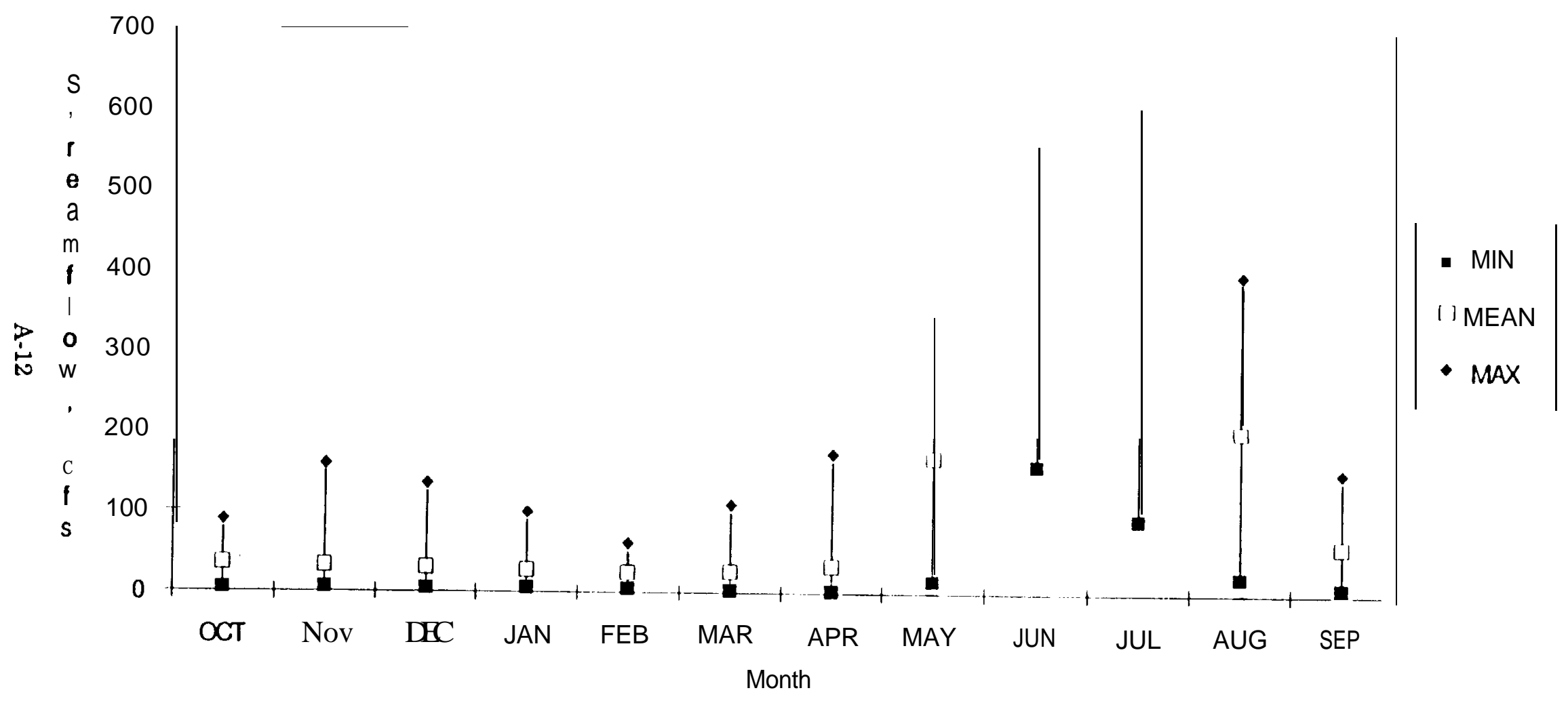


MONTHLY STREAMFLOW DATA

Data iimn U.S. Geological Survey

Monthly Sucamflow, m cfs

\begin{tabular}{|c|c|c|c|c|}
\hline \multicolumn{3}{|c|}{ Hurricane Creek near Joseph } & 13329500 & $1925-78$ \\
\hline & $\mathrm{MTN}$ & ME A N & MAX & \\
\hline OCT & 16 & 33 & 96 & \\
\hline NOV & 13 & 31 & 69 & \\
\hline DEC & 11 & 27 & 67 & \\
\hline JAN & 10 & 22 & 44 & \\
\hline FEB & 10 & 20 & 37 & \\
\hline MAR & 9 & 20 & 42 & \\
\hline APR & 14 & 46 & 111 & \\
\hline MAY & 64 & 165 & 292 & \\
\hline JUN & 116 & 266 & 439 & \\
\hline JUL & 41 & 164 & 355 & \\
\hline AUG & 25 & 60 & 113 & \\
\hline SEP & 20 & 36 & 62 & \\
\hline \multicolumn{3}{|c|}{ Lostine River near Lostinc } & 13330000 & $1913-82$ \\
\hline & Min & MEAN & MAX & \\
\hline OCT & 18 & 58 & 291 & \\
\hline $\mathrm{NOV}$ & 15 & 64 & 226 & \\
\hline DEC & 15 & 60 & 212 & \\
\hline JAN & 15 & 49 & 158 & \\
\hline FEB & 15 & 46 & 117 & \\
\hline MAR & 16 & 53 & 155 & \\
\hline APR & 36 & 158 & 393 & \\
\hline MAY & 203 & 525 & 909 & \\
\hline JUN & 332 & 805 & 1427 & \\
\hline JUL & 60 & 385 & 913 & \\
\hline AUG & 31 & 85 & 180 & \\
\hline SEP & 23 & 50 & 104 & \\
\hline \multicolumn{2}{|c|}{ BearCreek near Wallowa } & & 13330500 & $1925-82$ \\
\hline & $\mathrm{MIN}$ & MEAN & MAX & \\
\hline OCT & 7.6 & 25 & 160 & \\
\hline NOV & 8.2 & 40 & 220 & \\
\hline DEC & 7.3 & 50 & 194 & \\
\hline JAN & 5.2 & 43 & 136 & \\
\hline FEB & 4.5 & 47 & 147 & \\
\hline MAR & 11 & 65 & 186 & \\
\hline APR & 50 & 171 & 422 & \\
\hline MAY & 138 & 374 & 682 & \\
\hline JUN & 112 & 402 & 869 & \\
\hline JUL & 19 & 116 & 388 & \\
\hline AUG & 8.1 & 19 & 38 & \\
\hline SEP & 6.3 & 16 & 44 & \\
\hline
\end{tabular}


Hurricane Creek near Joseph, Gage No. 13329500

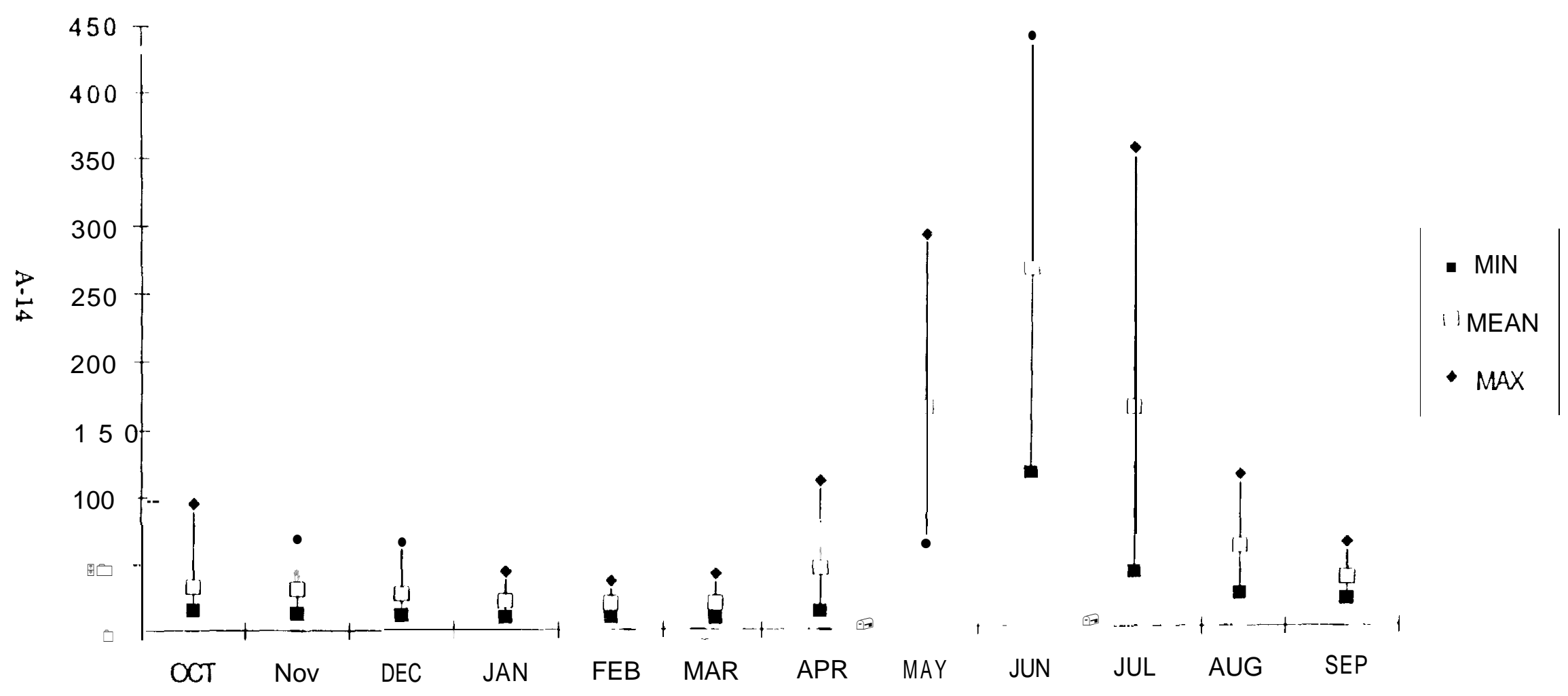


Lostline River near Loslline, Gage No.13330000

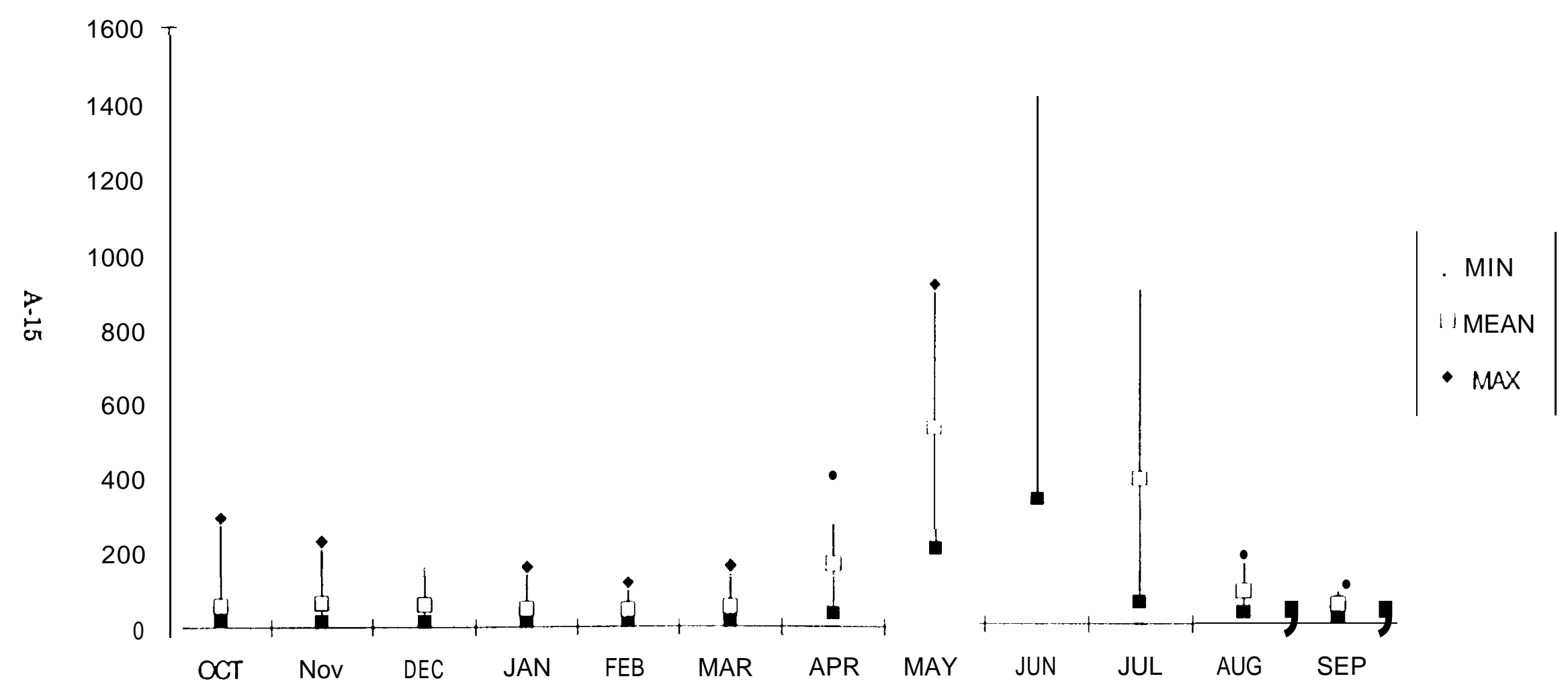


Bear Creek near Wallowa, Gage No. 13330500

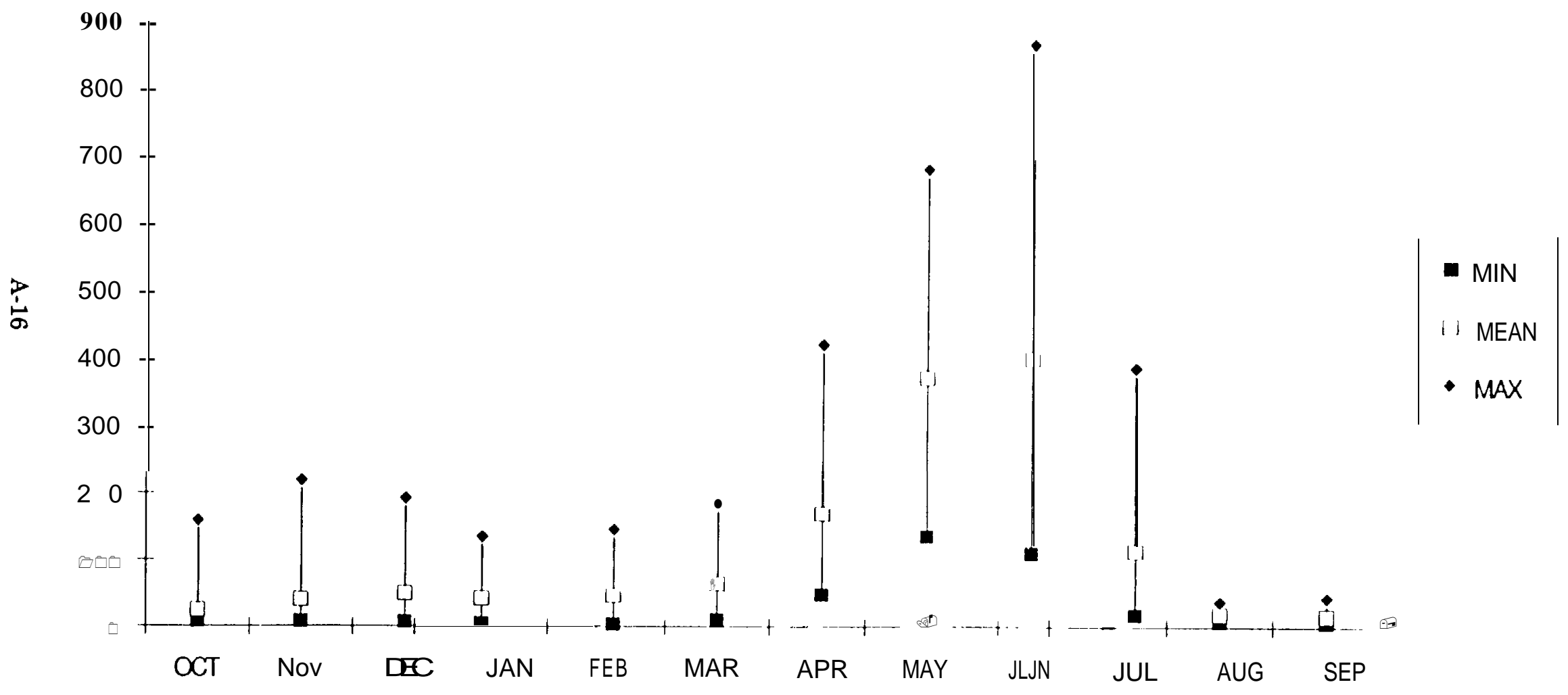


MONTHLY STREAMFLOW DATA

Data from U.S. Geological Survey

Monthiy Streamflow. in cis

\begin{tabular}{|c|c|c|c|c|}
\hline \multicolumn{2}{|c|}{ Minam River at Minam } & & 13331500 & \multirow[t]{14}{*}{$1966-82$} \\
\hline & $\mathrm{MN}$ & MEAN & MAX & \\
\hline$\alpha C T$ & 65 & 96 & 173 & \\
\hline NOV & 62 & 155 & 493 & \\
\hline $\mathrm{DEC}$ & 62 & 215 & 604 & \\
\hline JAN & 60 & 228 & 412 & \\
\hline FEB & 57 & 246 & 504 & \\
\hline MAR & 67 & 287 & 672 & \\
\hline APR & 235 & 464 & 862 & \\
\hline MAY & 484 & 1289 & 2016 & \\
\hline JUN & 668 & 1702 & 3125 & \\
\hline$\pi U L$ & 125 & 680 & 1392 & \\
\hline AUG & 73 & 154 & 257 & \\
\hline SEP & 53 & $\infty$ & 180 & \\
\hline \multicolumn{2}{|c|}{ Grande Ronde River at Rondowa } & & 13332500 & 1927.82 \\
\hline & MDN & MEAN & MAX & \\
\hline OCT & 343 & 641 & 1978 & \\
\hline NOV & 342 & 858 & 3346 & \\
\hline DEC & 358 & 1256 & 3942 & \\
\hline JAN & 298 & 1326 & 3554 & \\
\hline FEB & 395 & 1791 & 5029 & \\
\hline MAR & 611 & 2674 & 7600 & \\
\hline APR & 1498 & 4274 & 8089 & \\
\hline MAY & 1965 & 5576 & 10010 & \\
\hline JUN & 1561 & 4709 & 9662 & \\
\hline $\mathrm{JL}$ & 345 & 1712 & 4692 & \\
\hline AUG & 269 & 589 & 1098 & \\
\hline SEP & 318 & 543 & 933 & \\
\hline \multicolumn{2}{|c|}{ Grande Ronde River at Troy } & & 13333000 & $1945-82$ \\
\hline & MIN & MEAN & MAX & \\
\hline OCT & 603 & 915 & 2559 & \\
\hline NOV & 688 & 1239 & 3023 & \\
\hline DEC & 685 & 2158 & 6295 & \\
\hline JAN & 702 & 2273 & 6280 & \\
\hline FEB & 769 & 3095 & 7386 & \\
\hline MAR & 888 & 3893 & 11520 & \\
\hline APR & 2257 & 6335 & 10780 & \\
\hline MAY & 2368 & 7656 & 13820 & \\
\hline תUN & 2159 & 6035 & 11610 & \\
\hline JUL & 520 & 2291 & 4951 & \\
\hline AUG & 448 & 873 & 1375 & \\
\hline SEP & 574 & 798 & 1190 & \\
\hline
\end{tabular}


Minam River at Minam, Gage No. 13331500

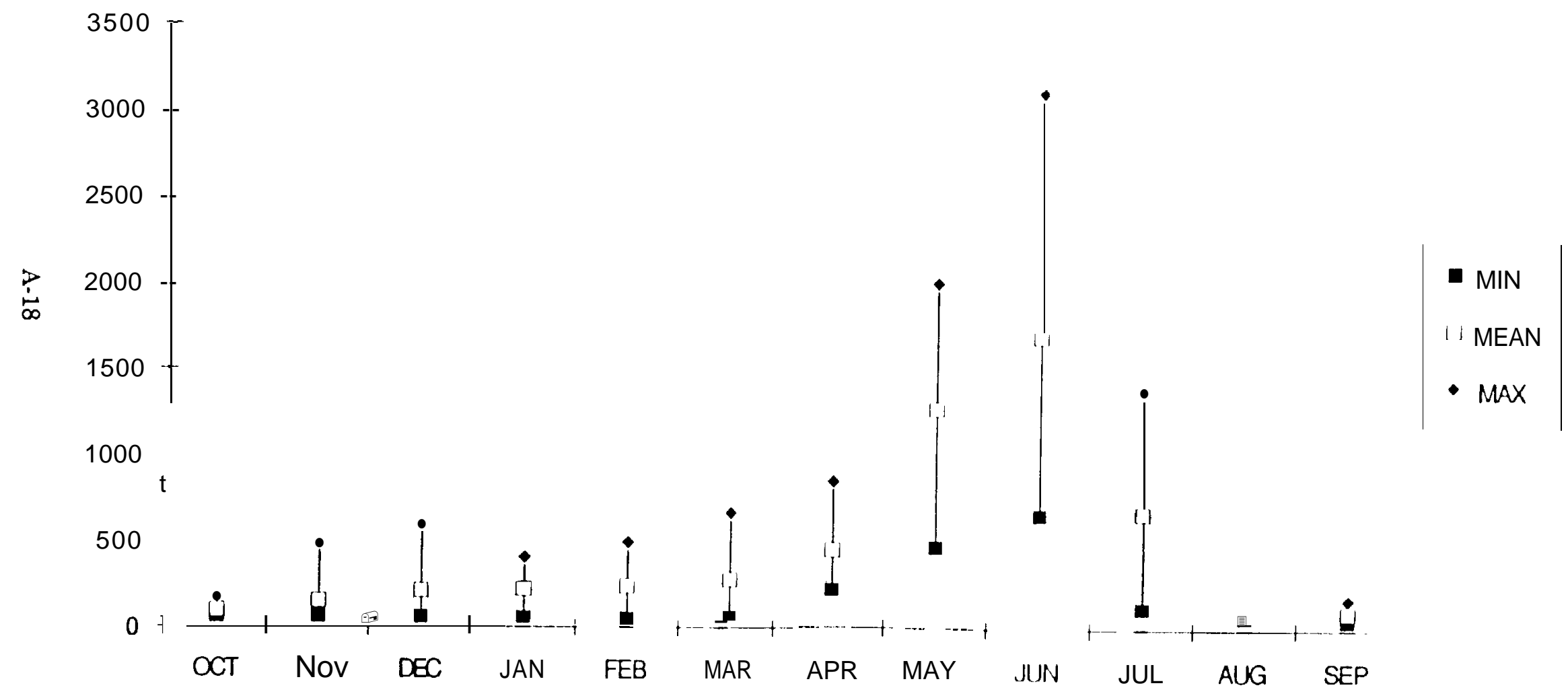


Grande Ronde River at Rondowa, Gage No. 13332500

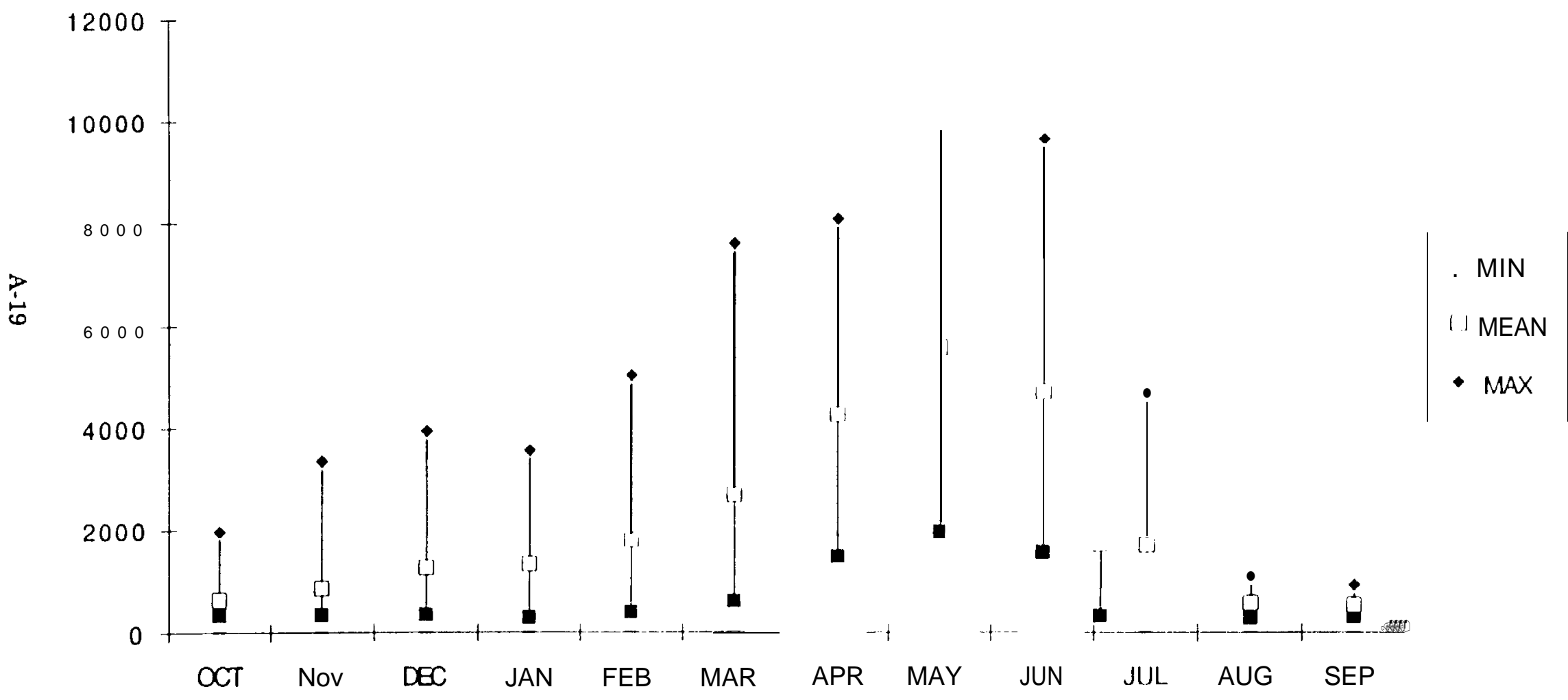


Grande Honde River at Troy, Gage No. 13333000

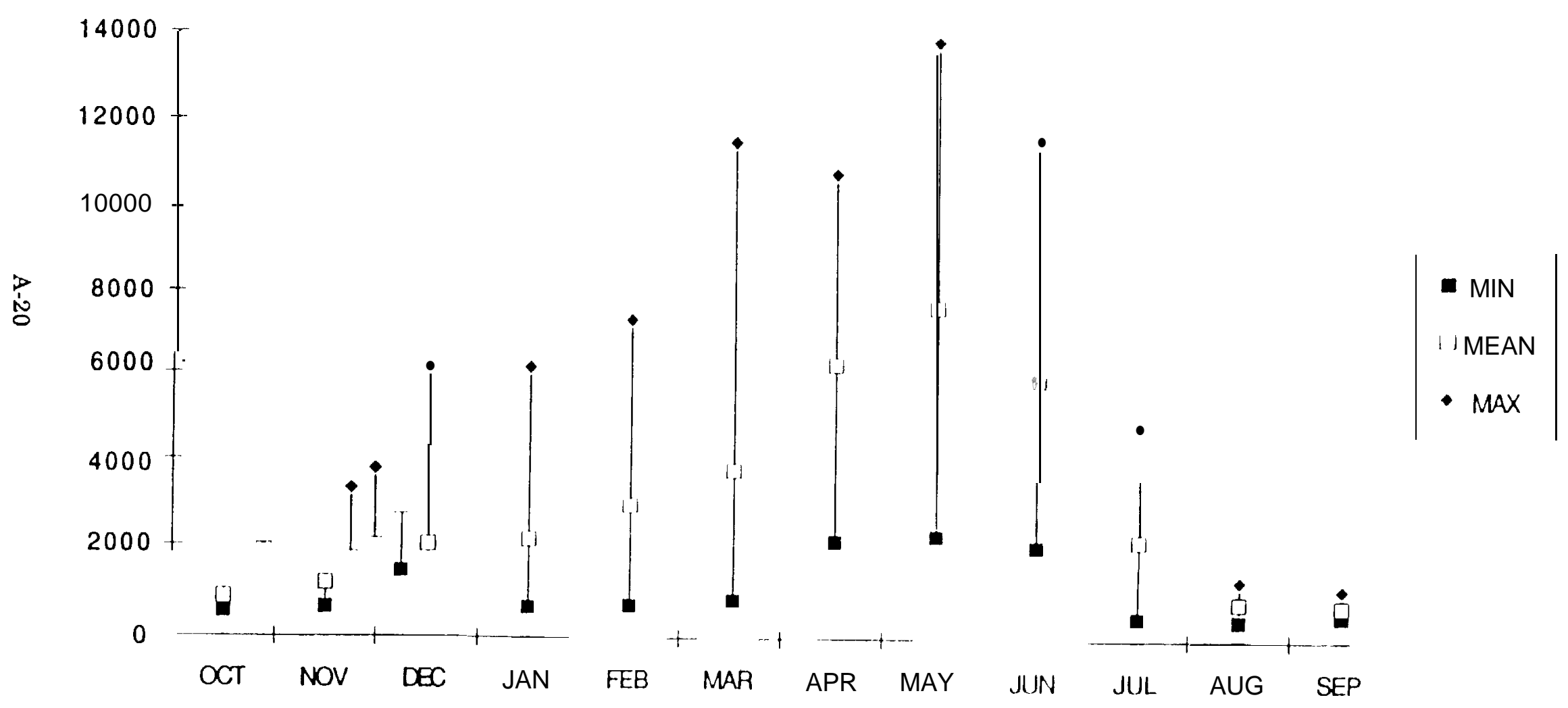


MONTHLY STREAMFLOW DATA

Daca from U.S. Geological Survey

Monthiy Streamflow, in cis

\begin{tabular}{|c|c|c|c|c|}
\hline \multicolumn{3}{|c|}{ S. Fork Walla Walla near Milion } & \multirow{2}{*}{$\begin{array}{r}14010000 \\
\text { MAX }\end{array}$} & \multirow[t]{14}{*}{$1907-82$} \\
\hline & $\mathrm{MIN}$ & MEAN & & \\
\hline$\infty C T$ & 84 & 111 & 180 & \\
\hline NOV & 89 & 135 & 245 & \\
\hline DEC & 93 & 171 & 376 & \\
\hline JAN & 92 & 175 & 378 & \\
\hline FEB & 102 & 188 & 326 & \\
\hline MAR & 111 & 213 & 399 & \\
\hline$A P R$ & 147 & 282 & 458 & \\
\hline MAY & 123 & 306 & 569 & \\
\hline JUN & 110 & 206 & 484 & \\
\hline$\pi \mathrm{L}$ & 85 & 124 & 193 & \\
\hline AUG & 81 & 108 & 143 & \\
\hline SEP & 82 & 107 & 151 & \\
\hline \multicolumn{3}{|c|}{ S. Fork Walla Walla beiow PP\&L. nr Milion } & 14010500 & $1904-4=$ \\
\hline & MIN & MEAN & MAX & \\
\hline$\infty C T$ & 81 & 101 & 180 & \\
\hline NOV & 85 & 126 & 239 & \\
\hline DEC & 100 & 160 & 335 & \\
\hline JAN & 92 & 158 & 283 & \\
\hline FEB & 105 & 169 & 290 & \\
\hline MAR & 149 & 237 & 360 & \\
\hline APR & 152 & 316 & 547 & \\
\hline MAY & 123 & 289 & 447 & \\
\hline JUN & 97 & 180 & 349 & \\
\hline ЛUL & 78 & 104 & 143 & \\
\hline AUG & 74 & 89 & 119 & \\
\hline SEP & 75 & 90 & 114 & \\
\hline \multicolumn{3}{|c|}{ N. Fork Walla Waila nr Milion-Freewater } & 14010800 & $1970-82$ \\
\hline & $\mathrm{MIN}$ & MEAN & MAX & \\
\hline$\infty \mathrm{CT}$ & 6.3 & 9.4 & 16 & \\
\hline NOV & 8.3 & 26 & 86 & \\
\hline DEC & 11 & 62 & 170 & \\
\hline JAN & 12 & 82 & 175 & \\
\hline FEB & 15 & 85 & 181 & \\
\hline MAR & 43 & 96 & 236 & \\
\hline APR & 55 & 119 & 222 & \\
\hline MAY & 26 & 102 & 198 & \\
\hline JUN & 11 & 45 & 136 & \\
\hline JUL & 6.7 & 13 & 21 & \\
\hline AUG & 5.8 & 8.3 & 11 & \\
\hline SEP & 4.7 & 7.7 & 10 & \\
\hline
\end{tabular}


So. Fork Walla Walla River near Milton, Gage No.14010000

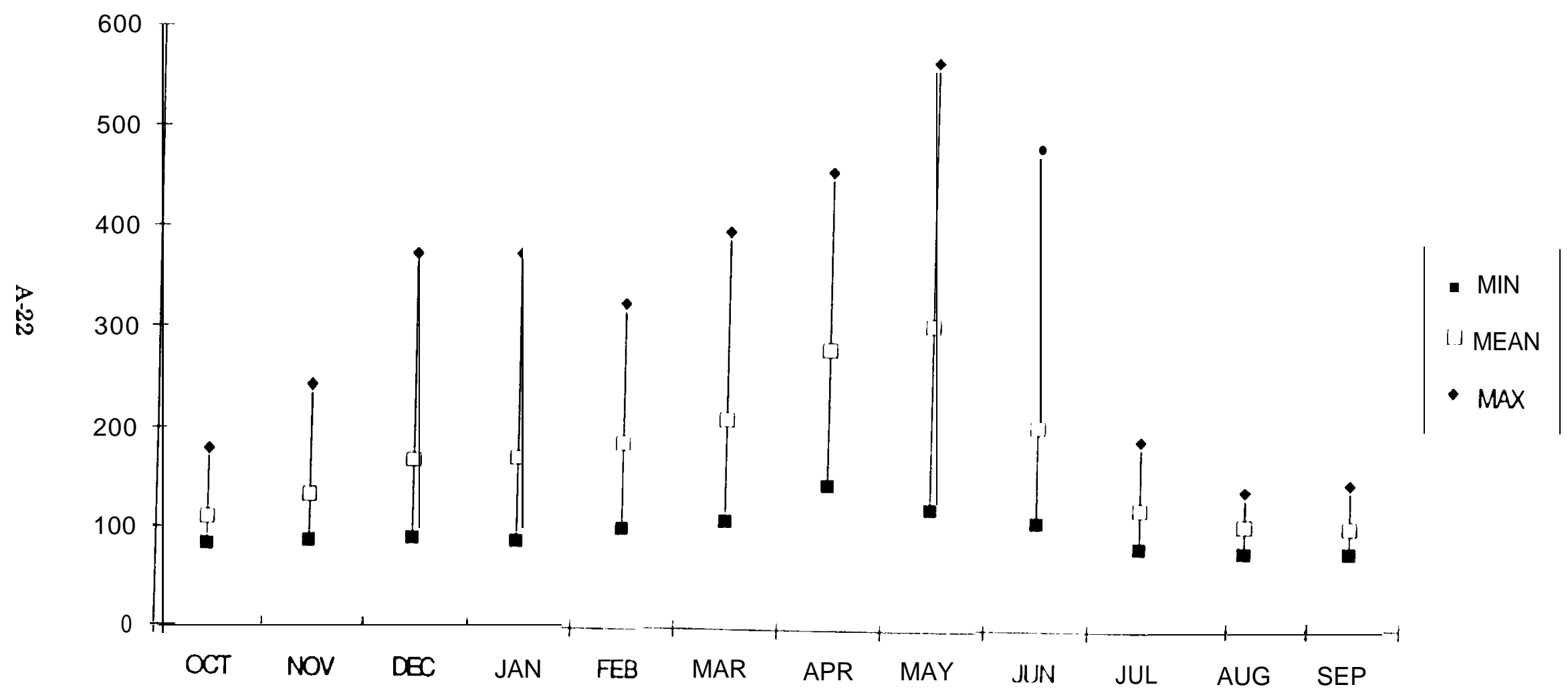


So. Fork Walla Walla Below Pacific Power \& Light, Gage No. 14010500

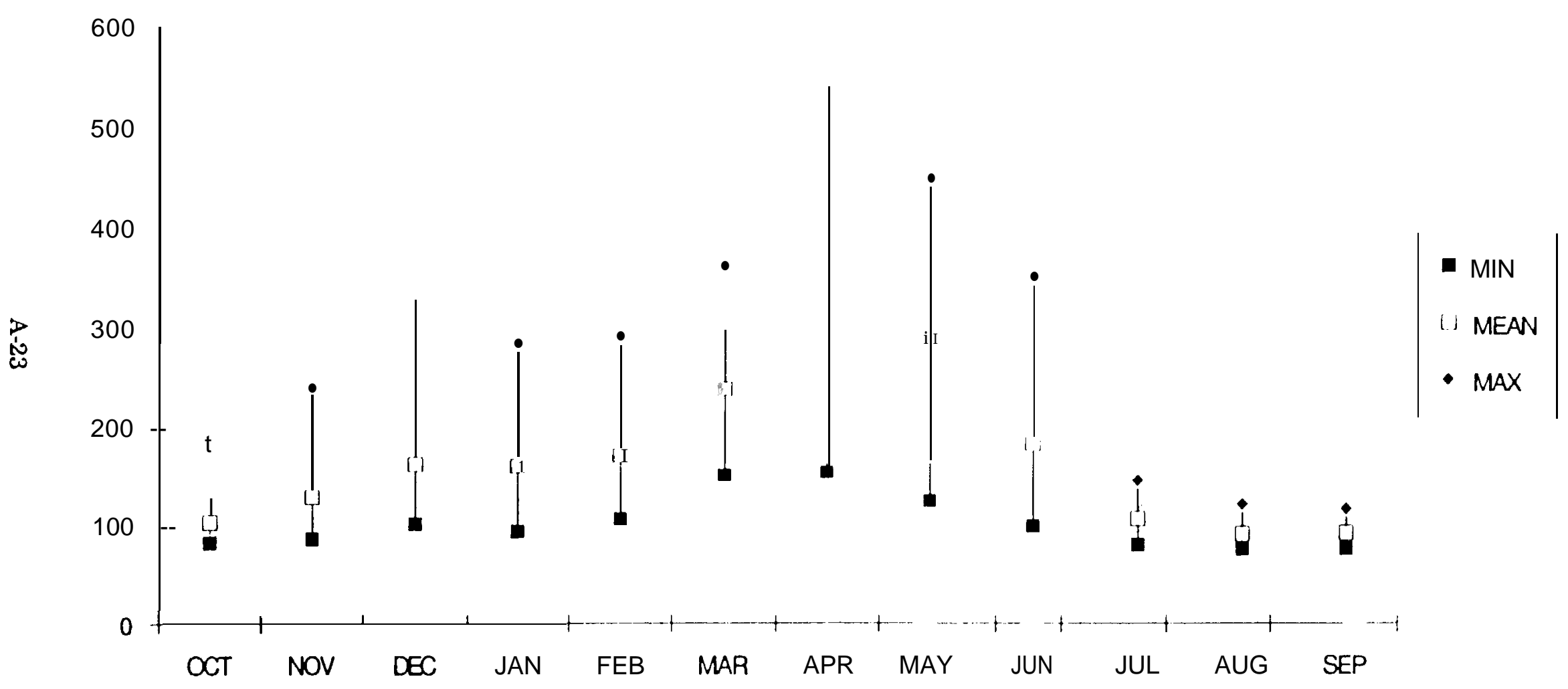


No. Fork Walla Walla River near Milton-Freewater, Gage No. 14010800

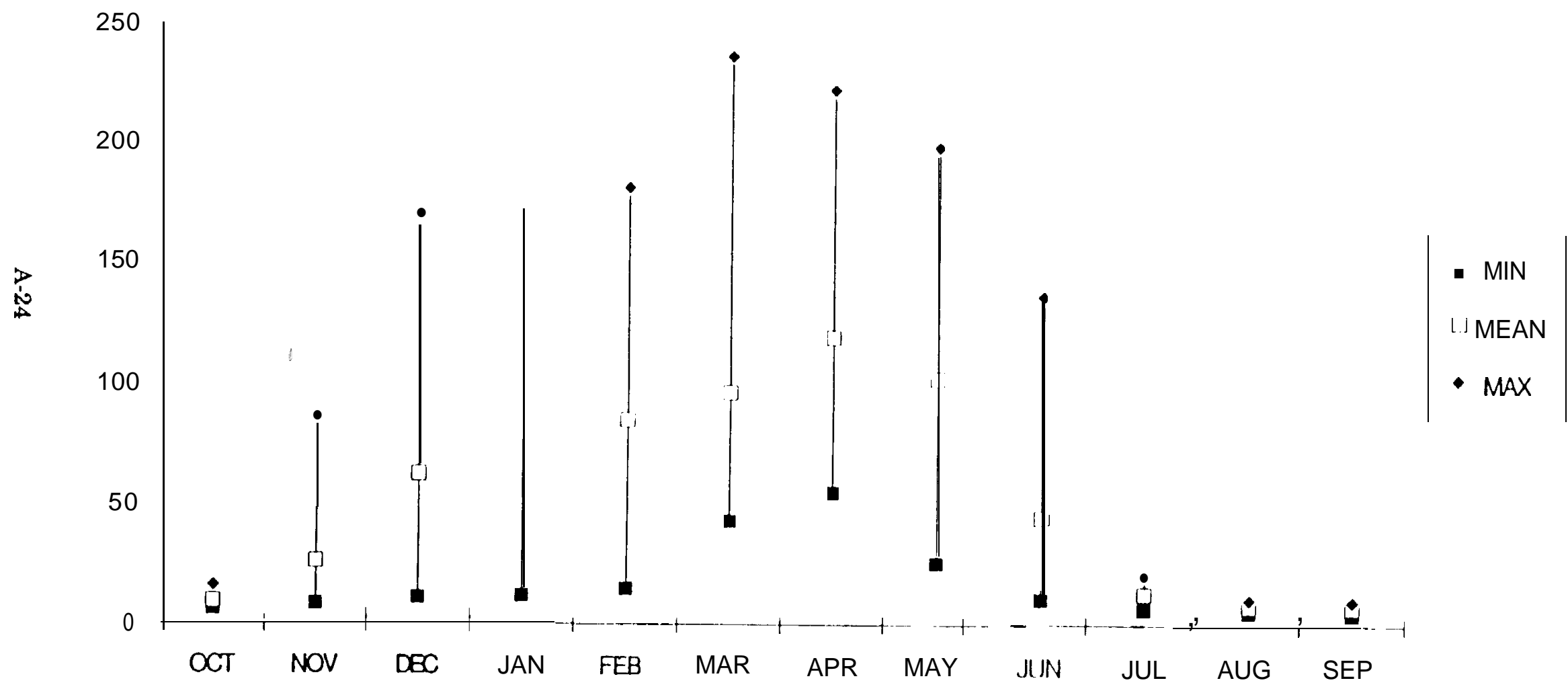


MONTHLY STREAMFLOW DATA

Data from U.S. Geological Survey

Monthly Streamflow. in cfs

\begin{tabular}{|lrrr|}
\hline N. Fork Walla Walla nr Milton & & 14011000 & $1931-69$ \\
& MNN & MEAN & MAX \\
OCT & 5.2 & 11 & 38 \\
NOV & 7.2 & 27 & 107 \\
DEC & 9 & 52 & 195 \\
JAN & 6.9 & 57 & 171 \\
FEB & 13 & 66 & 143 \\
MAR & 25 & 82 & 230 \\
APR & 24 & 120 & 204 \\
MAY & 9.6 & 97 & 249 \\
JUN & 4.4 & 41 & 170 \\
JUL & 2.3 & 7.9 & 28 \\
AUG & 1.9 & 3.5 & 7.8 \\
SEP & 2.1 & 5.3 & 26 \\
\hline
\end{tabular}


No Fork Walla Walla River near Milton, Gage No. 1401100

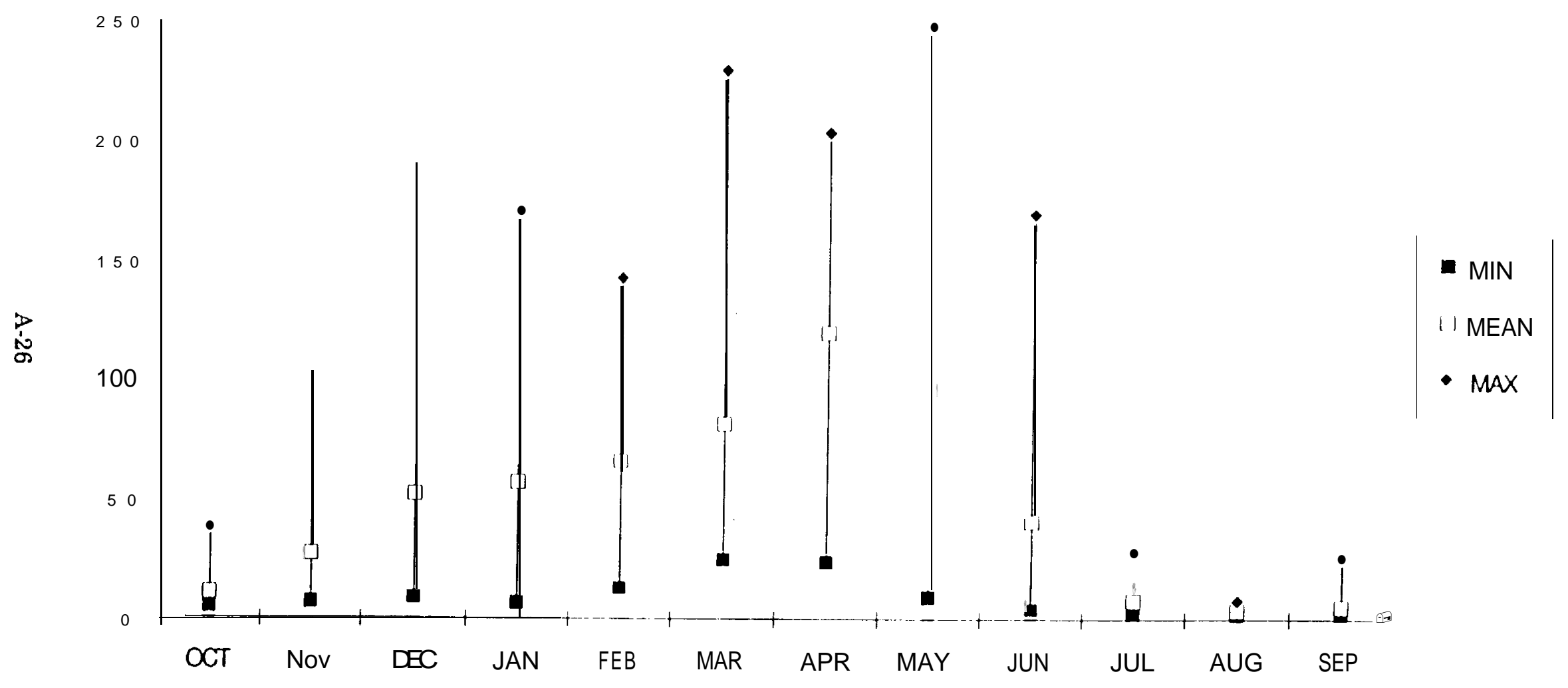




\title{
APPENDIX B
}

\section{SUMMARY OF WATER TEMPERATURE DATA}

This Appendix contains statistical information on water temperatures at locations in the Imnaha and Lostine River basins. The locations include:

- Imnaha River at Marr Ranch (pages B-3 to B-5)

- $\quad$ Fall Creek at Marr Ranch(pages B-6 to B-8)

- $\quad$ Fence Creek at Marr Ranch (pages B-9 to B-11)

- Little Sheep Creek (pages B-12 to B-14)

- Lostine River at Stratheam Ranch (pages B-15 to B-17).

The data was collected from in-situ Tempmentor installed and monitored by the Nez Perce Tribal Fisheries Office during 1990 and 1991. With the exception of the Little Sheep Creek site, all sites have 8 to 13 months of coverage.

Data Analysis

The data was collected at 0.5 to l-hour intervals. Daily maximums, minimums, and averages were calculated from the original data set. The temperature data was entered into the computer as maximum, minimum, and average daily temperatures. Descriptive statistical information on a monthly basis was developed using Statview computer software. The following parameters were generated on a monthly basis for each site:

\author{
Mean \\ Standard Deviation \\ Standard Error \\ Variance \\ Coefficient of Variation \\ Number of Observations \\ Minimum \\ Maximum Range \\ Sum \\ Sum of Squares \\ Number Missing \\ Percentiles \\ $\#<10$ th $\%$ \\ 10 th\% \\ $25 \operatorname{th} \%$ \\ 50 th $\%$ \\ 75th \% \\ \#> 90th \%
}


The daily temperature data is represented graphically in the following form:

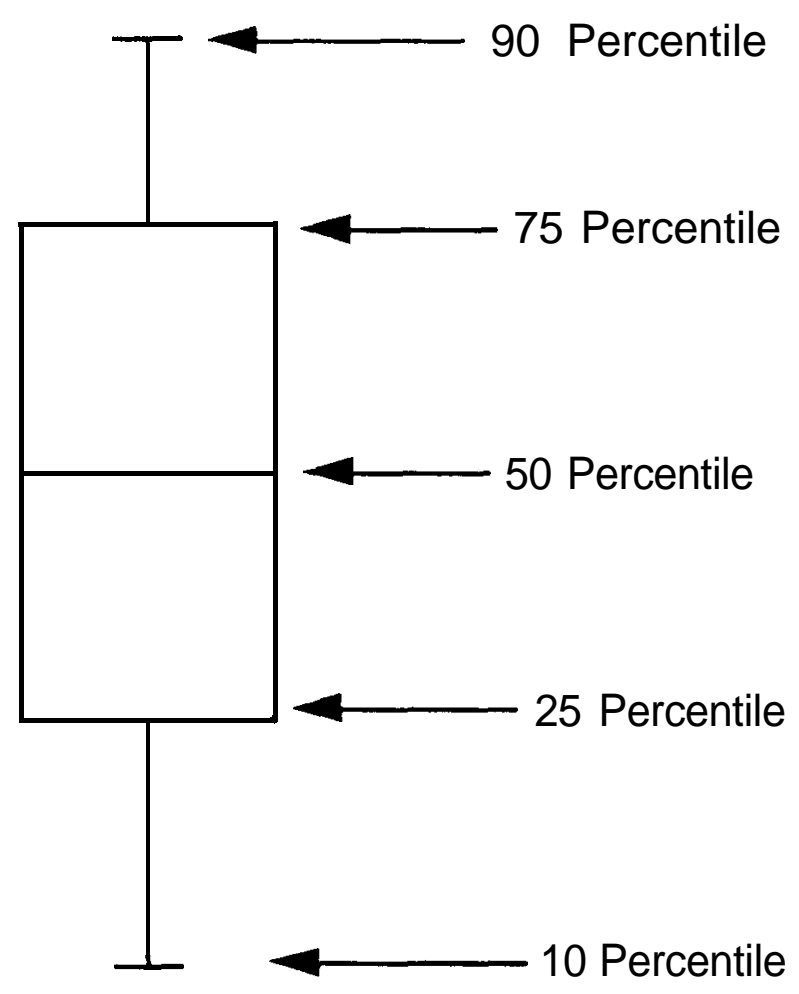

Circles above and below the 10 and 90 percentile limits represent discrete values less than or greater than these two limits. 
MARR Daily Maximums

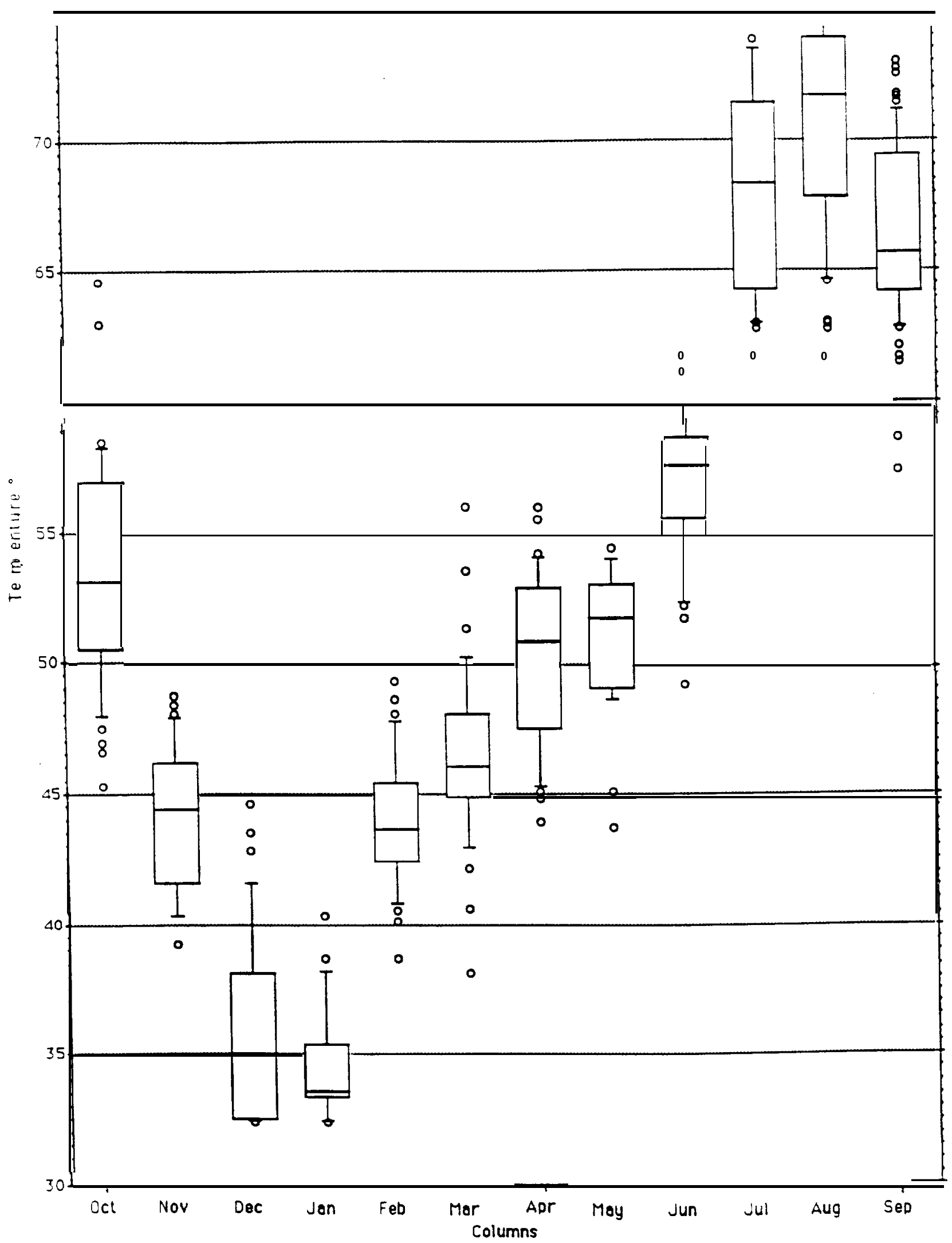

B-3 
MARR Daily Minimums

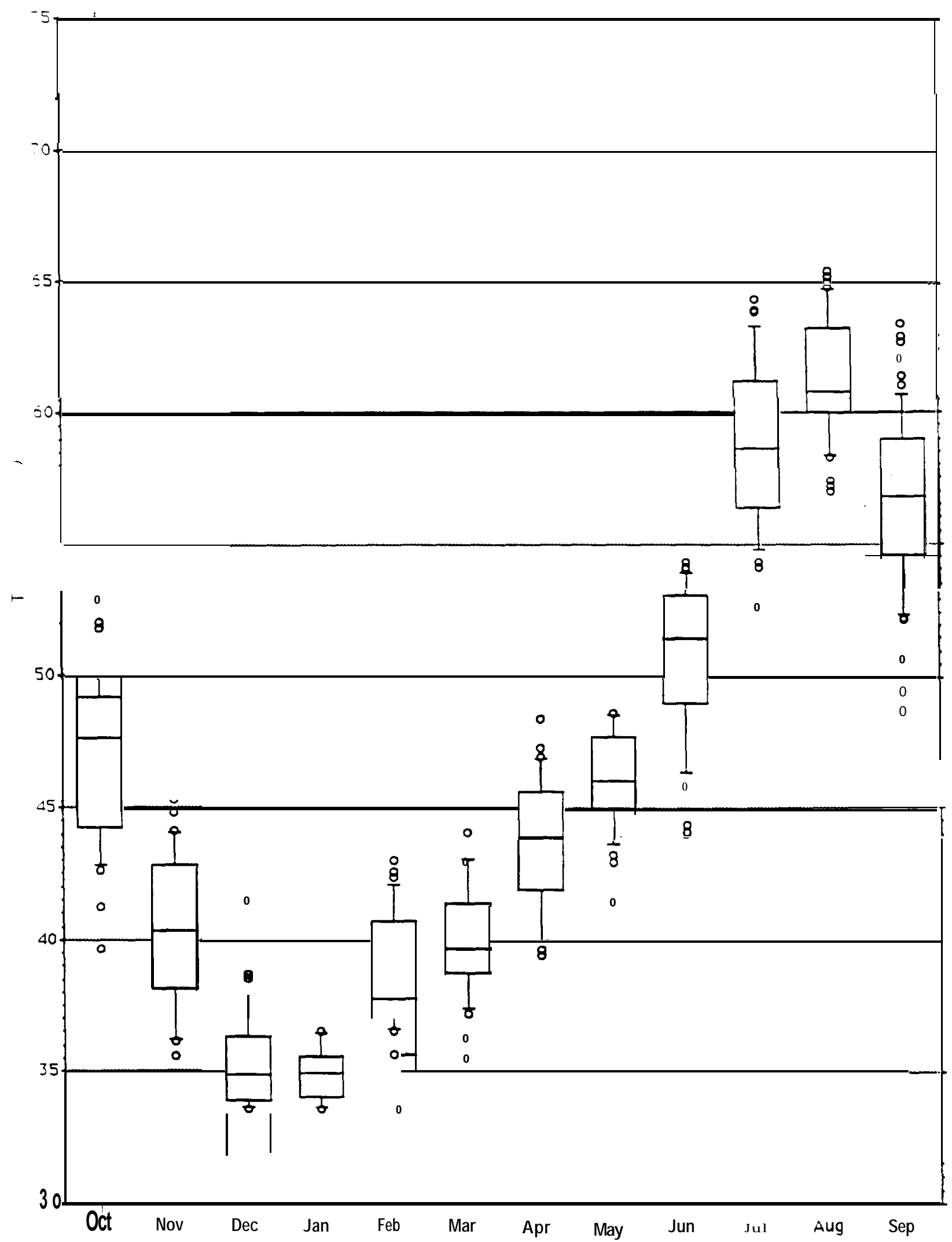


MARR Dally Averages

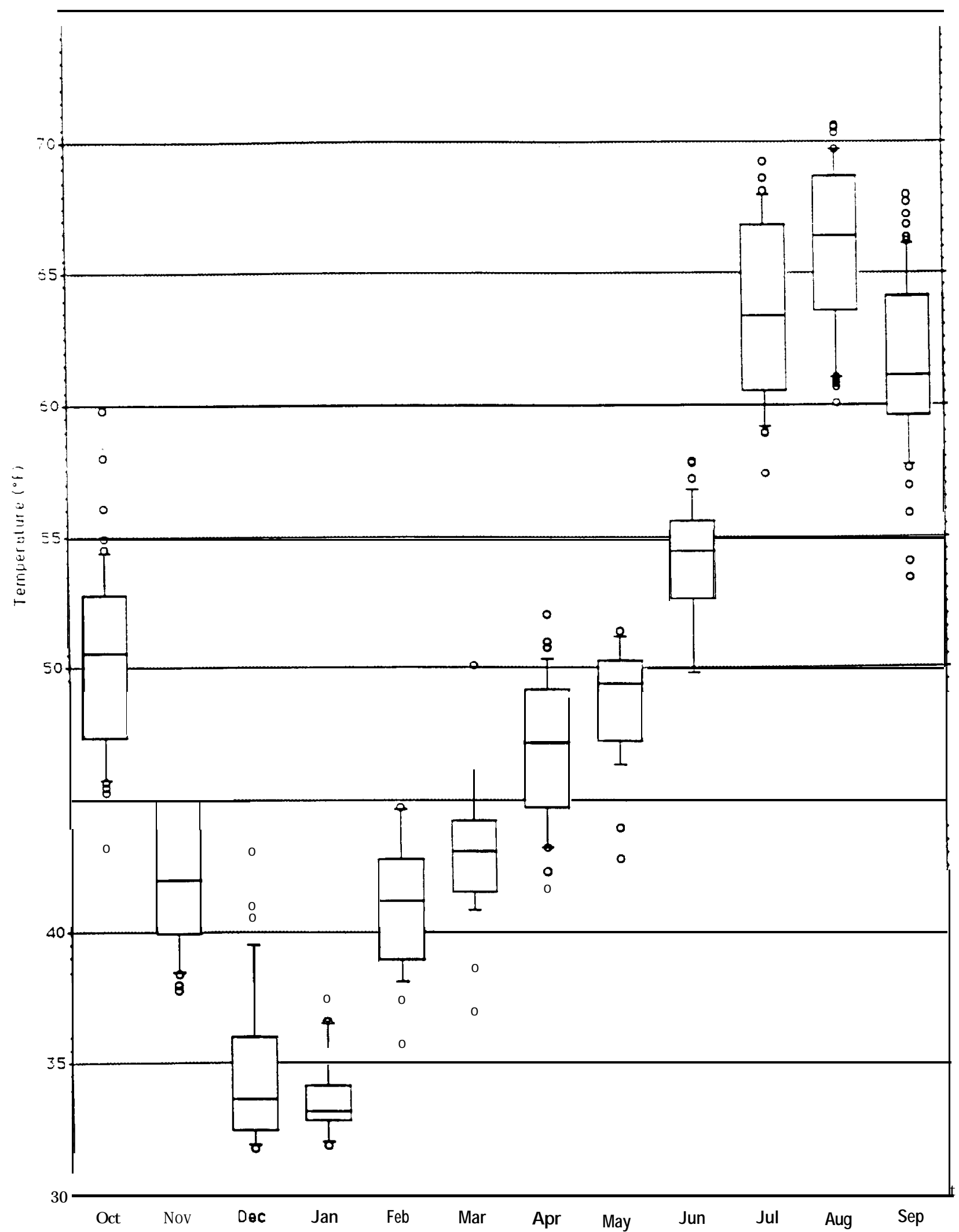


FALL CREEK Daily Maximums

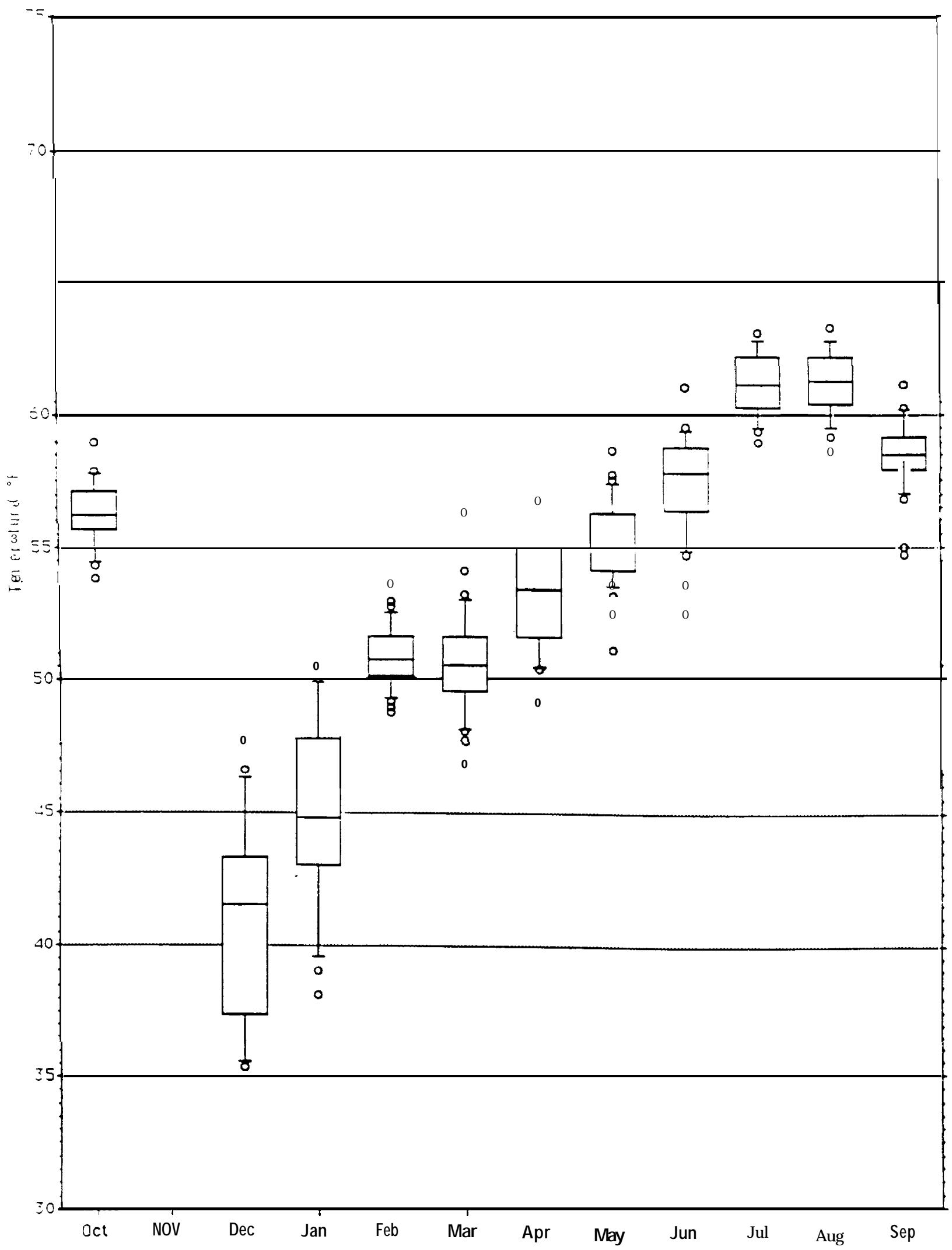


FALL CREEK Dally Minimums

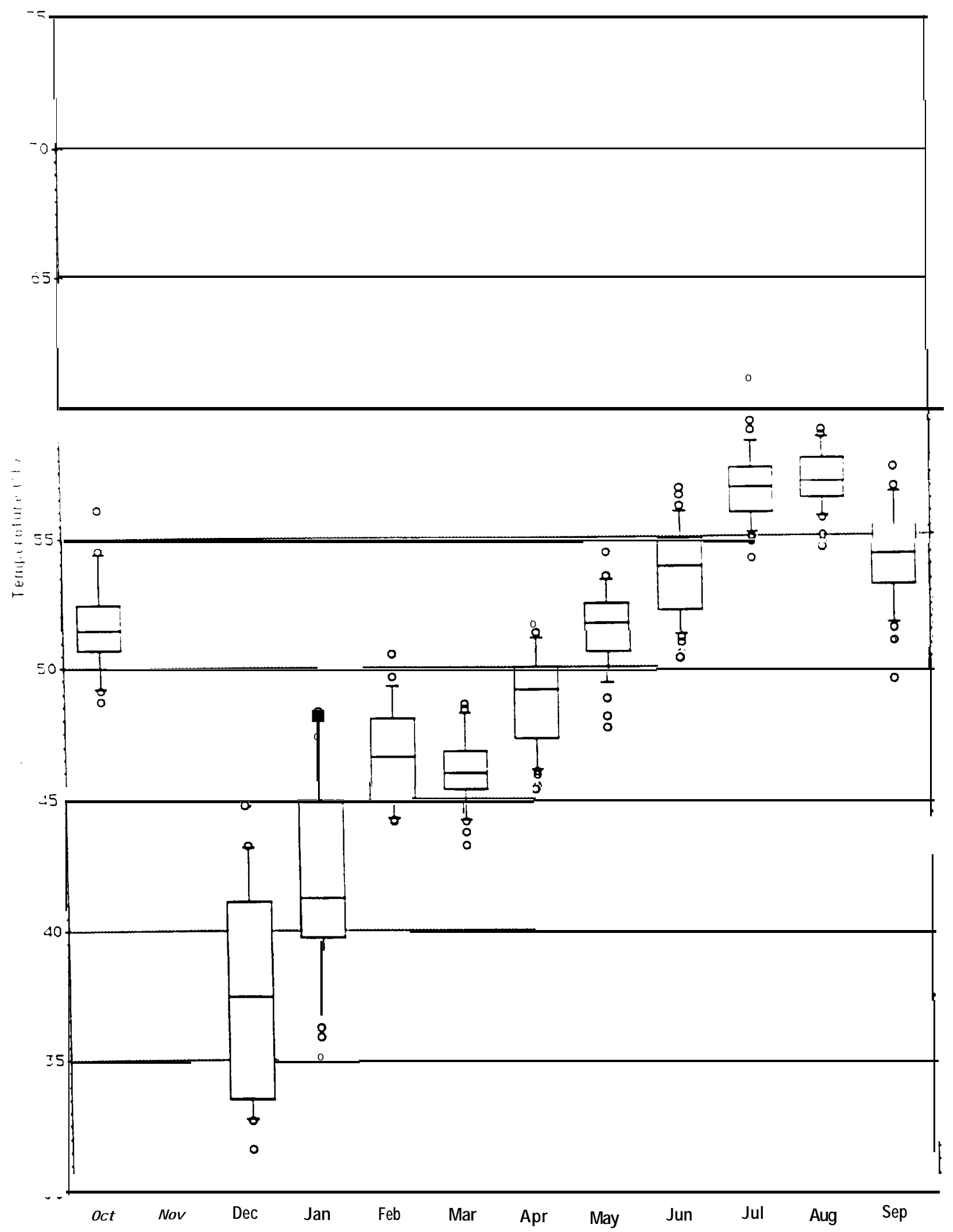


FALL CREEK Daily Averages

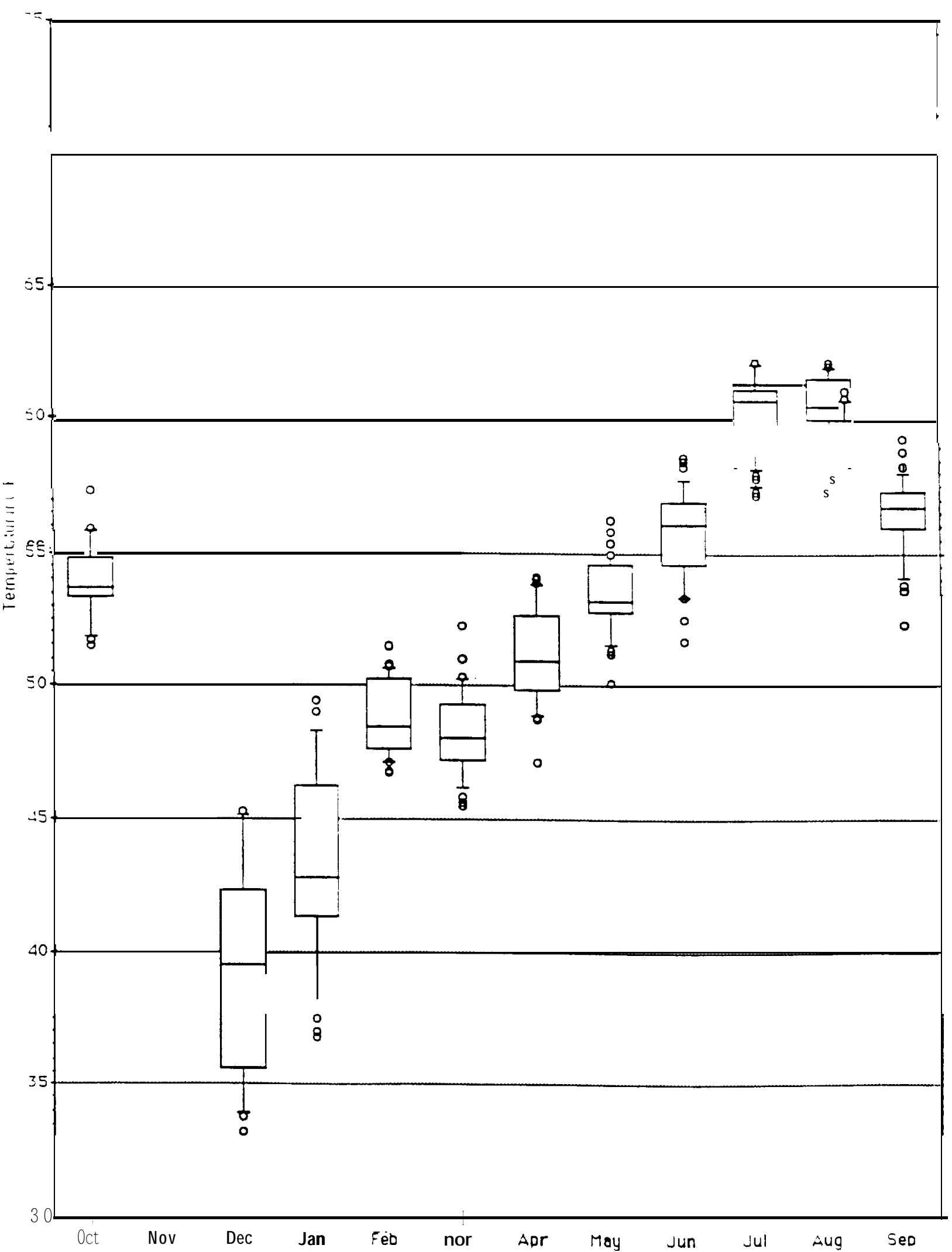


FENCE Doily Maximums

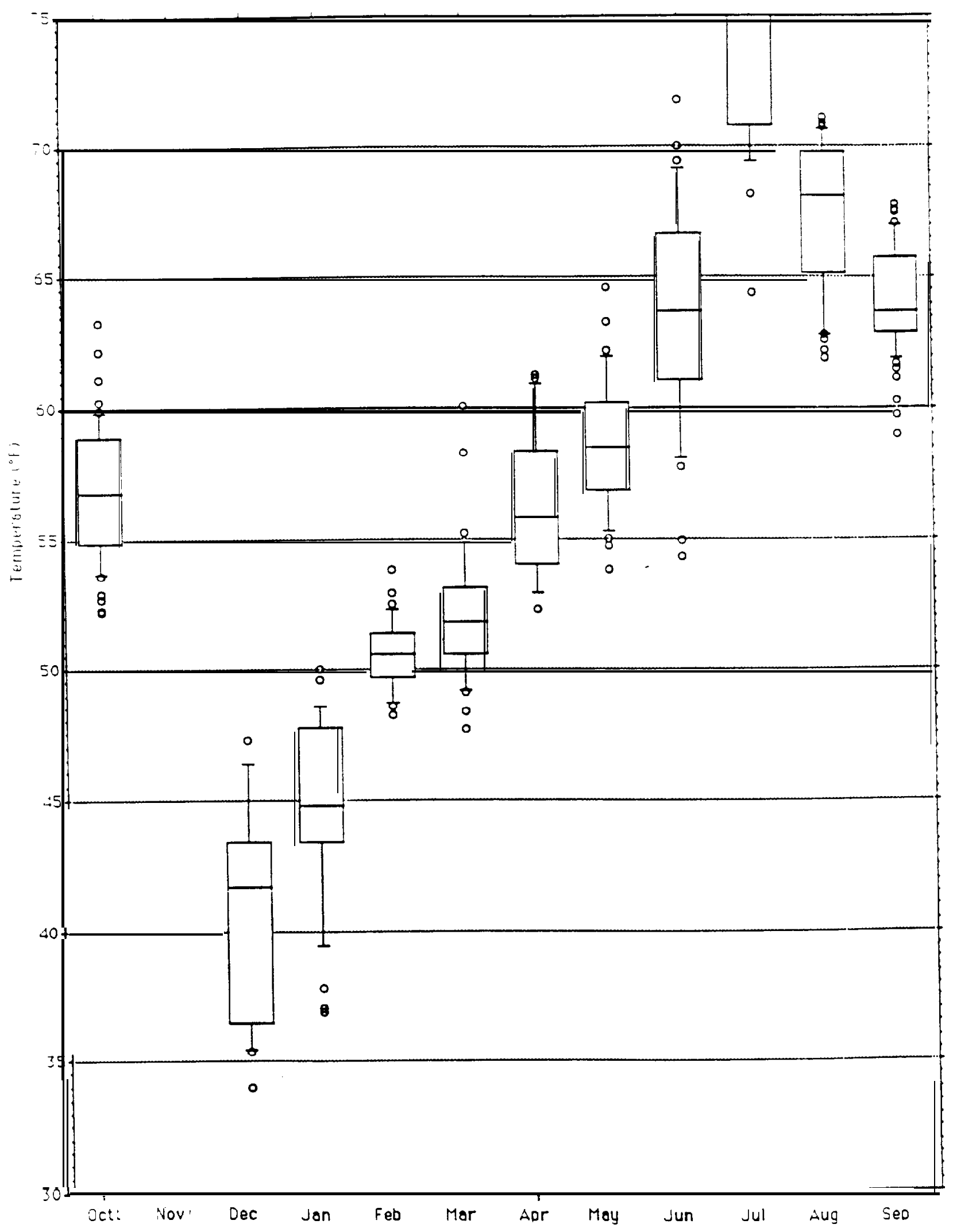


ENCE Daily Minimums

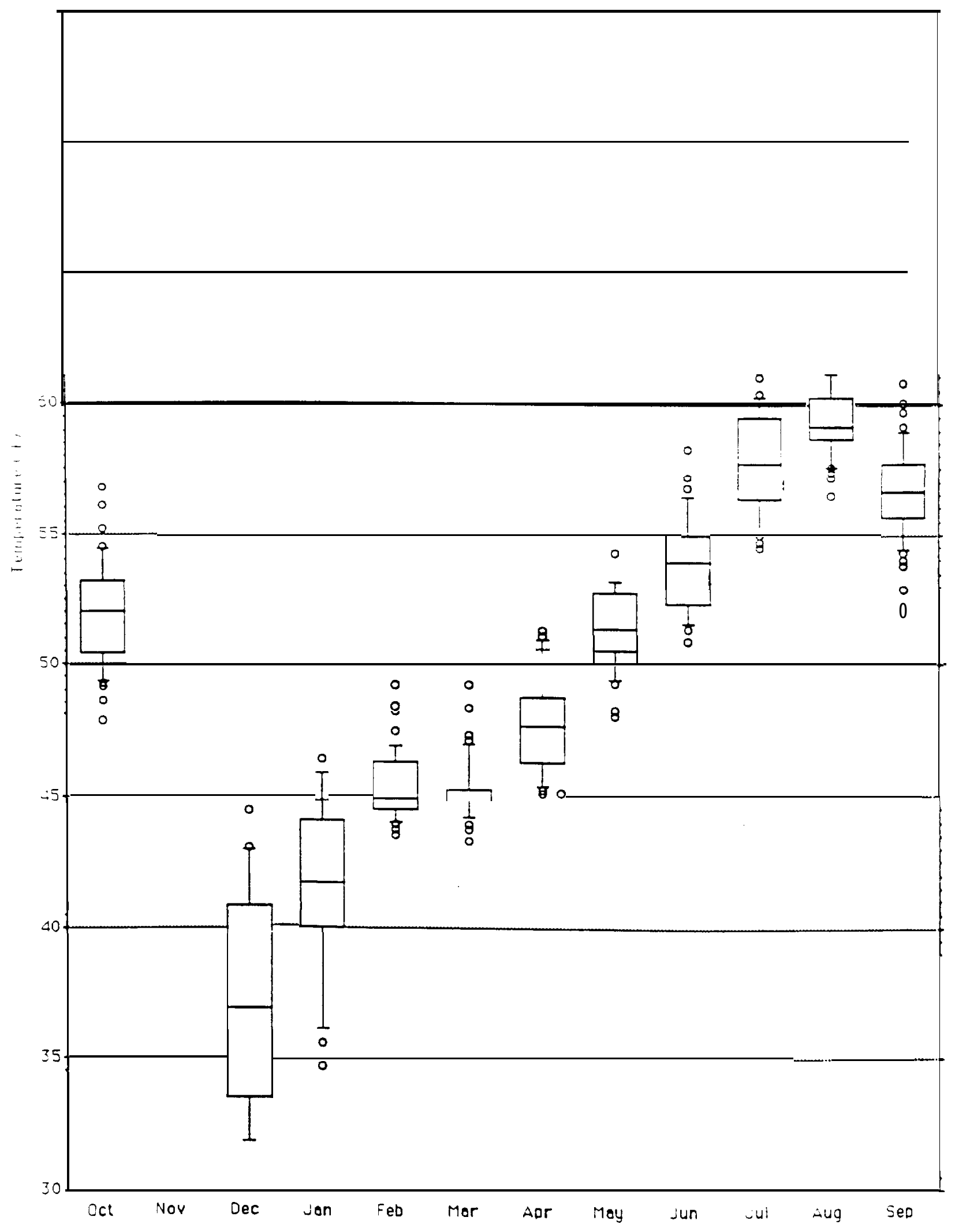




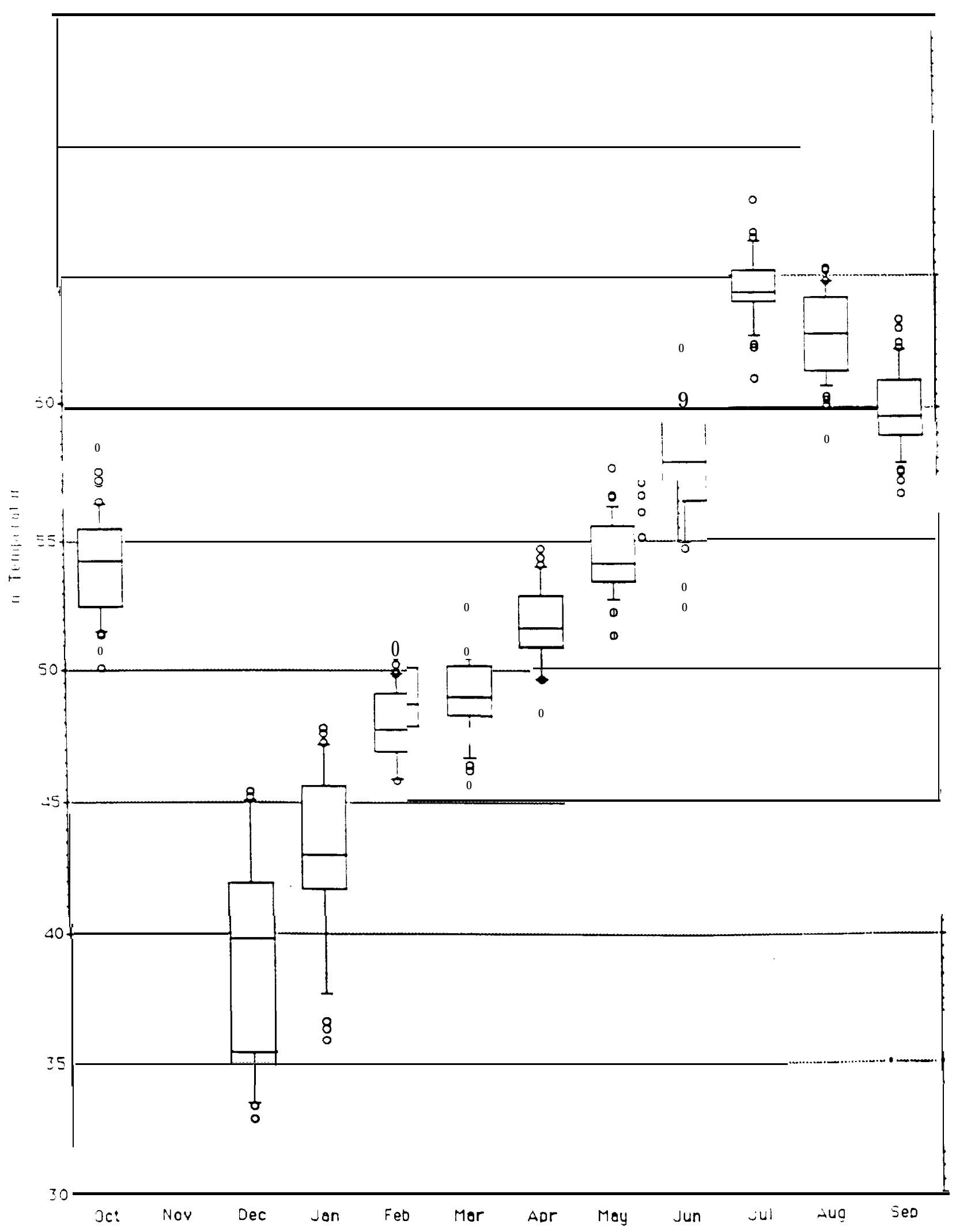


LITTLE SHEEP Daily Maximums

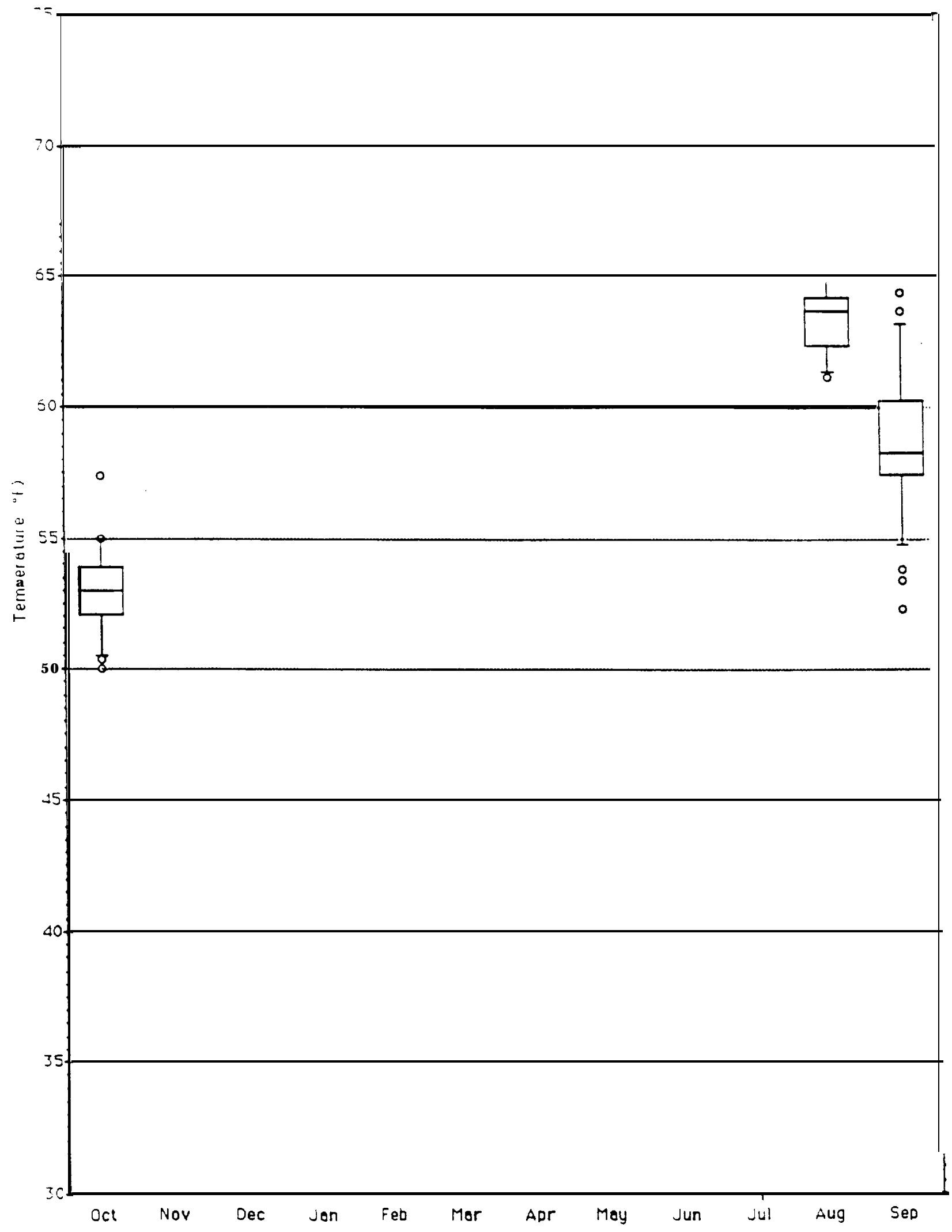


LITTLE SHEE? DoIlY MInImUMS

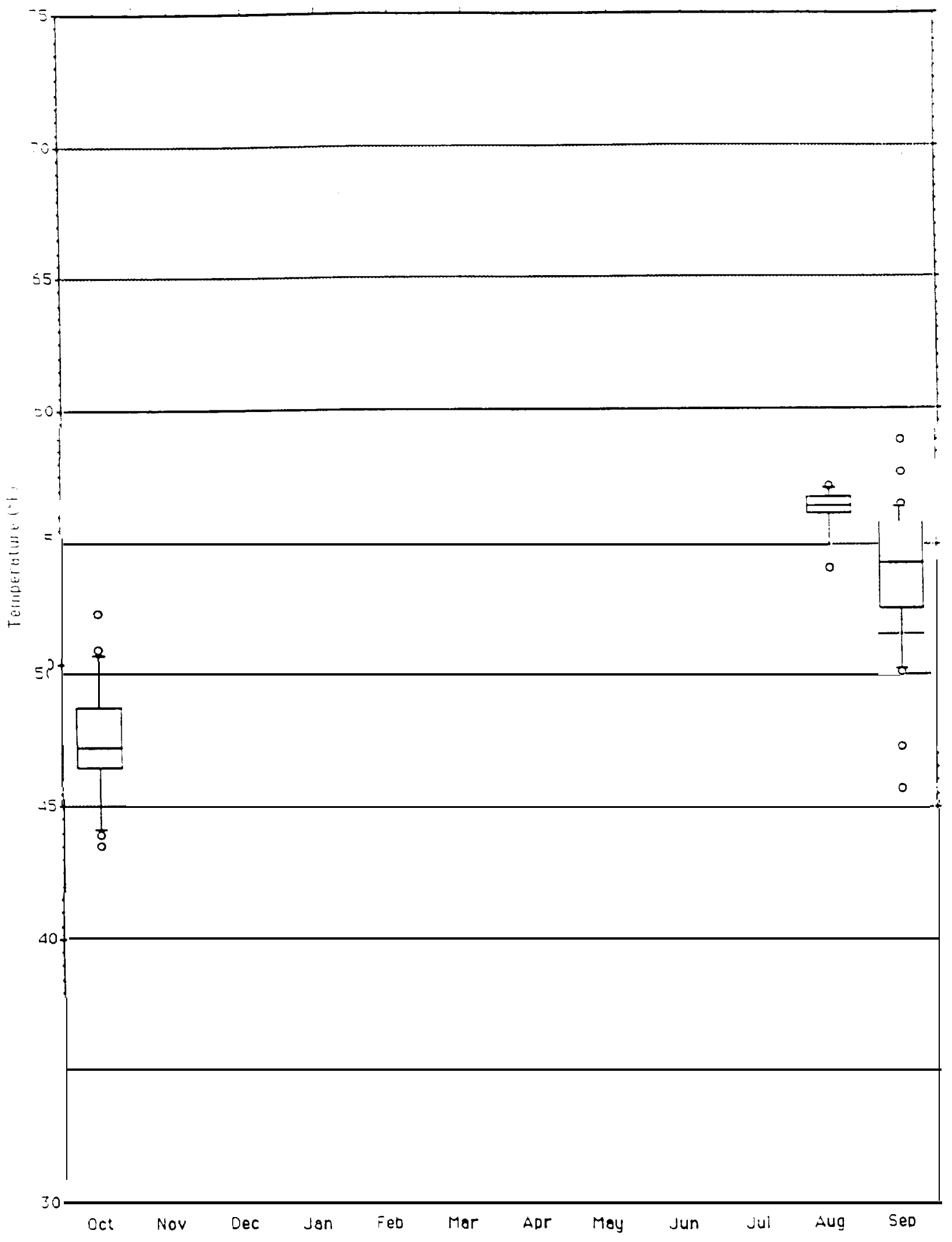

B-13 
LITTLE SHEEP Daily Averages

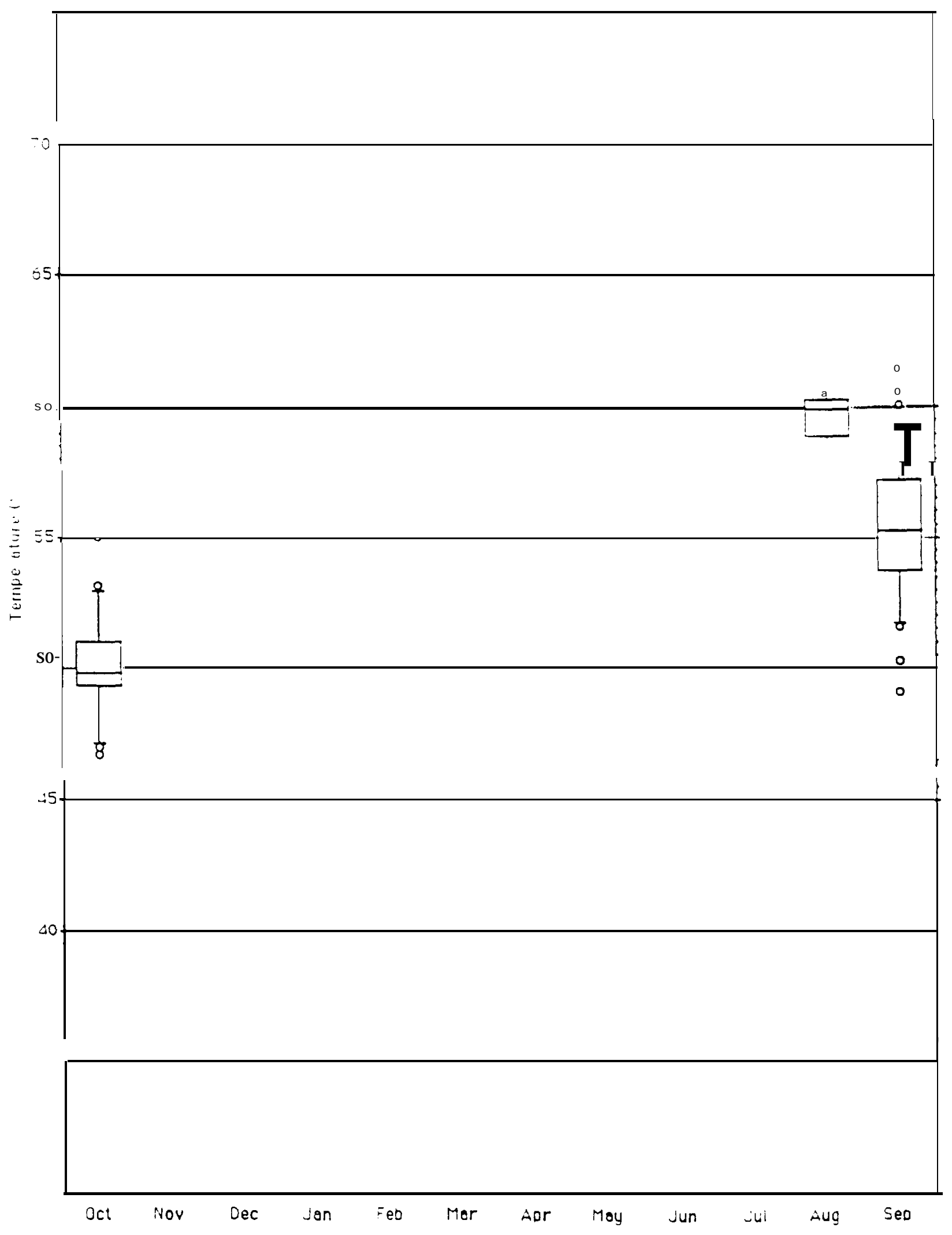




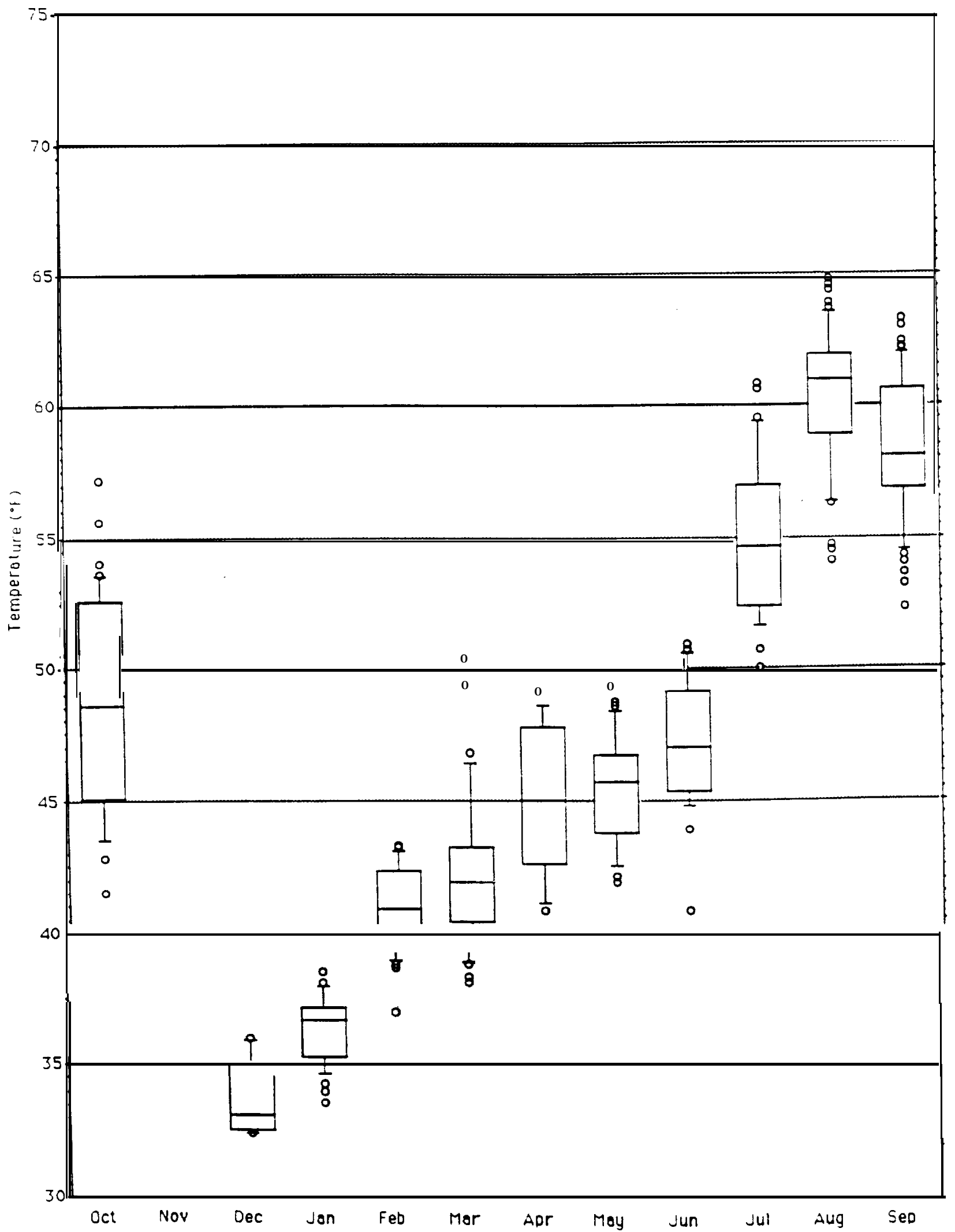




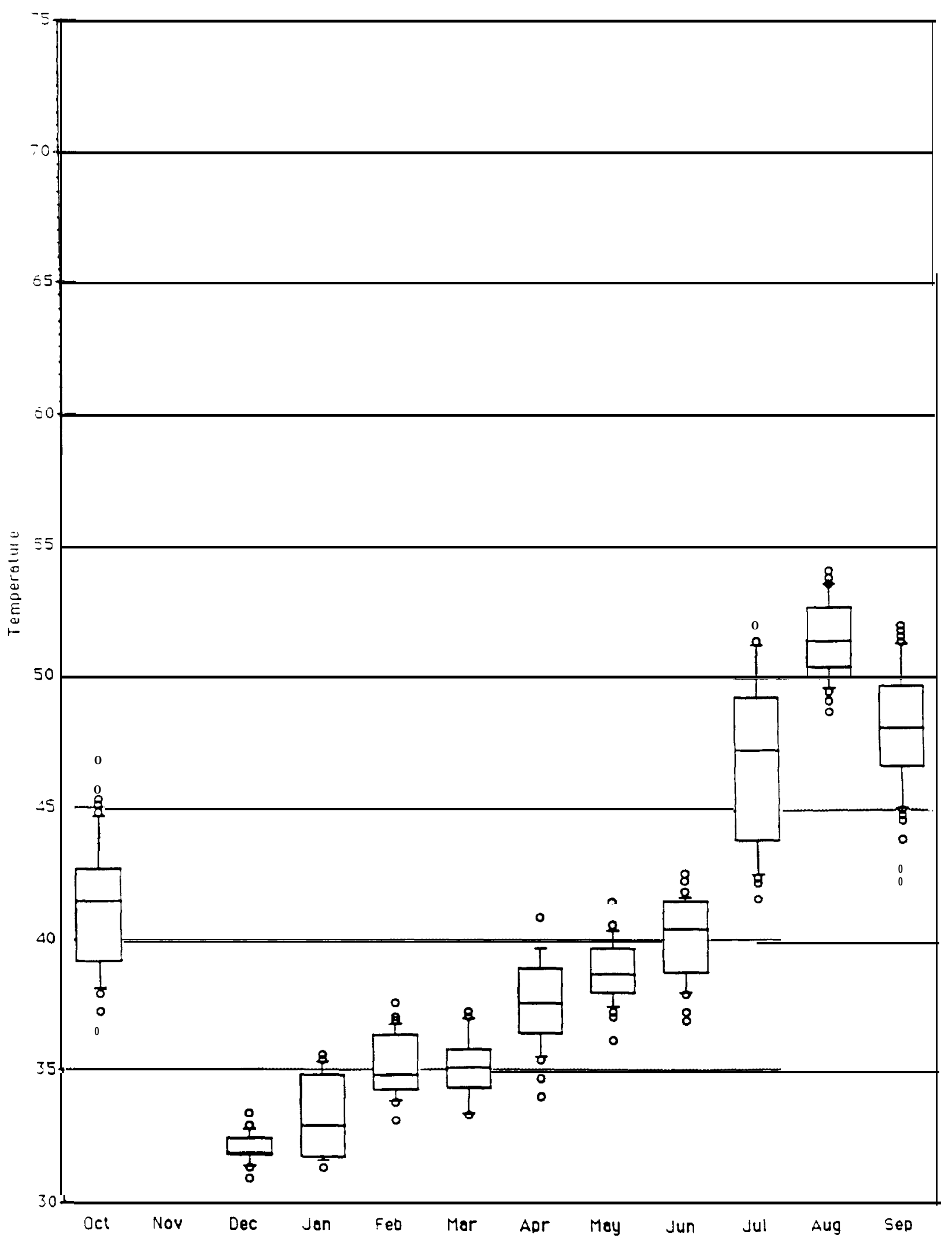


LOSTINE Daily Averages

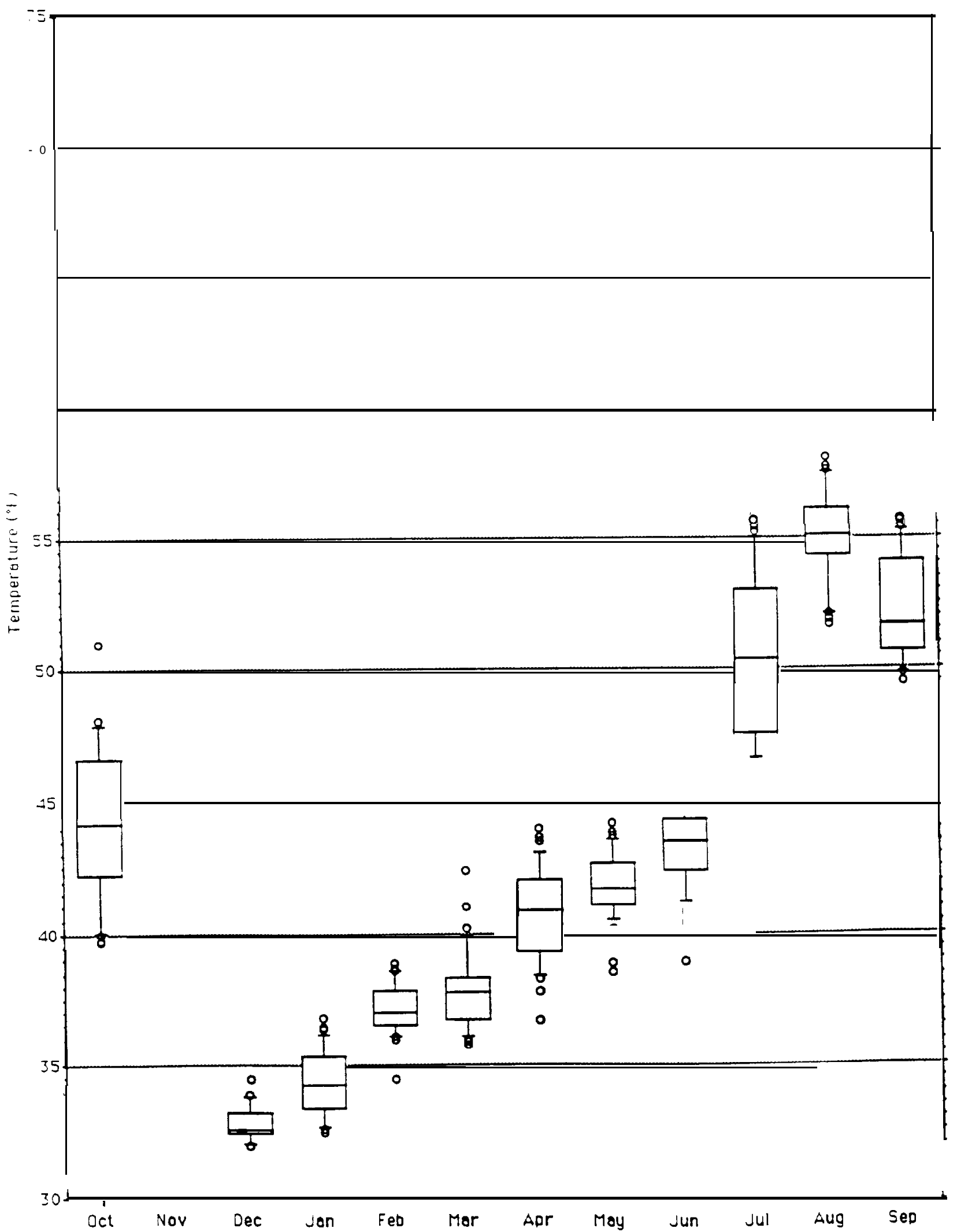




\section{APPENDIX C}

\section{SUMMARY OF WELL LOGS}

\section{GRANDE RONDE RIVER BASIN SITES}

Beaver Creek Area.

Well Owner and location

Robert Delve (4S/35E-2db)

Mike May (3S/35E-35)

Wayne \& Joyce Turner (3S/35E-35)

J. R. Able (3S/35E-36)

Rita Clark (3S/36E-3ldc)

Catherine Creek at Union Area.

Well Owner and location

Robert Bowles (4S/40E-1\&a)

V.E. Livingston (4S/40E-18cb)

Sam Leathers (4S/40E-18dc)

Boyd Tandy (4S/40E-18ab)

0 . C. Wilde (4S/40E-18cd)

M. C. Pyatt (4S/40E-18cc)

E. L. Quint $(4 \mathrm{~S} / 40 \mathrm{E}-18 \mathrm{cc})$

Homer F. Richey (4S/40E-18cc)

John Clausen (4S/40E-18cc)

Jim Weauer (4S/40E-18a)

Lewis Ash (4S/40E-18m)

City of Union (4S/40E-18q)

City of Union (4S/40E-18ca)

Leonard Spears (4S/40E-18)

City of Union (4S/40E-19ab)

City of Union (4S/40E-19b)

Raymond Royals (4S/40E-19cd)

Raymond Royal (4S/40E-19ca)

Raymond Royal (4S/40E-19ca)

Ralph Titus (4S/40E-19a)

Talbott Bennett (4S/40E-19da)

Mr. Myron Ricker (4S/40E-20da)

Don Robinson (4S/40E-20b)

Don Robinson (4S/40E-20ab)

Theron Anderson (4S/40E-20db)

City of Union (4S/40E-201) static

Depth Water Level Yield Capacity Temp.

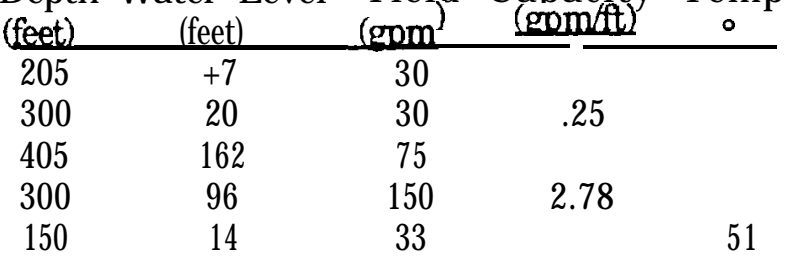

51

\begin{tabular}{|c|c|c|c|c|}
\hline $\begin{array}{l}\text { Depth } \\
\text { (feet) }\end{array}$ & $\begin{array}{c}\text { static } \\
\text { Water Level } \\
\text { (feet) }\end{array}$ & $\begin{array}{l}\text { Yield } \\
\text { (gom) }\end{array}$ & $\begin{array}{l}\text { Specific } \\
\text { Capacity } \\
\text { (gom/ft) }\end{array}$ & $\begin{array}{c}\text { Temp. } \\
\left({ }^{\circ} \mathbf{F}\right)\end{array}$ \\
\hline 48 & 30 & 8 & .16 & 52 \\
\hline $\boldsymbol{9}$ & I9 & 13 & .24 & 52 \\
\hline 55 & 7 & 35 & 1.3 & 59 \\
\hline 91 & 36 & 20 & .59 & 50 \\
\hline 54 & 7 & 16 & 1 & 32 \\
\hline 60 & 11 & 9 & .36 & 50 \\
\hline 82 & 28 & 8 & .27 & 52 \\
\hline 102 & 29 & 6 & .12 & 52 \\
\hline 126 & 24 & 4 & .05 & 5 \\
\hline 160 & 42 & 20 & .5 & 52 \\
\hline 150 & 30 & 13 & .11 & 56 \\
\hline 130 & 12 & & & \\
\hline 1295 & flow & 800 & 2.41 & 68 \\
\hline 20 & 16 & & & \\
\hline 1686 & 988 & 1922 & 14.3 & 69 \\
\hline 1200 & 225 & 1500 & 9.4 & 72 \\
\hline 86 & none & none & & \\
\hline 360 & 20 & 6 & .02 & 54 \\
\hline $\mathfrak{2} \mathbf{3}$ & dry & & & \\
\hline 255 & 95 & 30 & .21 & 5 \\
\hline 100 & 15 & 13 & .87 & 76 \\
\hline 208 & 27 & 6 & & 52 \\
\hline 55 & 5 & 40 & 8 & 74 \\
\hline 41 & 17 & 12 & 2 & 5 \\
\hline 80 & $\begin{array}{c}6 \\
14\end{array}$ & 20 & .57 & 57 \\
\hline
\end{tabular}


Lower Willow Creek Area (near Imbler).

Well Owner and location

Don McKinnis (1S/39E-4nl)

Russell Hug (1S/39E-5H)

James McKinnis (1S/39E-5N 1)

Cap Tuttle (1S/39E-8B 1)

Mr. Hauts (1S/39E-8Hl)

George Royes (1S/39E-8Ml)

Doyle Eisiminger (1S/39E-9cd)

Doyle Eisiminger (1S/39E-9cd)

Ruth Johnson (1S/39E-9d)

John Michel (1S/39E-9aa)

Paul Johnson (1S/39E-gab)

Leon Jackson (1S/39E-9dd)

Dennis Haughton (1S/39E-9dd)

Paul E. Johnson (1SI39E-9b)

Larry Starr (1S/38E-lb)

J. P. Corriell (1S/38E-2ba)

Jerry Talt (1S/38E-2dc)

Howard Fisher (1S/38E-2C 1)

Fred Behrens (1S/38E-2Rl)

Elgin Area.

Well Owner and location

Ronald Rademacher (1N/39E-9)

James Way (lN/39E-9da)

Bob Henson (1N/39E-9d)

Ernest Adams (lN/39E-9)

Albert Will (IN/39E-9)

John Rysdam (INI39E-9cb)

Don Thomson (lN/39E-9cd)

Arie Lee Rysdam (1N/39E-9cd)

Ali Zubi (lN/39E-9da)

R.L.Sanders (lN/39E-9dd)

Gorden Johnson (lN/39E-9dd)

Bob Funkhouser (lNI39E9dd)

Dan Looslie (lN/39E-9cb)

\begin{tabular}{ccccc}
$\begin{array}{c}\text { Depth } \\
\text { (feet) }\end{array}$ & $\begin{array}{c}\text { Static } \\
\text { Water Level } \\
\text { (feet) }\end{array}$ & $\begin{array}{c}\text { Yield } \\
\text { (gpm) }\end{array}$ & $\begin{array}{l}\text { Specific } \\
\text { Capacity } \\
\text { (gom/t) }\end{array}$ & $\begin{array}{c}\text { Temp. } \\
\text { (०F) }\end{array}$ \\
\hline 53 & 13 & 5 & & \\
402 & 200 & $\mathbf{2 2}$ & $\mathbf{2 . 2}$ & $\mathbf{5 4}$ \\
60 & & & & $\mathbf{5 4}$ \\
116 & 44 & & & $\mathbf{5 3}$ \\
300 & 4 & & & \\
150 & & 10 & & \\
465 & 16 & 250 & .86 & \\
1458 & 0 & 1600 & 10.7 & 70 \\
500 & 237 & 340 & .68 & \\
100 & & 25 & .69 & 57 \\
282 & 16 & 30 & .51 & 50 \\
52 & 3 & 15 & .5 & 49 \\
104 & 8 & 7.5 & .11 & 50 \\
90 & 26 & 68 & 7.56 & 50 \\
185 & 53 & 5 & .04 & 54 \\
105 & 30 & 20 & .8 & 55 \\
54 & 11 & 36 & 1.13 & 50 \\
123 & 8 & 30 & 1.88 & \\
103 & 6 & 10 & &
\end{tabular}

\begin{tabular}{|c|c|c|c|c|}
\hline $\begin{array}{l}\text { Depth } \\
\text { (feet) }\end{array}$ & $\begin{array}{c}\text { Static } \\
\text { Water Level } \\
\text { (feet) }\end{array}$ & $\begin{array}{l}\text { Yield } \\
\text { (gpm(g) }\end{array}$ & $\begin{array}{l}\text { Specific } \\
\text { Capacity } \\
\text { o(t) })\end{array}$ & $\begin{array}{c}\text { Temp. } \\
\end{array}$ \\
\hline 400 & 155 & 20 & 0.2 & 52 \\
\hline 170 & 42 & 23 & 0.3 & 48 \\
\hline 100 & 19 & 10 & 0.2 & \\
\hline 120 & 17 & 30 & 0.4 & 50 \\
\hline 104 & 21 & 30 & 1 & 52 \\
\hline 260 & 170 & 18 & 0.2 & 62 \\
\hline 134 & 38 & 9 & 0.1 & 50 \\
\hline 125 & 85 & 20 & 1 & 50 \\
\hline 120 & 26 & 11 & 0.1 & 51 \\
\hline 119 & 15 & 8 & 0.1 & 50 \\
\hline 115 & 27 & 18 & 0.2 & 51 \\
\hline 230 & 19 & 7 & 0.1 & 50 \\
\hline 283 & 75 & 12 & 0.1 & 49 \\
\hline
\end{tabular}


Sanderson Springs Area (Mill Creek).

Well Owner and location

Eric Barker (1N/38E-35ac)

Kent Siewell (lN/38E-35)

F.A. Perkins (lN/38E-35)

Marshall Kilby (lN/38E-35b)

Carl Rees (lN/38E-35ab)

Roger Morris (lN/38E-35ab)

H.B. Thomas (lN/38E-35ab)

Art Morris (lN/38E-26)

Alvy Pfefferkorn (lN/38E-26)

Claton Long (lN/38E-26cb)

Joe Scott (lN/38E-26)

Billy Sanderson (lN/38E-26bd)

Marvin Peterson (lN/38E-26)

Marvin Peterson (lN/38E-26)

WALLOWA RIVER SITES

Wallowa Hatchery Area.

Well Owner and location

Gilbert D Hansen (2S/44E-2cb)

Ernest Sasser (2S/44E-2)

Francis Stone (2S/44E-2cc)

J. D. Bane (2S/44E-2bd)

Norman Wither-rite (2S/44E-2q)

Wayne Reece (2SI44E-2n)

Seaside Associates (2S/44E-3aa)

Thane Homan (2S/44E-3ba)

U.S. Corps. Engineeers (2S/44E-3db)

Otis Fisher (2S/44E-31)

Lee Coggins (2S/44E-3bd)

OSFC (2S/44E3db)

Dept. Fish \& Wildlife (2S/44E-3d)

Dept Fish \& Wildlife (2S/44E-3d)

W. K. Zalleman C2S/44E-3g)

Otis Fischer (2S/44E-3k)

Wilber Herman (2S/44E-3p)

David S. Jackman (2S/44E-7cd)

Dave Davenport (2S/44E-16ac)

Myron Gibbs (1S/44E-44cc)

Harvey Bums RV Park (1S/44E-35b)

Don Smith (1S/44E-35)

JD Bane (1S/44E35bd)
Static

Depth Water Level Yield Capacity Temp.

\begin{tabular}{ccccc} 
(feet) & (feet) & (gom) & (gom/ft) & $\left({ }^{\circ} \mathbf{F}\right)$ \\
\hline 200 & 27 & 6 & 0.1 & 55 \\
80 & 21 & 25 & 0.5 & \\
90 & 21 & 20 & 0.5 & 52 \\
180 & 21 & 11 & 0.1 & \\
92 & 9 & 12 & 0.3 & 50 \\
80 & 9 & 30 & 1.5 & 5 \\
110 & 5 & 18 & 0.3 & 54 \\
90 & 3 & 60 & 1 & 52 \\
80 & 18 & 35 & 0.5 & \\
91 & 38 & 14 & 0.5 & 52 \\
80 & 10 & 18 & 0.3 & 5 \\
80 & 25 & 15 & 0.3 & 32 \\
221 & 36 & 40 & 0.5 & 52 \\
186 & 10 & 28 & 0.3 & 52
\end{tabular}

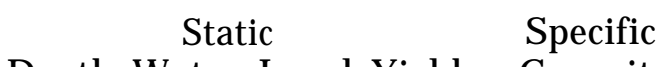

Depth Water Level Yield Capacity Temp.

\begin{tabular}{ccccc} 
(feet) & (feet) & (gom) & (gom/ft) & $\circ$ \\
\hline 65 & 11 & 30 & 1.88 & 54 \\
105 & 8 & 10 & & \\
50 & 5 & 30 & 3.75 & 49 \\
50 & 14 & 100 & 8.33 & 5 \\
38 & 4 & 30 & 15 & 49 \\
37 & 6.5 & 21 & 1.68 & 50 \\
300 & 132 & 25 & .42 & 5 \\
135 & 5 & 16 & .25 & 47 \\
255 & 5 & 35 & .15 & 55 \\
46 & 6 & 34 & 2.62 & 49 \\
71 & 11 & 10 & .18 & 49 \\
288 & 6 & 183 & 4.36 & 52 \\
795 & & 145 & & \\
942 & & 120 & & \\
86 & 13 & 9 & .28 & 48 \\
35 & 6 & 18 & 1.8 & 48 \\
$\mathbf{S}$ & 11 & 21 & 3.23 & 52 \\
150 & 9 & 35 & 23 & \\
80 & 42 & 30 & 3.75 & 49 \\
65 & 7 & 5 & .1 & 48 \\
257 & 35 & 50 & .48 & 5 \\
270 & 200 & 5 & .02 & 51 \\
121 & 10 & 280 & 3.1 & 5
\end{tabular}


Hayes Fork - Prairie Creek Area.

Well Owner and location

Jim Hubbard (2S/45E-16ac)

Guy Boyd (2S/45E-17bb)

Kit Construction (2S/45E-17)

3 Running M. Ranch (2S/45E-17)

Mike Musia (2S/45E-18)

Charles M. O’Neal (25/453-18)

John Bush (2S/45E-18aa)

Mike Kurts (2S/45E-18bb)

Glen Lathrop (2S/45E-18dd)

Miriam-Wallowa Confluence Area.

Well Owner and location

Myron Fleser (2N/41E-29)

Chuck Fleser (2N/41E-29)

\section{LOSTINE RIVER SITES.}

strathearn RanchArea

Well Owner and location

Bill Norman (1S/43E-27cc)

Terry Jones (1S/43E-34aa)

Dennis Longfellow (1S/43E-27cd)

Bruce Stratheam (1S/43E-34bc)

Bruce Stratheam (1S/43E-34bc) static

Depth Water Level Yield Canacity Temp.

\begin{tabular}{ccccc} 
(feet) & (feet) & (gom & (gom $)$ & (pit) \\
\hline 57 & 14 & 40 & $\mathbf{2 . 5}$ & $\mathbf{5 3}$ \\
80 & 35 & 30 & 2.73 & $\mathbf{5 3}$ \\
83 & 30 & 40 & 4 & 49 \\
75 & 20 & 45 & 1 & \\
45 & 1.8 & 35 & .78 & \\
175 & 41 & 45 & .54 & \\
79 & 7 & 40 & 6.7 & 52 \\
120 & 19 & 30 & 1.76 & 47 \\
60 & 13 & 30 & 6 & $\mathbf{5}$
\end{tabular}

Static

Depth Water Level Yield Capacity Temp.

\begin{tabular}{ccccc} 
(feet) & (feet) & (gom) & (goro/ft) & $\circ$ \\
\hline 47 & $\mathbf{+ 1}$ & $\mathbf{2 2}$ & 1 & $\mathbf{5 4}$ \\
144 & 92 & 30 & 5 & 54
\end{tabular}

static

Depth Water Level Yield Capacity Temp.

\begin{tabular}{ccccc} 
(feet) & (feet) & (gom) & (gom/A) & 0 F) \\
\hline 110 & 45 & 30 & 1.4 & 51 \\
240 & 160 & 10 & 0.2 & 52 \\
70 & & 30 & 3 & 51 \\
85 & 3367 & 30 & 1 & 5 \\
85 & 65 & 30 & 1 & 53
\end{tabular}




\section{IMNAHA RIVER BASIN SITES}

Imnaha Basin Well Logs

The following table lists Imnaha River area well logs on tile at the Oregon Department of Water Resources. All are completed in basalt or "hard rock".

Well Owner and location

Dale Burrell (6 miles $\mathrm{N}$ of Imnaha) Kenneth Stein (6 miles $\mathrm{N}$ of Imnaha)

Bud Maxwell (6 miles $\mathrm{N}$ of Imnaha) Ron Kellerman (6 miles N of Imnaha) Clyde Simmons (6 miles N of Imnaha) Russell Dotson (6 miles $\mathrm{N}$ of Imnaha) Marvin Maxwell (5 miles $\mathrm{N}$ of Imnaha) Paul Kriley (4.2 miles $\mathrm{N}$ of Imnaha) Dick Walley (3 miles $\mathrm{N}$ of Imnaha) Dave Dummer (3 miles $\mathrm{N}$ of Imnaha) Fred Wamock (3 miles $\mathrm{N}$ of Imnaha) Ferman Warnock (at Imnaha) Jim Bird (at Imnaha) E.V. Ulrich (at Imnaha) General Telephone Company (at Imnaha) 60 JIL Ranch (Sheep Cr., 1 mi. SW of Imnaha) 240 Bernard Henry (near forks of Sheep Cr.) 57 Dean Gibbs (near forks of Sheep Cr.) $\quad 150$ Michael Royes (3 mi S-SE of Imnaha) 60 Little Sheep Cr. Hatchery (upper Sheep Cr.> 100 Imnaha Fish Facility (31 mi. S of Imnaha) 165

\begin{tabular}{|c|c|c|c|c|}
\hline $\begin{array}{l}\text { Depth } \\
\text { (feet) }\end{array}$ & $\begin{array}{c}\text { Static } \\
\text { Water Level } \\
\text { (feet) }\end{array}$ & $\begin{array}{l}\text { Yield } \\
\text { (gnm) }\end{array}$ & $\begin{array}{l}\text { Specific } \\
\text { Capacity } \\
\text { (gom/ft) }\end{array}$ & $\begin{array}{c}\text { Temp. } \\
\circ\end{array}$ \\
\hline 230 & 110 & 20 & 0.2 & \\
\hline 160 & 8 & 20 & 0.2 & \\
\hline 1.50 & 15 & 90 & 1 & 54 \\
\hline 5 & 10 & 15 & 1.15 & 56 \\
\hline 102 & 16 & 30 & 5 & 56 \\
\hline 75 & 13 & 40 & 2 & 5 \\
\hline 260 & 135 & 16 & 0.2 & \\
\hline 110 & 60 & 6 & 0.5 & \\
\hline 49 & 30 & 20 & 3 & 54 \\
\hline 72 & 17 & 15 & 5 & 48 \\
\hline 360 & 6 & 6 & .02 & \\
\hline 135 & 29 & 35 & 0.3 & \\
\hline 250 & 136 & 30 & 0.3 & \\
\hline 34 & 18 & 8 & 1 & 5 \\
\hline ) 60 & 28 & 30 & 6 & 52 \\
\hline ) 240 & 18 & 10 & 0.2 & 54 \\
\hline 57 & 20 & 14 & 2 & 54 \\
\hline 150 & 8 & 30 & 0.4 & 58 \\
\hline 60 & 5 & 70 & 1.5 & \\
\hline 100 & 10 & 30 & 3 & 51 \\
\hline 165 & 41 & 30 & 3 & 48 \\
\hline
\end{tabular}

\section{WALLA WALLA RIVER BASIN SITES}

\section{Harris Park Area}

\begin{tabular}{|c|c|c|c|c|c|}
\hline Well Owner and location & $\begin{array}{l}\text { Depth } \\
\text { (feet) }\end{array}$ & $\begin{array}{c}\text { static } \\
\text { Water Level } \\
\text { (feet) }\end{array}$ & $\begin{array}{l}\text { Yield } \\
\text { (anm) }\end{array}$ & $\begin{array}{l}\text { Specific } \\
\text { Capacity } \\
(\text { gom/tt) }\end{array}$ & $\begin{array}{c}\text { Temp. } \\
\text { of }\end{array}$ \\
\hline Jim Gross (4N/37E-10cc) & 85 & +1 & $>100$ & 1.5 & 57 \\
\hline Robert Hergert (4N/37E-10) & 142 & 12 & $\mathrm{I} .5$ & 0.1 & 58 \\
\hline Umatilla Co. Parks (4N/37E-10dc) & 225 & 10 & 35 & 0.2 & 5 \\
\hline George Kraemer t4N/37E-10) & 162 & 24 & 60 & 0.5 & 58 \\
\hline Sam Brinker (5N/36E-25) & 140 & 19 & 80 & & 56 \\
\hline August T Turz (5N/36E-25d) & 104 & 6 & 50 & & 5 \\
\hline Bob Logan (5N/36E-25a) & 145 & 35 & 45 & & 52 \\
\hline David Kruse (5N/36E-25d) & 150 & 39. & 50 & & \\
\hline Dan Harsch (5N/36E-25) & 60 & 24 & 30 & 1.5 & 5 \\
\hline Robert TenEyck (5N/36E-26b) & 77 & 12 & 50 & & 50 \\
\hline Earl Frasier (5N/36E-26) & 200 & 40 & & & 5 \\
\hline Leon Huber (5N/36E-26) & 45 & 9 & 25 & 2.5 & 5 \\
\hline H. Poulsen (5N/36E-26Gl) & lo & 6 & & & \\
\hline Kenneth Ransom (5N/37E-3 lac) & 224 & +48 & 125 & & 54 \\
\hline Shaklenn Ardledge (5N/37E-3 1c)140 & 140 & +7 & 30 & & 61 \\
\hline
\end{tabular}


POWDER RIVER BASIN SITES

Eagle Creek Area (upstream from Newbridge).

Well Owner and location

Steve Eaton (8SA5E-29d)

James Clemmons (8S/45W- 33bd)

Frank Bandell (8S45E-33ddI)

Pat Sanders (8S/45E-33ac)

Emma Jeene Greener (8S/45.5E-3c) static Speciffe Depth Water Level Yield Capacity Temp. (feet) 190

55

325

385

106 (feet)

102

22

80

76
9 (onm)

8

(gom/ft)

6

3

6

6
8

.12

49

5

51 


\section{APPENDIX D SITE DATA SHEETS}

This Appendix includes the site data sheets that contain information developed at each site during site reconnaissance surveys. This information was used to conduct the site screening analysis presented in Section 8.0. Each site is represented by a data sheet containing standardized information and a section from a USGS 7.5" topographic map identifying the site boundaries. 
RIVER BASIN:

SITE NUMBER:

SITE NAME:

SITE LOCATION:

County :

Road Access Directions:

River Mile :

USGS 1:100,000 Quad Ref.:

Section: $\quad \mathbf{2 3}$
Grandc Ronde

GR1

$\mathrm{N} \& \mathrm{~S}$ Forks Catherine Ck.

Confluence of N \& S Forks of Catherine Ck.

Union

USFS Rd. \# 7785 off of Hwy 203.

32.5

Enterprise,Ore. USGS 7.5' Quad Ref.: Medical

Township: T5S Range: R41 E
OWNERSHIP

Owner Name:

Contact Name:

Contact Phone:

Zoning:

Land Use /Jurisdiction:
Private owner

Duane West, ODF\&W

(503) \% 3-2138

Undetermined

GENERAL CHARACTERISTICS

Proximity to road : $\quad$ Adjacent to gravel USFS road.

Proximity to power and type: None in area

Size (acres):

2 plus

General topography: Mostly level throughout site.

General soil type: Alluvial

Erosion potential: Moderate

Flood potential and history: Moderate

Upstream land use: Logging and grazing. Roadless in headwaters.

Water rights:

Undetermined

WATER SUPPLY

Gravity supply evaluation: Area appears to have good potential in both forks of creek.

Groundwater evaluation: N/A

ENVIRONMENTAL CHARACTERISTICS/CONSTRAINTS

Adjacent stream habitat: Moderate sized cobbles with moderate bedload movement.

Anadromous fish:

Yes - N. Fork roadless just above site.

Upland habitat type:

Lightly treed with alders and cottonwoods.

Wetlands:

None identified beyond riparian zone.

Permitting Considerations: Ownership, water rights, land use. 


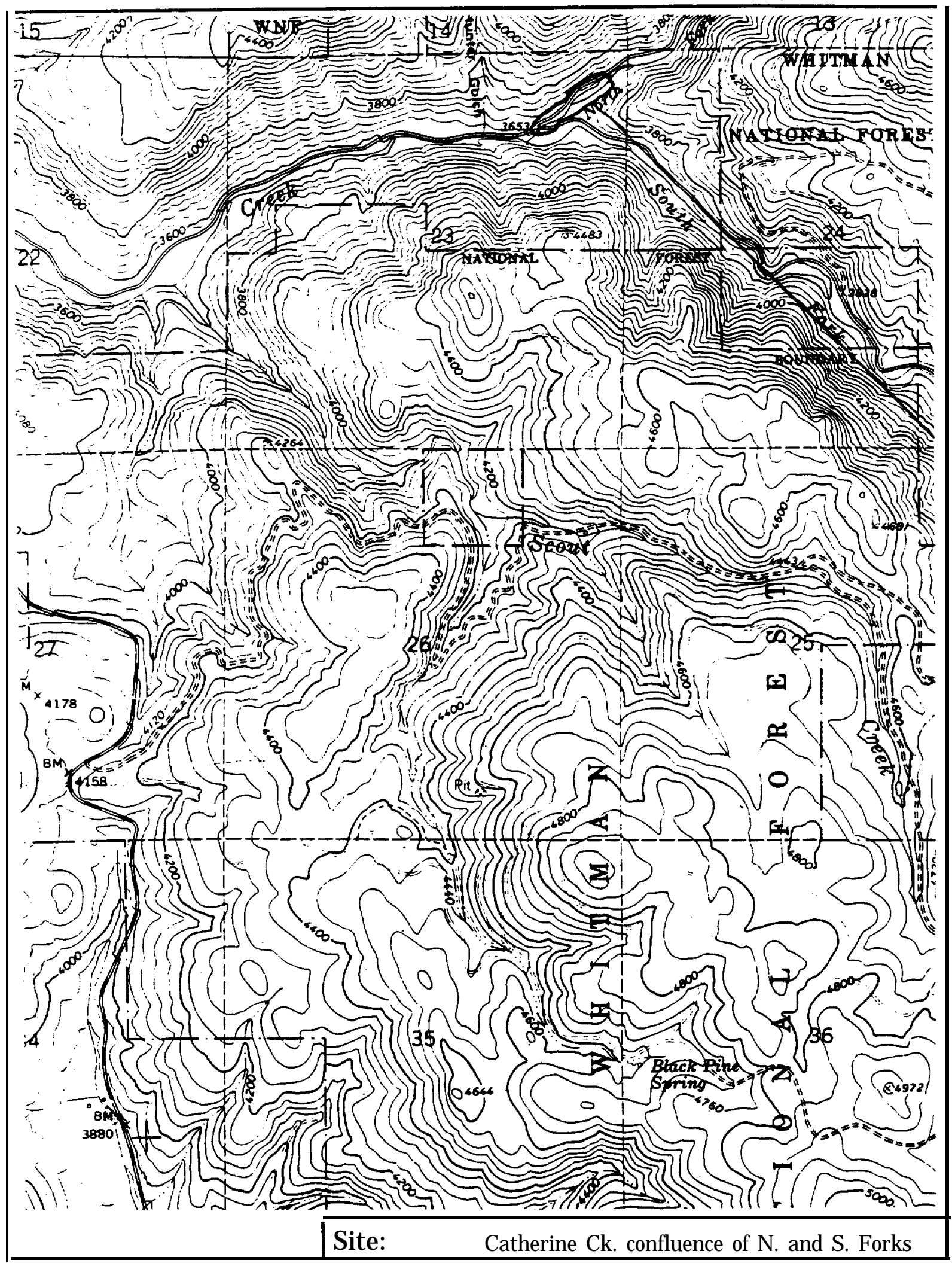




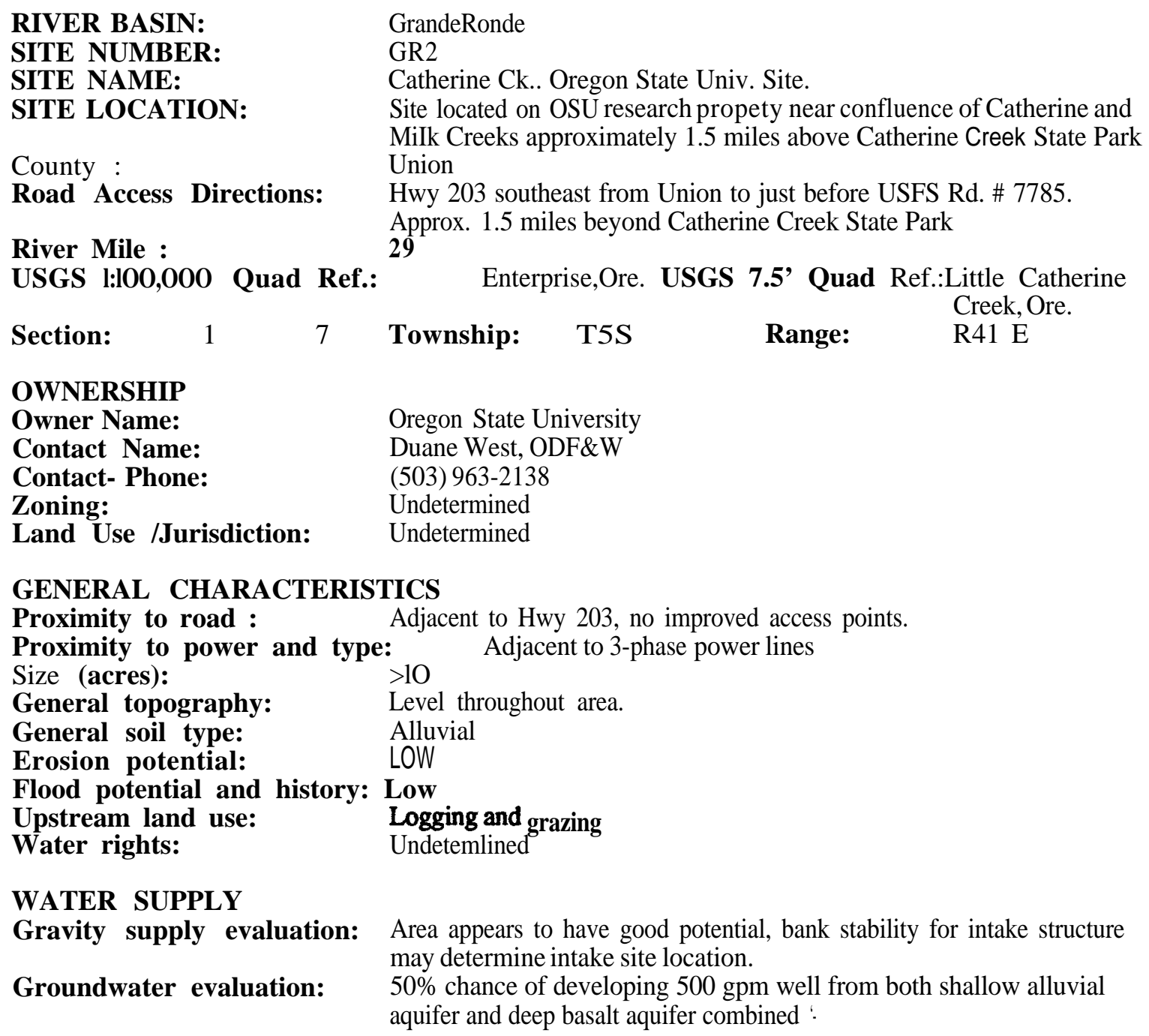

Section: $\quad 1$

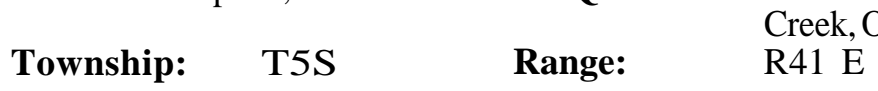$$
\text { Enterprise,Ore. USGS 7.5, Quad Ref.:Little Catherine }
$$

OWNERSHIP

Owner Name:

Contact Name:

Oregon State University

Contact- Phone:

Duane West, ODF\&W

(503) 963-2138

Undetermined

Land Use/Jurisdiction: Undetermined

GENERAL CHARACTERISTICS

Proximity to road : Adjacent to Hwy 203, no improved access points.

Proximity to power and type: Adjacent to 3-phase power lines

Size (acres): $>10$

General topography: Level throughout area.

General soil type: Alluvial

Erosion potential: LOW

Flood potential and history: Low

$\begin{array}{ll}\text { Upstream land use: } & \text { Logging and grazing } \\ \text { Water rights: } & \text { Undetemlined }\end{array}$

WATER SUPPLY

Gravity supply evaluation: Area appears to have good potential, bank stability for intake structure may determine intake site location.

Groundwater evaluation: $\quad 50 \%$ chance of developing $500 \mathrm{gpm}$ well from both shallow alluvial aquifer and deep basalt aquifer combined :

ENVIRONMENTAL CHARACTERISTICS/CONSTRAINTS

Adjacent stream habitat: Moderate sired gravels with moderate bedload movement.

Anadromous fish: Yes

Upland habitat type: Some conifers and grasses

Wetlands:

None identified beyond riparian zone, may need more detailcd survey prior to any development.

Permitting Considerations: Land use, water rights 


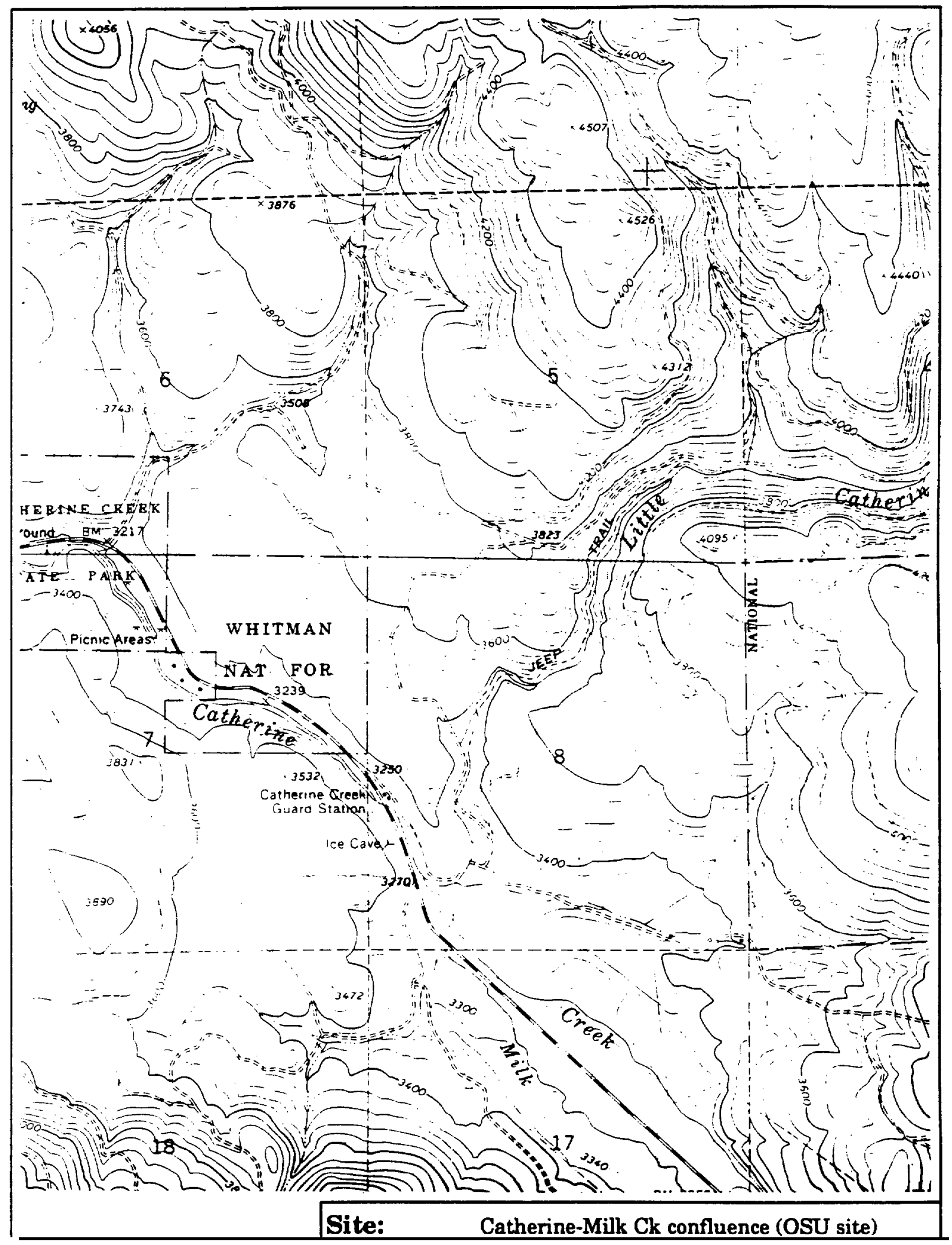




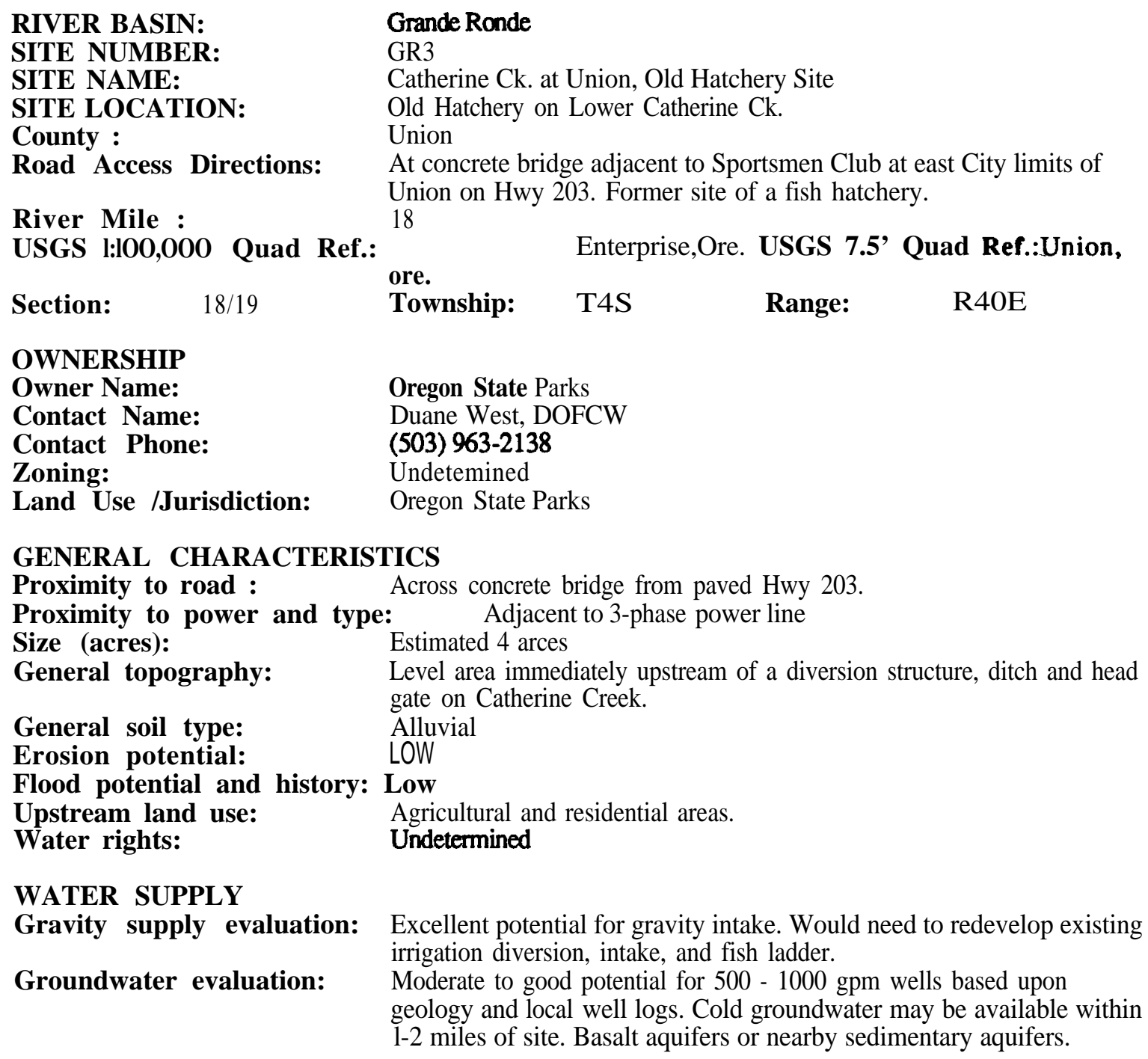

WATER SUPPLY

Gravity supply evaluation: Excellent potential for gravity intake. Would need to redevelop existing irrigation diversion, intake, and fish ladder.

Groundwater evaluation: Moderate to good potential for 500 - 1000 gpm wells based upon geology and local well logs. Cold groundwater may be available within 1-2 miles of site. Basalt aquifers or nearby sedimentary aquifers.

\section{ENVIRONMENTAL CHARACTERISTICS/CONSTRAINTS}

Adjacent stream habitat: Moderate sized gravels with moderate bedload movement, Anadromous fish: Yes Upland habitat type: Wetlands: Site overgrown with weeds and hardwoods. Some arcas of site appear to contain wetland vegetation, may require delineation prior to development.

Permitting Considerations: Land use, wetlands, water rights 


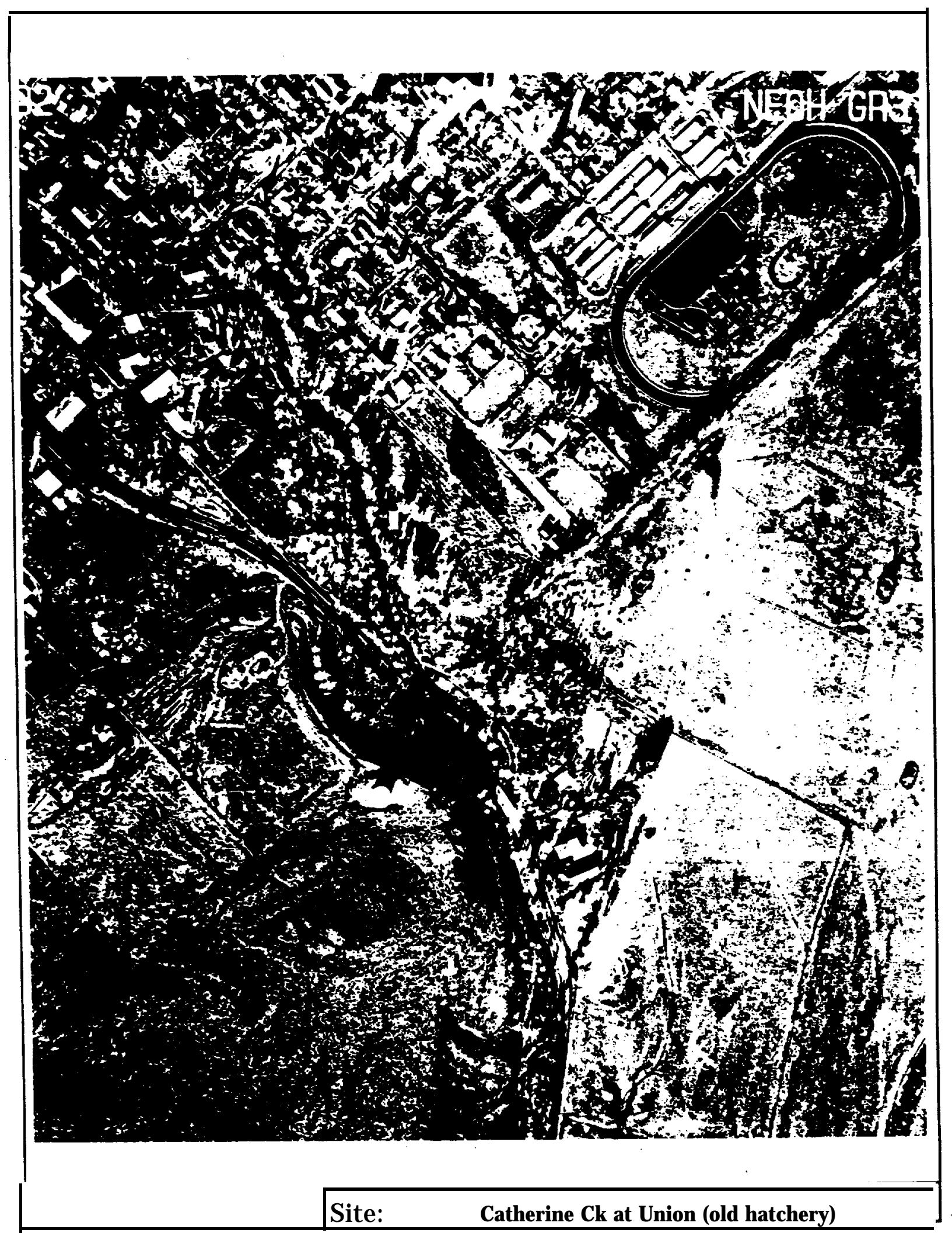




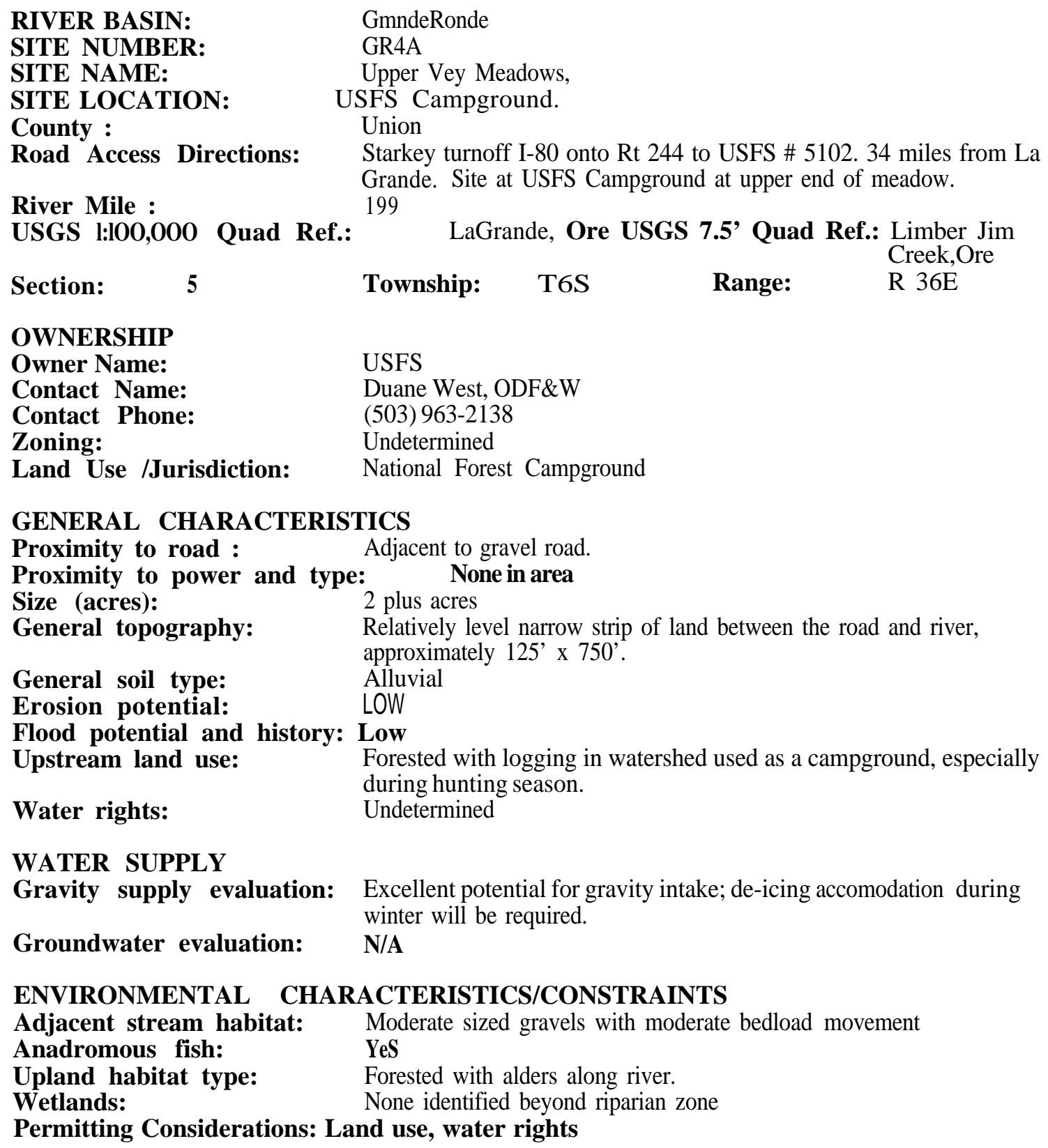




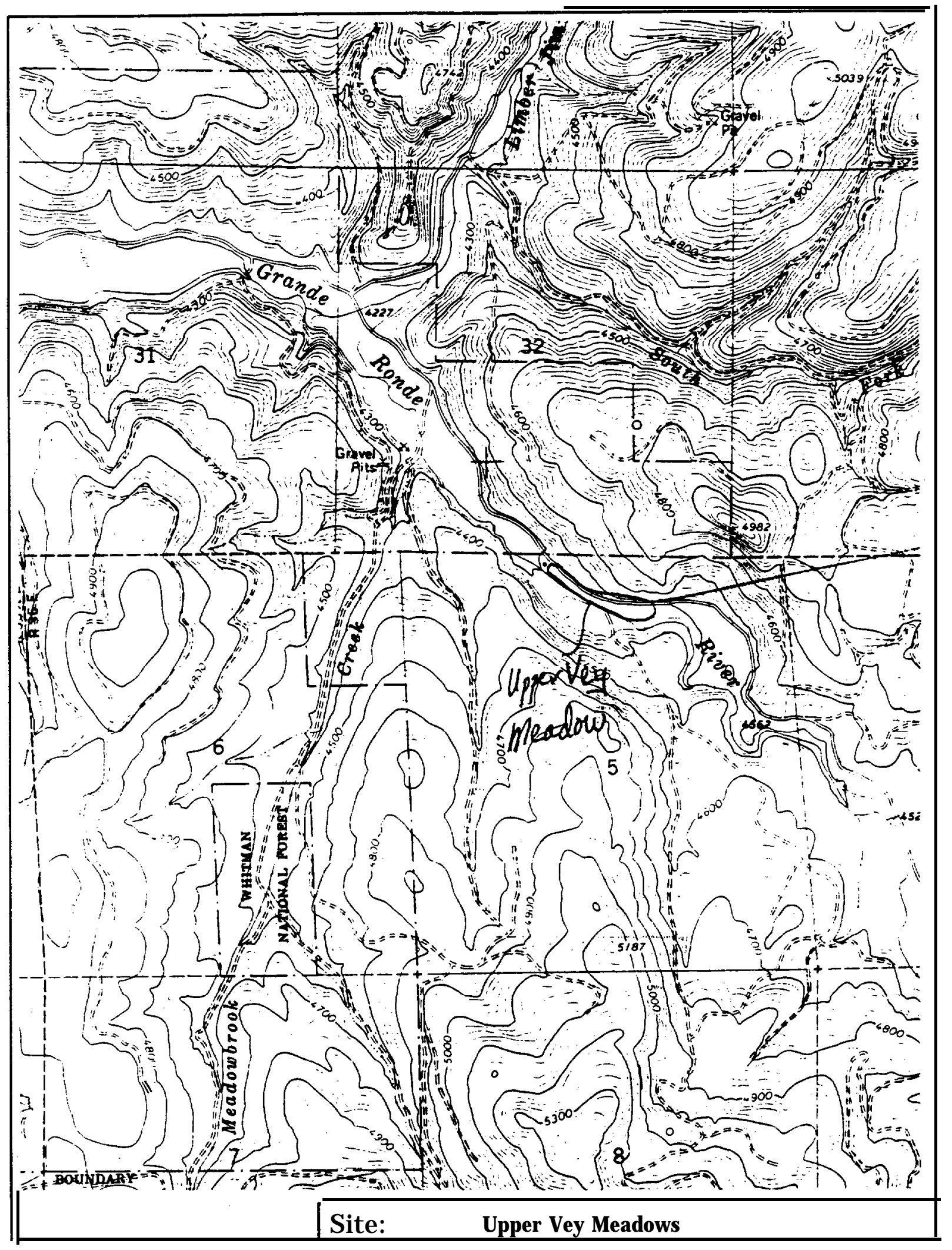


RIVER BASIN:

SITE NUMBER:

SITE NAME:

SITE LOCATION:

Road Access Directions:

River Mile :

USGS 1:100,000 Quad Ref.:
County :

Grande Ronde

GR4B

Lower Vey Meadows at splash dam,

Union

Starkey turnoff I-80 onto Rt 244 to USFS \# 5102. 34 miles from La Grande. Site at old splash dam at opening of Canyon into Vey Meadows.

199

Section:

OWNERSHIP

Owner Name:

Contact Name:

Contact Phone:

Zoning:

Land Use /Jurisdiction:
La Grande, Ore USGS 7.5' Quad Ref.: Limber Jim Creek.Ore
Township: T6S Range: R36E

\section{GENERAL CHARACTERISTICS}

Proximity to road : Adjacent to gravel road

Proximity to power and type: Noneinarea

Size (acres): $\quad$ Approx. 5

General topography: $\quad$ Flat area immediately upstream of splash dam

General soil type: Alluvial

Erosion potential: Low, except for grazing animals in upstream creek area.

Flood potential and history: Low

Upstream land use: $\quad$ Forested with logging in watershed

Water rights: Undetermined

WATER SUPPLY

Gravity supply evaluation: Stream is low gradient above splash dam, would require long supply line.

Groundwater evaluation: N/A

ENVIRONMENTAL CHARACTERISTICS/CONSTRAINTS

Adjacent stream habitat: Fine to medium bed materials.

Anadromous fish:

Yes

Upland habitat type: Grassy meadow, limited riparian zone

Wetlands:

None identified beyond riparian zone

Permitting Considerations: Land use, water rights 


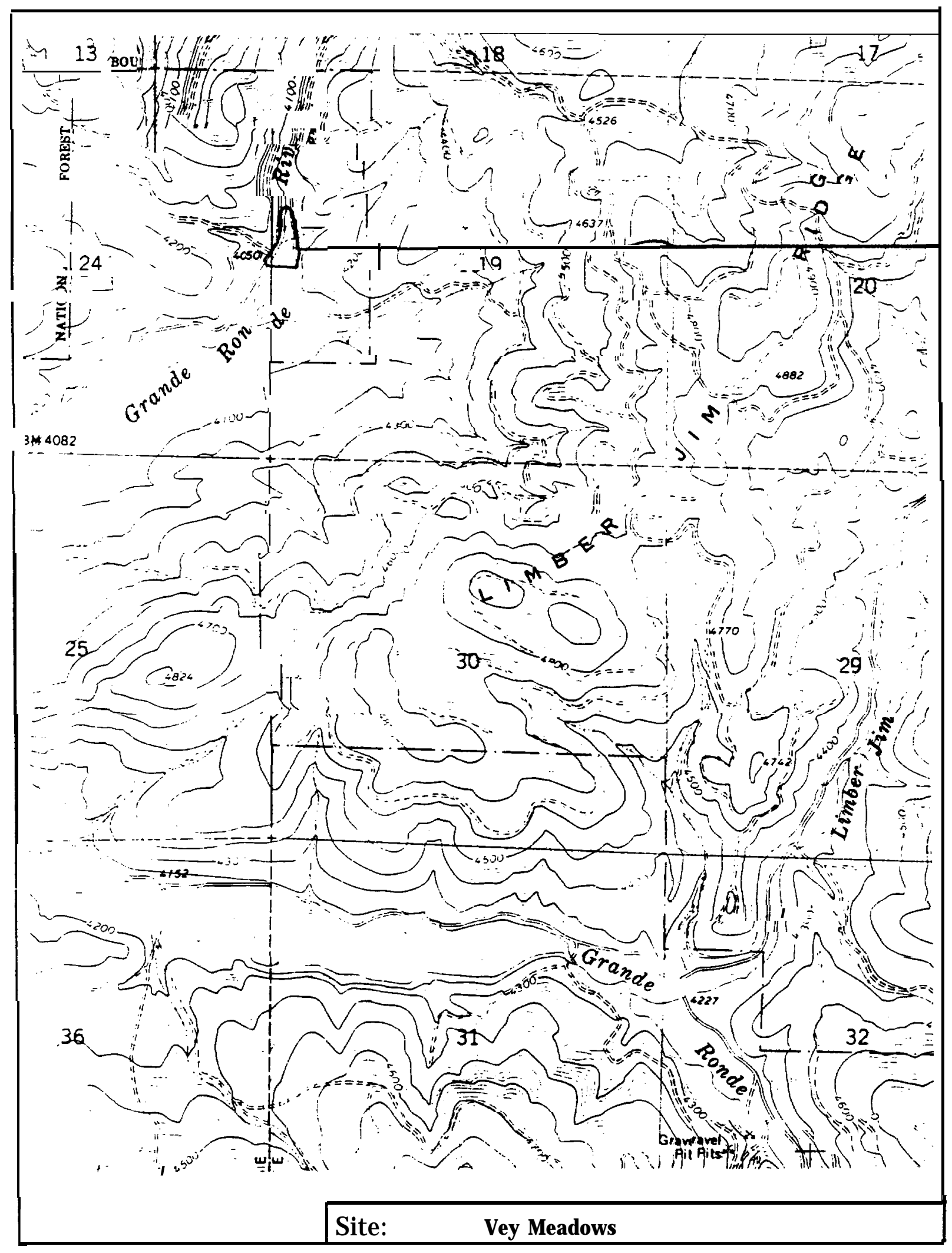




\begin{tabular}{|c|c|}
\hline $\begin{array}{l}\text { RIVER BASIN: } \\
\text { SITE NUMBER: } \\
\text { SITE NAME: } \\
\text { SITE LOCATION: }\end{array}$ & $\begin{array}{l}\text { GrandeRcmde } \\
\text { GR5 } \\
\text { sheep Creek } \\
\text { Intersection of USFS roads on Sheep Creek above (to west of) Vey } \\
\text { Meadows. }\end{array}$ \\
\hline County : & Union \\
\hline Road Access Directions: & $\begin{array}{l}\text { Starkey tumoff I- } 80 \text { onto Rt } 244 \text { to Vey Meadows past Vey ranch } \\
\text { house. West on East Sheep Road approx. } 0.5 \text { miles past Vey ranch } \\
\text { house Site at intersection of East Sheep Road with Sheep Creek. }\end{array}$ \\
\hline $\begin{array}{l}\text { River Mile : } \\
\text { USGS 1:100,000 Quad Ref.: }\end{array}$ & $201 \quad$ La Grande, Ore USGS 7.5, Quad Ref.: Fly \\
\hline Section: $\quad 12$ & Township: 6S \\
\hline $\begin{array}{l}\text { OWNERSHIP } \\
\text { Owner Name: } \\
\text { Contact Name: } \\
\text { Contact Phone: } \\
\text { Zoning: } \\
\text { Land Use /Jurisdiction: }\end{array}$ & $\begin{array}{l}\text { USFS } \\
\text { Duane West, ODF\&W } \\
\text { (503) } 963-2138 \\
\text { undetermined } \\
\text { National Forest Land }\end{array}$ \\
\hline $\begin{array}{l}\text { GENERAL CHARACTERIST } \\
\text { Proximity to road : } \\
\text { Proximity to power and type: } \\
\text { Size (acres): } \\
\text { General topography: } \\
\text { General soil type: } \\
\text { Erosion potential: } \\
\text { Flood potential and history: } \\
\text { Upstream land use: } \\
\text { Water rights: }\end{array}$ & $\begin{array}{l}\text { TICS } \\
\text { Adjacent to gravel road } \\
\text { <2 acres None } \\
\text { Flat, sloping downstrea } \\
\text { Alluvial } \\
\text { Low } \\
\text { Low } \\
\text { Forested with some logging. } \\
\text { Undetermined }\end{array}$ \\
\hline $\begin{array}{l}\text { WATER SUPPLY } \\
\text { Gravity supply evaluation: } \\
\text { Groundwater evaluation: }\end{array}$ & $\begin{array}{l}\text { Potential for gravity intake near culvert under road. } \\
\text { N/A }\end{array}$ \\
\hline $\begin{array}{l}\text { ENVIRONMENTAL CHARA } \\
\text { Adjacent stream habitat: } \\
\text { Anadromous fish: } \\
\text { Upland habitat type: } \\
\text { Wetlands: } \\
\text { Permitting Considerations: }\end{array}$ & $\begin{array}{l}\text { ACTERISTICS/CONSTRAINTS } \\
\text { Moderate sized gravels. } \\
\text { Yes } \\
\text { Some alders along stream, riparian fencing upstream. } \\
\text { None identified beyond riparian zone. }\end{array}$ \\
\hline
\end{tabular}




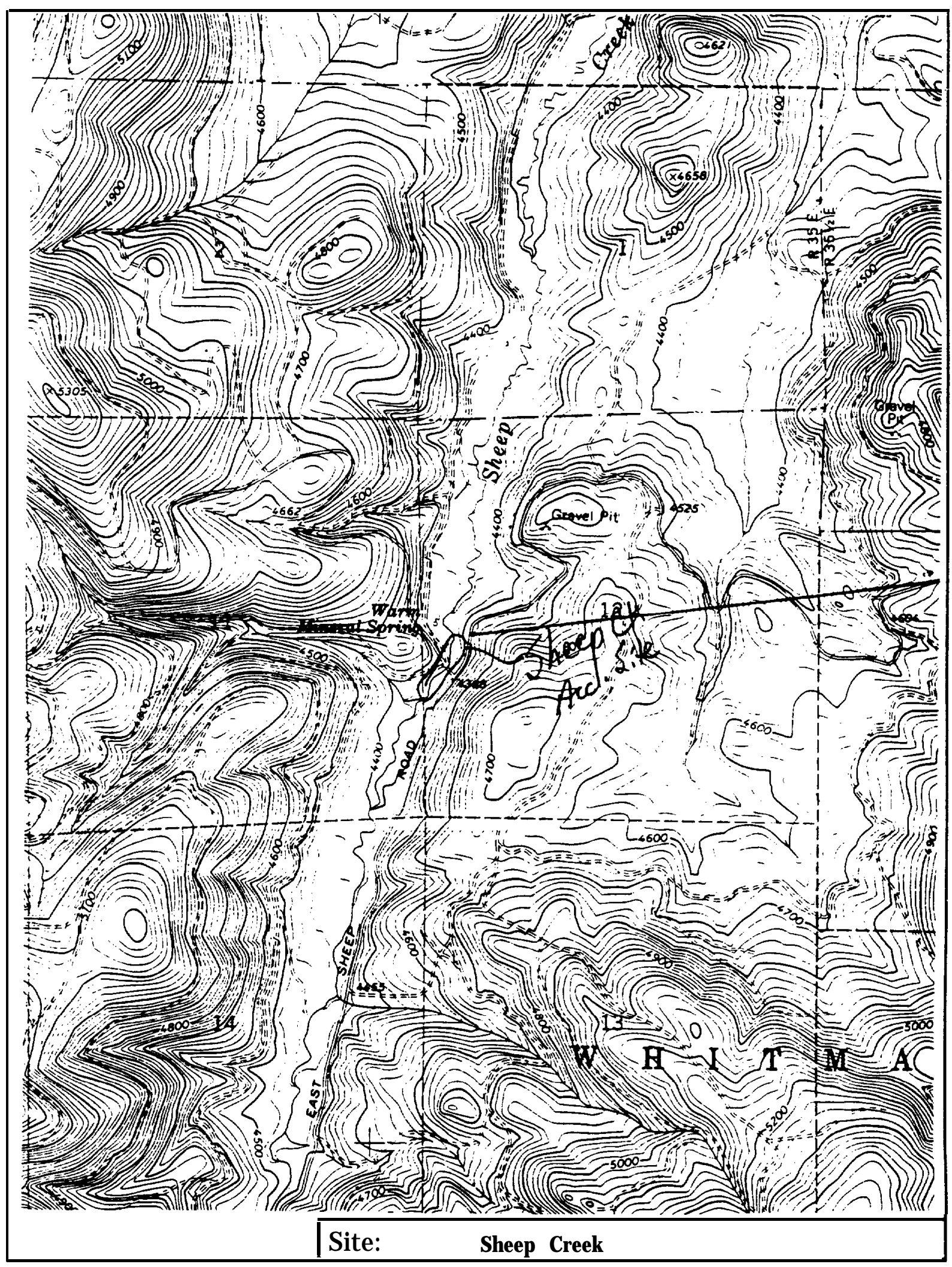




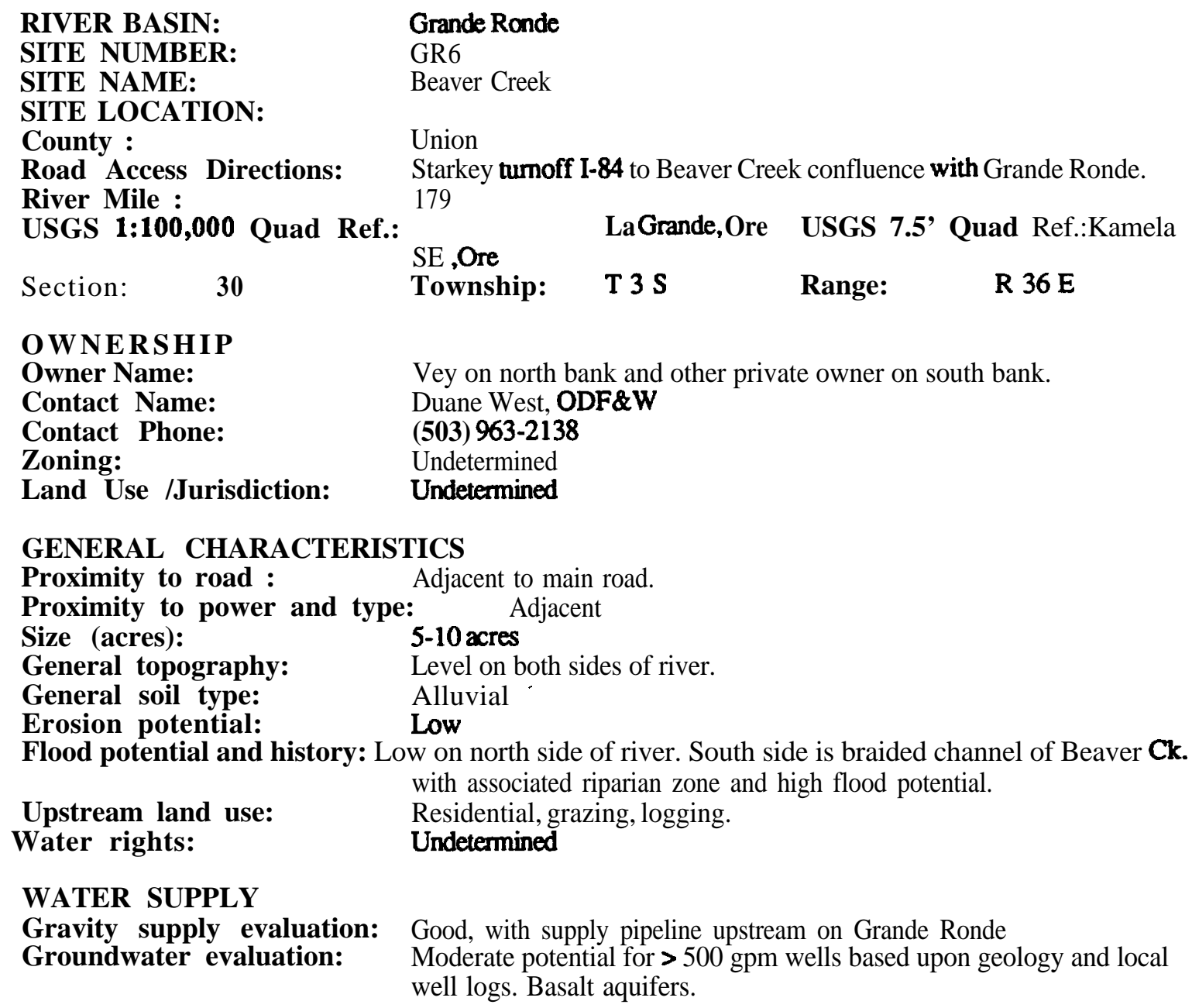

Permitting Considerations: Water rights and wetlands. 


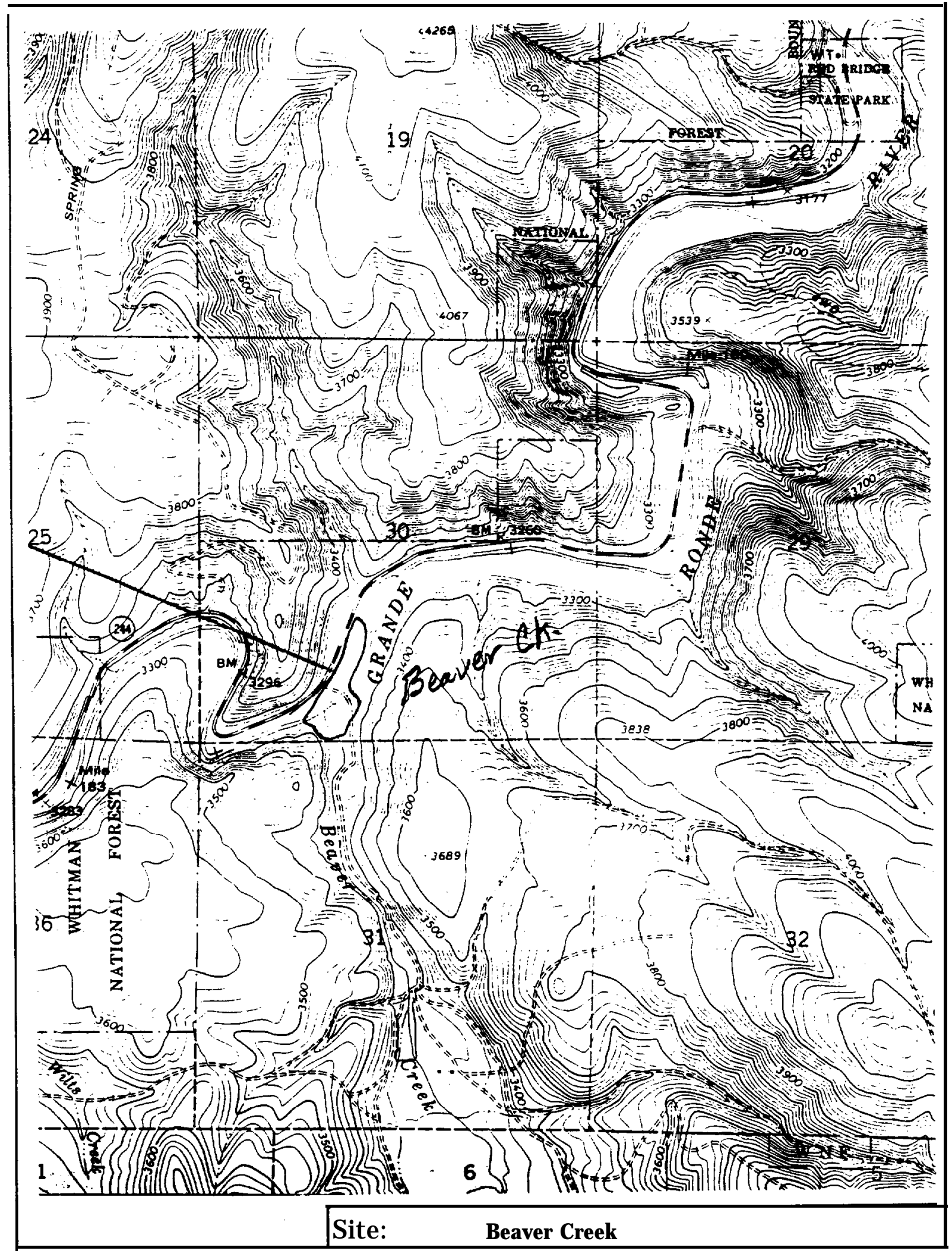




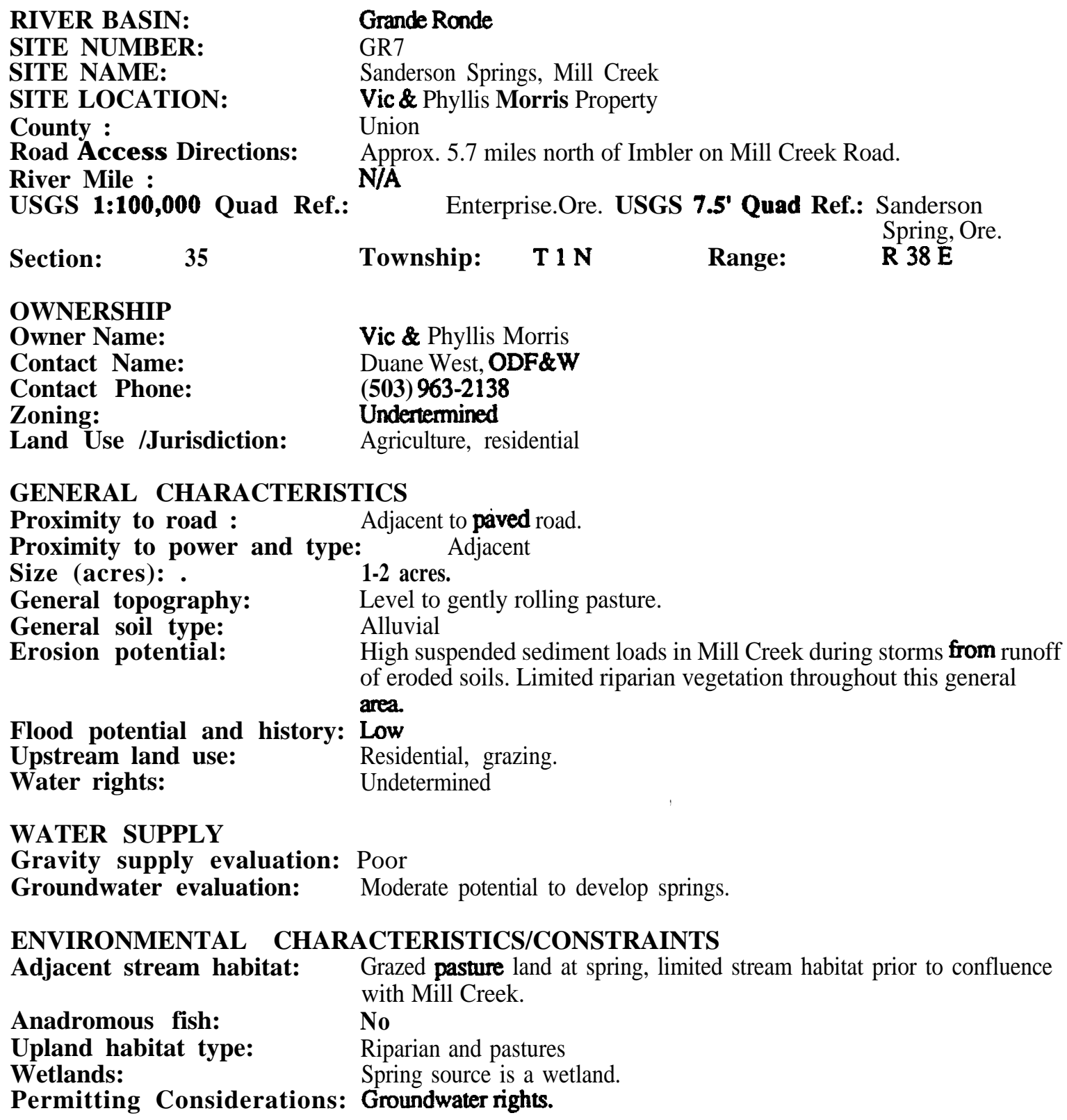

GENERAL CHARACTERISTICS

Proximity to road : $\quad$ Adjacent to paved road.

Proximity to power and type: Adjacent

Size (acres): . 1-2 acres.

General topography: Level to gently rolling pasture.

General soil type: Alluvial

Erosion potential: $\quad$ High suspended sediment loads in Mill Creek during storms from runoff of eroded soils. Limited riparian vegetation throughout this general

area.

Flood potential and history: Low

Upstream land use: $\quad$ Residential, grazing.

Water rights: $\quad$ Undetermined

WATER SUPPLY

Gravity supply evaluation: Poor

Groundwater evaluation: Moderate potential to develop springs.

ENVIRONMENTAL CHARACTERISTICS/CONSTRAINTS

Adjacent stream habitat: Grazed pasture land at spring, limited stream habitat prior to confluence

Anadromous fish: with Mill Creek.

Upland habitat type: $\quad$ Riparian and pastures

Wetlands: $\quad$ Spring source is a wetland.

Permitting Considerations: Groundwater rights. 


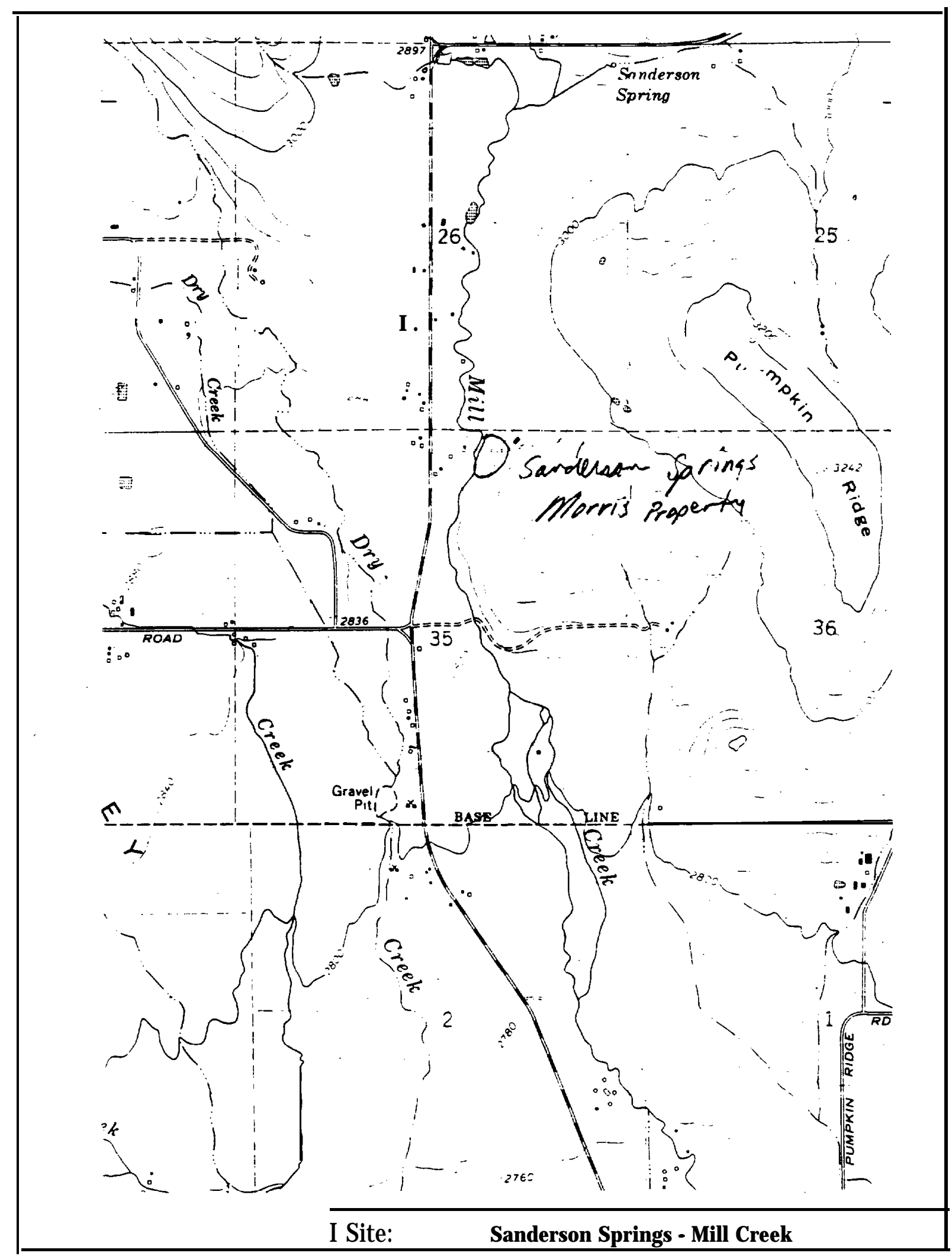


RIVER BASINं:

SITE NUMBER:

SITE NAME:

SITE LOCATION:

County :

Road Access Directions:

\section{Grande Ronde}

GR8

Lower Willow Creek near Imbler.

No specific site identified, general area of interest is the lower reach of Willow Creek from its confluence with the Grande Ronde River to approximately 1 mile upstream.

Union

Highway 82 approximately 2 miles north of Imbler, just south of Rhinehart. Courtney Lane to east off Highway 82 parallels Willow Creek on its north side, turns and crosses creek near limit of upstream area of interest.

Grande Ronde RM 105.5 is Willow Creek mouth (approx)

La Grande, Ore USGS 7.5' Quad Ref.:Imbler,

River Mile :
USGS 1:100,000 Quad Ref.: ore.

Section:

9

Township : 1S

Range:

$39 \mathrm{E}$

Undetermined

Owner Name:

Contact Name:

Duane West, ODF\&W

Contact Phone:

Zoning:

(503) 963-2138

Undetermined

Land Use /Jurisdiction:

\section{GENERAL CHARACTERISTICS}

Proximity to road : $\quad$ Adjacent to paved roads, no good access to stream within its lower reach.

Proximity to power and type: Power available along highway.

Size (acres):

General topography:

Various small,$<2$ acre, sites in this area

General soil type:

Erosion potential: Moderateduring high runoff

Flood potential and history: Moderate

Upstream land use: Agriculture, residential

Water rights:

Undetermined

WATER SUPPLY

Gravity supply evaluation: Undetermined

Groundwater evaluation: Moderate potential for 500 - 1000 gpm wells based upon geology and local well logs. Basalt aquifers or sedimentary aquifers.

ENVIRONMENTAL CHARACTERISTICS/CONSTRAINTS

Adjacent stream habitat: Convoluted channel within marshy area.

Anadromous fish: Yes

Upland habitat type:

Wetlands:

Permitting Considerations: Wetlands

Deciduous riparian zone, marsh vegetation

Yes. Development would require detailed delineation. 


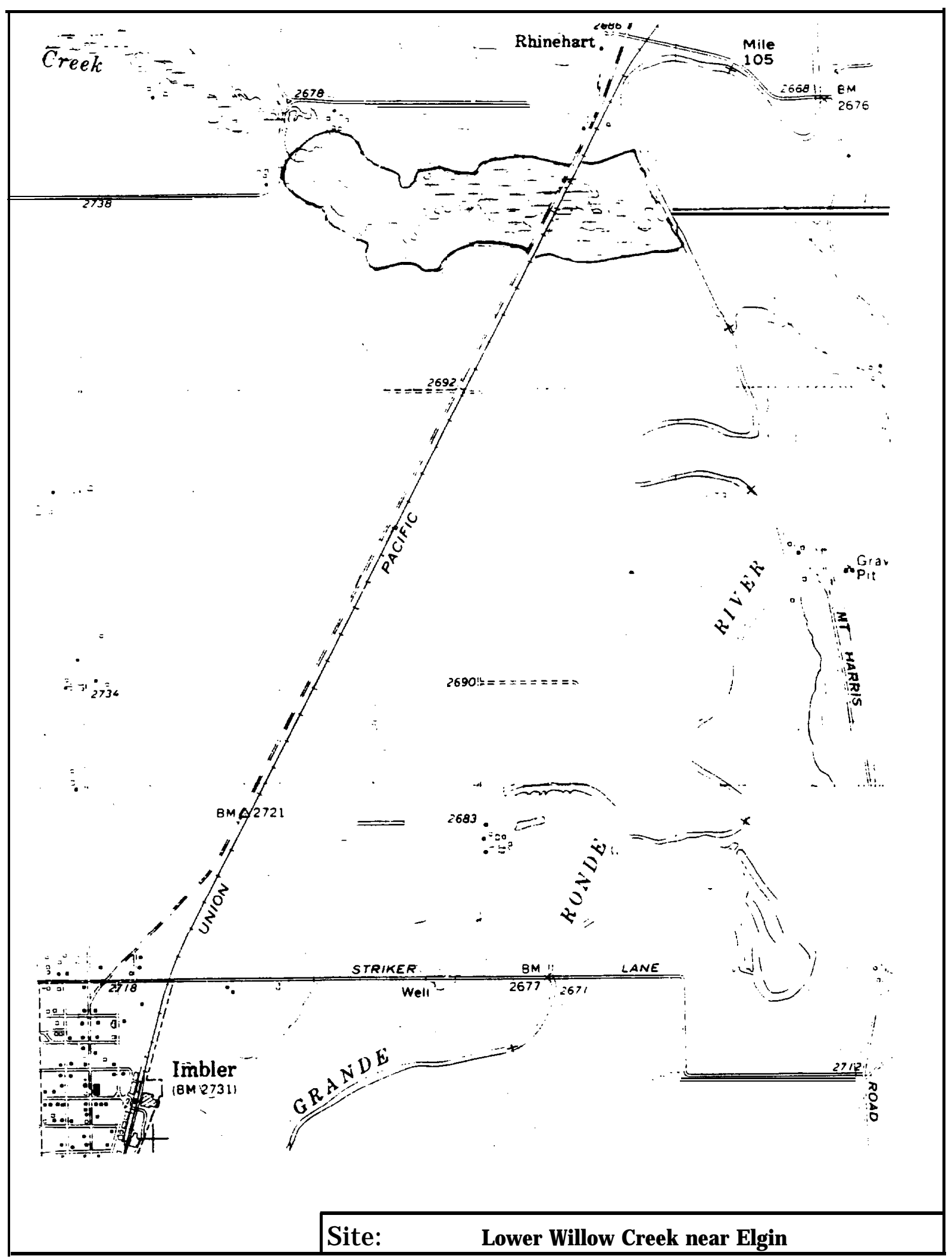


RIVER BASIN:

SITE NUMBER:

SITE NAME:

SITE LOCATION:

County :

Road Access Directions:

River Mile :

USGS 1:100,000 Quad Ref.:

Section: ?

OWNERSHIP

Owner Name:

Contact Name:

Contact Phone:

Zoning:

Land Use /Jurisdiction:
GrandeRonde

GR9

Indian Creek

Union

Hwy 82 to Elgin Lumber Rd. between Imbler and Elgin, Ore. left on Rinehart Lane to Indian Ck. Rd. Site above last house. Undetermined.

LaGrande, Ore

Township : 25

USGS 7.5' Quad Ref::Gasset Bluff, Range: $\quad 39 \mathrm{E}$

GENERAL CHARACTERISTICS

Proximity to road : Adjacent gravel road, site is below road in narrow, steep sloped area of

Private

Duane West, ODF\&W

(503) 963-2138

Undetermined

Undetermined

Proximity to power and type: drainage.

Size (acres): $\quad 5-10$

General topography: $\quad$ L e v e 1

General soil type: Alluvial

Erosion potential: Low

Flood potential and history: Low

Upstream land use: Grazing

Water rights: unknown

WATER SUPPLY

Gravity supply evaluation: Good, high gradient

Groundwater evaluation: N/A

ENVIRONMENTAL CHARACTERISTICS/CONSTRAINTS

Adjacent stream habitat: Narrow canyon with riffles and cascades above site.

Anadromous fish:

Yes

Upland habitat type:

Steep slope forested with conifers and deciduous trees

Wetlands:

Permitting Considerations:

Riparian zone, other not determined. 


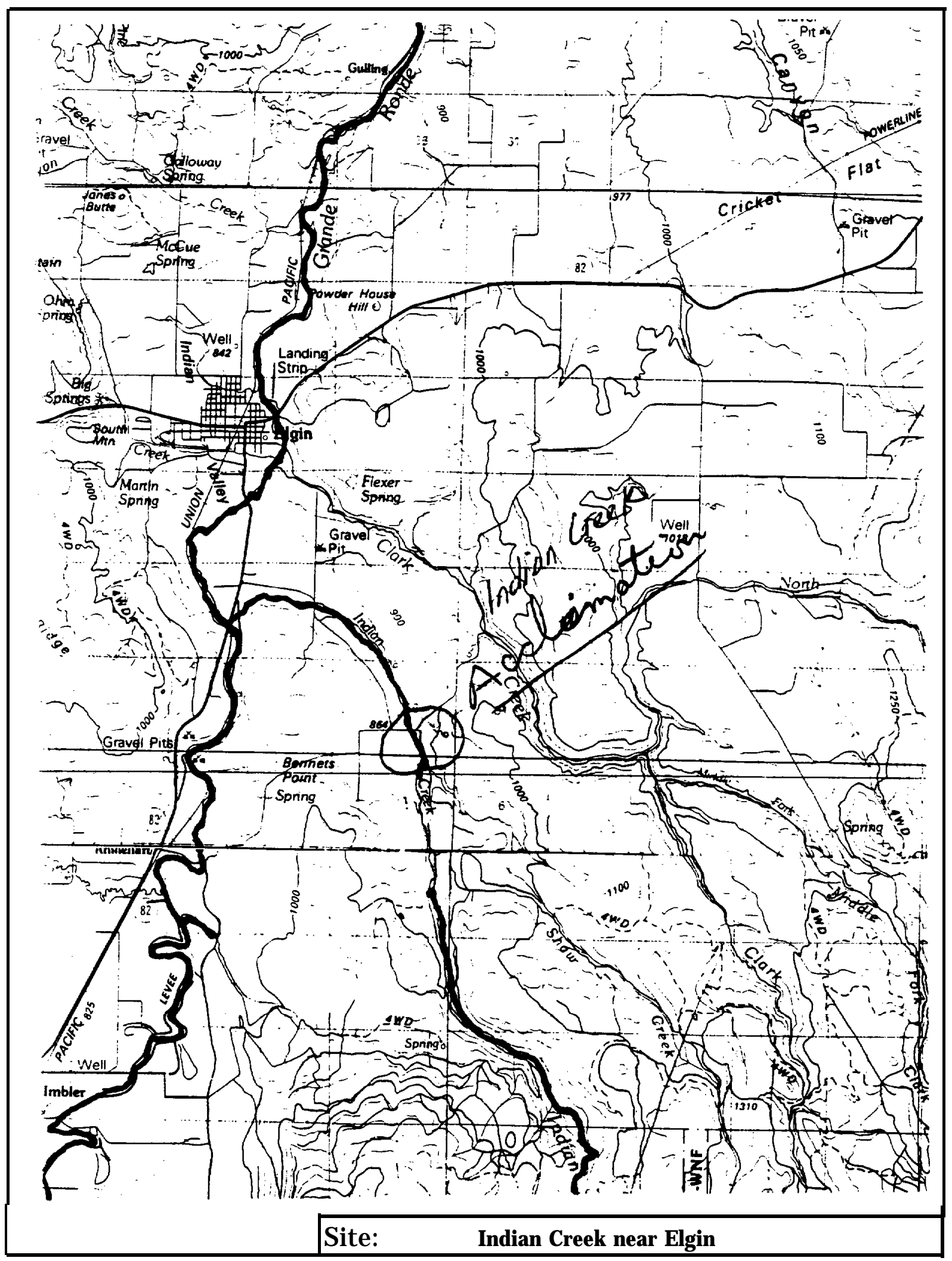


RIVER BASIN:

SITE NUMBER:

SITE NAME:

SITE LOCATION:

County :

Road Access Directions:

River Mile :

USGS 1:100,000 Quad Ref.:

OR

Section: $\quad 35$

Section: $\quad 2,10$

OWNERSHIP

Owner Name:

Contact Name:

Contact Phone:

Zoning:

Land Use/Jurisdiction:
Grande Ronde

GR10

Grande Ronde near Elgin

Approx. 4 mile reach of Grande Ronde River downstream of Elgin.

Union

Access off Palmer JcL. road heading north from Elgin. Two unpaved roads to east at approximately 1 and 1.5 miles north of Elgin lead to river. Railroad ROW parallels river in this area.

Approx. RM 94 to 99, just north of Elgin

La Grande, Ore USGS 7.5' Quad Ref.:Elgin,

Township: $2 \mathrm{~N}$

Township : $1 \mathrm{~N}$

Range: $\quad 39 \mathrm{E}$

Undetermined

Duane West. ODF\&W

(503) \%3-2138

Undetermined

Undetermined

GENERAL CHARACTERISTICS

Proximity to road : $\quad$ Unimproved dirt roads lead to site area

Proximity to power and type: Limited power availability depending on location within this

Size (acres):

General topography:

General soil type:

Erosion potential:

Upstream land use:

Water rights:

WATER SUPPLY

Gravity supply evaluation: Very low gradient in this reach

Groundwater evaluation:

Flat, level flood plain

Alluvial

Moderate during high runoff

Agriculture

Undetermined area

Numerous sites of 1 to several acrés

Moderate potential for $1000 \mathrm{gpm}$ wells based upon geology and local well logs. Basalt aquifers.

ENVIRONMENTAL CHARACTERISTICS/CONSTRAINTS

Adjacent stream habitat:

Anadromous fish:

Yes

Upland habitat type:

Pastureland with limited riaprian vegetation

Wetlands:

Specific sites considered within area would require delineation for nonriparian wetland areas

Permitting Considerations: Water rights, wetlands 


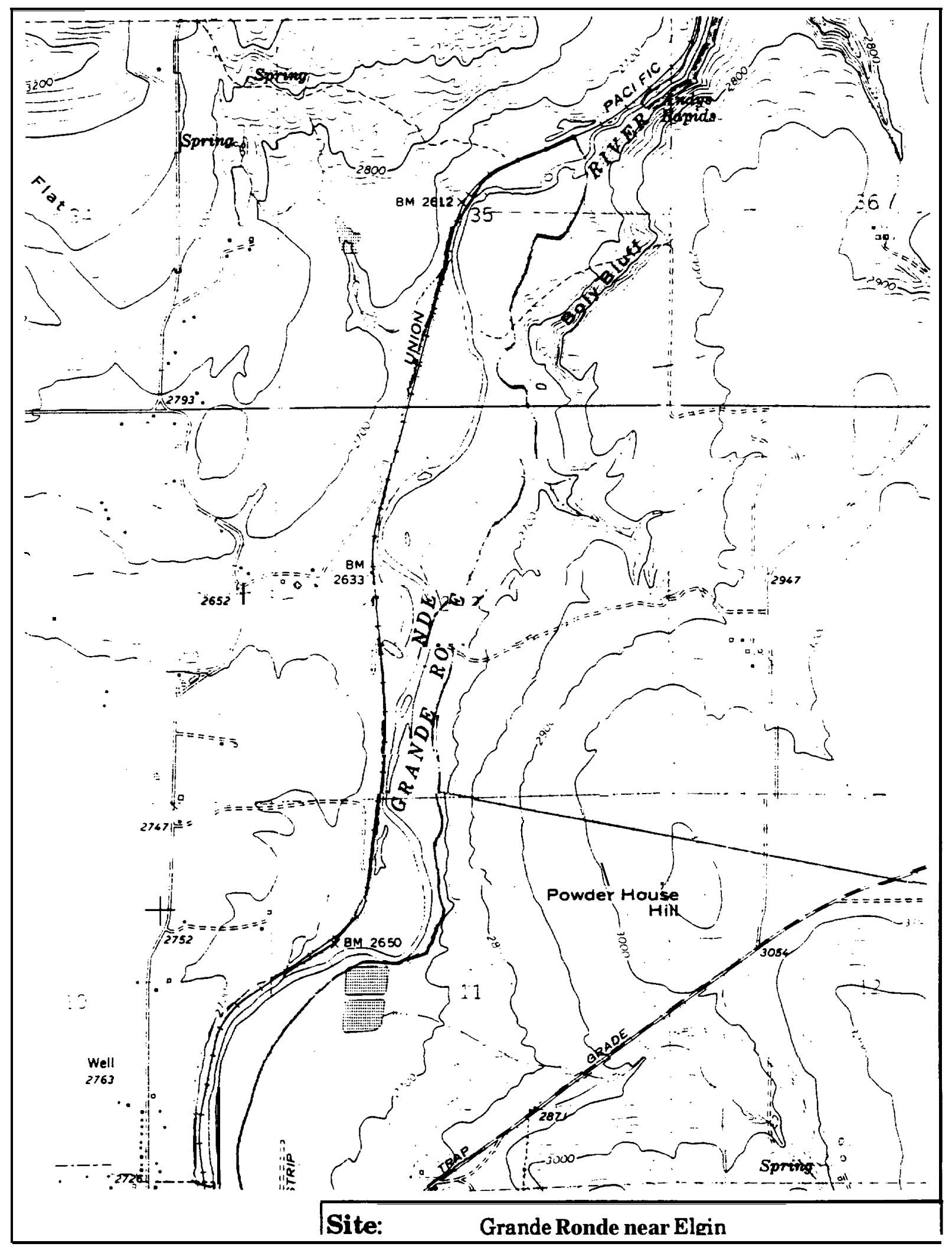


RIVER BASIN

SITE NUMBER

SITE NAME

SITE LOCATION

County

Road Access Directions

River Mile

USGS 1:100,000 Quad Ref. USGS 7.5' Quad Ref.

Section 18,19

OWNERSHIP

Owner Name

Contact Name

Contact Phone

Zoning .

Land Use /Jurisdiction

GENERAL CHARACTERIS

Proximity to road

Proximity to power

Size (acres)

General topography

General soil type

Erosion potential

Flood potential and history

Upstream land use

Water rights

WATER SUPPLY

Gravity supply evaluation Good, existing intake with some winter icing problems

Groundwater evaluation Good, existing groundwater development

ENVIRONMENTAL CHARACTERISTICS/CONSTRAINTS

Adjacent stream habitat

Anadromous fish

Upland habitat type

Wetlands

Permitting Considerations

Creek to hatchery

\section{Grande Ronde}

GR11.

LookingglassHatchery

Looking glass Hatchery

Union

Highway 82 east from Elgin for approx. 4.5 miles. North on Palmer JCL road approximately 12 miles to Palmer Jct. on the Grande Ronde

River. Approx. 2 miles north of Palmer Jct. along Lookingglass

Lookingglass Creek empties into Grande Ronde River at approximately RM 85

Rondowa, OR

$\begin{array}{lll}\text { Township } 3 N & \text { Range }\end{array}$

Hatchery operated by ODF\&W

Scott Lusted, Hatchery Manager

Undetermined

Existing fish hatchery

All weather gravel road to site, some winter access problems

Power to site

5-10

Developed on series of benches along Lookingglass Creek

Alluvial

Generally undeveloped upstream

Undetermined beyond current water rights for hatchery

Rocky, moderate to high gradient stream

Yes

Forested steep slope

None identified beyond riaprian zone

'Overlap with existing LSRCP facilities 


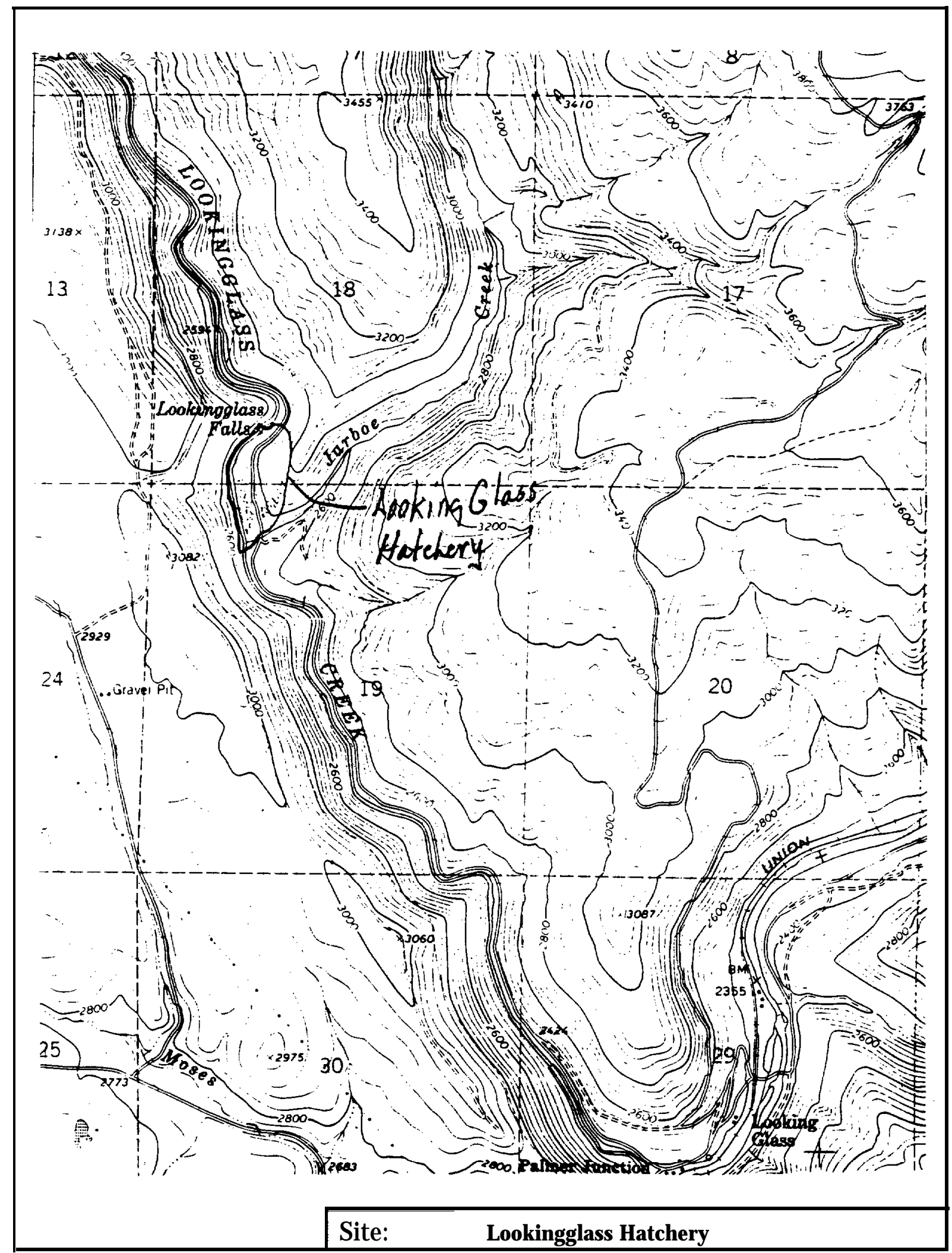


RIVER BASIN:

SITE NUMBER:

SITE NAME:

SITE LOCATION:

County :

Road Access Directions:
Grande Ronde

GR12

Wildcat Ck.

\section{Wallowa}

Estimated 8 miles southeast of Troy, Ore. on gravel road which parallel Grande Ronde R. Road begins at Hwy 3 bridge over river at Rattlesnake grade. It begins in Washington and parallels river from this point through Troy to Wildcat Ck.

River Mile : 54

USGS 1:100,000 Quad Ref.: USGS 7.5' Quad Ref.: Troy, OR

$\begin{array}{lllll}\text { Section: } & 19 & \text { Township : } & \text { 5N } & \text { Range: }\end{array}$

OWNERSHIP

Owner Name:

Contact Name:

Private

Brad Smith, ODF\&W

Contact Phone:

(503) 426-3279

Undetermined

Zoning:

Undetermined

GENERAL CHARACTERISTICS

Proximity to road : Adjacent gravel road.

Proximity to power and type: None

Size (acres): 2 plus;

General topography: Generally level

General soil type: Alluvial

Erosion potential: Moderate

Flood potential and history: Moderate during high flow periods.

Upstream land use: Grazing

Water rights: Undetermined

WATER SUPPLY

Gravity supply evaluation: Good

Groundwater evaluation: N/A

ENVIRONMENTAL CHARACTERISTICS/CONSTRAINTS

Adjacent stream habitat: River has moderate bedload movement

Anadromous fish:

Yes

Upland habitat type:

Wetlands:

Steep grass covered slopes

Permitting Considerations:

None identified beyond riparian zone 


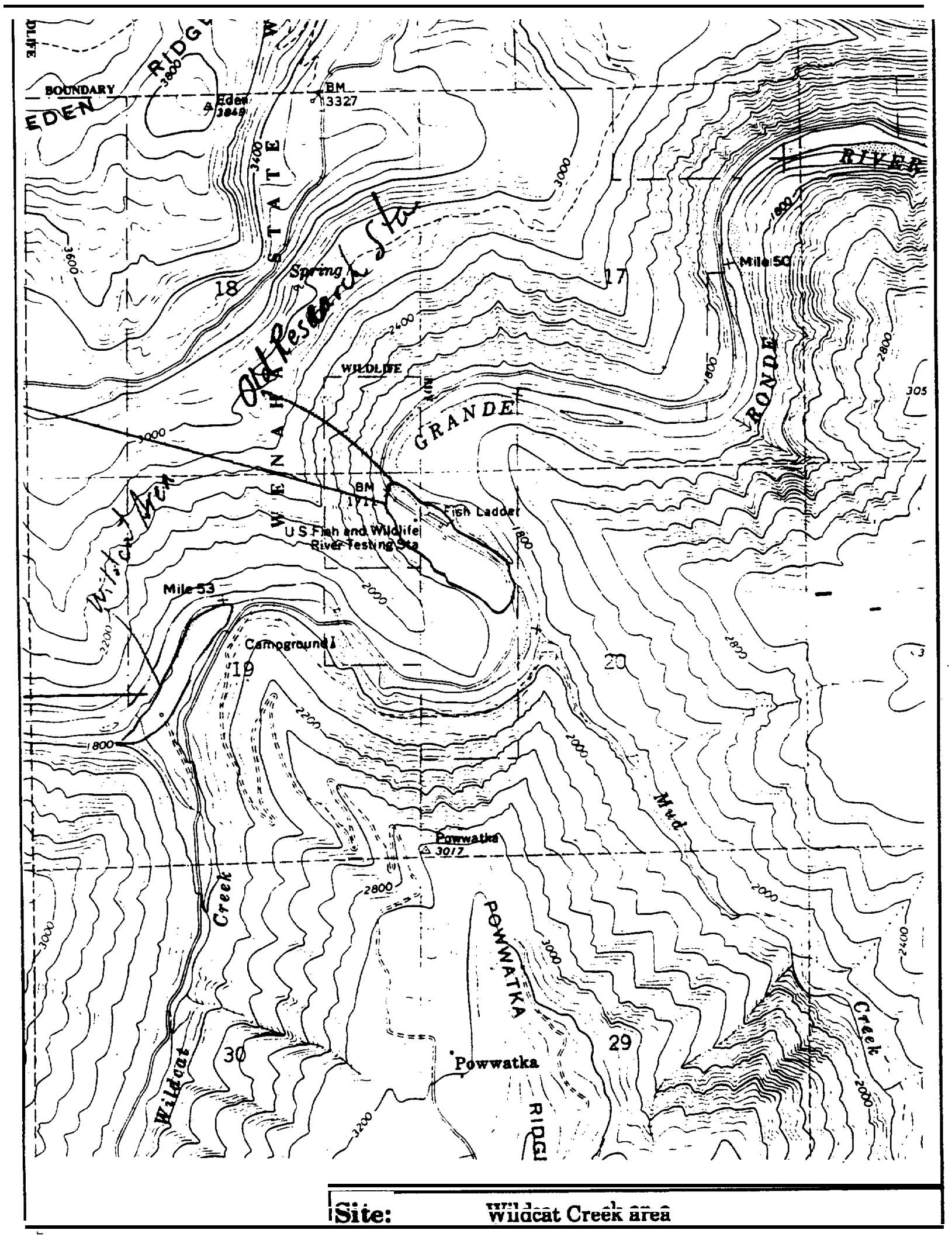


RIVER BASIN:

SITE NUMBER:

SITE NAME:

SITE LOCATION:

county :

Road Access Directions:
Grande Ronde

GR13

Fiih Ladder ( former USFWS Research Site)

\section{Wallowa}

Estimated 6 miles southeast of Troy, OR on gravel road. which parallels Grande Ronde R. Road begins at Hwy 3 bridge over river at Rattlesnake grade. It begins in Washington and parallels river from this point through Troy to Wildcat Ck.

River Mile : $51-52$

USGS 1:100,000 Quad Ref.: USGS 7.5' Quad Ref.:

Section: $\quad 19,20$

Troy, OR

Township: $\quad$ NN $\quad$ Range: 43E

OWNERSHIP

Owner Name:

Contact Name:

Contact Phone:

Zoning:

Land Use /Jurisdiction:
ODF\&W owns portion of site within Wenaha State Wildlife Area. Owner of portion with former facility unknown.

Brad Smith, ODF\&W

(503) 426-3279

Undetermined

Wenaha State Wildlife Area/State of Oregon

GENERAL CHARACTERISTICS

Proximity to road- : Adjacent gravel paved road

Proximity to power and type:

Size (acres):

General topography: Level around site.

General soil type: Alluvial

Erosion potential: Low

Flood potential and history: High flooding potential. Facility had experienced flood damage in the past.

Upstream land use: Grazing

Water rights: $\quad$ Undetermined

WATER SUPPLY

Gravity supply evaluation: Existing concrete channel approx. 40' x 100'. Channel is set up for direct diversion of river. There is potential for upgrading of existing structure for use as a facility or possibly use of diversion structure with a new facility.

Groundwater evaluation: N/A

ENVIRONMENTAL CHARACTERISTICS/CONSTRAINTS

Adjacent stream habitat: River has moderate bedload movement

Anadromous fish:

Yes

Upland habitat type:

Grain field adjacent to site which is planted by ODF \& W for wildlife.

Wetlands:

Permitting Considerations:

The site is on an old gravel bar of river.

None identified beyond riparian zone. 


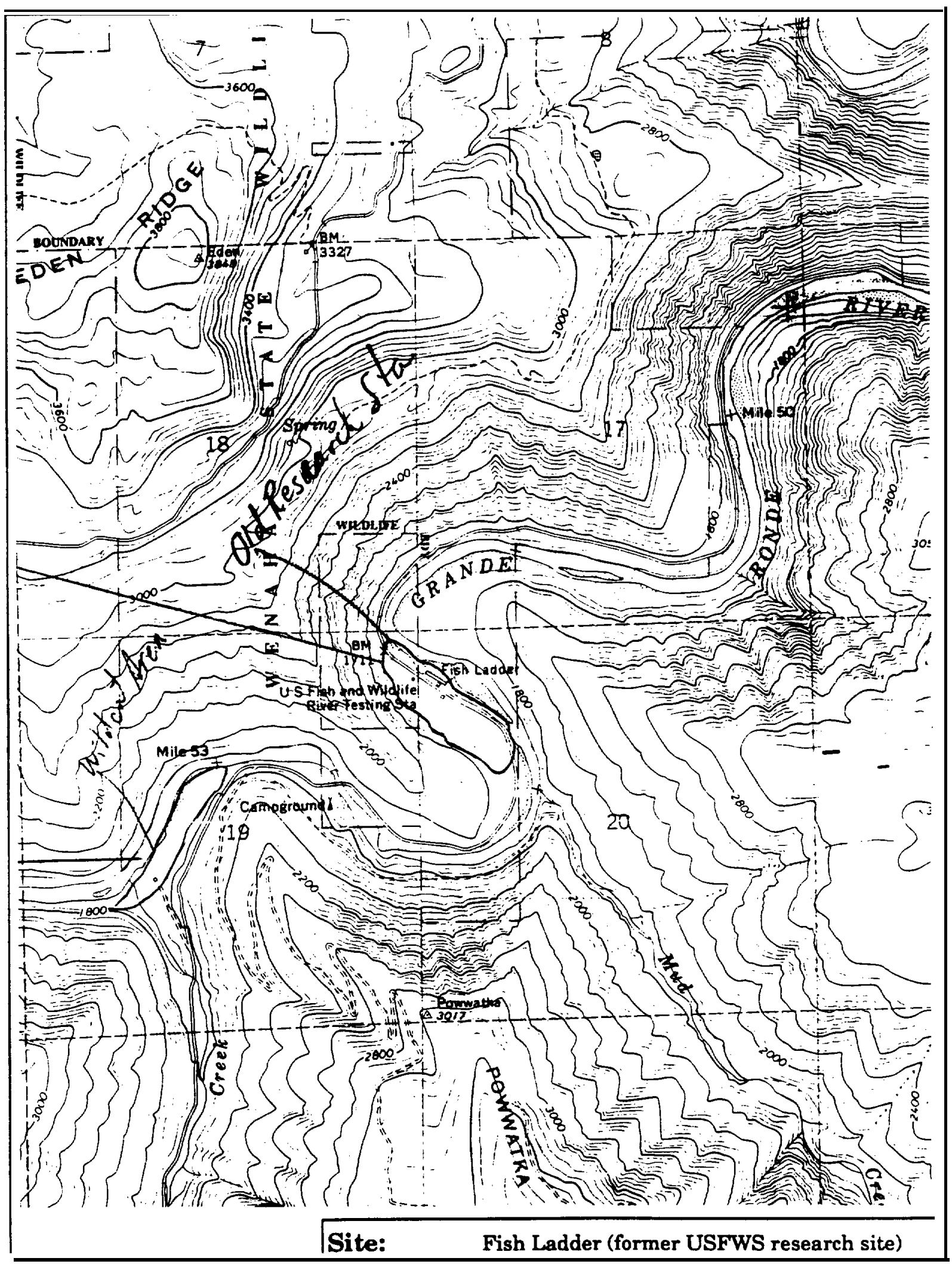




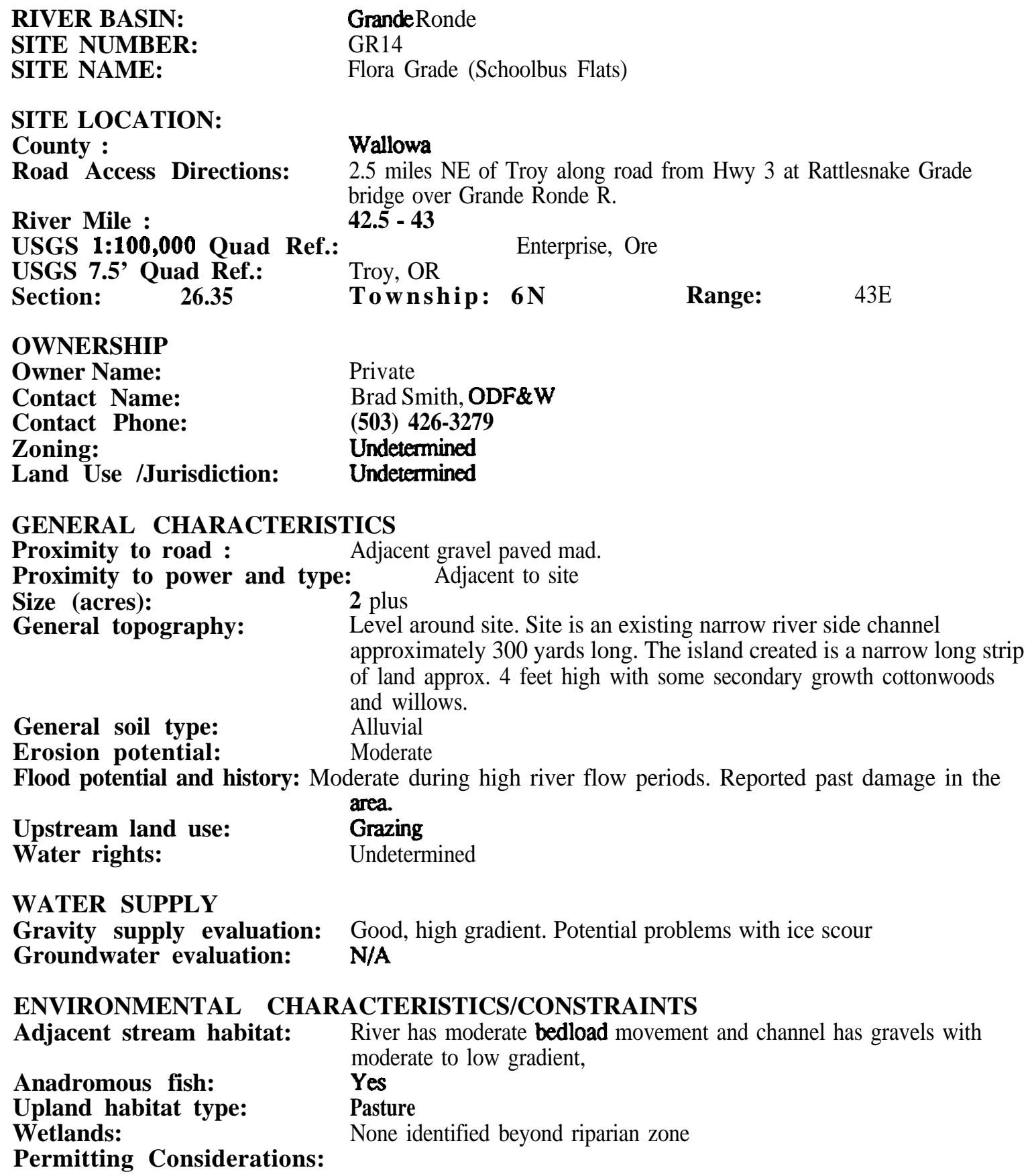




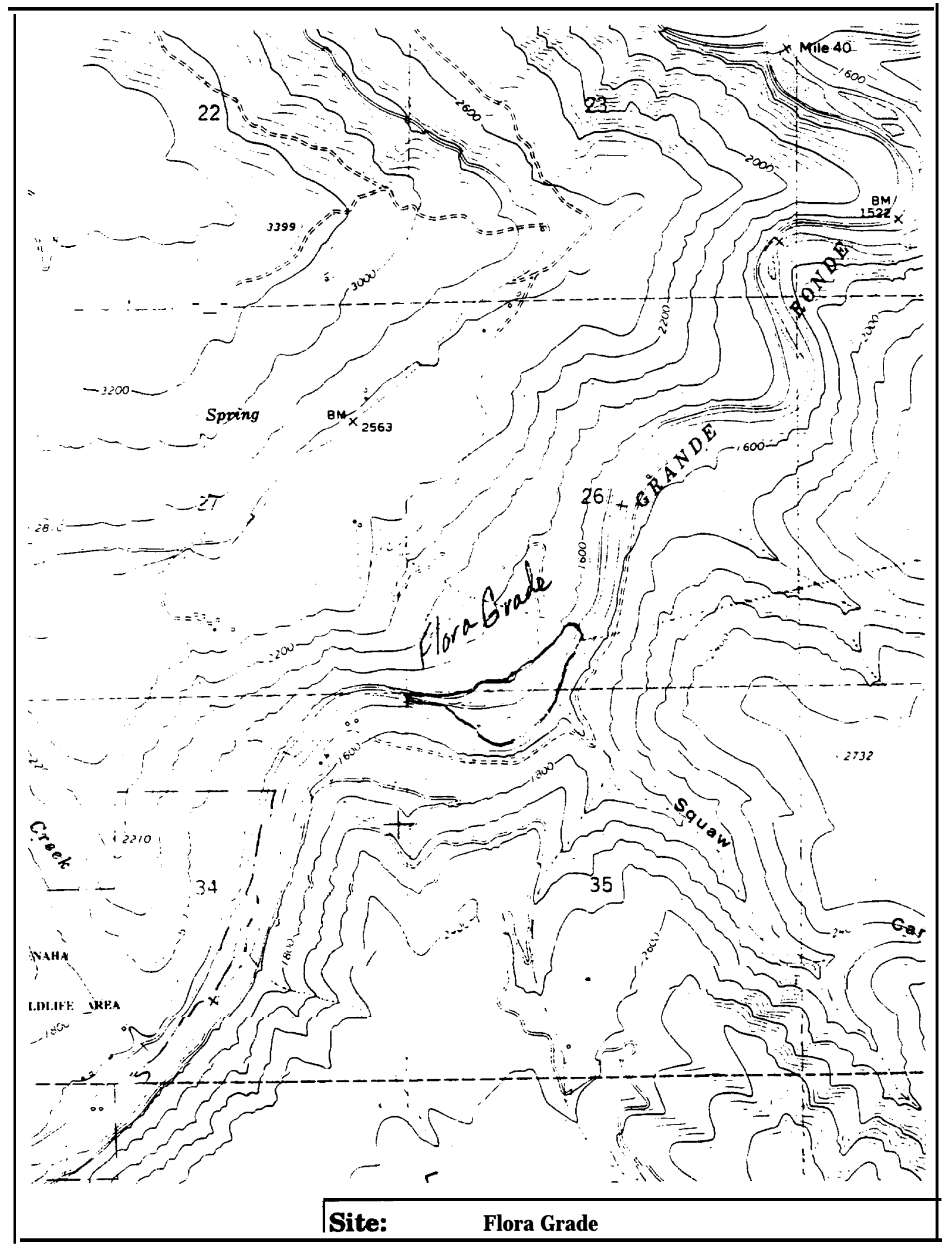


RIVER BASIN:

SITE NUMBER:

SITE NAME:

SITE LOCATION:

County :

Road Access Directions:
Grande Ronde

GR15

Cottonwood Creek. LSRCP Steelhead Acclimation Facility

Asotin, Wa.

Highway 129 north from Enterprise approximately 45 miles to bridge over Grande Ronde River. West along gravel road on north side of river forapproximately 2.25 miles to mouth of Cottonwood Creek.

River Mile : 28.7

USGS 1:100,000 Quad Ref.:

USGS 7.5' Quad Ref.:Mountain View, Wash.

Section: 33

Township : 7 N

Enterprise, Ore

Tow ns hip:

Washington Department of Wildlife

Brad Smith, ODF\&W

(503) 426-3279

Undetermined

Existing acclimation facility

OWNERSHIP

Contact Name:

Contact Phone:

Zoning:

Land Use /Jurisdiction:

GENERAL CHARACTERISTICS

Proximity to road :

Adjacent to road.

Proximity to power and type:

Size (acres):

Approx. 5

Power at existing facility

General topography:

General soil type:

Erosion potential:

Flood potential and history:

Upstream land use:

Water rights:

Level around site.

Alluvial

Low

Low

Grazing

Undetermined

\section{WATER SUPPLY}

Gravity supply evaluation: Existing gravity supply from Cottonwood Ck. used for steelhead acclimation. Could be developed to allow gravity supply from GRR if desired.

Groundwater evaluation: N/A

ENVIRONMENTAL CHARACTERISTICS/CONSTRAINTS

Adjacent stream habitat: River has moderate bedload movement

Anadromous fish:

Yes

Upland habitat type:

- Wetlands:

Permitting Considerations: steep slope, grassy

None identified beyond riparian zone. 


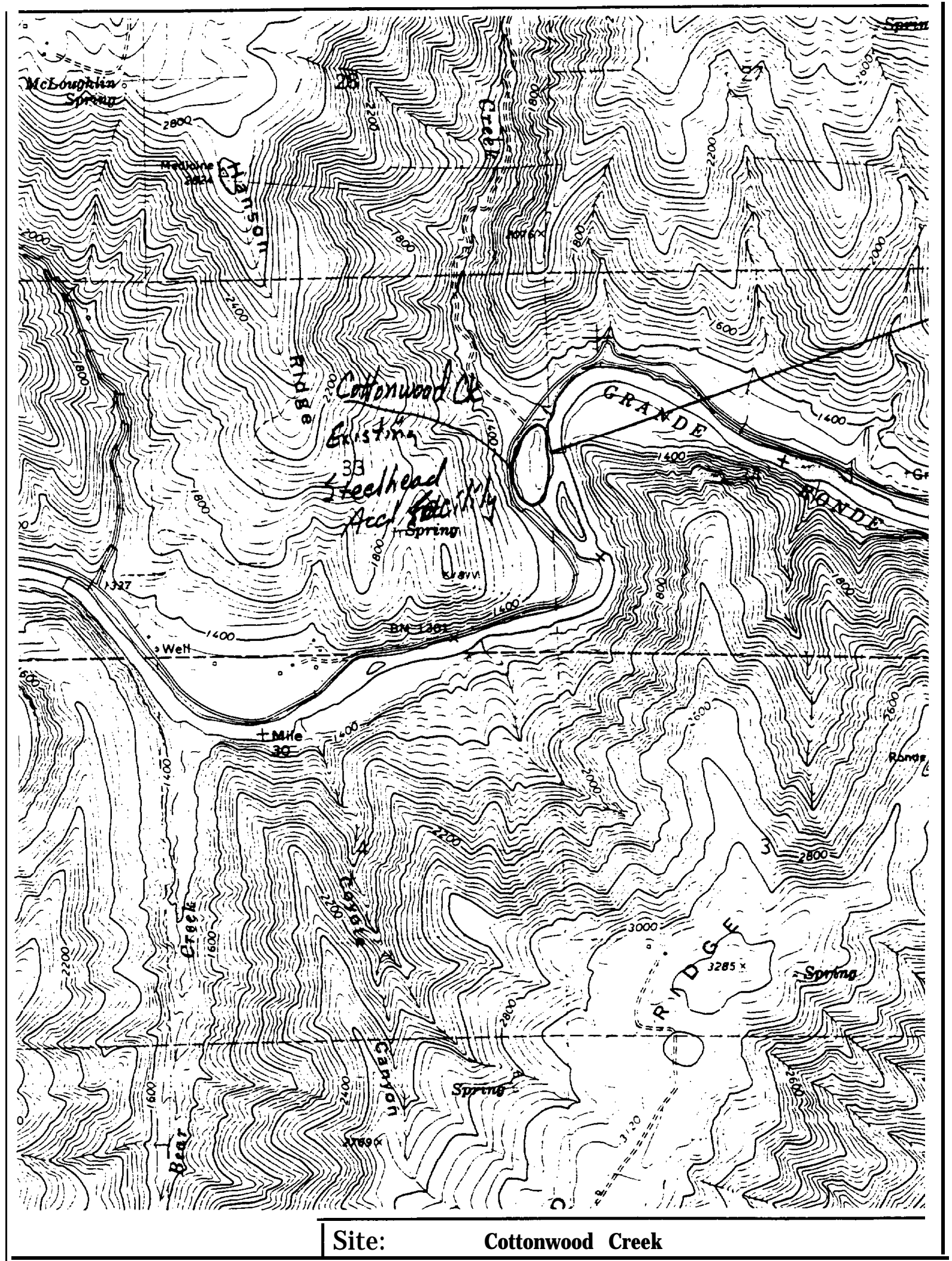




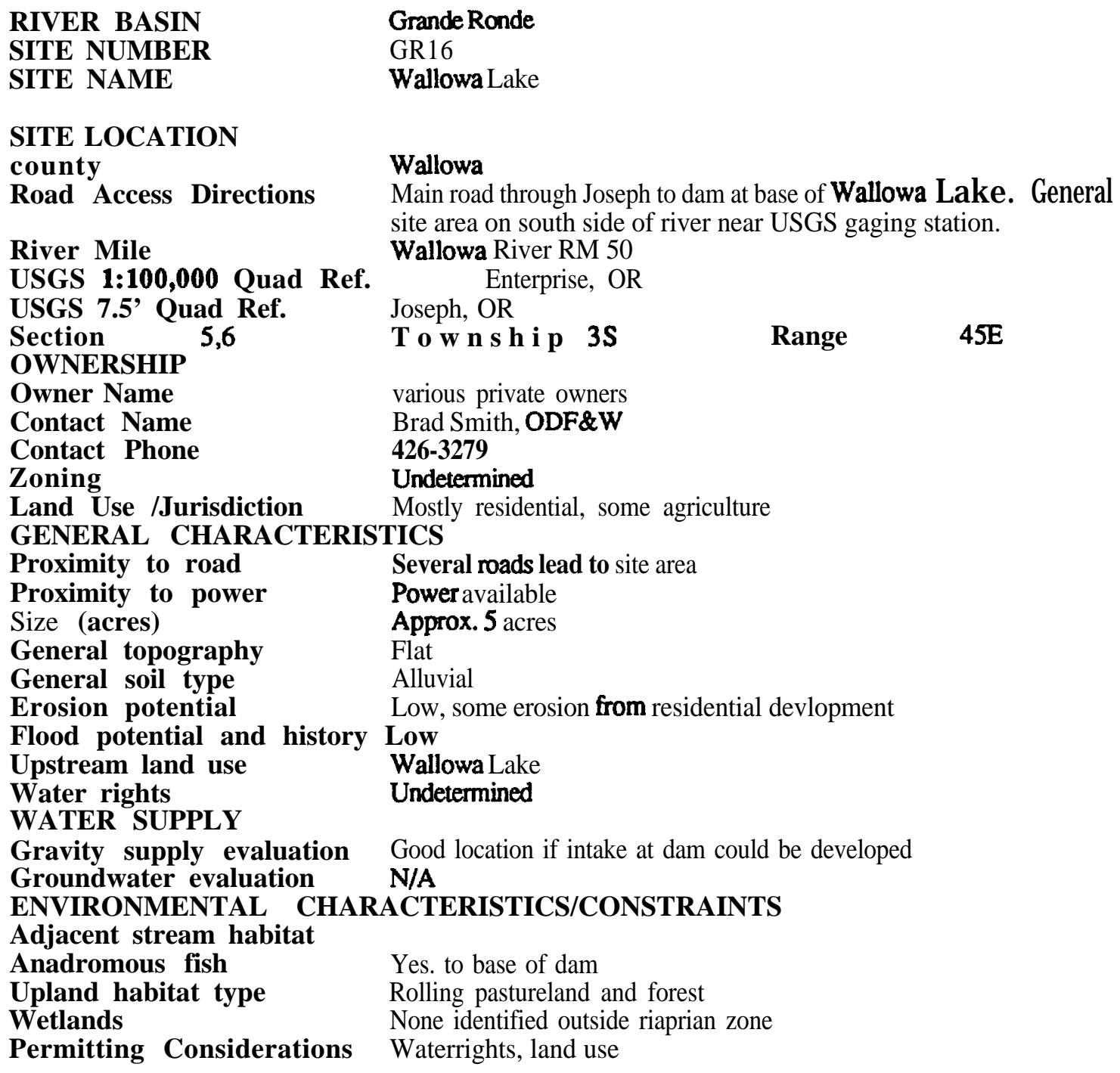




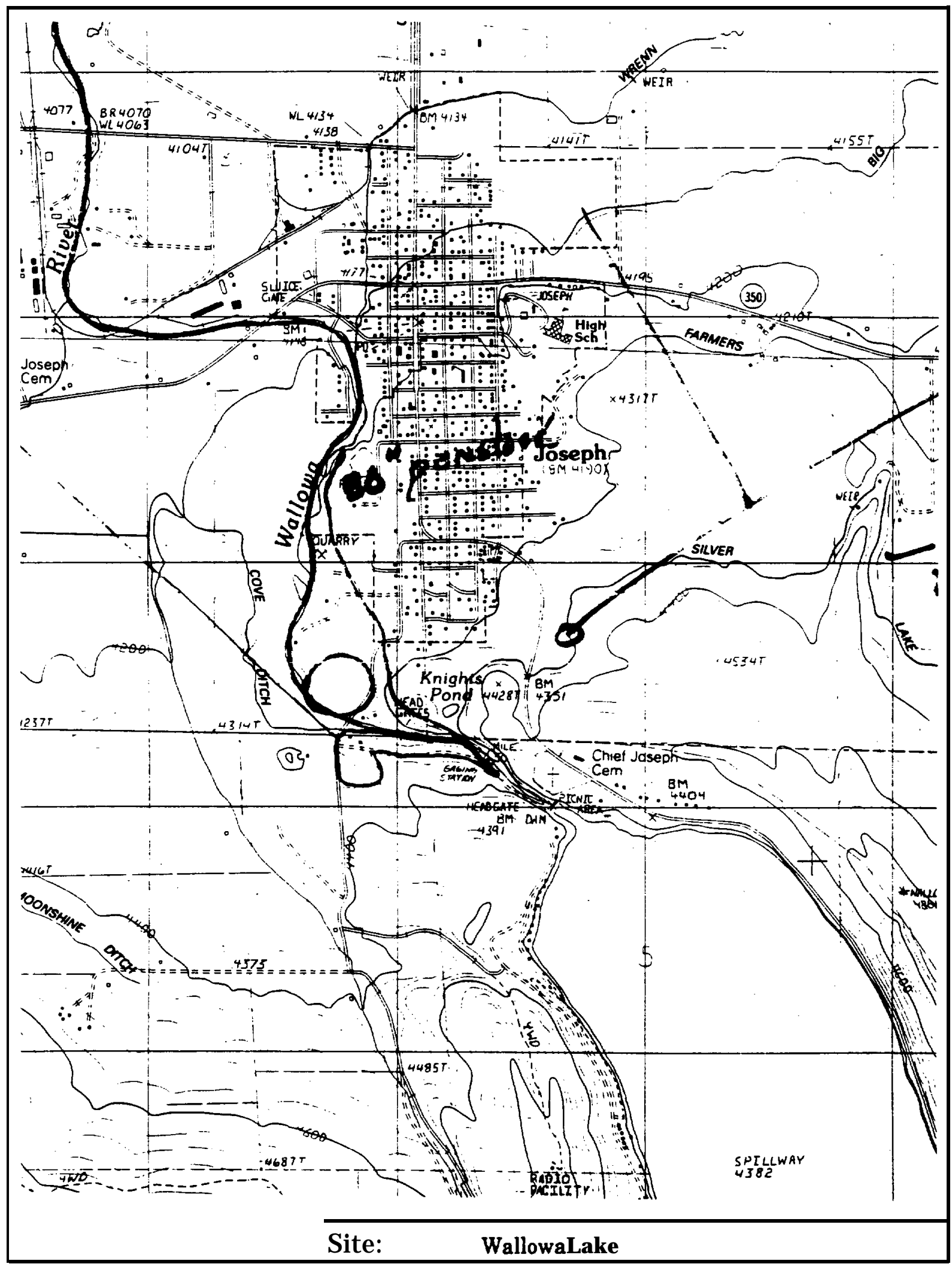




$\begin{array}{ll}\text { RIVER BASIN: } & \text { Wallowa } \\ \text { SITE NUMBER: } & \text { GR17 } \\ \text { SITE NAME: } & \text { Hayes Fork - Praire Ck. }\end{array}$

SITE LOCATION:

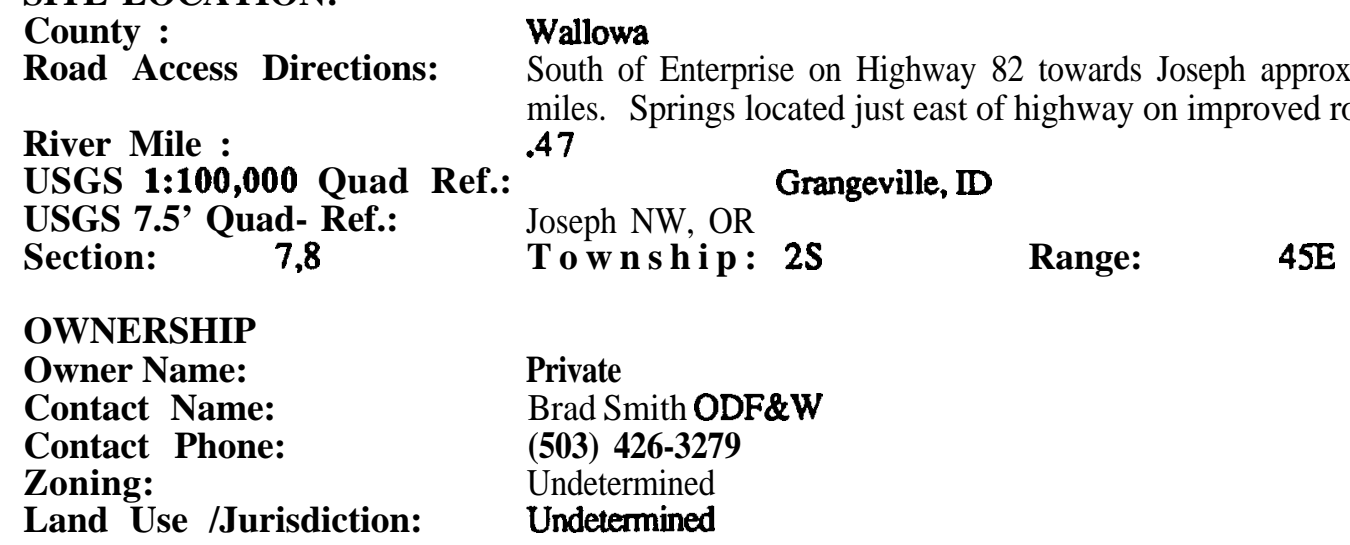

\section{GENERAL CHARACTERISTICS}

Proximity to road : Adjacent to gravel road.

Proximity to power and type: Power nearby

Size (acres): $\quad$ Some space for a small facility, but most of it appears to be wet

General topography: $\quad$ bettom

General soil type: Alluvial and very fine deposits.

Erosion potential: Low

Flood potential and history: Moderate

Upstream land use: Grazing

Water rights: Undetermined

\section{WATER SUPPLY}

Gravity supply evaluation: Low

Groundwater evaluation: Alluvial or glacial aquifers with good potential for $>\mathbf{5 0 0} \mathrm{gpm}$ wells.

\section{ENVIRONMENTAL CHARACTERISTICS/CONSTRAINTS}

Adjacent stream habitat: Moderate to fine materials in and along springs.

Anadromous fish:

No.

Upland habitat type: Pastures.

Wetlands: $\quad$ Yes, wet meadow vegetation at site.

Permitting Considerations: Water rights 


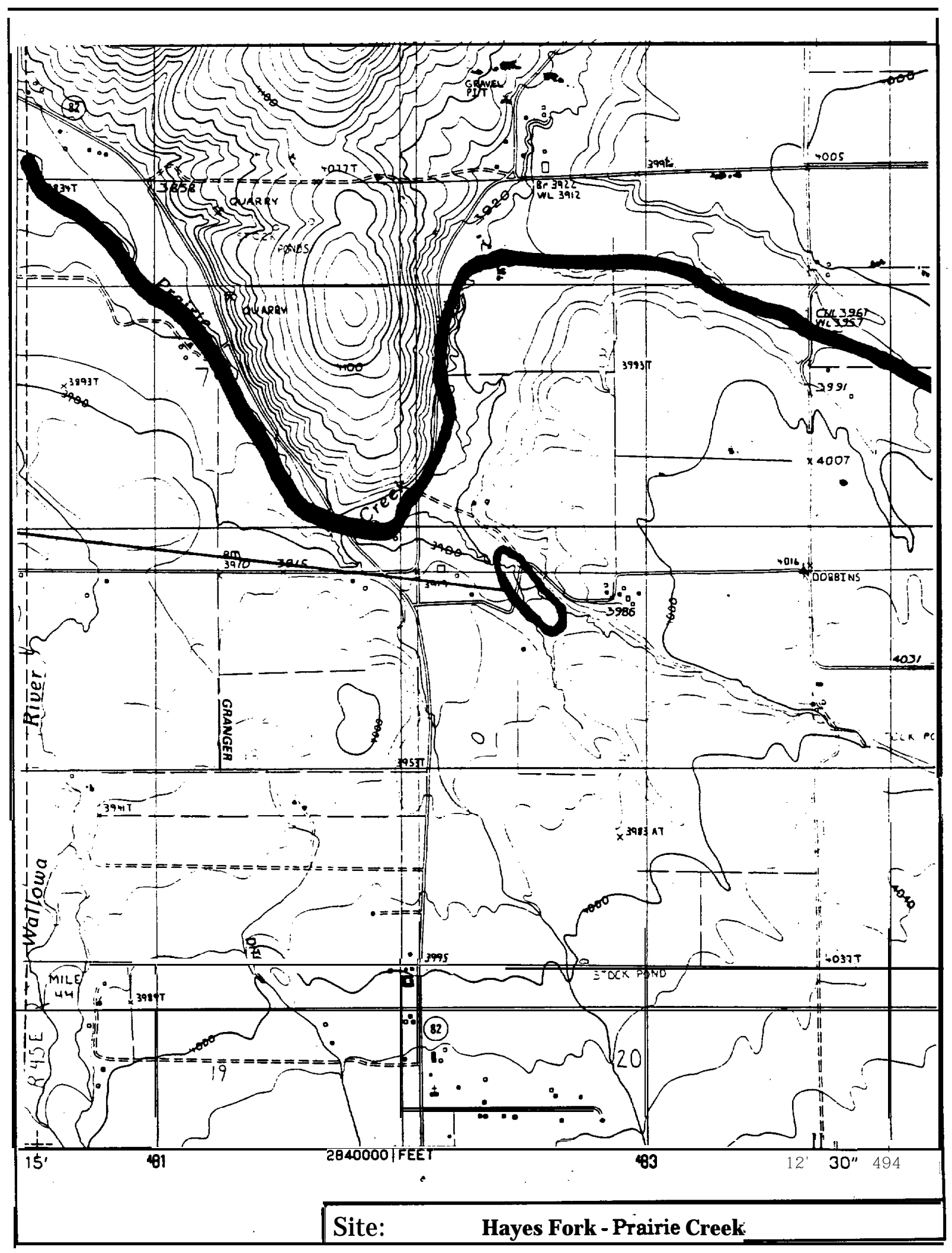




\begin{tabular}{|c|c|}
\hline $\begin{array}{l}\text { RIVER BASIN } \\
\text { SITE NUMBER } \\
\text { SITE NAME }\end{array}$ & $\begin{array}{l}\text { GrandeRonde } \\
\text { GR18 } \\
\text { Wallowa Hatchery }\end{array}$ \\
\hline $\begin{array}{l}\text { SITE LOCATION } \\
\text { County } \\
\text { Road Access Directions } \\
\text { River Mile } \\
\text { USGS 1:100,000 Quad Ref. } \\
\text { USGS 7.5' Quad Ref. } \\
\text { Section } \quad 3\end{array}$ & $\begin{array}{l}\text { Wallowa } \\
\text { On Fish Hatchery Road, SW side of Enterprise. } \\
\text { Wallowa River RM } 40 \\
\quad \text { Grangeville. ID } \\
\text { Enterprise, OR } \\
\text { Tow n s i p } 2 \text { 2S }\end{array}$ \\
\hline $\begin{array}{l}\text { OWNERSHIP } \\
\text { Owner Name } \\
\text { Contact Name } \\
\text { Contact Phone } \\
\text { Zoning } \\
\text { Land Use /Jurisdiction }\end{array}$ & $\begin{array}{l}\text { ODF\&W } \\
\text { Brad Smith, ODF\&W } \\
\mathbf{4 2 6 - 3 2 7 9} \\
\text { Undetermined } \\
\text { Existing hatchery }\end{array}$ \\
\hline $\begin{array}{l}\text { GENERAL CHARACTERIST } \\
\text { Proximity to road } \\
\text { Proximity tp power } \\
\text { Size (acres) } \\
\text { General topography } \\
\text { General soil type } \\
\text { Erosion potential } \\
\text { Flood potential and history } \\
\text { Upstream land use } \\
\text { Water rights }\end{array}$ & $\begin{array}{l}\text { TICS } \\
\text { Developed facility with improved road access } \\
\text { Developed facility with existing power supply } \\
5-10 \\
\text { Flat } \\
\text { Alluvial } \\
\text { Low } \\
\text { Low } \\
\text { Agriculture, residential } \\
\text { Undetermined }\end{array}$ \\
\hline $\begin{array}{l}\text { WATER SUPPLY } \\
\text { Gravity supply evaluation } \\
\text { Groundwater evaluation }\end{array}$ & $\begin{array}{l}\text { Good existing supply } \\
\text { Esixting development, Moderate potential for expanded development }\end{array}$ \\
\hline $\begin{array}{l}\text { ENVIRONMENTAL CHAR } \\
\text { Adjacent stream habitat } \\
\text { Anadromous fish } \\
\text { Upland habitat type } \\
\text { Wetlands } \\
\text { Permitting Considerations }\end{array}$ & $\begin{array}{l}\text { ACTERISTICS/CONSTRAINTS } \\
\text { Yes } \\
\text { Deciduous riparian zone, pasture } \\
\text { None identified beyond riparian zone }\end{array}$ \\
\hline
\end{tabular}




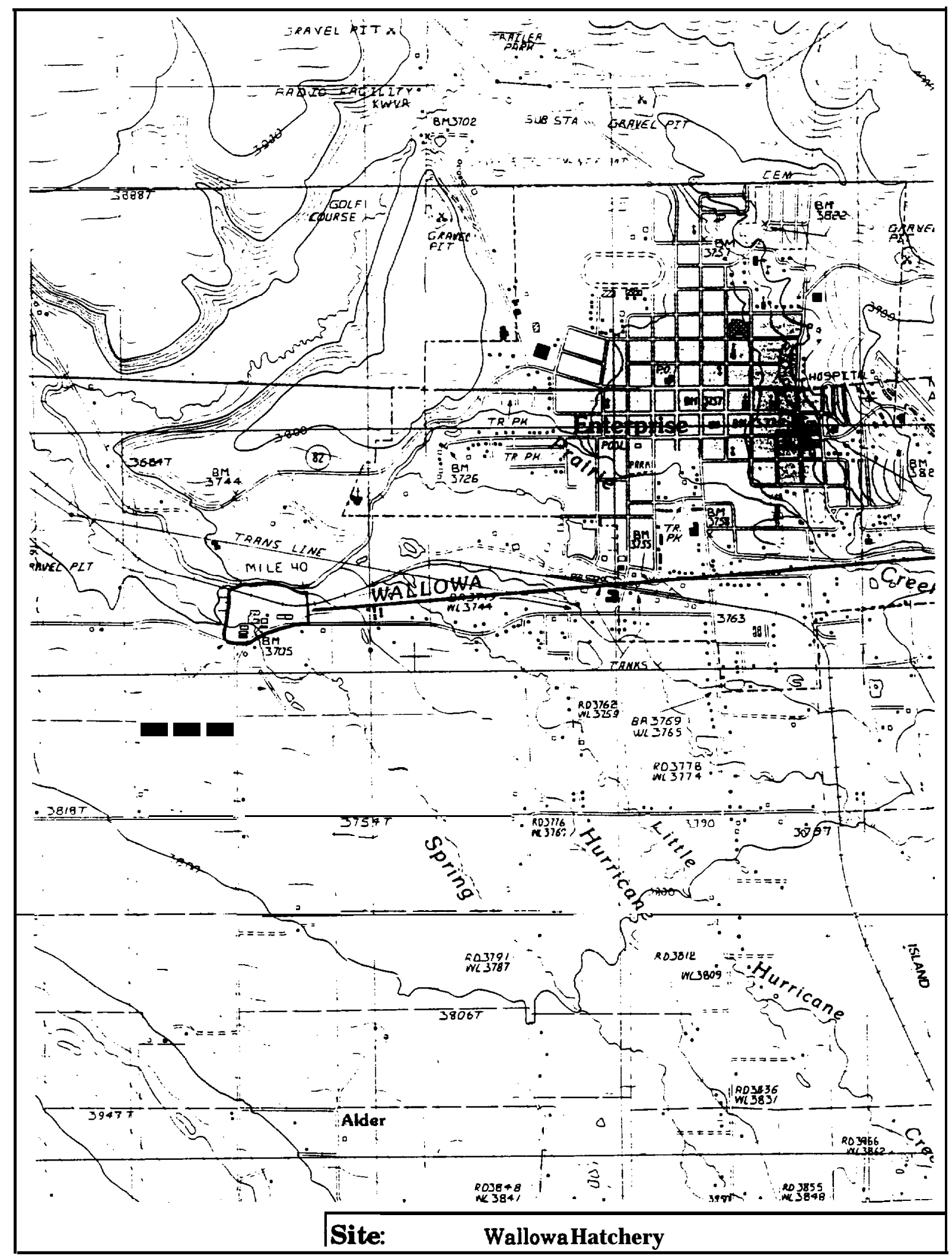




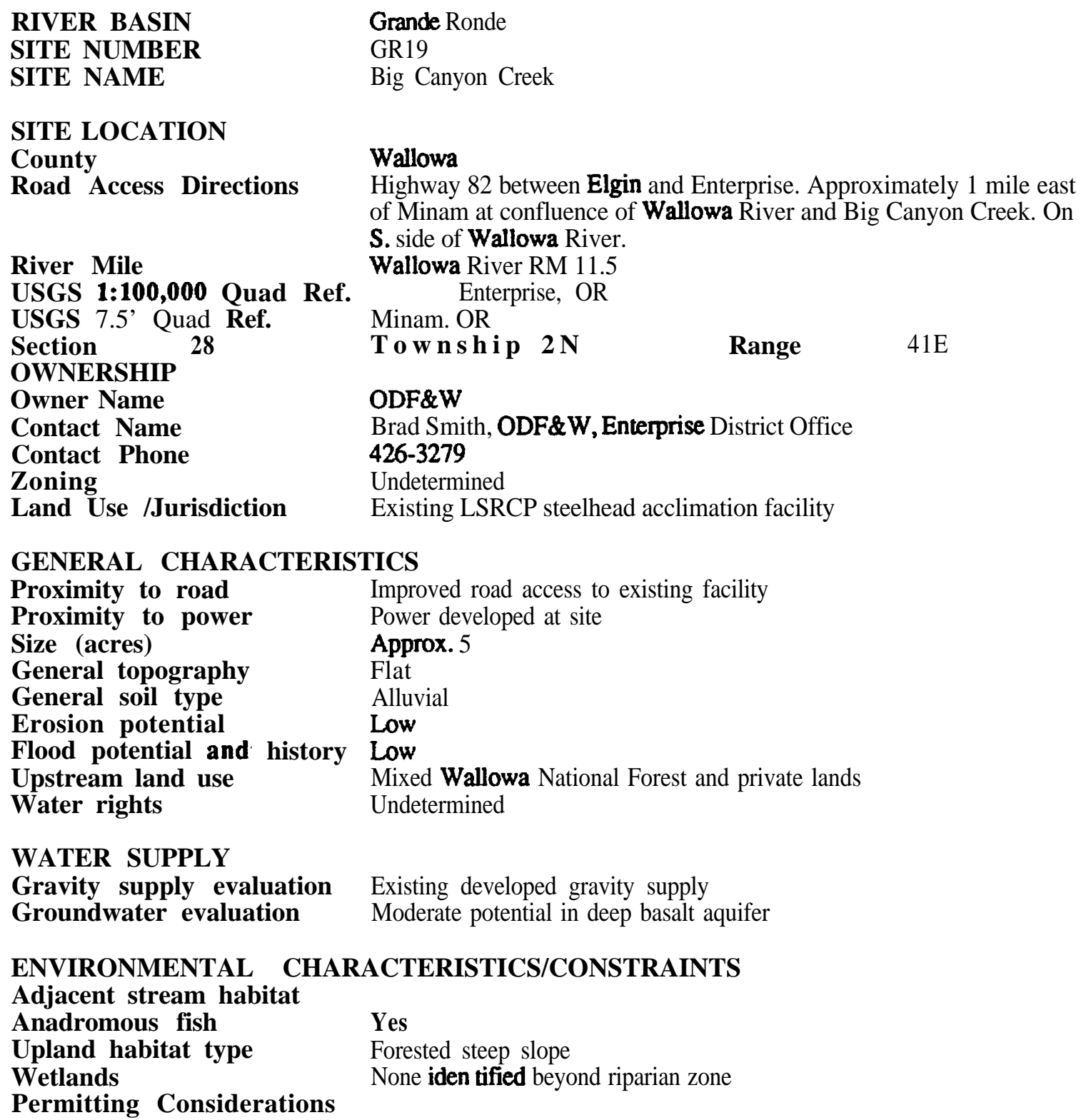




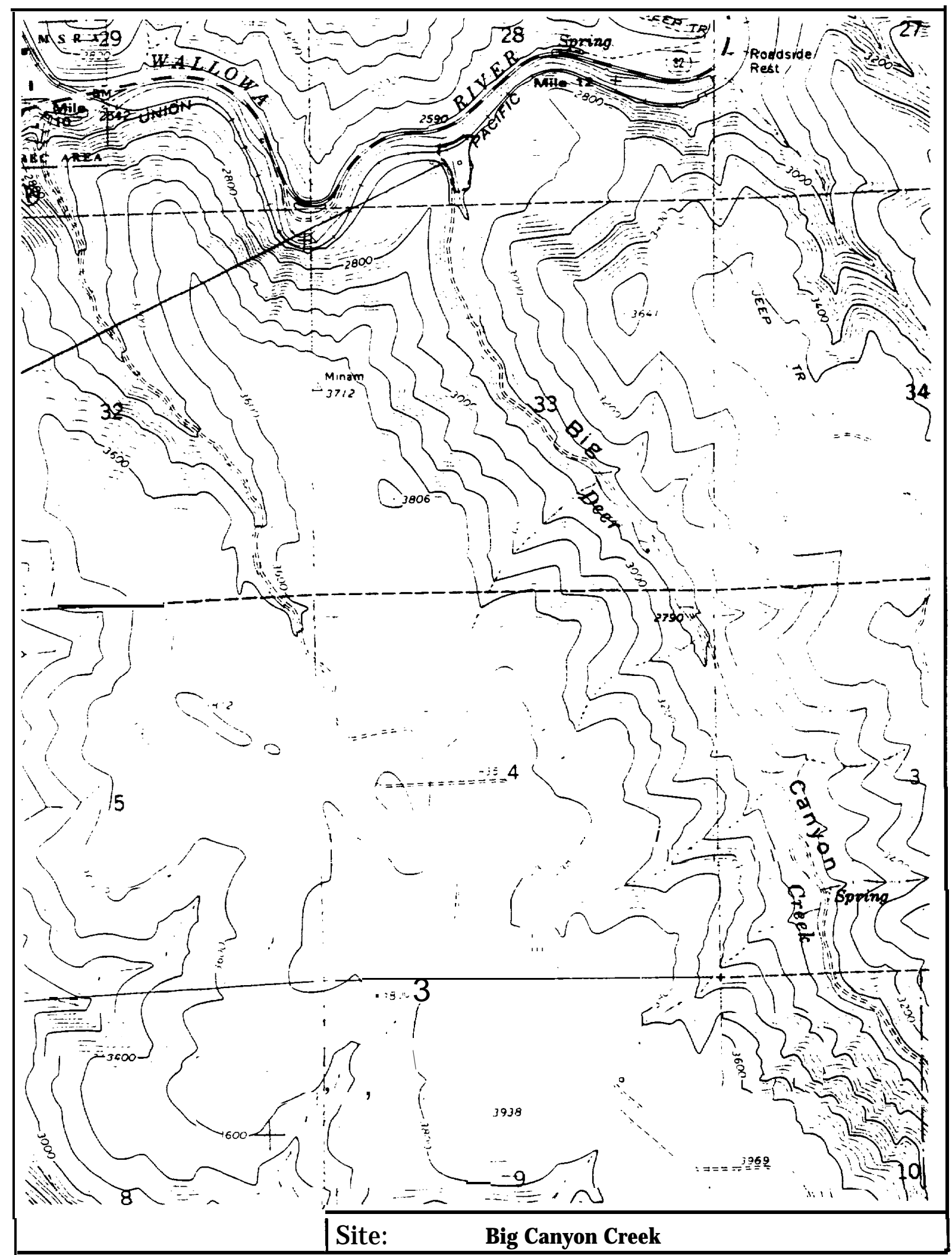


RIVER BASIN

SITE NUMBER

SITE NAME

S I T E L OCA T I O N

County

Road Access Directions

River Mile

USGS 1:100,000 Quad Ref. USGS 7.5' Quad Ref.

Section 29

OWNERSHIP

Owner Name

Contact Name

Contact Phone

Zoning

Land Use /Jurisdiction
Grande Ronde

GR20

Minam-Wallowa Confluence

\section{Wallowa}

Highway 82 east from Elgin to Minam. Site is flat bench between river and highway on south side of road just before highway bridge over river.

Wallowa River RM 9.5

Minam, OR

Enterprise, OR

Township 2 N

Range

$41 E$

Oregon State Parks

Brad Smith, ODF\&W, Enterprise District Office

426-3279

Undetermined

State Park/State of Oregon

GENERAL CHARACTERISTICS

Proximity to road

Proximity to power

Size (acres)

Adjacent to highway

Adjacent to power

General topography

General soil type

Approx. 5- 10

Flat bench approx. 10 feet above river

Alluvial

Moderate along river edge

Flood potential and history Moderate

Upstream land use

Water rights

Generally undeveloped, railroad and highway parallel Wallowa River Undetermined

WATER SUPPLY

Gravity supply evaluation

Groundwater evaluation

Potential upstream on Minam

Moderate potential for development of groundwater in deep basalt aquifer

ENVIRONMENTAL CHARACTERISTICS/CONSTRAINTS

Adjacent stream habitat Broad rocky stream with low gradient.

Anadromous fish

Yes

Upland habitat type

Forested steep slope

Wetlands

None identified beyond riparian zone.

Permitting Considerations

Land use and zoning in Minam State Recreation Area. Minam is Wild and Scenic River 


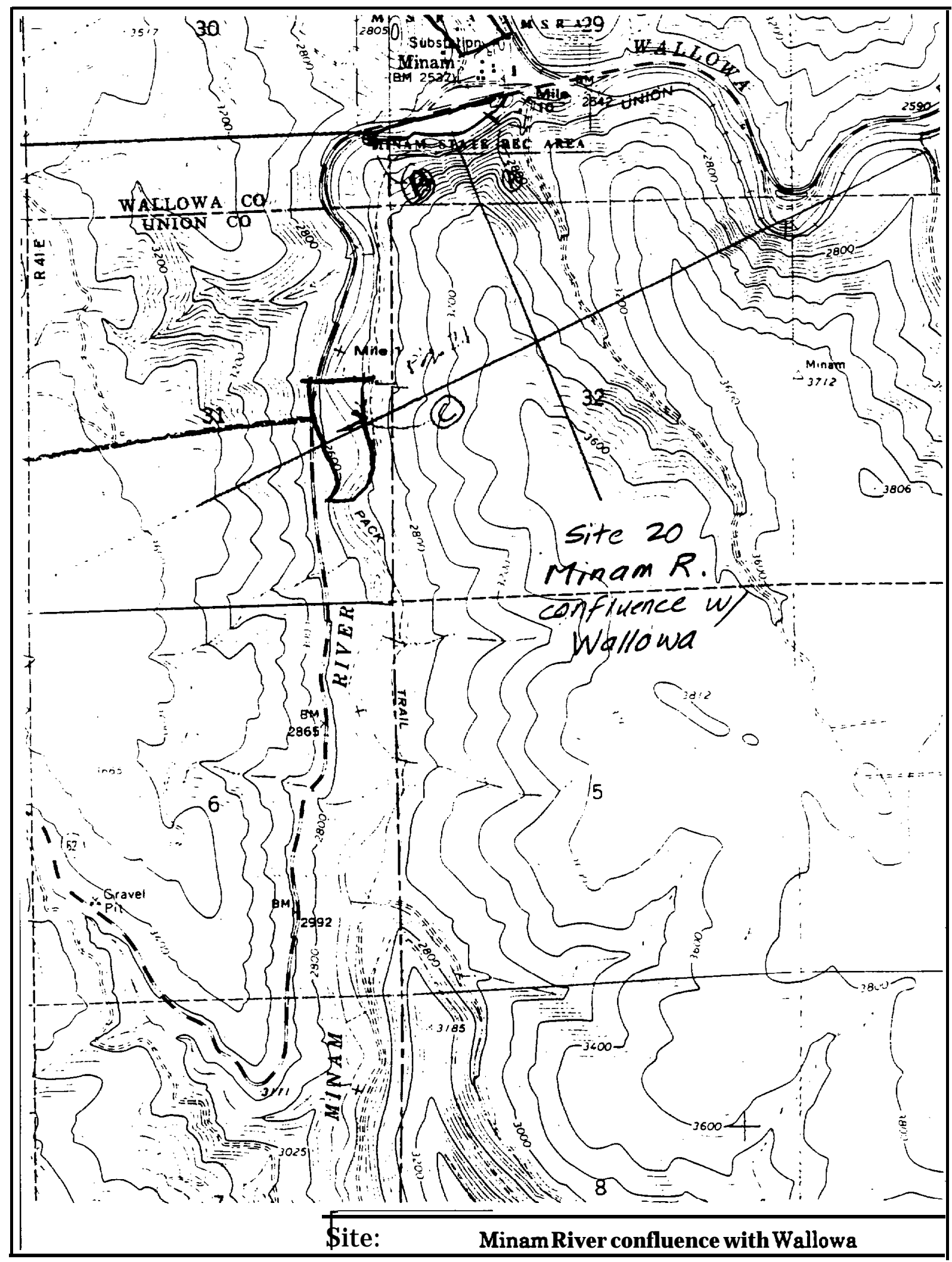




\begin{tabular}{|c|c|}
\hline $\begin{array}{l}\text { RIVER BASIN: } \\
\text { SITE NUMBER: } \\
\text { SITE NAME: }\end{array}$ & $\begin{array}{l}\text { Lostine River } \\
\text { GR21 } \\
\text { ODF\&W Big Horn Sheep Range }\end{array}$ \\
\hline $\begin{array}{l}\text { SITE LOCATION: } \\
\text { County : } \\
\text { Road Access Directions: }\end{array}$ & $\begin{array}{l}\text { Wallowa } \\
\text { Five plus miles south of Lostine on the Lostine River Rd. to area } \\
\text { south and east of Pole Bridge. }\end{array}$ \\
\hline $\begin{array}{l}\text { River Mile : } \\
\text { USGS 1:100,000 Quad Ref.: } \\
\text { USGS 7.5' Quad Ref.: Lostine, }\end{array}$ & OR $\quad$ Enterprise, OR \\
\hline Section: $\quad 10$ & Township: 2 S \\
\hline $\begin{array}{l}\text { OWNERSHIP } \\
\text { Owner Name: } \\
\text { Contact Name: } \\
\text { Contact Phone: } \\
\text { Zoning: } \\
\text { Land Use /Jurisdiction: }\end{array}$ & $\begin{array}{l}\text { ODF\&W } \\
\text { Brad Smith, ODF\&W, Enterprise District Office } \\
\mathbf{( 5 0 3 )} \mathbf{4 2 6 - 3 2 7 9} \\
\text { Undetermined } \\
\text { Big Game wintering area/ODF\&W. }\end{array}$ \\
\hline
\end{tabular}

GENERAL CHARACTERISTICS

Proximity to road : $\quad$ Adjacent to the paved Lostine River Rd

Proximity to power and type: Adjacent.

Size (acres): $>10$.

General topography: Level throughout area.

General soil type: Alluvial deposits.

Erosion potential: Low. The river has a very high gradient through this area which shows extremely high, large diameter bedload movement. Appears to have very severe icing condition which scours channel creating mounded gravel banks.

Flood potential and history: Potentially high immediately adjacent to the river.

Upstream land use: $\quad$ Eagle Cap Wilderness Area.

Water rights: $\quad$ Undetermined

WATER SUPPLY

Gravity supply evaluation: May be very difficult due to extremely high bedload movement.

Groundwater evaluation: Moderate to good potential for $>500$ gpm wells based upon geology and local well logs. Glacial or alluvial aquifers.

ENVIRONMENTAL CHARACTERISTICS/CONSTRAINTS

Adjacent stream habitat: Extreme large size bedload movement through entire area.

Anadromous fish: Steelhead and Chinook.

Upland habitat type: $\quad$ Evergreen trees and cottonwoods throughout site.

Wetlands: $\quad$ None identified outside riparian zone.

Permitting Considerations: Groundwater rights. 


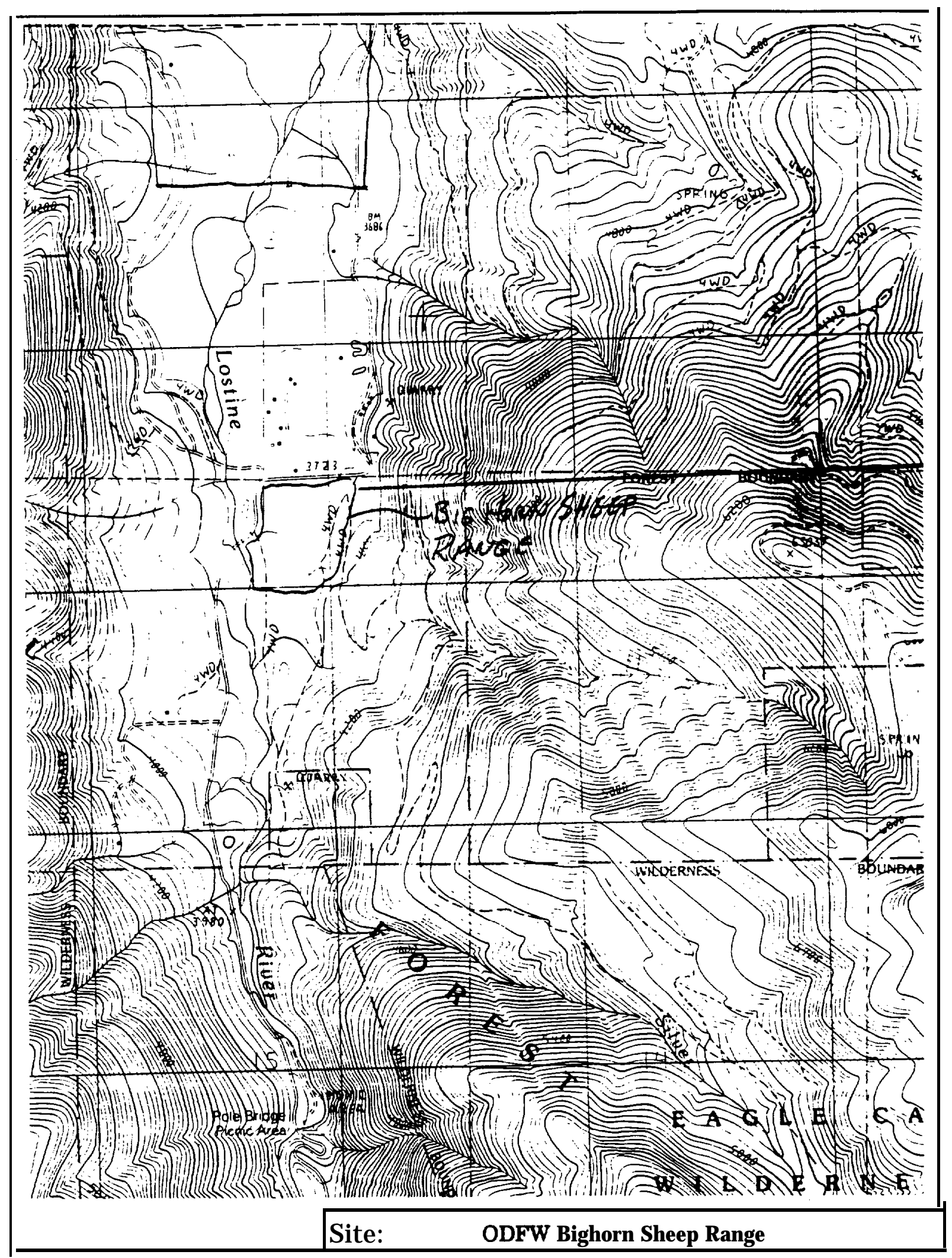


RIVER BASIN:

SITE NUMBER:

SITE NAME:

SITE LOCATION:

County :

Road Access Directions:

River Mile :

USGS 1:100,000 Quad Ref.: USGS 7.5' Quad Ref.:

Section: $\quad 34$

O W N E R S H I P

Owner Name:

Contact Name:

Contact Phone:

Zoning:

Land Use /Jurisdiction:
Lostine River

GR22

Strathearn Ranch

Wallowa

Approximately 4 miles south of Lostine on the Lostine River Rd. Site is approximately $\mathbf{1 0 0}$ yards off gravel drive leading to ranch on north side of moraine. 10

Lostine, OR

Enterprise, Ore.

Township: 1 S

Range:

$43 \mathrm{E}$

\section{GENERAL CHARACTERISTICS}

Proximity to road : Less than $\mathbf{1 / 2}$ mile on gravel road from Lostine River Rd.

Proximity to power and type: 3 Phase power to site.

Size (acres): Approximately 5 acres

General topography: Level bench adjacent to river.

General soil type: Alluvial deposits.

Erosion potential: Low

Flood potential and history: Low

Upstream land use: $\quad$ Farming and ranching.

Water rights:

Undetermined

WATER SUPPLY

Gravity supply evaluation: Possible using a weir which would have to be constructed in the vicinity of the reservoir to achieve adequate head. Buried supply pipeline under moraine to site.

Groundwater evaluation: Moderate to good potential for $>500 \mathrm{gpm}$ wells based upon geology and local well logs. Glacial or alluvial aquifers.

ENVIRONMENTAL CHARACTERISTICS/CONSTRAINTS

Adjacent stream habitat: Low bedload movement through a the relative flat gradient reach above potential site.

Anadromous fish: Steelhead and Chinook. Upland habitat type: $\quad$ Forested upland area. pasture, meadow and private residence. Wetlands: None identified outside riparian zone.

Permitting Considerations: Water rights. 


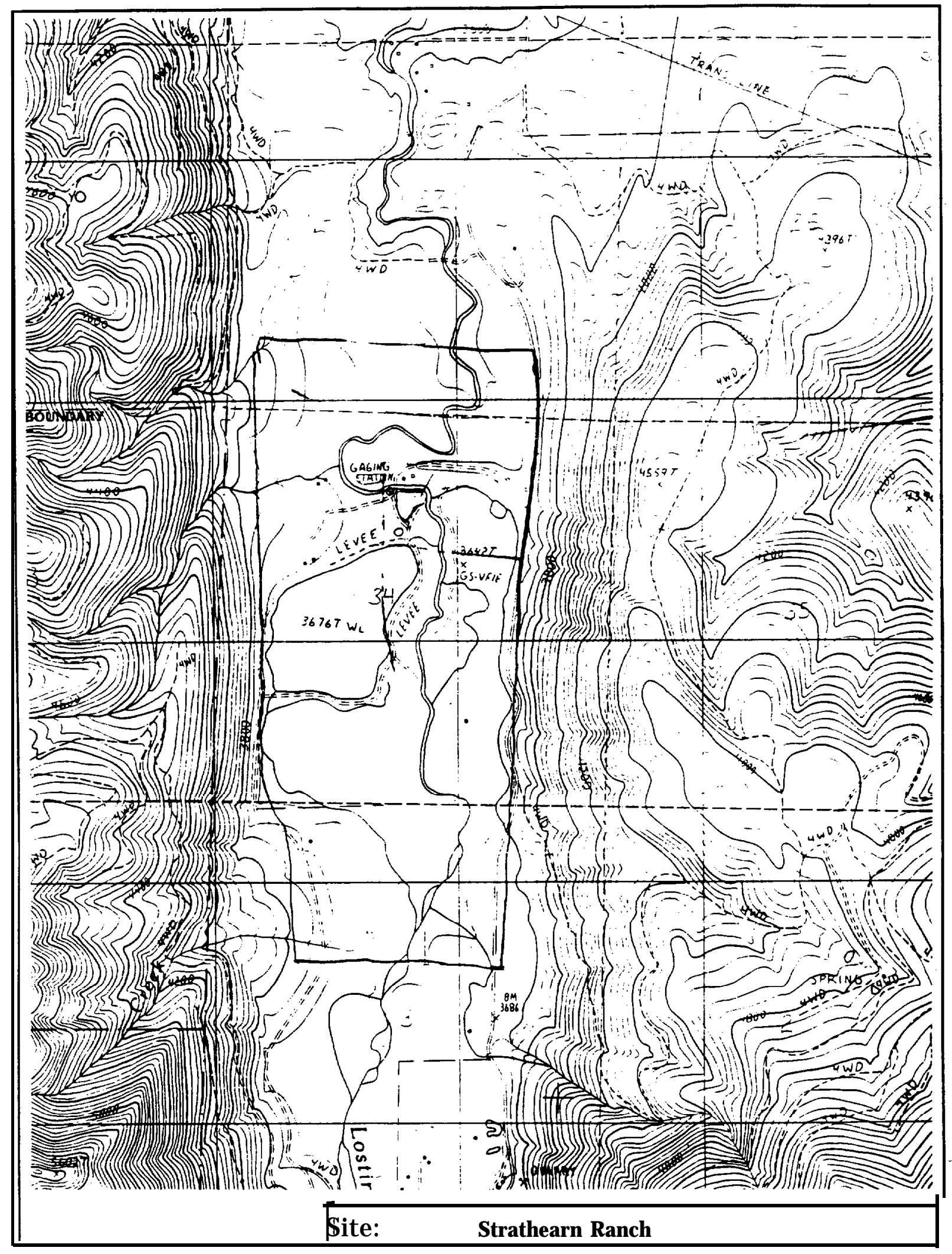


RIVER BASIN:

SITE NUMBER:

SITE NAME:

SITE LOCATION:

County :

Road Access Directions:

River Mile :

USGS 1:100,000 Quad Ref.:

USGS 7.5' Quad Ref.:

Section:

22

OWNERSHIP

Owner Name:

Contact Name:

Contact Phone:

Zoning:

Land Use /Jurisdiction:

GENERAL CHARACTERISTICS

Proximity to road :

Proximity to power and type:

This site is for adult capture facility. The existing dam and diversion is very old, but constructed to allow adult fish passage. Immediately upstream, the river is natrower. The best location for a capture facility would require obtaining private land across from paved road. Access would be by private drive and wood bridge.

\section{Size (acres):}

General topography:

General soil type:

Erosion potential:

Flood potential and

Upstream land use:

Water rights:

$$
\text { Adjacent. }
$$

Land is a very large pasture, $>\mathbf{1 0}$ acres.

Very limited level area available on east side. West side has narrow river bottom and flood plain with large pasture.

Alluvial deposits.

Low

Moderate

Farming and ranching.

Undetermined, irrigation diversion at dam.

\section{WATER SUPPLY}

Gravity supply evaluation: Possible using a diversion weir.

Groundwater evaluation: N/A

\section{ENVIRONMENTAL CHARACTERISTICS/CONSTRAINTS}

Adjacent stream habitat: High bedload movement.

Anadromous fish:

St\&head and Chinook.

Upland habitat type:

Wetlands:

Riparian vegetation along river. Upland area pasture

Permitting Considerations: Water rights. 


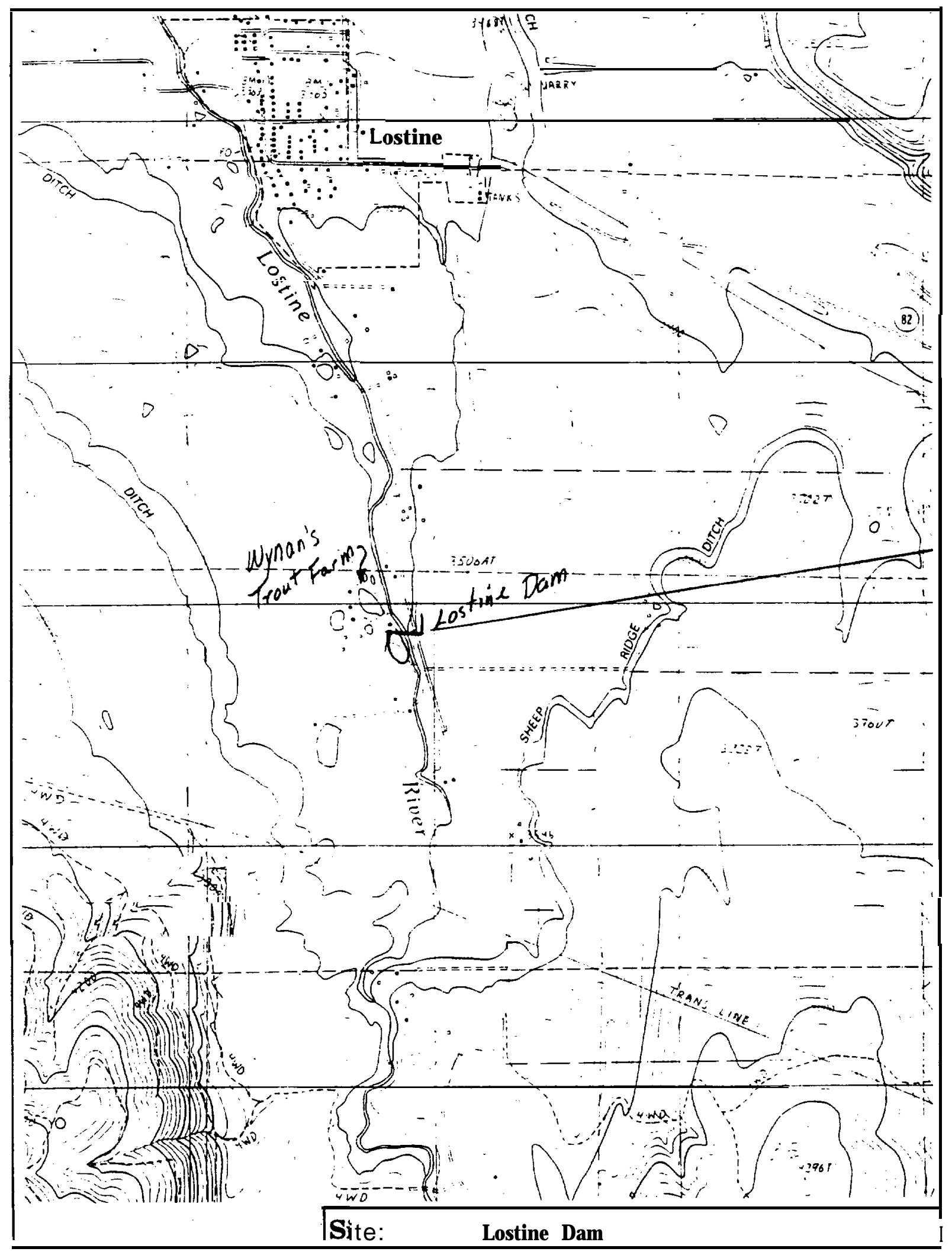


RIVER BASIN:

SITE NUMBER:

SITE NAME:

SITE LOCATION:

County :

Road Access Directions:

River Mile :

USGS 1:100,000 Quad Ref.: USGS 7.5' Quad Ref.:

Section: $\quad 32.33$

OWNERSHIP

Owner Name:

Contact Name:

Contact Phone:

Zoning:

Land Use/Jurisdiction:
Lostine River

GR24

Cross-Valley Diversion (Clear Water Ditch)Jerry Mc Clear Ranch)

\section{GENERAL CHARACTERISTICS}

Proximity to road : Estimated at $1 / 2$ mile upstream of ranch building. No vehicle access. A road would have to be constructed, which would encroach on field.

Proximity to power and type:

Wallowa

East on gravel road off Hwy 82, approximately 3 miles north of Lostine at the McClear Ranch.

Evans, Ore. Enterprise, Ore.

Township: 1 N

Range:

$43 \mathrm{E}$
Size (acres):

General topography:

General soil type:

Erosion potential:

Flood potential 'and history: High

Upstream land use: $\quad$ Farming and ranching.

Water rights:

WATER SUPPLY

Gravity supply evaluation: Possible using a diversion weir.

Groundwater evaluation: N/A

ENVIRONMENTAL CHARACTERISTICS/CONSTRAINTS

Adjacent stream habitat: High bedload movement.

Anadromous fish:

Upland habitat type:

Wetlands:

Permitting Considerations: Water rights Estimated at $1 / 2$ mile from ranch.

Very little on river. May he enough for small temporary adult holding, if site used for adult capture.

Limited level area available. River bottom and flood plain..

Alluvial deposits.

High

Farming and ranching.
Undetermined

Steelhead and Chino\&.

Mature cottonwoods and riparian vegetation along river. Upland area is farmed land.

River bottom riparian zone. 


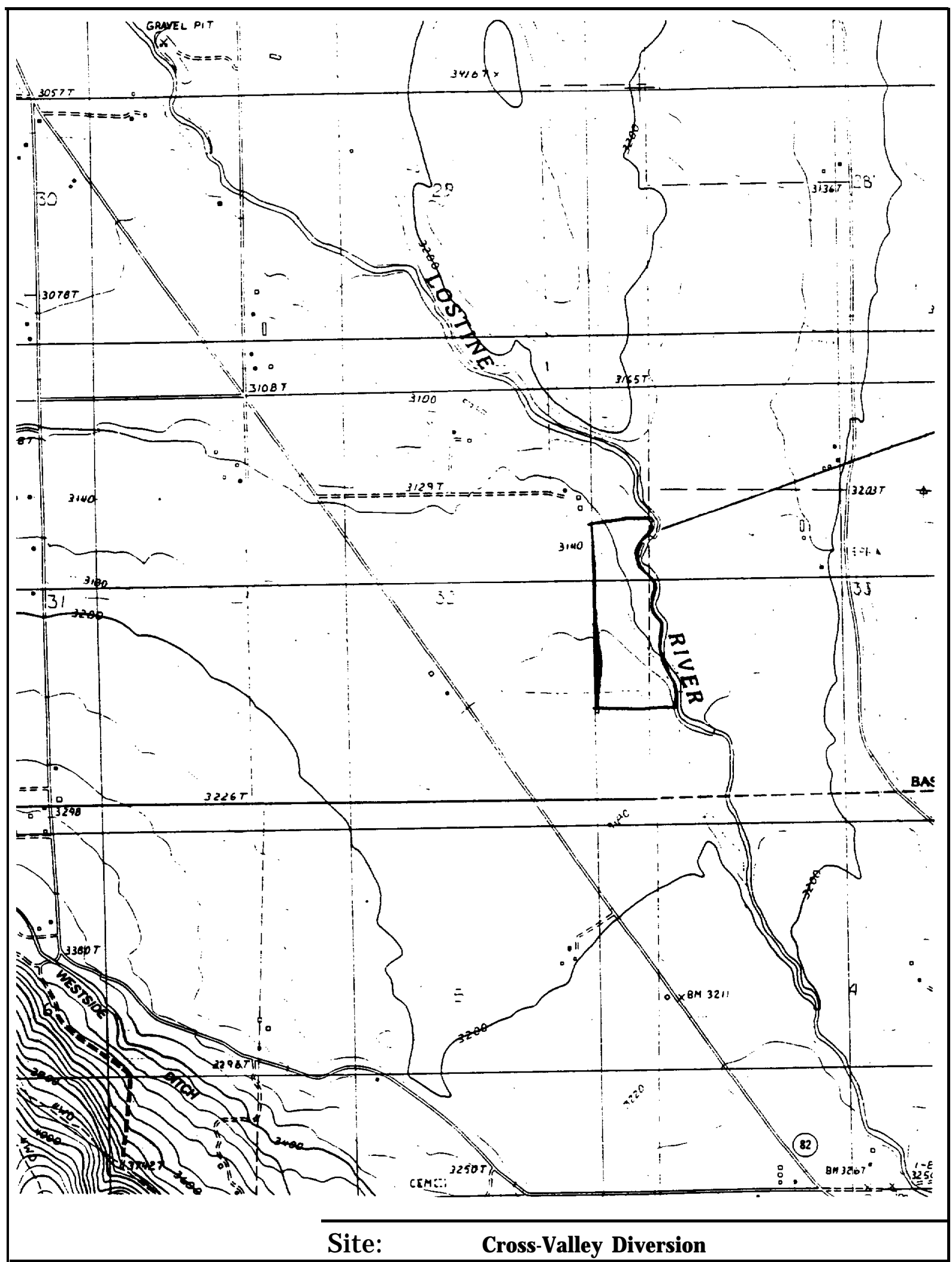




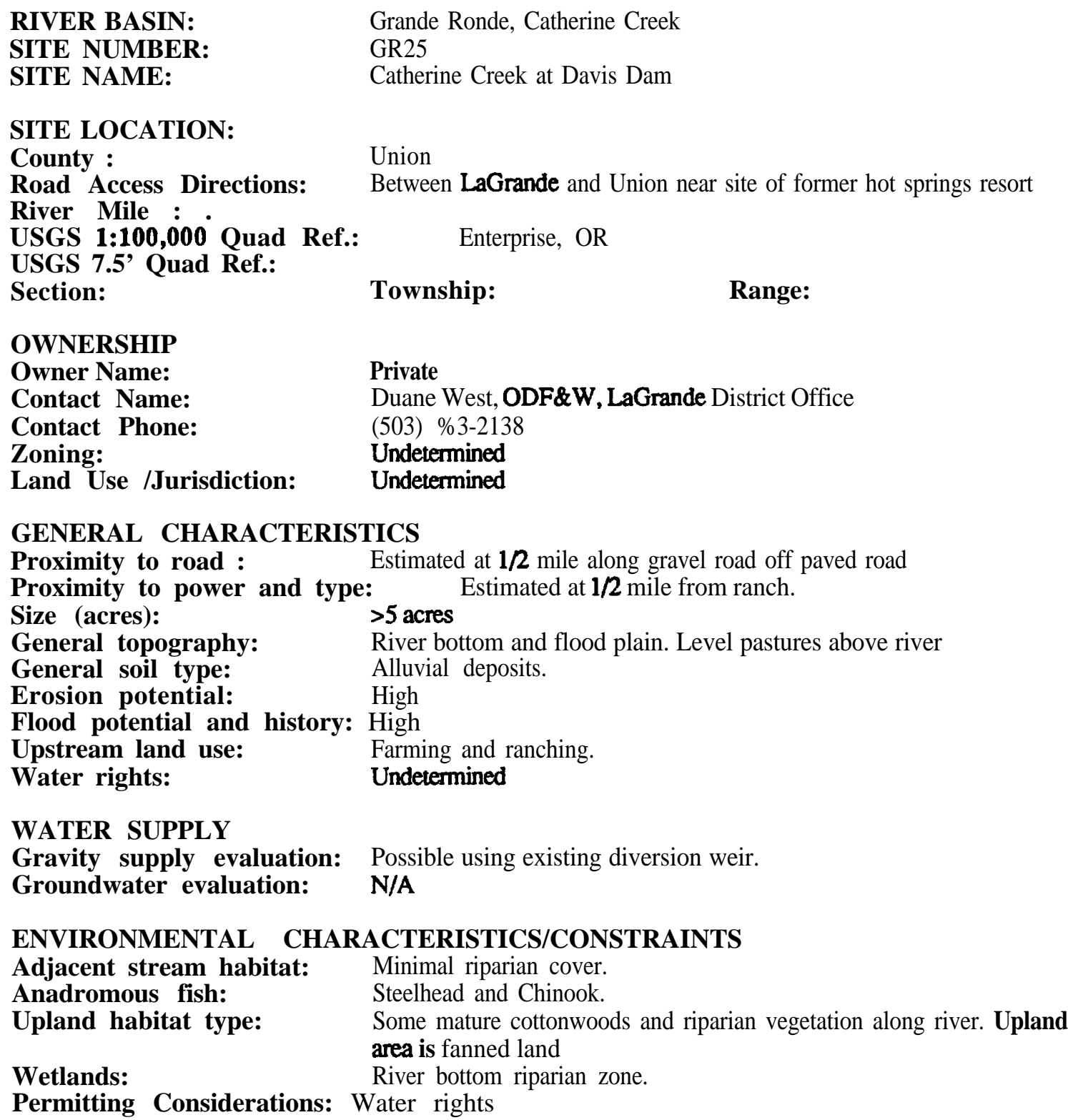




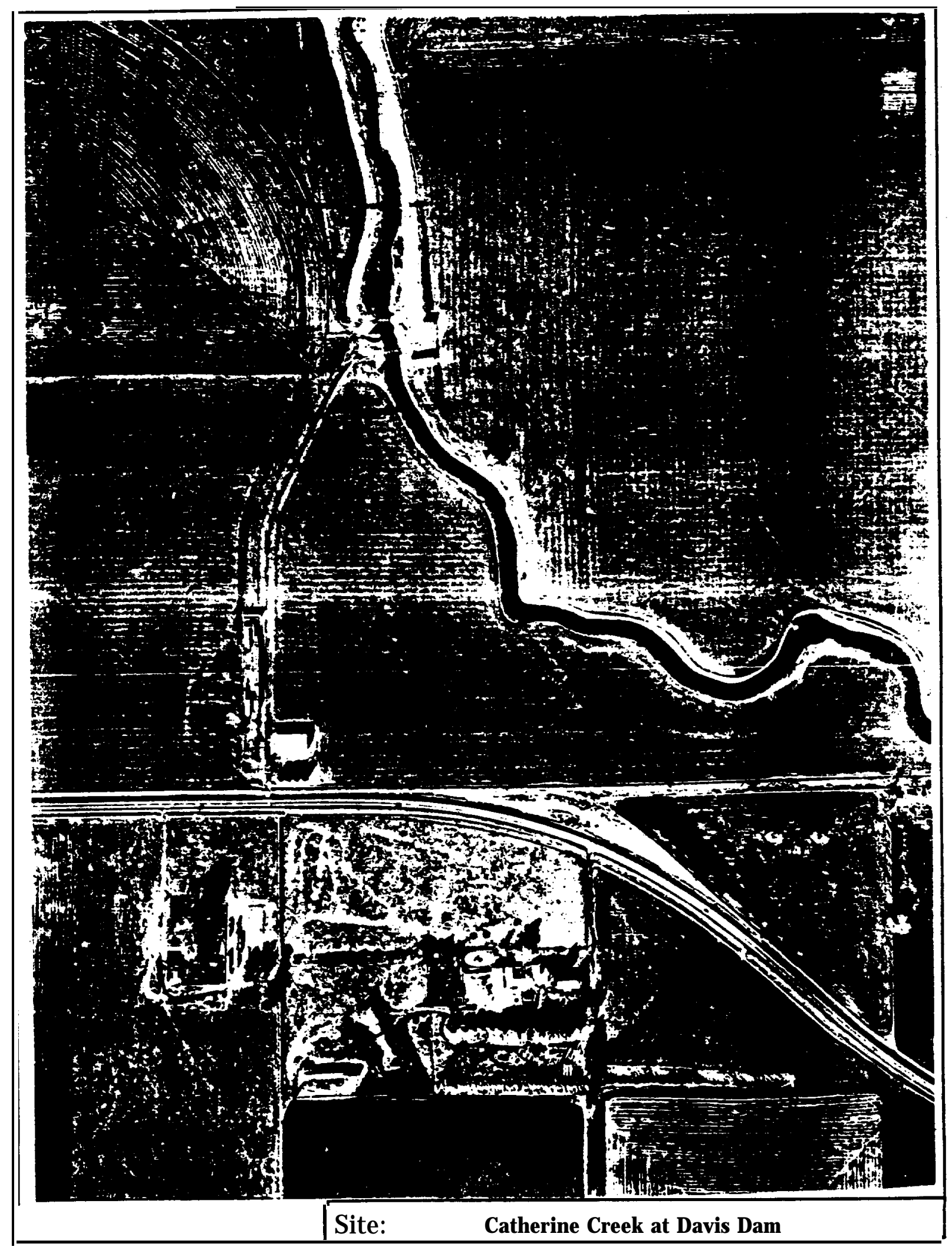


RIVER BASIN

SITE NUMBER

SITE NAME

SITE LOCATION

County

Road Access Directions
Grande Ronde, Minam River

GR26

Minam River $1 / 4$ to 1 mile above Wallowa Confluence

\section{Wallowa}

Highway 82 east from Elgin towards Enterprise. North on road next to grocery store at Minam. Site is flat bench behind grocery store and power substation on west side of Wallowa River. Most upriver site is approximately 1 mile south of Minam and reached by steep, dirt access road on E side of highway.

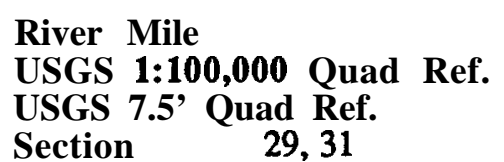

Minam River RM 0.25 to 1

Minam. OR

Enterprise, OR

Township 2N Range 41E

ODF\&W

Duane West, ODF\&W, Enterprise District Office

426-3279

Undetermined

State Park/State of Oregon

Land Use /Jurisdiction

\section{TICS}

GENERAL CHARA

Proximity to power

Size (acres)

General topography

General soil type

Erosion potential

Flood potential and history

Upstream land use

Water rights

WATER SUPPLY

Gravity supply evaluation

Groundwater evaluation
Adjacent to improved gravel road

Power substation at S. end of site

Approx. 10

Flat bench approx. 10 feet above river

Alluvial

Moderate along river edge

Moderate

Generally undeveloped, railroad and highway parallel Wallowa River

Undetermined

Potential intake location near Minam Wallowa confluence at Highway 82 bridge. Low head; pump station on river closer to site may be more practical.

Moderate potential for development of groundwater in deep basalt aquifer

ENVIRONMENTAL CHARACTERISTICS/CONSTRAINTS

Adjacent stream habitat Broad rocky stream with low gradient.

Anadromous fish

Yes

Upland habitat type

Forested steep slope

Wetlands

None identified beyond riparian zone.

Permitting Considerations

Land use and zoning in Minam State Recreation Area. 


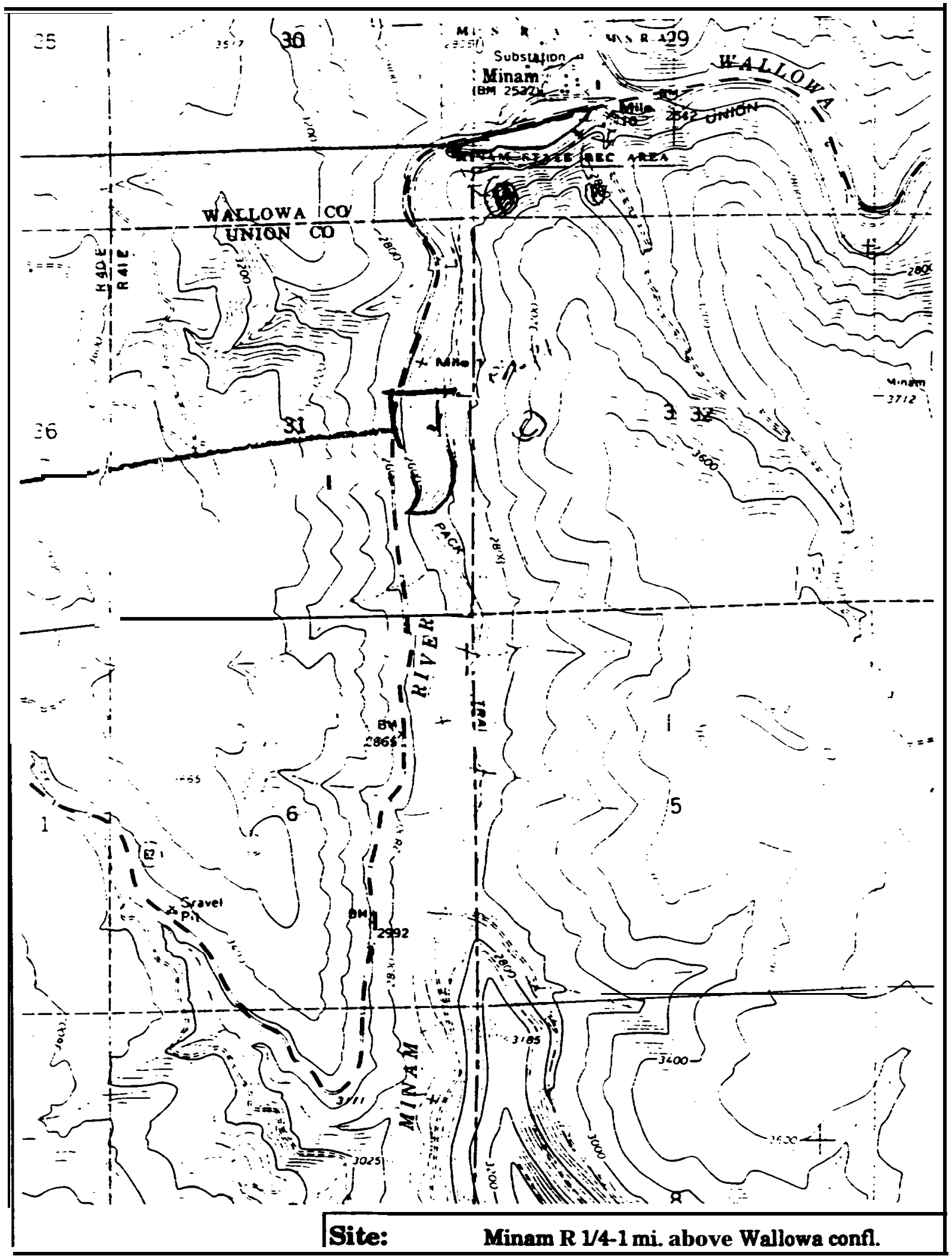


RIVER BASIN

SITE NUMBER

SITE NAME

SITE LOCATION

County

Road Access Directions

River Mile

USGS 1:100,000 Quad Ref. USGS 7.5' Quad Ref.

Section 29

OWNERSHIP

Owner Name

Contact Name

Contact Pbone

Zoning

Land Use /J urisoiction
Grande Ronde, Wallowa River

GR27

Wallowa River $1 / 2$ mile below Minam Confluence

\section{Wallowa}

Highway 82 east from Elgin towards Enterprise. North on road next to grocery store at Minam. Site is flat bench behind grocery store and power substation on west side of Wallowa River.

Wallows River RM 9.5

Enterprise, $O R$

Minam and Howard Butte, $O R$

Township 2 Range

4IE

Oregonstate Parks

Brad Smith, ODF\&W, Enterprise District Office

426-3279

Undetermined

State Park/State of Oregon

\section{GENERAL CHARACTERISTICS}

Proximity to road

Proximity to power

Size (acres)

General topography

General soil type

Erosion potea tial

Flood potential and bistory

Upstream land use

Water rights

WATER SUPPLY

Gravity supply evaluation

Groundwater evaluation
Adjacent to improved gravel road

Power substation at S. end of site

Approx. 10

Flat bench approx. 10 feet above river

Alluvial

Moderate along river edge

Moderate

Generally undeveloped, railroed and highway parallel Wallowa River

Undetermined

Potential intake location near Minam Wallowa confluence at Highway 82 bridge. Low head; pump station on river closer to site may be more practical.

Moderate potential for development of groundwater in deep besalt aquifer

ENVIRONMENTAL CHARACTERISTICS/CONSTRAINTS

Adjacent stream habitat Broad rocky stream with low gradient.

Aaadromous fish

Yes

Upland babitat type

Forested steep slope

Wetlands

None identified beyond riparian zone.

Permitting Considerations Land use and zoning in Minam State Recreation Area. 


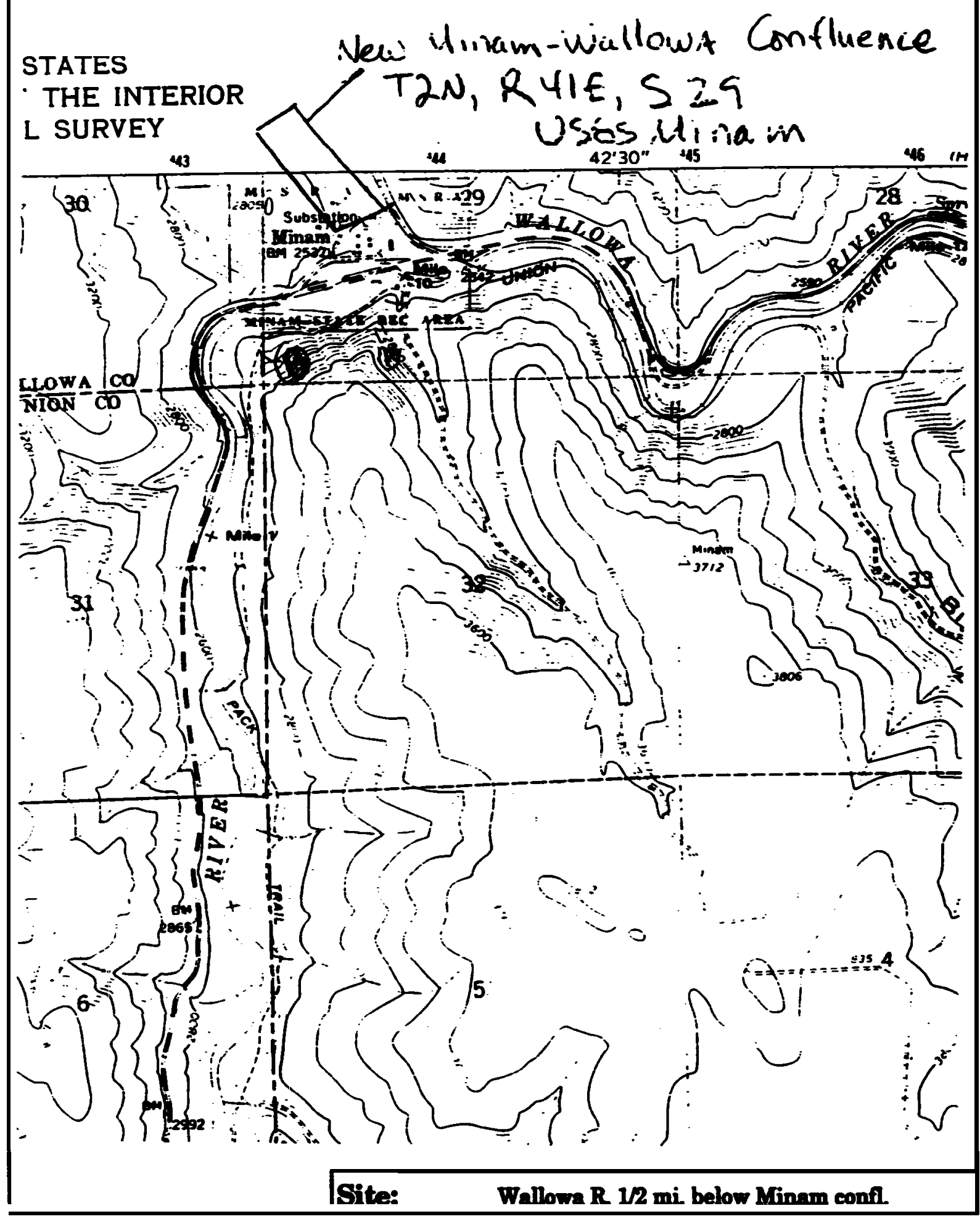


RIVER BASIN:

SITE NUMBER:

SITE NAME:

SITE LOCATION:

County :

Road Access Directions

River Mile :

USGS 1:100,000 Quad Ref.:

USGS 7.5' Quad Ref.:

Section: $\quad 4,5$
Grande Ronde, Wenaha River

GR28

Wenaha River $1 / 4$ mile above Troy

Wallowa

At Troy, OR. Cross Wemina River at mouth heading south out of Troy. Weat along grovel road adjacent to Wensha River to large flat area epproximady $1 / 2$ mile outside town. 45.25

Troy, OR

Towasbip: $5 \mathrm{~N}$

Range:

43E

OWNERSHIP

Owner Name:

ODFew

Contact Name:

Brad Smith, ODF\&W, Enterprise District Office

Contact Phone:

(503) 426-3279

Zoning:

Undetermined

Land Use /Jurisdiction:

Wild and Scenic River/USFS jurisdiction

GENERAL CHARACTERISTICS

Proximity to road :

Proximity to power and type:

Size (acres):

Adjacent gravel roed.

General topography:

General soil type:

Erosion potential:

Flood potential and history: Moderate during high flow periods.

Upstream land use:

Water rights:

None at site. Available in town.

5 (approx.)

Generally level

Alluvial

Moderne

Grasing, Naiomal Forest land, Wenatra Stute Wildife Area Undetermined

WATER SUPPLY

Gravity supply @ val oatloa: Cood

Groundwater evaluation: N/A

ENVIRONMENTAL CHARACTERISTICS/CONSTRAINTS

Adjacent stream habitat: River has moderate bedloed movement

Anadronous fish:

Yes

Upland labitat type:

Wetlands:

Permitting Considerations:

Sieep grass covered siopes

None identified beyond riparien zone

Wildand Scenic River restrictions 


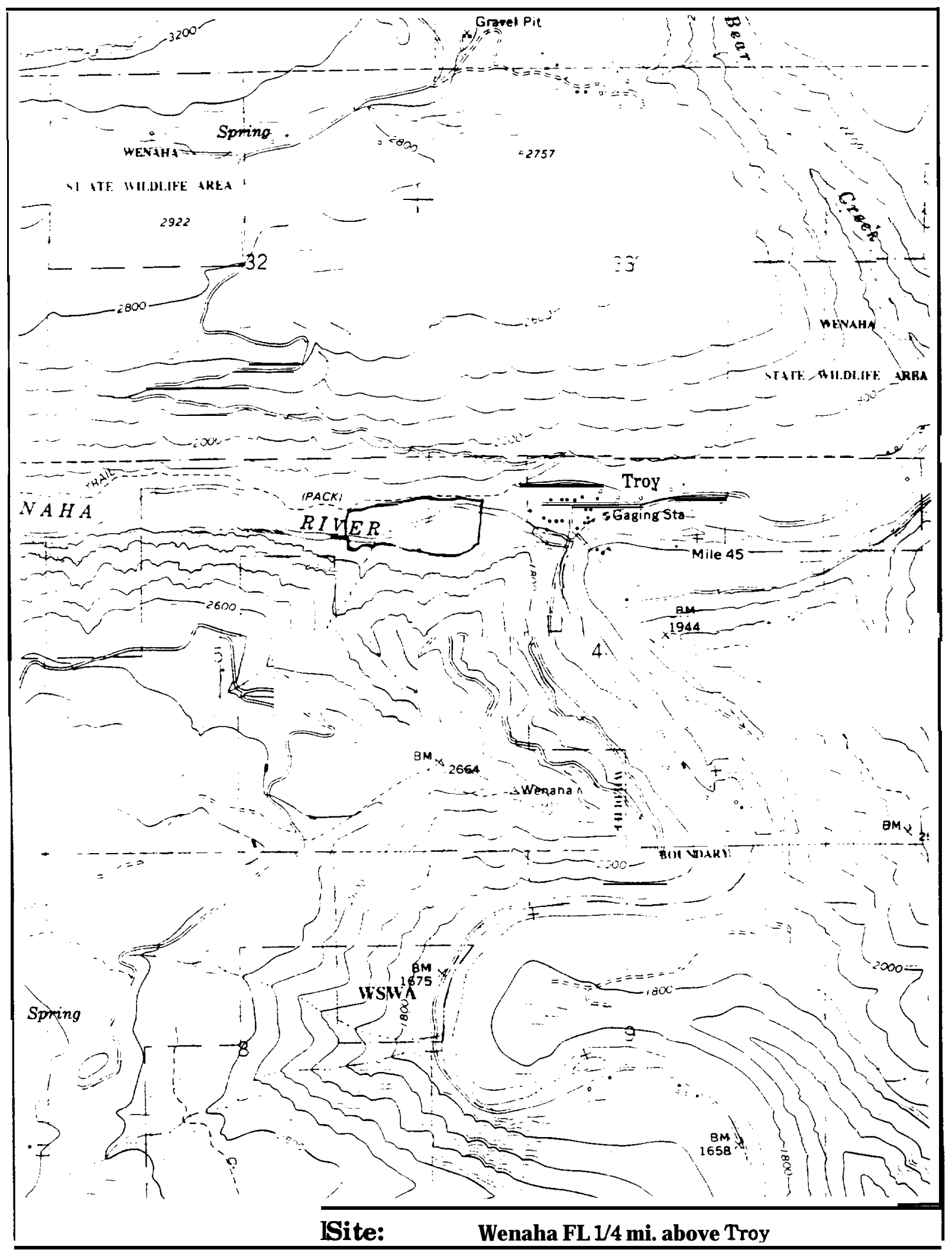


RIVER BASIN

SITE NAME

SITE LOCATION

County

Road Access Directions

River Mile

USGS 1:100,000 Quad Ref.

USGS 7.5' Quad Ref.

Section

unmapped

OWNERSHIP

Owner Name

Contact Name

Contact Phone

Zoning

Land Use /Jurisdiction
Imnaha

11

Indian Crossing

Wallowa

SE. from Enterprise towards Imnaha, S on Forest Service Road 39 towards State Hwy. 86 and Halfway shortly after entering Little Sheep

Creek drainage. Continue on FS 39 over pass and down Gumboot

Creek drainage to Imnaha River. Follow road along Imnaha River upstream bearing west at Ollokot Campground onto dirt road.

Continue along Imnaha River approximately 9 miles to Indian

Crossing Campground. Site on west side of river across bridge. RM 57

Deadman Pt., OR

Township $5 S$

Range

$47 \mathrm{E}$

\section{U.S. Forest Service}

Brad Smith, ODF\&W, Enterprise District Office

(503) 426-3279

Undetermined

Wild and Scenic River and Hells Canyon National Recreation

Area/USFS jurisdiction

GENERAL CHARACTERISTICS

Proximity to road

Proximity to power

Size (acres)

General topography

General soil type

Erosion potential

Flood potential and history Low

Upstream land use

Water rights

WATER SUPPLY

Gravity supply evaluation Good potential at site below bridge on $\mathrm{W}$ side of river

Groundwater evaluation N/A

ENVIRONMENTAL CHARACTERISTICS/CONSTRAINTS

Adjacent stream habitat

Anadromous fish

Upland habitat type

Wetlands

Permitting Considerations
9 miles from all weather road. Not maintained during winter

2-3 acres in flats along river

flat to rolling with rock outcrops

Alluvial

Low

Eagle Cap Wilderness Area

Undetermined
Moderate gradient. Boulder, riffle, pool complexes

Yes

Forested steep slope

None observed outside riparian zone

Wild and Scenic River restrictions, National Recreation Area

restrictions 


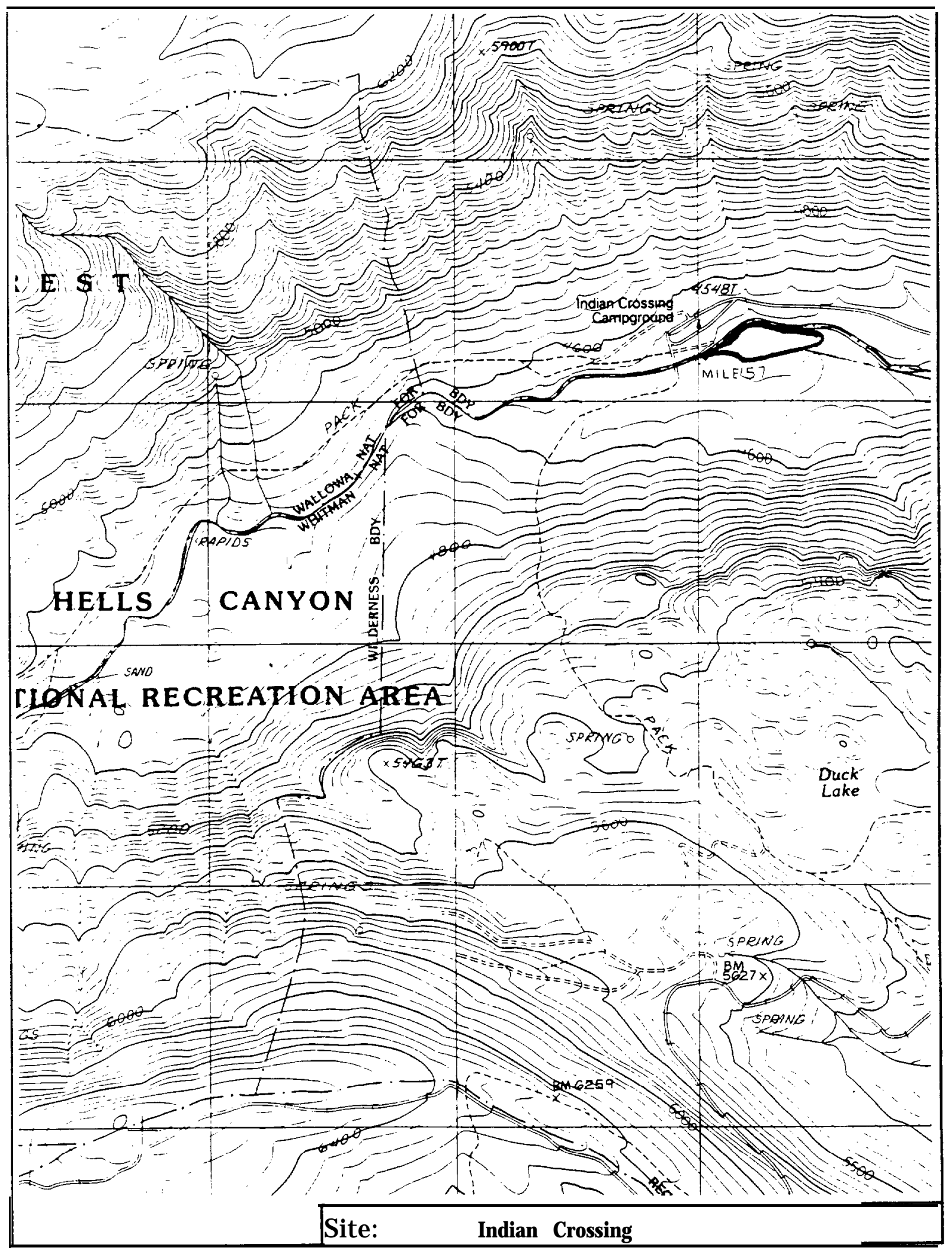


$\begin{array}{ll}\text { RIVER BASIN: } & \text { Imnaha } \\ \text { SITE NUMBER: } & \text { I2 } \\ \text { SITE NAME: } & \text { Gumboot Creek (Fish Weir) }\end{array}$

SITE LOCATION:

County : $\quad$ Wallowa

Road Access Directions: South of Town of Imnaha on Upper Imnaha Road, USFS Rd \#3955 in Hells Canyon National Recreation Area, Wallowa National Forest. On Imnaha R. immediately downstream of Gumboot Ck. At existing

River Mile : Gumboot Ck. LSRCP Imnaha Satellite facility (Fish Weir).

USGS 1:100,000 Quad Ref: USGS 7.5' Quad Ref.: $\quad$ Puderbaugh Ridge, Ore.

$\begin{array}{lllll}\text { Section: } & 30 & \text { Township: T } 4 \text { S } & \text { Range: } & \text { R E }\end{array}$

OWNERSHIP

Owner Name:

Contact Name:

Contact Phone:

Zoning:

Land Use /Jurisdiction:

\section{ODF\&W}

Brad Smith,ODF\&W, Enterprise District Office.

(503) 426-3279

Unknown

Existing Facility/ U.S. Forest Service -Nat. Rec. Area

GENERAL CHARACTERISTICS

Proximity to road : $\quad$ Adjacent to ah-weather gravel road.

Proximity to power and type: 3-Phase adjacent to site.

Size (acres): $\quad$ Some space available for expansion of existing acclimation facility or

other small facility.

General topography: Level

General soil type: Alluvial deposits.

Erosion potential: LOW

Flood potential and history: Low

Upstream land use: National Forest, Hells Canyon National Recreation Area

Water rights: Unknown

WATER SUPPLY

Gravity supply evaluation: Existing gravity intake for existing acclimation facility which is in use March and April. Some minor icing problems, but facility has only been in use for two seasons. Acclimation pond sized at $250 \mathrm{~K}$ smolts at $15 / \mathrm{lb}$.

Groundwater evaluation: Unknown at this time.

ENVIRONMENTAL CHARACTERISTICS/CONSTRAINTS

Adjacent stream habitat: Moderate to high bedload movement.

Anadromous fish: Steelhead and Spring Chinook.

Upland habitat type: $\quad$ Forested.

Wetlands: $\quad$ No identified wetlands on site.

Permitting Considerations: Water rights, Restrictions within NRA and Wild and Scenic Rivers Act 


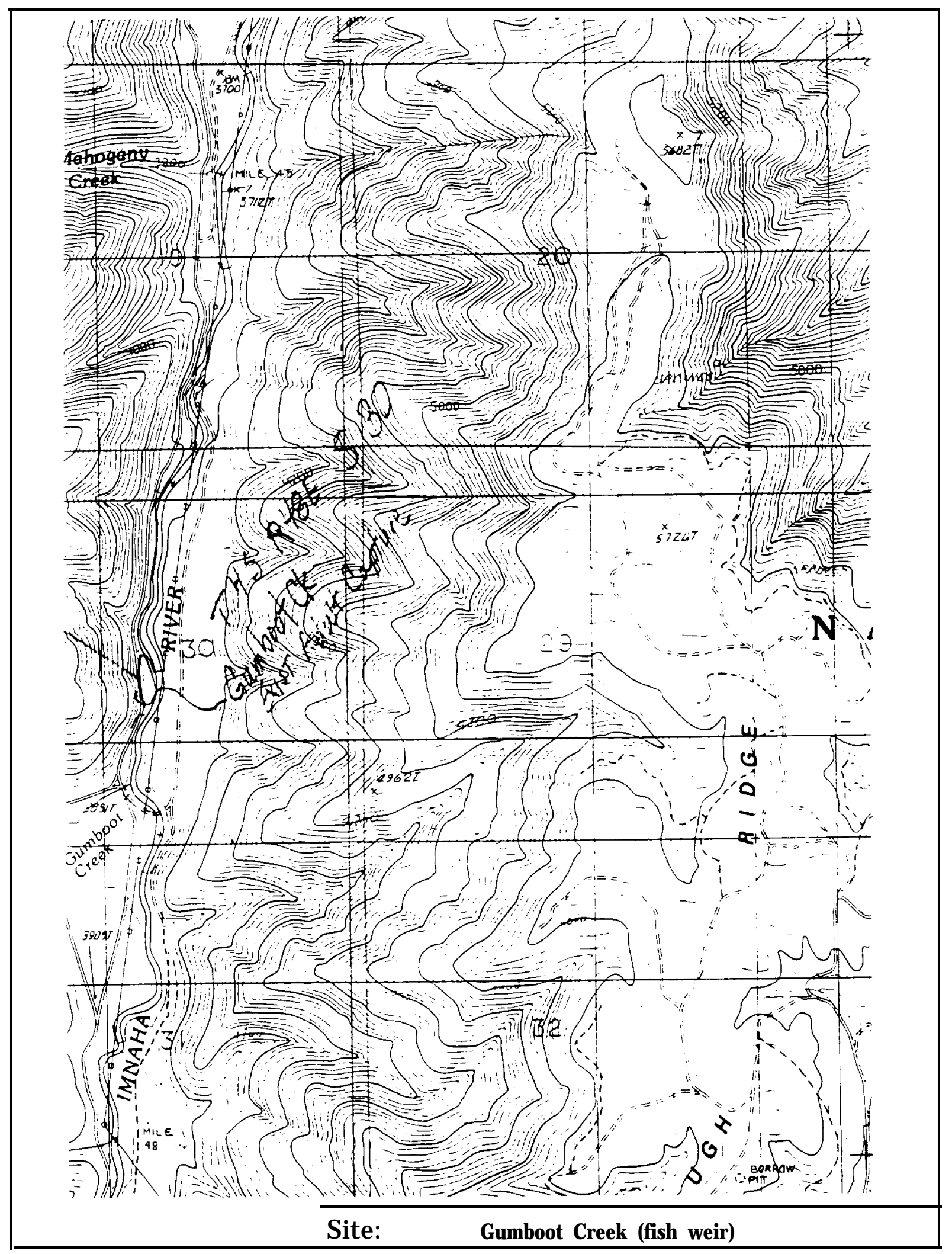


RIVER BASIN:

SITE NUMBER:

SITE NAME:

SITE LOCATION:

County :

Road Access Directions:

River Mile :

USGS 1:100,000 Quad Ref.:

USGS 7.5' Quad Ref.:

Section: $\quad 16 / 21$

OWNERSHIP

Owner Name:

Contact Name:

Contact Phone:

Zoning:

Land Use/Jurisdiction:
Imnaha

I3

Imnaha/ Confluence of Grouse Ck.

Wallowa

16 miles south of Town of Imnaha on Upper Imnaha Road. USFS Rd \#3955. On Imnaha R. at confluence of Grouse Ck. 35

Jaynes Ridge, OR

Township: $\quad$ T $3 \mathrm{~S}$

Range:

R $48 \mathrm{E}$

\section{GENERAL CHARACTERISTICS}

Proximity to road : $\quad$ Adjacent to ah-weather gravel road.

Proximity to power and type: 3-Phase adjacent to sites.

Size (acres): $\quad$ Very limited area at site.

General topography: Moderate slopes.

General soil type: Aluvial deposits.

Erosion potential: Low

Flood potential and history: Low

Upstream land use: Grazing

Water rights: Unknown

WATER SUPPLY

Gravity supply evaluation: Site well above river.

Groundwater evaluation: N/A

ENVIRONMENTAL CHARACTERISTICS/CONSTRAINTS

Adjacent stream habitat: Moderate to high bedload movement.

Anadromous fish:

Steelhead and Spring Chinook.

Upland habitat type: Pasture and forest.

Wetlands:

No identified wetlands on site beyon riparian zone.

Permitting Considerations: Water rights 


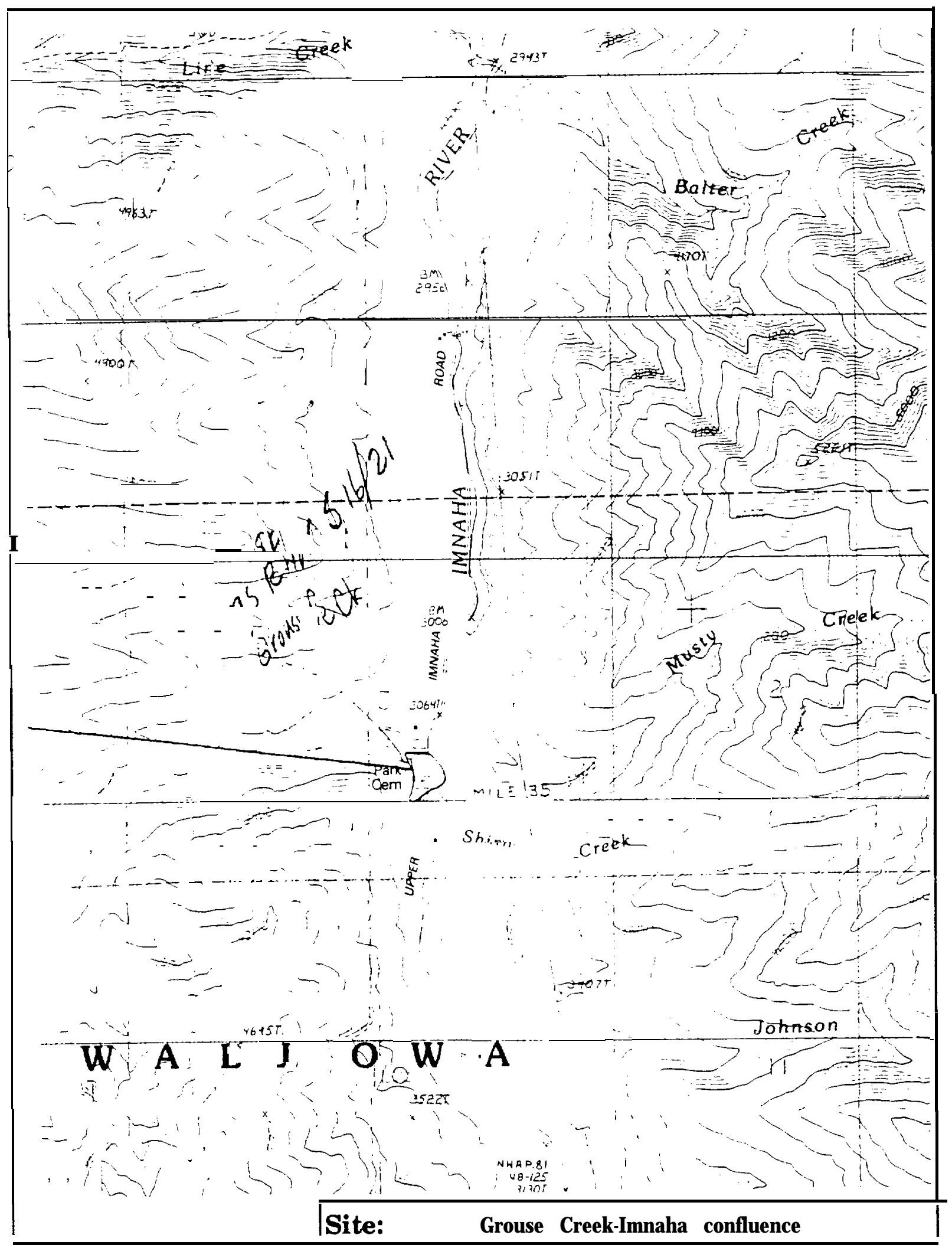


RIVER BASIN

SITE NUMBER

SITE NAME

SITE LOCATION

County

Road Access Directions

River Mile

USGS 1:100,000 Quad Ref.

USGS 7.5' Quad Ref:

Section unmapped

OWNERSHIP

Owner Name

Contact Name

Contact Phone

Zoning

Land Use /Jurisdiction
Imnaha

14

Big Sheep-Lick Creek Confluence

Wallowa Co.

SE. from Enterprise towards Imnaha. S on Forest Service Road 39 towards State Hwy. 86 and Halfway shortly after entering Little Sheep Creek drainage. Continue up to Big Sheep Creek and bear NE on FS road 140 down Big Sheep Creek drainage. Approximately 2 miles to site area at confluence of Big Sheep Creek and Lick Creek.

Approximate RM 32-33 on Big Sheep Creek Enterprise, OR

Lick Creek, OR

Towns ip 4S Range 46E

U.S. Forest Service, Wallowa Nat'l. Forest

Brad Smith ODF\&W

(503) 426-3279

Undetermined

Undetermined

GENERAL CHARACTERISTICS

Proximity to road

Proximity to power

Approximately 2 miles from all-weather road. Winter snow access difficulty

Size (acres)

General topography

General soil type

Erosion potential

No power in vicinity

5-10 acres over broad area

Flat to gently sloping

Alluvial

Moderate, recent burned area on upper drainage of Big Sheep Creek continuing down close to site area.

Flood potential and history Low

Upstream land use National Forest (Big Sheep), Nat. Rec. Area (Lick Creek).

Water rights

Undetermined

WATER SUPPLY

Gravity supply evaluation Good potential at a number of locations

Groundwater evaluation N/A

ENVIRONMENTAL CHARACTERISTICS/CONSTRAINTS

Adjacent stream habitat Pool, Riffle complexes

Anadromous fish

Yes

Upland habitat type

Wetlands

Forested steep slope, fire damge

Much of the site area appears to contain wetland vegetations.

Permitting Considerations

Development would require delineation of these areas.

Wetlands 


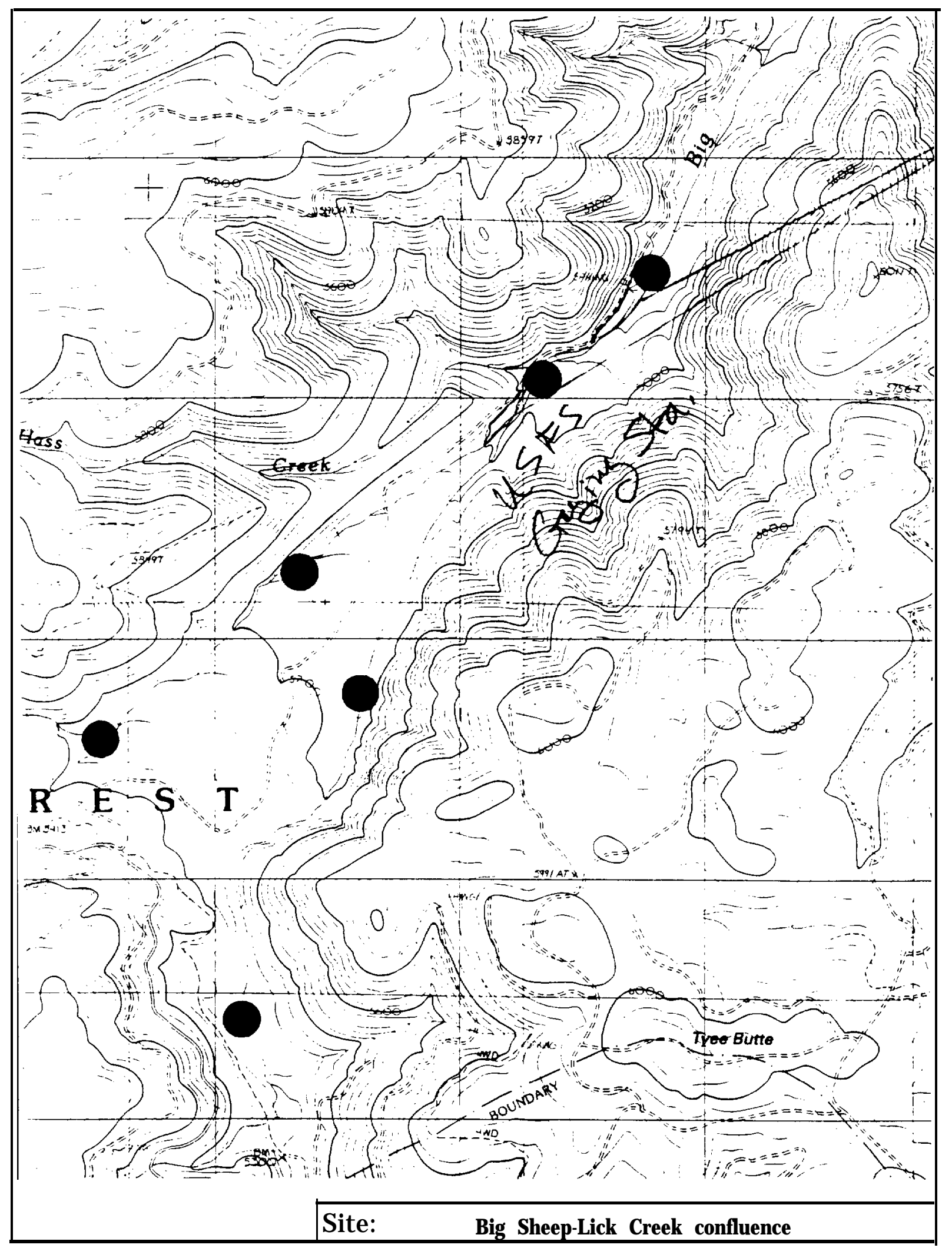


$\begin{array}{ll}\text { RIVER BASIN: } & \text { Imnaha } \\ \text { SITE NAME: } & \text { I5 } \\ \text { SITE NAME: } & \text { Big Sheep Creek - Imnaha Confluence }\end{array}$

SITE LOCATION:

County : $\quad$ Wallowa

Road Access Directions: On Imnaha R. immediately upstream of the Town of Imnaha, in the area adjacent the confluence of Big Sheep Creek. Two possible sites. Site 1 on west bank of Imnaha R. immediately upstream of Big Sheep Ck. Site 2 on the east bank, directly across from Big Sheep Ck.Both sites on paved road, immediately upstream of the Town of Imnaha.

River Mile : 19

USGS 1:100,000 Quad Ref.: USGS 7.5' Quad Ref.:

Section: $\quad 16 / 21$

Imnaha, OR

Grangeville, ID

Township: $\quad$ T $1 \mathrm{~N}$

Range:

R $48 \mathrm{E}$

Private/Unknown

Brad Smith ODF\&W, Enterprise District Office

(503) 426-3279

Undetermined

Undetermined

Land Use /Jurisdiction:

GENERAL CHARACTERISTICS

Proximity to road : Both sites immediately adjacent to paved road.

Proximity to power and type: 3-Phase adjacent to sites.

Size (acres): 3 plus

General topography: Both sites with moderate slopes.

General soil type: Alluvial deposits.

Erosion potential: Low

Flood potential and history: Low

Upstream land use: $\quad$ Stock yard at site 1 and hav field/cattle grazing on site 2 .

Water rights: Unknown

WATER SUPPLY

Gravity supply evaluation: Good gravity or pumped supply potential.

Groundwater evaluation: Low to moderate potential for $>500$ gpm wells based upon geology and local well logs. Igneous and metamorphic aquifers. Town water supplied from spring located in the area.

\section{ENVIRONMENTAL CHARACTERISTICS/CONSTRAINTS}

Adjacent stream habitat: Moderate to high bedload movement.

Anadromous fish:

Upland habitat type:

Steelhead and Spring Chinook.

Wetlands:

Pasture and stock yard.

Permitting Considerations: Water rights if well or spring supply used. 


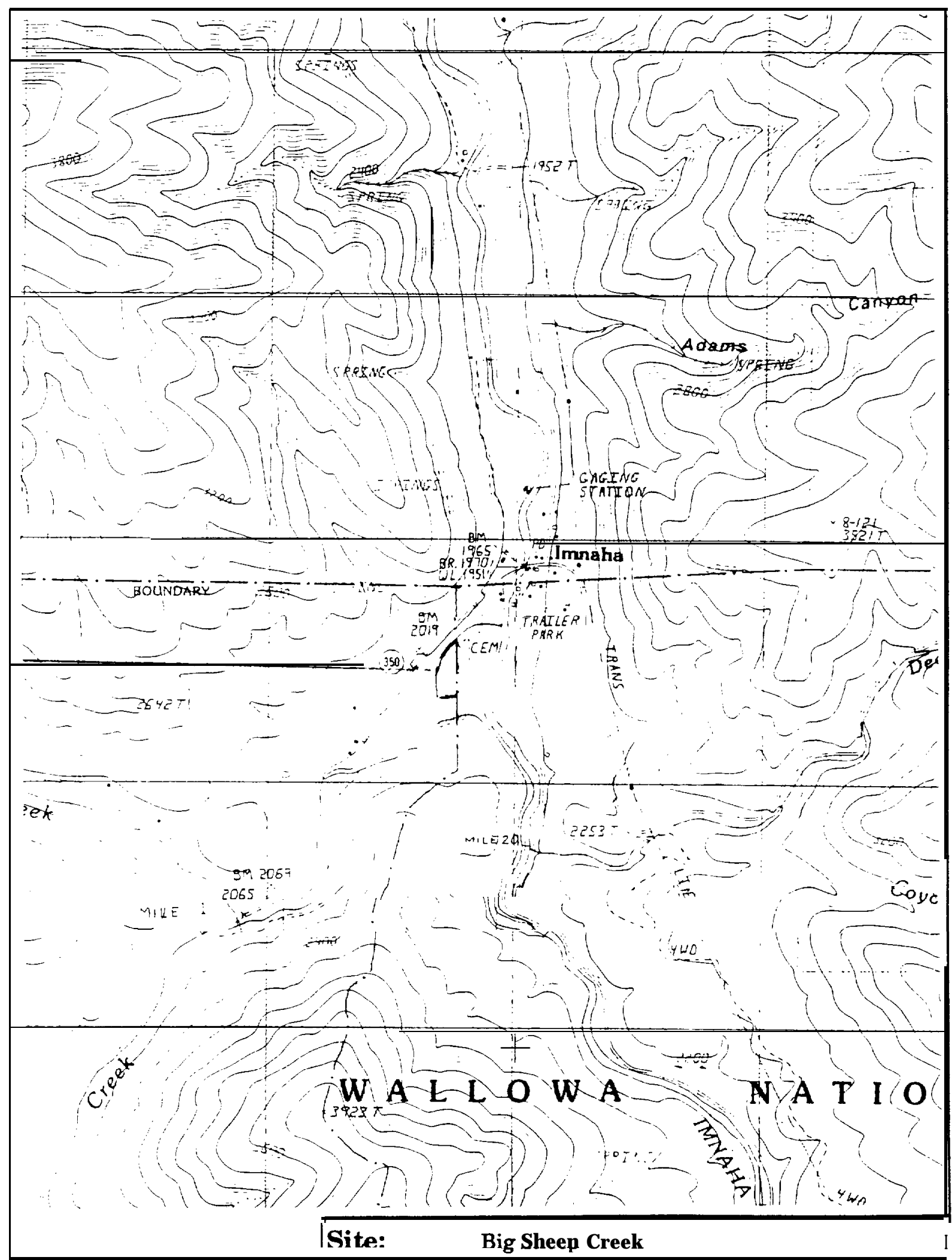


$\begin{array}{ll}\text { RIVER BASIN: } & \text { Imnaha } \\ \text { SITE NAME: } & 16 \\ \text { SITE NAME: } & \text { Big Sheep/ Little Sheep Creek }\end{array}$

SITE LOCATION:

County :

Road Access Directions:

River Mile :

USGS 1:100,000 Quad Ref.:

USGS 7.5' Quad Ref.:

Section:

31

OWNERSHIP

Owner Name:

Contact Name:

Contact Phone:

Zoning:

Land Use /Jurisdiction:

\section{Wallowa}

Estimated 25 miles from Joseph on paved road from Joseph to Imnaha. Site in area near bridge over Big Sheep Creek, immediately below confluence of Big and Little Sheep Creek. Two potential sites exist at this location. They are seperated by the private gravel road which goes up Big Sheep Creek.

Imnaha R. 23.4, Big Sheep Ck 3.2

Imnaha, Ore.

Grangeville, ID

Township: $\quad$ T $1 \mathrm{~N} \quad$ Range: $\quad$ R 48 E

Private/ Unknown

Brad Smith ODF\&W, Enterprise District Office

(503) 426-3279

Undetermined

Undetermined

GENERAL CHARACTERISTICS

Proximity to road : $\quad$ Adjacent to paved road, across wooden bridge would require rebuilding.

Proximity to power and type: 3-Phase adjacent to site

Size (acres): 2 - estimated 2 acre sites.

General topography: $\quad$ Site 1 is low land with riparian vegetation and potential wetland. Site

2 is upland with moderate side slope.

General soil type:

Erosion potential:

Alluvial deposits

Site 1 is moderate to high and Site 2 is extremely low.

Flood potential and history: Site 1 is moderate to high and Site 2 is extremely low.

Upstream land use:

Forested with potential logging and grazing. Cattle and sheep grazing along creek immediately above site.

Water rights:

Unknown

WATER SUPPLY

Gravity supply evaluation: Site 1 has moderate potential but quantity may be limited. Site 2

would most likely require pumping and quantity may be limiting.

Groundwater evaluation: Low to moderate potential for $>500 \mathrm{gpm}$ wells based upon geology and local well logs. Igneous and metamorphic aquifers.

ENVIRONMENTAL CHARACTERISTICS/CONSTRAINTS

Adjacent stream habitat: Small river gravels with moderate bedload movement.

Anadromous fish:

Steelhead and Spring Chinook.

Upland habitat type:

Grazing of sheep and cattle at and immediately above site.

Wetlands:

Site 1 has riparian vegetation including a long and narrow strip of cattails running through it.

Permitting Considerations: Water rights on both sites and wetland determination on Site 1. 


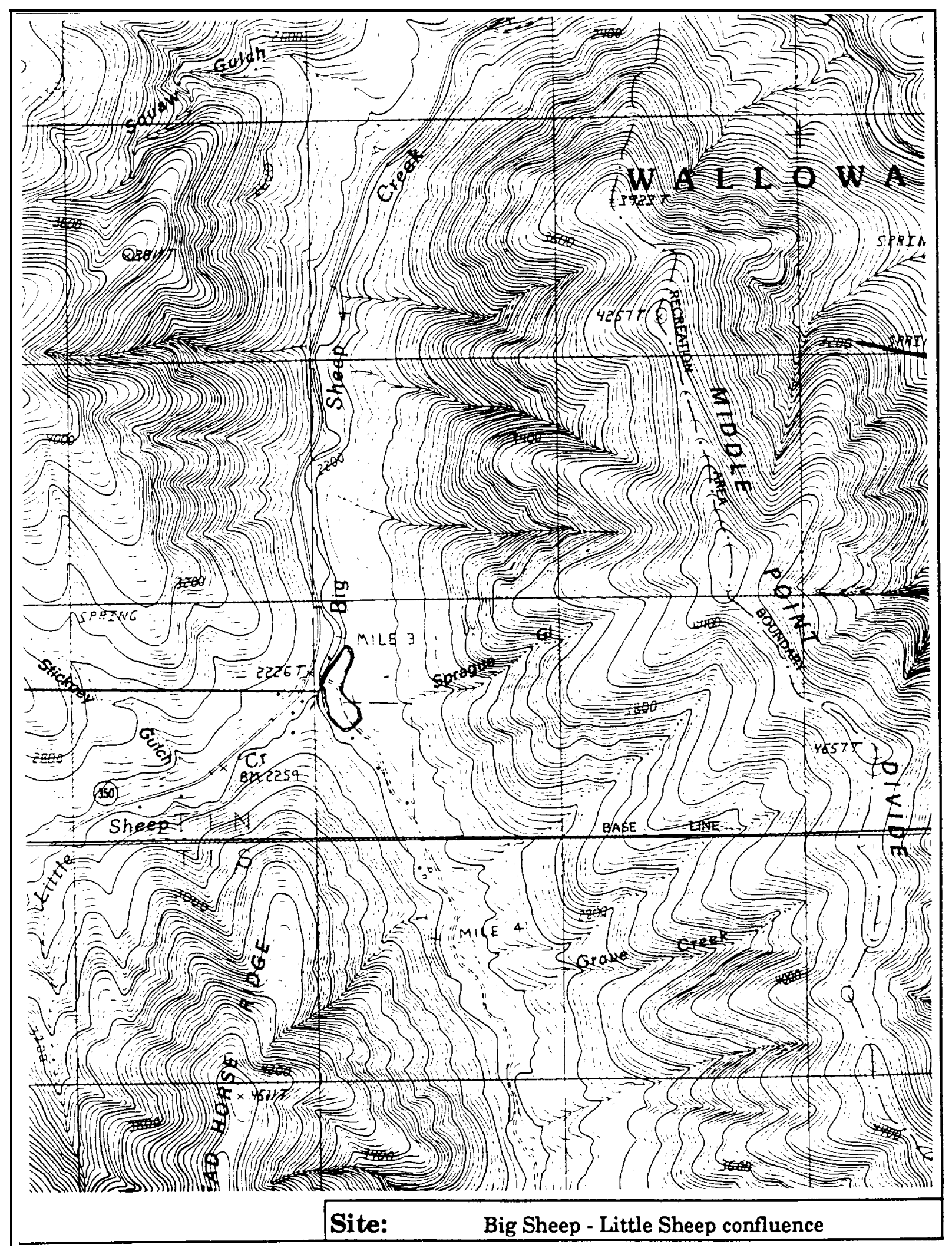




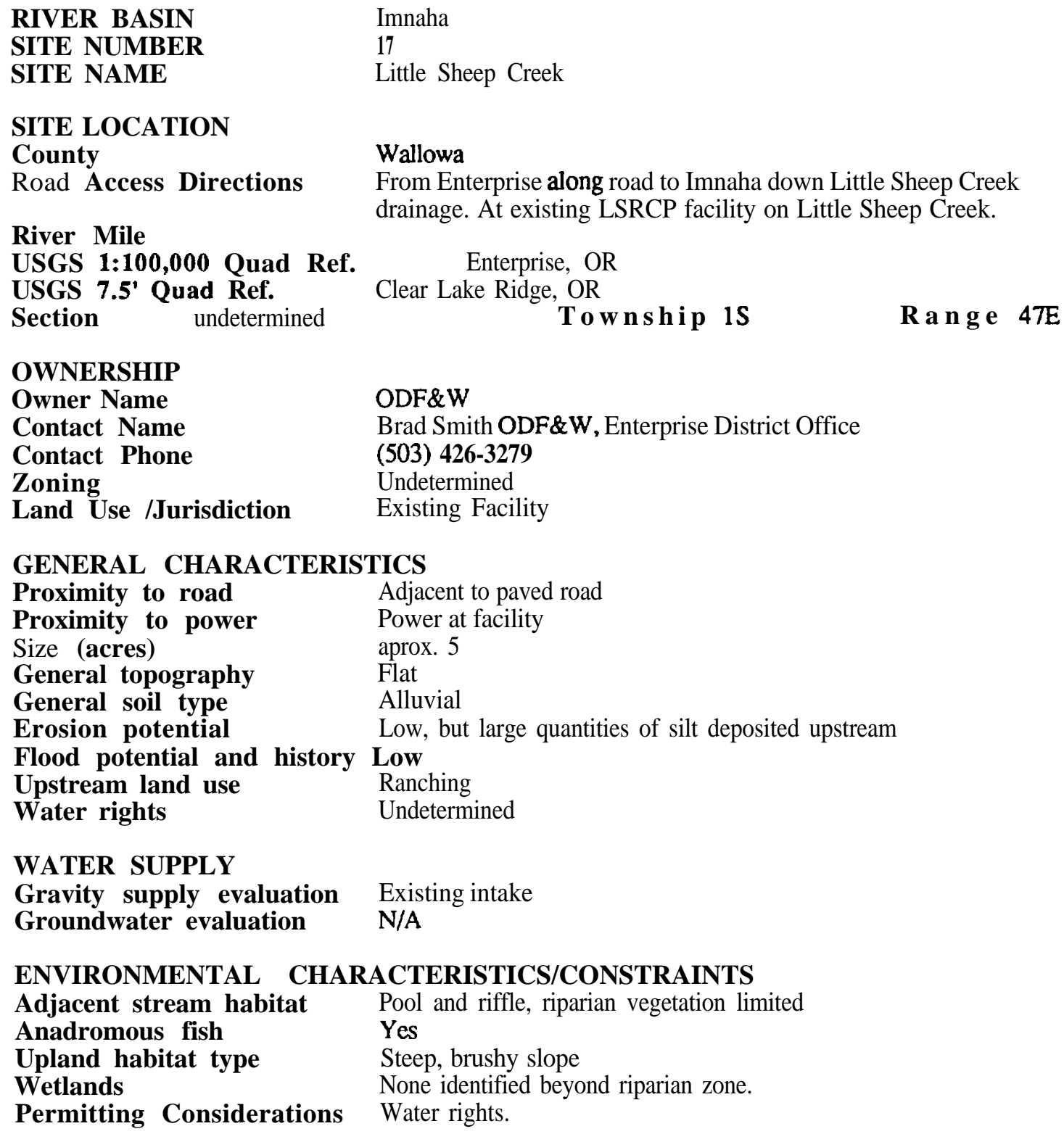




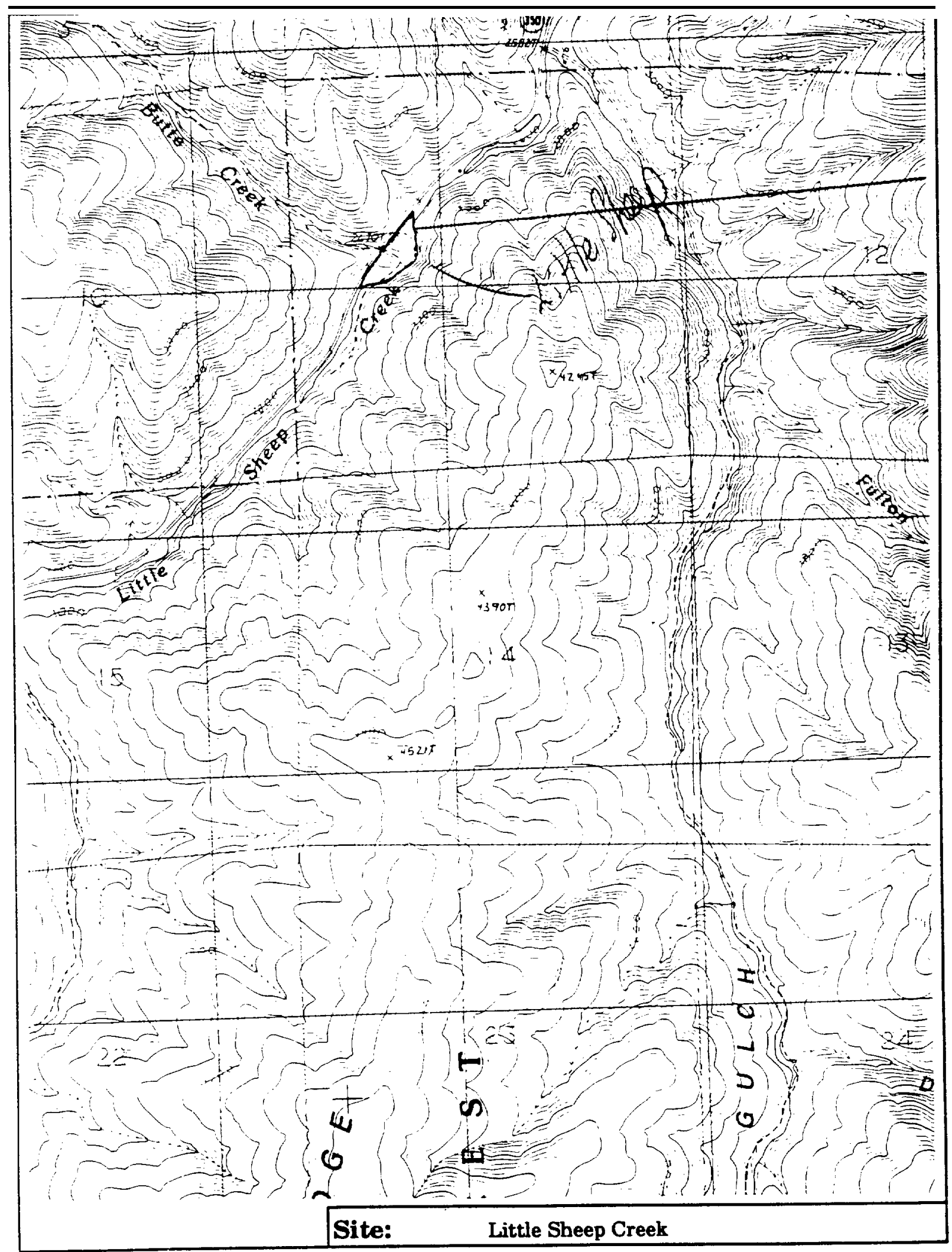


RIVER BASIN:

SITE NUMBER:

SITE NAME:

SITE LOCATION:

County :

Road Access Directions:

River Mile :

USGS 1:100,000 Quad Ref.: USGS 7.5' Quad Ref.:

Section: Comer of 16,17,20,21 Township: OR

OWNERSHIP

Owner Name:

Contact Name:

Contact Phone:

Zoning:

Land Use /Jurisdiction:
Imnaha

18

Marr Ranch

\section{Wallowa} Fall Ck.

14

Haas Hollow, OR

Lower Imnaha Rd., which is paved, to private dirt lane along Fence Ck. Site is on the ranch. immediately adjacent to river. On Imnaha $R$. immediately below confluence of Fence $\mathrm{Ck}$. and extends along river to

Grangeville, ID

GENERAL CHARACTERISTICS

Proximity to road : $\quad$ Adjacent to paved road, down private dirt lane.

Proximity to power and type:3-Phase adjacent to site. Major power corridor through area.

Size (acres): 5 plus

General topography: Entire site level.

General soil type: Aluvial deposits

Erosion potential: Low

Flood potential and history: Site is in flood plain. Gene Marr indicated that area was only moderately inundated during extreme river flows and this was caused by ice jams immediately above site. There was very minimal physical evidence of eroding flow, ice scouring action or old river braid channels on the site.

Upstream land use:

Water rights:

Cattle grazing along river immediately above site.

Unknown

WATER SUPPLY

Gravity supply evaluation: Good gravity or pumped supply potential.

Groundwater evaluation: Low potential for $500 \mathrm{gpm}$ wells based upon geology. Some potential from Fence and Fall Creeks.

ENVIRONMENTAL CHARACTERISTICS/CONSTRAINTS

Adjacent stream habitat: Moderate to high bedload movement.

Anadromous fish:

Steelhead and Spring Chinook.

Upland habitat type:

Sparse mature cottonwoods and scrub willows on site. Very steep

Wetlands: canyon walls with springs immediately adjacent to site.

Permitting Considerations: Water rights to springs and wetland impact if springs are used as water supply will have to be determined. 


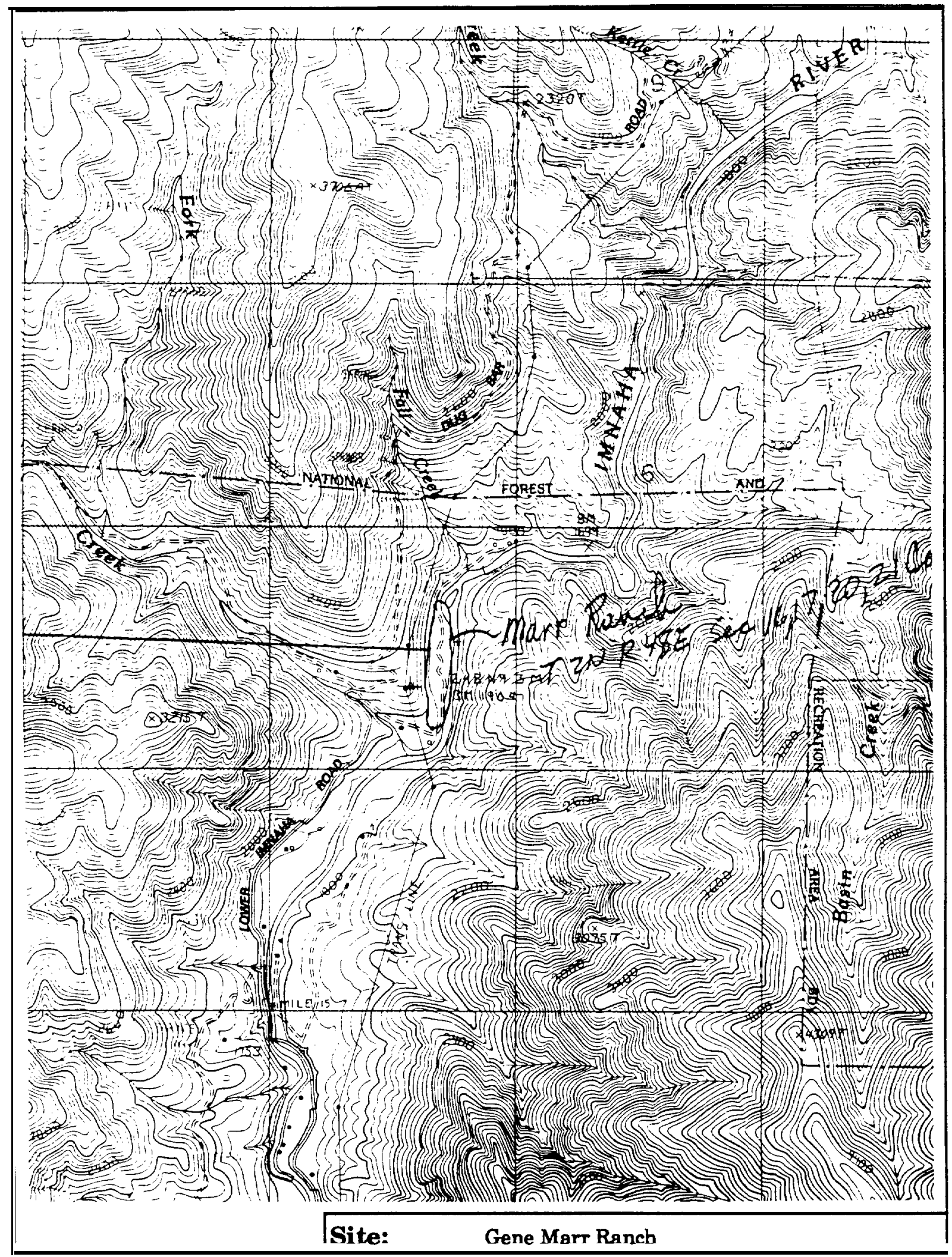


$\begin{array}{ll}\text { RIVER BASIN: } & \text { Imnaha } \\ \text { SITE NUMBER: } & 19 \\ \text { SITE NAME: } & \text { Horse Creek }\end{array}$

SITE LOCATION:

County : Wallowa

Road Access Directions: North of Town of Imnaha on Lower Imnaha Road which continues as

the Dug Bar Rd. at Fence Ck. Dug Bar Rd. is gravel/dirt, narrow, steep grades, switch backs and sharp comers. Site is on Imnaha R. in the area near the bridge which crosses the Imnaha R. immediately down stream of Horse Creek.

River Mile : 9.6

USGS 1:100,000 Quad Ref.: Grangeville. ID

USGS 7.5' Quad Ref.: Haas Hollow, OR

Section: $\quad 3$ 35

Township:

T $3 \mathrm{~N}$

Range:

R $48 \mathrm{E}$

OWNERSHIP

Owner Name:

Contact Name:

Contact Phone:

Zoning:

Land Use /Jurisdictio:

USFS Wallowa National Forest, Hells Canyon National Recreation

\section{Area.}

Brad Smith ODF\&W, Enterprise District Office

(503) 426-3279

Undetermined

Undetermined

GENERAL CHARACTERISTICS

Proximity to road : Adjacent to dirt road.

Proximity to power and type: Main power corridor $1 / 3$ mile west and approximately 600 feet

Size (acres): in elevation above site.

General topography: $\quad$ Limited level area available.

General soil type: Alluvial deposits.

Erosion potential: Low

Flood potential and history: Low

Upstream land use: $\quad$ National Forest, Hells Canyon National Recreation Area

Water rights: Unknown

WATER SUPPLY

Gravity supply evaluation: Possible, but due to limited low level site. most likely would require pumped intake.

Groundwater evaluation: Low potential for $>500$ gpm wells based upon geology. No local well $\log$ data. Igneous and metamorphic aquifers.

ENVIRONMENTAL CHARACTERISTICS/CONSTRAINTS

Adjacent stream habitat: Moderate to high bedload movement.

Anadromous fish: Steelhead and Chinook.

Upland habitat type: $\quad$ Grassland and sagebrush with willows and cottonwoods along river channel.

Wetlands: $\quad$ No identified wetlands on site.

Permitting Considerations: Water rights and National Recreation Area, scenic consideration for building of any structures. 


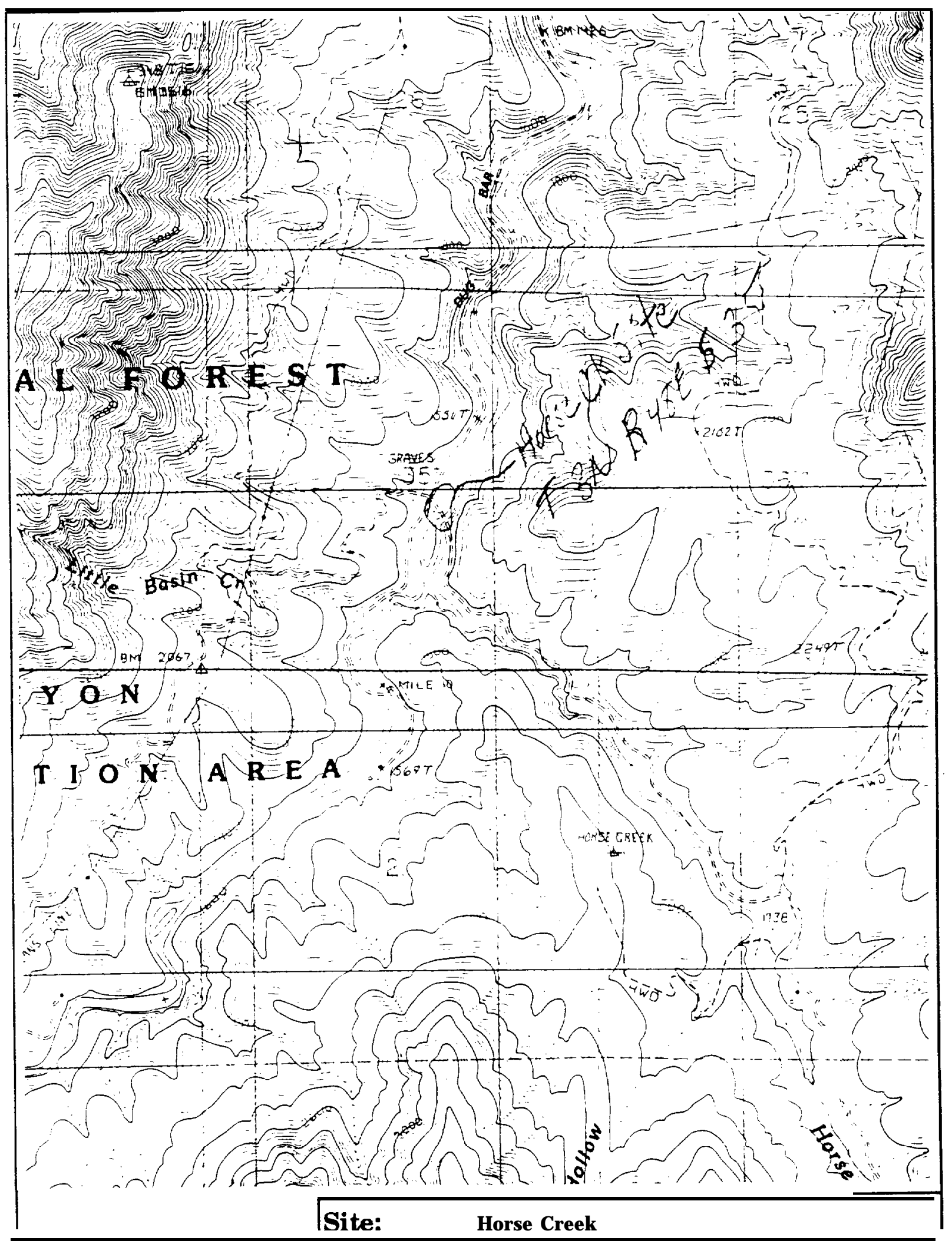


RIVER BASIN:

SITE NUMBER:

SITE NAME:

SITE LOCATION:

County :

Road Access Directions:
Imnaha

I10

Wayne Marks Property
Wallowa

Imnaha River Rd. upstream from town of Imhaha approximately 4.8 miles to barbed-wire gate in fence leading to bridge across Imnaha.

Cross bridge and follow tracks through fenced pastures and about 4 to 6 gates. Site is located at final gate at top end of large meadow across river from house and corrals. Marks home is across river at downstream end of site. Site is on west side of river opposite road, across from and betweeen mouths of Dunlap and Thorn Creeks (on E. side of river). 24.25

River Mile :

USGS 1:100,000 Quad Ref.: USGS 7.5' Quad Ref.:

Section: undesignated

Sheep Creek Divide, OR

Township: T is

Range: $\quad$ R 48 E

OWNERSHIP

Owner Name:

Contact Name:

Wayne Marks

Contact Phone:

Brad Smith ODF\&W, Enterprise District Office

(503) 426-3279

Zoning:

Undetermined

Land Use /Jurisdiction:

Hells Canyon NRA/US Forest Service

GENERAL CHARACTERISTICS

Proximity to road : $\quad$ Approximately 0.5 miles through fields from all weather gravel road. Proximity to power and type: 3-Phase adjacent to site across Imnaha River.

Size (acres): 5 plus

General topography: $\quad$ Flat, sloping gradually downstream and to river.

General soil type: Alluvial deposits

Erosion potential: Low

Flood potential and history: Upstream end of site may be prone to flooding.

Upstream land use: $\quad$ Cattle grazing along river immediately above site.

Water rights: Owner has old diversion ditch on site, unused for a number of years.

WATER SUPPLY

Gravity supply evaluation: Good gravity supply potential, approx. 10-12' drop across site

Groundwater evaluation: Potential for 500 gpm wells in deep basalt based upon geology.

ENVIRONMENTAL CHARACTERISTICS/CONSTRAINTS

Adjacent stream habitat: Moderate to high bedload movement

Anadromous fish:

Steelhead and Spring Chinook.

Upland habitat type:

Wetlands:

Steep slope, rocky and brushy

Permitting Considerations: Wild and Scenic River Act limits on development type and structures 


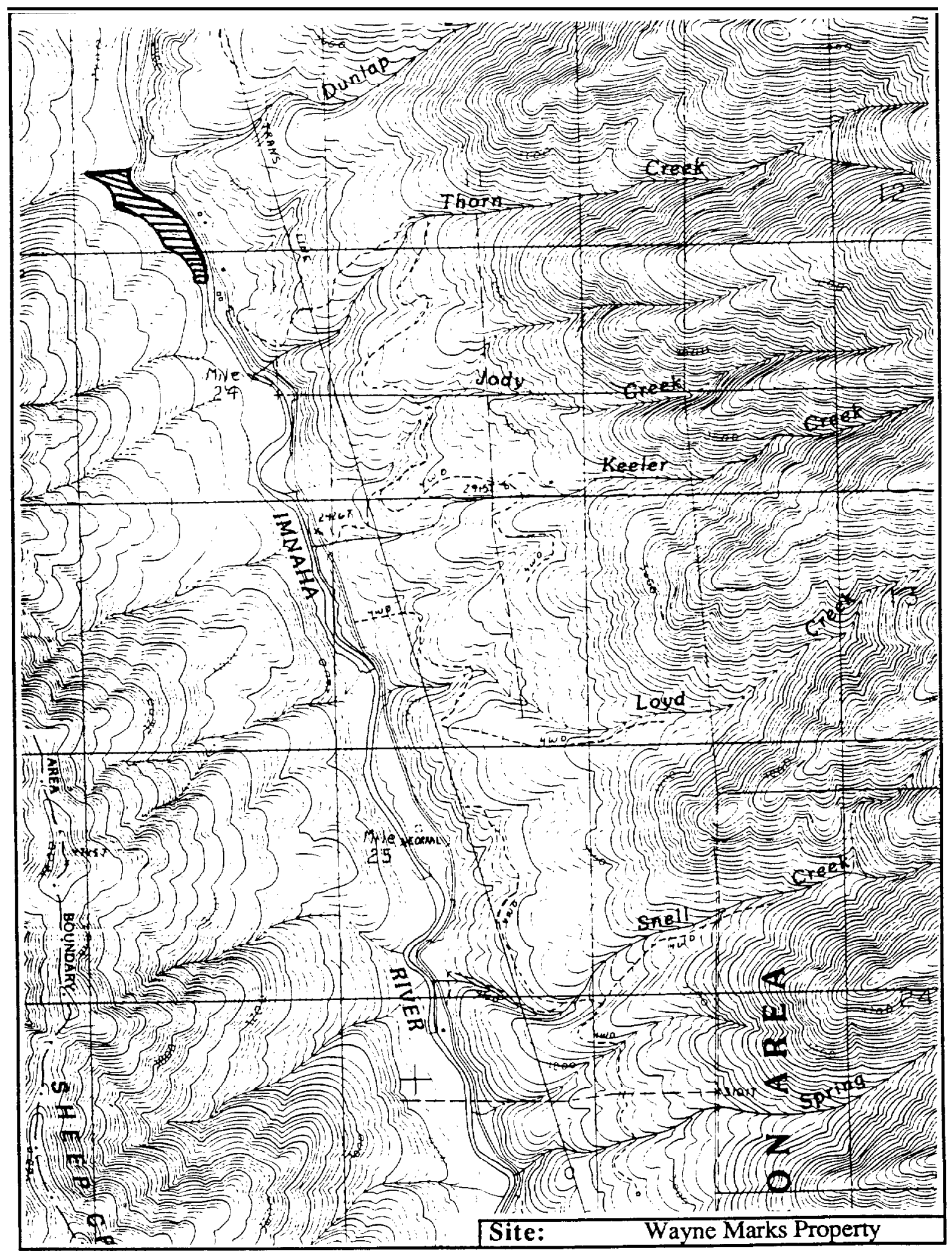


RIVER BASIN

SITE NUMBER

SITE NAME

SITE LOCATION

County

Road Access Directions

River Mile

USGS 1:100,000 Quad Ref. USGS 7.5' Quad Ref.

Section

- OWNERSHIP

Owner Name

Contact Name

Contact Phone

Zoning

Land Use/Jurisdiction
Walla Walla

WW1

NE 8th Street Bridge

Umatilla

Take NE 8th Street east out of Milton-Freewater to crossing of Walla Walla River. Existing ladder on NW side of river at NE 8th St. bridge.

Pendleton

Milton-Freewater

$\begin{array}{llll}\text { Tow n h ip } & \text { 5N } & \text { Range } & 35 E\end{array}$

Undetermined

Don Sampson, CTUIR

(503) 2764109

undetermined

undetermined, within City Limits

\section{GENERAL CHARACTERISTICS}

Proximity to road

Proximity to power

Size (acres)

Adjacent to paved road

3-phase power along NE 8th

cl acre

General topography

General soil type

Erosion potential

fiat, channeled river bank with rip-rap

alluvial

appears to be low

Flood potential and history undetermined

Upstream land use

Water rights

urban

undetermined, ladder just downstream of irrigation diversion

WATER SUPPLY

Gravity supply evaluation n/a

Groundwater evaluation n/a

ENVIRONMENTAL CHARACTERISTICS/CONSTRAINTS

Adjacent stream habitat

Anadromous fish

channelized stream with wide bed, meandering channel

Upland habitat type

Wetlands

Stcelhead

Permitting Considerations

urban, developed

riparian zone, other types not determined

Water rights 


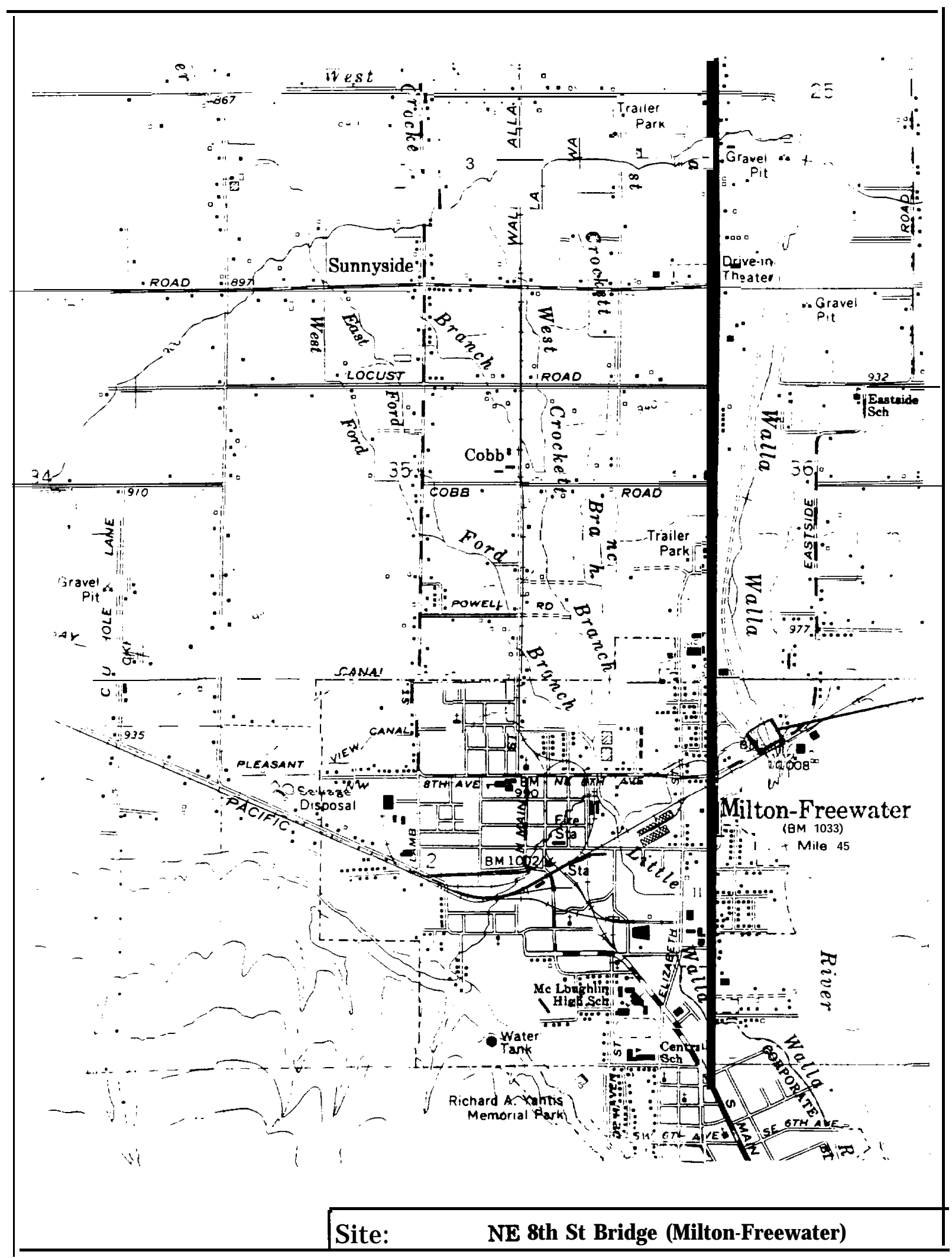


RIVER BASIN

SITE NUMBER

SITE NAME

SITE LOCATION

County

Road Access Directions
Walla Walla

WW2

9th and Walnut (9th Ave. Bridge)

Umatilla

On east side of Milton-Freewater just off state highway at intersection of 9th Ave. and Walnut St. Existing smolt/kelt trap located just downstream of the 9th Ave. Bridge on west side of river.

River Mile

USGS 1:100,000 Quad Ref. USGS 7.5' Quad Ref.

Section 12

Pendleton

Milton-Freewater

Tow n s i p $5 \mathrm{~N}$

Range

$35 \mathrm{E}$

OWNERSHIP

Owner Name

Undetermined

Contact Name

Don Sampson, CTUIR

(503) 2764109

Zoning

undetermined

Land Use /Jurisdiction

undetermined

GENERAL CHARACTERISTICS

Proximity to road adjacent to paved road

Proximity to power 3-phase power along road

Size (acres)

General topography

General soil type alluvial

$<1$ acre

Erosion potential low

Flood potential and history low

Upstream land use urban, developed

Water rights all water to irrigation at site

WATER SUPPLY

Gravity supply evaluation n/a

Groundwater evaluation n/a

ENVIRONMENTAL CHARACTERISTICS/CONSTRAINTS

Adjacent stream habitat irrigation canal has woody brushy riparian habitat

Anadromous fish

Upland habitat type

steelhead above site in mainstem, none below trap

Wetlands

urban, developed

Permitting Considerations

riparian zone, other types not determined

undetermined 


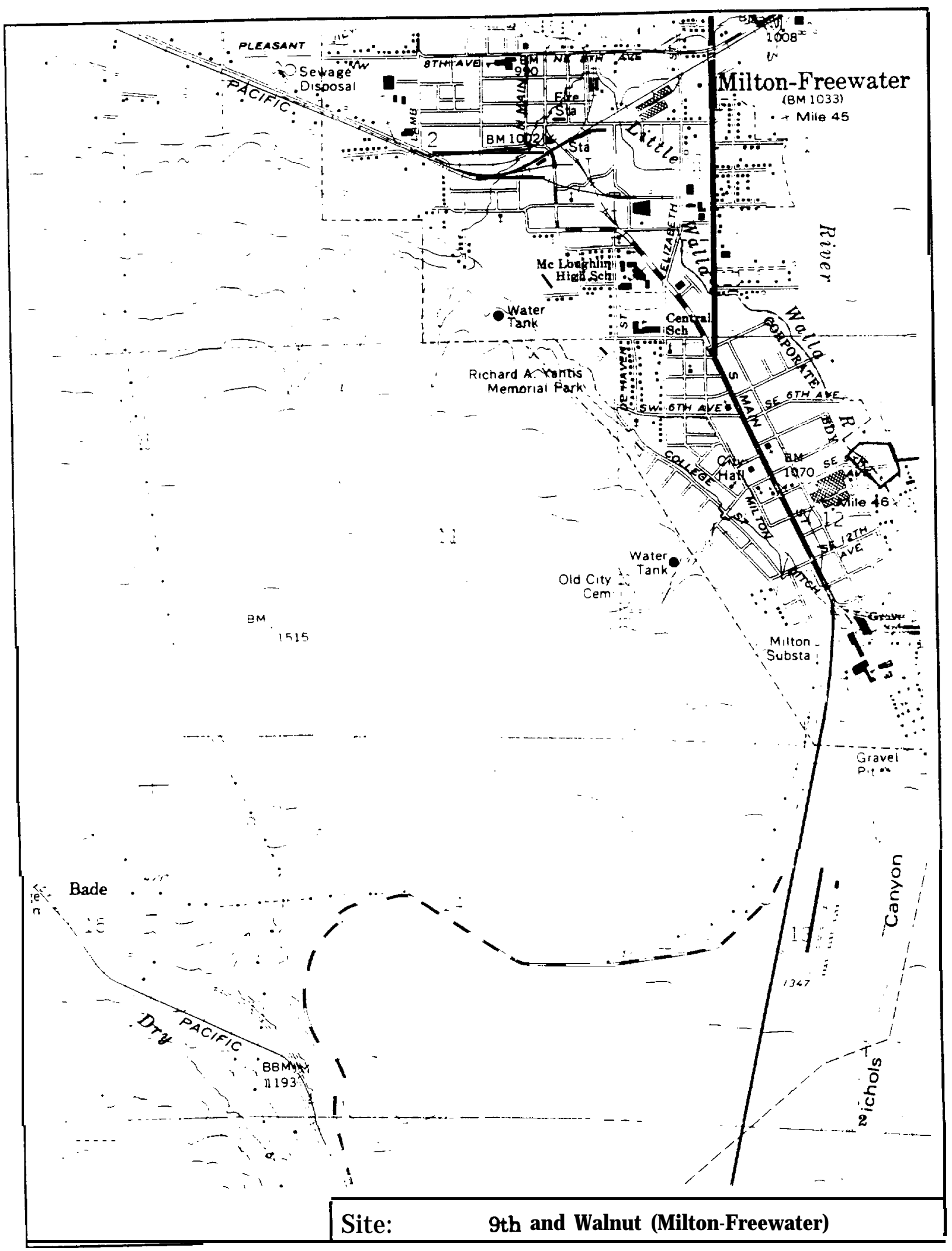


RIVER BASIN

SITE NUMBER

SITE NAME

SITE LOCATION

County

Road Access Directions

River Mile

USGS 1:100,000 Quad R

USGS 7.5' Quad Ref.

Section 10

OWNERSHIP

Owner Name

Contact Name

Contact Phone

Zoning

Land Use /Jurisdiction
Walla Walla

WW3

Harris Park No. 1

Umatilla

S. Fork Walla Walla Road at road mile 7.25, Harris County Park

GENERAL CHARACTERISTICS

Proximity to road

Proximity to power

Size (acres)

General topography

General soil type

Erosion potential

Flood potential and history

Upstream land use

Water rights

Paved road to near site, gravel to site

3 -phase power to site

6 to 8 acres

Flat bench next to S. Fork

alluvial

low

Blalock Mountain

Township $4 \mathrm{~N}$

Range

$37 \mathrm{E}$

Umatilla County Parks and Recreation

Gene Miller, Park Manager

(503) 9384237

undetermined

county park/Umatilla County

WATER SUPPLY

Gravity supply evaluation

appears low, history undetermined

BLM and USFS land, undeveloped, 1 gravel road undetermined

Good potential location, reports of freezing solid in Dec.-Jan. period. Temperature and flow information show suitable conditions for most facility types. Need verification.

Groundwater evaluation Potential, requires further investigation

ENVIRONMENTAL CHARACTERISTICS/CONSTRAINTS

Adjacent stream habitat riffles, pools

Anadromous fish

S tcelhead at and above site

Upland habitat type

Wetlands

Forested and grassy steep-slopes

Permitting Considerations

riparian zone cattails and rushes

Current land use as park may present permitting constraints. 


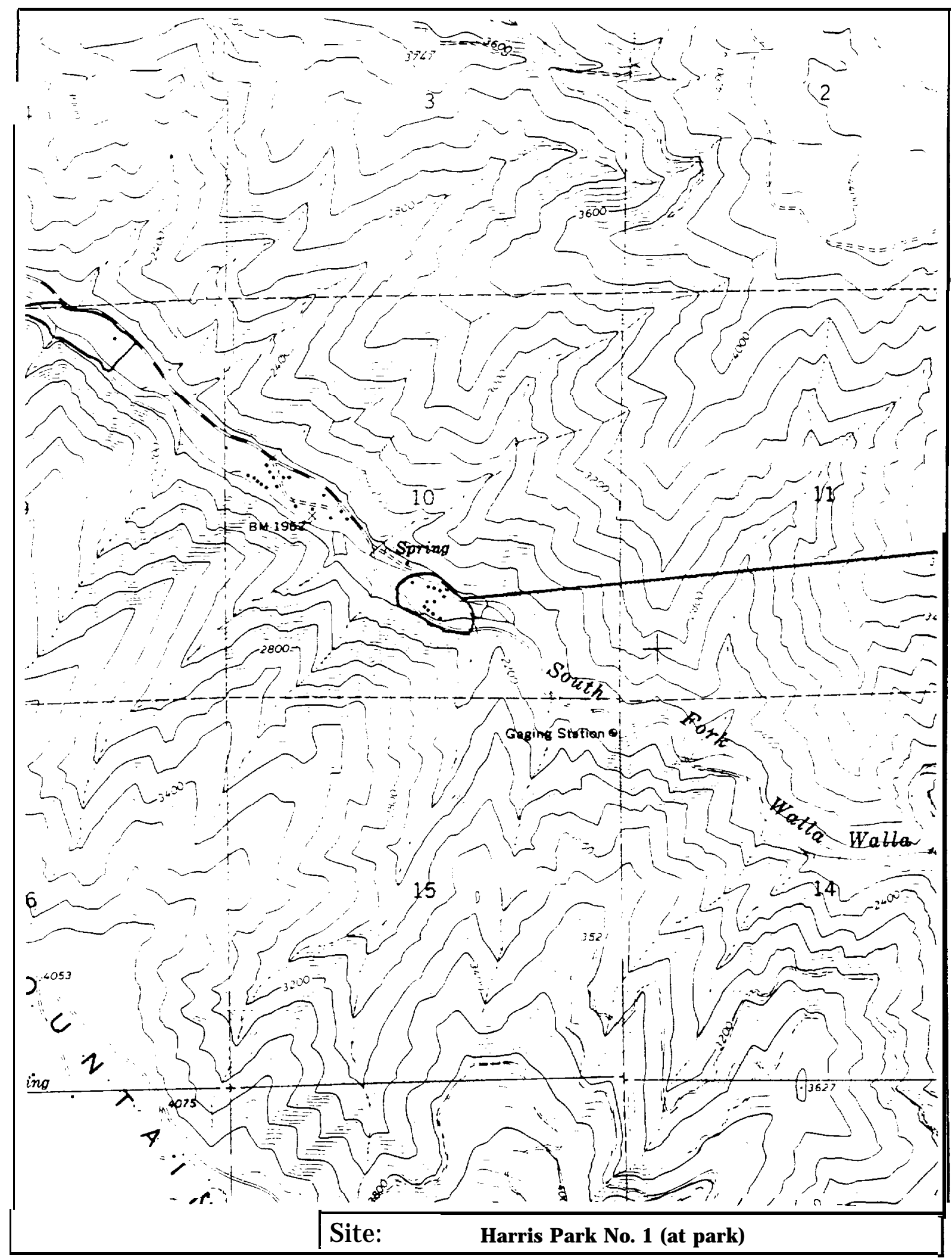




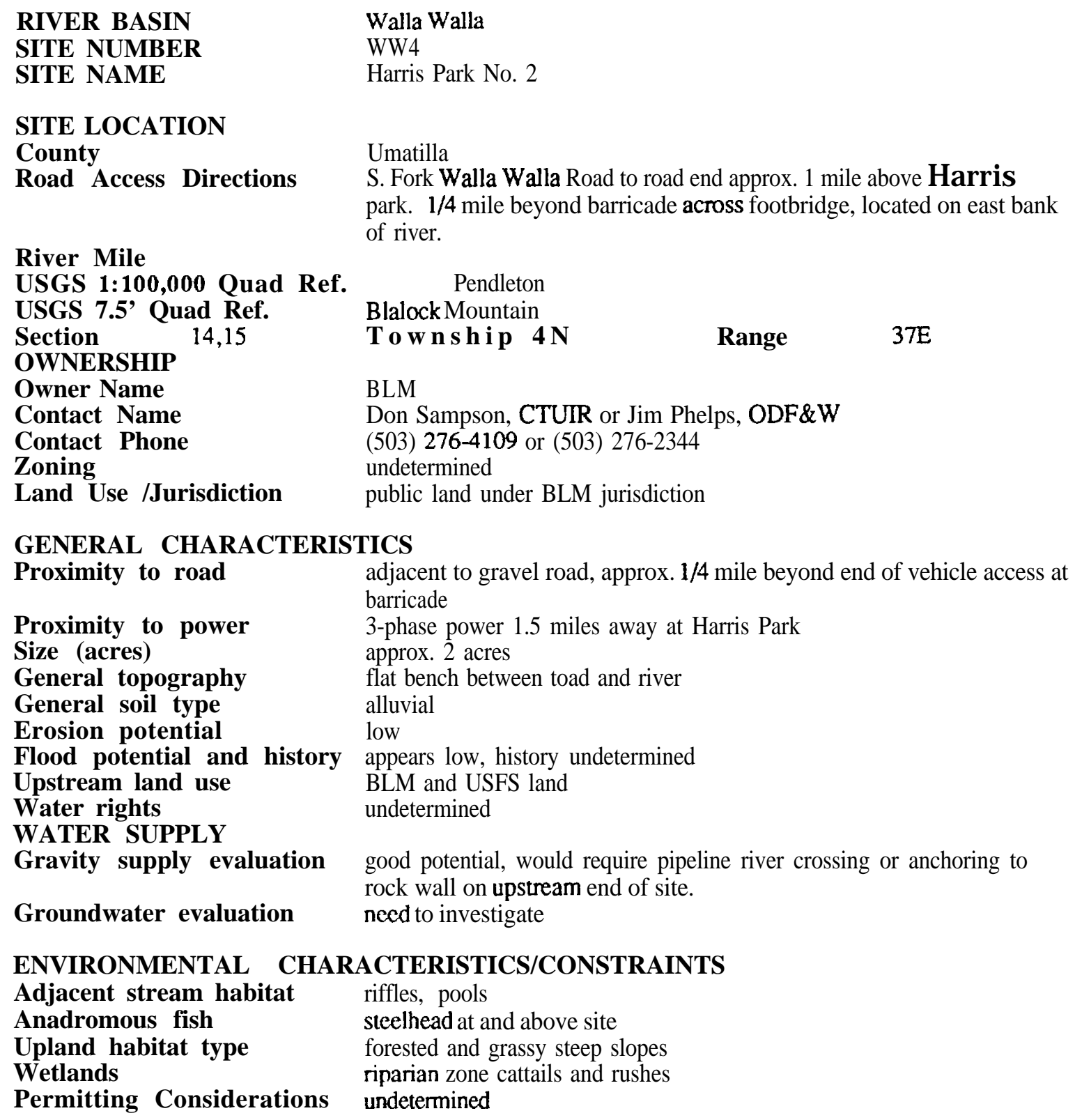




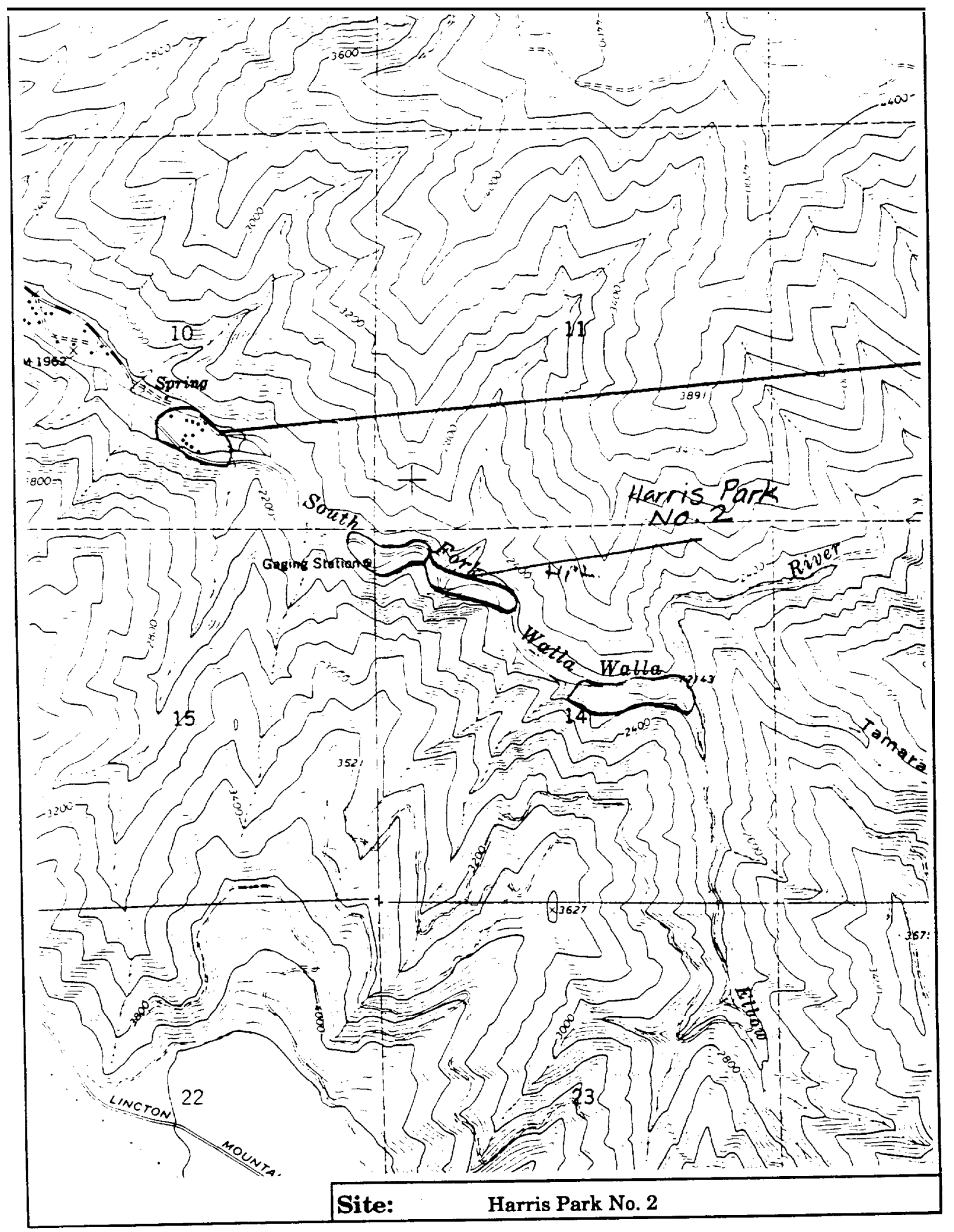


RIVER BASIN

SITE NAME

SITE LOCATION

County

Road Access Directions
SITE NUMBER

Walla Walla

WW5

S. Fork - Elbow Creek confluence

Umatilla

S. Fork Walla Walla Road to road end approx. 1 mile above Harris park. 1/2 mile beyond barricade across footbridge, located at Elbow Creek and South Fork confluence.

River Mile
USGS 1:100,000 Quad Ref.
USGS 7.5' Quad Ref.
Section 14
OWNERSHIP
Owner Name
Contact Name
Contact Phone
Zoning

Pendleton

Blalock Mountain

Township 4N $\quad$ Range $\quad 37 E$

BLM

Don Sampson, CTUIR or Jim Phelps, ODF\&W

(503) 276-4109 or (503) 276-2344

undetermined

undeveloped public land under BLM jurisdiction

GENERAL CHARACTERISTICS

Proximity to road

Proximity to power

Size (acres)

adjacent to gravel road but approximately 0.5 miles beyond road end at barricade.

General topography

General soil type

Erosion potential approximately 1.75 miles away at Harris Park 2 to 4 acres

mostly flat

alluvial

Flood potential and history appears to be low, history unknown

Upstream land use

Water rights

undeveloped wilderness

undetermined

\section{WATER SUPPLY}

Gravity supply evaluation

Groundwater evaluation

good potential

potential as gravity backup

\section{ENVIRONMENTAL CHARACTERISTICS/CONSTRAINTS}

Adjacent stream habitat riffles, pools

Anadromous fish

steelhead at and above site

Upland habitat type

forested and grassy steep slope

Wetlands

riparian zone cattails and rushes.

Permitting Considerations

undetermined 


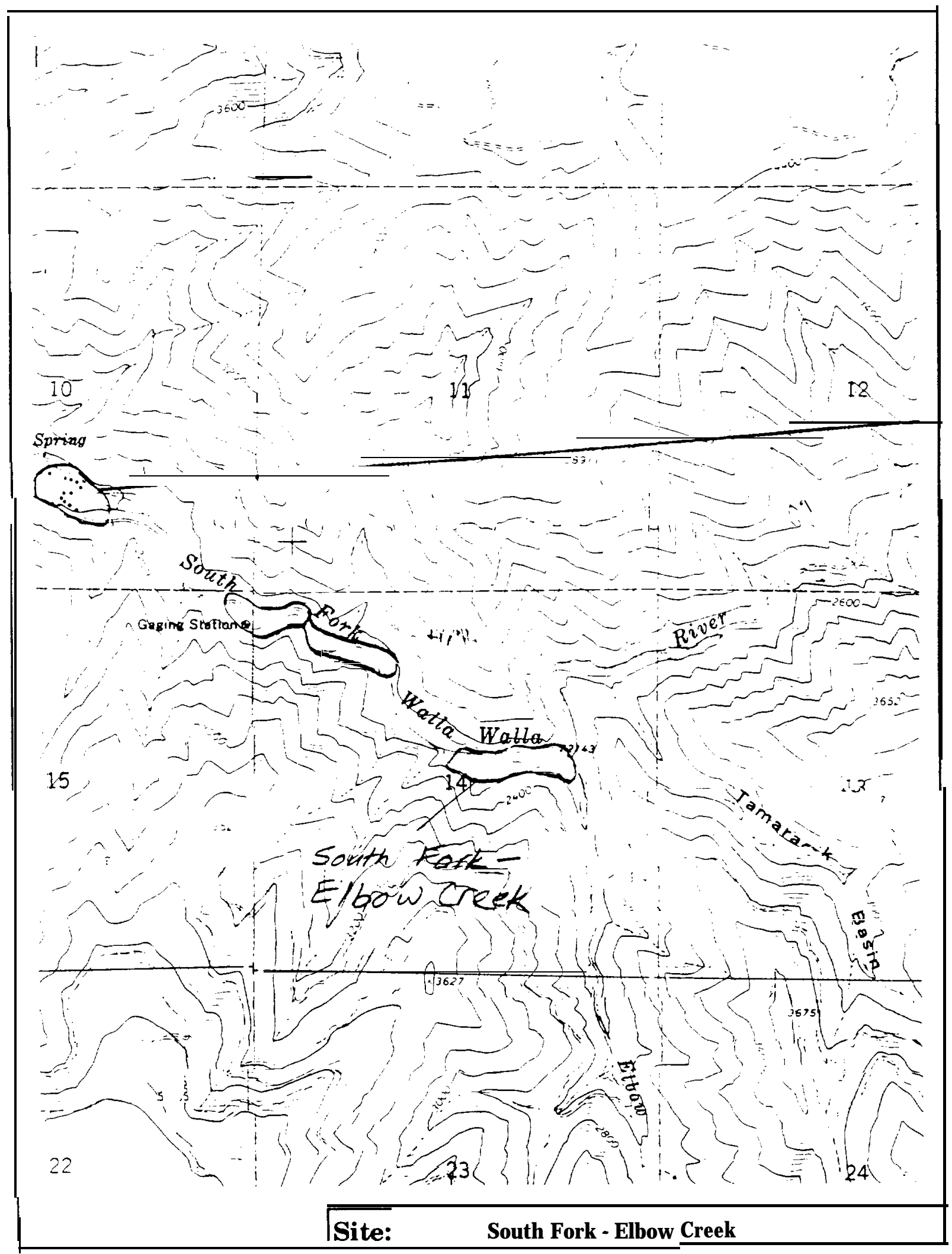




\begin{tabular}{|c|c|}
\hline $\begin{array}{l}\text { RIVER BASIN } \\
\text { SITE NUMBER } \\
\text { SITE NAME }\end{array}$ & $\begin{array}{l}\text { Walla Walla } \\
\text { WW6 } \\
\text { Russell Walker }\end{array}$ \\
\hline $\begin{array}{l}\text { S ITE LOCATION } \\
\text { County } \\
\text { Road Access Directions }\end{array}$ & $\begin{array}{l}\text { Umatilla } \\
\text { S. Fork Road to approximately mile } 6 \text { to } 7.25 \text {. Flat land along river } \\
\text { below Harris Park }\end{array}$ \\
\hline $\begin{array}{l}\text { River Mile } \\
\text { USGS 1:100,000 Quad Ref. } \\
\text { USGS 7.5' Quad Ref. } \\
\text { Section } 9 \\
\text { OWNERSHIP } \\
\text { Owner Name } \\
\text { Contact Name } \\
\text { Contact Phone } \\
\text { Zoning } \\
\text { Land Use /Jurisdiction }\end{array}$ & $\begin{array}{l}\text { Pendleton } \\
\text { Blalock Mountain } \\
\text { Tow n s h i p } \mathbf{4} \text { N Range } \\
\text { Russell Wlaker } \\
\text { Don Sampson, CTUIR or Jim Phelps, ODF\&W } \\
\text { (503) 276-4109 or (503) 276-2344 } \\
\text { undetermined } \\
\text { undetermined }\end{array}$ \\
\hline $\begin{array}{l}\text { GENERAL CHARACTERIS } \\
\text { Proximity to road } \\
\text { Proximity to power } \\
\text { Size (acres) } \\
\text { General topography } \\
\text { General soil type } \\
\text { Erosion potential } \\
\text { Flood potential and history } \\
\text { Upstream land use } \\
\text { Water rights }\end{array}$ & $\begin{array}{l}\text { TICS } \\
\text { access off paved S. Fork Road } \\
\text { 3-phase power available } \\
>10 \text { acres } \\
\text { flat, river-bottom } \\
\text { alluvial } \\
\text { low } \\
\text { low } \\
\text { County park and undeveloped roadless } \\
\text { undetermined }\end{array}$ \\
\hline $\begin{array}{l}\text { WATER SUPPLY } \\
\text { Gravity supply evaluation } \\
\text { Groundwater evaluation }\end{array}$ & $\begin{array}{l}\text { Good potential } \\
\text { Moderate shallow zone potential, Low deep zone potential }\end{array}$ \\
\hline $\begin{array}{l}\text { ENVIRONMENTAL CHAR } \\
\text { Adjacent stream habitat } \\
\text { Anadromous fish } \\
\text { Upland habitat type } \\
\text { Wetlands }\end{array}$ & $\begin{array}{l}\text { ACTERISTICS/CONSTRAINTS } \\
\text { Modcrate gradient, pool and riffle } \\
\text { stcelhead at and above this area } \\
\text { flat, river bottom pasture land and forested slopes } \\
\text { None identified, some seeps in pasture area that may contain wetland } \\
\text { vegetation } \\
\text { Water rights }\end{array}$ \\
\hline
\end{tabular}




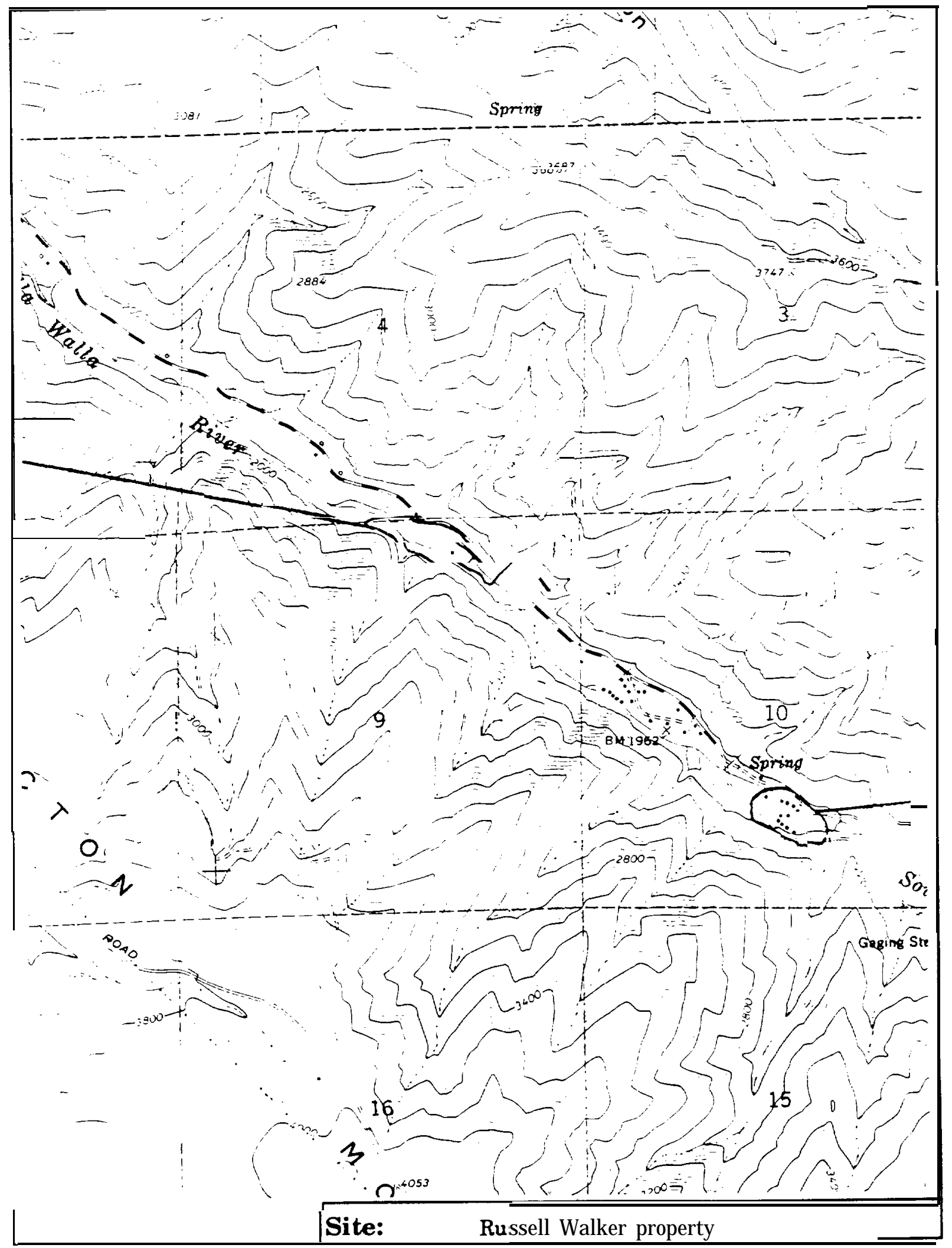


RIVER BASIN

SITE NUMBER

SITE NAME

SITE LOCATION

County

Road Access Directions

River Mile

USGS 1:100,000 Quad Ref. USGS 7.5' Quad Ref.

Section
Walla Walla

WW7

Wolf Fork confluence with Touchet River

ColumbiaCO., WA

Wolf Fork Road to SW 5.6 miles outside Dayton, WA (Follow signs to ski area from Dayton). Cross Touchet River going west and park at gravel turnout. Wolf Fork Road is off S 4th Street which is off Main St.

Touchet River RM 59 (approx.)

Dayton, WA

Township 9N $\quad$ Range 39E

private, unknown

Don Sampson, CTUIR

(503) 2764109

undetermined

agriculture

GENERAL CHARACTERISTICS

Proximity to road paved road to within $1 / 4$ ile of confluence

Proximity to power

Size (acres)

General topography

General soil type

3-phase power along road.

undetermined, probably $1-4$ developable acres

Erosion potential

flat to gently rolling

alluvial

undetermined

Flood potential and history undetermined

Upstream land use

Water rights

catle grazing, agriculture

undetermined

WATER SUPPLY

Gravity supply evaluation appears poor, pumping may be required with any holding facility Groundwater evaluation N/A

ENVIRONMENTAL CHARACTERISTICS/CONSTRAINTS

Adjacent stream habitat small 10-1 5" wide riffle, low gradient

Anadromous fish

possibly steelhead

Upland habitat type

Wetlands

mixed coniferous, deciduous grassland. Steep slope away from

confluence

Permitting Considerations

riparian zone wetlands, others undetermined

undetermined water rights and property ownership 


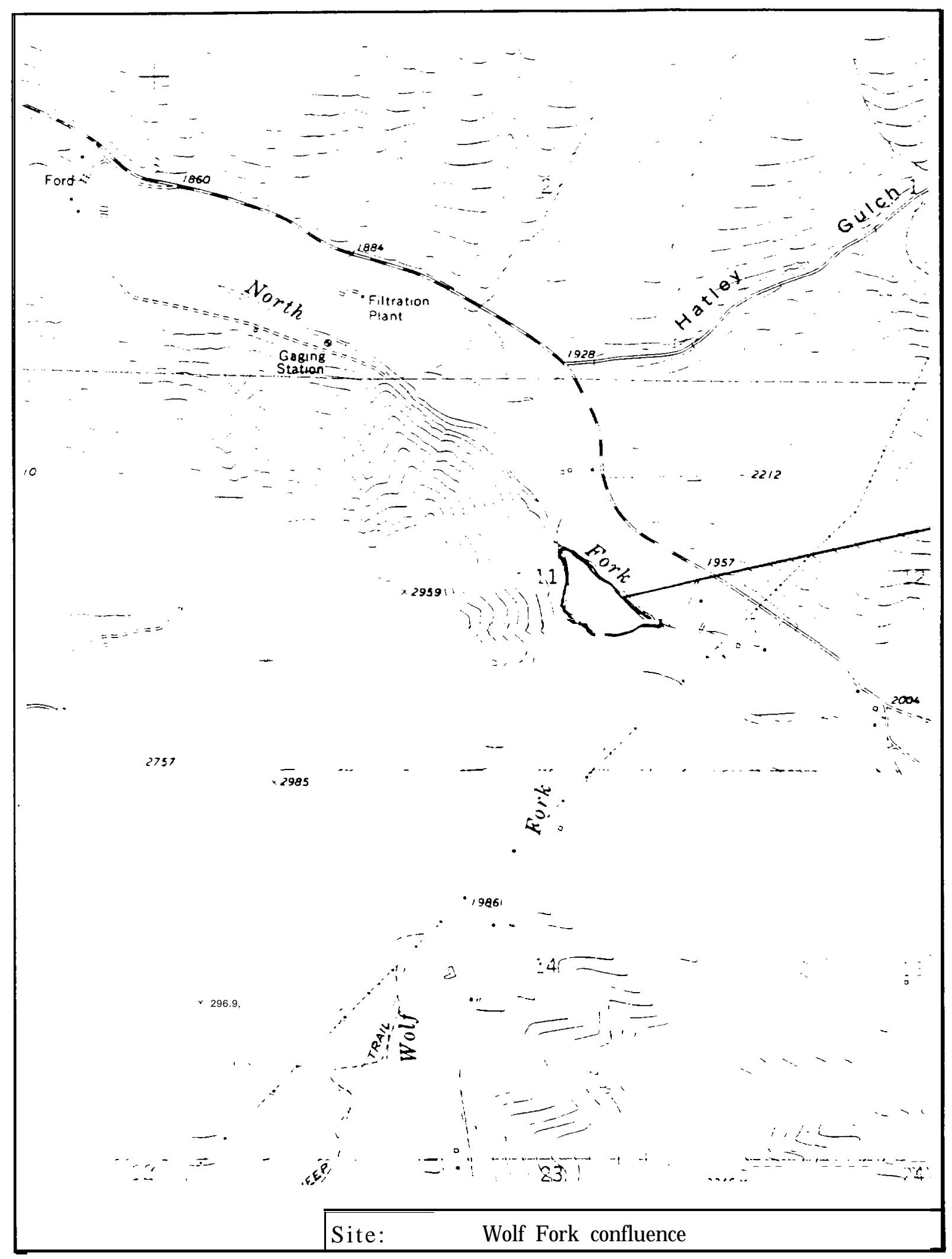


RIVER BASIN

SITE NUMBER

SITE NAME

SITE LOCATION

County

Road Access Directions

River Mile

USGS 1:100,000 Quad Ref.

USGS 7.5' Quad Ref.

Section
Walla Walla

WW8

WDW Dayton Conditioning Pond

Columbia

Turn off Main St. in Dayton on Cottonwood Road of west side of Touchet River. Approx. 1 mile on Cottonwood Road to facility.

Touchet River RM 53.5 to 54 (approx.)

Dayton, WA

$\begin{array}{llll}\text { Township } & 10 \mathrm{~N} & \text { Range } & 39 \mathrm{E}\end{array}$

Washington Department of Wildlife

Don Sampson, CTUIR

(503) 2764109

undetermined

undetermined

GENERAL CHARACTERISTICS

Proximity to road

Proximity to power

Size (acres)

General topography

General soil type

Erosion potential

road to all areas of facility

power to facility

asphalt pond approx. 1 acre

flat

alluvial

low, west bank has armor rock on dike, east bank is flatter with dike.

Flood potential and history appears low, history undetermined

Upstream land use urban, some agriculture

Water rights

undetermined

WATER SUPPLY

Gravity supply evaluation existing low head intake about $1 / 4$ mile upstream of pond

Groundwater evaluation undetermined

ENVIRONMENTAL CHARACTERISTICS/CONSTRAINTS

Adjacent stream habitat

Anadromous fish

some deciduous trees and grasses in riparian zone

Upland habitat type steelhead

Wetlands

Permitting Considerations

brush and grass, some trees

appears minimal outside riparian zone

undetermined 


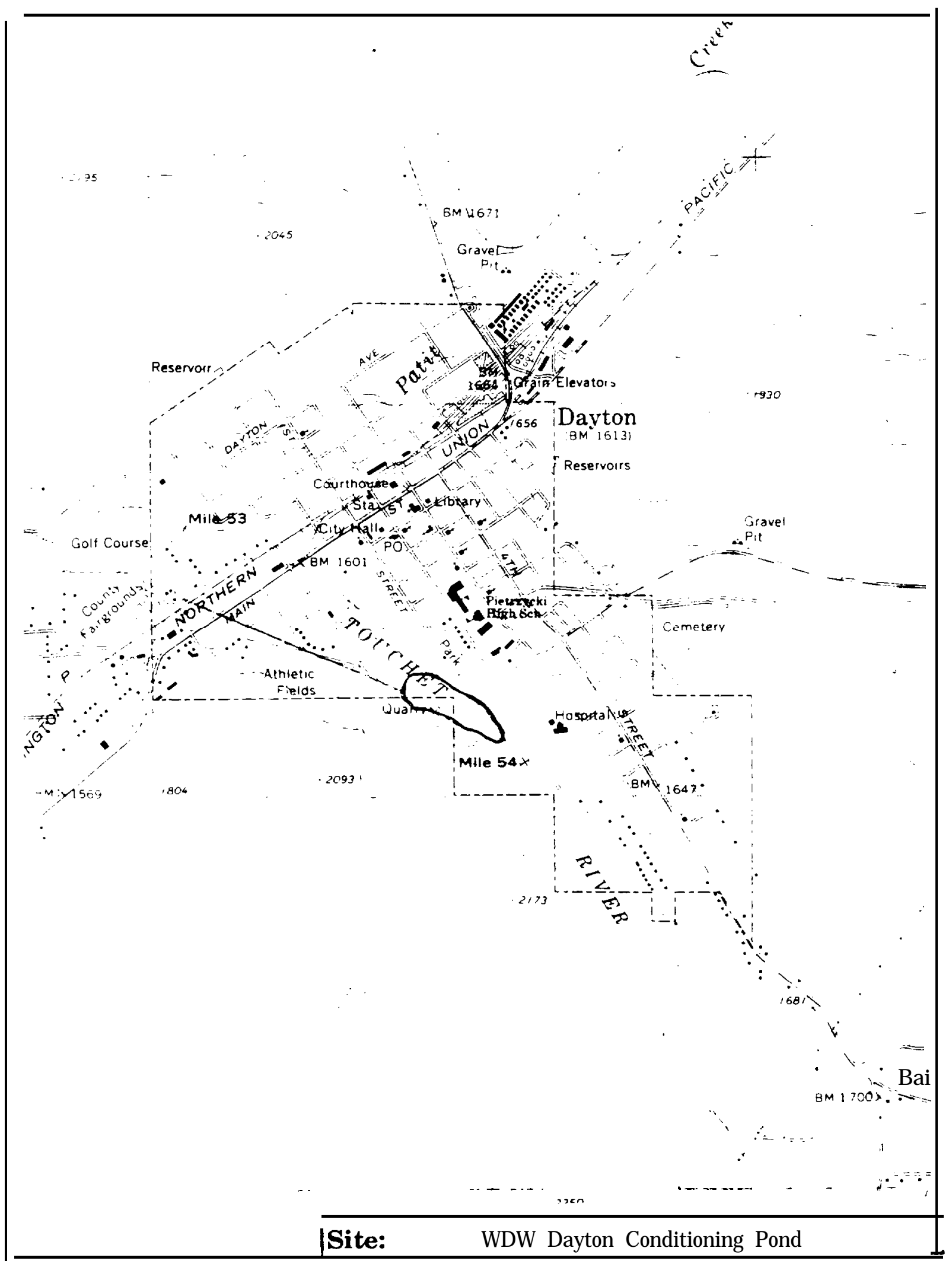


RIVER BASIN

SITE NUMBER

SITE NAME

SITE LOCATION

County

Road Access Directions

River Mile

USGS 1:100,000 Quad Ref.

USGS 7.5' Quad Ref.

Section
Walla Walla

WW9

Railroad Bridge

Walla Walla, WA

On dirt road near Zangar Jct. at mouth of Walla Walla River where railroad bridge crosses river.

Walla Walla mainstem RM 8 (approx.)

Zangar Jct., WA - OR

Towns h i p $\mathbb{N}$

Range

32E

OWNERSHIP

Owner Name

Contact Name

Private, undetermined

Contact Phone

Don Sampson, CTUIR

(503) 2764109

Zoning

Land Use /Jurisdiction

undetermined

undetermined

\section{GENERAL CHARACTERISTICS}

Proximity to road

Proximity to power

Size (acres)

General topography

General soil type

Erosion potential

dirt road to site

power along railroad

approx. 5 acres

flat

alluvial

Flood potential and history appears low, history undetermined

Upstream land use

Water rights

agriculture

undetermined

WATER SUPPLY

Gravity supply evaluation

Groundwater evaluation

low potential, river very low gradient

N/A

ENVIRONMENTAL CHARACTERISTICS/CONSTRAINTS

Adjacent stream habitat Anadromous fish

some deciduous trees and grasses in riparian zone

Upland habitat type

Yes

Wetlands

brush and grass, some trees

Permitting Considerations

appears minimal outside riparian zone

undetermined 


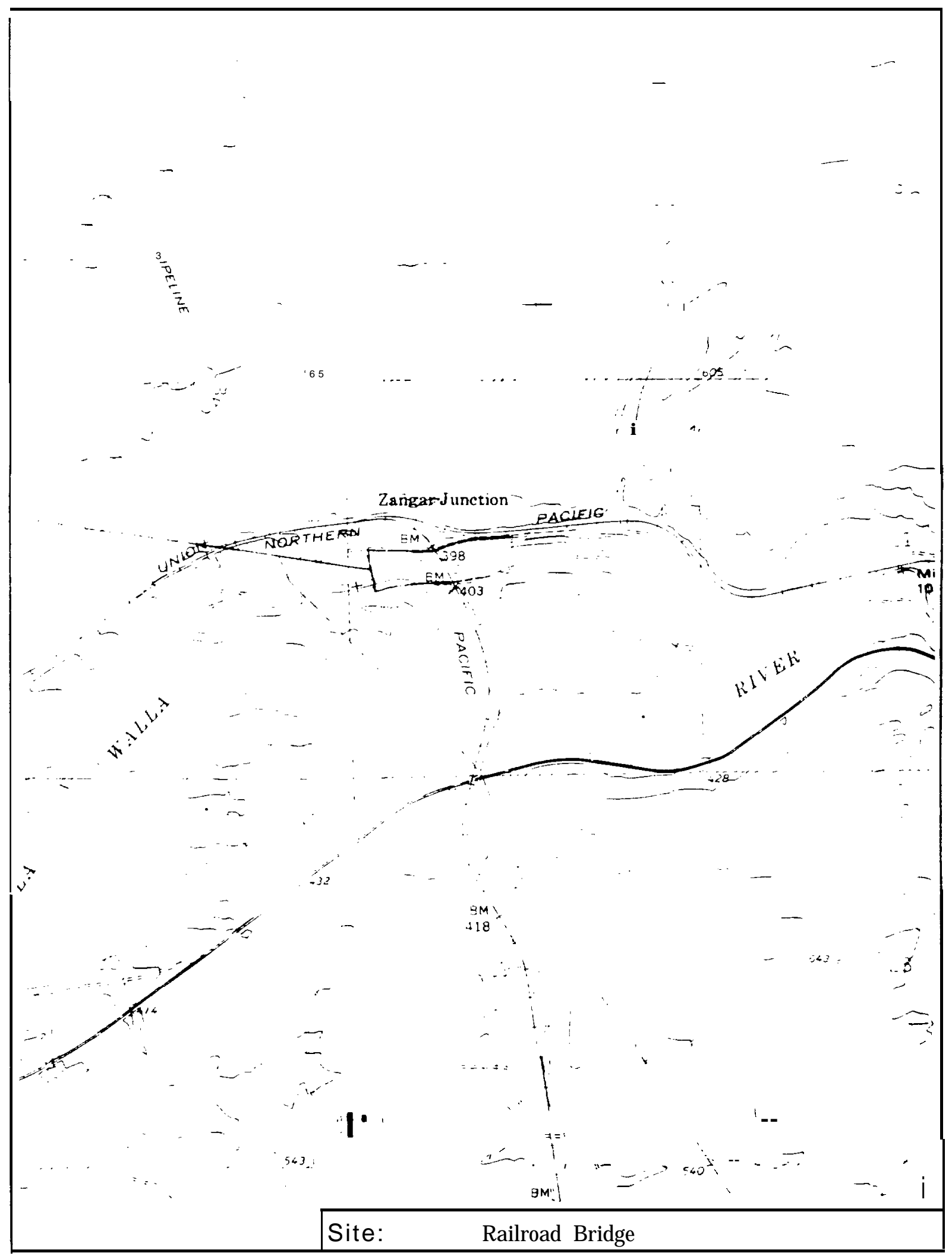




\begin{tabular}{|c|c|}
\hline $\begin{array}{l}\text { RIVER BASIN } \\
\text { SITE NUMBER } \\
\text { SITE NAME }\end{array}$ & $\begin{array}{l}\text { Walla Walla } \\
\text { WW10 } \\
\text { Pond at Forest Service Boundary }\end{array}$ \\
\hline $\begin{array}{l}\text { SITE LOCATION } \\
\text { County } \\
\text { Road Access Directions } \\
\text { River Mile } \\
\text { USGS 1:100,000 Quad Ref. } \\
\text { USGS 7.5' Quad Ref. } \\
\text { Section } \quad 5\end{array}$ & $\begin{array}{l}\text { Columbia } \\
\text { On N. Fork Touchet River Road outside Dayton just below Lewis } \\
\text { Creek. National Forest Boundary sign near site. } \\
\text { undetermined } \\
\text { Eckler Mtn., WA } \\
\text { Township } 8 \text { N } \quad \text { Range } \quad 40 E\end{array}$ \\
\hline $\begin{array}{l}\text { OWNERSHIP } \\
\text { Owner Name } \\
\text { Contact Name } \\
\text { Contact Phone } \\
\text { Zoning } \\
\text { Land Use /Jurisdiction }\end{array}$ & $\begin{array}{l}\text { U.S. Forest Service } \\
\text { Don Sampson, CTUIR } \\
\text { (503) 2764109 } \\
\text { undetermined } \\
\text { undetermined/U.S. Forest Service }\end{array}$ \\
\hline $\begin{array}{l}\text { GENERAL CHARACTERIS } \\
\text { Proximity to road } \\
\text { Proximity to power } \\
\text { Size (acres) } \\
\text { General topography } \\
\text { General soil type } \\
\text { Erosion potential } \\
\text { Flood potential and history ap } \\
\text { Upstream land use } \\
\text { Water rights }\end{array}$ & $\begin{array}{l}\text { TICS } \\
\text { adjacent to paved road } \\
\text { power nearby } \\
\text { pond approx. } 1 \text { acre } \\
\text { flat } \\
\text { alluvial } \\
\text { low } \\
\text { pears low, history undetermined } \\
\text { National Forest } \\
\text { undetermined }\end{array}$ \\
\hline $\begin{array}{l}\text { WATER SUPPLY } \\
\text { Gravity supply evaluation }\end{array}$ & $\begin{array}{l}\text { Existing pond elevated on bench above Touchet River. Supply line } \\
\text { from river would need to be brought in from upstream. Current supply } \\
\text { from small drainages. } \\
\text { undetermined }\end{array}$ \\
\hline $\begin{array}{l}\text { ENVIRONMENTAL CHAR } \\
\text { Adjacent stream habitat } \\
\text { Anadromous fish } \\
\text { Upland habitat type } \\
\text { Wetlands }\end{array}$ & $\begin{array}{l}\text { ACTERISTICS/CONSTRAINTS } \\
\text { Mixed pool, riffles, boulders } \\
\text { steelhead } \\
\text { forested steep slope } \\
\text { Pond may have developed wetland vegetation over time. Delineation } \\
\text { survey would be required prior to development. } \\
\text { undetermined }\end{array}$ \\
\hline
\end{tabular}




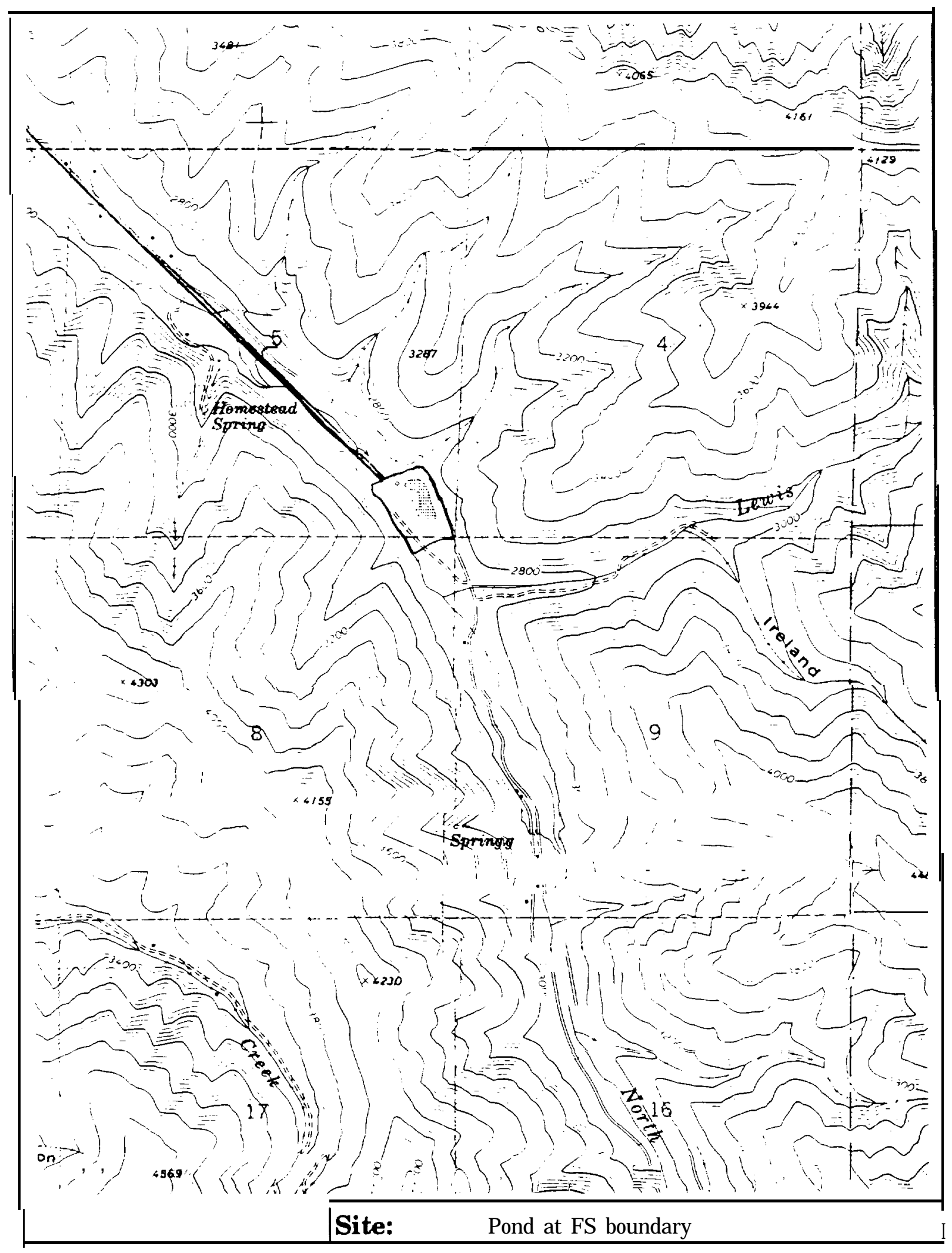

